Universidad de Lima

Facultad de Ingeniería y Arquitectura

Carrera de Arquitectura

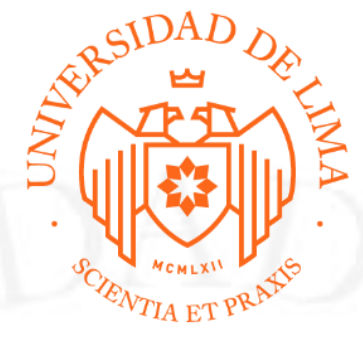

\title{
PARQUE LINEAL RIBEREÑO Y CENTRO DE INTERPRETACIÓN COMO PROYECTOS DE REGENERACIÓN URBANA EN LA CIUDAD DE HUANCAYO
}

Trabajo de suficiencia profesional para optar el Título Profesional de Arquitecto. Proyecto de Fin de Carrera

Paola Lucianne Aucahuasi Oviedo

20111549

Rocio Sara Llimpe Rojas

20110672

Asesor

Karina Puente Frantzen

Lima - Perú

septiembre de 2019 


\section{LINEAR PARK AND INTERPRETATION CENTER AS A PROJECT OF URBAN REGENERATION IN HUANCAYO CITY}




\section{TABLA DE CONTENIDO}

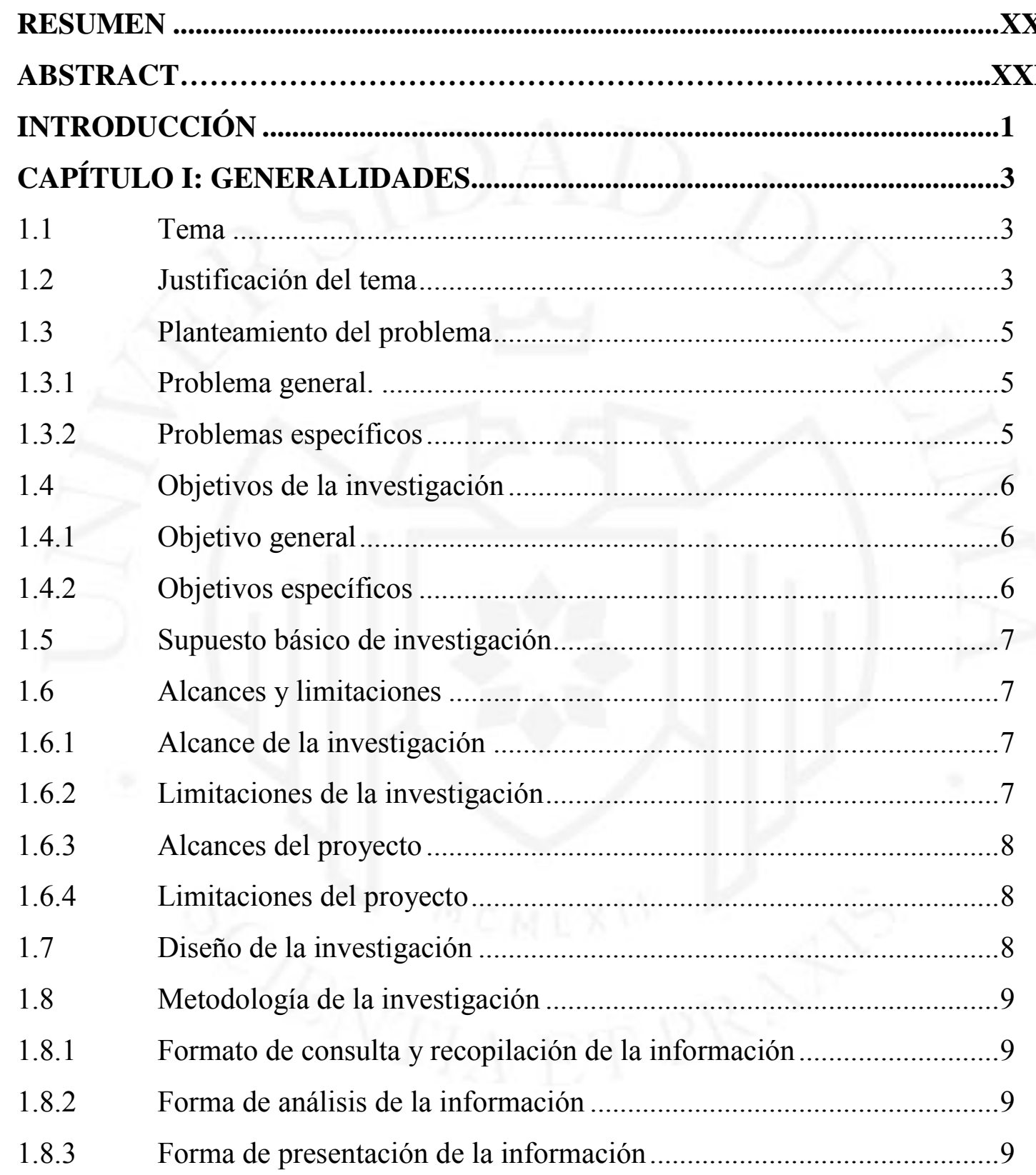

\section{CAPÍTULO II: MARCO REFERENCIAL ..................................................................10}

2.1 Intervenciones urbanas en borde de río en el mundo............................10

2.1.1 Relación histórica de la ciudad y el río ..............................................10

2.1.2 Casos de éxito de intervenciones urbanas en bordes de río .....................11 


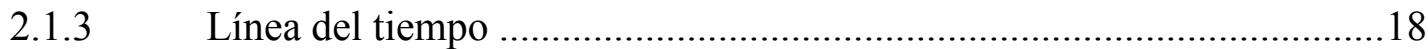

2.2 Propuestas urbanas en bordes de río en el Perú ....................................20

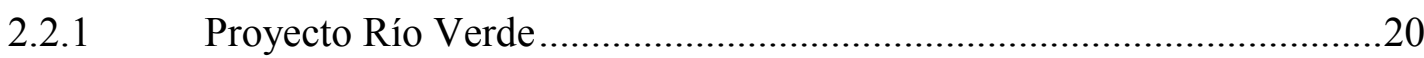

2.3 Beneficios actuales de la intervención en bordes de río ........................22

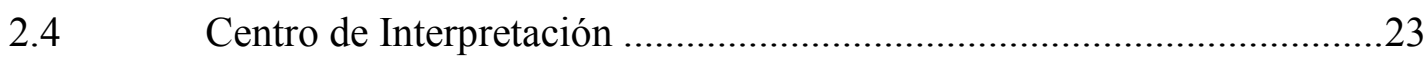

2.4.1 Origen a los Centros de interpretación.................................................23

2.4.2 Concepto de Centros de Interpretación..............................................24

2.5 Historia del crecimiento urbano de Huancayo .......................................25

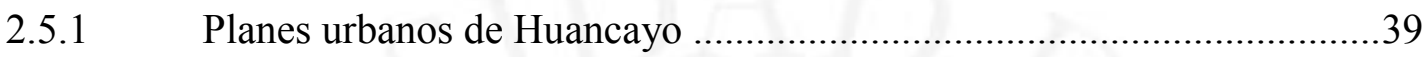

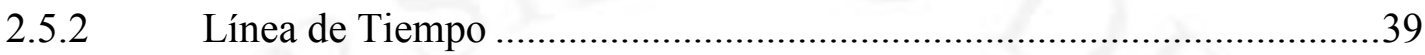

2.6 Situación actual de la ciudad de Huancayo............................................4

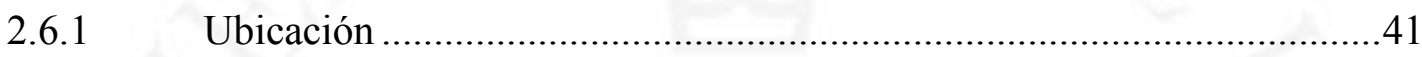

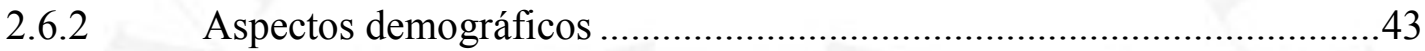

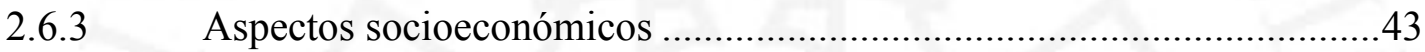

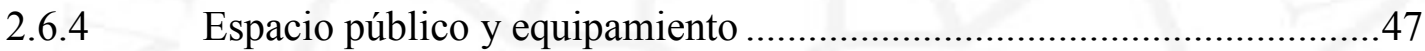

2.7 Situación actual del Río Shullcas...........................................................49

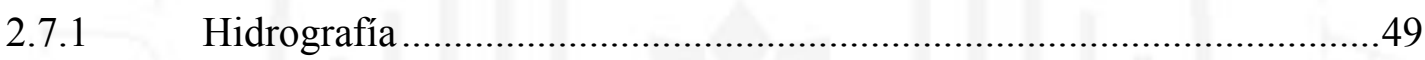

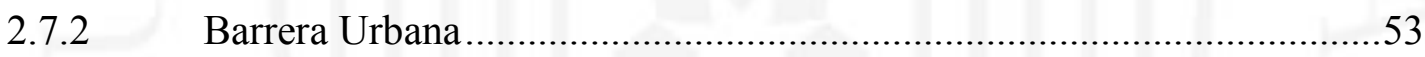

2.7.3 Contaminación del Río Shullcas ..........................................................56

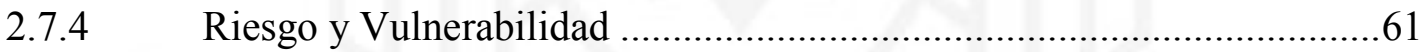

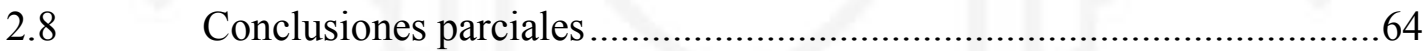

CAPÍTULO III: MARCO TEÓRICO......................................................................66

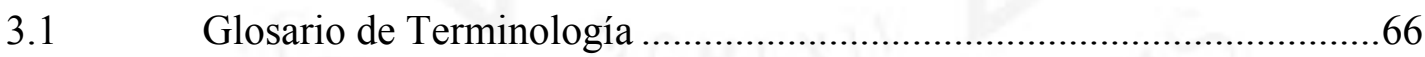

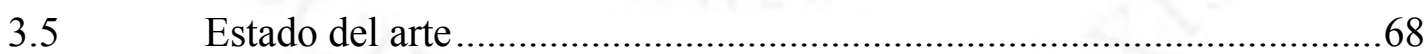

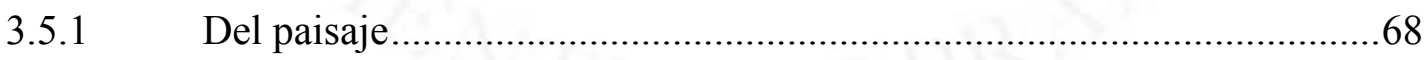

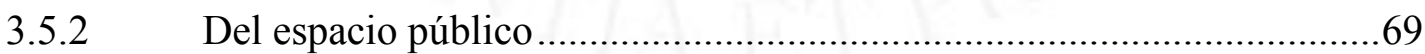

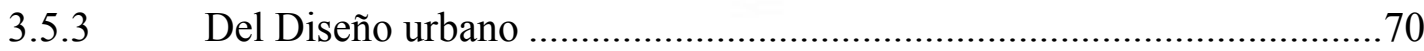

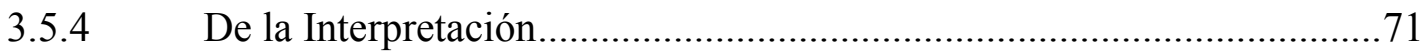

3.2 Revaloración de la ciudad desde el paisaje ...........................................73

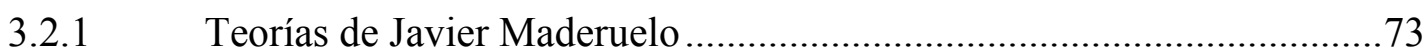

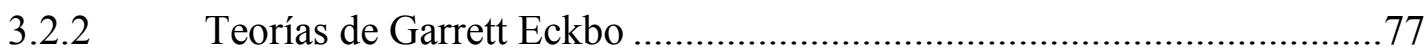

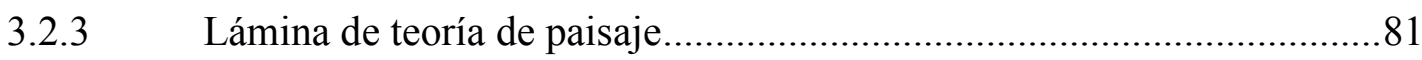

3.3 El papel del espacio público y las áreas verdes en la ciudad ..................83 


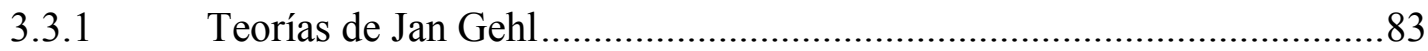

3.3.2 Teorías de Frederick Law Olmsted .......................................................85

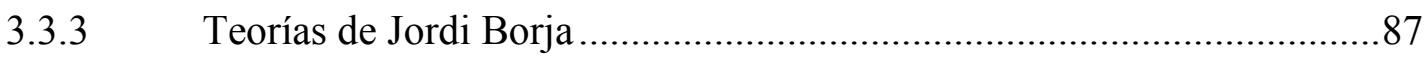

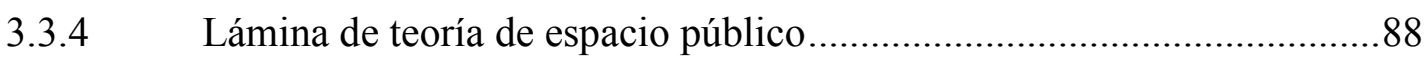

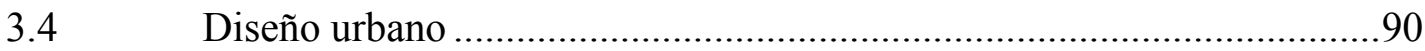

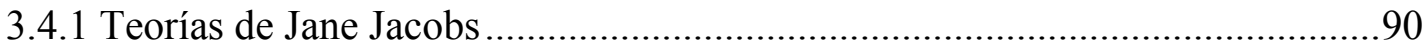

3.4.2 Teorías de Kevin Lynch ...................................................................93

3.4.3 El borde hídrico como articulador urbano ….......................................95

3.4.4 Lámina de teoría de Diseño urbano .....................................................97

3.5 La Interpretación como herramienta de educación ................................99

3.5.1 Primeras aproximaciones a la interpretación ........................................99

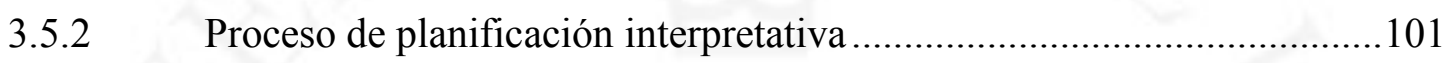

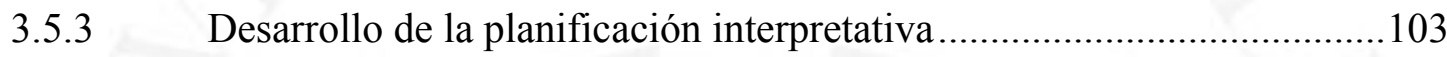

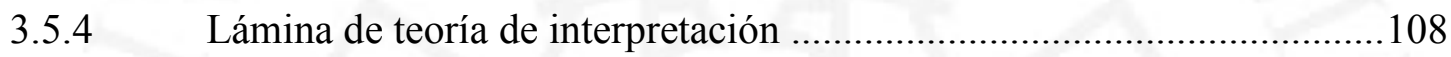

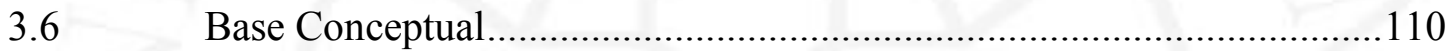

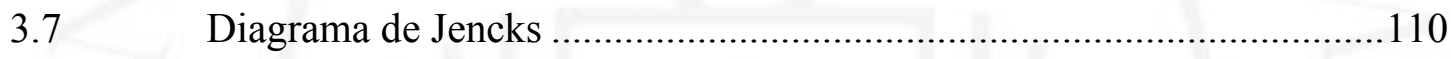

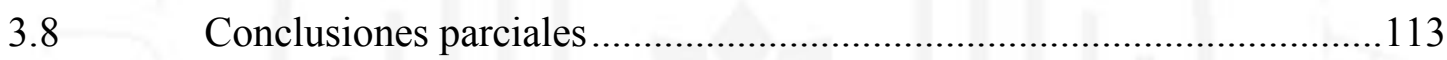

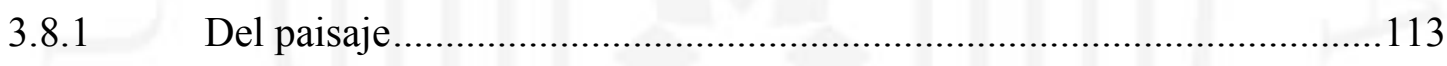

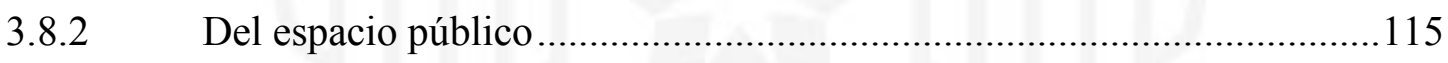

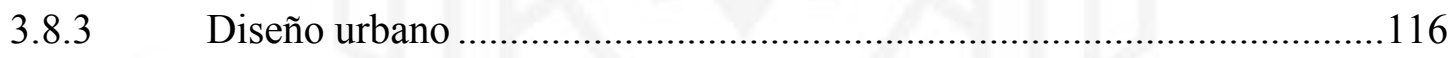

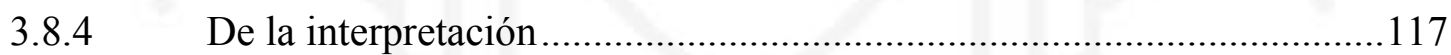

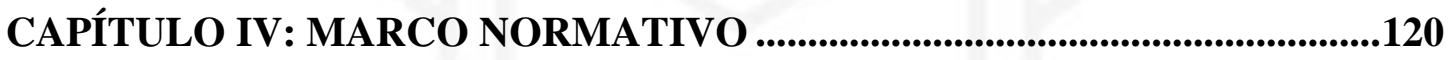

4.1 Metodologías de intervención en el paisaje .........................................120

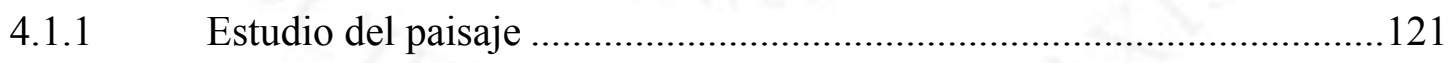

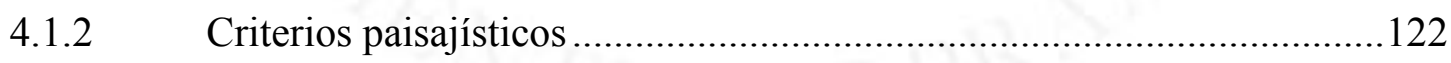

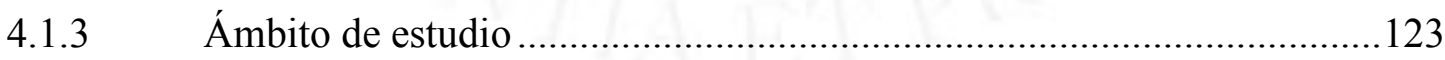

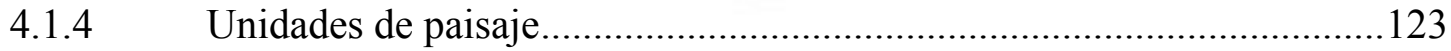

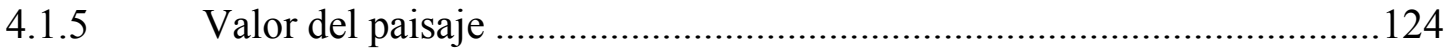

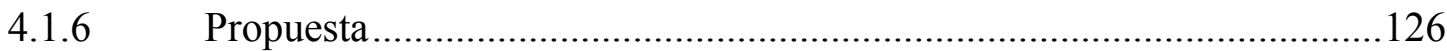

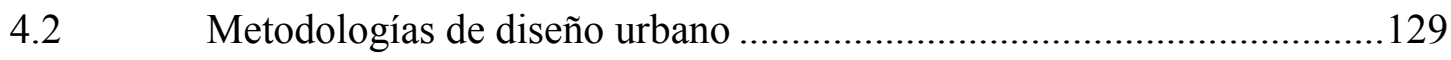

4.3 Tipologías de espacio público.........................................................136

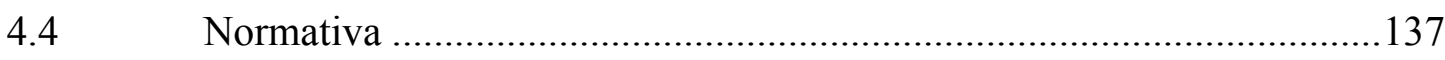

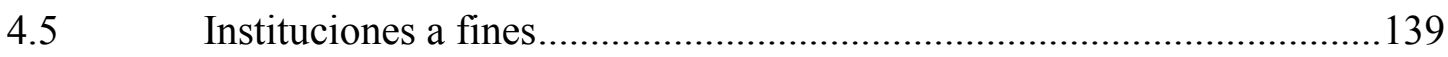




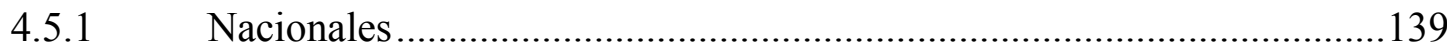

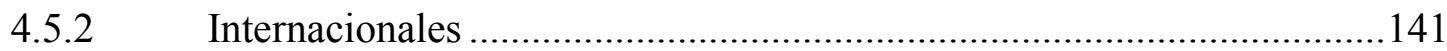

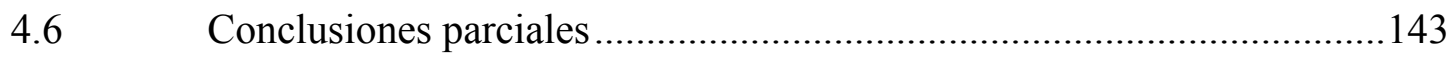

4.6.1 De la metodología de intervención del paisaje ....................................143

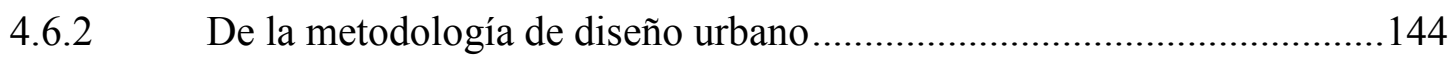

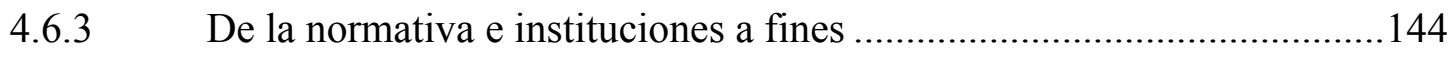

CAPÍTULO V: MARCO OPERATIVO .................................................................146

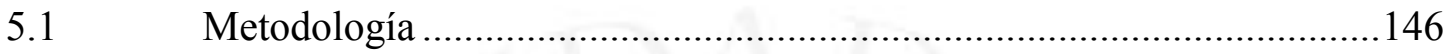

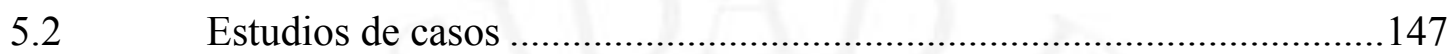

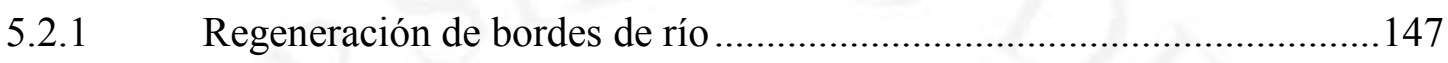

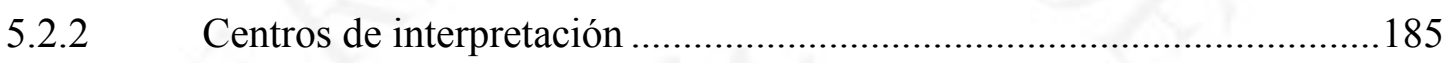

5.3 Cuadro comparativo y gráfica de casos análogos .................................243

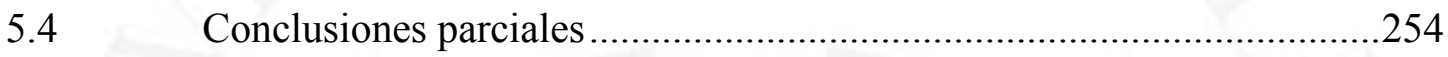

5.4.1 De intervenciones de regeneración de bordes de ríos ...........................254

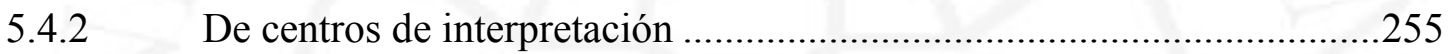

CAPÍTULO VI: MARCO CONTEXTUAL ............................................................257

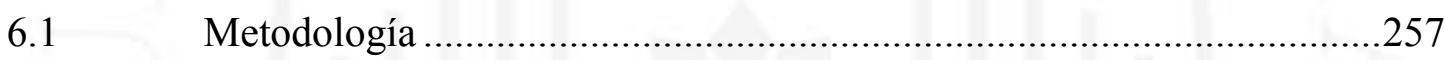

6.2 Plan Maestro Parque Llineal Ribereño Shullcas(Paisaje local)257

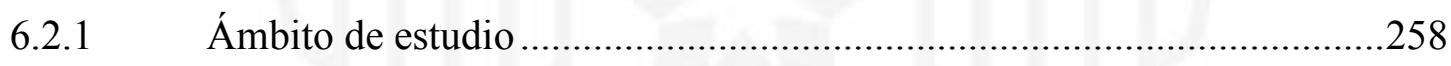

6.2.2 Análisis de componentes del paisaje local .........................................258

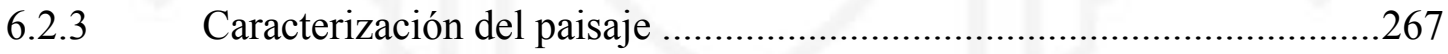

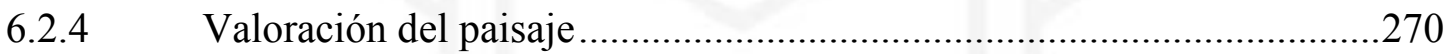

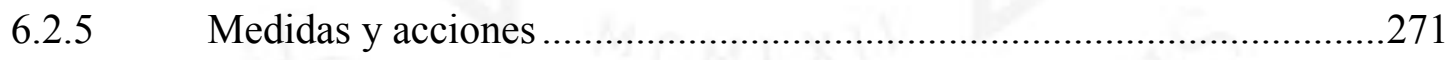

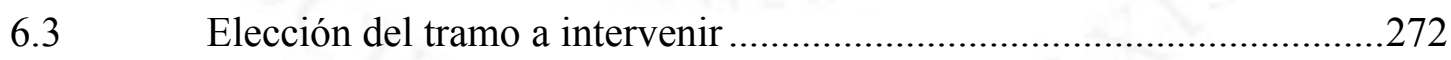

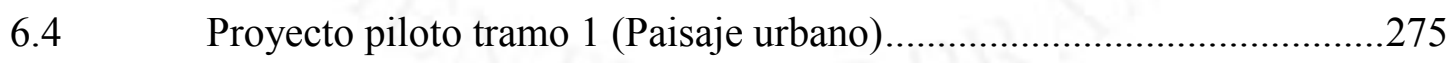

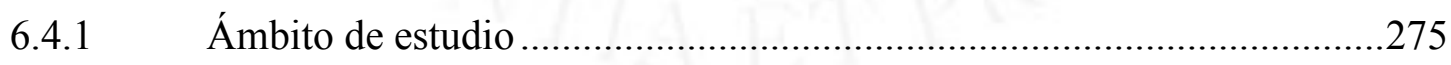

6.4.2 Análisis de componentes del paisaje urbanos....................................275

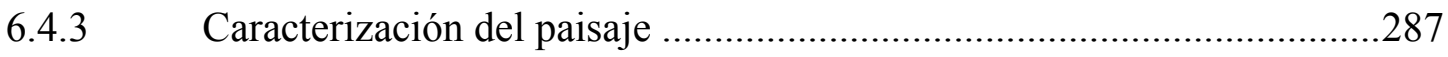

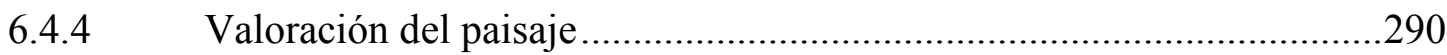

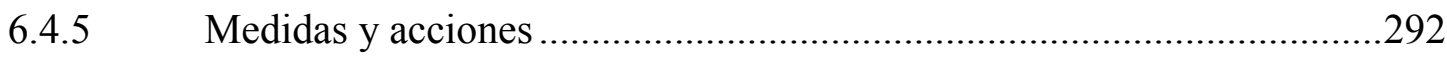

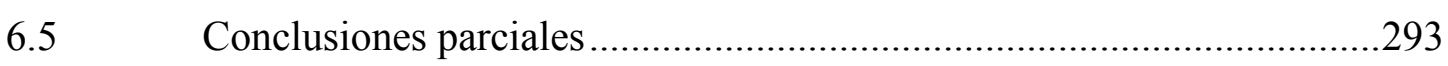

CAPÍTULO VII: CONCLUSIONES FINALES...........................................296

CAPÍTULO VIII: PROYECTO..........................................................................302 


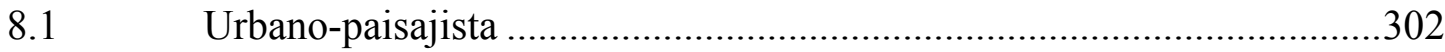

8.1.1 Parque Lineal Ribereño Shullcas ..........................................................302

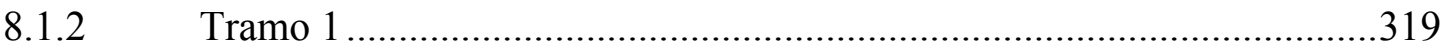

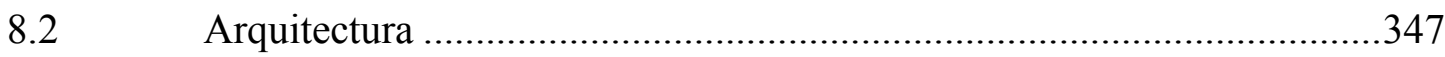

8.2.1 Centro de Interpretación del Agua (CIA) …........................................347

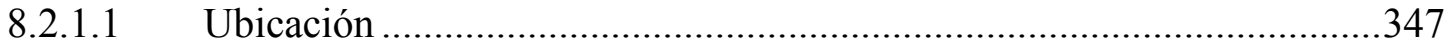

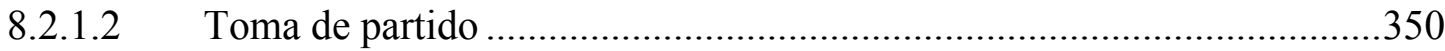

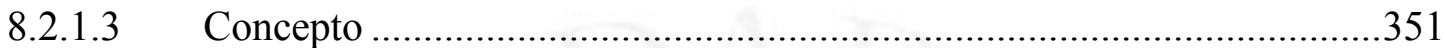

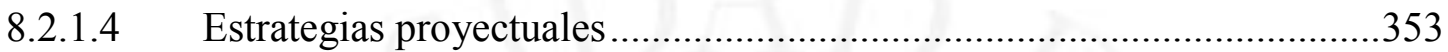

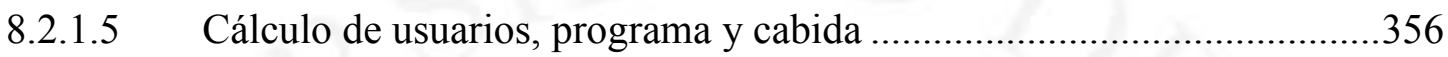

8.2.1.6 Propuesta Centro de Interpretación del Agua Huancayo .........................359

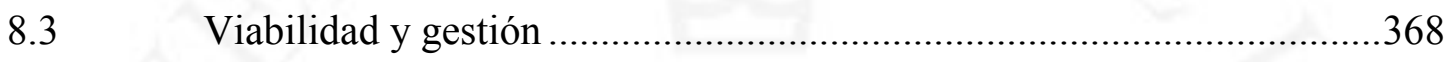

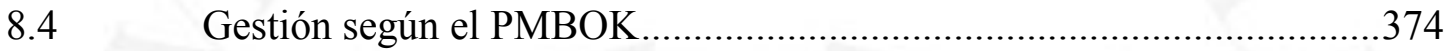

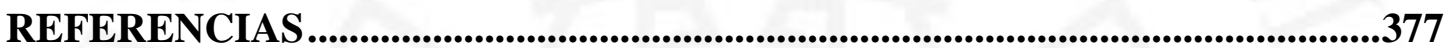




\section{ÍNDICE DE TABLAS}

Tabla 2. 1 Indicadores cuantitativos y cualitativos de proyectos de éxito en intervención urbana de ríos

Tabla 2. 2 Infraestructura de recreación pasiva ........................................................ 48

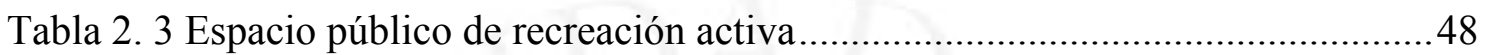

Tabla 4. 1 Tabla de recomendaciones para cada área de acción..................................134

Tabla 4. 2 Tabla de recomendaciones para cada área de acción................................... 135

Tabla 5. 1 Cuadro de objetivos del intervennciones de regeneración de bordes de río 254

Tabla 8. 1 Aplicación del Marco Teórico al diseño del Parque Lineal Ribereño Shullcas

Tabla 8. 2 Aplicación del Marco normativo y operativo al diseño de la propuesta del Parque Lineal Ribereño Shullcas 315

Tabla 8. 3 Aplicación del Marco Teórico al diseño del Plan Piloto Tramo 1 .342

Tabla 8. 4 Aplicación del Marco Teórico al diseño del Centro de Interpretación del Agua 


\section{ÍNDICE DE FIGURAS}

Figura 2. 1 Mapa de red de alcantarillado de 1900 de la ciudad de Madrid.................... 12

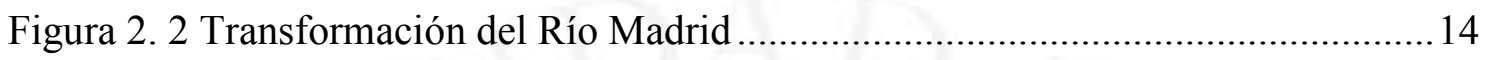

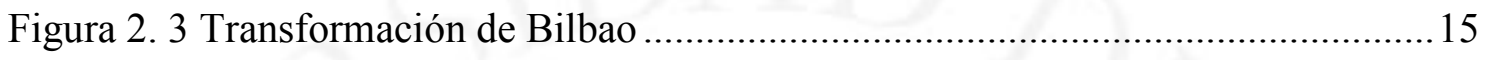

Figura 2. 4 Sectorización del Parque del Río Medellín ................................................ 17

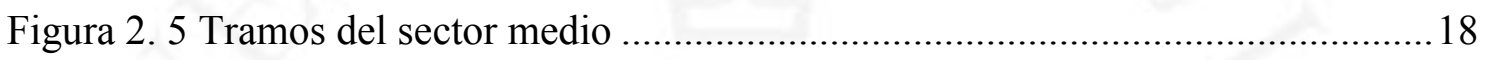

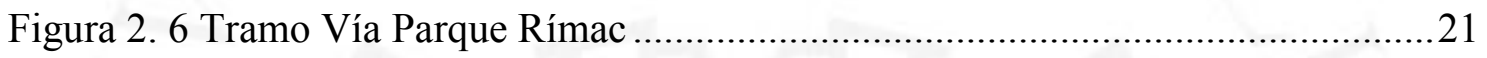

Figura 2. 7 Tramo del Proyecto Río Verde ......................................................................2 22

Figura 2. 8 Trayecto del Camino Real de los Incas, ubicación del Tambo y plaza

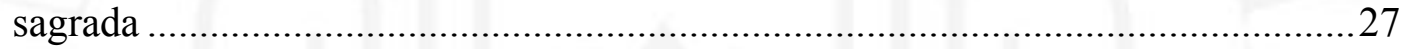

Figura 2. 9 Periodo Prehispánico: Llacta Huancayok..................................................28

Figura 2. 10 Constitución urbana del núcleo religioso en la ciudad ..............................29

Figura 2. 11 La Fundación Española: Pueblo de Indios de la Santísima Trinidad de

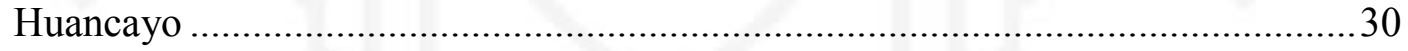

Figura 2. 12 Periodo colonial: crecimiento urbano de Huancayo (1616) ....................... 31

Figura 2. 13 Imagen de la Feria Dominical en la Calle Real ...................................... 32

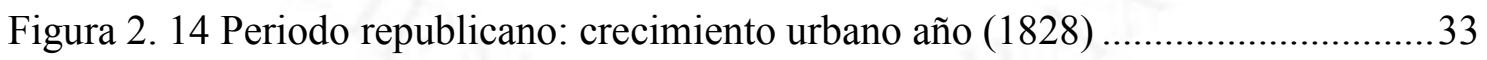

Figura 2. 15 Crecimiento de la trama urbana, aparición de vías perpendiculares a la

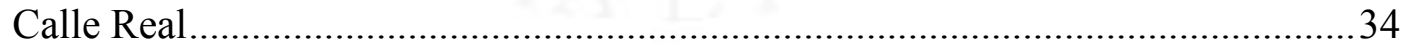

Figura 2. 16 Periodo Contemporáneo: crecimiento urbano (1908) …............................ 35

Figura 2. 17 Periodo Contemporáneo: Nuevos hitos en la trama urbana ........................36

Figura 2. 18 Periodo Contemporáneo: Expansión urbana de los distritos más grandes de

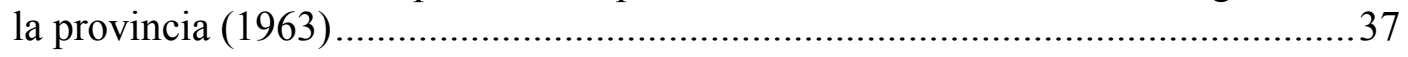

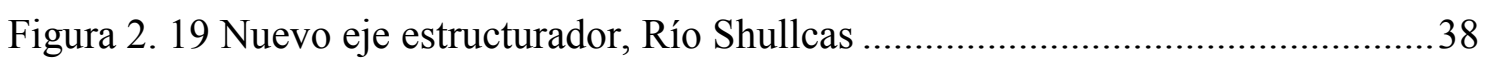


Figura 2. 20 Provincias de la Región Metropolitana de Junín 41

Figura 2. 21 Sectores de la Región Metropolitana de Huancayo.....................................42

Figura 2. 22 Mapa Hidrográfico de la subcuenca del Río Shullcas................................50

Figura 2. 23 Mapa de Cobertura vegetal de la Subcuenca del Shullcas ........................51

Figura 2. 24 Trama urbana de las márgenes del Río Shullcas ......................................53

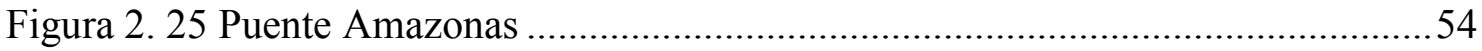

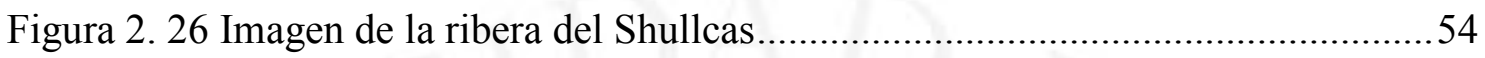

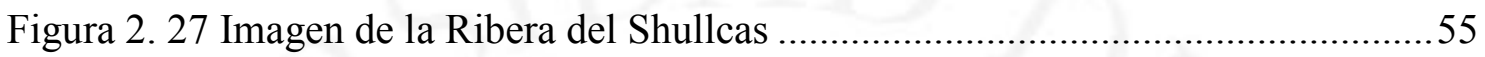

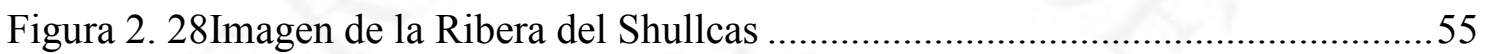

Figura 2. 29 Contaminación de residuos sólidos en la ribera del Shullcas.....................56

Figura 2. 30 Contaminación de residuos sólidos en la ribera del Shullcas.....................57

Figura 2. 31Contaminación de agua del Río Shullcas ....................................................57

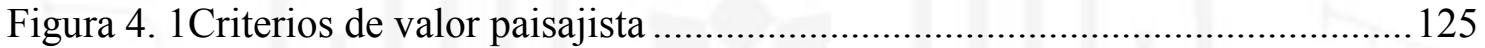

Figura 4. 2 Diagrama que presenta los pasos de gestión del espacio público ...............130

Figura 4. 3 Análisis de la vida y espacio público ..................................................... 131

Figura 4. 4 Coordinación para la creación de un plan con visión................................. 132

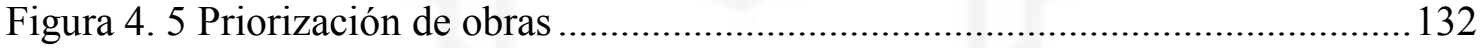

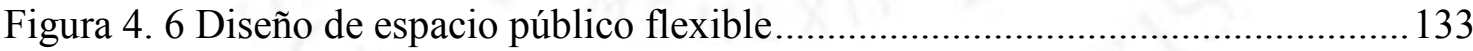

Figura 5. 1 Mapa de ubicación de proyectos análogos ............................................. 147 


\section{TABLA DE LÁMINAS}

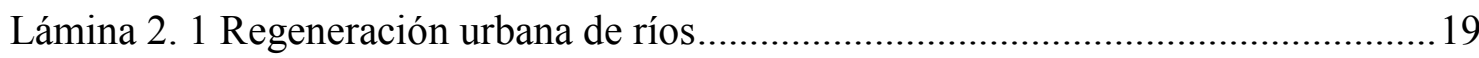

Lámina 2. 2 Historia del crecimiento urbano de Huancayo .........................................40

Lámina 2. 3 Mapa de la cuenca hidrográfica del Río Shullcas.....................................52

Lámina 2. 4 Mapa de peligros de suelos por residuos sólidos......................................58

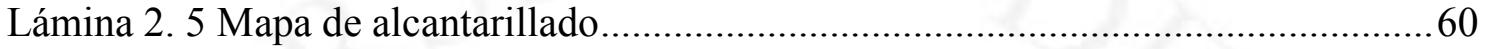

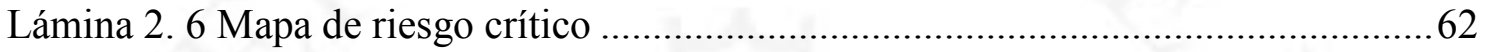

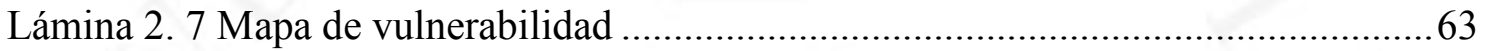

Lámina 3. 1 Revalorando la ciudad desde el paisaje .................................................. 82

Lámina 3. 2 El papel del espacio público y las áreas verde en la ciudad ......................89

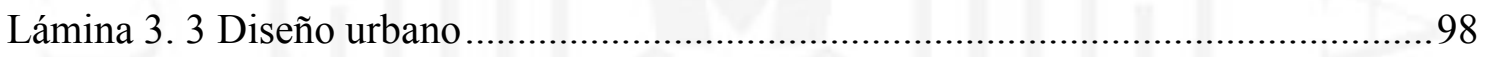

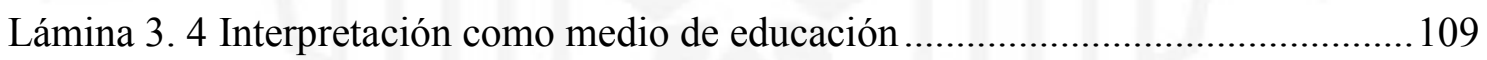

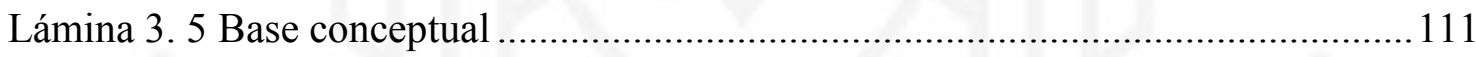

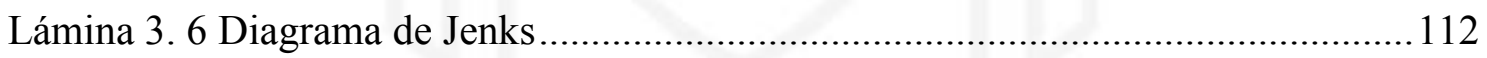




\section{TABLA DE FICHAS}

Ficha 5. 1 Regeneración urbana Río Manzanares-Ficha del proyecto ......................... 148

Ficha 5. 2 Regeneración urbana Río Manzanares - Historia ....................................... 149

Ficha 5. 3 Regeneración urbana Río Manzanares - Historia ...................................... 150

Ficha 5. 4 Regeneración urbana Río Manzanares - Historia ....................................... 151

Ficha 5. 5 Regeneración urbana Río Manzanares - Historia ...................................... 152

Ficha 5. 6 Regeneración urbana Río Manzanares - Historia ...................................... 153

Ficha 5. 7 Regeneración urbana Río Manzanares - Historia ....................................... 154

Ficha 5. 8 Regeneración urbana Río Manzanares - Historia ....................................... 155

Ficha 5. 9 Regeneración urbana Río Manzanares - Ubicación...................................... 156

Ficha 5. 10 Regeneración urbana Río Manzanares - Ubicación.....................................157

Ficha 5. 11 Regeneración urbana Río Manzanares - Ubicación...................................158

Ficha 5. 12 Regeneración urbana Río Manzanares - Ubicación................................... 159

Ficha 5. 13 Regeneración urbana Río Manzanares - Ubicación................................... 160

Ficha 5. 14 Regeneración urbana Río Manzanares - Ubicación..................................... 161

Ficha 5. 15 Regeneración urbana Río Manzanares - Programa.................................... 162

Ficha 5. 16 Regeneración urbana Río Manzanares - Programa.................................... 163

Ficha 5. 17 Regeneración urbana Río Manzanares - Programa.................................... 164

Ficha 5. 18 Regeneración urbana Río Manzanares - Programa.................................... 165

Ficha 5. 19 Regeneración urbana Río Manzanares - Programa..................................... 166

Ficha 5. 20 Regeneración urbana Río Manzanares - Espacio....................................... 167

Ficha 5. 21 Regeneración urbana Río Manzanares - Tecnología ................................. 168

Ficha 5. 22 Regeneración urbana Río Manzanares - Tecnología ................................. 169

Ficha 5. 23 Regeneración urbana Río Manzanares - Tecnología .................................170 
Ficha 5. 24 Regeneración urbana Río Manzanares - Tecnología 171

Ficha 5. 25 Regeneración urbana Río Manzanares - Impacto social............................. 172

Ficha 5. 26 Regeneración urbana Río Manzanares - Resumen .................................... 173

Ficha 5. 27 Regeneración urbana Río Cheonggyecheon - Ficha del proyecto .............. 174

Ficha 5. 28 Regeneración urbana Río Cheonggyecheon - Historia ............................... 175

Ficha 5. 29 Regeneración urbana Río Cheonggyecheon - Historia ............................... 176

Ficha 5. 30 Regeneración urbana Río Cheonggyecheon - Ubicación ............................177

Ficha 5. 31 Regeneración urbana Río Cheonggyecheon - Ubicación ............................ 178

Ficha 5. 32 Regeneración urbana Río Cheonggyecheon - Ubicación ........................... 179

Ficha 5. 33 Regeneración urbana Río Cheonggyecheon - Programa ........................... 180

Ficha 5. 34 Regeneración urbana Río Cheonggyecheon - Programa ............................ 181

Ficha 5. 35 Regeneración urbana Río Cheonggyecheon - Espacio ................................ 182

Ficha 5. 36 Regeneración urbana Río Cheonggyecheon - Impacto social ................... 183

Ficha 5. 37 Regeneración urbana Río Cheonggyecheon - Resmen .............................. 184

Ficha 5. 38 Centro Cultural y de Interpretación Jean Marie Tjibaou - Ficha del proyecto

Ficha 5. 39 Centro Cultural y de Interpretación Jean Marie Tjibaou - Historia ............ 186

Ficha 5. 40 Centro Cultural y de Interpretación Jean Marie Tjibaou - Historia ............ 187

Ficha 5. 41 Centro Cultural y de Interpretación Jean Marie Tjibaou - Historia ............ 188

Ficha 5. 42 Centro Cultural y de Interpretación Jean Marie Tjibaou - Historia ............ 189

Ficha 5. 43 Centro Cultural y de Interpretación Jean Marie Tjibaou - Ubicación ........ 190

Ficha 5. 44 Centro Cultural y de Interpretación Jean Marie Tjibaou - Ubicación ........ 191

Ficha 5. 45 Centro Cultural y de Interpretación Jean Marie Tjibaou - Programa ......... 192

Ficha 5. 46 Centro Cultural y de Interpretación Jean Marie Tjibaou - Programa ......... 193

Ficha 5. 47 Centro Cultural y de Interpretación Jean Marie Tjibaou - Programa ......... 194

Ficha 5. 48 Centro Cultural y de Interpretación Jean Marie Tjibaou - Espacio ............ 195

Ficha 5. 49 Centro Cultural y de Interpretación Jean Marie Tjibaou - Espacio ............ 196 
Ficha 5. 50 Centro Cultural y de Interpretación Jean Marie Tjibaou - Tecnología .......197

Ficha 5. 51 Centro Cultural y de Interpretación Jean Marie Tjibaou - Tecnología ....... 198

Ficha 5. 52 Centro Cultural y de Interpretación Jean Marie Tjibaou - Tecnología.......199

Ficha 5. 53 Centro Cultural y de Interpretación Jean Marie Tjibaou - Tecnología ......200

Ficha 5. 54 Centro Cultural y de Interpretación Jean Marie Tjibaou - Tecnología ......201

Ficha 5. 55 Centro Cultural y de Interpretación Jean Marie Tjibaou - Impacto social 202

Ficha 5. 56 Centro de interpretación La antigua Zumarrága- Ficha del proyecto ........203

Ficha 5. 57 Centro de interpretación La antigua Zumarrága - Historia .........................204

Ficha 5. 58 Centro de interpretación La antigua Zumarrága - Historia ........................205

Ficha 5. 59 Centro de interpretación La antigua Zumarrága - Historia ........................206

Ficha 5. 60 Centro de interpretación La antigua Zumarrága - Ubicación .....................207

Ficha 5. 61 Centro de interpretación La antigua Zumarrága - Ubicación ....................208

Ficha 5. 62 Centro de interpretación La antigua Zumarrága - Programa .....................209

Ficha 5. 63 Centro de interpretación La antigua Zumarrága - Programa .....................210

Ficha 5. 64 Centro de interpretación La antigua Zumarrága - Programa .....................211

Ficha 5. 65 Centro de interpretación La antigua Zumarrága - Espacio ........................212

Ficha 5. 66 Centro de interpretación La antigua Zumarrága - Espacio ........................213

Ficha 5. 67 Centro de interpretación La antigua Zumarrága - Tecnología....................214

Ficha 5. 68 Centro de interpretación La antigua Zumarrága - Tecnología...................215

Ficha 5. 69 Centro de interpretación La antigua Zumarrága - Tecnología...................216

Ficha 5. 70 Centro de interpretación La antigua Zumarrága - Impacto social .............217

Ficha 5. 71 Centro de interpretación de la naturaleza de Salburúa- Ficha del proyecto

Ficha 5. 72 Centro de interpretación de la naturaleza de Salburúa- Historia ...............219

Ficha 5. 73 Centro de interpretación de la naturaleza de Salburúa- Historia ...............220

Ficha 5. 74 Centro de interpretación de la naturaleza de Salburúa- Ubicación .............221

Ficha 5. 75 Centro de interpretación de la naturaleza de Salburúa- Ubicación............222 
Ficha 5. 76 Centro de interpretación de la naturaleza de Salburúa- Programa .223

Ficha 5. 77 Centro de interpretación de la naturaleza de Salburúa- Programa .224

Ficha 5. 78 Centro de interpretación de la naturaleza de Salburúa- Espacio. .225

Ficha 5. 79 Centro de interpretación de la naturaleza de Salburúa- Espacio. 226

Ficha 5. 80 Centro de interpretación de la naturaleza de Salburúa- Tecnología 227

Ficha 5. 81 Centro de interpretación de la naturaleza de Salburúa- Tecnología .228

Ficha 5. 82 Centro de interpretación de la naturaleza de Salburúa- Impacto social.....229

Ficha 5. 83 Centro de interpretación de los ríos - Ficha del Proyecto .230

Ficha 5. 84 Centro de interpretación de los ríos - Historia .231

Ficha 5. 85 Centro de interpretación de los ríos - Historia .232

Ficha 5. 86 Centro de interpretación de los ríos - Ubicación 233

Ficha 5. 87 Centro de interpretación de los ríos - Ubicación .234

Ficha 5. 88 Centro de interpretación de los ríos - Programa 235

Ficha 5. 89 Centro de interpretación de los ríos - Programa 236

Ficha 5. 90 Centro de interpretación de los ríos - Espacio 237

Ficha 5. 91 Centro de interpretación de los ríos - Espacio 238

Ficha 5. 92 Centro de interpretación de los ríos - Espacio 239

Ficha 5. 93 Centro de interpretación de los ríos - Espacio 240

Ficha 5. 94 Centro de interpretación de los ríos - Tecnología 241

Ficha 5. 95 Centro de interpretación de los ríos - Impacto social .242

Ficha 5. 96 Cuadro comparativo de Regeneración Urbana de Ríos .243

Ficha 5. 97 Cuadro comparativo de Regeneración Urbana de Ríos 244

Ficha 5. 98 Cuadro comparativo de Regeneración Urbana de Ríos 245

Ficha 5. 99 Cuadro comparativo de Regeneración Urbana de Ríos 246

Ficha 5. 100 Cuadro comparativo de Centros de Interpretación 247

Ficha 5. 101 Cuadro comparativo de Centros de Interpretación 248 
Ficha 5. 102 Cuadro comparativo de Centros de Interpretación .249

Ficha 5. 103 Cuadro comparativo de Centros de Interpretación .250

Ficha 5. 104 Cuadro comparativo de Centros de Interpretación .251

Ficha 5. 105 Cuadro resumen .252

Ficha 5. 106 Cuadro resumen .253

Ficha 8. 1 Definición del ámbito de intervención Parque Lineal Ribereño Shullcas ...303

Ficha 8. 2 Objetivos y estrategias: Conectar. .306

Ficha 8. 3 Objetivos y estrategias: Crear espacio público 307

Ficha 8. 4 Objetivos y estrategias: Tejer. 308

Ficha 8. 5 Objetivos y estrategias: Incorporar nuevo equipamiento. 309

Ficha 8. 6 Objetivos y estrategias: Recuperar patrimonio natural 310

Ficha 8. 7 Parque Lineal Ribereño Shullcas - Planta general 316

Ficha 8. 8 Parque Lineal Ribereño Shullcas - Resultado cuantitativo del equipamiento e infraestructura ecológica.

Ficha 8. 9 Parque Lineal Ribereño Shullcas -Fotomontaje 318

Ficha 8. 10 Plan Piloto Tramo 1 - Definición del ámbito de intervención 320

Ficha 8. 11 Plan Piloto Tramo 1 - Caracterización de zonas 322

Ficha 8. 12 Plan Piloto Tramo 1 - Concepto e idea 324

Ficha 8. 13 Plan Piloto Tramo 1 - Estrategias Generales y cabida 326

Ficha 8. 14 Plan Piloto Tramo 1 - Estrategias Generales 329

Ficha 8.15 Objetivos y estrategias: Movilidad y transporte 330

Ficha 8. 16 Objetivos y estrategias: Movilidad y transporte 331

Ficha 8. 17 Programa y actividades 332

Ficha 8.18 Objetivos y estrategias: Programa y actividades 333

Ficha 8.19 Objetivos y estrategias: Programa y actividades .334

Ficha 8. 20 Objetivos y estrategias: Relación transversal del programa con el río 335 
Ficha 8. 21 Objetivos y estrategias: Relación transversal del programa con el río .......336

Ficha 8. 22 Objetivos y estrategias: Pavimentos ............................................................337

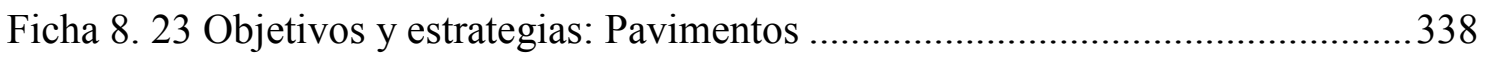

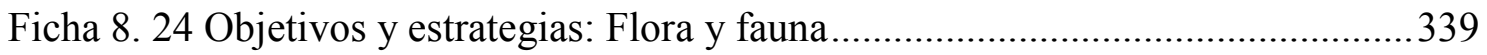

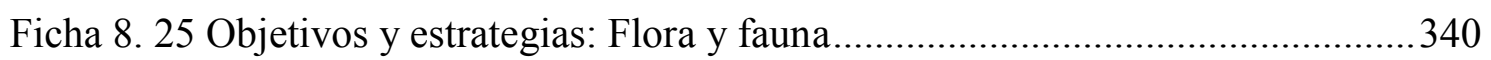

Ficha 8. 26 Plan Piloto Tramo 1 - Resultado cuantitativo de equipamiento e

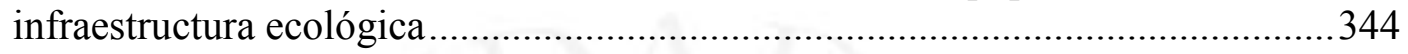

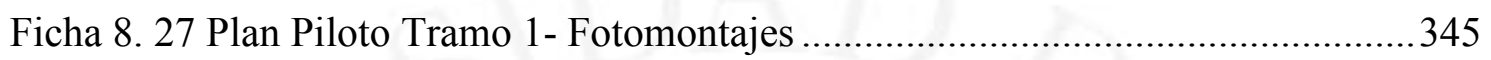

Ficha 8. 28 Plan Piloto Tramo 1 - Fotomontaje Jardín Botánico ..................................346

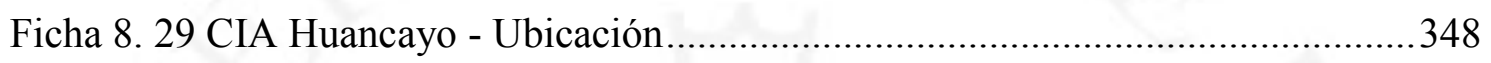

Ficha 8. 30 CIA Huancayo - Emplazamiento y su relación con la vegetación..............349

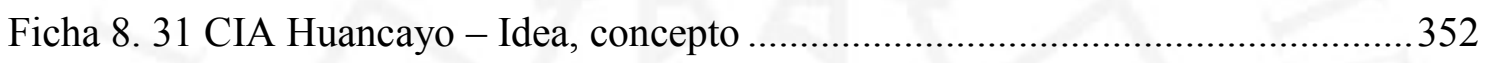

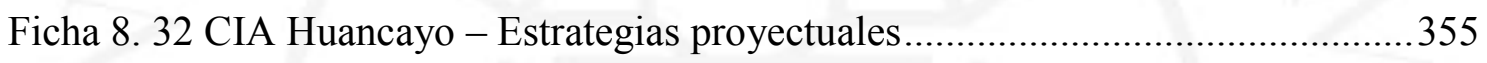

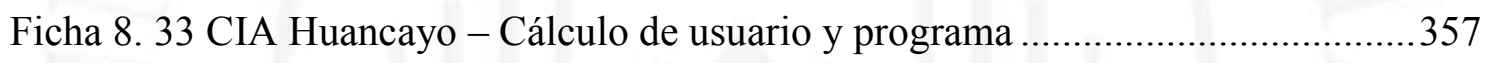

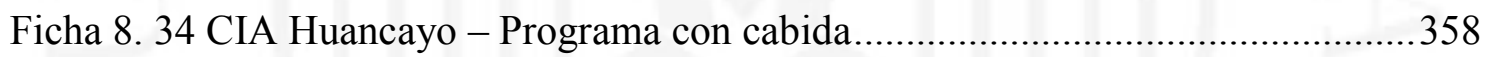

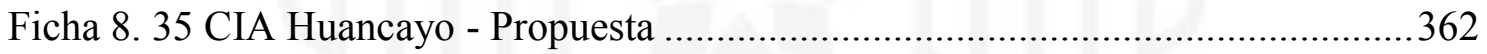

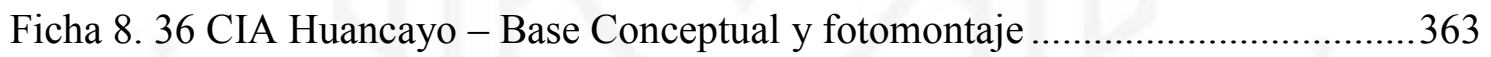

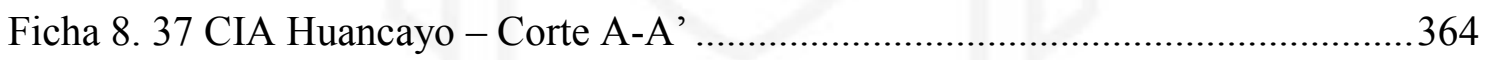

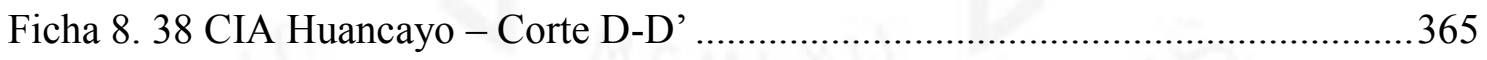

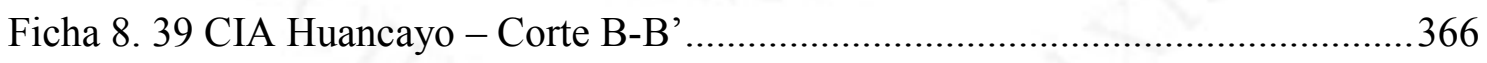

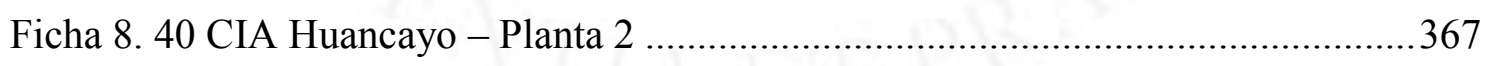

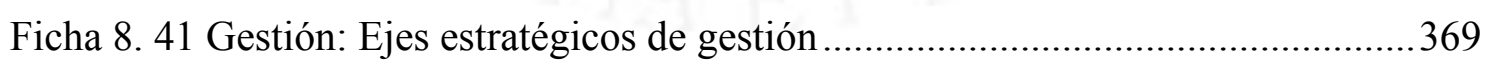

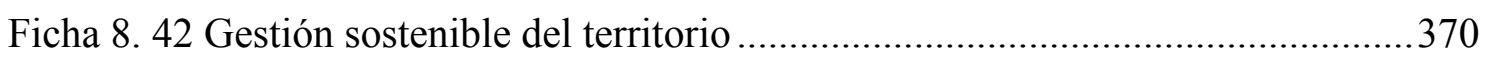

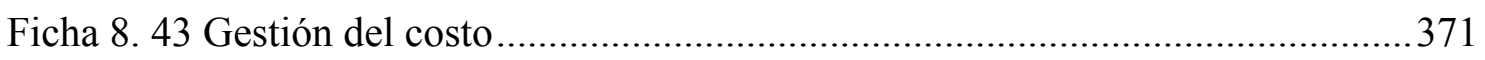

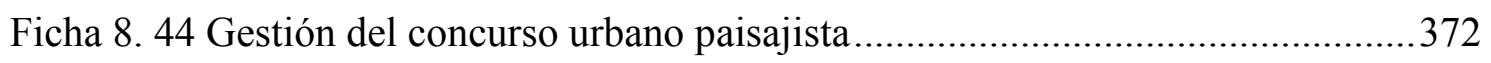

Ficha 8. 45 Gestión de los componentes del Parque Llineal Ribereño Shullcas ...........373

Ficha 8. 46 Gestión del Plan Piloto Tramo 1 según la metodología del PMBOK.........375 
Ficha 8. 47 Gestión del Plan Piloto Tramo 1 según la metodología del PMBOK.........376 


\section{RESUMEN}

El Río Shullcas se encuentra en la provincia de Huancayo departamento de Junín entre los distritos del Tambo y Huancayo. El Shullcas, al igual que los ríos que forman parte de una ciudad consolidada, en sus orígenes fue un recurso natural generador de vida y desarrollo. Sin embargo, tras la expansión demográfica se produjo el deterioro afectando el vínculo de la ribera como un espacio fragmentado con la ciudad.

Por otra parte, los asentamientos informales, la ausencia de espacio público, el equipamiento insuficiente, la pérdida de terrenos agrícolas y falta de conexiones son algunas consecuencias del crecimiento acelerado no planificado que muchas ciudades latinoamericanas padecen En el caso de Huancayo inició su crecimiento a partir del eje estructural del camino inca (Calle Real) pero, en la actualidad, el aumento poblacional ha ocasionado la transformación de la huella urbana estableciendo un nuevo eje estructurador territorial que sigue el recorrido del Río Shullcas.

Actualmente, existen casos de éxito de regeneración de ríos como El río Manzanares- España y Río Medellín-Colombia que muestran resultados positivos en la mejora de condiciones urbanas a través de la implementación de un plan maestro con enfoque integral que se preocupa por el vínculo entre el río y la ciudad retomando el sentido original ambiental y a su vez afiance el carácter cultural.

Así, se plantea la propuesta integral del Parque Lineal Ribereño a modo de Plan Maestro que interviene la ribera como un espacio de conexión, articulación, integración y activación entre lo urbano y natural incorporando espacios públicos y equipamiento como respuesta de regeneración urbana desde un enfoque urbano- paisajista desarrollando un plan piloto que sirva como proyecto de reacción inmediata, además de proponer el Centro de Interpretación del Agua como equipamiento cultural que concientice y eduque a la población sobre el cuidado del recurso natural. 


\begin{abstract}
The Shullcas River is located in the province of Huancayo department of Junín, between the districts of Tambo and Huancayo. The Shullcas, like all the rivers that are part of a consolidated city, was originally a natural resource, generating life and development. However, after the demographic expansion, deterioration occurred, affecting the riverside link, becoming a fragmented space within the city.

On the other hand, informal settlements, lack of public spaces, insufficient equipment, loss of agricultural land and lack of connections are some consequences of the unplanned accelerated growth that many Latin American cities suffer. In the case of Huancayo, its growth began from of the structural axis of the Inca Trail (Calle Real) but, nowadays, population increase has caused the transformation of the urban footprint by establishing a new territorial structuring axis that follows the Shullcas River route.

Currently, there are cases of successful regeneration of rivers such as the Manzanares River- Spain and the Medellín-Colombia River, that shows positive results in the improvement of urban conditions through the implementation of a master plan with a comprehensive approach that worries about the link between the river and the city, retaking the original environmental sense and in turn fortifies the cultural character.

Thereby, a integral proposal of the Ribereño Linear Park is brought forward as a Master Plan that intervenes the riverbank as a space of connection, articulation, integration and activation between the urban and natural incorporating public spaces and equipment in response to urban regeneration from an urban-landscape approach, developing a pilot plan that serves as an immediate reaction project, in addition to proposing the Water Interpretation Center as cultural equipment that will raise awareness and educate the population about the care of this natural resource.
\end{abstract}




\section{INTRODUCCIÓN}

«Pero es necesario hoy no solo construir la ciudad, sino además construir un paisaje resultante del respeto entre lo natural y lo cultural. Para eso, los pueblos del Mantaro, y en especial Huancayo, deberán volver la mirada hacia sí mismos y reconciliarse con su hermoso valle, que dicen es el valle interandino más grande del Perú. Ojalá lo sea para siempre.»

-Enrique Bonilla Di Tolla, 2010

El asentamiento de las primeras civilizaciones ha estado relacionado a la presencia de un río, el cual se usaba como elemento sustentador de vida, medio de comunicación y desarrollo. Por ello territorialmente la ciudad y el río son indisolubles. En la historia occidental la relación se observa en las civilizaciones de Egipto con el Río Nilo y el de Mesopotamia con el Río Éufrates. Del mismo modo, el Perú no es ajeno a esta relación dado que los ríos son los ejes organizadores del territorio que delimitan los valles en las cordilleras. Civilizaciones prehispánicas como los Huari, Chancas Huancas e Incas demuestran el vínculo existente.

Con el desarrollo económico, las ciudades han ido expandiéndose generando transformaciones urbanas a largo plazo que han afectado el vínculo entre el río y la ciudad. Los asentamientos informales, la ausencia de espacio público, el equipamiento insuficiente, pérdida de terrenos agrícolas y falta de conexiones son el resultado del crecimiento acelerado no planificado. Esto mismo ha ocurrido en la provincia Huancayo, la cual se asienta en la margen derecha de la cuenca del Mantaro (principal afluente del Valle). Asimismo, la provincia está conformada por 28 distritos siendo los principales El Tambo y Huancayo. Ambos se ubican contiguos a la ribera del Río Shullcas. 
En la actualidad, múltiples proyectos y planes, demuestran que existe una preocupación por reintegrar el río a la ciudad desde un enfoque urbano paisajista, que retome el sentido original ambiental y otorgue un nuevo sentido cultural. Existen casos de éxito de regeneración de ríos como El río Manzanares- España, Río Nervión- España y Río Medellín-Colombia que demuestran resultados positivos que mejoran las condiciones urbanas a través de la implementación de planes maestros.

Al igual que diversas ciudades en el mundo, Huancayo ha sufrido un crecimiento acerado en los últimos años. A pesar que la ciudad inició su desarrollo en el siglo XIX a partir del eje estructural del camino inca (Calle Real) con 10,000 habitantes, en la actualidad, el aumento poblacional, ha ocasionado el incremento de la huella urbana trasversalmente al eje original creando un nuevo eje estructurador que sigue el recorrido del Río Shullcas. Hoy Huancayo cuenta con 503139 habitantes.

La presente tesis realizará un Parque Lineal Ribereño a modo de Plan Maestro que surge como respuesta a la problemática mencionada anteriormente. El interés es investigar la manera en cómo se puede transformar y hacer uso de los espacios abiertos ligados al río con un enfoque urbano paisajista que otorgue a la ciudad nuevas oportunidades para la creación de proyectos recreativos, culturales, deportivos, etc. Asimismo, como proyecto piloto se propone un Centro de Interpretación del Agua con la finalidad de ser una herramienta educativa que sirva para la capacitación de la población de Huancayo sobre el cuidado del recurso. 


\section{CAPÍTULO I: GENERALIDADES}

\subsection{Tema}

Se desarrollará el diseño de un Parque Lineal Ribereño a modo de plan maestro, como proyecto paisajístico de regeneración urbana en la ribera del Río Shullcas en la Provincia de Huancayo, departamento de Junín.

La investigación pondrá en evidencia las oportunidades que existen en dichos espacios para la intervención con proyectos de escala intermedia como la del Parque Lineal Ribereño Shullcas y proyectos puntuales como un Centro de Interpretación del Agua.

Ambos proyectos de carácter público-privado tienen como objetivo crear un eje paisajista nuevo en la ciudad incorporando espacios públicos abiertos, equipamientos culturales, deportivos y recreativos con la finalidad de revalorar el patrimonio natural de la zona, contribuir a que el río no sea una barrera urbana e integrar y recuperar los bordes degradados o poco definidos.

El estudio desarrollará con mayor detalle el Plan Maestro del Parque Lineal Ribereño Shullcas y concluirá con la propuesta arquitectónica a nivel de anteproyecto del Centro de Interpretación del Agua, como un espacio que busca educar y concientizar a la población sobre el cuidado del recurso, el río y la naturaleza en la ciudad que es el generador de identidad usando como herramienta la interpretación.

\subsection{Justificación del tema}

La ciudad de Huancayo, capital de Junín, concentra principalmente la producción de agua potable, considerando al Río Shullcas como el único abastecedor para dicha producción. Así lo indica el Informe de Diagnostico Hidrológico Rápido de la Subcuenca del Río Shullcas, elaborado por Consorcio para el Desarrollo Sostenible de la Ecorregión Andina(2015) al indicar que la captación número 24, ubicada en la zona media de la microcuenca del Río Shullcas, es la abastecedora de agua de la ciudad. 
Sin embargo, pese a la importancia del río, se ha visto afectado principalmente por la contaminación del agua y la ribera, debido al crecimiento urbano no planificado, la explotación del recurso y falta de educación de la población. Desde un enfoque urbano, el crecimiento no planificado de la ciudad ha ocasionado el asentamiento de viviendas al borde del río, la disminución del cauce natural, la característica de ser una barrera entre los distritos del Tambo y Huancayo y la condición de haberse convertido en un paisaje degradado y subutilizado.

A partir de lo mencionado, el Río Shullcas se ha convertido en el nuevo eje estructural de la ciudad con una extensión aproximada de $10.35 \mathrm{~km}$. carece de características de un eje estructural ejemplar debido a la falta de espacio público, vías conectoras y equipamiento necesario que permitan la articulación.

A continuación, se mencionará los principales problemas urbanos en Huancayo que nos servirán de base para la propuesta del Parque Lineal Ribereño Shullcas.

- $\quad$ Falta de espacio público: Huancayo se compone por área recreativa pasiva y activa. El área recreativa pasiva está conformada por parques y plazas que contabilizan un área mínima $1.5 \mathrm{~m}^{2}$ por habitante, ubicando esta cifra por debajo de lo establecido por la Organización Mundial de la Salud que corresponde a $9 \mathrm{~m}^{2}$ por habitante. Mientras, el área recreativa activa está compuesto por áreas destinadas al deporte que contabilizan un área mínima de $1.6 \mathrm{~m}^{2}$ por habitante, siendo los estándares internacionales de $10 \mathrm{~m} 2 \mathrm{de}$ área deportiva por habitante, para la recreación y practica de algún deporte. (Municipalidad Provincial de Huancayo, 2014)

- Fragmentación urbana: Huancayo es una ciudad desarticulada debido a la condición del Río Shullcas como borde natural que divide a los distritos del Tambo y Huancayo. Cuenta con 7 puentes vehiculares a lo largo del recorrido que van acompañados de una sección peatonal muy angosta ( $2 \mathrm{~m}$ lineales) no amigable, ni segura.

- $\quad$ Falta de equipamiento cultural: Conformado principalmente por servicio recreativo, salud, cultural, comercio y educación. El mayor porcentaje corresponde al comercio con $50.2 \%$ a diferencia de la infraestructura cultural con $2.2 \%$; salud $3.3 \%$ y recreativo $11.2 \%$. para una población de 503,139 habitantes 
Los argumentos expuestos justifican la necesidad de intervenir los bordes del Río Shullcas como un espacio de conexión, articulación y activación entre lo urbano y natural con el diseño de un Parque Lineal que incorpore con múltiples espacios públicos, nuevo equipamiento y revalore el patrimonio natural.

El Plan Maestro del Parque Ribereño Shullcas propone contribuir a la solución de los problemas urbanos de conexión, por medio de un sistema de transporte integrado; la falta de espacios públicos, con un conjunto de parques, plazas y áreas de deporte; articulación de la ciudad, a través de corredores verdes; creación de nuevo equipamiento (comercial, cultural, recreativo y ecológico), como aporte al incremento de servicio; y la recuperación del patrimonio natural, por medio de la inserción de flora y fauna nativa del valle que acompaña en el desarrollo.

La propuesta se complementa con el desarrollo del diseño de un centro de interpretación que aporta al incremento de equipamiento cultural faltante. El centro busca contribuir a la educación ambiental y cuidado del río.

\subsection{Planteamiento del problema}

\subsubsection{Problema general.}

En la base la justificación se plantea la siguiente pregunta:

¿Hasta qué punto, a través del uso de herramientas urbanísticas y arquitectónicas, el diseño de un Parque Lineal Ribereño y un Centro de Interpretación del Agua contribuirán a la regeneración urbana de los bordes del río y mejorar la relación con la ciudad?

\subsubsection{Problemas específicos}

- ¿Es posible que un proyecto de espacio público a escala urbana logre regenerar los bordes del Río Shullcas y evitar que siga siendo una barrera urbana para la ciudad de Huancayo? 
- ¿Hasta qué nivel puede contribuir el diseño de una red de equipamientos públicos, educativos, culturales, deportivos, ambientales y comerciales a mejorar la relación de la ciudad y sus habitantes con el Río Shullcas?

- ¿Qué incidencia puede tener el diseño de un Centro de Interpretación del Agua (CIA) como proyecto piloto dentro del Parque Lineal Ribereño Shullcas?

\subsection{Objetivos de la investigación}

\subsubsection{Objetivo general}

Elaborar una propuesta de parque lineal ribereño, a modo de Plan Maestro, para la regeneración urbana de los bordes del Río Shullcas identificando posibles espacios potenciales para proyectos de equipamiento urbano, movilidad sostenible, nuevos espacios públicos que recupere los valores perdidos del paisaje natural. Además de desarrollar el Centro de Interpretación del Agua como proyecto piloto de equipamiento cultural para concientizar y educar a la población sobre el cuidado del recurso natural.

\subsubsection{Objetivos específicos}

- Indicar los diferentes cambios que ha tenido la ciudad de Huancayo a través del tiempo en la ribera del río Shullcas a fin de identificar la problemática.

- Relacionar términos, conceptos y teorías de intervenciones urbanas de carácter paisajista en bordes de río en el mundo para determinar un tipo de metodología de diseño.

- Analizar diferentes ejemplos de éxito relacionados a la regeneración urbana de ríos como los proyectos del Río Manzanares, Río Nervión y Río Medellín. Así también estudiar la manera cómo un equipamiento cultural (centro de interpretación) puede mejorar las condiciones sociales y medioambientales de una ciudad por medio de referentes. 


\subsection{Supuesto básico de investigación}

Como supuesto básico de la investigación se dice lo siguiente: Si se plantea una intervención integral a modo de Plan Maestro que integre aspectos relacionados al paisaje, espacio público, movilidad y equipamientos urbanos, el proyecto podría tener un impacto en la regeneración urbana del Río Shullcas mejorando sus condiciones medioambientales, sociales, culturales y su relación con la ciudad de Huancayo.

\subsection{Alcances y limitaciones}

\subsubsection{Alcance de la investigación}

- La investigación se desarrollará en la ciudad de Huancayo, departamento de Junín, delimitándose específicamente en la ribera del Río Shullcas.

- Se estudiará las conexiones transversales a lo largo del río para proponer un sistema integral de movilidad de acuerdo a las dinámicas urbanas que articulen la ciudad.

- Se investigará la historia de la ciudad de Huancayo desde la fundación hasta la actualidad para identificar el proceso de expansión urbana.

- En el presente proyecto no se propone o se plantea un plan de descontaminación del río dado que se sitúa en el supuesto de que el agua del Río Shullcas se encuentra en proceso de descontaminación de acuerdo a lo estipulado por el Plan Maestro Optimizado (PMO) a cargo de la Municipalidad Provincial de Huancayo y Servicio de Alcantarillado Municipal Huancayo.

\subsubsection{Limitaciones de la investigación}

- La investigación se basará en censos existentes del Instituto de Estadística e Informática, Ministerio del Ambiente y Autoridad Nacional del Agua.

- Debido a la falta de material físico en la investigación, se recurrirá al uso de datos académicos de Concytec, Alicia y ScienceDirect. 


\subsubsection{Alcances del proyecto}

- El proyecto se establecerá en la subcuenca del Río Shullcas cerca a la intersección del Río Mantaro y Shullcas, distrito de Huancayo, departamento de Junín.

- Se desarrollará un anteproyecto urbano-paisajista y arquitectónico con planos en diversas escalas que tome en cuenta los temas de funcionalidad, espacialidad, aspectos climáticos, huella ecológica y entorno urbano.

- El proyecto se realizará considerando los lineamientos de los reglamentos de La Autoridad Nacional del Agua, parámetros urbanos y Reglamento Nacional de Edificaciones vigente.

- La presente investigación utilizará teorías relacionadas al diseño urbano, paisaje, espacio público, museología y centro de interpretación.

- No se desarrollará un presupuesto de obra detallado, ni fases de construcción debido a la escala del proyecto.

- No se desarrollará Directrices de normativa y parámetros de intervención urbana relacionado al suelo y regularización de densidades, alturas $y$ volúmenes, tipologías arquitectónicas y empleo de materiales, texturas y colores correspondientes al paisaje

\subsubsection{Limitaciones del proyecto}

- Por la envergadura del proyecto y el tiempo disponible, no se realizará un estudio de suelos, impacto ambiental y vial.

- No se desarrollará actividades relacionadas al diseño participativo debido a la escala del proyecto. Para información relevante se utilizará el Plan de Desarrollo de Huancayo 2015-2025.

\subsection{Diseño de la investigación}

El tipo de estudio en el que se basa esta investigación es de carácter explicativo, ya que se analizarán referentes para comparar y poder establecer el impacto que cada proyecto tiene en su entorno utilizando, como fuentes primarias (informes, proyecto de desarrollo urbano y referentes proyectuales); asimismo, se utilizarán fuentes secundarias de carácter cuantitativo (Instituto Nacional de Estadística e Informática, Autoridad Nacional del 
Agua y Ministerio del Ambiente) para conocer los aspectos demográficos de la población; la normativa relacionado a las fajas marginales ; y aspectos medioambientales.

\subsection{Metodología de la investigación}

\subsubsection{Formato de consulta y recopilación de la información}

- La metodología de recolección de información será a través de informes, tesis, registros, libros, base de dato electrónica, científica y gráfica que aportarán datos teóricos, condiciones actuales, problemas de la ciudad, población, etc. Además, se utilizará fuentes como artículos de revistas, periódicos y censos nacionales.

- Se realizará visitas al lugar y su entorno para obtener información a través de la observación.

- Se realizará un levantamiento topográfico con dron del terreno y entorno inmediato del proyecto piloto del Centro de Interpretación del Agua.

\subsubsection{Forma de análisis de la información}

El método de análisis de la investigación se realizará por medio de mapeos, gráficos comparativos, porcentuales, líneas del tiempo, cuadros, registro fotográfico para el análisis respectivo.

\subsubsection{Forma de presentación de la información}

- La información teórica se presentará por escrito en una monografía estructurada por capítulos y detallada en un índice de temas, figuras, láminas, diagramas y tablas. Se presentará gráficos de análisis de la ciudad de elaboración propia. Finalmente se incluirán las referencias utilizadas en la investigación mediante la citación bibliográfica de estilo APA.

- La información del Proyecto urbano-paisajista y arquitectónico se presentará en un dossier conformado por cuatro capítulos: Parque Lineal Ribereño Shullcas, Tramo 1, Centro de Interpretación del Agua y gestión. El documento presentará gráficos de análisis y planimetría de propuesta. 


\section{CAPÍTULO II: MARCO REFERENCIAL}

\subsection{Intervenciones urbanas en borde de río en el mundo}

\subsubsection{Relación histórica de la ciudad y el río}

Desde los inicios de la civilización, el río ha cumplido un papel importante en el desarrollo de la agricultura y el crecimiento de población. Los primeros asentamientos humanos se establecieron en zonas estratégicas en donde los recursos naturales del entorno eran primordiales. La relación río y ciudad se estableció de manera simultánea tomando al río como un elemento productivo que abastecía y proporcionaba vida a la ciudad. (Gavidia, 2002)

Sin embargo, con el trascurrir de los años, el crecimiento urbano, en muchas ciudades en el mundo ha causado que el río se convierta en depósitos de basura y en la desembocadura de desagües causando riesgo para la población.

Ante este hecho, como medio de solución, se realizó el entubamiento1 de los ríos con la finalidad de expulsar las aguas servidas hacia las afueras de la ciudad. Años más tarde la idea del río como obstáculo cambió y se concientizó sobre los efectos de la contaminación y la necesidad de preservación de los recursos para la supervivencia humana (Gonzáles, Hernández, Perló, \& Zamora, 2010).

De este modo, con el transcurrir de los años, se puede notar que los ríos han cumplido diferentes roles en la ciudad. Pasando como suministradores de recursos hasta en depósitos de desechos, en donde la ciudad no se vincula y no forma parte de ella.

No obstante, la nueva mirada hacia los ríos y la relación con la ciudad es de poder transfórmalos en un nuevo paisaje cultural y poder reconciliar con el entorno generando un modelo en el que el río sea un elemento dinamizador que sea parte de la ciudad.

\footnotetext{
${ }^{1}$ Entubamiento, acción de encausar el río mediante tubos enterrados
} 


\subsubsection{Casos de éxito de intervenciones urbanas en bordes de río}

En las intervenciones de regeneración de ríos existen diferentes modos de afrontar el problema, los cuales se clasifican en estrategias territoriales y arquitectónicas. Las estrategias territoriales comprenden las propuestas de parques o corredores verdes lineales en la zona de las riberas; y con respecto a las arquitectónicas, estas son puntuales, construcciones de puentes, plazas, edificaciones, equipamientos, etc. implantadas al borde de los ríos. (de la Cal y Pellicer, 2002)

La necesidad de resolver los problemas de fragmentación urbana, deterioro y desuso de las riberas ha propiciado el planteamiento de distintas estrategias que garanticen la integración, revalorización cultural y medio ambiental del río y el entorno inmediato A continuación, se describirá ejemplos emblemáticos de intervenciones urbanas que reúnen dichas características como lo son el caso del Río Manzanares, Río Nervión de Bilbao y Río Medellín. Dichos proyectos a escala urbana han cambiado o están en proceso de cambio de las condiciones urbano-paisajista de los ríos y el entorno inmediato.

\subsubsection{Río Manzanares, España}

El Río Manzanares ubicado en Madrid-España, posee un recorrido de $92 \mathrm{~km}$ que atraviesa varios distritos de la ciudad. Durante el periodo del siglo XIX, el casco urbano aún no se extendía a las orillas del río y era considerado periferia de Madrid. En aquellos tiempos, la relación existente entre Madrid y el Río Manzanares era de un vertedero de aguas residuales de modo que para el año 1900 existía un total de 6 alcantarillas que finalizaban en el río. (Pinto, Gili, \& Velasco, 2015)

Para esos años, el Río Manzanares se había convertido en la cloaca de los residuos de la capital, sus aguas siempre negras manifestaban un deterioro alarmante. Así se aprecia en el mapa de red de alcantarillado de 1900 de la ciudad de Madrid. 
Figura 2. 1 Mapa de red de alcantarillado de 1900 de la ciudad de Madrid.

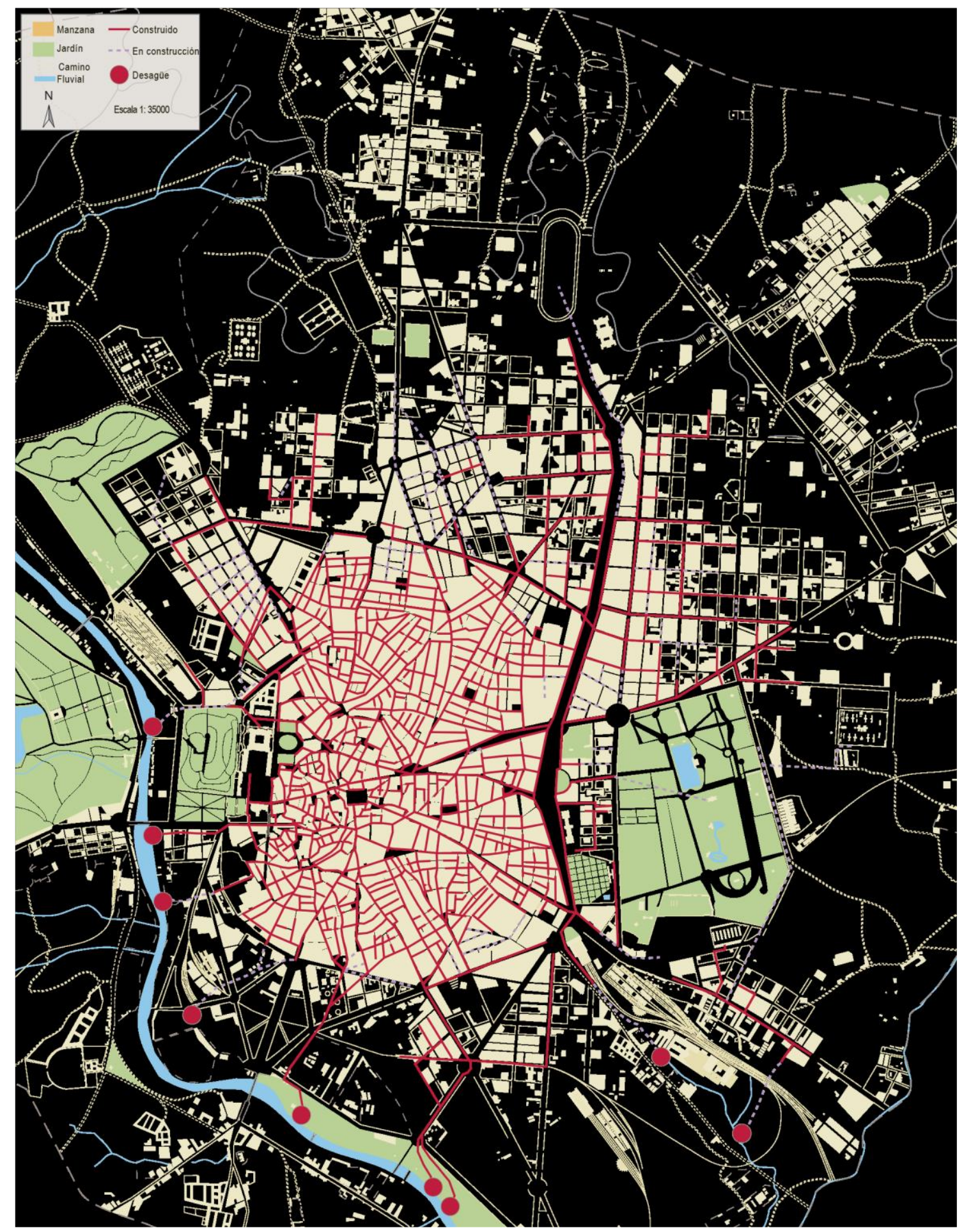

Fuente: Comunidad Madrid

http://www.madrid.org/bvirtual/BVCM019290.pdf 
No obstante, existía preocupación de las autoridades por el problema de higiene a causa del alcantarillado. Las primeras acciones de saneamiento fueron la depuración de las aguas residuales vertidas al río y el encausamiento de este. En 1914 se realizó las primeras obras de canalización, pero no fue hasta 1925 que se concluyó el primer tramo y en 1948 se retomó la siguiente sección concluyendo en 1974. Por otra parte, la primera estación depuradora de aguas residuales ubicada en el barrio la China al margen izquierdo se encontraba concluida en 1950 y posteriormente, en 1980 la ciudad contaba con 7 depuradoras (Pinto, Gili, \& Velasco, 2015).

Los intentos y acciones por la recuperación del Río Manzanares desde un aspecto de salubridad pública empezaron a notarse; sin embargo, la idea de entender el borde del río como un escenario urbano integrado a la ciudad aún no era contemplado.

En los años 1970 se estableció un cambio para la ciudad y el río a partir de la construcción de la autopista M-30. El recorrido de la autopista evitaba el paso al casco urbano y bordeaba el Río Manzanares, de modo que obstaculizaba la relación de los ciudadanos con el río, además de mencionar la contaminación causada por los autos. Posteriormente, ante los problemas de contaminación y de fragmentación de la ciudad, entre el 2003 y 2007 se realizó el soterramiento del tramo Oeste de la vía M-30 causando, la eliminación del tráfico y la liberación de aproximadamente de 150 hectáreas correspondientes a la autopista y zonas aledañas a ella (Ayuntamiento de Madrid, 2010)

La medida dio la posibilidad de ver a la ciudad de Madrid y al río como una unidad, aprovechando el área desocupada por la vía a partir de la construcción de un parque urbano. De este modo, integrando la ciudad por medio de la implementación de estrategias a diferentes escalas (territorial, metropolitana, urbana y local) que como resultado logran conectar, incrementar áreas verdes y recuperar del paisaje del río (Ayuntamiento de Madrid, 2010)

Actualmente, tras la propuesta y gestiones realizadas en la regeneración del Río Manzanares, se puede señalar que las intervenciones elaboradas proponen el reencuentro de la población con su entorno inmediato con una nueva imagen hacia la ribera y el río, en donde se promueve espacios de interacción y de confluencia para la puesta en valor del patrimonio del lugar, a partir de los diferentes lineamientos sostenibles planteados. 

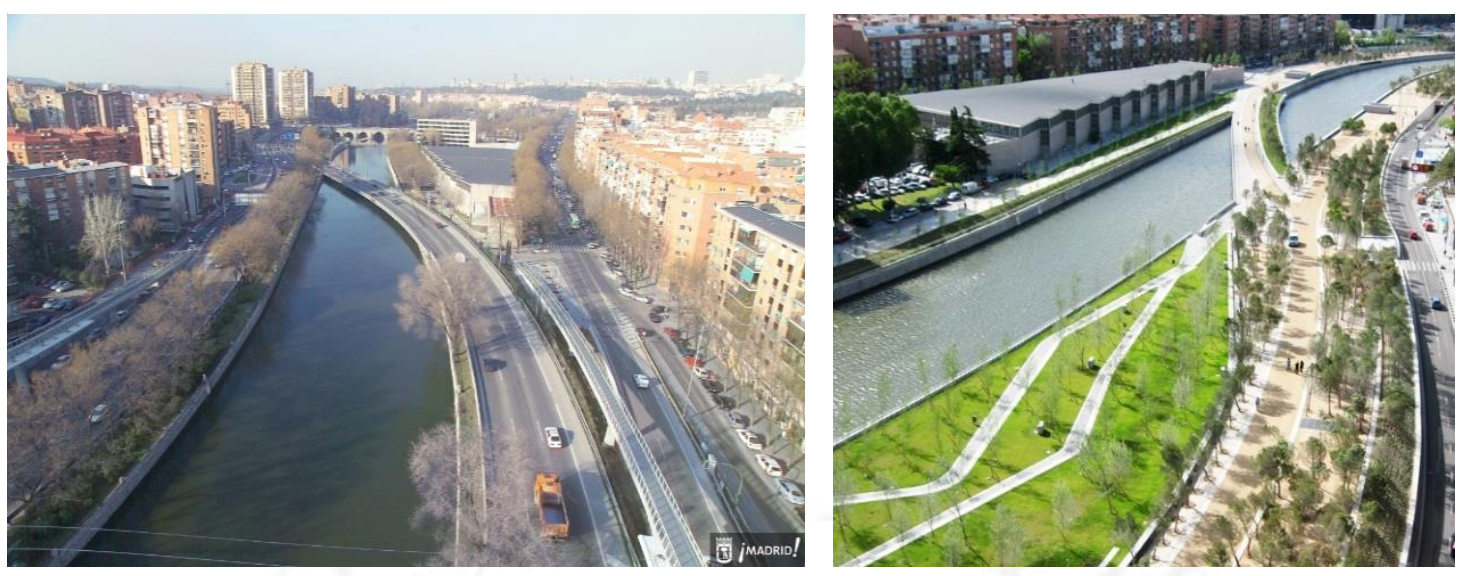

Nota: Puente Oblicuo en el 2005 y 2011

Fuente: Ayuntamiento de Madrid

https://www.madrid.es/portales/munimadrid/es/Inicio/Vivienda-y-urbanismo/Urbanismo/Madrid-RioEspecial-

Informativo/?vgnextfmt=default\&vgnextoid=5acc7f0917 afc $110 \mathrm{VgnVCM} 2000000 \mathrm{c} 205 \mathrm{a} 0 \mathrm{aRCRD} \& \mathrm{vgne}$ xtchannel=2af331d3b28fe410VgnVCM1000000b205a0aRCRD\&page $=0 \&$ idCapitulo $=5879501$

\subsubsection{Río Nervión, España}

La ciudad de Bilbao se encuentra en la cuenca de Nervión al Norte de España. Desde 1511 fue considerada como una villa mercantil y posteriormente a finales del siglo XIX se consolidó como ciudad industrial. El carácter de la metrópolis en sus inicios fue portuario. Se establecieron industrias, fundiciones y todo tipo de manufacturas de barcos en la ribera convirtiéndose en la principal actividad productiva de la ciudad. Sin embargo, actualmente es uno de los lugares más emblemáticos en todo el mundo debido a la transformación urbana realizada (Otaola, 2000).

A inicios de los años 80, Bilbao sufrió una fuerte crisis económica tras la caída del petróleo. La situación de la ribera era lamentable a causa del abandono de las plantas. La trama discontinua y desconectada de un margen con el otro daba una imagen urbana deteriorada y con serios problemas de contaminación (Otaola, 2000).

A partir de la nueva realidad que atravesaba la ciudad, se implementaron propuestas de recuperación y rehabilitación de las riberas de río y todo el sector urbano. A continuación, se procederá a explicar los planes y proyectos que ayudó a Bilbao a ser una de las ciudades más visitadas en el mundo. 
Las primeras acciones que propiciaron el cambio estructural en la ciudad fue la proyección del Plan Urbano Metrópoli -30 bajo la gestión de la sociedad Bilbao Ría 2000. El plan plantea cuatro ejes de actuación que buscan la recuperación de la ciudad desde un enfoque urbano, ambiental y socioeconómico. Los puntos planteados fueron la accesibilidad integral, regeneración medioambiental y urbana; inversión de recursos humanos y centralidad cultural. Estos lineamientos se reflejan con la rehabilitación de las áreas ribereñas sin uso para la proyección de parques, galerías, áreas de recreación, residenciales y oficinas (Otaola, 2000).

Las obras más representativas sobre la ciudad han sido los proyectos del Metro de Bilbao del arquitecto Norman Foster, El terminal del aeropuesto de Sondika, diseñado Santiago Calatarava; el Palacio del Congreso y de la Música, por el arquitecto Soriano; y el El Museo Guggenheim, por Frank Gehry.Asimismo, se estableció el Plan Integral de Saneamiento de aguas residuales y nuevos accesos y conecciones dentro y fuera de la ciudad.(Otaola, 2000).

Con la recuperación de áreas en abandono y la implementación de los nuevos planes urbanos se entiende que la ciudad de Bilbao buscó reinventarse cambiando el carácter de ciudad portuaria a una ciudad turística-cultural resolviendo conflictos urbanos. Posteriormente, dándose a conocer al mundo a través de una intensiva campaña de marketing urbano utilizando al Guggenheim como hito urbano representativo de la ciudad que alcanzo impacto internacional

Figura 2. 3 Transformación de Bilbao
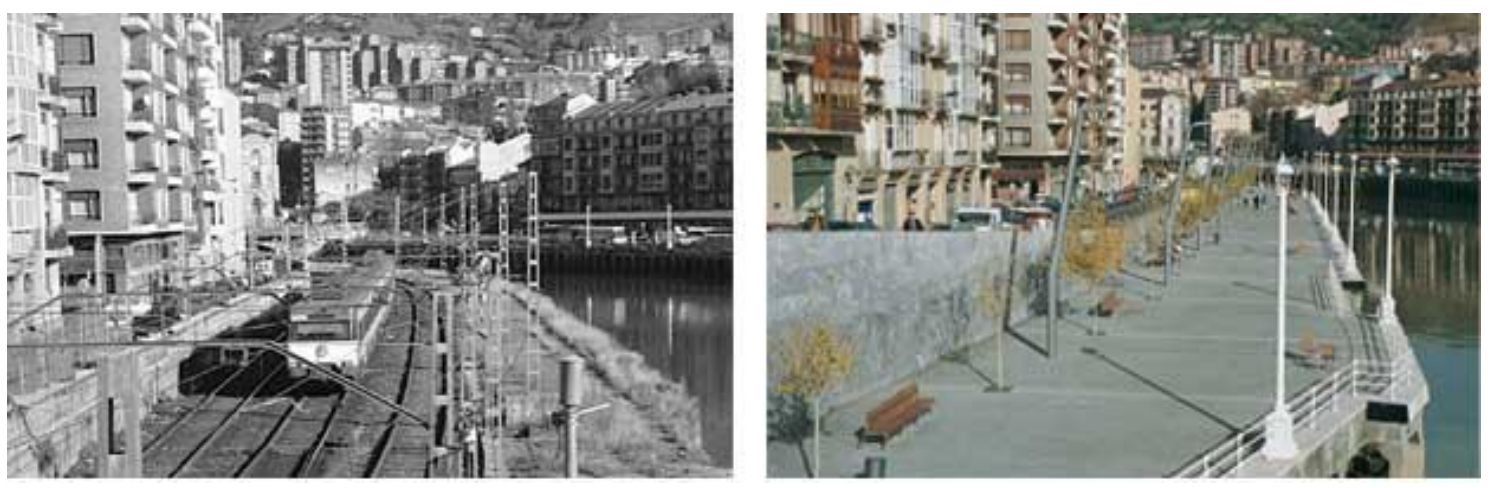

Nota: Estación de la Naja

Fuente: Bilbao Internacional

http://www.bilbaointernational.com/cirugia-urbanistica/ 


\subsubsection{Río Medellín, Colombia}

La ciudad de Medellín, en conjunto con otros 9 municipios, conforma el Área Metropolitana del Valle de Aburrá de donde nace el Río Medellín. El origen surge en los altos de San Miguel en Caldas y desemboca en el Río Grande. Medellín al igual que muchas ciudades latinoamericanas que se establecieron contiguas a los ríos, ha presentado problemas con el uso y estado de los bordes de la ribera debido al abuso del recurso y al crecimiento urbano no planificado en los bordes (Betancur, 2012).

El Río Medellín o Aburrá a inicios del siglo XX era considerado un referente paisajístico natural de carácter recreativo, sin embargo, en 1940 el río ya presentaba daños a consecuencia directa de la expansión poblacional e industrial. Fueron varios factores como el crecimiento económico industrial, la problemática agraria y la violencia en el campo que contribuyeron al aumento de población y trasformación de la ciudad (Betancur, 2012).

Las primeras acciones que reflejan los daños causados al río se dan en 1942 con el proyecto de canalización que se hizo con el fin de evitar próximas inundaciones y poder dar uso a las riberas a modo de eje vial. En 1946, el municipio realizó la construcción de un sistema de alcantarillado que trasladaba aguas residuales al Río Medellín (Betancur, 2012).

En 1948 tras los problemas relacionados con el río, hubo aspiraciones para mejorar las condiciones y desarrollo de la ciudad, por lo que se contrató al estudio Town Planning Associates conformado por los arquitectos Sert y Wiener que plantearon el Plan Piloto y el Plan Regulador (Perez, y otros, 2015).

En el Plan Piloto se planteó establecer en las rectas transversales al río parques lineales destinados a la recreación y deporte, además de proponer la integración del centro tradicional con el borde del río por medio de la implementación de equipamiento público que integre la ciudad y refuerce el eje estructurador en el territorio a partir del mismo (Perez, y otros, 2015).

Las obras ejecutadas para dar inicio a la transformación fueron la construcción de la planta de tratamiento de aguas negras y las vías paralelas al río. En los próximos años, no se tuvo una visión clara de la futura Medellín hasta 1995. A partir de este año, luego 
de varios diagnósticos y planes elaborados de manera individual por parte de los municipios, se buscó la integración de la ciudad de manera que entre los años 1995 y 1998 se elabora el Plan Estratégico de Medellín y el Valle de Aburrá 2015 (Pérez, 2012), el cual sirvió como base para la elaboración del Primer Plan de Ordenamiento Territorial que se adoptado en el 1999. (Perez, y otros, 2015)

Como parte de los lineamientos definidos en los planes, Medellín busca ser una ciudad accesible, acogedora, integrada con calidad ambiental (Pérez, 2012). Así la propuesta de parque lineal como estrategia de recuperación urbana del río surge de la necesidad de establecer un espacio de inclusión que conecte la ciudad con espacios públicos, equipamiento intervención ambiental y movilidad. El proyecto en el 2013 se lanzó a concurso internacional para la elaboración del diseño del parque del río que consta de una extensión de 26.2 kilómetro con un área de 424 Ha y sectorizado por 3 zonas con un total de 10 tramos ("La Empresa de Desarrollo Urbano", s.f.)

Figura 2. 4 Sectorización del Parque del Río Medellín

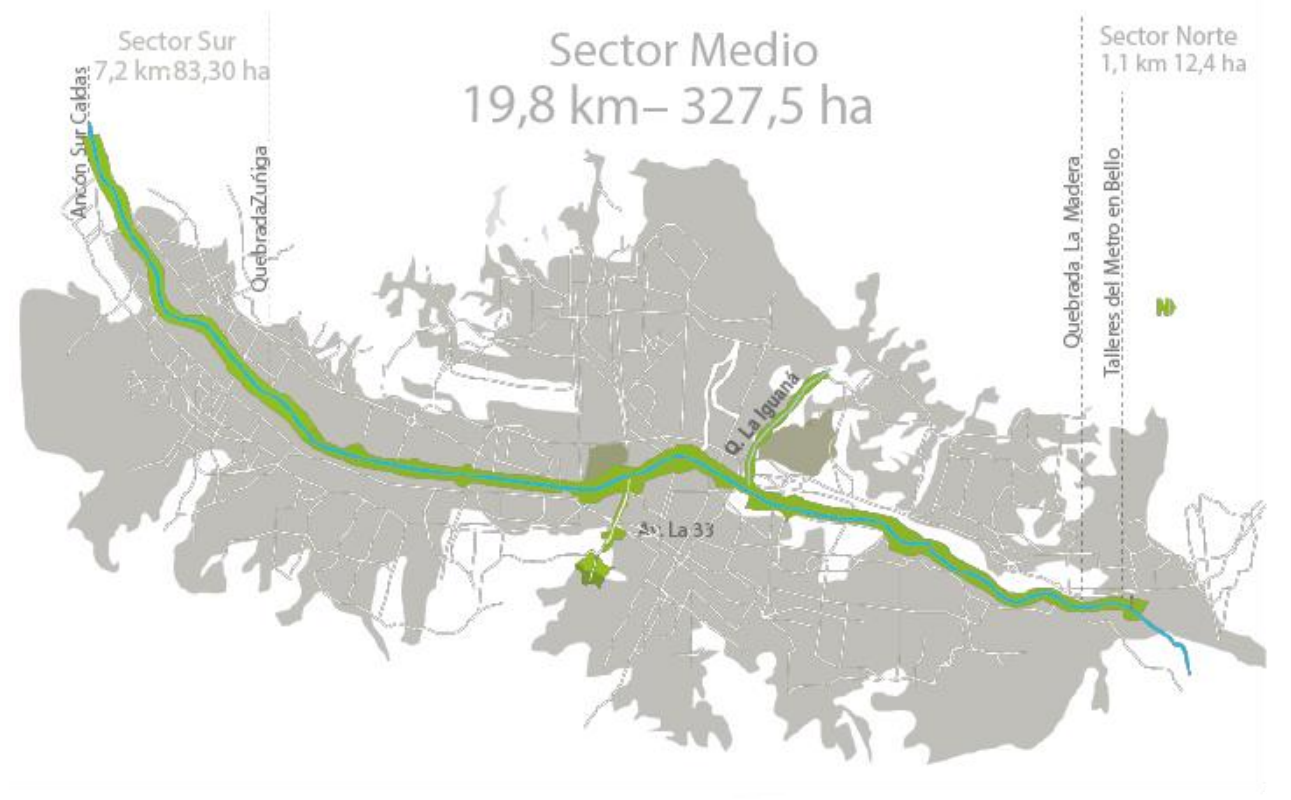

Fuente: Alcaldía de Medellín

https://www.medellin.gov.co/irj/go/km/docs/pccdesign/SubportaldelCiudadano_2/PlandeDesarrollo_0_1 6/Publicaciones/Shared\%20Content/Documentos/2014/PresentacionParquesRioMedellin_servidores.pdf 
Figura 2. 5 Tramos del sector medio

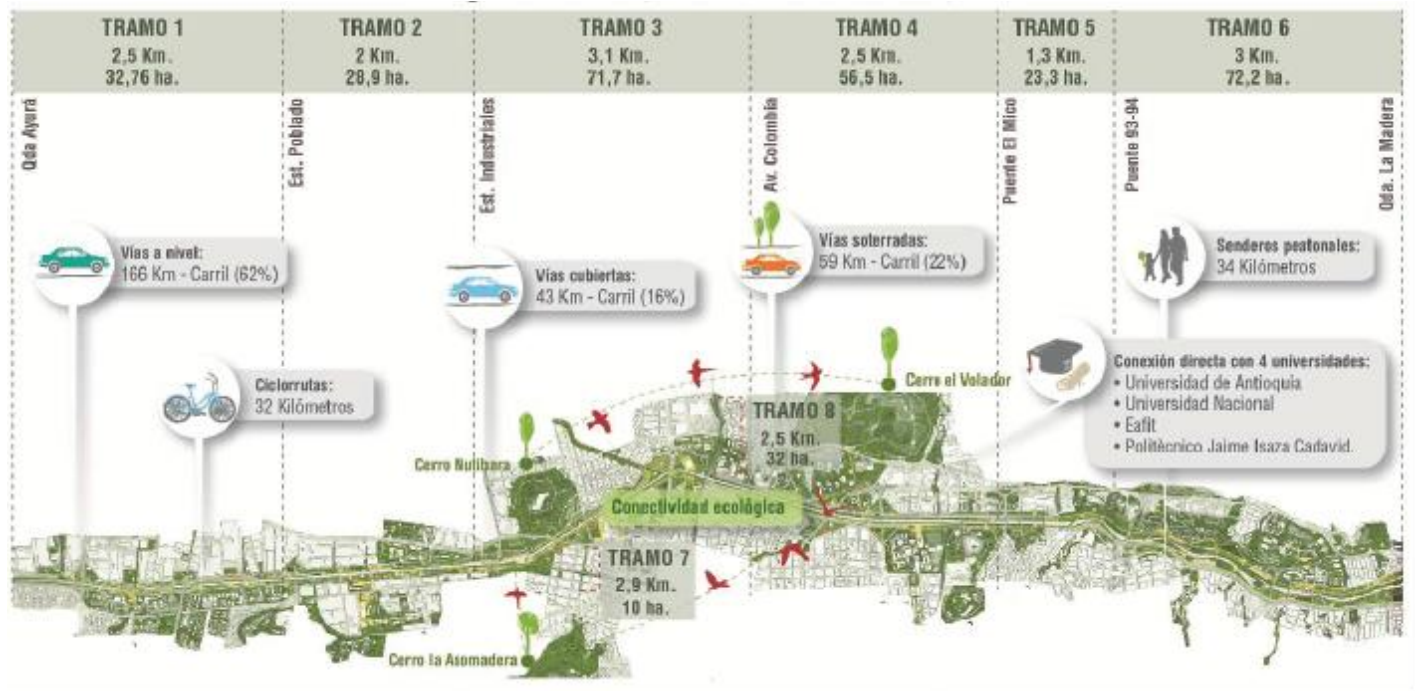

Nota: Longitud total y área total: $19.8 \mathrm{Km}$ y $327,5 \mathrm{Ha}$ respectivamente

Fuente: Alcaldía de Medellín

https://www.medellin.gov.co/irj/go/km/docs/pccdesign/SubportaldelCiudadano_2/PlandeDesarrollo_0_1 6/Publicaciones/Shared\%20Content/Documentos/2014/PresentacionParquesRioMedellin_servidores.pdf

De las acciones mencionadas, en los últimos años, por parte del Municipio de Medellín, la ciudad presenta un proceso de transformación que busca solucionar problemas urbanos desde una perspectiva territorial integral. Concibe al río como eje ordenador y como medio de oportunidad para la implementación de espacios que permitan la inclusión, equidad e integración de la población con el río.

Por otra parte, cabe señalar, la importancia de la gestión para la materialización del proyecto "Parques del Río Medellín" la cual se plantea por tramos, estableciendo etapas de construcción a corto, mediano y largo plazo.

\subsubsection{Línea del tiempo}

A continuación, la lámina 2.1 presenta una línea del tiempo que conforma el tema renegación urbana de ríos que va desde 1960 hasta 2016 en diversas ciudades del mundo 


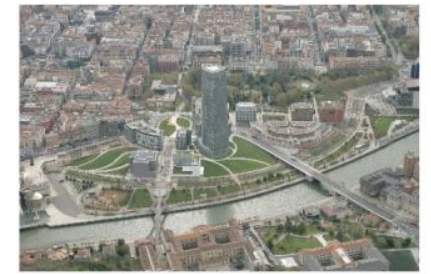

RIOO NERVIÓN,BILBAO
MALECON 2000,ECH Inicio del proceso de regeneración urbana de la ciudad de Guayaquil

MALECÓN 2000, ECU Inicio de obra del espacio p[ublico de malecón.

MALECÓN 2000, ECU Innaguracilon de diseño de $2.5 \mathrm{~km}$ del malecón.

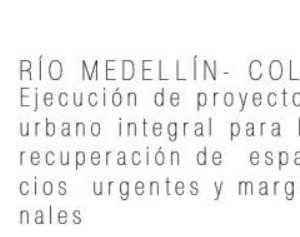

RÍO MEDELLÍN- COL Se plantea plan direc tor de medellín buscando un modelo de recuperación del río como una centralida lineal.

RÍO MAPOCHO Inaguración del proyecto parque fluvial Renato Poblete.

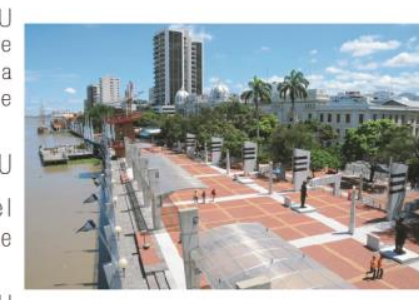

93
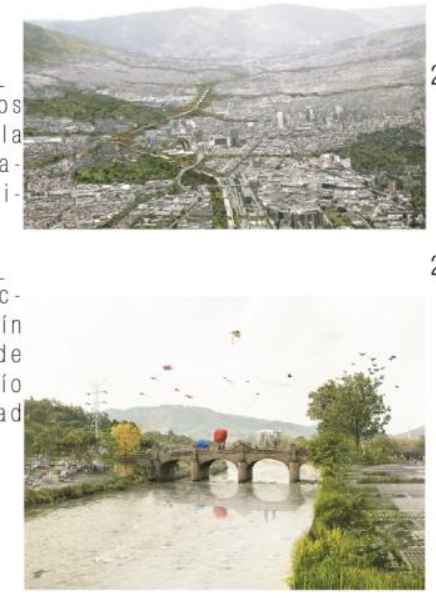

RIO SENA, PARIS

Proyecto de recuperación de un tramo del margen izquier da(Rive Gauche) con la peatonalización

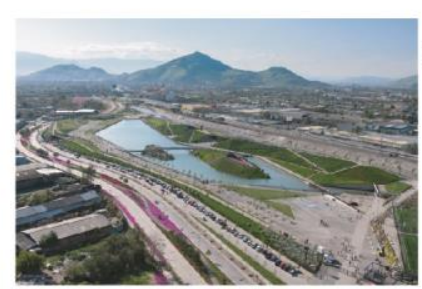
2004
06

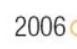

2006

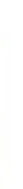

RÍO SENA, FRANCIA

1960Da fruto la ejecución de planes de limpieza de las aguas del río.

${ }_{1970}^{\text {RÍO NERVIÓN, BILBAO }}$ Crisis industrial, generando problmeas medioambientales

90

RÍO NERVIÓN, BILBAO

1991 Creación fundación Bilbao metropoli encargada en la recuperación de zonas degradas

RÍO MAPOCHO, CHILE

1994 Planteamiento de un parque metropolitano atravez de red de parques

RIOO MAPOCHO, CHILE Primer taller como 1991 aporte para el plan maestro del Río Mapo. cho

RIOO NERVIÓN,BILBAO 1992 Planificación del proyecto Bilbao ría 2000 y la fialización del diseño el plan de revita.

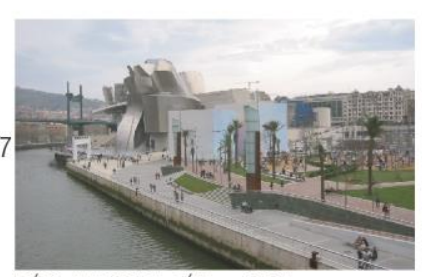

RIOO NERVIÓN, BILBAO Innaguración del Museo Guggenheim de Bilbao

1999RÍO MEDELLÍN-COL

Se plantea el primer ordenamiento territorial, el río es elfoco de integra. ción de la ciudad

RIOO CHEONGGYECHEON Presentación del proyec. to de recuperación del 2003 RIO CHEONGGYECHEON bajo una autopista parque lineal de $5.8 \mathrm{~km}$

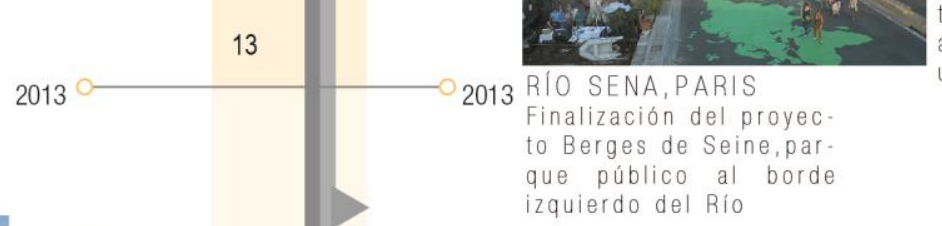

RIO CHEONGGYECHEON ignaguración de la obra como un nuevo centro verde para la ciudad de Seúl

RIO SENA, PARIS Paris busca retoma las riberas eliminando secciones de vias. Inicio del proyecto de transformación de la autopista Pompidou en un balneario.
2016 RIOO SENA,PARIS La orilla derecha (Rive Droite) inicio fases de prueba para su peatonali. zación en parte de su recorrido.
2016 RÍO MEDELLÍN, COL lanzamiento del concurso proyecto para el río Medellín como un espacio público integra- 


\subsection{Propuestas urbanas en bordes de río en el Perú}

Tras el mal uso y descuido del recurso del río, actualmente existe una nueva mirada de revaloración del río en ciudades Latinoamericanas. Las secuelas de abandono y descuido han generado la preocupación y necesidad de resolver problemas urbanos relacionados a la desarticulación. De este modo, las riberas se han convertido en espacios de oportunidad para reconectar la ciudad. Así, este panorama no es ajeno a la realidad latinoamericana, donde los ríos eran concebidos como límites del casco urbano (Rojas, 1997).

En el Perú, múltiples culturas se establecieron cerca de los ríos manteniendo un vínculo estrecho con el uso del bien pero que posteriormente se fue perdiendo debido a la explotación del recurso indiscriminado. Posteriormente, se agravo la situación a consecuencia de la expansión urbana no planificada que terminó por deterioro el río volviéndolo una barrera urbana degradad.

\subsubsection{Proyecto Río Verde}

Lima a mediados del siglo $\mathrm{xx}$, tras las continuas migraciones de personas provenientes del campo,sufrió transformaciones territorialmente de tal envergadura que el estado peruano no estuvo preparado para afrontar. El asentamiento informal trajo consigo aspectos negativos donde las viviendas carecían de servicios básicos y las condiciones urbanas no eran adecuadas por falta de planificación.

Desde los inicios, el Río Rímac ha sido pieza importante en el desarrollo de la ciudad de Lima. Sin embargo, el crecimiento urbano ha saturado las riberas del río. Actualmente se encuentra viviendas informales que vierten residuos soldos y liquidos industriales y domésticas. En sectores donde no existeviviendas son usados como depósito de residuos de construcción y demolición. Sin embargo, hay un sector ocupado por la entidad de Servicio de Agua Potable y Alcantarillado de Lima (SEDAPAL) que ha implementado de área verde (Municipalidad Metropolitana de Lima e Intituto Metropolitano de Planificación, 2014a).

Las autoridades se encuentran preocupadas por las condiciones de la ribera del río, por lo que esta preocupación ha generado el plantamiento de un proyecto Vía Parque Rímac que surge como iniciativa privada con el fin de integrar la ciudad utilizando el eje natural de Río a partir de una vía expresa a escala metropolitana. El proyecto está 
compuesto por la conexión de la vía de Evitamiento y la nueva vía expresa (Av. Morales Duárez).La iniciativa conecta 9 distritos con el Cercado de Lima, San Martín de Porres y el Callao por medio de $9 \mathrm{~km}$ de vías nuevas y $2 \mathrm{~km}$ de longitud debajo del Río Rimac en un lapso de 20 min desde Ate y el Callao (Municipalidad Metropolitana de Lima e Intituto Metropolitano de Planificación, 2014b)

Figura 2. 6 Tramo Vía Parque Rímac

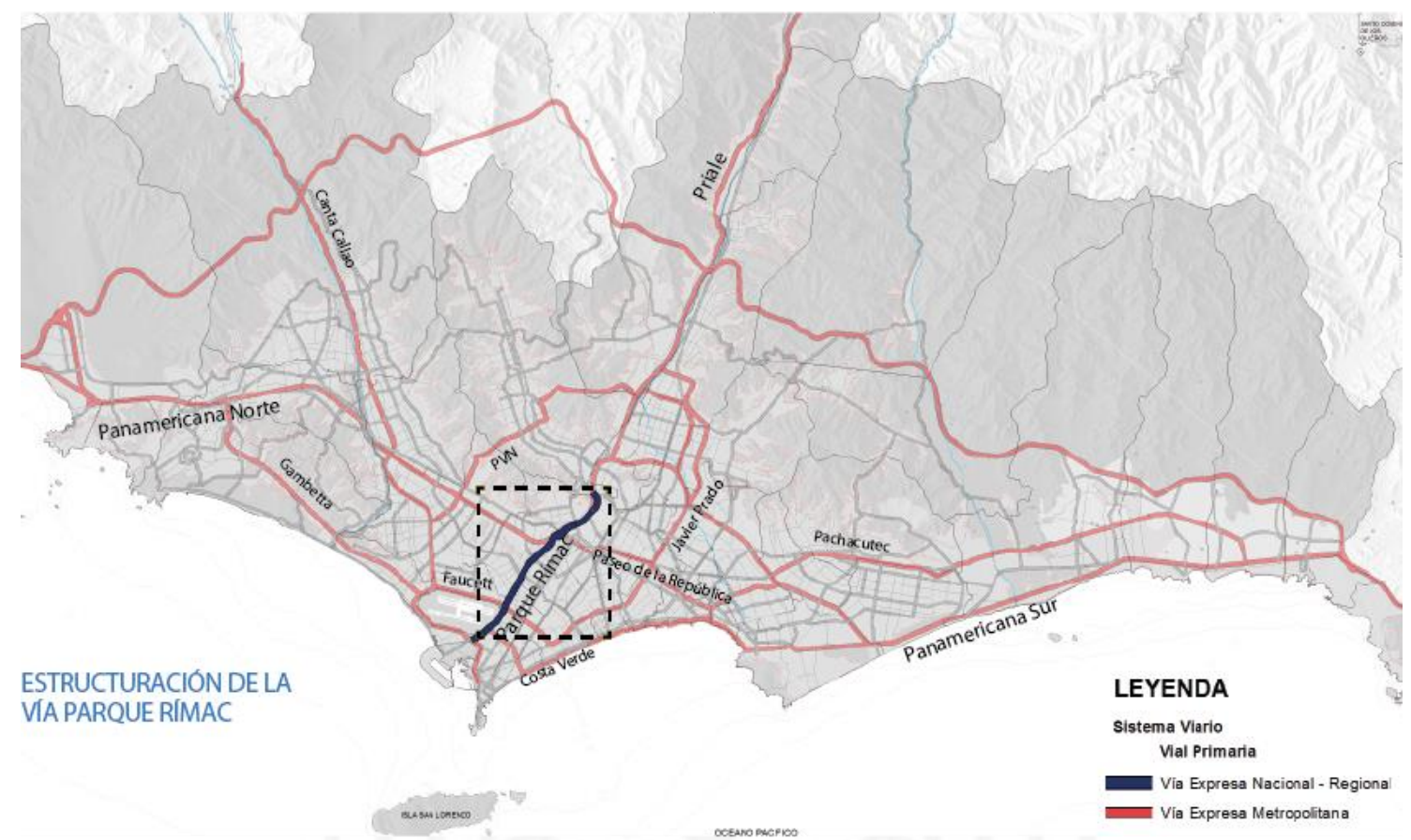

Fuente: Plan Metropolitano de Desarrollo Urbano Plam Lima y Callao 2035

La intervención propone mejorar las condiciones urbanas y ambientales de la ribera del Río Rímac con la construcción de 6km del Parque Río Verde en la zona de Cantagallo.El proyecto incluye parques y servicios comunales a lo largo de $4 \mathrm{~km}$ y $25 \mathrm{Ha}$ de áreas verdes,infraestructura deportiva, recreativa y comercial (Municipalidad Metropolitana de Lima e Intituto Metropolitano de Planificación, 2014a). 
Figura 2. 7 Tramo del Proyecto Río Verde

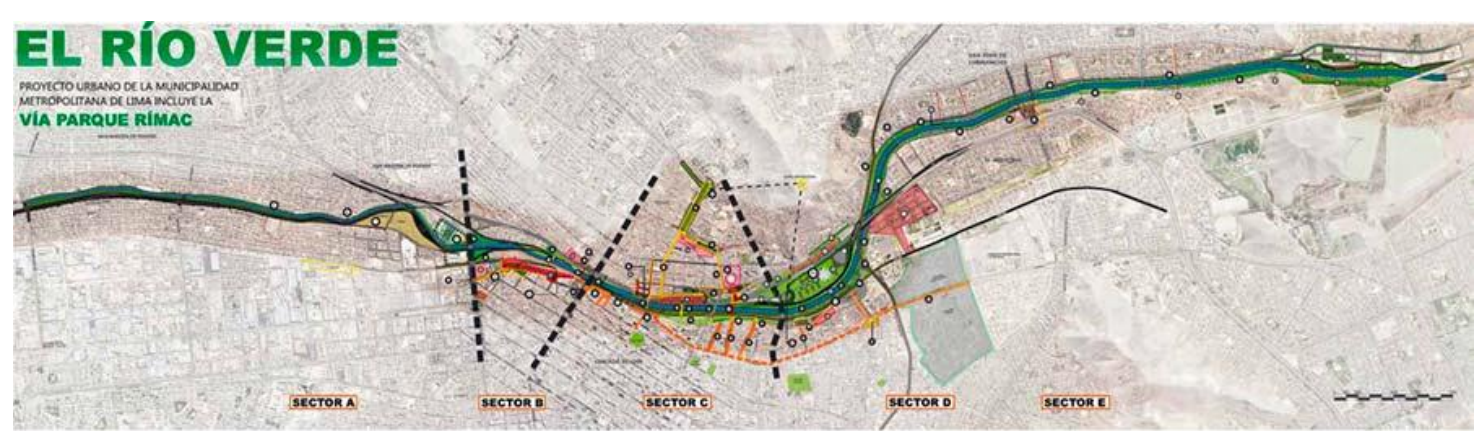

Nota: Longitud total y área total: $4 \mathrm{Km}$ y $25 \mathrm{Ha}$ respectivamente

Fuente: Fondo Verde

https://www.fondoverde.org/noticias/620-gestion-y-planificacion-de-rios-urbanos-como-corredoresverdes

\subsection{Beneficios actuales de la intervención en bordes de río}

Los beneficios principales de intervención de bordes de río son:

- La mejora de la movilidad, a partir de un sistema de trasporte integrado e incorporación de corredores verdes que interconectan la ciudad

- la mejora de la calidad de vida a través de la de una red de equipamientos y espacio público al servicio de la población,

- la mejora ambiental con la recuperación del ecosistema del valle y con la preservación e incorporación de especies autóctonas.

- desarrollo de conciencia ambiental, por medio de proyectos ambientales y culturales y

- control del crecimiento urbano en los bordes del río. 
A continuación se presenta un cuadro de indicadores que respaldan los beneficios que las intervenciones han causado en aspecto social con el uso y sentido de Identidad; ambiental, con el aumento significativo de flora y fauna; y el económico medio de la actividad turística.

Tabla 2. 1Indicadores cuantitativos y cualitativos de proyectos de éxito en intervención urbana de ríos

\begin{tabular}{|c|c|c|c|}
\hline Aspectos & Indicadores & Río Manzanares & Río Nervión \\
\hline \multirow{2}{*}{ Social } & Visitantes & 1 millón anuales & más de 1 millón anuales \\
\cline { 2 - 4 } & Actividades & más de 4000 & más de 6000 \\
\hline \multirow{2}{*}{ Ambiental } & Flora & 2000 árboles & se ha duplicado la flora \\
\cline { 2 - 4 } & Fauna & 50 especies de aves & 38 especies de fauna \\
\hline Económico & Turismo & - & Premio Euskadi de Turismo 2004 \\
\hline
\end{tabular}

Fuente: Elaboración propia en base a la página web Bilbao Ría 2000, Diario el País, Madrid, Revista PH91

http://www.bilbaoria2000.org/ria2000/cas/bilbaoRia/bilbaoRia.aspx?primeraVez=0 http://www.iaph.es/revistaph/index.php/revistaph/article/view/3883

\subsection{Centro de Interpretación}

\subsubsection{Origen a los Centros de interpretación}

La creación de los centros de interpretación surge a partir de los cambios del concepto de los museos. A continuación, se describirá los orígenes y la evolución del museo.

Los inicios de la creación del museo moderno ${ }^{2}$ data del siglo XVIII y comienzos del siglo XIX donde se desarrolla una arquitectura relacionada a la preservación, investigación y colección. El término oficial de museo según el Comité Internacional de Museos ( ICOM, 2017) señala en el artículo 3:

Un museo es una institución permanente sin fines de lucro al servicio de la sociedad y de su desarrollo, abierta al público, que adquiere, conserva, investiga, transmite y expone el patrimonio tangible e intangible de la humanidad y de su entorno para la educación, el estudio y el deleite. (p.3)

\footnotetext{
${ }^{2}$ Museo moderno, Concepto en donde se alberga y exponen obras al público en general.
} 
La evolución de los centros de interpretación parte de las diferentes necesidades por trasmitir cultura. así a mediados del siglo XX, el proceso de cambio significo la incoporación de nuevas funciones como tiendas, talleres, laboratorios y bibliotecas en los museos ( Comité Internacional para la Museología de ICOM, 2009).

Ante la incoporación de dichos cambios funcionales de los museos, los nuevos conceptos museológicos varían y buscan nuevos medios de transmitir el pasado, el cual no se basa únicamente en la exposición de la obra sino en la explicación adecuada de la misma Por consecuencia, la interpretación surge como herramienta de trasmisión desde otro enfoque, el educativo.

Este medio de educación y difusión de la cultura generó la creación de un nuevo equipamiento que conlleve a la enseñanza en diversos temas. Así, en los años 80 el surgimiento de la interpretación del patrimonio (materiales e inmateriales) ha propiciado nuevos espacios como "Aulas naturales", "Centro de visitantes" "Centros de Interpretación” (Martín, 2011).

Se puede entender que el desarrollo de los museos ha ido variando de acuerdo a necesidades, contextos que buscan la conservación y transmisión de la cultura de modo que el objeto de exposición pierde el carácter primordial y aparecen medios de comunicación en la interpretación del patrimonio.

\subsubsection{Concepto de Centros de Interpretación}

Como se mencionó anteriormente, el inicio de este tipo de espacios se encuentra estrechamente relacionado con la comprensión del término de la interpretación y en particular al de patrimonio. A continuación, se explicará el concepto.

La primera publicación referida a este concepto se dio en la obra de Freeman Tilden "Interpreting our Heritage" en 1957, en ella establece los fundamentos de esta disciplina, sin embargo se basa únicamente en los parques naturales sin englobar el ámbito general de lo que implica el patrimonio. Define la interpretación como "una actividad educativa que pretende revelar significados e interrelaciones a través del uso de objetos originales por contacto directo con el recurso o medios ilustrativos, no limitándose a dar una mera información de los hechos" (Tilden, 2006). 
Posteriormente, en 1985, en el Congreso Mundial de Interpretación se postuló que la interpretación del patrimonio posee un panorama amplio y no se basa únicamente para temáticas ambientales sino que abarca todo lo que rodea al hombre tanto desde el ámbito ambiental como cultural, de manera que las dos materias se integran y el territorio se concibe como el escenario en donde trascurrieron los procesos históricos. (Arcila \& López, 2015).

Asimismo, otras disciplinas como la educación, ecoturismo, turismo rural y turismo cultural implementan el concepto considerando el recurso no únicamente de desde una perspectiva educativa sino además como recurso económico (Bazan, 2014).

Así, los centros de interpretación comienzan a ser piezas importantes en el desarrollo local como espacios de trasmisión cultural. La primera aproximación del término de centro de interpretación, atribuida por Jorge Morales Miranda señala que "la interpretación debería posibilitar un contacto con el objeto real afuera, en el entorno del parque o del sitio histórico" (Morales, La interpretación del patrimonio natural y cultural : todo un camino por recorrer, 1998).

Por consiguiente, podemos entender que la primera aproximación de los centros de interpretación estuvo relacionada al contexto y a los recursos del lugar. Sin embargo, esta visión se fue ampliando con temas relacionados al ámbito cultural, en búsqueda de la educación a través de la transmisión del patrimonio, educando a los visitantes.

\subsection{Historia del crecimiento urbano de Huancayo}

A continuación, se analizará los antecedentes históricos del crecimiento urbano de la ciudad de Huancayo y se tomará referencia desde el periodo prehispánico, seguido de la fundación española, periodo republicano hasta el periodo contemporáneo con la finalidad de entender la evolución de la ciudad y su estado actual.

\section{Periodo Prehispánico}

La cultura Huanca o Wanca es considerada como una de las más poderosas del mundo andino, Fue una nación fuerte que se implantó en el Valle del Mantaro (Cortez Mallma, 2010). 
El origen de los Huancas se remonta a los años 1200 con una duración hasta el año1460 aproximadamente. Ocupaban las actuales provincias de Jauja, Concepción y Huancayo. La organización urbana del reino Huanca estaba dividida en cuatro provincias (Hatun Xauxa, Lurin Huanca, Hanan Huanca y Chongos) donde cada una estaba gobernada por un caudillo y la capital de la cultura Huanca fue la urbe llamada Tunanmarca cerca de la provincia de Jauja (Espinoza Soriano, 1971)

Los Huancas tenían una personalidad belicosa y altiva, no eran fáciles de conquistar; sin embargo, en 1460, el inca Capac Yupanqui (hermano de Pachacutec) conquista a la cultura Huanca con la caída de la capital (Tunanmarca) incorporando los pueblos huancas a los ayllus o llactas incas. (Espinoza Soriano, 1971)

Los incas reordenaron el territorio dividiendo en tres provincias Jatunsausa, Urinhuanca y Ananhuanca donde la provincia de Ananhuanca contenía al ayllu o llacta Huancayo y estaba conformada por mitimaes (indígenas del imperio inca que eran enviados a cumplir funciones al servicio del Inca Pachacútec). En la margen derecha del Río Shullcas, el inca mandó a construir un Tambo real (posada para el descaso del inca y la comitiva) (María Pinilla, 2004). 
Figura 2. 8 Trayecto del Camino Real de los Incas, ubicación del Tambo y plaza sagrada

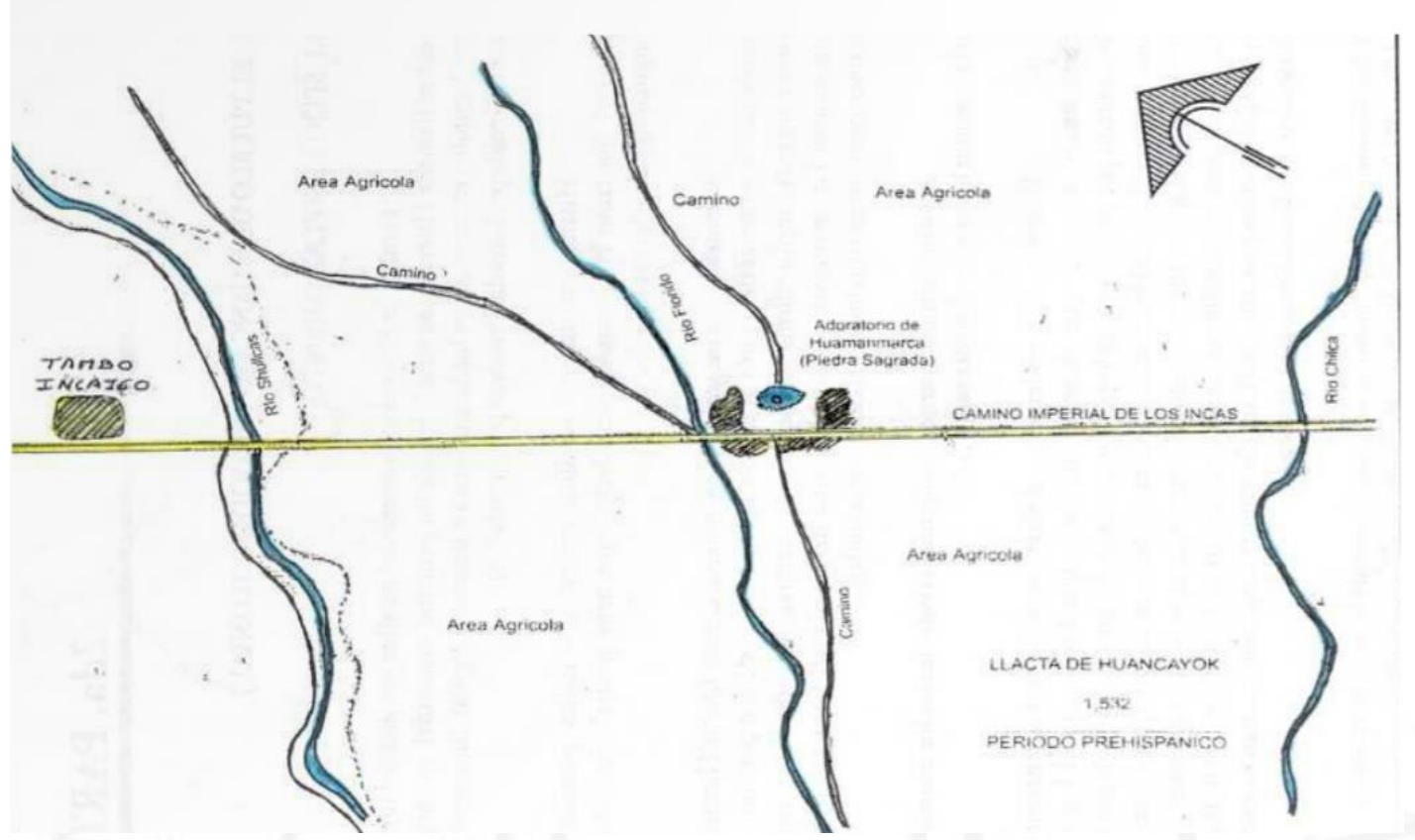

Fuente: Enciclopedia Departamental Junín, 1838

En el Valle del Mantaro, los incas construyeron el "Camino inca o Camino Real" que iba de Cusco a Cajamarca y a la altura de Acostambo este se subdividía en dos. La primera ingresaba por Sapallanga, seguido por Huancayo (Calle Real) pasaba por la provincia de Concepción hasta llegar a Jauja (Jatunsausa) y continuar hasta Tarmatambo. La segunda iba por la margen derecha del Río Mantaro pasando por Rumichaca, Huacrapuquio, Huamancaca, Pilcomayo, Muquiyauyo hasta llegar a Jauja (Jatunsausa). Ambos ramales terminaban en Jatunsausa, ya que fue uno de los asentamientos incas importantes en el Tahuantinsuyo. (Cortez Mallma, 2010) 
Figura 2. 9 Periodo Prehispánico: Llacta Huancayok

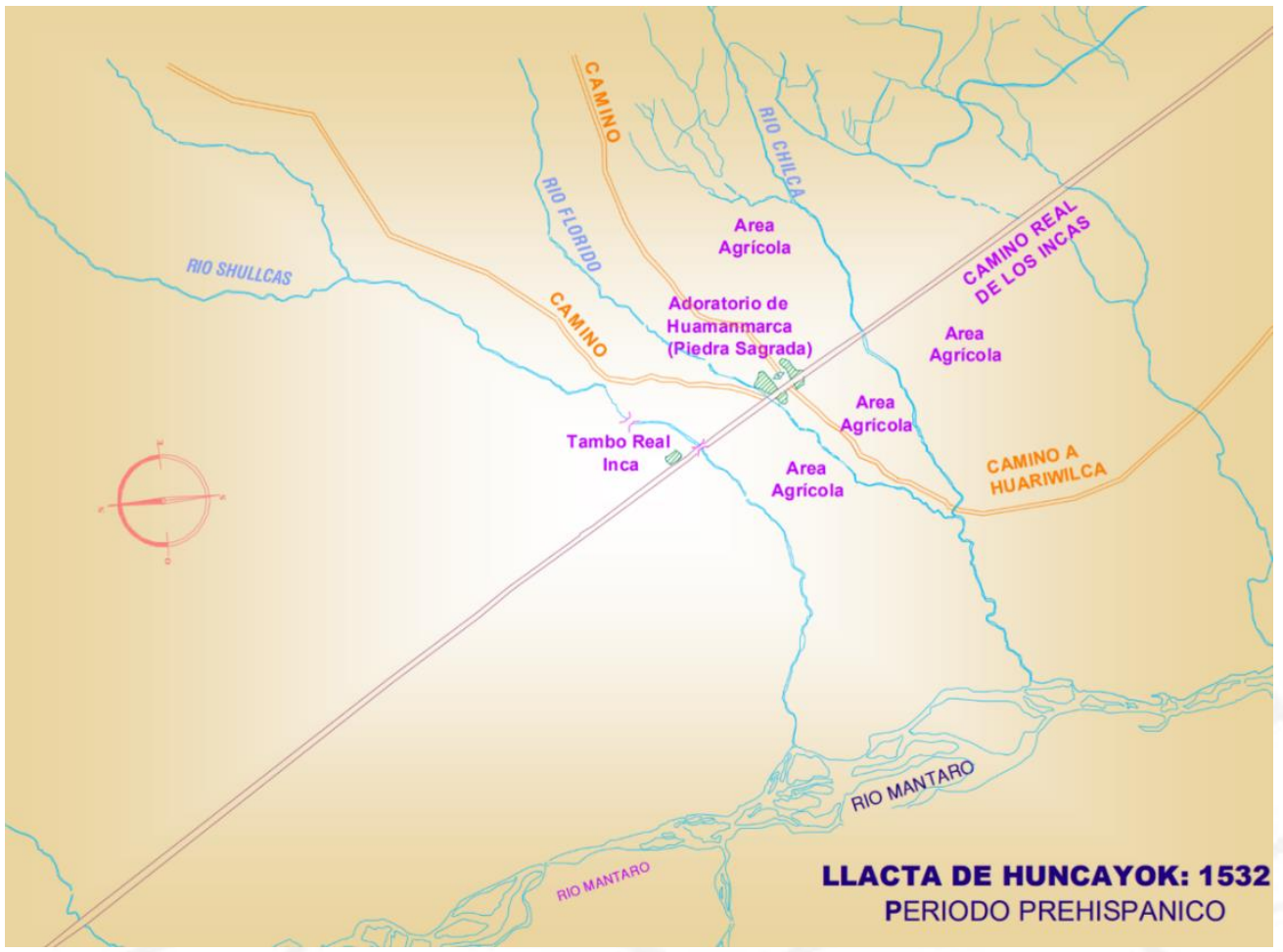

Fuente: Municipalidad Provincial de Huancayo (PDU,2006-2011)

http://bvpad.indeci.gob.pe/doc/estudios_CS/Region_Junin/huancayo/huancayo_PDU.pdf

\section{$\underline{\text { La fundación española }}$}

La convivencia de quechuas y huancas no debió ser agradable, debido al sometimiento que tuvieron las huancas, por esta razón, a la llegada de los españoles, los huancas y españoles generan alianzas para combatir contra los incas. Esta conexión puede explicar la decisión que tomó Francisco Pizarro (1534) para fundar la primera capital del Perú en la provincia de Jauja (Bonilla Di Tolla, 2010).

A $45 \mathrm{~km}$ de Jauja se encuentra Huancayo, que hasta la llegada de los españoles era un ayllu donde existía una piedra que los indios adoraban y tenía el nombre de Huancayoc. El ayllu o llacta Huancayo que los incas habían fundado era parte del “Camino inca o Camino Real”, no tenía importancia geopolítica. En 1553 a modo de evangelización se manda a construir la primera capilla. Alrededor de la nueva capilla y la Calle Real empieza a crecer el poblado de Huancayo de manera lineal. (María Pinilla, 2004). Sin embargo, hasta ese momento Huancayo solo era conocido como un pueblo de intercambio comercial y punto de encuentro de los diversos caminos del valle. 
Es en 1570 que el Virrey Toledo transita por el poblado de Huancayo y le llama la atención factores del valle como el clima, geografía, la ecología, etc. y ordena a Jerónimo Da Silva hacer un estudio detallado del poblado. En 1571, luego de los resultados del estudio, el Virrey Toledo ordena la planificación de un pueblo de corte español y en 1572 se realiza el trazado urbano ortogonal considerando a la Calle Real como el eje estructurador de la ciudad. Este trazado estaba compuesto por una plaza central y lotes que fueron destinados para el monasterio o iglesia principal y solares para los curacas. Y se funda el pueblo de indios de la Santísima Trinidad de Huancayo (Samalvides, 2005).

Figura 2. 10 Constitución urbana del núcleo religioso en la ciudad

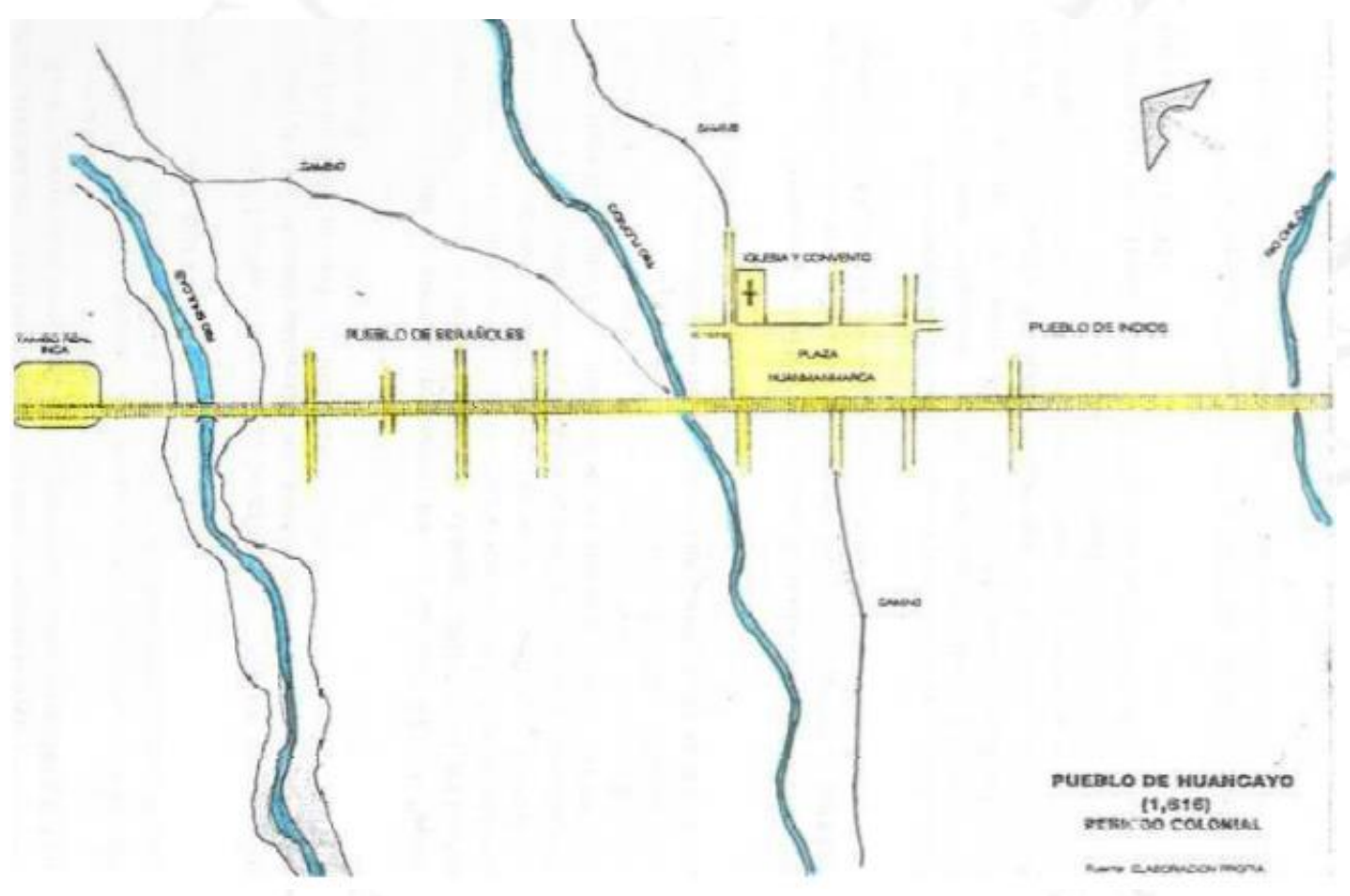

Fuente: Enciclopedia Departamental Junín, 1838 
Figura 2. 11 La Fundación Española: Pueblo de Indios de la Santísima Trinidad de Huancayo

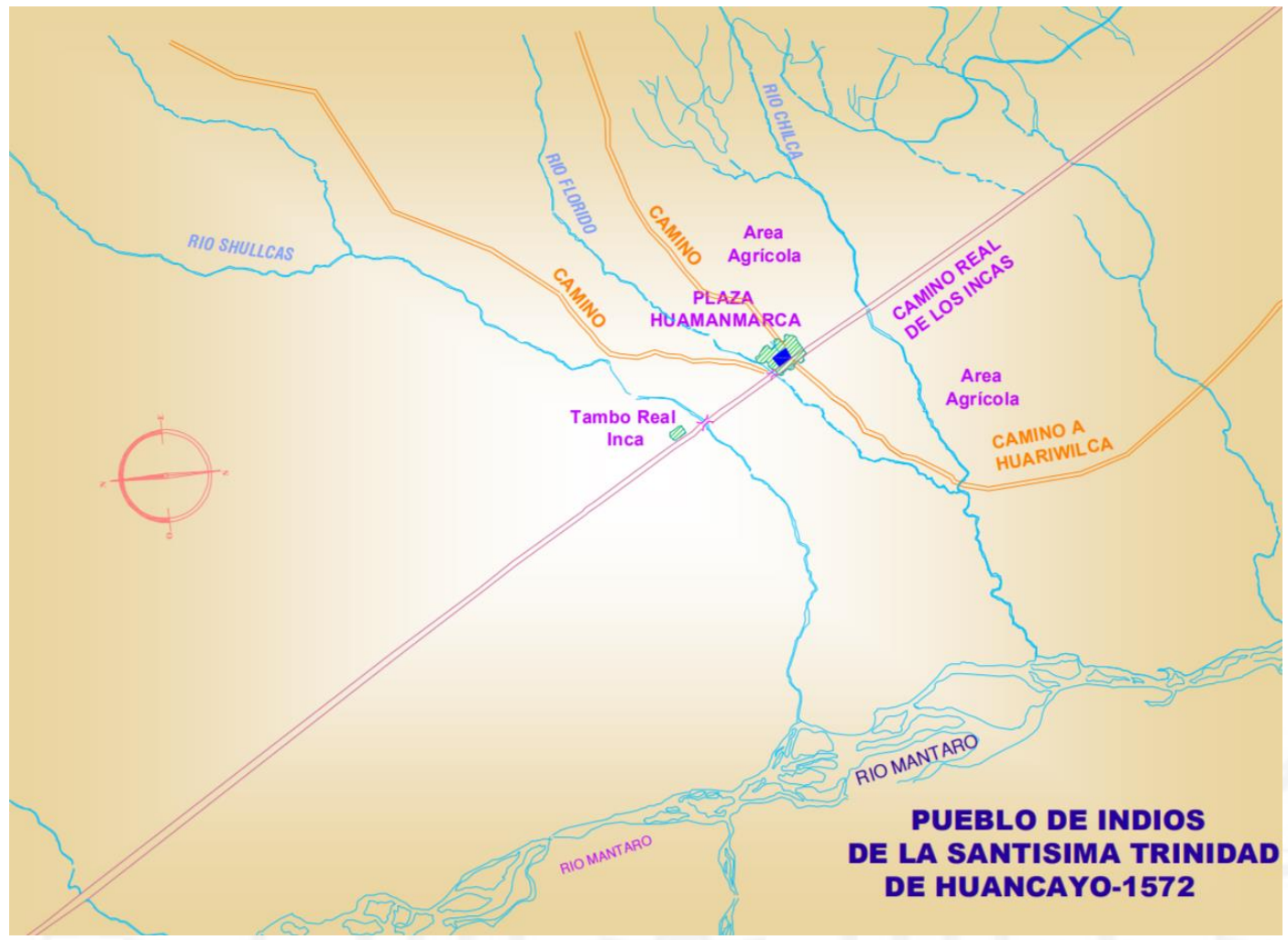

Fuente: Municipalidad Provincial de Huancayo (PDU,2006-2011)

http://bvpad.indeci.gob.pe/doc/estudios_CS/Region_Junin/huancayo/huancayo_PDU.pdf

\section{$\underline{\text { Periodo Colonial }}$}

Para el siglo XVII- XVIII, las colonias fueron reorganizadas y Huancayo aparece como curato $^{3}$ de la subdelegación de Jauja. De esta manera alcanza a ser una de las ciudades más importantes del Valle del Mantaro (María Pinilla, 2004)

El centro administrativo de toda la región era la provincia de Concepción; sin embargo, Huancayo, por estar en el centro de la red de caminos del valle, se había convertido en la ciudad comercial y administrativa más importante, quitando protagonismo a las demás.

\footnotetext{
${ }^{3}$ Según el Diccionario de la Real academia española curato significa territorio bajo la jurisdicción espiritual del cura.
} 
Figura 2. 12 Periodo colonial: crecimiento urbano de Huancayo (1616)

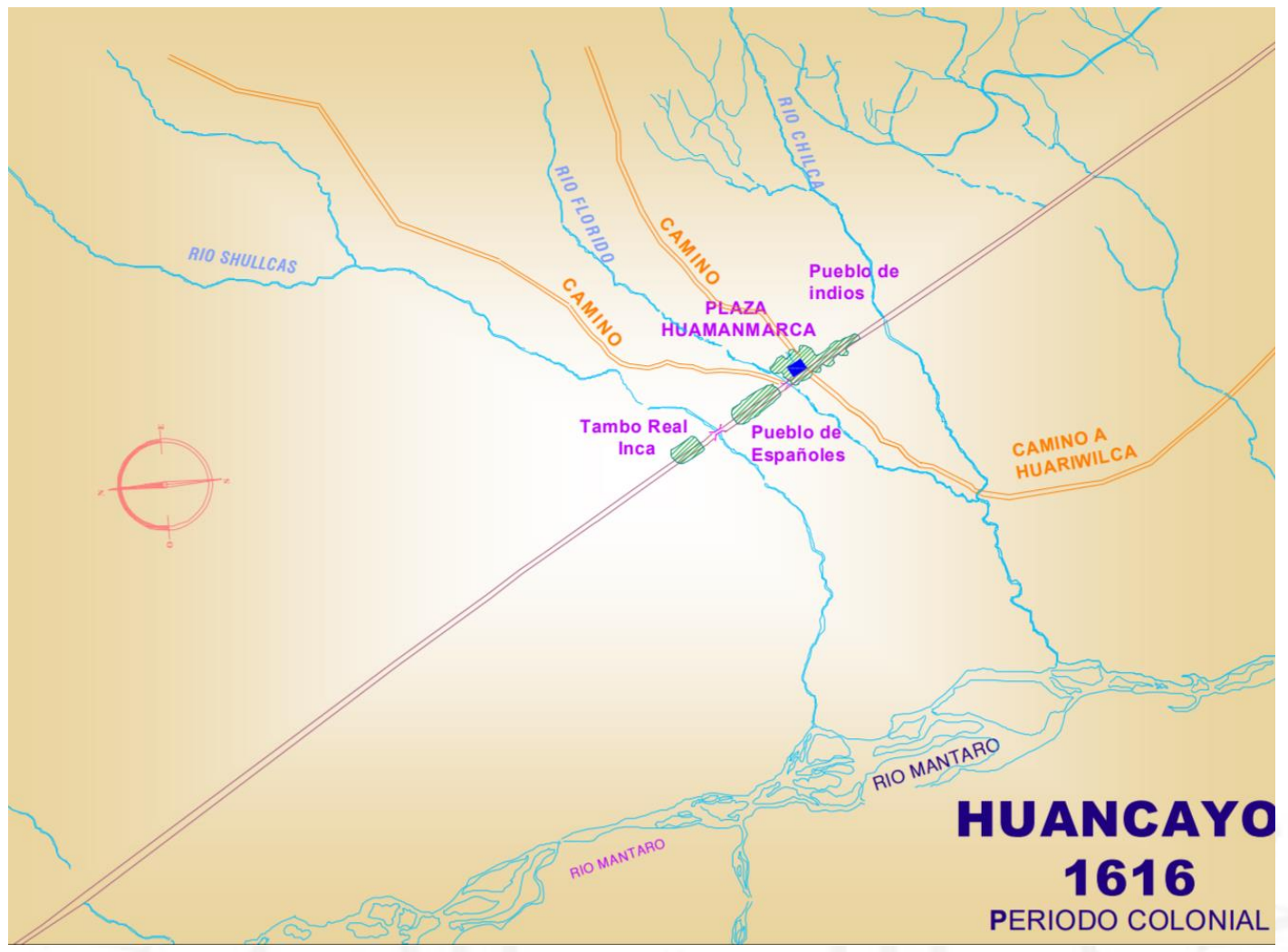

Fuente: Municipalidad Provincial de Huancayo (PDU,2006-2011)

http://bvpad.indeci.gob.pe/doc/estudios_CS/Region_Junin/huancayo/huancayo_PDU.pdf

\section{Periodo Republicano}

En el periodo republicano, la ciudad cobró vida comercial debido a su ubicación. La Calle Real se convirtió en el eje comercial más importante por la aparición de la Feria Dominical. La creación de la feria se atribuye a la presencia de las tropas de soldados en la Guerra de la Independencia que iban de compras y abastecimiento en dicho evento (María Pinilla, 2004) 
Figura 2. 13 Imagen de la Feria Dominical en la Calle Real

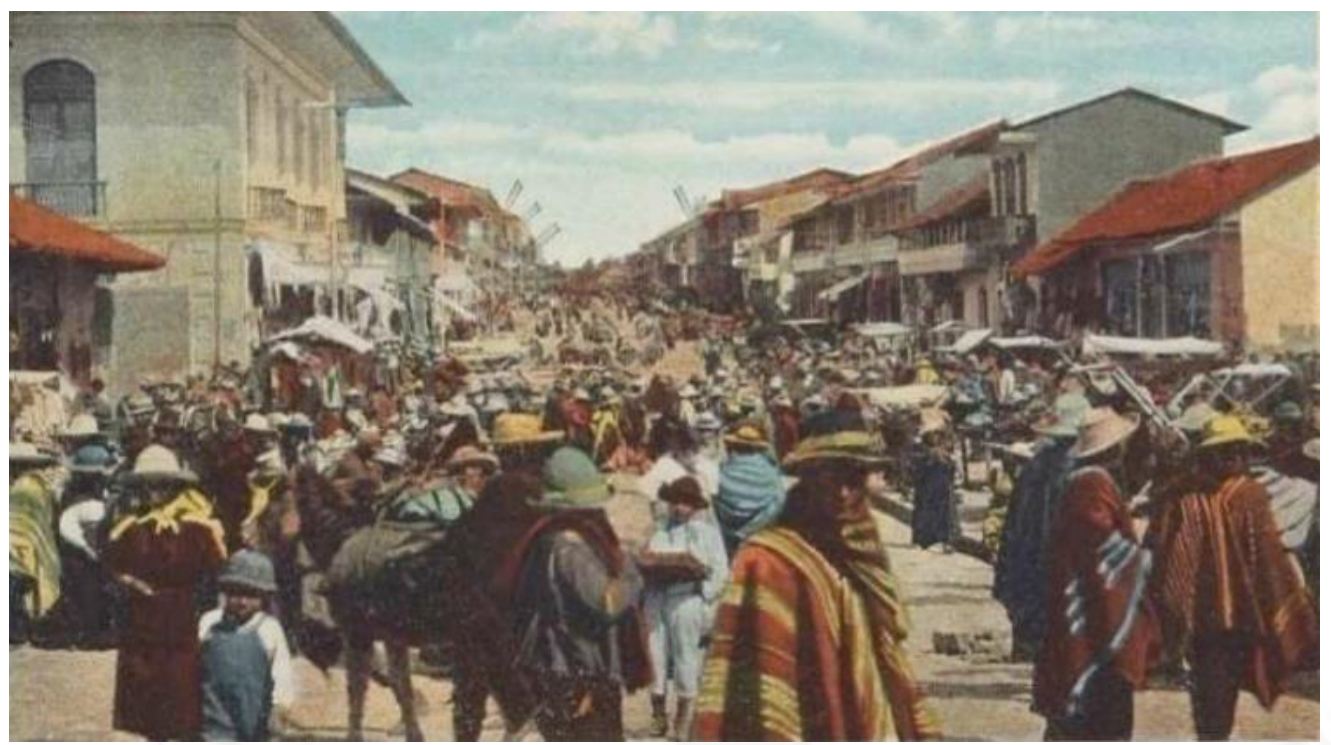

Fuente: Enciclopedia Departamental Junín

A inicios del siglo XIX, Huancayo siguió creciendo aceleradamente y era notorio en la huella urbana, ya que contaba con un vecindario compuesto por 132 manzanas, 3 plazas, 2 iglesias y una capilla. Sin embargo, no contaba con una plaza, ni iglesia principal, por lo que se realiza una modificación al tejido, incrementando la Plaza Constitución y la catedral (Plan de Desarrollo Urbano de Huancayo [PDU], 2015). Con la aparición de esta plaza mayor, la plaza Huamanmarca quedó relegada a segundo plano quedando la sede del cabildo como nodo del lugar (Samalvides, 2005). 
Figura 2. 14 Periodo republicano: crecimiento urbano año (1828)

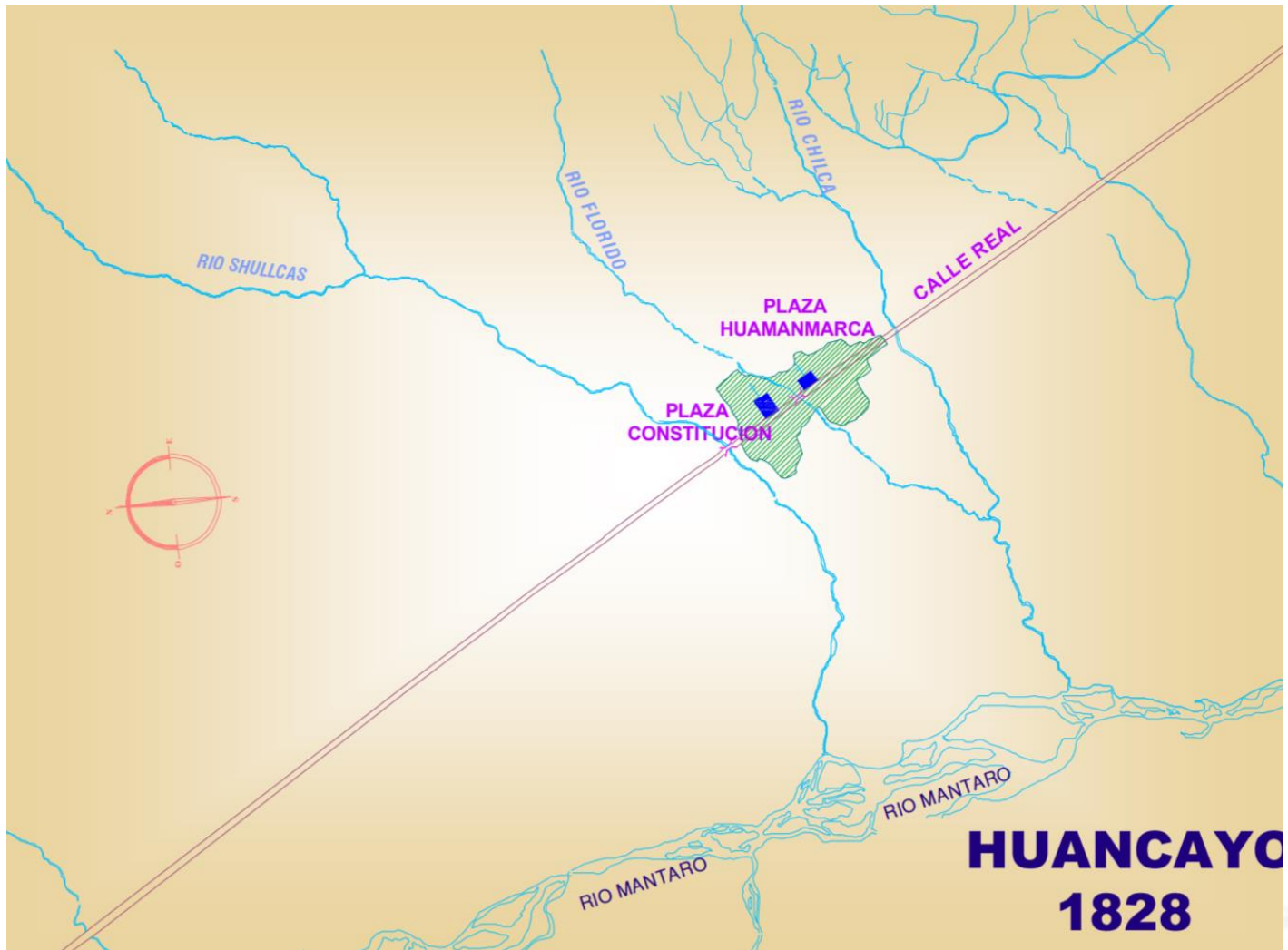

Fuente: Municipalidad Provincial de Huancayo (PDU, 2006-2011)

http://bvpad.indeci.gob.pe/doc/estudios_CS/Region_Junin/huancayo/huancayo_PDU.pdf

A mediados del siglo XIX. se incrementa el crecimiento urbano debido a la construcción de carreteras que ocasionan un flujo de población constante. Asimismo, la aparición de bancos, casas de cambio, aseguradoras, casas de préstamo, incrementaron la economía de la ciudad y alteraron el territorio urbano. La expansión de la ciudad se dio en dirección sur y este debido a que el Río Shullcas era visto como un límite natural y no se concebía la idea de ciudad pasando aquel borde. Al haber una expansión urbana acelerada la ciudad continuó su crecimiento en la margen derecha del Río Shullcas, en sentido oeste, con la trama ortogonal española y se creó los distritos del Tambo y Chilca (Chávez, 1925) 
Luis Samalvides (2005) menciona que el siglo XIX está conformado por eventos importantes que promovieron el crecimiento urbano de la provincia de Huancayo, estos fueron:

- $\quad 1840$ hacia adelante, la creación de la burguesía local ocasionó impulso en el desarrollo de nuevo equipamiento como los hospitales, colegios emblemáticos, creación de puentes de conexión entre distritos, etc.

- En 1864, se crea la Provincia de Huancayo, teniendo y es nombrada como capital de la región Junín.

- En 1902 se construye la Av. Giráldez.

- El año 1908 se inaugura el Ferrocarril Central como equipamiento de transporte regional.

Figura 2. 15 Crecimiento de la trama urbana, aparición de vías perpendiculares a la Calle Real

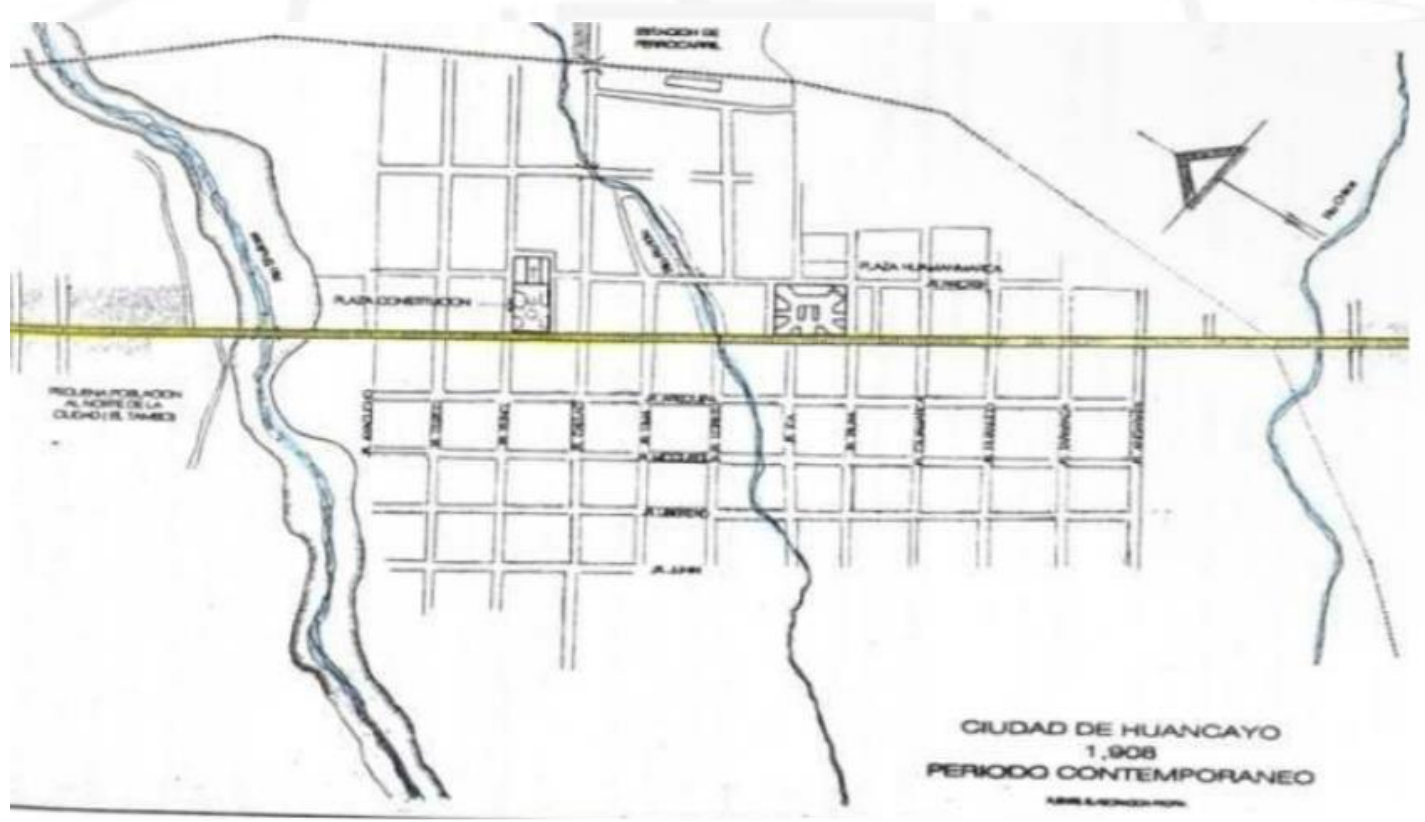

Fuente: Enciclopedia Departamental Junín, 1838 


\section{$\underline{\text { Periodo Contemporáneo }}$}

Con la llegada del Ferrocarril Central (1908) llegó también el periodo contemporáneo donde la ciudad inicia la expansión urbana en dirección este incorporando las vías del tren a la trama y creando un eje transversal importante de la Av. Giráldez. (Plan de Desarrollo Urbano de Huancayo [PDU], 2015).

Figura 2. 16 Periodo Contemporáneo: crecimiento urbano (1908)

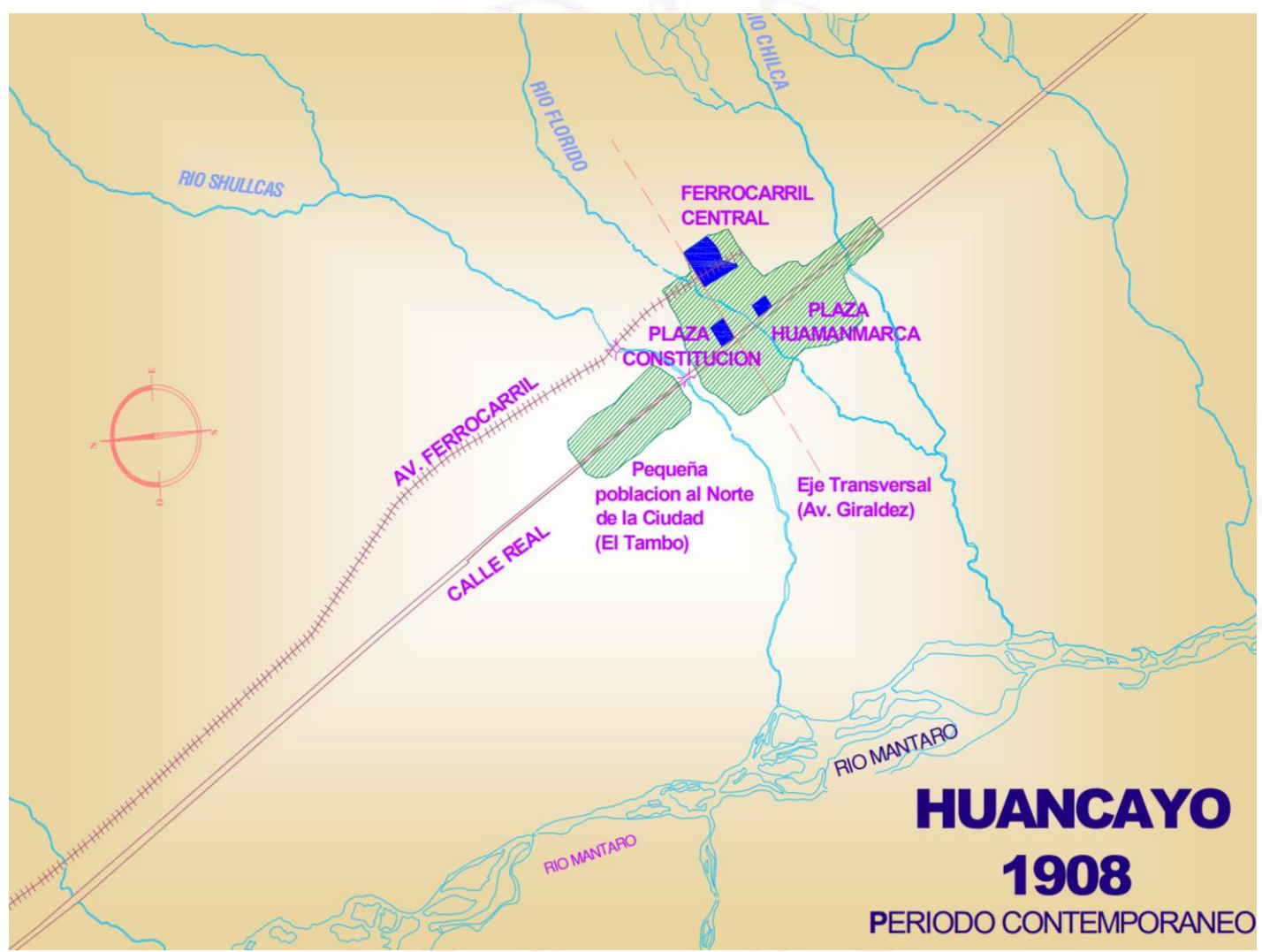

Fuente: Municipalidad Provincial de Huancayo (PDU,2006-2011)

http://bvpad.indeci.gob.pe/doc/estudios_CS/Region_Junin/huancayo/huancayo_PDU.pdf

Por el crecimiento de la ciudad surge la necesidad de generar el primer Plan Regulador que es formulado en el año 1944 por el Ing. Oswaldo Raez Patiño. Siendo un hito más en el proceso urbano (Samalvides, 2005)

En 1954, el Municipio de Huancayo para fines urbanos apertura la nueva calle circunvalación (Av. Los Próceres de Chilca) dando pie a la creación del distrito de Chilca. 
Figura 2. 17 Periodo Contemporáneo: Nuevos hitos en la trama urbana

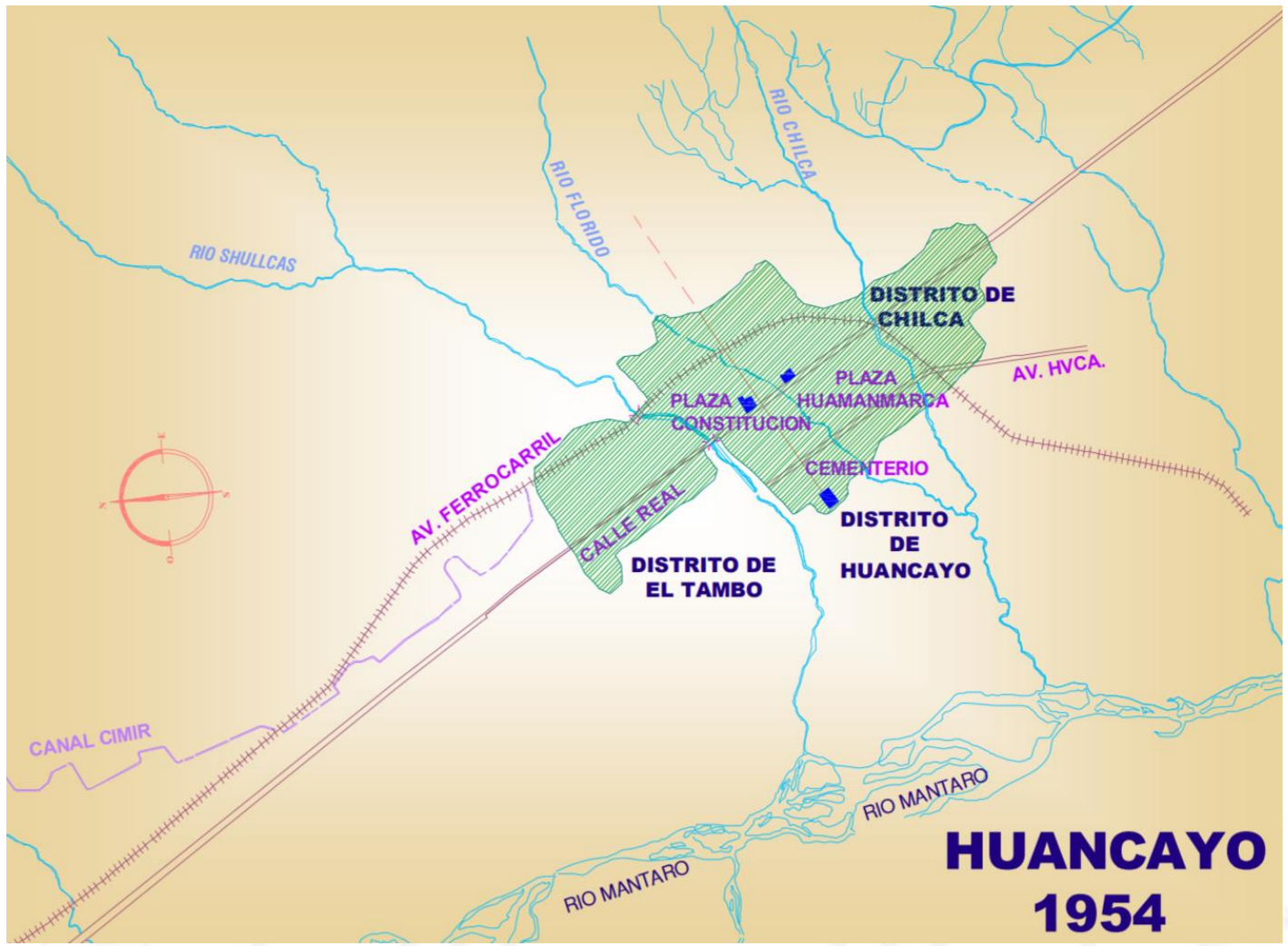

Fuente: Municipalidad Provincial de Huancayo (PDU,2006-2011)

http://bvpad.indeci.gob.pe/doc/estudios_CS/Region_Junin/huancayo/huancayo_PDU.pdf

Para 1963-1964 Huancayo se convierte en una de las ciudades más importantes del país. Contaba con equipamiento educativo, salud, transporte y comunicaciones con impacto regional, tuvo avances urbanos que imprimieron velocidad en el proceso de modernización. A fines del siglo XX Huancayo era considerada como la ciudad comercial progresista del país. Sus principales actividades comerciales eran la agricultura, manufactura y a la producción de recursos básicos como electricidad y agua (Plan de Desarrollo Urbano de Huancayo [PDU], 2015). 
Figura 2. 18 Periodo Contemporáneo: Expansión urbana de los distritos más grandes de la provincia (1963)

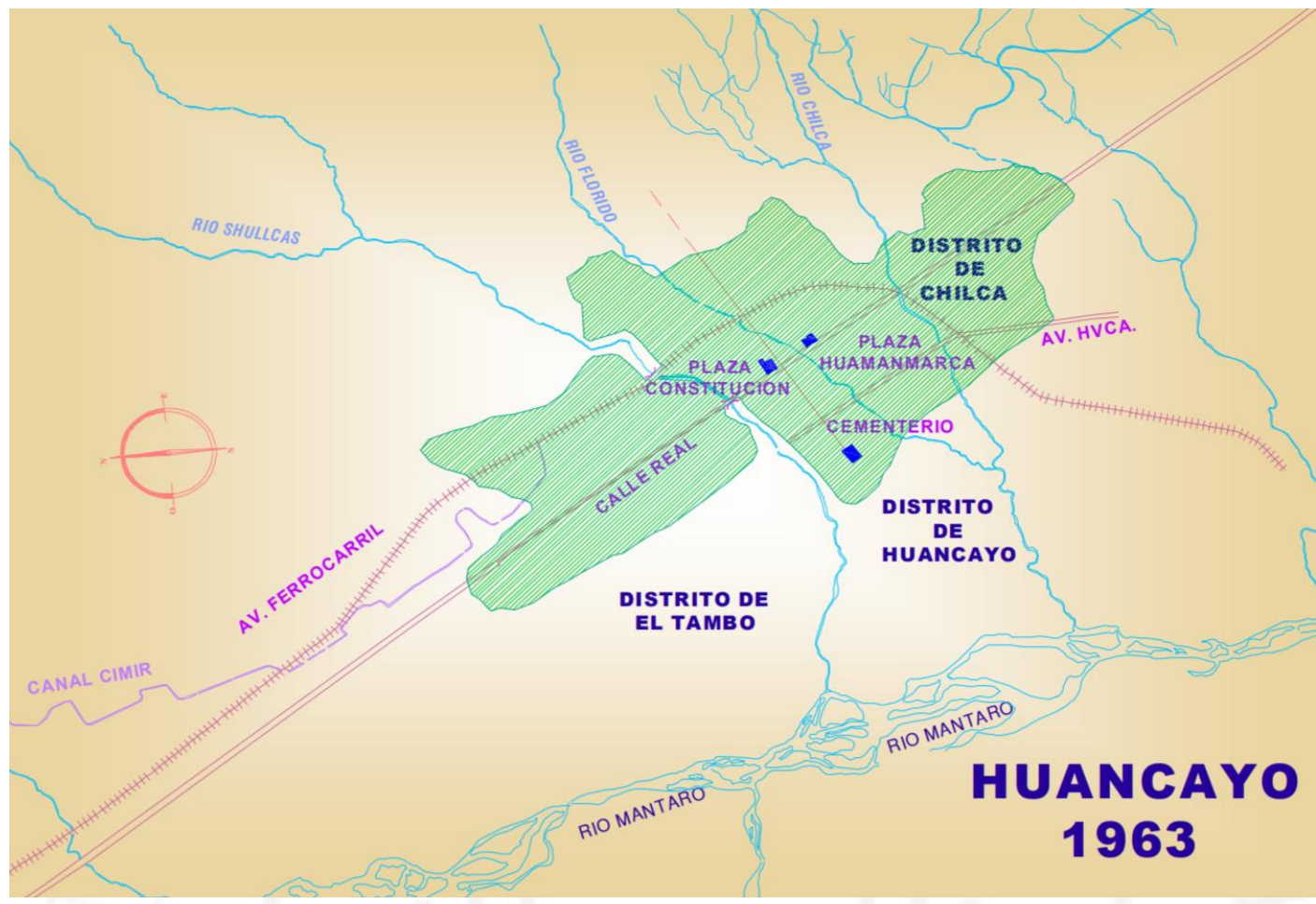

Fuente: Municipalidad Provincial de Huancayo (PDU,2006-2011)

http://bvpad.indeci.gob.pe/doc/estudios_CS/Region_Junin/huancayo/huancayo_PDU.pdf

En el siglo XXI el crecimiento urbano lineal de Huancayo ha generado procesos de conurbación entre distritos y provincias del Valle ocasionando que en los núcleos periféricos se formen áreas suburbanas sin planificación las cuales causan pérdida de terrenos agrícolas o asentamientos en zonas de riesgo (Plan de Desarrollo Urbano de Huancayo [PDU], 2015).

Alrededor del año 2002 Huancayo se moderniza y los gobiernos locales dieron prioridad a las inversiones viales en la ciudad. Hasta ese año la ciudad ocupaba aproximadamente 3,200 Ha. (Plan de Desarrollo Urbano de Huancayo [PDU], 2015). Las actividades económicas ya no solo eran comerciales, sino también de prestación de servicios a otros centros urbanos del Valle y la Región. La ciudad inicia un crecimiento urbano tomando como eje estructurador al Río Shullcas. 
Figura 2. 19 Nuevo eje estructurador, Río Shullcas

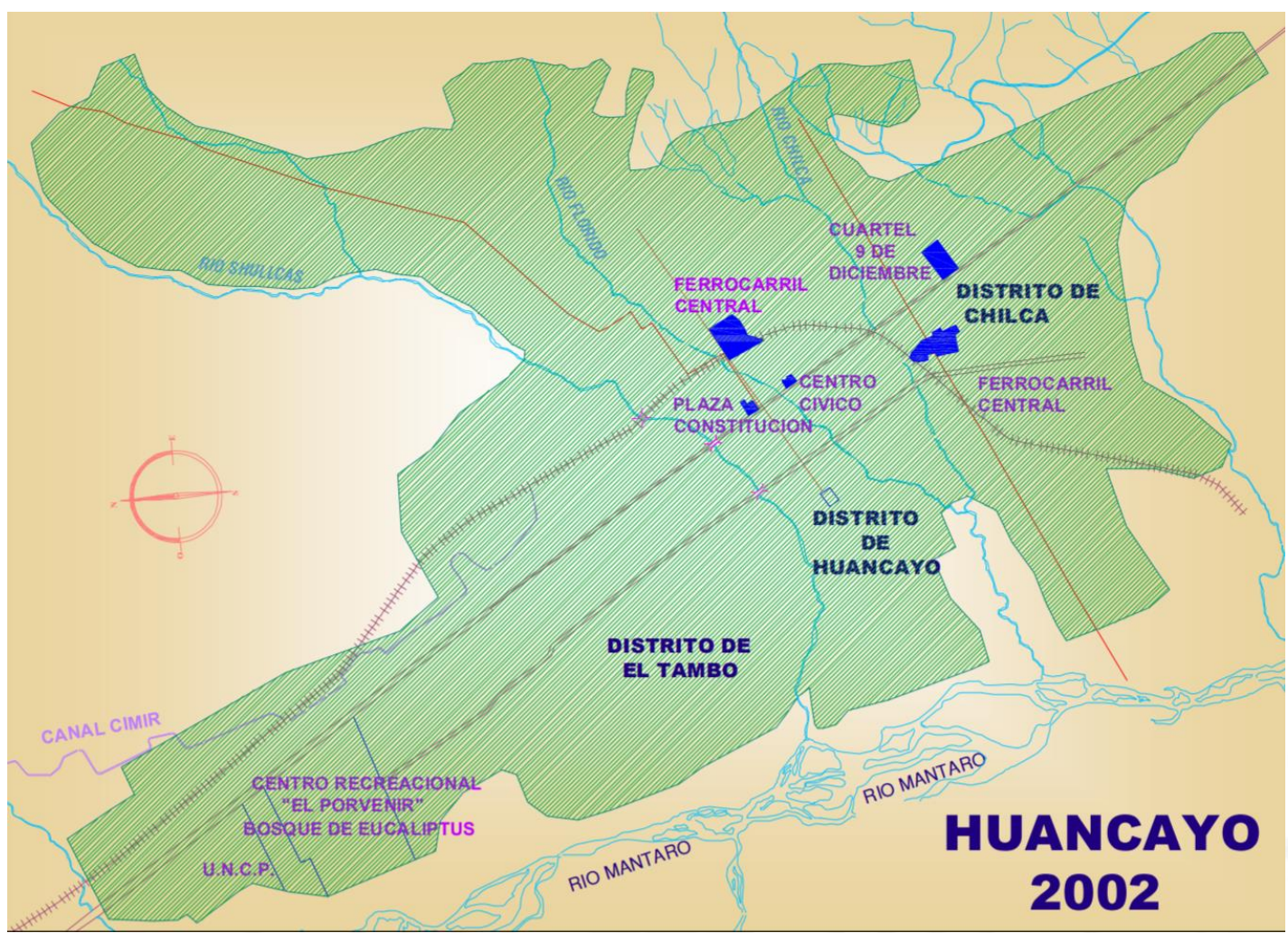

Fuente: Municipalidad Provincial de Huancayo (PDU,2006-2011)

http://bvpad.indeci.gob.pe/doc/estudios_CS/Region_Junin/huancayo/huancayo_PDU.pdf

\section{$\underline{\text { Actualidad }}$}

Actualmente el proceso de expansión urbana no respeta el patrimonio natural. Huancayo apuesta por la modernidad, pero no planifica, se observa en la arquitectura y en la ciudad que sufre constantes transformaciones sin preservar su pasado y solo apostar por el futuro. Sin embargo, no es errada la visión que tiene, pero la preservación del patrimonio permite entender y valorar la historia de la ciudad. (Bonilla Di Tolla, 2010).

Huancayo no tiene claro que debe preservar la relación con el valle y está generando un desequilibrio entre el área urbana y rural; el crecimiento demográfico de baja densidad está ocasionando procesos de conurbación que a la larga ocasionarán problemas urbanos (Bonilla Di Tolla, 2010). 


\subsubsection{Planes urbanos de Huancayo}

En el proceso de crecimiento urbano de la ciudad de Huancayo se han generado planes ordenamiento territorial basados en el eje estructurante de la Calle Real. Surge una necesidad de planificar y ordenar la periferia, el transporte, equipamiento, vías y otros factores de la ciudad. El primer plan regulador es elaborado por el Ing. Oswaldo Ráez Patiño, el cual tuvo una vigencia de 10 años aproximadamente. (Plan de Desarrollo Urbano de Huancayo [PDU], 2015)

A continuación, se lista los siguientes planes.

- 954 Plan Regulador de la Ciudad de Huancayo (1,954-1,980), elaborado por el Ministerio de Fomento a solicitud de la Municipalidad Provincial de Huancayo y la Representación parlamentaria de Junín

- 1958 Plan Regulador de Chilca, formulado por la Oficina Nacional de Planes urbanos (ONPU) la cual se formuló un año después de la creación del distrito de Chilca en 1,957

- 1960 Plan Regulador para la Ciudad de Huancayo

- 1971 Plan de Expansión Urbana de la Ciudad de Huancayo

- 1972 Plan de Zonificación Comercial e Industrial

- 1978 Plan Director de Huancayo; así como su respectivo reajuste $(1,979)$

- 1996 Plan Director de Huancayo (1,996-2,005), así como su respectivo ajuste $(2,002)$

- 2,006 Plan de Desarrollo Urbano de Huancayo (2,006-2,011).

\subsubsection{Línea de Tiempo}

A continuación, (Lámina 2.2) presenta una línea del tiempo que conforma el crecimiento urbano de Huancayo que va desde el periodo prehispánico hasta la actualidad. 
FUENTE: Plan de Desarrollo Urbano Huancayo 2015-2025/ Enciclopedia Departamental Junín
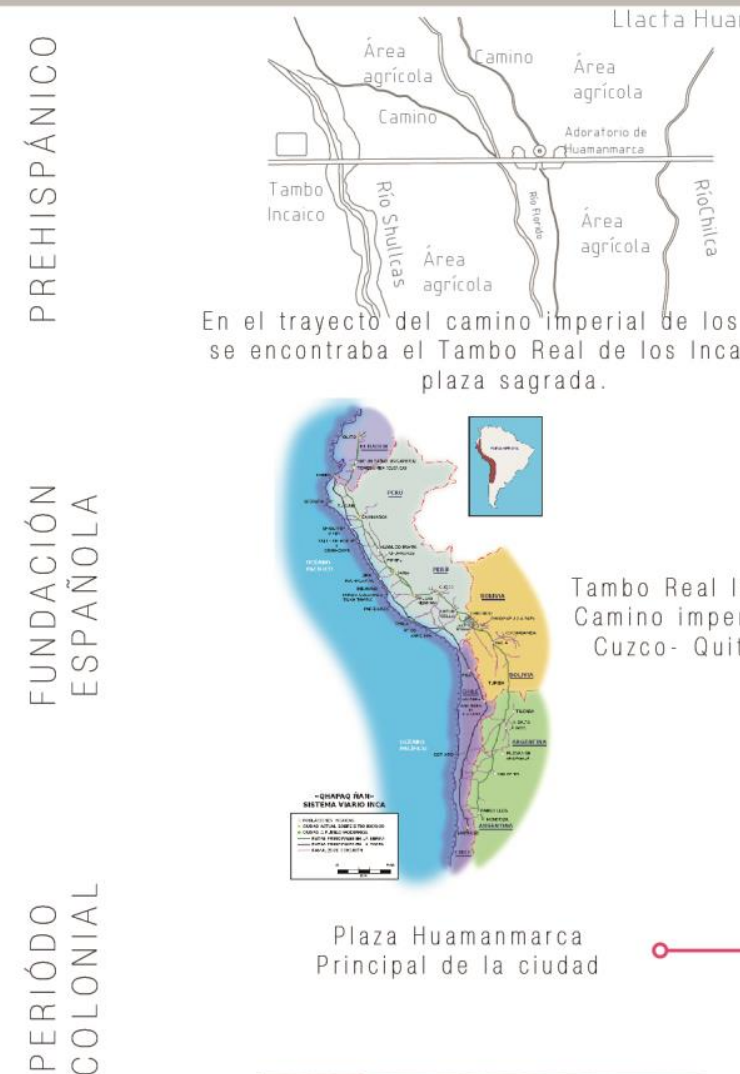

En el trayecto del camino imperial be los incas. se encontraba el Tambo Real de los Incas y su plaza sagrada.

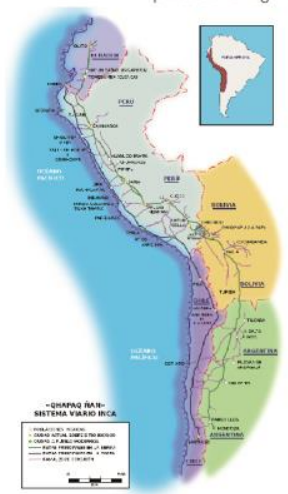

Tambo Real Inc Camino imperial Cuzco- Quito

Plaza Huamanmarca Principal de la ciudad

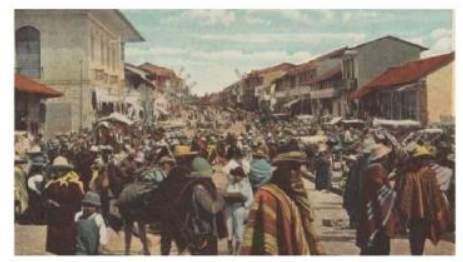

Comercio más importante FERIA DOMINICAL - CALLE REAL

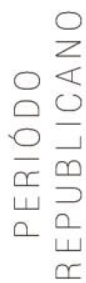

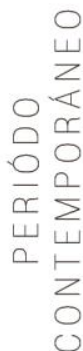

JURÓ LA CONSTITUCIÓN DEL CÁDIZ EN LA PLAZA CONSTITUCIÓN

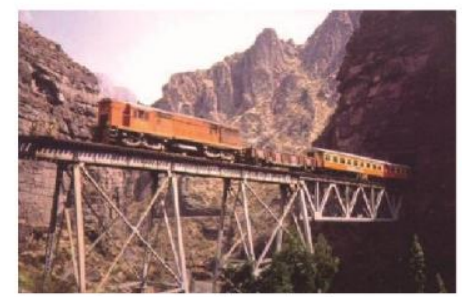

ferrocarril central

LIMA-HUANCAYO

CIUDAD COMERCIAL APARICIÓN DE PLANES URBANOS

\section{$\stackrel{10}{0}$}

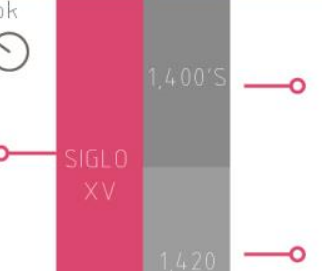

$\longrightarrow$

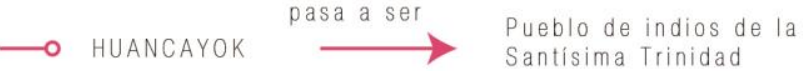

1565

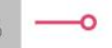

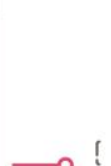

1572

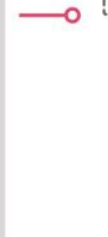

1.600

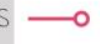

manzanas cuadradas, plaza, calles rectas $y$ estrechas

Viviendas de dos niveles

Huancayo es el poblado de mayor jerarquia en el Valle por la ruta estratégica.

CUSCO-LIMA

$1,700^{\prime} \mathrm{s}$
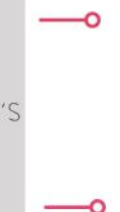

Creación de

la nueva población al

Norte de la ciudad

Hecho

$1,800^{\prime} \mathrm{s}$

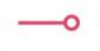

importante

Nueva catedral

Plaza constitución(《)

CAYOK se perfila en

Ia CALLE REAL

Fundación de las primeras ciudades

de Silva trazar una trama
urbana que incluya:

Plaza e Iglesia

Independencia de HUANCAYO

Creación

PROVINCIA DE

HUANCAYO

1908: Inaguración del ferrocarril central LIMA-HUANCAYO

1943: Creación del distrito El Tambo

1,945 Primer Plan Regulador de la ciudad de Huancayo (elaborado por el Ing. Oswaldo Ráez Patiño, el cual tuvo una vigencia de 10 años aproximadamente);

1,954 Plan Regulador de la Ciudad de Huancayo

(1,954-1,980), elaborado por el Ministerio de Fomento a solicitud de la Municipalidad Provincial de Huancayo y la Representación parlamentaria de Junín:

1,960 Plan Regulador para la Ciudad de Huancayo:

1,971 Plan de Expansión Urbana de la Ciudad de Huanca. yo:

1,972 Plan de Zonificación Comercial e Industrial;

1,978 Plan Director de Huancayo; así como su respectivo reajuste $(1,979)$;

1,996 Plan Director de Huancayo $(1,996-2,005)$, así como su respectivo ajuste $(2,002)$

2,006 Plan de Desarrollo Urbano de Huancayo

Ejes de crecimeinto principales en la ciudad de Huanca-

Eje oeste: Huancayo-Chupaca

Eje Norte: Huancayo.Concepción-Jauja

Eje sur: Huancayo - Huayucachi

Centro de la ciudad 


\subsection{Situación actual de la ciudad de Huancayo}

\subsubsection{Ubicación}

El Valle del Mantaro es el valle más grande del Perú. Se ubica en los Andes Centrales y abarca parcialmente los departamentos de Junín, Cerro de Pasco, Huancavelica y Ayacucho (Grupo de Análisis para el Desarrollo [GRADE], 2009).

La zona del valle que pertenece al departamento de Junín cuenta con una extensión territorial de 53 kilómetros de longitud y ancho variable de 4 a 21 kilómetros. Presenta un relieve muy accidentado por la cercanía a la Cordillera Central y Occidental. Estas a su vez originan las más importantes redes hidrográficas del valle como el Río Mantaro. El departamento de Junín está conformado por la Región Metropolitana del Mantaro (RMM) que contempla las provincias de Junín, Tarma, Chanchamayo, Satipo, Huancayo, Chupaca, Concepción, Jauja y Yauli tal como muestran los siguientes mapas (Plan de Desarrollo Urbano de Huancayo [PDU], 2015)

Figura 2. 20 Provincias de la Región Metropolitana de Junín
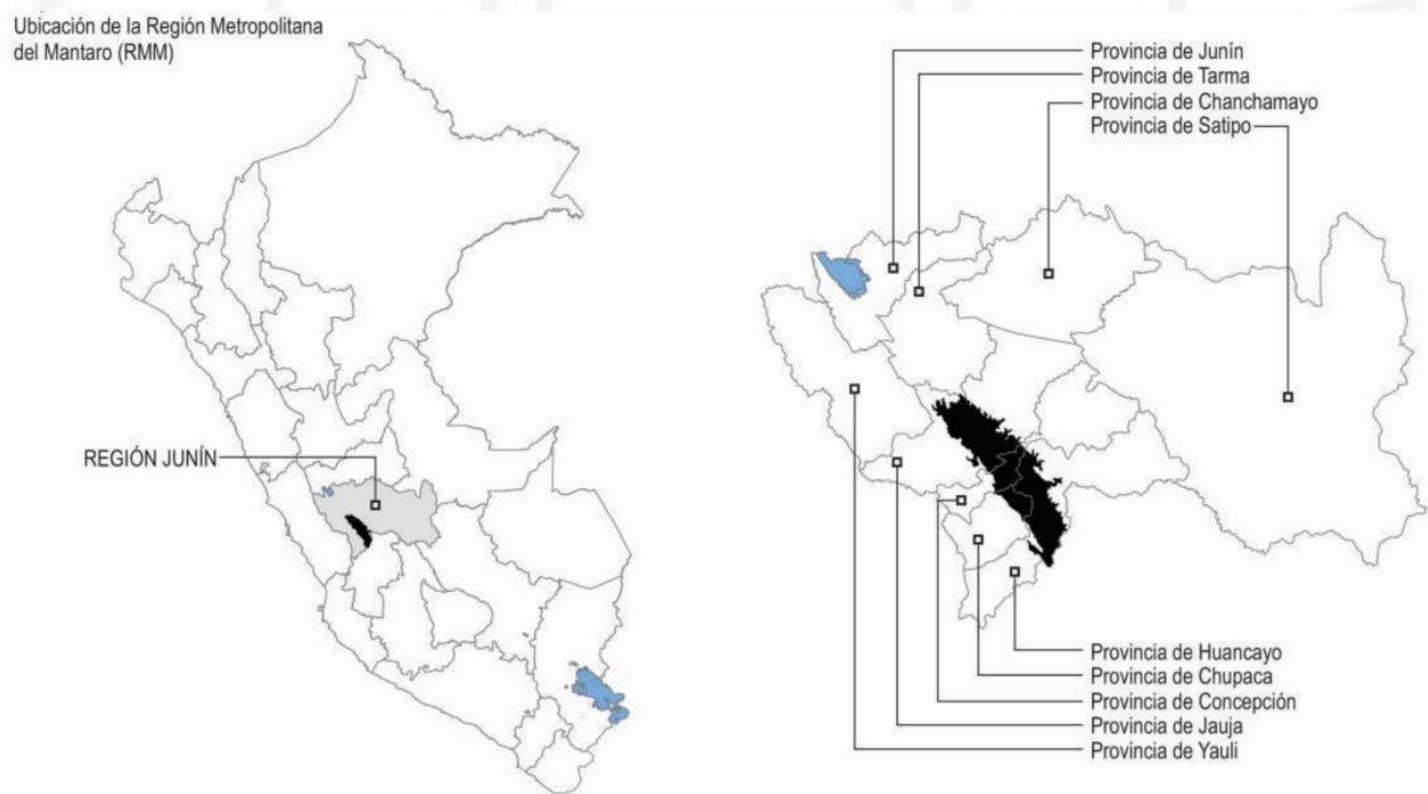

Nota: Ubicación de la Región Metropolitana del Mantaro

Fuente: Plan de Desarrollo Urbano de Huancayo 2015-2025 (PDUH)

https://www.munihuancayo.gob.pe/documentos/2015/gerencia_subgerencia/desarrollo_urbano/plan/Diag nosticoPDU.pdf 
Figura 2. 21 Sectores de la Región Metropolitana de Huancayo

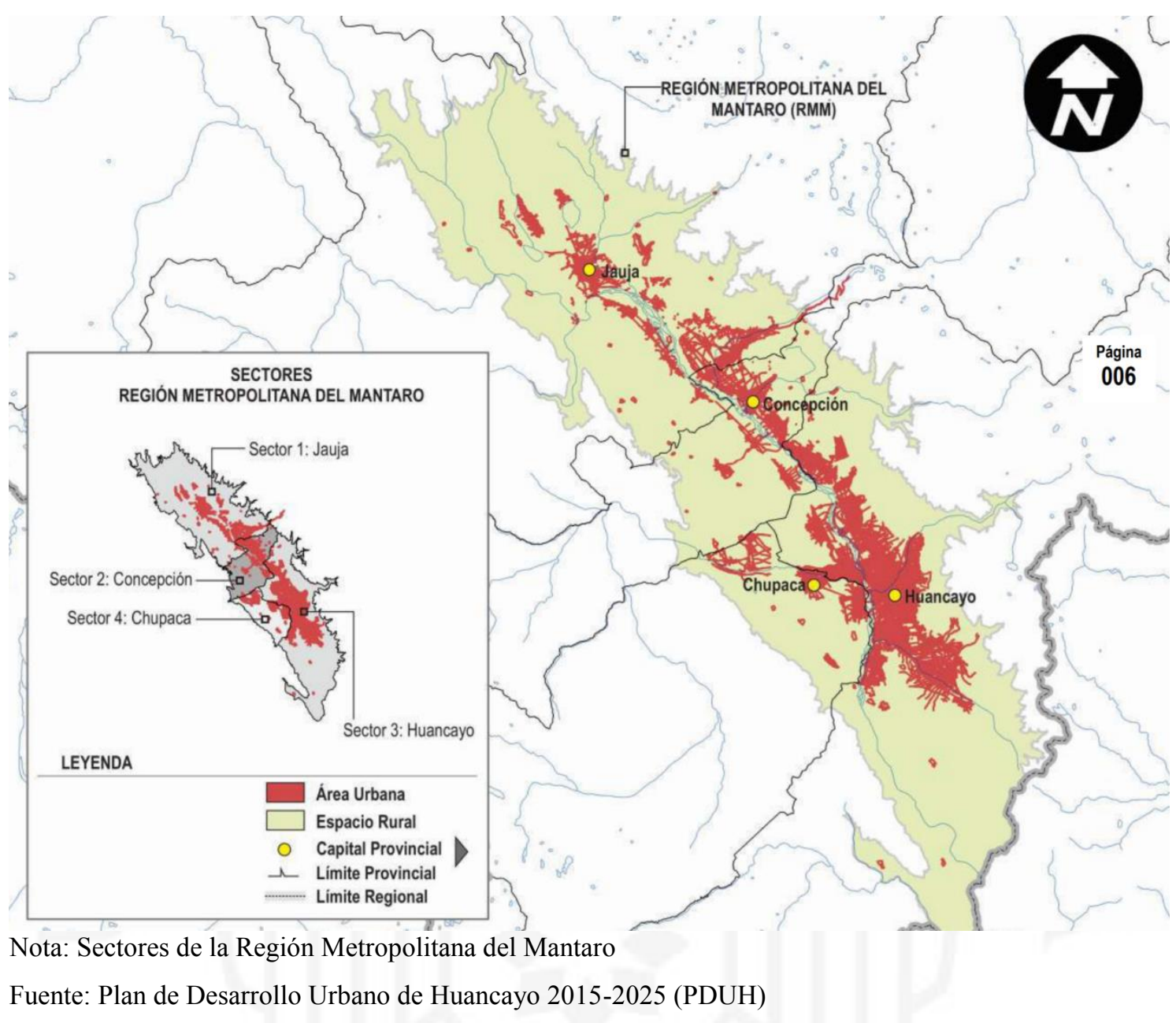

https://www.munihuancayo.gob.pe/documentos/2015/gerencia_subgerencia/desarrollo_urbano/plan/Diag nosticoPDU.pdf

La provincia de Huancayo es la capital de la Región Metropolitana del Mantaro y está ubicada a una altitud de 3200 m.s.n.m. (al centro del valle y con una superficie de $31,941 \mathrm{~km}^{2}$ ). Está conformada por el Área Central Metropolitana de la Ciudad de Huancayo $(\mathrm{ACMH})$ que engloba a los distritos de Huancayo, Tambo y Chilca se ubica en la margen izquierda del Río Mantaro, sobre una explanada que contiene a la subcuenca del Río Shullcas (cono aluvional del Nevado Huaytapallana). 


\subsubsection{Aspectos demográficos}

La provincia de Huancayo, que está conformado por 28 distritos, contaba con una población aproximada en el año 2015 de 503,139 habitantes según el Censo Nacional, concentrando al 37\% de la población de la región Junín (Instituto Nacional de Estadística e Informática [INEI], 2007).

De los 28 distritos que conforman la provincia de Huancayo, el distrito del Tambo cuenta con 161,429 personas y Huancayo con 116,953 personas, siendo los distritos más poblados de la provincia. Por otro lado, solo el $6 \%$ de la población de la provincia es rural, esto nos permite concluir que hay una expansión urbana acelerada de la ciudad (Instituto Nacional de Estadística e Informática [INEI], 2007).

Diagrama 2. 1 Porcentaje de población de las provincias de la Región Junín

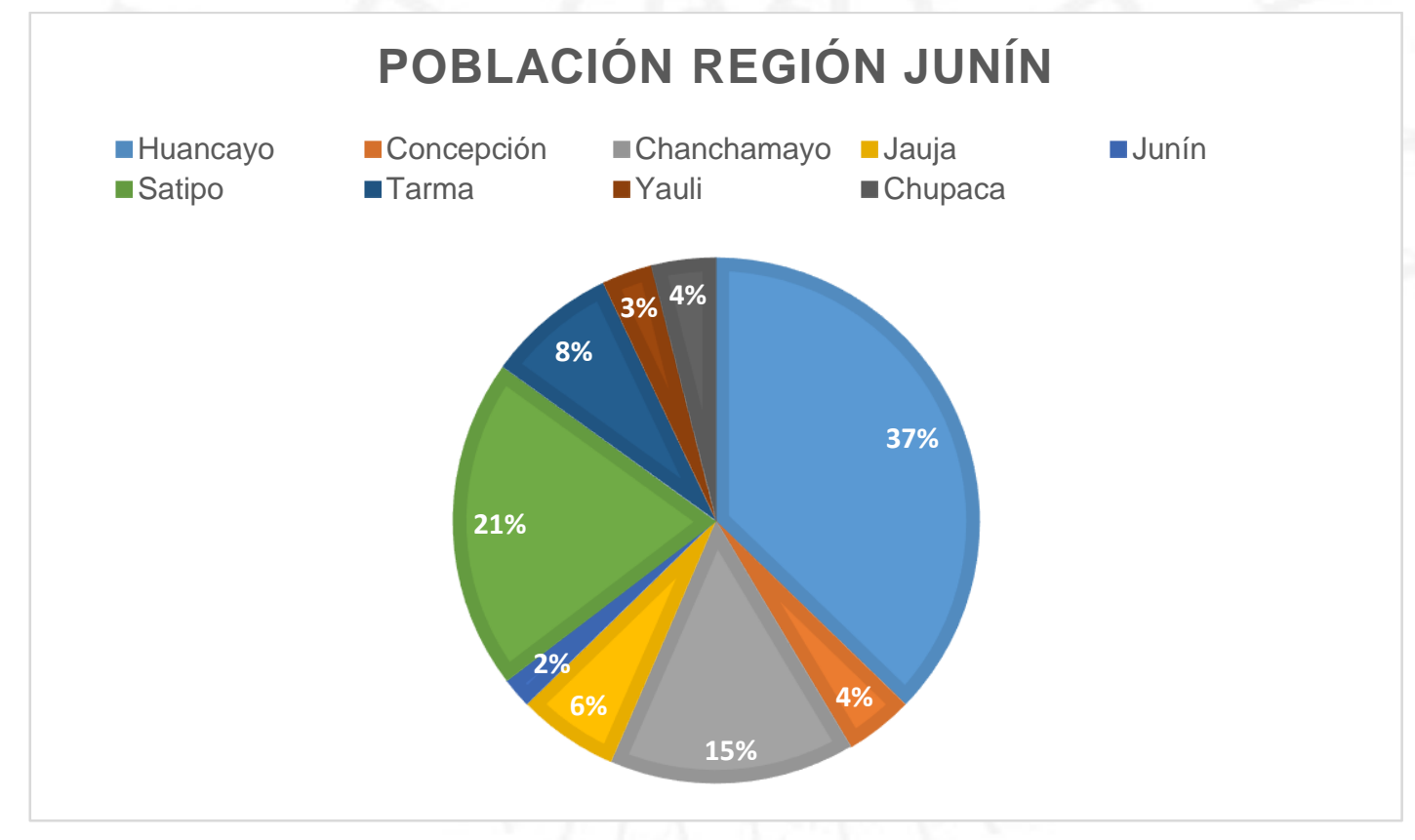

Fuente: Elaboración propia a partir de fuentes investigadas (INEI,2009)

\subsubsection{Aspectos socioeconómicos}

De los 28 distritos con los que cuenta la provincia, para el aspecto socioeconómico se tomará en cuenta los que conforman el Área Central Metropolitano de Huancayo (Huancayo, Tambo y Chilca) (Municipalidad Provincial de Huancayo, 2015) 
El crecimiento urbano acelerado de la provincia de Huancayo está provocando la necesidad de nueva infraestructura pública que es inexistente en la actualidad. Esta necesidad se ve reflejada en los índices de estudio de nivel de educación, acceso a servicios básicos, entre otras variables que se describen a continuación.

Diagrama 2. 2 Población urbana y rural según nivel de estudios culminados de la Provincia de Huancayo

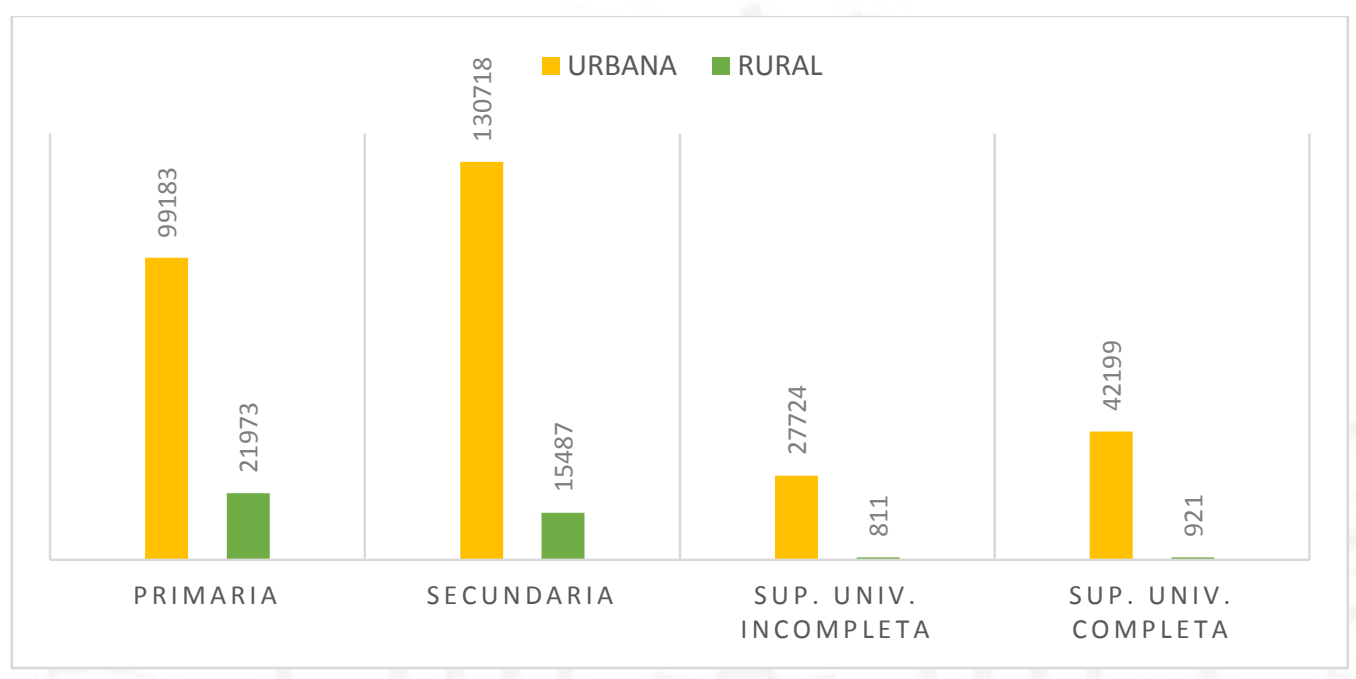

Fuente: Elaboración propia a partir de fuentes investigadas (INEI, 2009)

En la gráfica se observa que la población con primaria y secundaria completa es urbana y rural; sin embargo, al observar los datos respecto a la educación superior universitaria la población urbana es la que continúa con este tipo de estudios, mientras que la población rural en cantidades mínimas. El panorama es grave al ver que el área urbana y rural no tiene equidad de educación. 
Diagrama 2. 3 Población urbana según nivel de estudios culminados de la Provincia de Huancayo

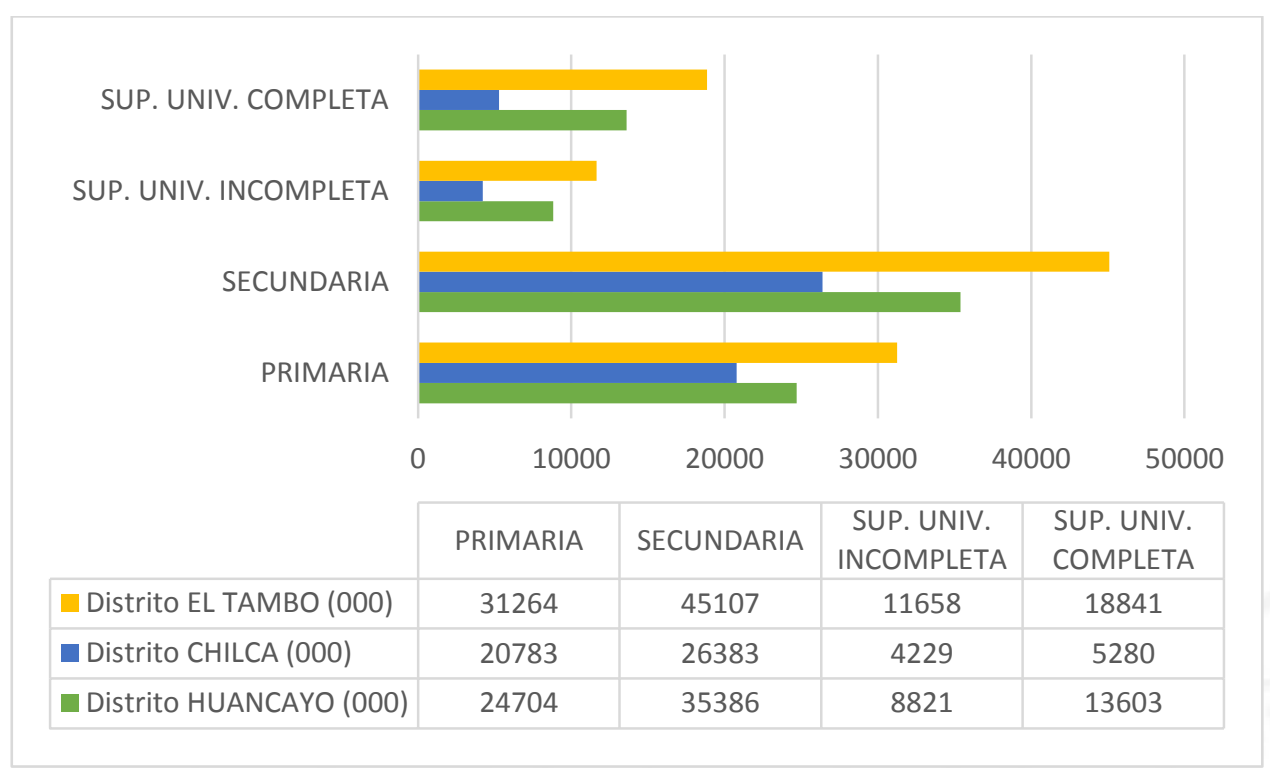

Nota: Área urbana conformada por el Área Central Metropolitano de Huancayo

Fuente: Elaboración propia a partir de fuentes investigadas (INEI, 2009)

Respecto al nivel de educación, los distritos de Tambo y Huancayo presentan mayor población con primaria y secundaria. Los resultados demuestran que la población mayoritaria en el ACMH es “joven”, esto significa un bajo nivel de especialización laboral y por ello menor competitividad, siendo necesario la creación de nuevo equipamiento que aporte en la educación y concientización de la población. 
Diagrama 2. 4 Formas de abastecimiento de agua potable en la Provincia de Huancayo

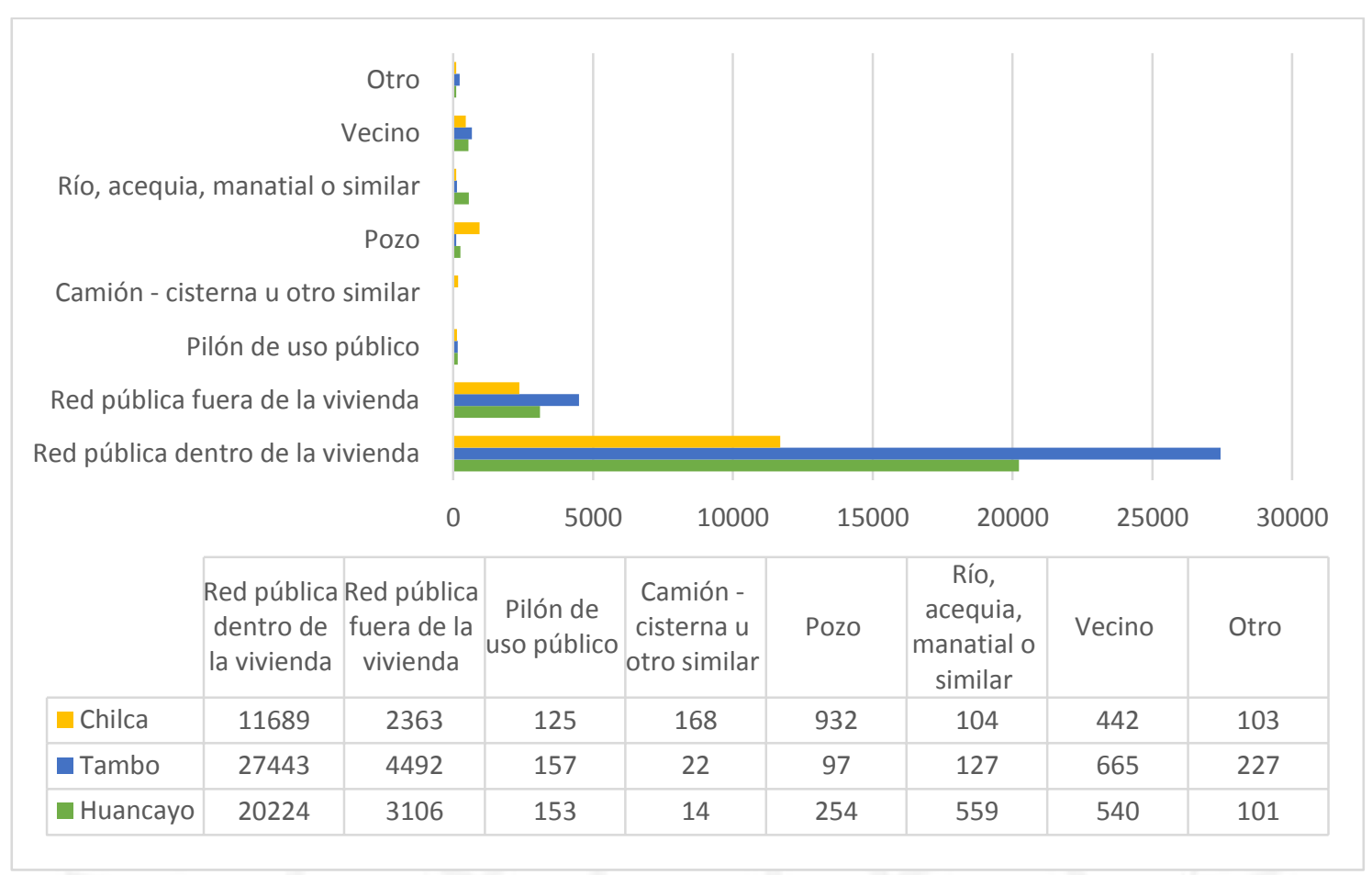

Fuente: Elaboración propia a partir de fuentes investigadas (INEI,2009)

Según los resultados de la gráfica la principal forma de abastecimiento del servicio de agua potable es la red pública dentro de la vivienda y el distrito del Tambo presenta mayor población con este tipo de abastecimiento. Sin embrago, aún hay población urbana que no cuenta con redes de abastecimiento de agua potable dentro de la vivienda. ocasionando una baja calidad de vida y una falta de acceso al agua apta para el consumo humano, además del equipamiento necesario para la producción de agua potable.

En relación al alumbrado eléctrico por red pública, la gráfica demuestra que el Área Central Metropolitano de Huancayo (ACMH) está cubierto en su totalidad. 
Diagrama 2. 5 Cobertura de alumbrado eléctrico por distrito

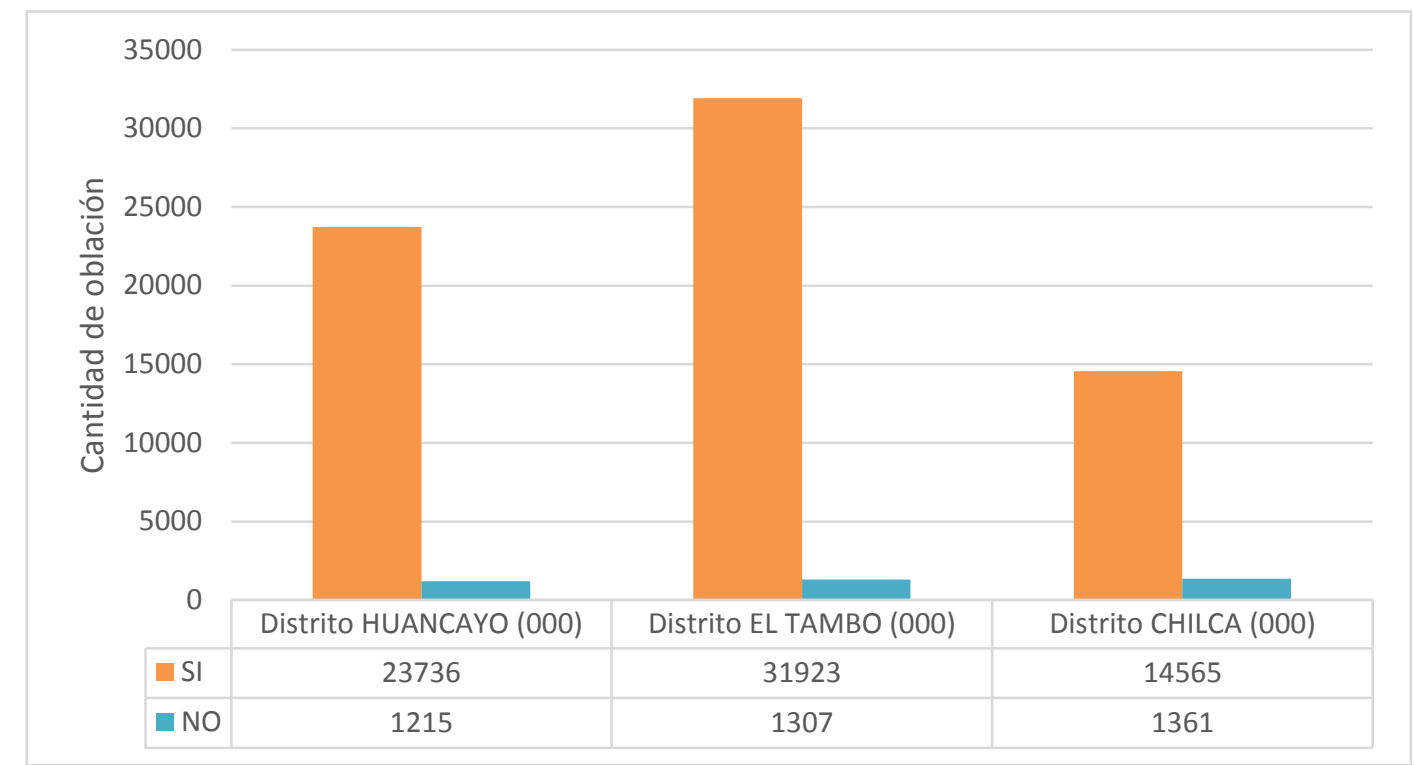

Fuente: Elaboración propia a partir de fuentes investigadas (INEI,2009)

\subsubsection{Espacio público y equipamiento}

El espacio público en Huancayo se compone por área recreativa pasiva y activa. El área recreativa pasiva está conformada por parques y plazas que contabilizan un área mínima $1.5 \mathrm{~m}^{2}$ por habitante, ubicando esta cifra por debajo de lo establecido por la Organización Mundial de la Salud que corresponde a $9 \mathrm{~m}^{2}$ por habitante. Mientras, el área recreativa activa está compuesto por áreas destinadas al deporte que contabilizan un área mínima de $1.6 \mathrm{~m}^{2}$ por habitante, siendo los estándares internacionales de $10 \mathrm{~m} 2$ de área deportiva por habitante, para la recreación y practica de algún deporte. (Municipalidad Provincial de Huancayo, 2014).

La tabla 2.2 muestra la cantidad de parques, plazas y áreas verdes de los sectores que conforman la provincia de Huancayo y la tabla 2.3 referente al espacio público de recreación activa. 
Tabla 2. 2 Infraestructura de recreación pasiva

\begin{tabular}{|c|c|c|c|c|c|c|c|c|c|c|}
\hline Sectores urbanos & Población & Parques & $\mathrm{m} 2$ & Plazas & $\mathrm{m} 2$ & $\begin{array}{c}\text { Parques } \\
\text { ecológicos }\end{array}$ & $\mathrm{m} 2$ & Total & $\%$ & Áreas verdes \\
\hline Cajas Chico & 12,002 & 3 & 18,839 & & & & & 18,839 & 2000 & \multirow{26}{*}{$\begin{array}{l}\text { Calles, } \\
\text { alamedas, } \\
\text { rotondas, } \\
\text { jirones, pasajes } \\
\text { prolongaciones } \\
\text { triángulos, } \\
\text { avenidas }\end{array}$} \\
\hline Cerrito de la Libertad & 5,437 & 1 & 880 & & & 1 & 2,076 & 2,956 & 314 & \\
\hline Chorrillos & 2,836 & 10 & 33,385 & & & 2 & 4,574 & 37,959 & 4030 & \\
\hline Constitución & & 3 & 8,401 & & & & & 8,401 & 892 & \\
\hline Huancayo & 33,749 & 5 & 9,922 & 1 & 7,309 & & & 17,231 & 1829 & \\
\hline Inmaculada & & 1 & 390 & & & & & 390 & 41 & \\
\hline Madre Wanka & & 2 & 1,923 & & & & & 1,923 & 204 & \\
\hline Palian & 4,622 & 1 & 495 & & & & & 495 & 53 & \\
\hline Pichcus & 2,285 & 1 & 1,200 & & & 1 & 600 & 1,800 & 191 & \\
\hline Ramiro Priale & & 1 & 90 & & & & & 90 & 10 & \\
\hline San Carlos & 14,564 & 2 & 17,636 & & & 6 & 30,842 & 48,478 & 5146 & \\
\hline Yauris & & 4 & 12,790 & & & 2 & 3,487 & 16,277 & 1728 & \\
\hline Cooperativa Santa Isabel & 3,036 & & & & & & & & 0 & \\
\hline La Rivera & 1,244 & & & & & 1 & 2,149 & 2,149 & 228 & \\
\hline Ocopilla & 8,238 & & & & & 1 & 3,600 & 3,600 & 382 & \\
\hline Corazon Wanka & & & & & & & & & 0 & \\
\hline Los Libertadores & 1,610 & & & & & 1 & 1,851 & 1,851 & 196 & \\
\hline $\begin{array}{l}\text { Pultuquia } \\
\end{array}$ & 7,593 & & & & & & & & 0 & \\
\hline $\begin{array}{l}\text { Yanama } \\
\end{array}$ & 2,458 & & & & & & & & 0 & \\
\hline San Antonio & 3,239 & & & & & 1 & 850 & 850 & 90 & \\
\hline Salcedo & 530 & & & & & & & & 0 & \\
\hline Corona del Fraile & & & & & & & & & 0 & \\
\hline Otros & 4,195 & & & & & & & & 0 & \\
\hline Panchito & & & & & & 2 & 4,546 & 4,546 & 483 & \\
\hline Acopalca & & & & & & 1 & 900 & 900 & 96 & \\
\hline Hualmita & & & & & & 1 & 942 & 942 & 100 & \\
\hline Total & 107,665 & 35 & 105,951 & 1 & 7,309 & 20 & 56,417 & 169,677 & & 121,493 \\
\hline
\end{tabular}

Fuente: Memoria 2014

https://www.munihuancayo.gob.pe/documentos/2014/informe_anual/memoria2014.pdf

Tabla 2. 3 Espacio público de recreación activa

DISTRITO DE HUANCAYO: ESPACIOS PUBLICOS DE RECREACION ACTIVA, 2014

\begin{tabular}{|c|l|l|c|r|}
\hline $\mathbf{N}^{*}$ & \multicolumn{1}{|c|}{ JUNTA VECINAL } & \multicolumn{1}{c|}{ NOMBRE DEL CAMPO DEPORTIVO } & m2 & \multicolumn{1}{c|}{$\%$} \\
\hline 1 & AAHH Sta Rosa & Losa deportiva Santa Rosa & 750 & 1 \\
\hline 2 & Cerrito de la Libertad & losa deportiva múltiple & 4,200 & 7 \\
\hline 3 & Cerrito de la Libertad & Las Rosas & 1,200 & 2 \\
\hline 4 & Chorrillos & Chorrillos & 4,632 & 8 \\
\hline 5 & Chorrillos & Campeones Nacionales & 2,680 & 5 \\
\hline 6 & Chorrillos & Miguel Grau & 4,829 & 8 \\
\hline 7 & Chorrillos & Polideportivo Familia Wanka & 15,000 & 26 \\
\hline 8 & Soto Valle & Loza deportiva Soto Valle & 1,226 & 2 \\
\hline 9 & Corazón Wanka & Saúl Muñoz Menacho & 893 & 2 \\
\hline 10 & Corazón Wanka & José G. Condorcanqui & 593 & 1 \\
\hline 11 & Los Libertadores & Chacabuco & 862 & 2 \\
\hline 12 & Ocopilla & Losa deportiva Canta Gallo & 735 & 1 \\
\hline 13 & Pultuquia & Hugo Gavino & 3,072 & 5 \\
\hline 14 & Salcedo & Salcedo & 2,948 & 5 \\
\hline 15 & San Carlos & Garay Salas & 2,516 & 4 \\
\hline 16 & Yanama & Carlos Cueto Fernandini & 1,656 & 3 \\
\hline 17 & Yauris & Juan Goyzueta & 2,908 & 5 \\
\hline 18 & Yauris & Leandra Lora Revollar & 3,000 & 5 \\
\hline 19 & La Rivera & Losa Los Jasmines & 405 & 1 \\
\hline 20 & Palian & Los Bosques & 900 & 2 \\
\hline 21 & Cooperativa Santa Isabel & Coop Sta Isabel & 1,500 & 3 \\
\hline 22 & Ocopilla & Canta Gallo & 700 & 1 \\
\hline TOTAL & & & 57,205 & 100 \\
\hline
\end{tabular}

Fuente: Memoria 2014

https://www.munihuancayo.gob.pe/documentos/2014/informe_anual/memoria2014.pdf 
En relación al equipamiento, está conformado por servicio recreativo, salud, cultural, comercio y educación. El mayor porcentaje corresponde al comercio con 50.2\% a diferencia de la infraestructura cultural con $2.2 \%$; salud $3.3 \%$ y recreativo $11.2 \%$. El equipamiento de mayor déficit es el servicio cultural. Esto significa que actualmente Huancayo no apuesta por la revaloración del patrimonio.

\subsection{Situación actual del Río Shullcas}

\subsubsection{Hidrografía}

El sistema hidrográfico del Valle del Mantaro (Lamina 2.3) está conformado por el Río Mantaro. Este se origina en la laguna Junín a unos 4080 m.s.n.m. y tiene un recorrido sobre la basta meseta del Bombón de $735 \mathrm{~km}$. en dirección sureste donde se ubican las importantes provincias como La Oroya, Jauja, Concepción y Huancayo. La cuenca del Río Mantaro contiene 20 subcuencas, de las cuales la del Shullcas será tema de esta investigación (Autoridad Nacional del Agua [ANA], 2010)

La subcuenca del Shullcas está ubicada en la Cordillera Oriental del Valle del Mantaro, en la provincia de Huancayo, departamento de Junín. Inicia su recorrido en el Nevado Huaytapallana, con 5,557 m.s.n.m. y finaliza en el Río Mantaro con 3200

m.s.n.m. La longitud de recorrido es aproximadamente de $35.9 \mathrm{~km}$. (Ministerio del Ambiente [MINAM], 2013) 
Figura 2. 22 Mapa Hidrográfico de la subcuenca del Río Shullcas

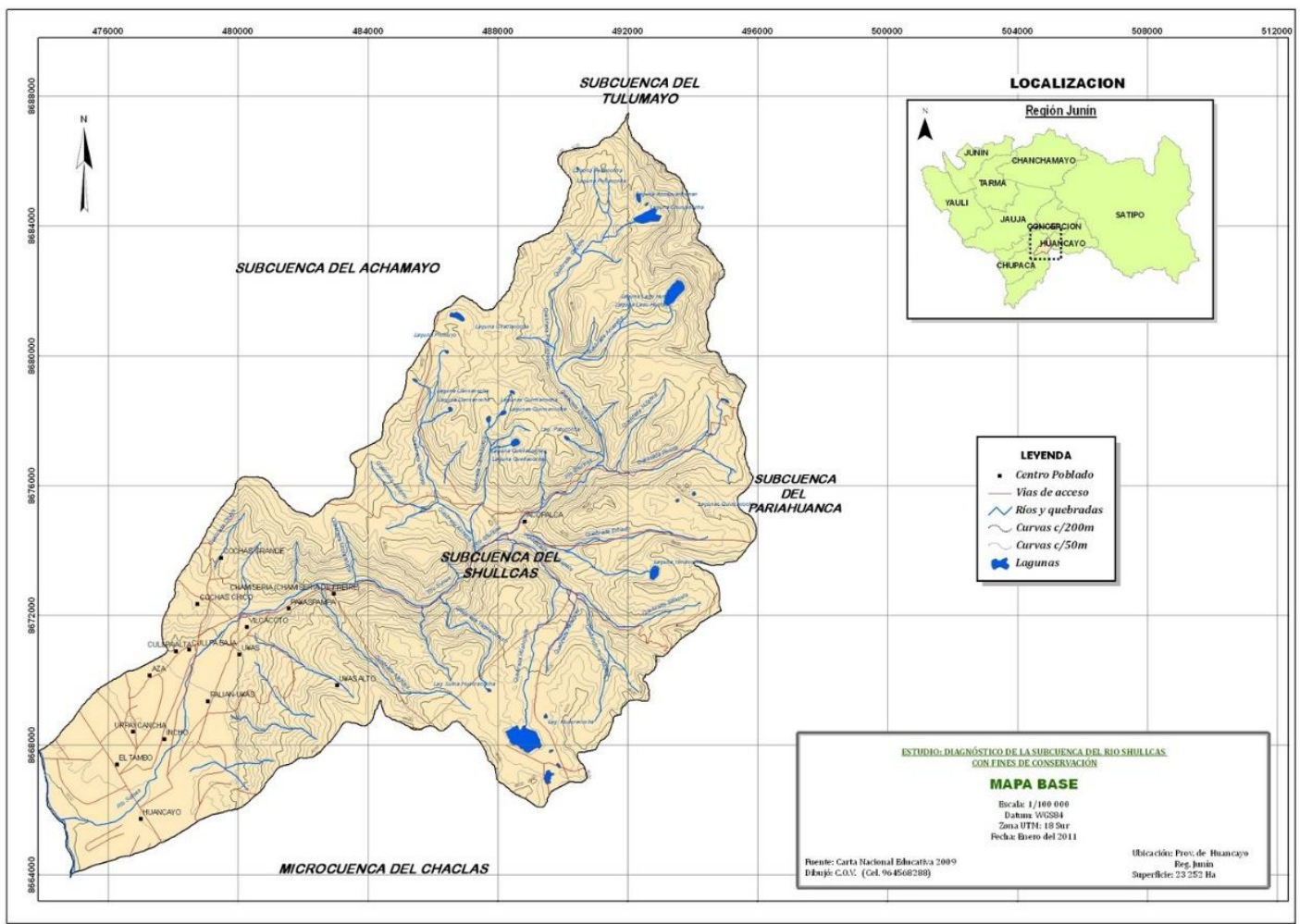

Fuente: Mapas Temáticos del Perú

http://mapasplanosperu.blogspot.com/

La topografía accidentada genera la existencia de una diversidad de microclimas que permiten el desarrollo de la agricultura a lo largo del eje del Río Shullcas como muestra el siguiente mapa (Ministerio del Ambiente [MINAM], 2013). 
Figura 2. 23 Mapa de Cobertura vegetal de la Subcuenca del Shullcas

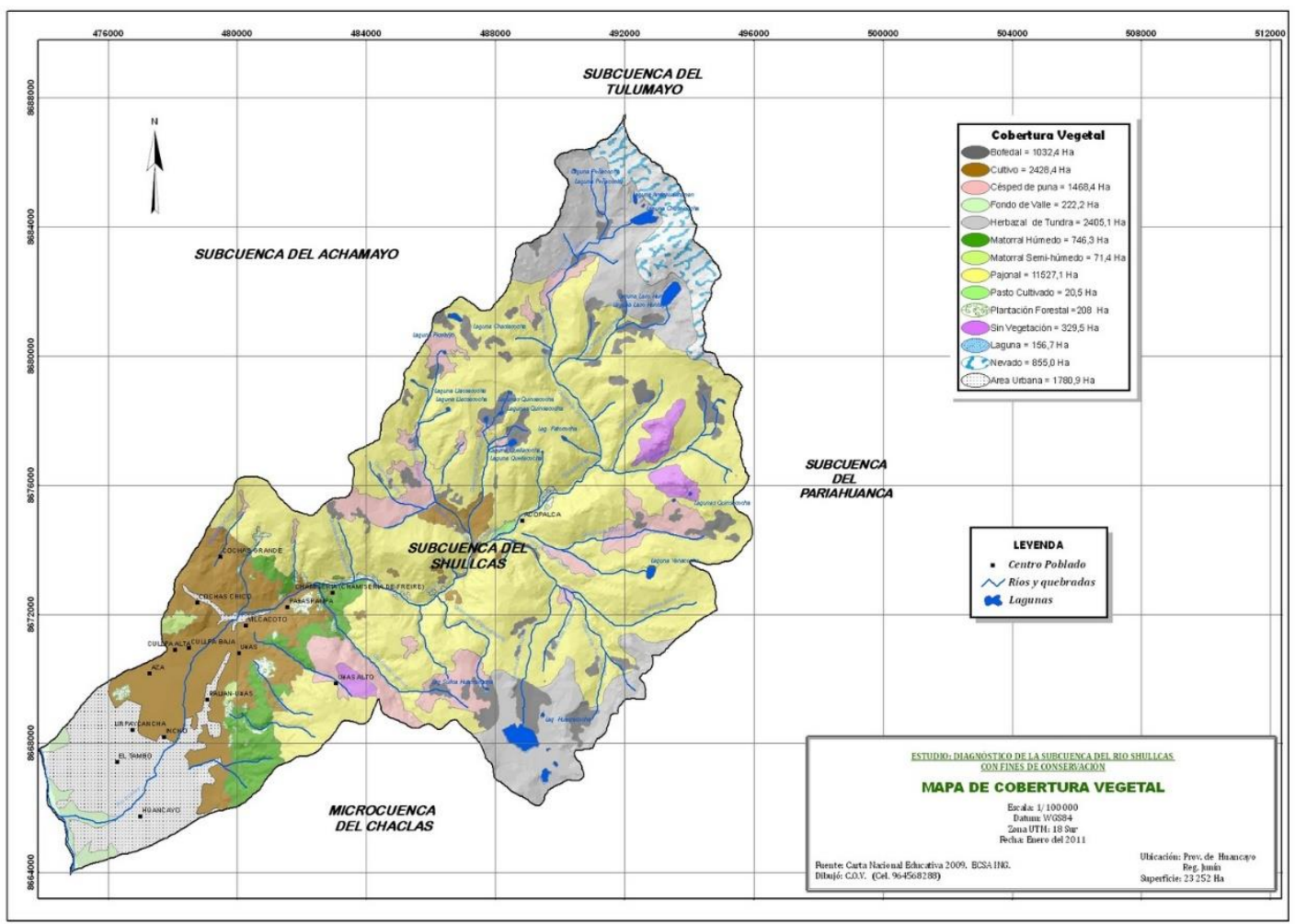

Fuente: S/A Recuperado de:

http://mapasplanosperu.blogspot.com/

El Río Shullcas es la fuente Hídrica principal de agua potable de la ciudad, mantiene un caudal promedio de $5 \mathrm{~m} 3 / \mathrm{s}$; sin embargo, tiene variaciones de acuerdo a las precipitaciones. El río pertenece a un régimen nivo lacustre, es decir sus fuentes de abastecimiento son las lagunas de Chuspicocha y Lazuntay en fusión con el hielo glaciar del Nevado Huaytapallana permitiendo un caudal permanente (Ministerio del Ambiente [MINAM], 2013). 
FUENTE: Indeci-PNUD / Municipalidad Provincial de Huancayo

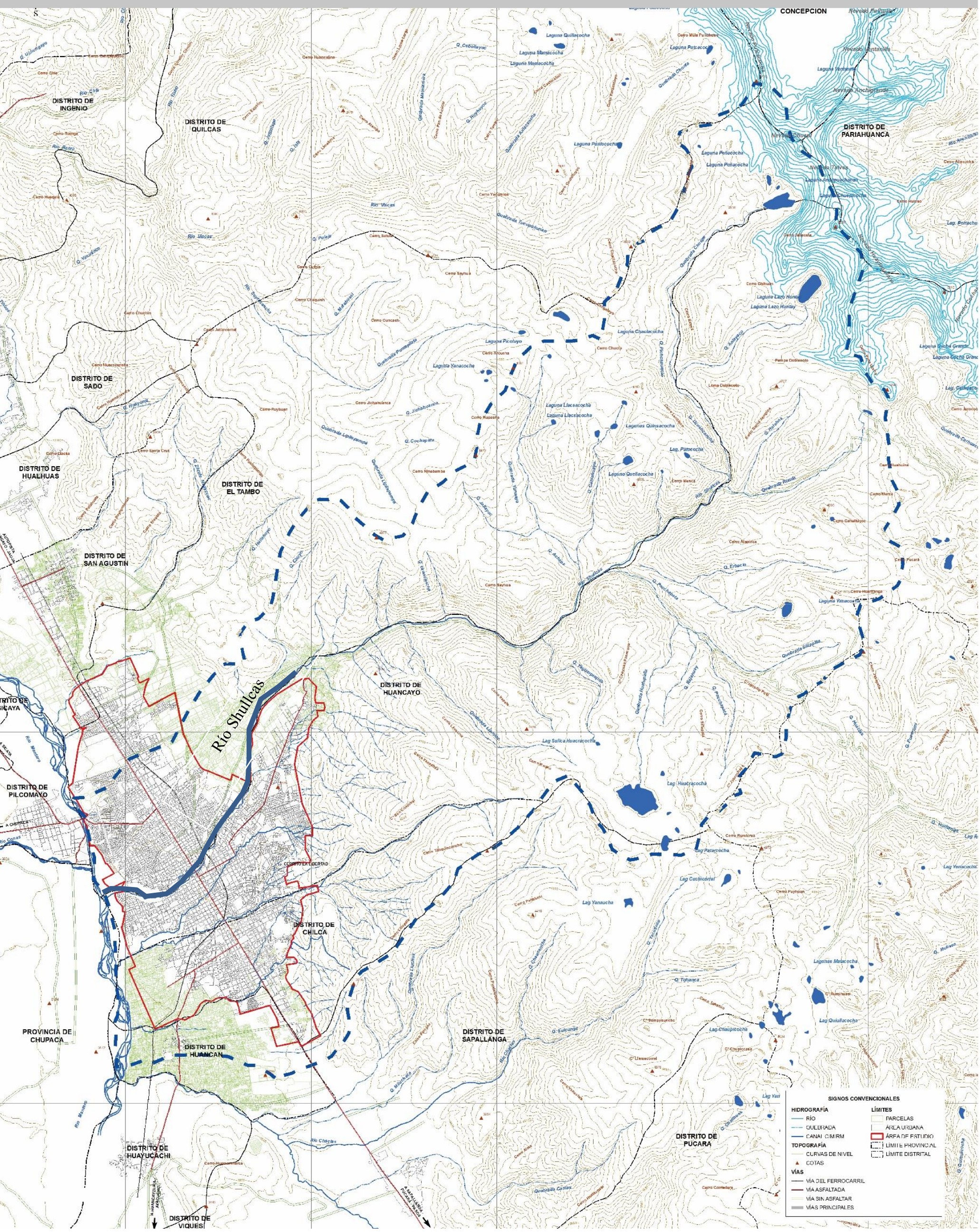




\subsubsection{Barrera Urbana}

Nos referimos a barrera urbana a la ruptura de tramas en el casco urbano de la ciudad. Se puede observar (Figura 2.24) al Río Shullcas como una barrera urbana que desarticula y divide el territorio ya que este no presenta un tratamiento en la transición de tramas. Las imagen adjunta (Figura 2.26 y figura 2.27) muestra la invasión del área libre en la ribera del río creando un límite al borde de esta. En la imagen (Figura 2.25 y figura 2.28) se puede observar la consolidación de viviendas al borde del río que ha ocacionado la descontinuidad de la trama urbana.

Figura 2. 24 Trama urbana de las márgenes del Río Shullcas

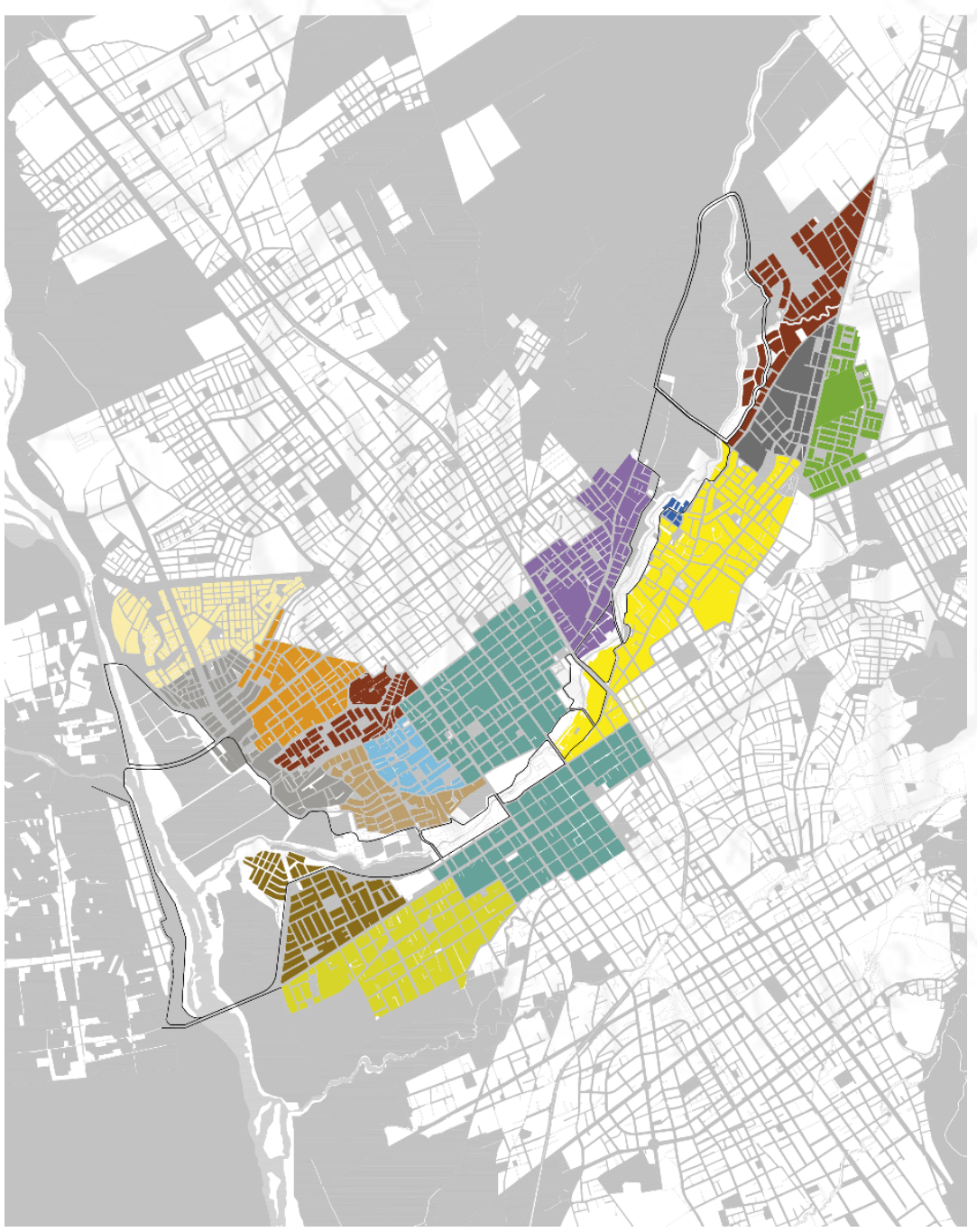

Nota: Los colores representan las distintas tramas en el entorno inmediato del Río Shullcas

Fuente: Elaboración propia basada en el PDU Huancayo 2015 
Figura 2. 25 Puente Amazonas

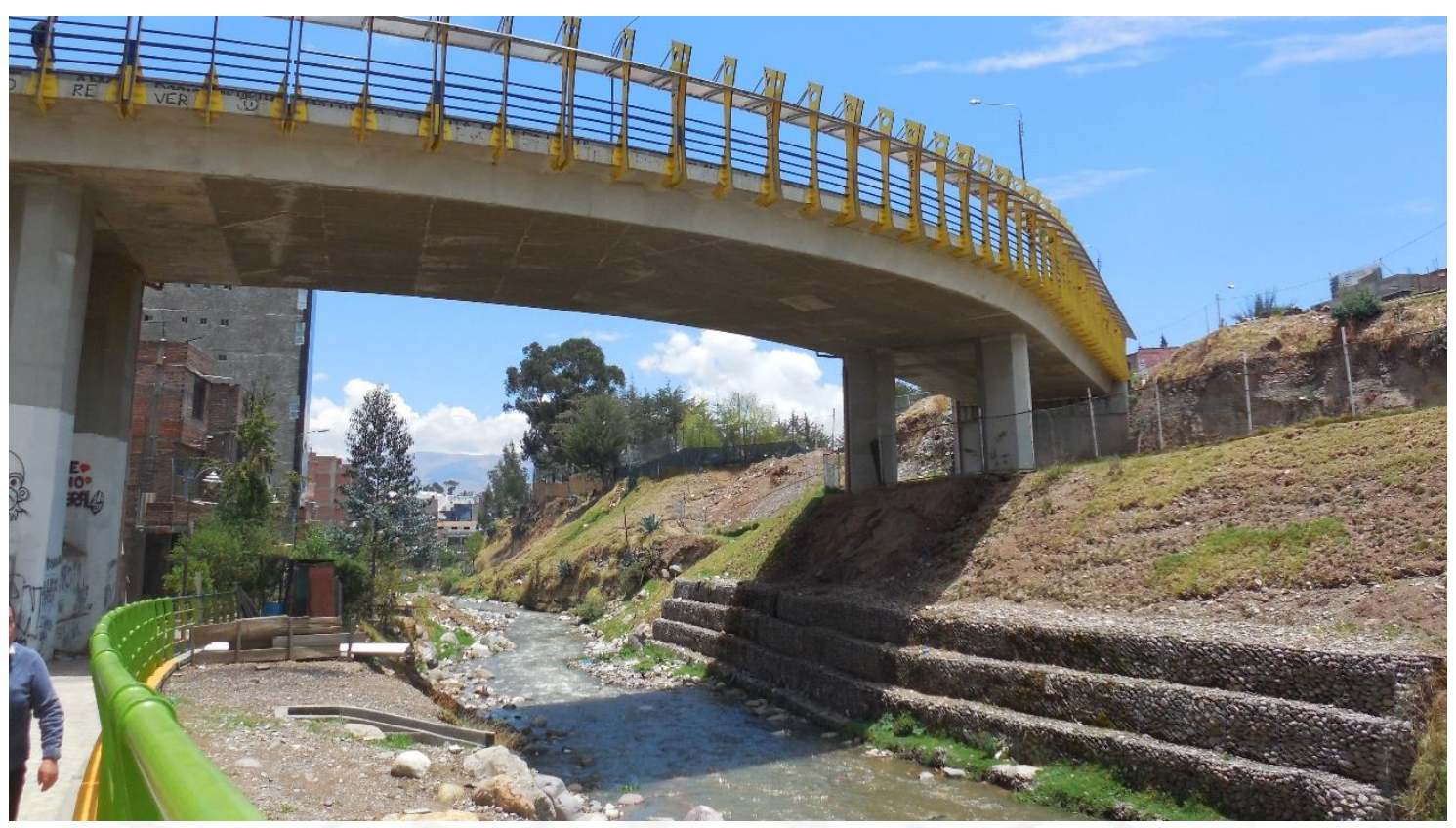

Nota: Vista peatonal que muestran las edificaciones asentadas en el borde del Río Shullcas

Fuente: Elaboración propia

Figura 2. 26 Imagen de la ribera del Shullcas

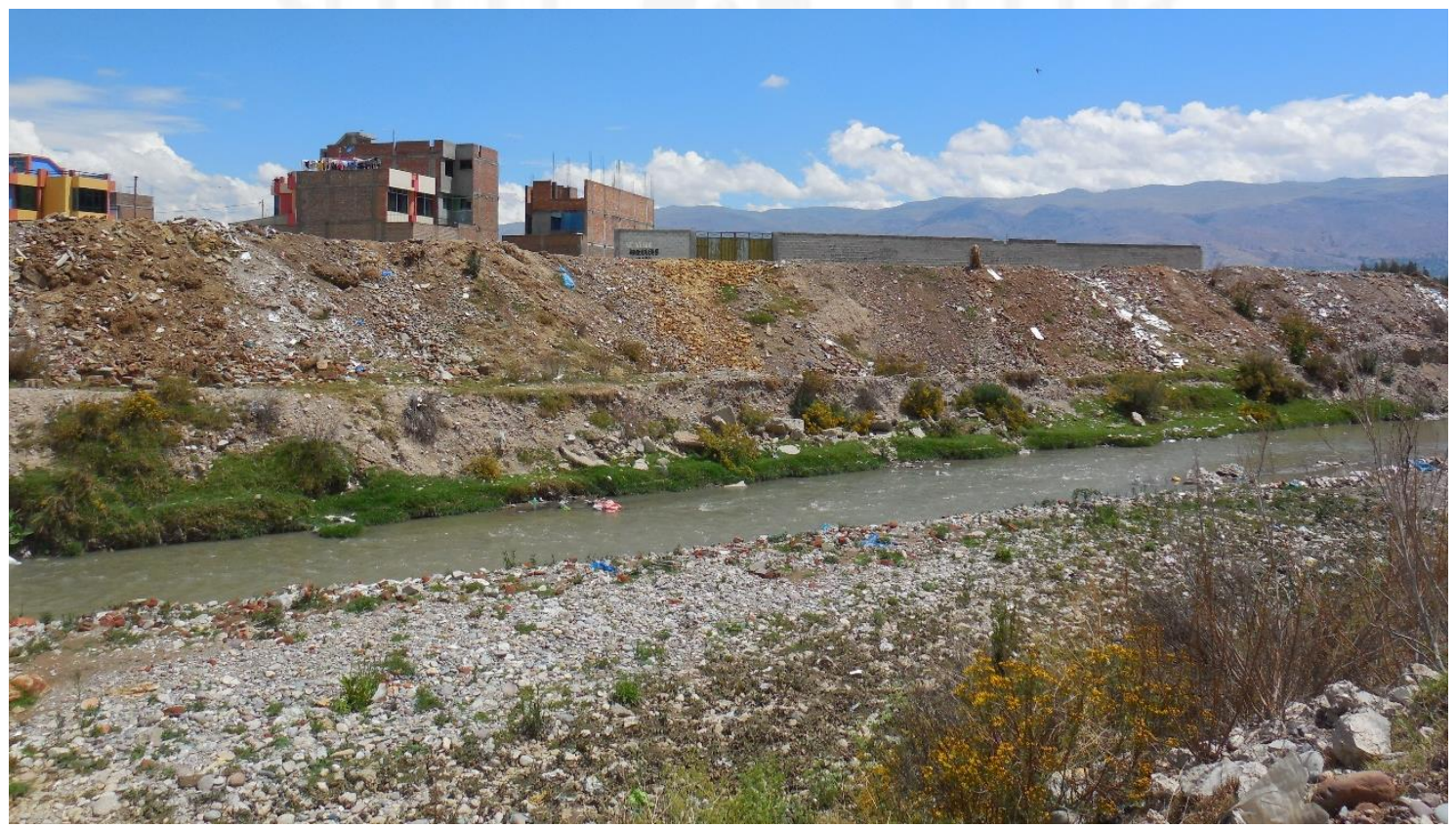

Nota: Vista peatonal que muestran el Shullcas como barrera urbana

Fuente: Elaboración propia 
Figura 2. 27 Imagen de la Ribera del Shullcas

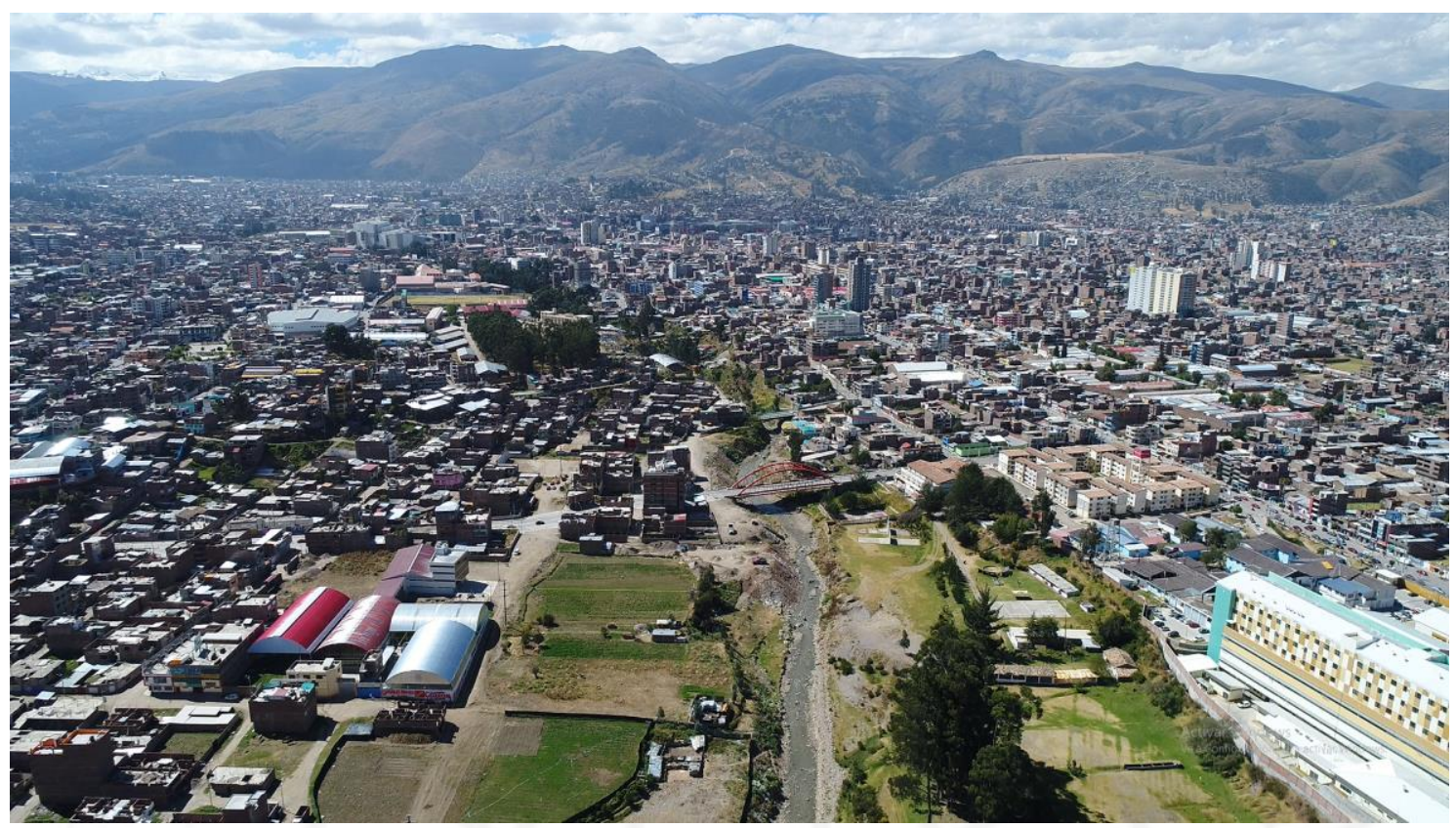

Nota: Vista aérea a la altura del Hospital Regional Daniel Alcides Carrión

Fuente: Elaboración propia

Figura 2. 28Imagen de la Ribera del Shullcas

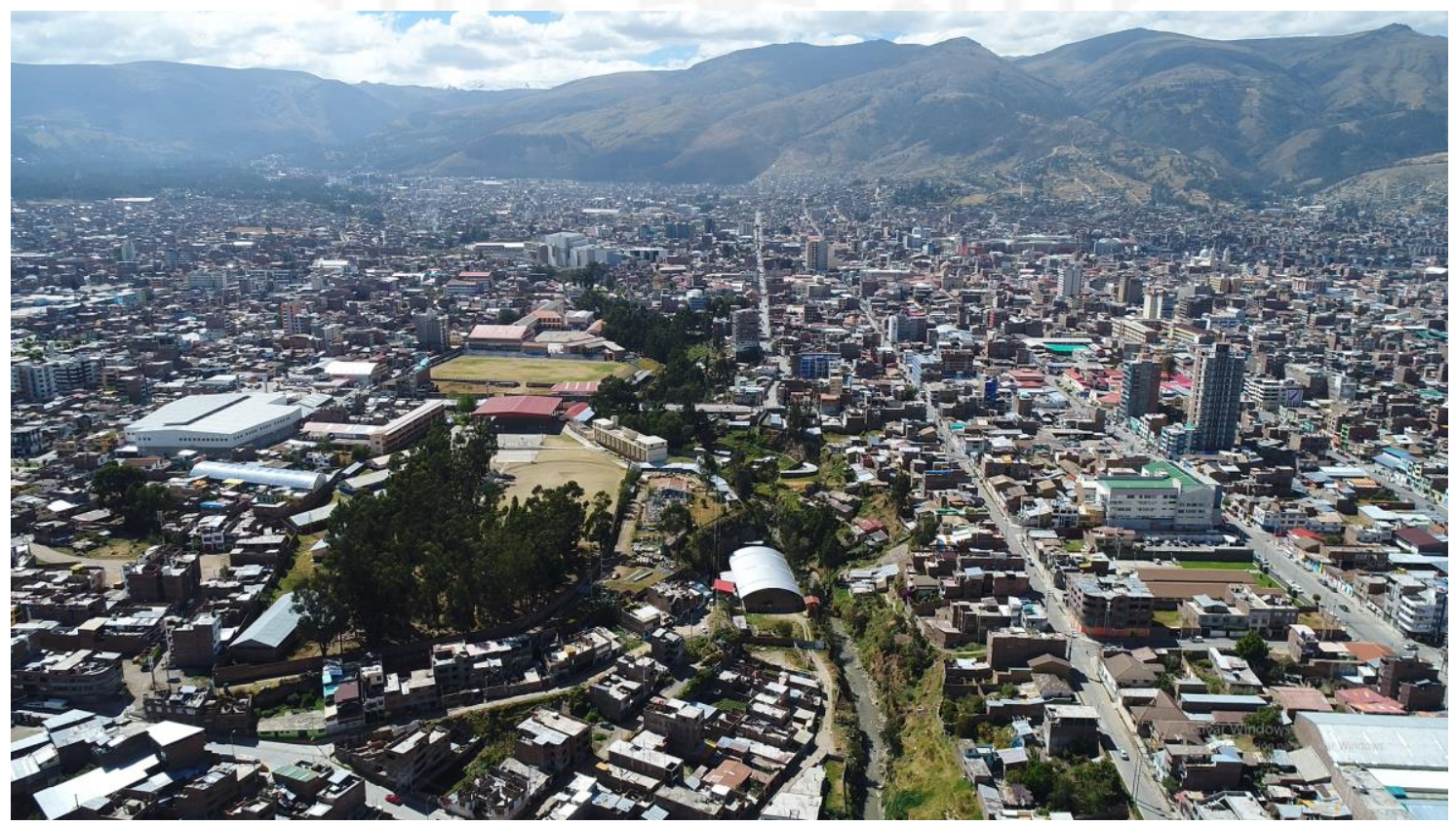

Nota: Vista aérea a la altura del Puente Huancavelica

Fuente: Elaboración propia 


\subsubsection{Contaminación del Río Shullcas}

Desde el punto de vista medioambiental, la situación del Río Shullcas se agrava por la contaminación de desechos sólidos (domésticos, industriales y de construcción) ubicados en botaderos informales a cielo abierto. (Figura 2.29, figura 2.30 y figura 2.31).

El 56\% del territorio de la región Junín tiene un mal manejo y segregación de los residuos sólidos, asimismo el 78\% de los distritos no cuenta con un relleno sanitario autorizado y en consecuencia el río es el más afectado por la contaminación, ya que se utiliza como botadero (Organismo de Evaluación y Fiscalización Ambiéntal [OEFA], 2014, p. 72-73).

El exceso de contaminación del río ha generado zonas de riesgo alto a lo largo del recorrido. Se puede encontrar botaderos de basura a cielo abierto compuestos de residuos sólidos, domésticos, industriales, etc. En el mapa (Lámina 2.4) se observa las zonas de alto riesgo por la contaminación de residuos sólidos. (Municipalidad Provincial de Huancayo, 2015). Como resultado, la contaminación de los bordes del Río Shullcas ocasiona efectos en la salud humana, alteración del suelo de entorno inmediato al río, la desaparición de la biodiversidad del valle generando así la pérdida del patrimonio natural.

Figura 2. 29 Contaminación de residuos sólidos en la ribera del Shullcas

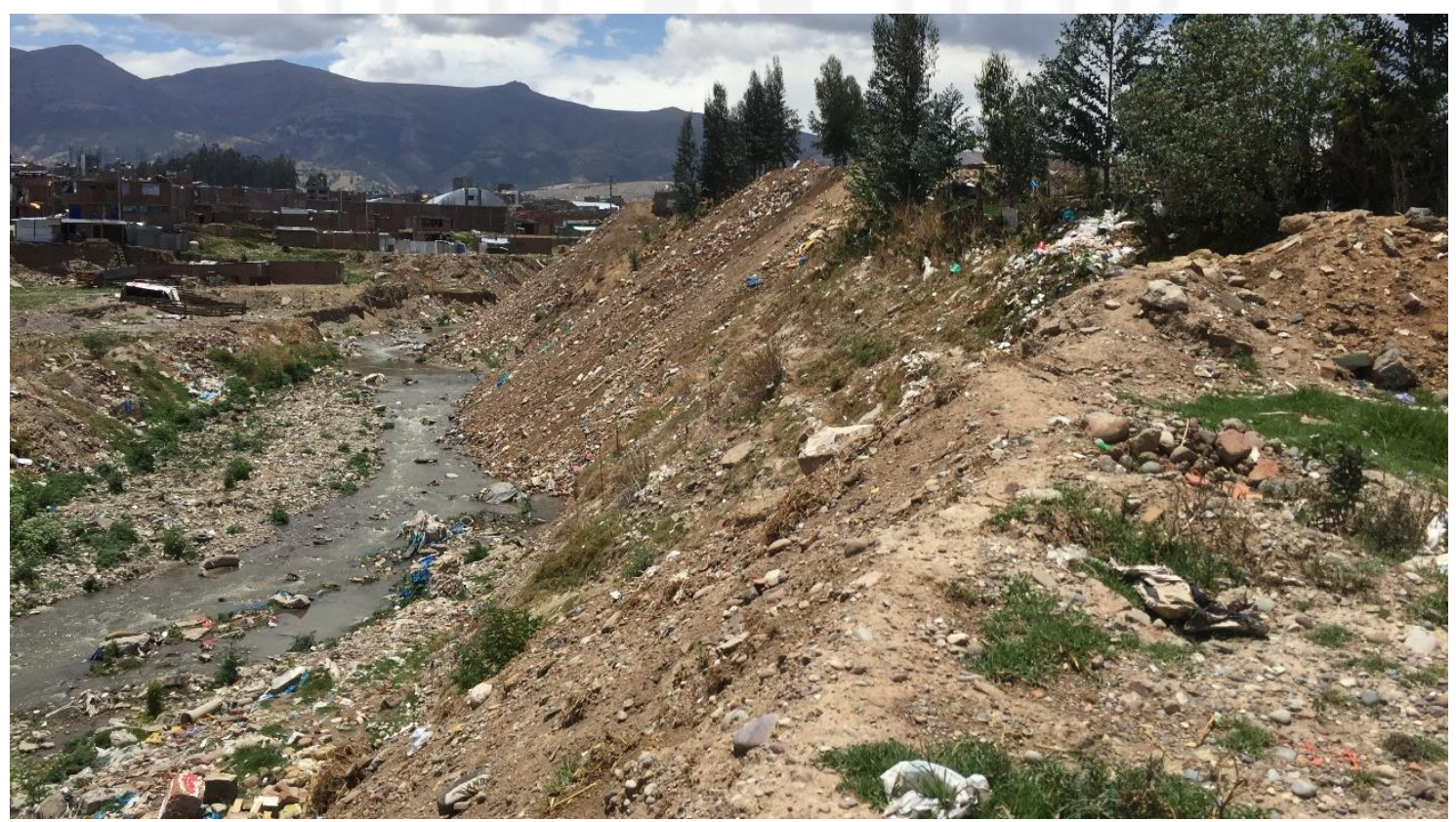

Nota: Vista peatonal de la margen derecha del Río Shullcas

Fuente: Elaboración propia 
Figura 2. 30 Contaminación de residuos sólidos en la ribera del Shullcas

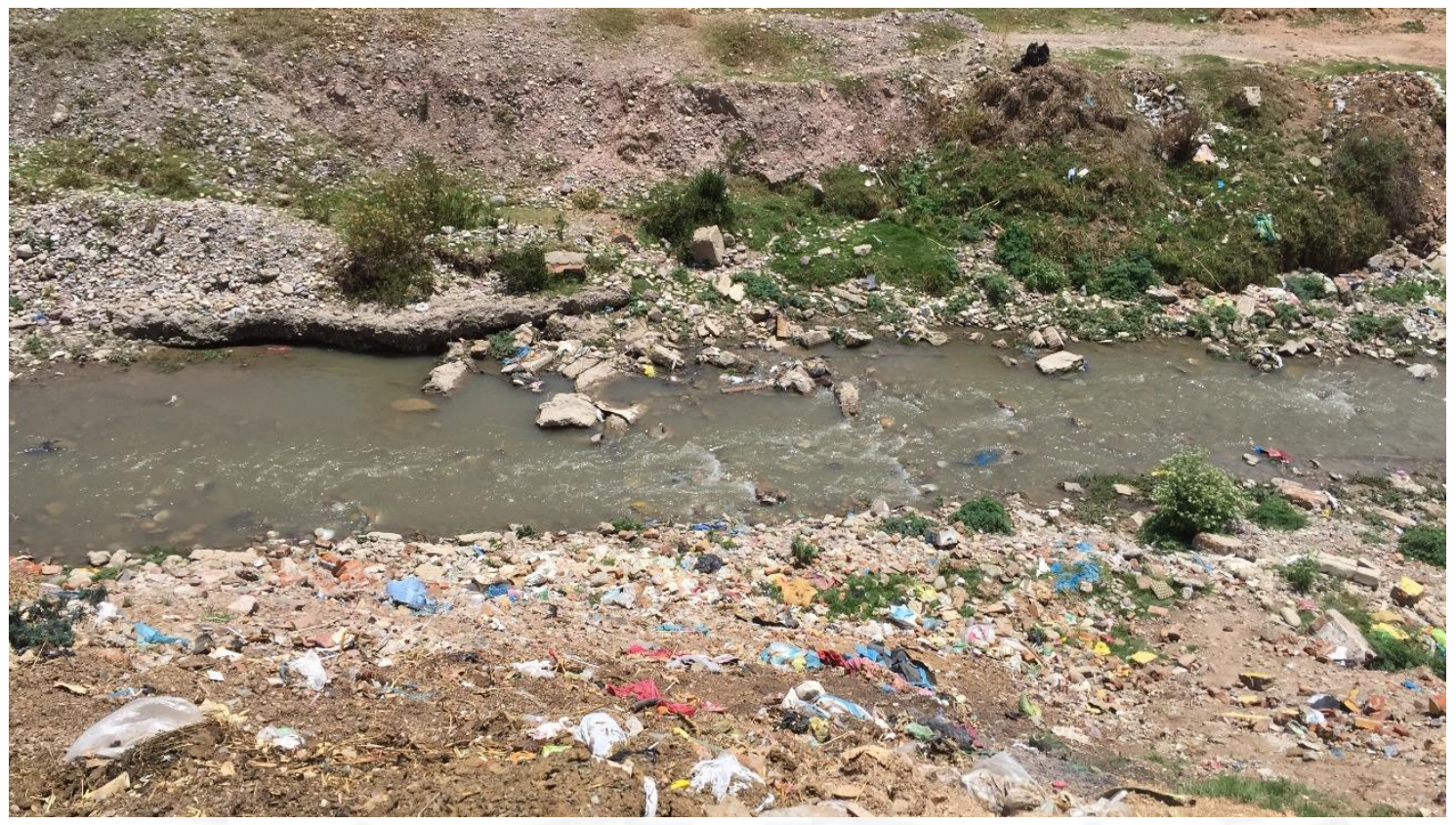

Nota: Vista peatonal de la margen izquierda del Río Shullcas

Fuente: Elaboración propia

Figura 2. 31Contaminación de agua del Río Shullcas

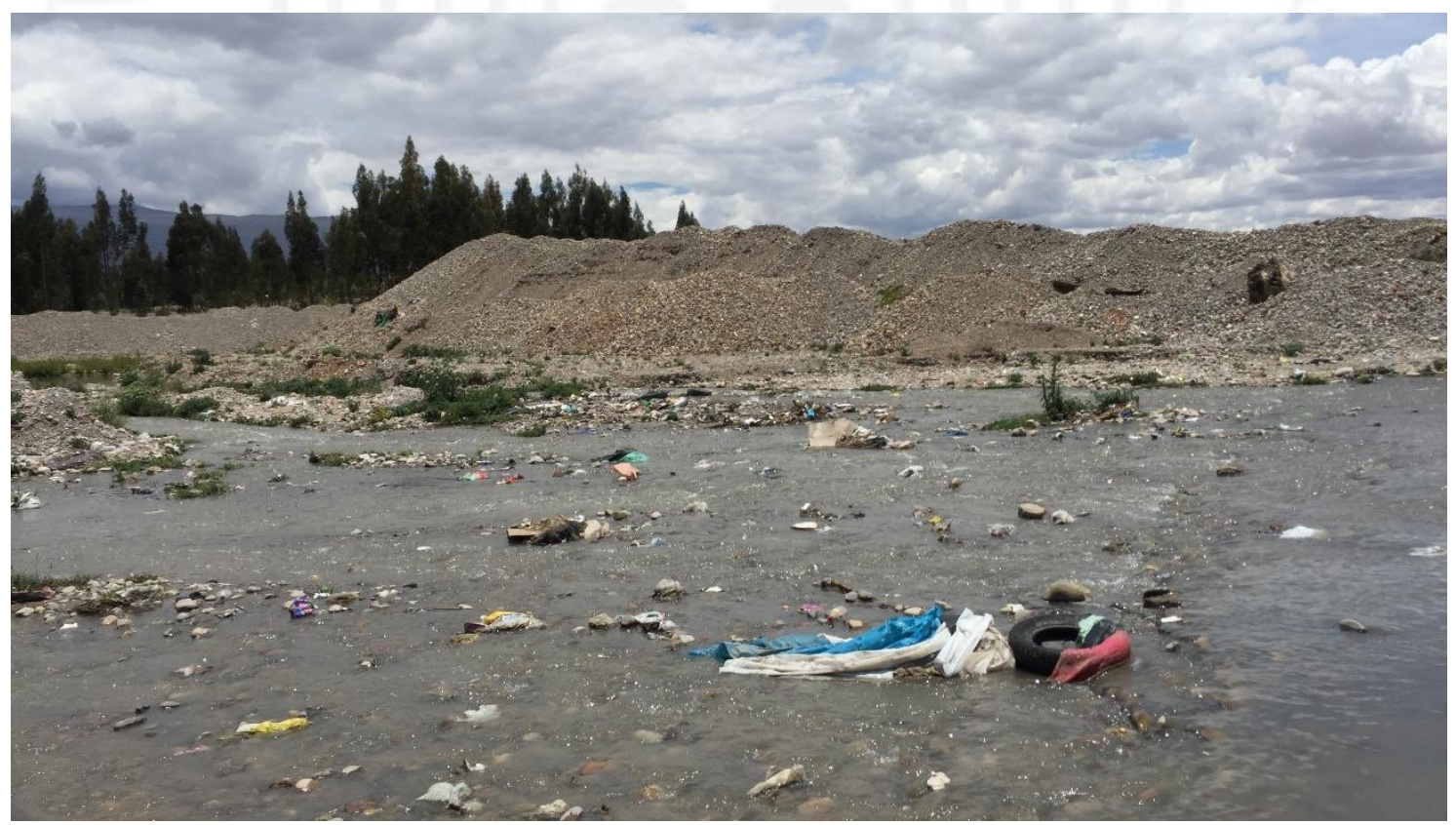

Nota: Vista peatonal a la altura del cruce del Río Mantaro y Shullcas

Fuente: Elaboración propia 
FUENTE: Indeci-PNUD / Municipalidad Provincial de Huancayo

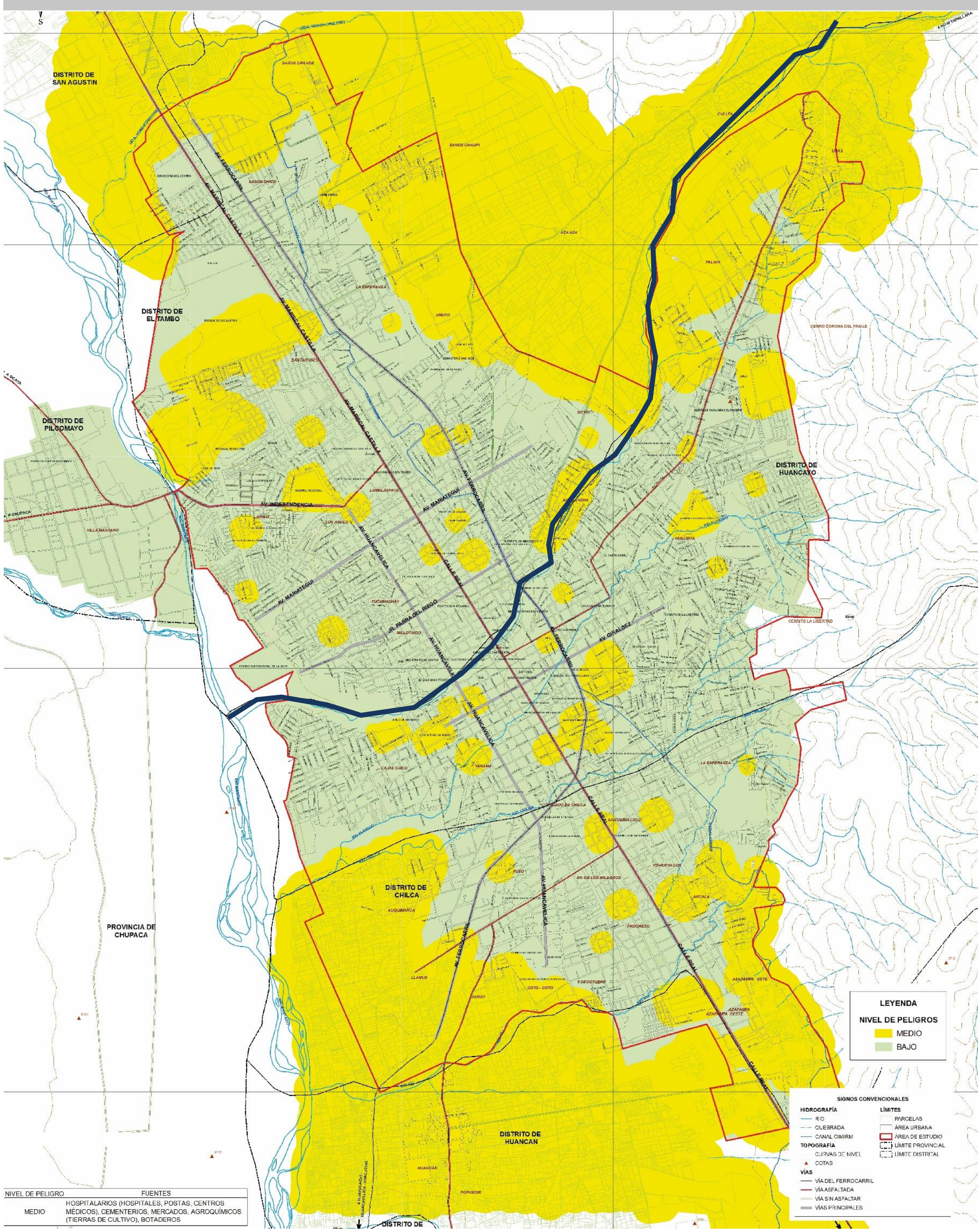


La contaminación del agua del Río Shullcas es un problema con el que se enfrenta actualmente la provincia de Huancayo. La expansión urbana ha ocasionado el aumento del consumo hídrico como también el crecimiento de aguas residuales. Estas se transportan por el alcantarillado de la ciudad culminando el itinerario en el río Shullcas. Se puede encontrar 20 bocatomas aproximadas de alcantarillado a lo largo del río ocasionando destrucción de la biodiversidad acuícola y del recurso hídrico. El mapa adjunto (Lámina 2.5) muestra la red, el recorrido y la culminación del alcantarillado de la provincia de Huancayo. Se observa la necesidad de concientizar y educar a la población sobre el cuidado del agua y el patrimonio natural. Además de generar en puntos estratégicos nuevo equipamiento que este orientado a la limpieza de aguas residuales.

Esto significa que el nivel de contaminación del río es medio-alto, es decir no puede ser usado para consumo humano, ni como medio de recreación, ni como actividad acuícola.

Actualmente existe un Plan Maestro Optimizado (PMO) a cargo de la Municipalidad de Huancayo y el Servicio de Alcantarillado de Huancayo que propone la mejora y creación de plantas de tratamiento a lo largo de Río Shullcas. 
FUENTE: Indeci-PNUD / Municipalidad Provincial de Huancayo

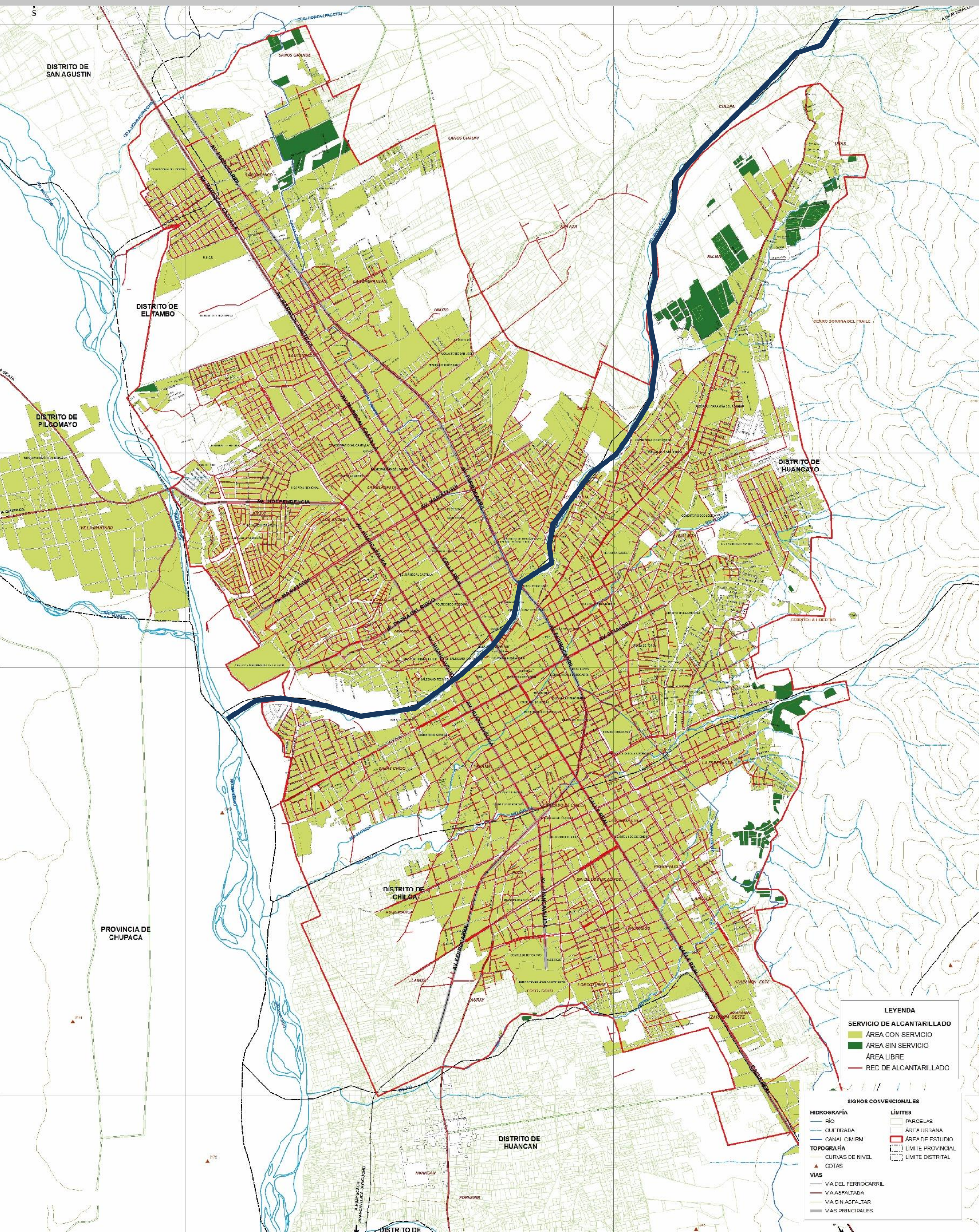




\subsubsection{Riesgo y Vulnerabilidad}

El nivel de riesgo en la provincia de Huancayo se mide a partir de variables como el tipo de suelo, obras de mitigación, posibilidad de desastres naturales, nivel de napa freática, vulnerabilidad de vivienda, etc. El riesgo es la combinación de peligro y vulnerabilidad y el siguiente mapa (Lámina 2.6) muestra las zonas de riesgo crítico de la provincia de Huancayo. Como resultado del estudio realizado por el Instituto Nacional de Defensa Civil (INDECI), las zonas de muy alto riesgo son las fajas marginales de los ríos y el entorno inmediato. Esto significa que son zonas donde debe primar proyectos de espacio público, espacio temporal recreativo, deportivo.

Por otro lado, el mapa (Lámina 2.7) muestra el nivel de vulnerabilidad de la provincia de Huancayo a partir del estudio de variables como: materialidad de la vivienda, zonas inundables, estado de conservación y nivel de mantenimiento del casco histórico. El resultado muestra que el área que presenta vulnerabilidad muy alta se encuentra en la periferia de la ciudad, asimismo el casco urbano y las fajas marginales de los ríos de la provincia de Huancayo tienen un nivel de vulnerabilidad alto-medio. Es necesario enfatizar que las fajas marginales que presentan una vulnerabilidad alta pueden ser recuperadas con intervención urbano-paisajista 
FUENTE: Indeci-PNUD / Municipalidad Provincial de Huancayo

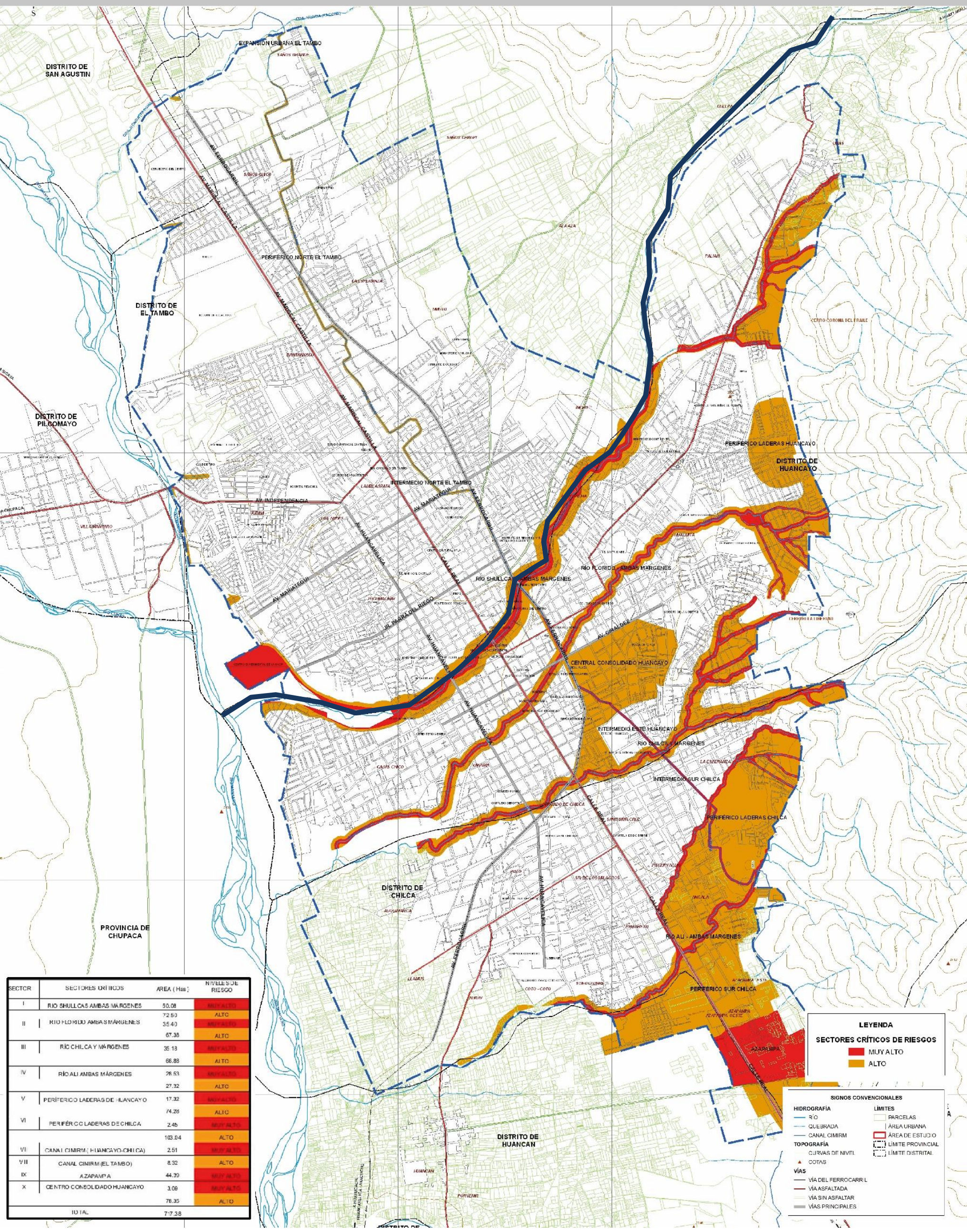




\subsection{Conclusiones parciales}

En el mundo existen intervenciones de borde de río que han logrado resultados positivos a partir de la planificación integral y gestión en equipo a corto, mediano y largo plazo. En este tipo de proyectos la importancia de una continuidad gubernamental es indispensable para culminar los planes debido a la escala del proyecto.

En la actualidad, existen proyectos realizados en diversas ciudades, como Medellín, donde los procesos de transformación urbanos buscan solucionar la problemática desde una perspectiva integral. Se concibe al río no solo como fuente de abastecimiento de agua, sino como eje estructurador y como medio de oportunidad para la implementación de espacios que permitan la inclusión, equidad e integración de la población con el río.

En otros casos como el Río Manzanares, se toma al río como una oportunidad para aprovechar el área desocupada y proponer la incorporación de un parque urbano a escala metropolitana. Además de la implementación de estrategias a diferentes escalas, territorial, metropolitana, urbana y local que como resultado logren conectar la ciudad, incrementar áreas verdes y recuperar el paisaje del río.

A partir de la descripción del proceso de casos de regeneración urbana de ríos mencionados se infiere que los bordes de río son espacios de oportunidad que contribuyen a resolver problemas urbanos causados por la expansión de la ciudad.

En el Perú, aún un no se ha realizado una intervención integral de borde del río que demuestren resultados beneficiosos para la población. El caso del Proyecto Río verde, es un proyecto puntual que no se ha implementado, sin embargo, ha quedado como precedente de actuaciones de debieran realizarse para la recuperación de la ribera del Río Rímac.

Por otro lado, los centros de interpretación son herramientas de educación que generan vínculos a partir de la experiencia del visitante y tiene como objetivo concientizar al visitante sobre la importancia del patrimonio.

De los antecedentes históricos del crecimiento urbano de Huancayo se concluye que el eje estructurador de la ciudad fue el camino inca (Calle Real) generando una trama urbana lineal transversal al Río Shullcas. Sin embargo, en la actualidad existe un nuevo eje estructurante establecido por este río. 
Con respecto a la idiosincrasia de la población huancaína, la lógica de desarrollo es incentivada por la "Modernidad". Esto se observa en el desinterés por preservar el patrimonio natural y arquitectónico.

La ciudad de Huancayo en ninguno de los planes promulgados presenta estrategias de intervención urbana en los bordes de ríos de tipo urbano paisajista, esto se debe a que el río ha sido considerado como una barrera urbana que fractura la ciudad y fuente de abastecimiento desde la fundación .Los únicos estudios elaborados con relación al río son de diagnóstico de mejora y creación de plantas de tratamiento a lo largo del mismo

Actualmente, Huancayo presenta problemas en los bordes del Río Shullcas que es tema de la investigación. Los problemas están relacionados con el asentamiento de viviendas informales en zonas de vulnerabilidad alta, la presencia de descargas de aguas residuales y contaminación de residuos sólidos en las fajas del Río. Además de la falta de espacio público, movilidad y equipamiento en la ciudad. 


\section{CAPÍTULO III: MARCO TEÓRICO}

\subsection{Glosario de Terminología}

Antrópica:

Según la Real academia española: Proveniente del término griego traducido al español (antropo-) que significa hombre" (DRAE, 2019).

\section{Diversidad urbana}

Resulta difícil definir “ejes verdes”, debido a que está compuesta por dos palabras. Si separamos cada una; el término eje según el Diccionario de la Real Academia [DRAE] significa "Línea que divide por la mitad el ancho de una calle o camino, u otra cosa semejante" (DRAE, 2019). Asimismo, para el término verde el significado según el Diccionario de la Real Academia [DRAE] es "Dicho de un lugar: Destinado a ser parque o jardín, y en el que no se puede edificar. Zona, espacio verde" (DRAE, 2019). Por lo tanto, se puede interpretar para esta tesis que un eje verde es un camino o calle con vegetación que interconecta espacios verdes de la ciudad dando al peatón otra percepción del espacio. Genera un sistema de infraestructura verde gestionada para cumplir funciones ambientales, sociales en la ciudad.

\section{Espacio público}

Jordi Borja (2014) define al espacio público como:

El espacio público es la ciudad. Dentro de la ciudad, el espacio público tiene tres dimensiones: la social-cultural, la política y la estrictamente urbanística... El espacio público entonces requiere una serie de condiciones: la accesibilidad, la seguridad, la calidad del entorno, la polivalencia, su carácter evolutivo, etc... El espacio público tiene además una dimensión social-cultural, que es de cohesión, de identidad, de referencias icónicas o simbólicas, de convivencia; y, por lo tanto, de mezcla de diversidad de los distintos colectivos (p. 103).

\section{Ejes verdes}

Resulta difícil definir "ejes verdes”, debido a que está compuesta por dos palabras. Si separamos cada una; el término eje según el Diccionario de la Real Academia [DRAE] significa "Línea que divide por la mitad el ancho de una calle o camino, u otra cosa 
semejante" (DRAE, 2019). Asimismo, para el término verde el significado según el Diccionario de la Real Academia [DRAE] es "Dicho de un lugar: Destinado a ser parque o jardín, y en el que no se puede edificar. Zona, espacio verde" (DRAE, 2019). Por lo tanto, se puede interpretar para esta tesis que un eje verde es un camino o calle con vegetación que interconecta espacios verdes de la ciudad dando al peatón otra percepción del espacio. Genera un sistema de infraestructura verde gestionada para cumplir funciones ambientales, sociales en la ciudad.

\section{Interpretación:}

Según Tilden, es la actividad educativa que pretende revelar significados e interrelaciones a través del uso de objetos originales, por un contacto directo con el recurso o por medios ilustrativos, no limitándose a dar una mera información de los hechos. (Tilden, 2006)Por otro lado, según Peart: Proceso de comunicación diseñado para revelar al público significados e interrelaciones de nuestro patrimonio natural y cultural, a través de su participación en experiencias de primera mano con un objeto, artefacto, paisaje o sitio (Peart, 1977)

\section{Paisaje:}

Según Garrett Eckbo, es la relación del hombre con la naturaleza. Actualmente implica la relación de edificios y áreas libres. A una escala de parque le corresponde la ciudad y espacios abiertos tanto urbanos como rurales o naturales. (Eckbo, 1950) .Por otro lado, Según Maderuelo, el espacio físico natural sino es una construcción cultural, conjunto de ideas y sentimientos concebidos a partir de un lugar y sus elementos. (Maderuelo, Aquello que llamamos paisaje, 2004)

\section{Paisaje urbano:}

Según Maderuelo es la imagen que se concibe de la ciudad (Maderuelo, El pasisaje urbano, 2010)

\section{Planificación interpretativa:}

Según Morales: Proceso que analiza necesidades y oportunidades para la interpretación (Morales, Interpretación de Patrimonio, 2004) 


\subsection{Estado del arte}

\subsubsection{Del paisaje}

El enfoque de teorías utilizadas para la revaloración de la ciudad a partir del paisaje se basa en los autores, Javier Maderuelo y Garrett Eckbo, los cuales proporcionan conceptos de la idea de paisaje, la intervención del paisaje y la labor del paisajista o arquitecto paisajista. A continuación, se detallara los aportes para la presente tesis de cada autor mencionado.

Los artículos considerados como "Aquello que llamamos paisaje" (2004) de Javier Maderuelo, teórico representativo de arquitectura y arte ha proporcionado aportes que parten de la definición general del paisaje y mención de hechos en la historia de tipos de intervenciones antrópicas en el paisaje para beneficio propio que son el reflejo de nuevas perspectivas de desarrollo humano.

Asimismo, la conferencia “El paisaje urbano" (2010) aporta ideas de la evolución del concepto de paisaje relacionando a la ciudad. Hace referencia a la planificación urbana que contemple la idea de paisaje para considerar intervenciones que desarrollen una imagen de ciudad integral con carácter propio a fin de reforzar la identidad de la población con su territorio.

Por otra parte, el autor Garret Eckbo (1950) pionero del Movimiento Moderno del Paisaje en Norteamérica, en su libro "Landscape for living” proporciona teorías para la práctica de intervenciones de paisajes e espacio público teniendo en cuenta los tipos de trasformaciones existentes del paisaje conformados por el medio urbano, rural y natural. Se centra en intervenciones urbano-rurales y dentro de la ciudad. En ambos casos se propone estrategias de diseño que se basan en la idea de equilibrio territorial a partir de la definición de escala de la propuesta y del entendimiento del carácter del lugar considerando la integración de elementos naturales en la estructura urbana con la misma jerarquía que elementos urbanos. Finalmente, hace reflexión sobre la labor del paisajismo como medio de estructura de la sociedad a causa de su función de organizador de espacios abiertos en la ciudad que integre el paisaje y sea accesible para todos. 


\subsubsection{Del espacio público}

Con respecto al papel del espacio público y las áreas verdes en la ciudad los textos utilizados fueron de los teóricos Jan Gehl, Frederick Law Olmsted y Jordi Borja. A continuación, se mencionará los textos utilizados y el aporte de cada teoría a esta investigación.

El libro "Cities for peole" (2010) del teórico urbanista Jan Gehl presenta propuestas convincentes sobre cómo hacer que los espacios urbanos desolados sean atractivos para las personas mediante la dimensión humana. Gehl argumenta que las personas tienden a mirar hacia adelante la mayor parte del tiempo, por lo tanto, lo que está a la vista del peatón debe captar su atención e interés para querer quedarse generando áreas de permanencia en el espacio público. Los espacios de permanencia deben ser seguros, saludables y sostenibles para la ocupación del usuario. Asimismo, menciona que la ciudad está hecha para el peatón, por lo tanto, los espacios deben ser hechos para los ciclistas y peatones. Gehl define que una ciudad sobrevive sola si los residentes hacen uso de los espacios públicos de manera continua y los residentes lo harán solo cuando estos espacios se encuentren limpios, seguros e interesantes.

Por otro lado, en el libro "La humanización del espacio urbano: La vida social entre los edificios" (2006) el teórico urbanista Jan Gehl hace un aporte relacionado a la vida del espacio público y las actividades que realizan los residentes en su vida diaria. Clasifica las actividades en tres tipos para entender la necesidad de contacto que tienen los usuarios, las dinámicas del entorno social y actividades de convivencia. Asimismo, Gehl hace hincapié en que las necesidades de las personas no solo son las básicas, sino que explora las necesidades más allá de la supervivencia. Para Gehl la ciudad es el entorno público, por lo tanto, debe tener características que propicien el contacto humano.

El libro "Landscape into Cityscape" (1968) del teórico paisajista Frederick Law Olmsted argumenta que los parques son planificados para la experiencia del usuario con el paisaje, contienen una diversidad de espacios con actividades diferentes para la interacción de todos los visitantes. Para Olmsted el espacio público es un sistema de parques que dan a la ciudad áreas de convivencia con el patrimonio natural.

El texto "Ciudadanía y globalización" (2002) de la revista CLAD Reforma y Democracia del teórico y sociólogo Jordi Borja aporta que todo ciudadano tiene derechos 
humanos fundamentales, entre los cuales, el derecho a un espacio público de calidad es una condición básica a la inserción en la ciudad formal. Asimismo, sostiene que el derecho a la ciudad supone la tolerancia en el espacio público. Para Borja la calidad del espacio público es primordial para los ciudadanos, este tiene funciones urbanas, socioculturales y políticas. El espacio público es el lugar de vida social, de relación de lo construido con la población y sus actividades, además cumple funciones de conexión, continuidad, de identidad y algunas veces de monumentalidad; es un espacio accesible, polivalente, de convivencia y tolerancia.

Por otra parte, el texto "La ciudad del deseo" (2002) del teórico y sociólogo Jordi Borja aporta que en la ciudad los espacios principales son los públicos y promueven encuentros y vida social. El espacio público indica la calidad de vida y las características de la ciudadanía. Borja reflexiona sobre como la ciudad debe emerger conmo un espacio colectivo y referente cultural. Es importante que los usuarios planteen visiones de la ciudad del deseo, al involucrar a la población los proyectos tendrán resultados con impacto social.

Finalmente, "La entrevista a Jordi Borja" (2014) realizada por la revista La Colmena de la Pontifica Universidad Católica del Perú al teórico y sociólogo Jordi Borja considera que el espacio público es la ciudad, es el lugar donde interactúan diversos actores.

\subsubsection{Del Diseño urbano}

Con respecto al diseño urbano los textos utilizados fueron de los teóricos Jane Jacobs y Kevin Lynch. A continuación, se mencionará los textos utilizados y el aporte de cada teoría a esta investigación.

El libro "Muerte y vida de las grandes ciudades" (1961) de la activista sociopolítica Jane Jacobs aporta una investigación de cómo funcionan las ciudades a escala humana. Sustenta que la seguridad de un espacio público depende de los usuarios que lo utilicen, asimismo aboga por generar espacios para los niños. Asimismo, comenta sobre la importancia del contacto casual en las aceras. Para Jacobs la única garantía de éxito de los barrios es fomentar la diversidad de usos, además de incrementar el comercio, ya que si las calles tienden a quedarse vacías se desertizan y se convierten en lugares inseguros. 
Jacobs menciona unos factores destructivos en la ciudad que son las cicatrices urbanas (vías de tren, parques mal diseñados, riberas de ríos u otros) que las etiqueta como fronteras del vacío, ya que cortan la comunicación peatonal entre barrios ocasionando pérdida de la actividad económica.

Por otra parte, el libro "La imagen de la ciudad" (1976) del urbanista Kevin Lynch aporta cinco elementos de la ciudad que ayudan al visitante a ubicarse desde un nivel perceptual. Por lo tanto, el teórico propone un lenguaje, una metodología para preguntar a las personas sobre cuál es la percepción que tienen de imagen de la ciudad, cómo les puede servir estos elementos para poder ubicarse en el espacio y no es un libro de elementos proyectuales, ya que el modo en que se realiza el análisis usando estos elementos, afectará al modo en que se diseña una propuesta urbana

\subsubsection{De la Interpretación}

El desarrollo de la interpretación como herramienta de educación se sostiene de los siguientes de autores pioneros y contemporáneos del tema: Freeman Tilden, Bob Peart, Don Aldridge, Badaracco y Scull., John Veverka. A continuación, se hará referencia de los textos considerados por cada uno de ellos como base teórica.

El libro de Freeman Tiden titulado “Interpretación de nuestro patrimonio” (2006) versión traducida al español del libro original "Interpreting.Our Heritage" (1957) es uno de los primeros libros que aporta al tema de interpretación. El libro se compone por 15 capítulos en los cuales empieza con la postulación de los principios de la interpretación, Asimismo hace referencia de la importancia de entender al usuario como visitante que solo atenderá lo que le parezca atractivo de modo que se requiere del uso objetos o medios variados y originales para capturar su atención. Además, sostiene la idea de cómo poder transmitir un mensaje de manera efectiva al usuario a partir de la provocación y no la imposición de información.

Por otra parte, Bob Peart reconocido investigador canadiense sobre la conservación y educación de la naturaleza en su artículo "Definition of Interpretation" (1977) hace referencia de la idea conceptual de la interpretación considerándola como proceso de comunicación, la cual se sostiene que la experiencia es el medio para establecer vinculo del usuario con el recurso, objeto o sitio interpretado. 
En el texto Don Aldridge considerado principal impulsador de la interpretación en el ámbito europeo sostiene en su conferencia llamada "Mejora de la Interpretación de los Parques y la Comunicación con el Público" (1973) en la Segunda Conferencia Mundial sobre Parques Nacionales realizada en Estados Unidos sostiene otro enfoque de la interpretación enfocada al territorio como patrimonio y a la conservación del ambiente.

John Veverka, en el texto "Tips and concepts for planning truly 'Interpretive' Exhibit" (2030) actual doctor representativo de la interpretación de parques y recreación establece la idea de "exhibir" determinándola como los medios de comunicación parte esencial para la efectividad de la interpretación de manera que considera la interacción como medio efectivo para captar la atención del visitante. Asimismo, resalta la importancia de la planificación como apoyo en la elaboración de objetivos de la interpretación clasificándolas en aprendizaje, comportamiento y emocional.

Jorge Morales, reconocido consultor, formador y ex-vicepresidente de la Asociación para la Interpretación del Patrimonio de España, expone en su conferencia "La interpretación ambiental y la gestión del medio"(1983) en la Jornadas de Educación Ambiental, la consigna de la interpretación como herramienta de trasmitir por medio de del deseo de generar el interés y no como una actividad educativa, sosteniendo el carácter recreativo del proceso de interpretación.

Asimismo, Morales es el artículo "La planificación interpretativa asegura la excelencia en interpretación" (2004) sostiene que la planificación interpretativa es un instrumento para el analisis y la toma de desiciones con la finalidad de trasmitir la idea interpretaiva, satisfacer al usurios, proteger el recurso y la mejorar de calidad de los habitantes locales. Para ello, hace mención del modelo comunicativo que se establece en el proceso interpreativo para poder establecer las etapas que implican la planificación categorizandola en 8 etapas que garantizan el éxito de lso objetivos de la interpretación. 


\subsection{Revaloración de la ciudad desde el paisaje}

Referirnos sobre el paisaje resulta ser un tema extenso que a pesar de lo distintos enfoques existentes se comparte una idea en común basada en la subjetividad sobre un contexto territorial, el cual funciona como medio espacial en que se aprecia el paisaje. A partir de esta primera aproximación base la presente tesis abarcara teorías sobre del paisaje con el fin de ponerlas en práctica en el planteamiento de estrategias proyectuales del proyecto de tesis. De este modo, se toma como base teórica artículos, conferencias y libros de autores como Javier Maderuelo, teórico representativo de arquitectura y Garret Eckbo, pionero del Movimiento Moderno del Paisaje en Norteamérica.

. Los temas a tratar serán la conceptualización del término, las intervenciones en el territorio, así como la mención sobre las consecuencias de la acción del hombre sobre el paisaje en actualidad.

\subsubsection{Teorías de Javier Maderuelo}

En el artículo: "Aquello que llamamos paisaje" Maderuelo parte de la usual confusión del término a causa de la intervención o implicancia de diferentes ámbitos en la idea del paisaje. Las áreas de estudio como el arte, ecología, prácticas urbanas, actividades turísticas han aportado al término, sin embargo, la extensión conceptual ha causado la dificultad del entendimiento claro y preciso. (Maderuelo, 2004)

La palabra paisaje suele ser concebido por un sustrato físico conformado por elementos tangibles de la naturaleza establecida en un sitio determinado, no obstante, estos elementos se convierten en paisaje al ser percibidos, contemplados como una unidad que produzca un sentimiento que sea interpretado. Por lo que se entiende que el paisaje no es un espacio físico natural sino es una construcción cultural, conjunto de ideas y sentimientos concebidos a partir de un lugar y sus elementos (Maderuelo, 2004).

Por otra parte, el entendimiento del concepto también está de la mano con la evolución por lo que es importante resaltar como el paisaje, en el transcurso de los años, ha experimentado una metamorfosis desde la utilización, apropiación hasta el abuso de su uso. El territorio ha pasado por cambios, los lugares objetos de contemplación paisajística han ido transformándose por la acción humana de manera consiente e 
inconsciente. En consecuencia, se puede entender que la idea paisaje es susceptibles a dichos cambios de manera positiva o negativa (Maderuelo, 2004).

A partir de lo expresado anteriormente, el paisaje es una idea, un concepto abstracto establecido individual o colectivamente sobre un determinado territorio o espacio que requiere de interpretación en un tiempo específico ya que es de carácter mutable a causa de la $\mid$ o natural. Algunos ejemplos tangibles del proceso de cambio del paisaje realizados por el hombre son las explotaciones mineras, la agricultura, la construcción y la expansión urbana entre otros.

De igual forma las ideas recopiladas de la conferencia "La construcción del pensamiento en la última década" Maderuelo sostienen que las actividades como huellas físicas en el cambio del paisaje son extensas; sin embargo, la presente tesis se centrará en contexto vivencial en donde el ser humano se relaciona diariamente con él.

Por otro lado, otro aspecto importante a mencionar para el estudio de la tesis es la composición del paisaje, el cual se refiere a la propia intervención del hombre sobre el territorio de forma consciente para un fin determinado.

Las primeras acciones de la composición en el paisaje de forma reflexiva se dan en el siglo XIII por medio de la inserción de jardines paisajista en las ciudades la cual recrear artificialmente la naturaleza a manera de escenarios secuenciados para el disfrute y contemplación. Con el tiempo, estas intervenciones repercutieron positivamente en la ciudad misma dando origen a la idea de ciudad jardín (Howard). Asimismo en el siglo XIX, otras corrientes como las higienistas (Haussmann y Cerda), modernistas (Gropius y Le Corbusier) moldearon físicamente la ciudad a imagen del ideal de metrópoli (ETS de Aruitectura Universidad de Málaga, 2015).

En el mismo siglo, la mirada de paisaje se trasladó a la ciudad como construcción social conformando la idea del paisaje urbano como la imagen perceptual que se concibe de la ciudad. Así, los elementos de la ciudad constituidos por construcciones, plazas y vías, no son más elementos individuales agregados sino son las unidades de la composición integral del carácter de la ciudad. (ETS de Aruitectura Universidad de Málaga, 2015)

La aparición de actividades de contemplación en la ciudad surge por medio de la incorporación de paseos de carácter recreativo el cual se define como el placer de salir 
para apreciar la ciudad. Convirtiendo a la metrópoli en el escenario de la imagen representativa de la población. De esta forma elementos que componen el paisaje urbano como la disposición de la arquitectura en las fachadas de las viviendas empezó a corresponder a esta práctica de contemplar la ciudad. (ETS de Aruitectura Universidad de Málaga, 2015)

Con lo descrito sobre el término del paisaje urbano, se entiende que es la idea figurativa de la ciudad, así como la idea de paisaje es una construcción cultural del territorio. La ciudad como lugar que reúne pensamientos, creencias, emociones es el reflejo físico cultural, por lo que cualquier cambio en el pensamiento social generará transformaciones en las unidades de composición urbana. De este modo en la historia se puede apreciar los cambios y la evolución de la ciudad específicamente en la integración de espacios nuevos para el desarrollo, mejora y disfrute de la misma.

Por otra parte, en el artículo "El paisaje urbano" Maderuelo complementa el aporte del concepto del paisaje anteriormente mencionado a partir del estudio de los efectos del término en el tiempo y en principal el del presente.

La contemplación de la ciudad contribuyo a la configuración de escenarios urbanos como espacios pictóricos específicos del hábitat, trabajo y dinámicas sociales. Sin embargo, en el siglo XIX en París problemas como la expansión urbana, la necesidad de nueva infraestructura reclamaban otro tipo de espacios urbanos diferentes a los escenográficos del tiempo. Así la conformación del boulevard y la creación de las grandes plazas y parques adecuados a la vida social fueron elementos importantes para la nueva configuración de la ciudad (Maderuelo, 2010).

Asimismo, es importante indicar que gran parte de las transformaciones urbanas fueron realizadas por ingenieros que se encargaron de la construcción y planificación de la metrópoli. Si bien es cierto que los arquitectos también fueron piezas en la formación de la imagen de la ciudad, se centraron en el diseño de edificaciones particulares sin contemplar el diseño integral de la ciudad. (Maderuelo, 2010).

Continuando en el siglo XIX, las transformaciones de la ciudad continuaron a través de la implementación de espacios urbanos que cubría las necesidades de la población. Estas intervenciones consideradas como aportes en la composición del paisaje urbano fueron piezas importantes para la nueva imagen de la metrópoli. Asimismo, cabe 
resaltar de la trascendencia de la actuación urbana de forma integral para la planificación de la ciudad para así poder establecer una imagen clara y optima de la urbe.

Posteriormente, paisajistas y urbanistas fueron autores de varias intervenciones urbanas en el mundo, un claro ejemplo de esto es la creación del Central Park de Nueva York. Mientras el urbanismo se ocupaba de la planificación y la determinación de equipamientos urbanos, el paisajismo se ocupa de aspectos como el carácter, composición, coherencia visual expresados con materiales, texturas, colores, etc. para la configuración de ambientes urbanos (Maderuelo, 2010). De este modo las ciudades empezaron a manifestar la preocupación de proyectar una imagen de ciudad sana.

En el siglo XXI el gobierno municipal, tras la idea del paisaje urbano como la imagen proyectada de la ciudad, buscó aprovechar esta condición para atraer inversiones económicas. Actividades como el turismo, comercio y otras actividades se han sumado al interés de establecer una ciudad que proporcione áreas recreativas y culturales para la atracción de capital. Sin embargo, cabe resaltar que en muchos casos la búsqueda de proyectar un ideal de ciudad ha establecido una visual limitada que replica espacios. Esta copia una tras otra de modelos de desarrollo de ciudad ha causado la perdida de elementos simbólicos cultuales que a largo plazo conlleva a la pérdida de identidad de la población con la propia ciudad (Maderuelo, El pasisaje urbano, 2010).

Como se puede entender, esta situación se ha generalizado principalmente por la falta de un objetivo integral para el bienestar en general de la población y no para unos cuantos. Se requiere de una planificación global del paisaje urbano que contemple la solución de diversos problemas urbanos y no del enfoque de una parte, asimismo es necesario contemplar el carácter particular propio de la colectividad en cada propuesta para que la población se sienta parte haciendo uso y disfrute de manera óptima considerando que el paisaje y en particular el urbano es el reflejo de la construcción social 


\subsubsection{Teorías de Garrett Eckbo}

La definición del diseño del paisaje es un tema claramente expresado por Garrett Eckbo, señala en su libro "Landscape for living” (paisaje para vivir) teorías, prácticas y reflexiones a futuro sobre la labor del arquitecto paisajista.

En el contexto norteamericano a mediados del siglo XIX, la concepción de parque y áreas recreativas eran espacios distintos y distantes uno de otro según el autor. El parque era considerado como en espacio público en el que se realizan actividades pasivas de relajación y contemplación. Mientras que los espacios de recreación eran considerados para actividades activas, de juego, arte, música y actividades de la comunidad. Sin embargo, posteriormente, estas actividades comenzaron a establecerse en conjunto logrando un balance de actividades necesarias para la sociedad. (Eckbo, 1950)

Para el diseño del paisaje en parque y áreas recreativas públicas, Eckbo menciona la importancia de consideraciones urbanas, la búsqueda consciente de la esencia del lugar y la proporción de un espacio al alcance de todos. Asimismo, plantea dos finalidades directas por lo que se establece este tipo de proyectos. La primera, para la proporción de aire puro y saludable a la población y la segunda, para equilibrar el contraste de las calles y casas de la ciudad con respecto a los espacios libres. (Eckbo, 1950)

Por otro lado, desde un enfoque de conservación de los recursos del medioambiente en la ciudad, los parques y áreas de recreación se han convertido en parte de las estrategias de preservación de dicha práctica a causa de la amenaza existente del crecimiento y tugurización urbana (Eckbo, 1950)

Estas aproximaciones con respecta al diseño del paisaje plantea la necesidad de intervenir espacios de descanso o de recreación de carácter integral y accesible que proporcione beneficios a la ciudad y la población en general.

De este modo, el Eckbo sostiene que la labor de la conservación del suelo y la práctica del diseño de paisaje es un compromiso basado en la claridad estética operacional entre la naturaleza y el ser humano creando un nuevo balance y armonía a escala. La realización de una conservación efectiva y verdadera que tiene como finalidad la protección de los recursos naturales y humanos requiere de la planificación urbana y regional. (Eckbo, 1950) 
Asimismo, con lo mencionado podemos comprender que el autor trata de extenderse en el tema para tener una mayor comprensión de la importancia de la preservación de los recursos, ya que estos son elementos insustituibles para el desarrollo del ser humano además de ser parte del contexto físico de la ciudad. Podemos entonces resalta que elementos naturales como los ríos o canales que en muchos casos aún forman parte del medio urbano son de vital importancia en la preservación.

Al igual que Maderuelo, Eckbo define al contexto en que vivimos como el resultado de la acción del hombre y del paisaje natural, la expresión cultural física en el territorio de la acción de ambos. De esta manera se considera que la suma de acciones del hombre establece un patrón social y que a su vez la suma de acciones naturales constituye un patrón físico que en conjunto establece patrones sociales y físicos que dan como resultado el lugar que vivimos. Asimismo, se debe considerar la complejidad del resultado del medio, debido a la complementariedad de múltiples patrones sociales propios del desarrollo evolutivo de los seres humanos que transforman el hábitat con el fin de satisfacer necesidades, expresar aspiraciones y valores de la sociedad. (Eckbo, 1950)

Con ello, Eckbo determina que espacialmente tres medio físico en que patrones sociales han transformado territorios: urbano, rural y "natural ${ }^{4 "}$. El medio urbano es el de mayores cambios generados por el hombre, los cuales se aprecian con la arquitectura y la planificación de las ciudades. Estas variaciones contantes e indefinidas sobre el medio requieren de un equilibrio entre el medio urbano y el entorno rural. Sin embargo, en muchos casos la ciudad se ha extendido con asfalto y concreto, pobreza espacial y hacinamiento excluyendo, la vegetación y espacios abierto (Eckbo, 1950)

A partir de la relación del hombre y el medio físico inmediato, se puede entender las causas de las transformaciones del medio y en particular el urbano, el de mayor alteración. Así, se plantea una intervención equilibrada entre la incorporación de nuevas construcciones y la conservación de recursos naturales.

El autor, señala la labor del paisajismo como disciplina que tiene como objetivo la compresión de las bases del medio físico para la organización y control de los

\footnotetext{
${ }^{4} \mathrm{El}$ autor menciona que actualmente aludir al término territorio natural es irreal debido al avance del hombre de conquista y apropiación del suelo.
} 
componentes del paisaje natural con el fin del uso y disfrute del mismo. Además indica que no solo debe comprenderse el medio que rodea al ser humano sino también al hombre mismo él quien hace uso del diseño del entorno urbano, rural o "natural" (Eckbo, 1950).

En el manifiesto "Landscape for living”, hace referencia a la intervención en el paisaje como expresión del hombre sobre la tierra a partir de la construcción. Se refiere a la ciudad como una manta de bordes difusos, sin orden y sin término que degradan los sitios naturales. De ese modo expone los problemas de no concebir un paisaje integral entre la ciudad y medio rural próximo degradado. El primero, la relación del avance de la construcción sobre el control ambiental; segundo, la relación de la forma, espacio, disposición en la calidad y cantidad de la ciudad y el campo; y el último, la explotación del medio natural a partir del expansión urbana (Eckbo, 1950).

Por lo anteriormente expuesto Eckbo, propone el desarrollo de un nuevo arte que confluya entre el medio ambiente y lo construido. El trabajo del arquitecto paisajista es el de integrador, mediador, conciliador, coordinador y armonizador con las zonas del paisaje natural, el cual concilie entre la ciudad y el campo las formas físicas de la naturaleza y las manifestaciones del hombre en el paisaje a escala y densidad proporcional (Eckbo, 1950).

Con lo expuesto, se entiende que se debe resaltar la problemática de los bordes difusos de ciudad y el medio rural, el cual son contemplados como áreas indistintas entre sí y dificulta la integración y preservación del recurso al interponerse uno sobre otro. Por lo que se propone considerar ambas estéticas para mantener un equilibrio del hombre con la naturaleza ya que él es responsable del crecimiento o disminución de la calidad del medio rural.

Así determina Eckbo que la arquitectura del paisaje no es un arte de la naturaleza sino el diseño del paisaje humanizado. De manera que la arquitectura y el paisajismo requieren de un nexo que resuelva problemas de relación de la ciudad con el campo. Para ello es importante entender los cambios existentes de la arquitectura para realizar cambios en el diseño del paisaje. Sin embargo, la forma o disposición no es la preocupación principal sino lo es el extremo de la explotación de la ciudad sobre el medio rural generando degradación y su consecuente desaparición (Eckbo, 1950). 
Esto se aprecia claramente en las distintas etapas del hombre y el paisaje natural, en el cual existía una humanización consiente del paisaje en el siglo XVII, mientras que en el siglo XIX existe un rechazo por este a diferencia nuevamente del siglo XX que busca reconectarse con el medio natural. (Eckbo, 1950).De modo, se entiende actualmente la necesidad de preservar el paisaje rural de la expansión de la ciudad, la necesidad de establecer espacios de reflexión y recreación que incorpore elementos naturales

El texto resalta continuamente la búsqueda del equilibrio territorial, el cual no requiere de la competencia de la ciudad sobre el campo o viceversa. Sino de la integración de la biología saludable de la naturaleza en la ciudad como la incorporación de recurso humano en el campo. Se debe entender de que las actividades del hombre transforman el paisaje y altera el equilibrio de las fuerzas naturales, sin embargo, se busca un nuevo balance que pueda acortar la brecha entre ambos y formar una unidad que se verá reflejada en términos de calidad y cantidad de la vegetación. (Eckbo, 1950).

Asimismo, menciona de la relevancia de la escala de la intervención como componente base para el inicio del diseño. La escala se determina entre la estructura y el sitio, el cual debe tener una relación con el paisaje de manera que mantengan una proporción adecuada. En el caso de construcciones acordes con espacios abiertos posibilita relaciones espaciales con cada elemento como el agua, plantaciones, suelo y formas estructurales. A diferencia de un inadecuando espacio abierto con el edificio, el paisaje natural se convierte en un elemento decorativo. (Eckbo, 1950).

De este modo la consideración del equilibrio de lo construido en el sitio es indispensable para la planificación urbana. Dando la posibilidad de la intervención de la arquitectura del paisaje a escala de ciudad fusionando la labor con el urbanismo. Con ello, el parque y espacio libres se convierten en esqueleto funcional de la comunidad de manera que articule y disponga una relación con del paisaje natural y el paisaje urbano del sitio como una unidad (Eckbo, 1950).

Por consiguiente, se comprende que la definición de escala en el diseño paisajístico es parte de una intervención equilibrada que busca cualitativamente y cuantitativamente la incorporación de elementos naturales en el medio urbano; además, del balance entre el paisaje urbano y el medio rural que comprenden una escala mayor en donde no se permite la degradación de una sobre otra. Asimismo, la escala también 
determina el grado de planificación urbana que se requerirá para la gestión de corto, mediano o largo plazo para la integración territorial.

Por último, parte del libro hace recomendaciones a considerar al momento de intervenir el paisaje, además de manifestar reflexiones sobre el tema, los cuales parte de ellos se mencionarán con el fin de hacer uso en el planteamiento de estrategias en la propuesta paisajística de la tesis.

Con lo que respecta a la intervención del paisaje, Eckbo menciona que no se debería forzar al paisaje nativo ningún tipo de paisaje extranjero. Por lo contrario, se debe incorporar formas espaciales y relaciones formales propias del lugar a manera de potencializar el carácter del lugar. Así, la relevancia del diseño en la intervención no son las reglas formales sino los principios de enfoque del lugar (Eckbo, 1950).

Con ello se debe tomar en cuenta las diferencias de cada región como el clima, la vegetación las condiciones del suelo, etc. y resolver cada tipo de organización espacial de manera independiente de acuerdo a sus condiciones con la finalidad de que la población se identifique y genere un vínculo propio con el carácter de la cultura del lugar.

Finalmente, la concepción del autor sobre el paisajismo, como estructura de la sociedad debido a la labor de organización de los espacios abiertos en donde individuos viven, trabajan y juegan (Eckbo, 1950), permite la reflexión a modo de contrate con la realidad actual del diseño del paisaje. Lo cual será de gran ayuda para determinar el objetivo de la propuesta como contribución a la solución de problemas urbanos en bordes de ríos.

\subsubsection{Lámina de teoría de paisaje}




\section{REVALORANDO LA CIUDAD DESDE EL PAISAJE}

PAISAJE
ESPACIO PÚBLICO

\section{2 .6}

LÁMINA

3.1
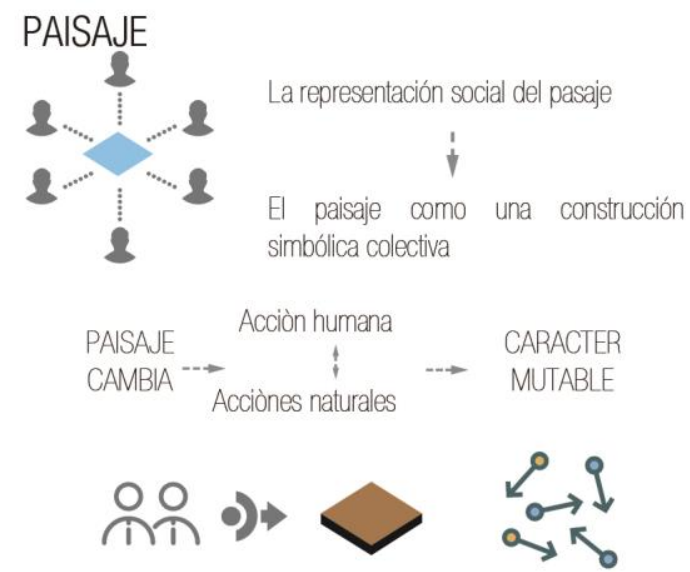

COMPOSICIÓN DEL PAISAJE $\quad----->$ Jardines (Escenarios)

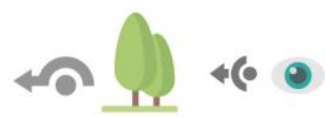

PAISAJE URBANO Imagen perceptual

Ciudad (Escenario) ณ̊ำ

COMPOSICIÓN DEL PAISAJE URBANO

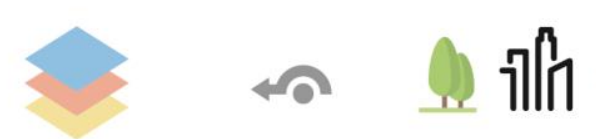

URBANISMO

Planificación + Determinación equipamiento urbano

PAISAJISMO Composición,configuración de espacios urbanos

PLANIFCACIÓN URBANA

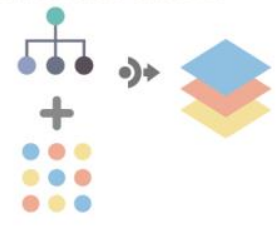

$\ominus$

Replica de modelos

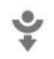

Perdida de elementos simbolicos

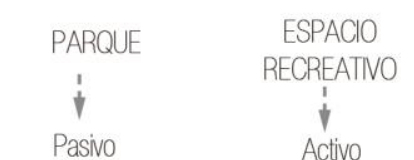

Pasivo Activo

Pasivo Activo tibla

DISEÑO ESPACIO PÙBLICO

- Accesible

- Escencia del Lugar

Consideraciónes urbanas

TRANFORMACIONES DEL PAISAJE

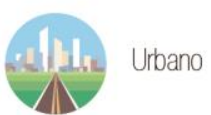

\section{ती}
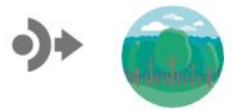

Rural

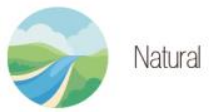

PAISAJISMO

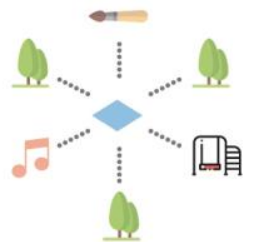

Paisaje uso y disfrute
CONSERVACIÓN

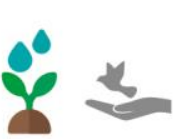




\subsection{El papel del espacio público y las áreas verdes en la ciudad}

El espacio público, es aquel espacio que no posee un propietario, está en el territorio para ser usado por el ciudadano de diversas formas. Los espacios públicos pueden ser calles, parques, plazas, puentes u otros de uso colectivo, están hechos para los ciudadanos y las dinámicas que estos generen.

Por lo tanto, diseñar un espacio público, no solo implica la arquitectura, sino también el campo social y cultural. Es necesario entender que al ser un espacio de cohesión social necesita actividades o programas específicos, implica conocer a los usuarios y la motivación que tienen para pasar por ahí, asimismo es necesario entender porque algunos espacios públicos funcionan mejor que otros.

Por el grado de complejidad que tiene un espacio público es de vital importancia entender teorías que nos proporcionan bases conceptuales; citamos a teóricos como: Frederick Law Olmsted, que es considerado como el padre de la arquitectura del paisaje, fue arquitecto paisajista, crítico social y periodista estadounidense; Jan Gehl, arquitecto urbanista danés y consultor del diseño urbano, su carrera se ha centrado en mejorar la calidad de vida urbana al reorientar el diseño de la ciudad hacia el peatón; y Jordi Borja que es un geógrafo urbanista y político español, licenciado en sociología y ciencias políticas, profesor en la Universidad Abierta de Cataluña (UOC) donde es responsable del Área de Gestión de la Ciudad y Urbanismo. Los tres teóricos nos proporcionaran puntos de vista diferentes para lograr un diseño integrado de espacio público.

\subsubsection{Teorías de Jan Gehl}

Jan Gehl establece que hablar de espacio público es muy amplio. Por lo tanto, para poder comprender el término, es necesario ubicarse en un contexto, en una escala y un punto de vista específico de análisis.

La determinación de un espacio público esta relacionado al tipo de actividad que se realiza, no es suficiente con crear espacios para el usuario, sino que estos espacios deben estar activos para que el peatón pueda entretenerse, Según Gehl (2006), así lo afirma con lo mencionado.

Que las personas y los acontecimientos se agrupen en el tiempo y en el espacio es un requisito para que pase algo, pero es más importante qué actividades se pueden 
desarrollar. No basta con crear espacios que permitan a la gente ir y venir. También debe haber condiciones favorables para deambular y entretenerse en esos espacios (p. 143)

El espacio público debe permitir funciones básicas como poder caminar, estar de pie y sentarse a pasar el tiempo. Estas son actividades básicas que se deben considerar; asimismo hay actividades estimulantes como los juegos de niños o las actividades de jardín para los adultos que ocasionan permanencia al peatón.

Asimismo, Jan Gehl (2006) clasifica a las actividades que el usuario pueda realizar en un espacio público en 3 tipos (actividades necesarias, opcionales y sociales). Cada actividad tiene una particularidad, las actividades necesarias son las obligatorias, son independientes del entorno externo como ir al trabajo, al colegio, etc. los participantes no tienen elección de transitar por un espacio que no sea público; las actividades opcionales son aquellas en la que la participación es voluntaria y necesita de condiciones fisicas externas que permita la interacción, como dar un paseo y tomar aire fresco, tomar sol, etc; y las actividades sociales son las que necesariamente dependen de la presencia de personas, se dan de manera espontánea y en espacios públicos, dependen de las otras actividades. Por lo tanto, cuando a las actividades necesarias y opcionales se le da mejores condiciones de diseño de espacio público se refuerzan directamente y generan actividades sociales (p. 17-20).

Con lo mencionado se puede inferir que el mejor atributo que puede tener un espacio público es cubrir las necesidades que cada actividad demanda, además de brindar al usuario áreas de permanencia donde pueda socializar y activar el espacio público. Es importante tener en cuenta al momento del diseño que los lugares de estancia deben incitar al usuario a permanecer con actividades de acuerdo a la cultura, además de ofrecer un buen microclima, seguridad e intimidad. Esto se refuerza con lo que sostiene Gehl Las áreas de permanencia en un espacio público deben estar ubicados cada 100 metros aproximadamente, con distancias cortas y variación de funciones urbanas. (Gehl, 2006)

Ver, hablar u oír son características de las actividades mencionadas, por ejemplo, cuando se realiza actividades necesarias, caminar es la acción predominante, tanto en la calle, parque o plaza y conlleva características como ver u oír, en consecuencia, los espacios deben contener diversos tipos de caminos con texturas y formas que generen sensaciones al peatón. Asimismo, cuando se realiza actividades sociales, estar sentado o 
parado son acciones predominantes que engloban las tres características, por lo tanto, las áreas del espacio público deben contener lugares de estancia con las condiciones favorables como sombra, mobiliario, etc. que, en relación a las condiciones externas, como el clima, permitan al usuario la prolongación del tiempo de estancia. Los bordes son los más utilizados para este propósito, ya que posibilitan al usuario tener una visión amplia del espacio en el que se encuentran. (Gehl, 2006)

Por otro lado, el teórico establece principios para lograr que el usuario ocupe el espacio público. El primero es ubicar usos cercanos; segundo, intentar que los usos sean variados y que generen sensacion de seguridad; tercero, diseñar ciclovías para un transporte sostenible; cuarto, quitar barreras entre el espacio público y los edificios; quinto, aumentar la vida en el espacio público para invitar al peatón a prolongar la estancia. (Gehl, 2010)

Finalmente, para Jan Gehl la ciudad es el lugar de encuentro por excelencia, las calles, parques y plazas son los espacios públicos peatonales. La ciudad no es del automóvil, ya que este deteriora la calidad urbana, por lo tanto, es del peatón. (Gehl, 2006)

El espacio público es funcional cuando contempla espacios para diversas actividades relacionadas a la vida diaria de los usuarios, es atractivo cuando estos espacios cubren necesidades que permitan la permanencia del usuario y es sostenible si incluye transporte integrado y cero emisiones de carbono.

\subsubsection{Teorías de Frederick Law Olmsted}

Hablar de espacio verde público es hablar de parque experimental. Como lo menciona el historiador Dr. Charles E. Beveridges en el texto "Mount Royal In The Works Of Frederick Law Olmsted": Los parques son planeados para la experiencia con el paisaje, estos tienen un significado especial ya que sirven para la interacción con el visitante a

\footnotetext{
5 Es un historiador que los últimos cuarenta y cinco años de su vida se ha dedicado a la investigación de la carrera de Frederick Law Olmsted. Ha escrito sobre los años formativos, paisajistas, entre otros; además de impartir unas doscientas conferencias sobre el teórico.

Por otro lado, ha servido como consultor histórico para cuarenta proyectos dedicados a la preservación y restauración de las obras paisajísticas de Olmsted.
} 
partir de la creación de una serie de escenas. Asimismo, este espacio colectivo debe generar un impacto a diversas escalas, desde la vecinal hasta la metropolitana. Al diseñar un parque se debe tener en cuenta la recuperación de la flora nativa, además de la inserción de flora exótica para dar un efecto de riqueza, arte y naturaleza (Beveridge, 2009).

Se puede decir entonces que el espacio público debe relacionarse activamente con el visitante y es importante que contenga diversas actividades con impactos de acuerdo a la dimensión del proyecto. Por otro lado, es importante revalorar especies nativas de flora, e incrementar flora exótica para generar un sentido de identidad al usuario.

En el siglo XX, el valor social del espacio público adquirió mayor relevancia. No se podía hablar de espacio público si no había igualdad social y étnica. Frederick Law Olmsted (1968), en relación al parque como espacio público colectivo, menciona que:

Los parques públicos son válvulas sociales de seguridad, mezclan las clases sociales y las etnias en unas recreaciones y unos placeres (burgueses) comunes. Nadie que haya observado de cerca la conducta de la gente que visita Central Park podrá dudar de que el parque ejerce una influencia clara de armonía y educación sobre las clases más desafortunadas y desamparadas de la ciudad, una influencia que favorece la cortesía, el autocontrol y las mesuras (como se citó en Sorkin, 2004, p. 179)

Todas las personas tienen necesidad de contacto, tanto visual, auditivo, físico, etc. Esto es posible solo en el espacio público, ya que es el lugar donde se entabla la comunicación de diversas formas. Por esta razón, es importante entender la relación entre el elemento físico y social en el paisaje urbano.

Otra teoría que también nos será útil para esta investigación está relacionada a la creación de un sistema de parques. Frederick Law Olmsted (1968) en el texto "Landscape into Cityscape" menciona que en la ciudad se debe crear un sistema de parques que está compuesto por una serie de espacios públicos y corredores verdes, cada uno con un propósito particular para brindar pluralidad a los residentes de la ciudad; asimismo proporcionar una estructura pública que ordene el territorio (p. 7). 


\subsubsection{Teorías de Jordi Borja}

Para Jordi Borja, hacer ciudad en la actualidad es hacer ciudad sobre ciudad; crear nuevas centralidades y ejes articuladores que establezcan compromisos en el tejido urbano. Solucionar los problemas de ciudad engloba hacer proyectos que resuelvan 2, 3 o varios problemas a la vez (Borja, 2002). Es importante mencionar que lo primordial dentro de una ciudad es diseñar el espacio público y ejes verdes para articular lo existente y lo nuevo. Asimismo, actuar sobre los bordes para tejer la trama urbana con ejes circulatorios públicos proporcionará a la ciudad un impacto social.

Jordi Borja (2012) visualiza al espacio público como la ciudad y la ciudad como el espacio público. Este es un espacio preparado culturalmente para otorgar continuidad y referencia, hitos urbanos y entornos protectores, cuya fuerza significante trasciende sus funciones aparentes y es concebido como instrumento de redistribución social, de cohesión comunitaria y de autoestima colectiva ( $p .1)$

El espacio público busca ser un espacio mixto, justo y colectivo, en donde se refuerza las relaciones entre habitantes a partir del entorno. En el ámbito barrial se visualiza al espacio público en la vida social y la relación con lo construido. En el ámbito de ciudad, el espacio público cumple funciones de conexión, continuidad e imagen de identidad y monumentalidad.

Desde el aspecto sociocultural, Jordi Borja menciona que el espacio público es un lugar de relación, de contacto entre los usuarios y algunas veces de expresión comunitaria. La dinámica de la ciudad y el comportamiento de la gente pueden crear espacio público que no estaba previsto como tal. Para Borja lo que define la naturaleza del espacio público es el uso (Borja, 2002)

El espacio público desde el punto de vista jurídico se define como un espacio regulado por la administración pública, que es propietaria de ese suelo urbano y que garantiza la accesibilidad. Según Jordi Borja el espacio público moderno proviene de la separación de la propiedad privada y pública cuyo destino es de uso social característico de la vida urbana (Borja, 2012)

Finalmente, el espacio público es el entorno en el que se da la vida social, es el lugar donde se puede relacionar las prácticas sociales con las miradas urbanas. Asimismo, 
el espacio público no es solo un espacio físico, sino es aquel lugar donde se expresa las dinámicas económicas, relaciones de poder y relaciones sociales.

\subsubsection{Lámina de teoría de espacio público}


EL PAPEL DEL ESPACIO PÚBLICO Y LAS ÁREAS VERDES EN LA CIUDAD

LÁMINA

FUENTE: Libro Landscape into Cityscape/ Libro Variaciones sobre un parque temàtico/Libro Cities for people/ La humanización del espacio urbano/ La ciudad del deseo/ Ciudadanía y globalización/ Espacio público y derecho a la ciudad

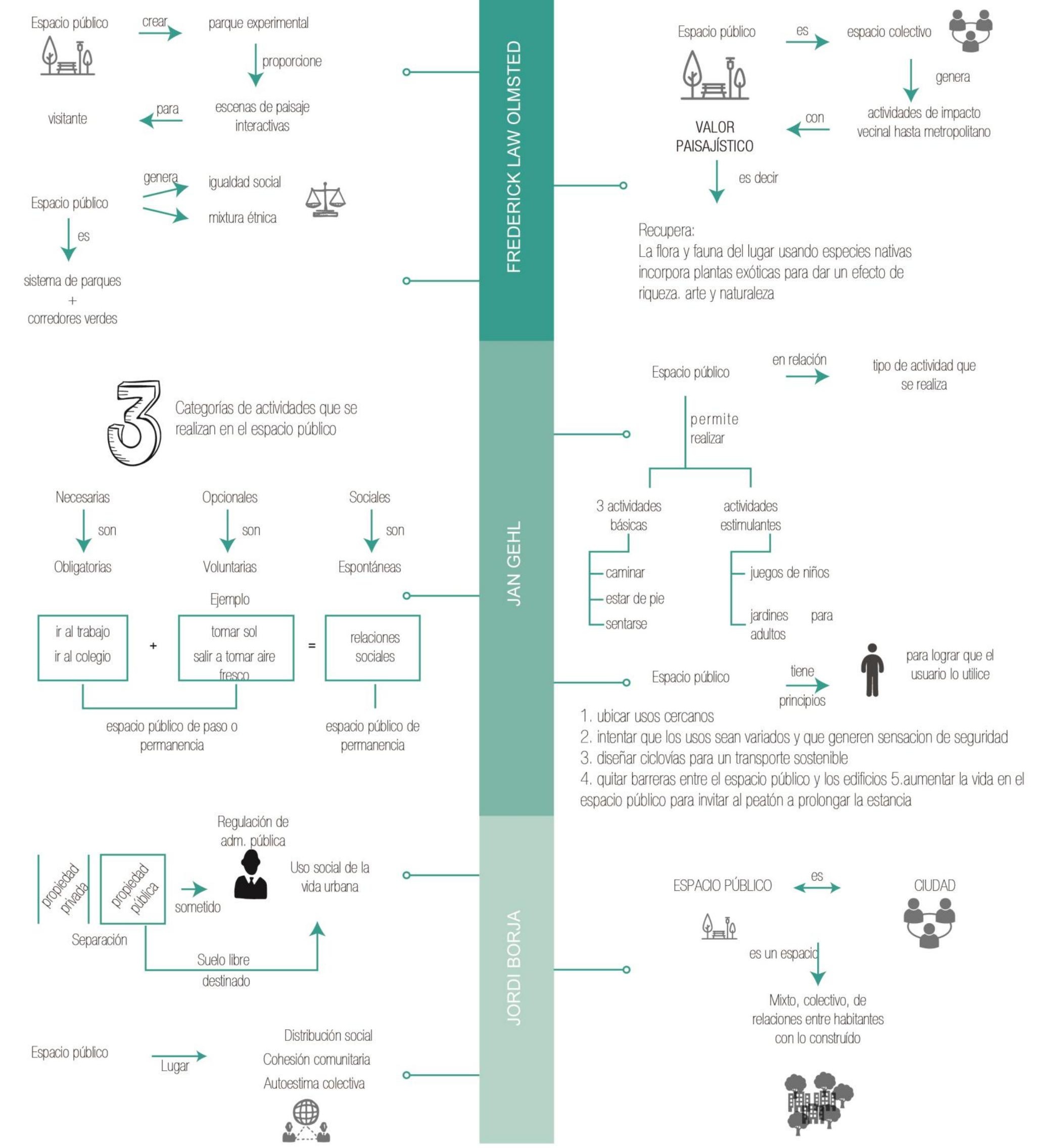

sistema de parques
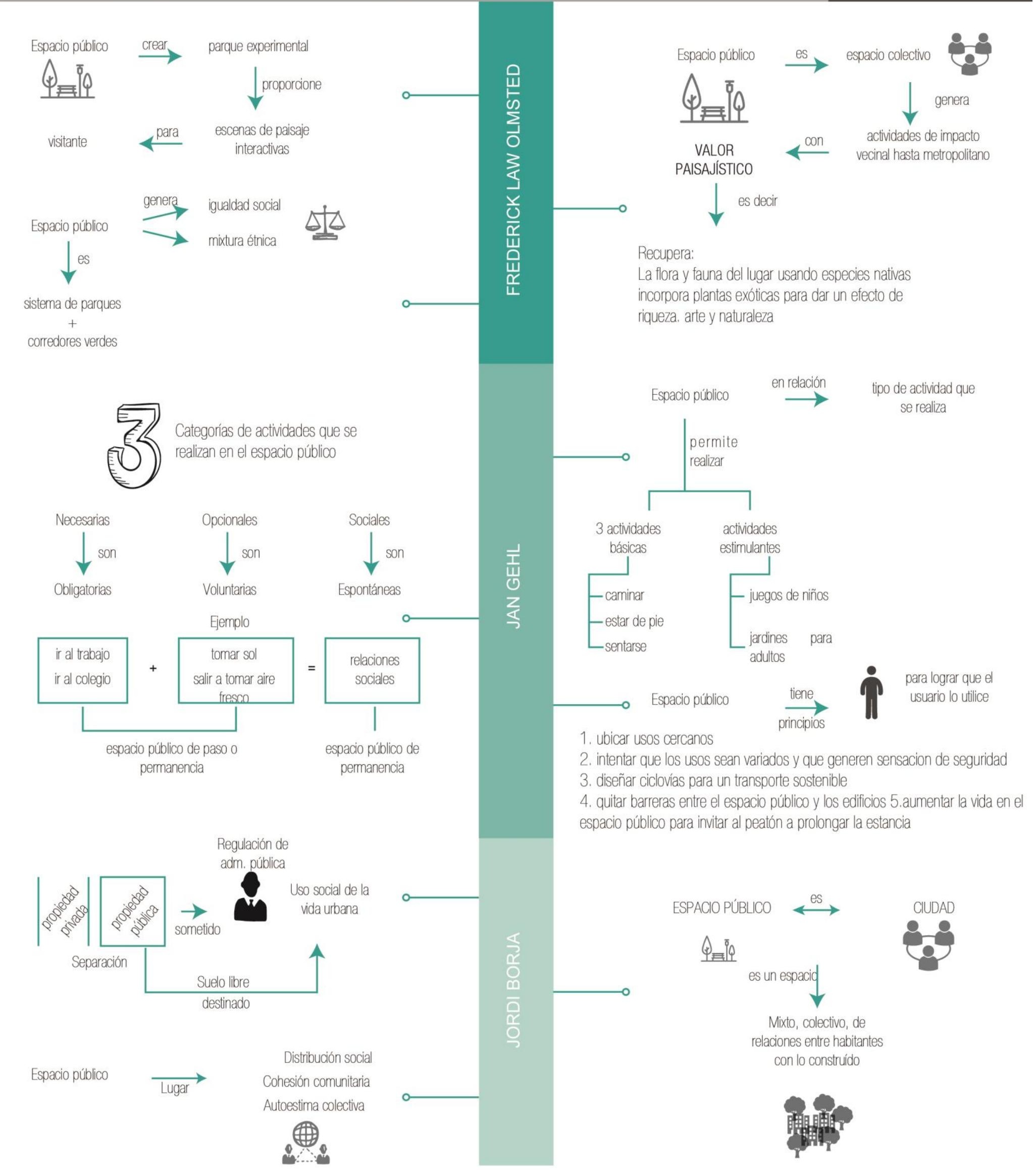

corredores verdes

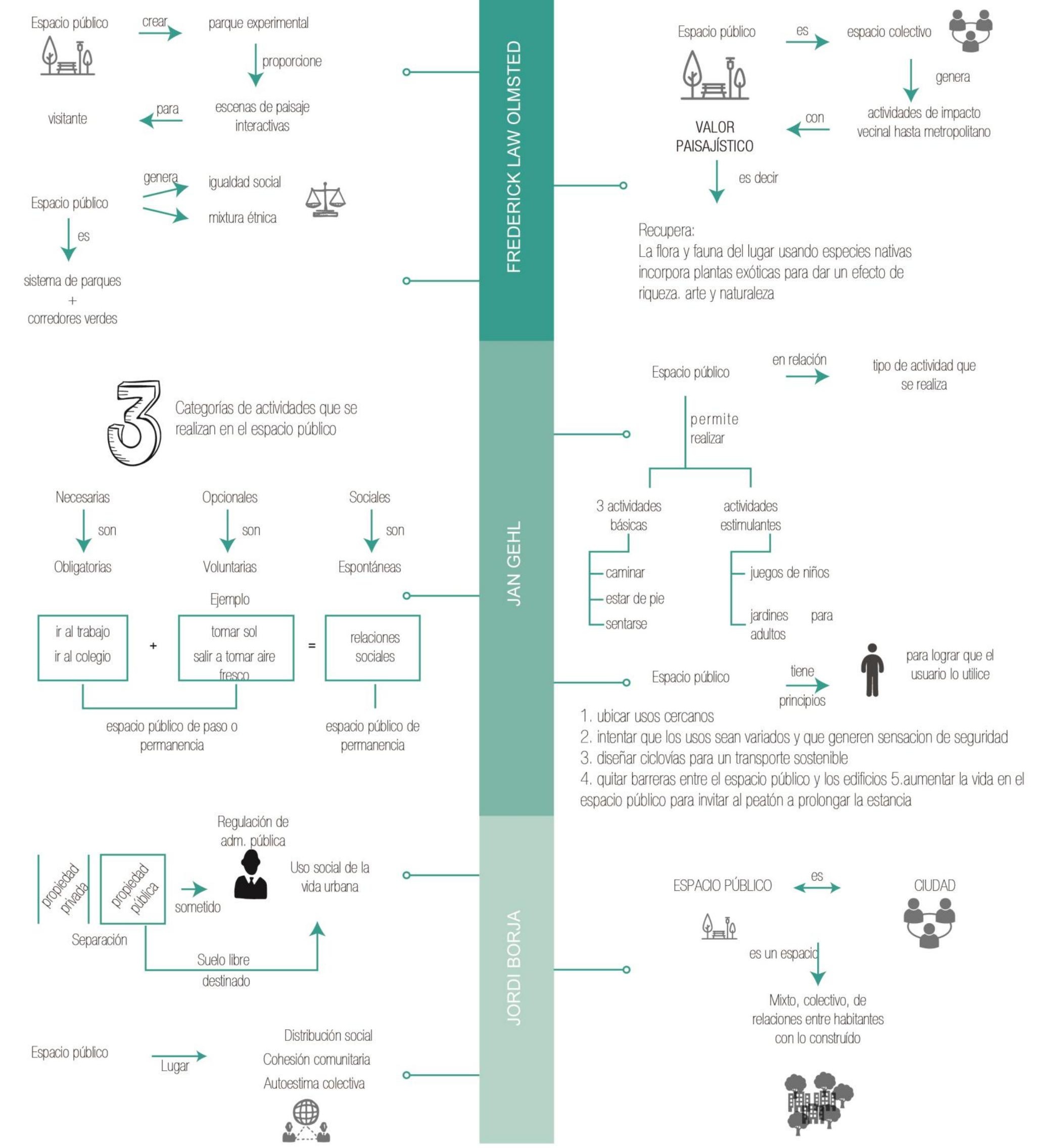

espacio público de paso o permanencia
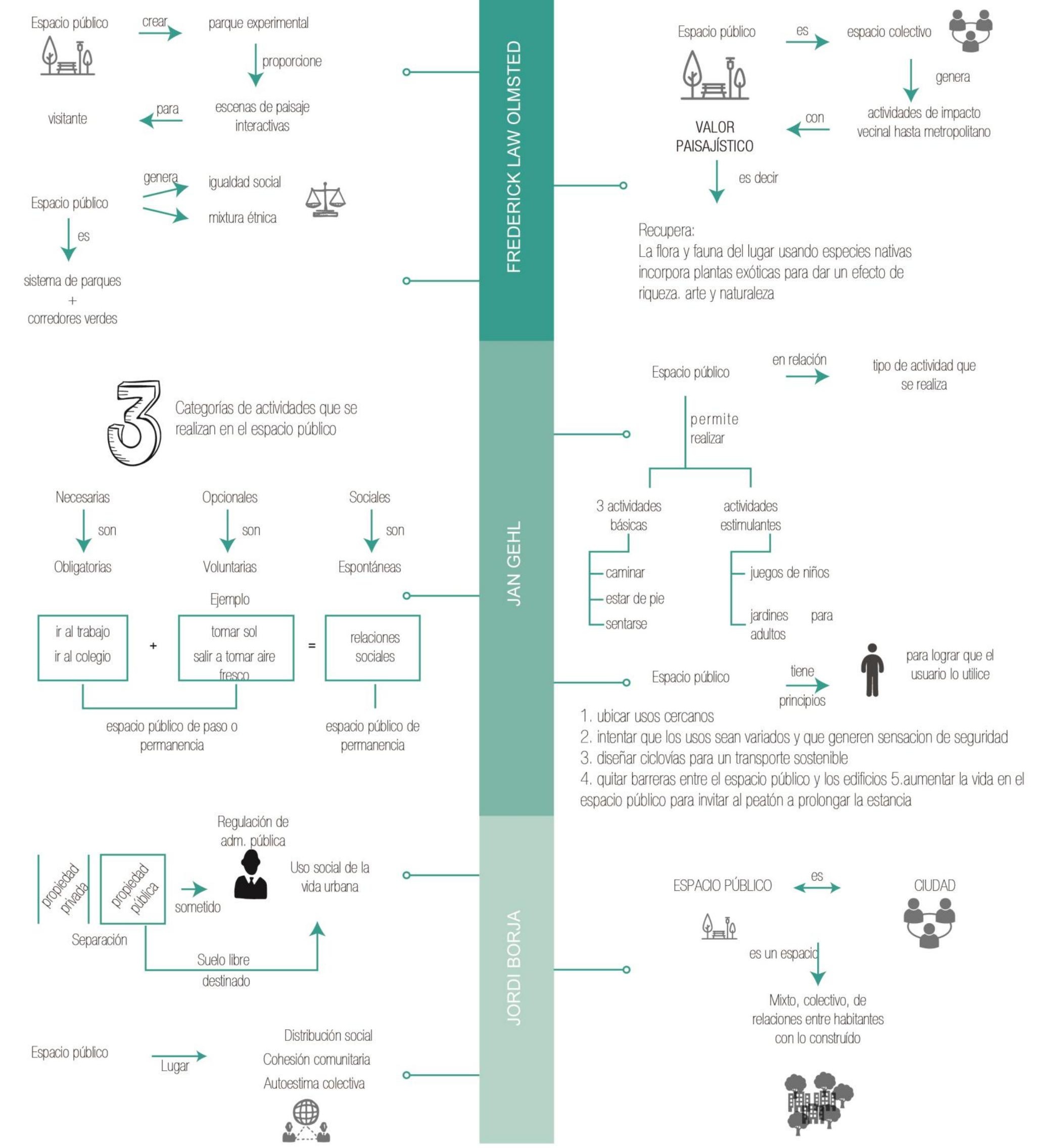

permanencia

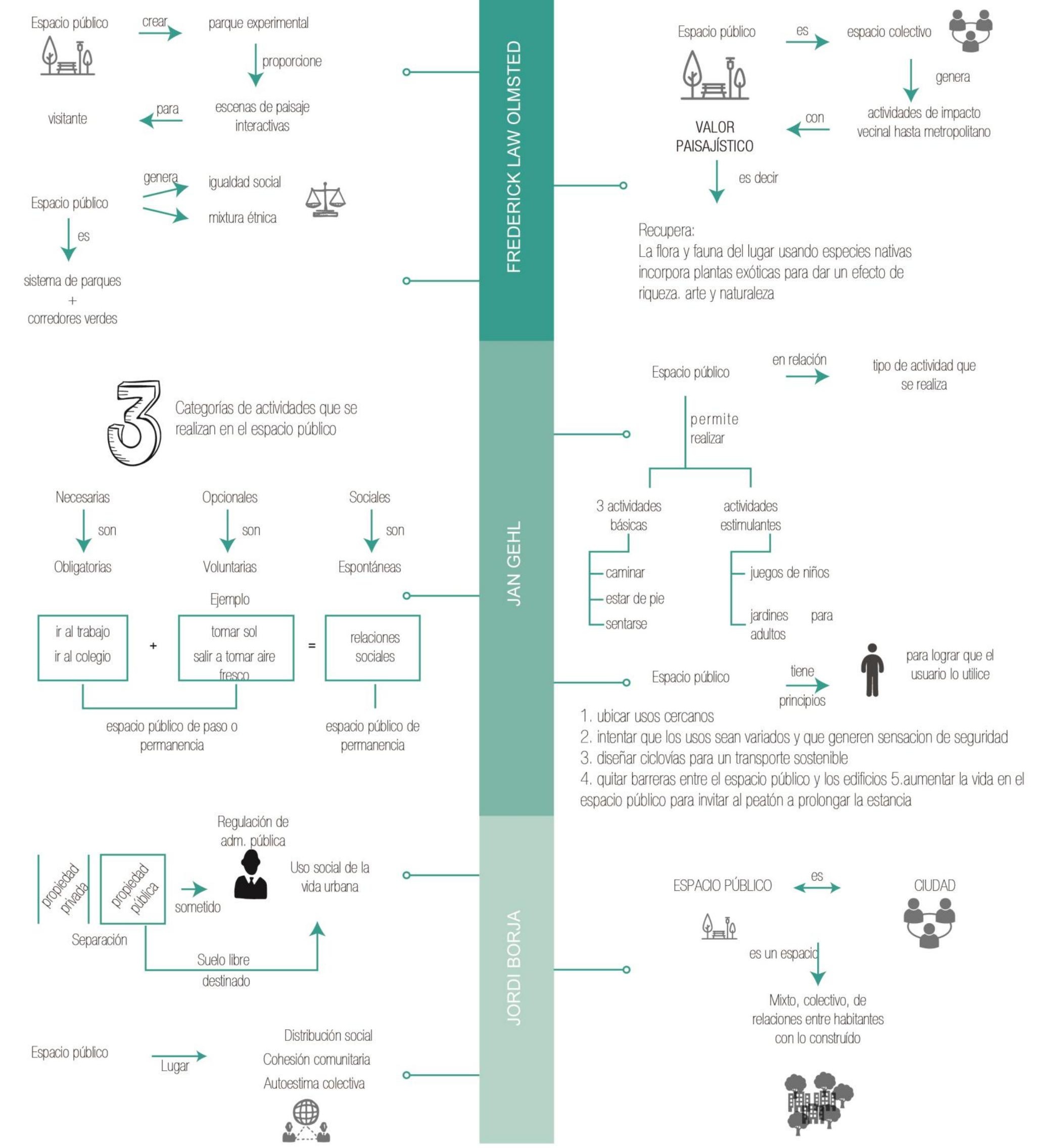

Distribución social

Espacio público

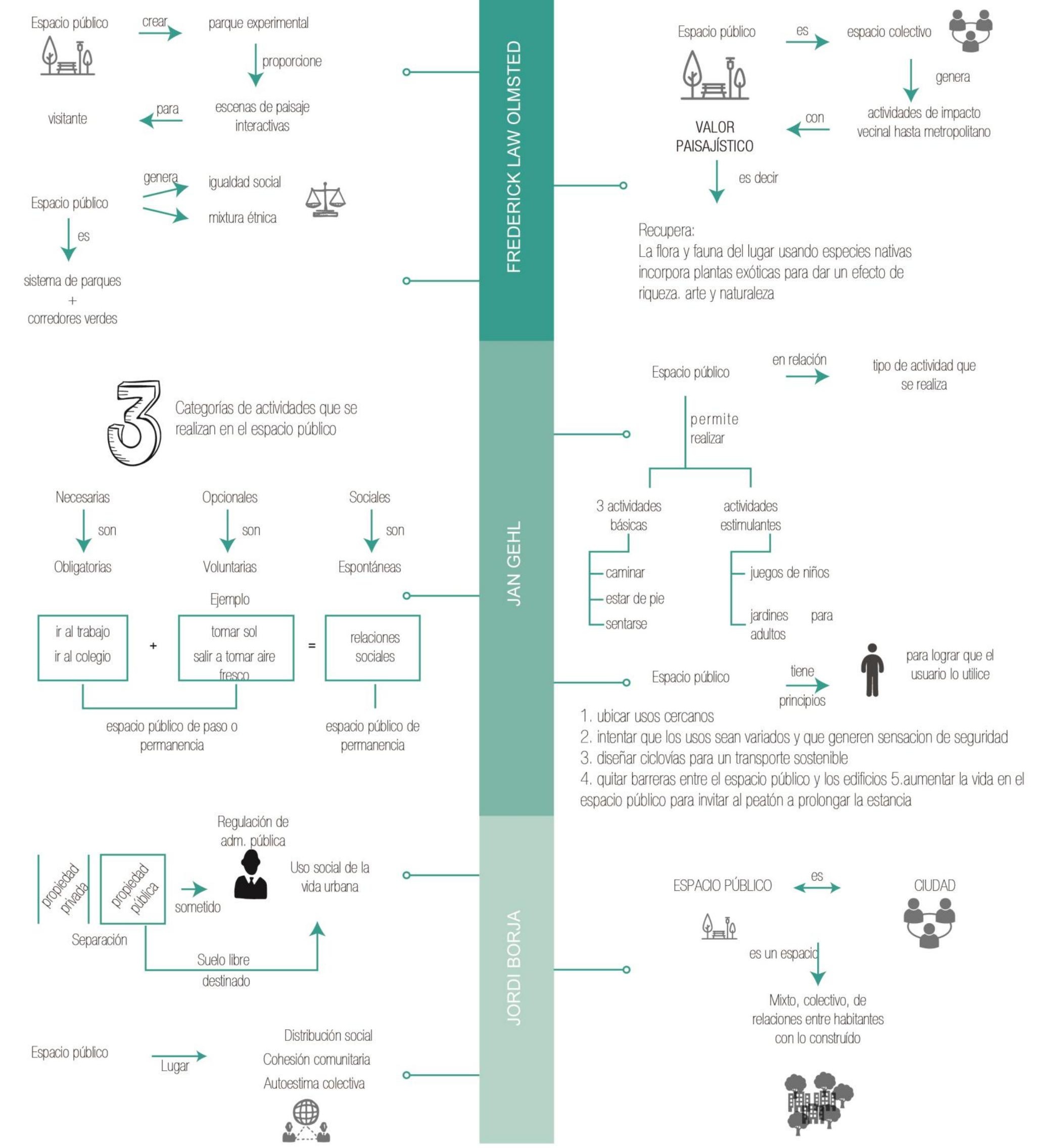
$\longrightarrow \quad$ Lugar $\quad$ Cohesión comunitaria Autoestima colectiva PAISAJÍSTICO

Recupera:

La flora y fauna del lugar usando especies nativas incorpora plantas exóticas para dar un efecto de riqueza. arte y naturaleza
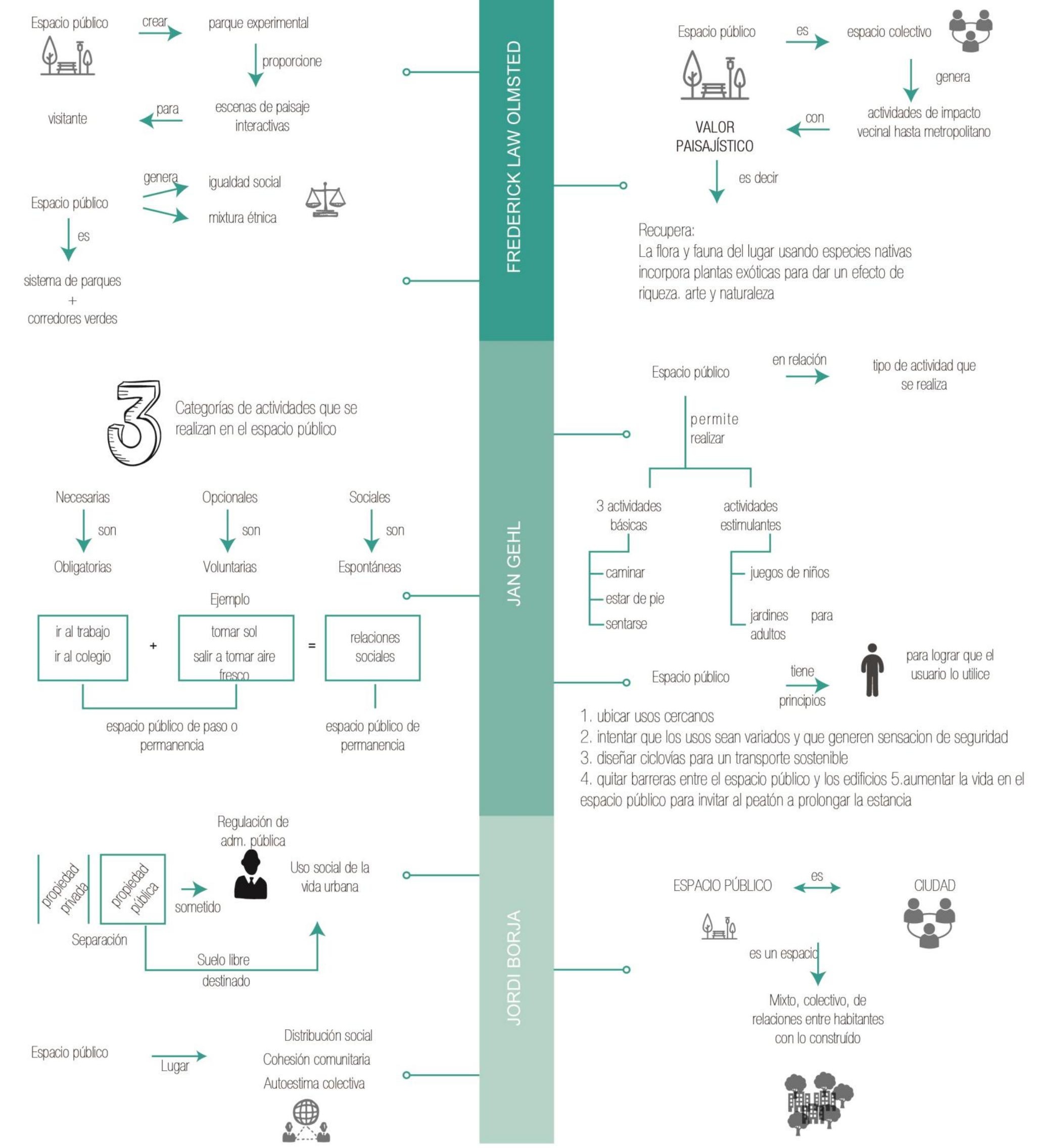

\section{2}




\subsection{Diseño urbano}

Diseñar la ciudad implica dar forma al espacio público de las ciudades basándose en el aspecto funcional y estético. El diseño urbano propone una vida urbana más cómoda gestionando el espacio urbano donde se lleva a cabo la vida social.

Por el grado de complejidad y amplitud que tiene el diseño urbano, es importante para el desarrollo de nuestra tesis entender teorías que nos proporcionan bases conceptuales; citamos a 2 especialistas en el tema. Jane Jacobs que, a pesar de no ser una urbanista, como activista sociopolítica se preocupó por la ciudad desde un enfoque humano, es decir, desde entender el uso, la vida y actividades dentro de los espacios públicos de las ciudades; y Kevin Lynch que fue urbanista estadounidense, aportó a la disciplina del planeamiento urbano y diseño urbano con estudios sobre cómo la gente percibe y se desplaza por las ciudades.

\subsubsection{Teorías de Jane Jacobs}

Para Jane Jacobs las ciudades hace 70 años aproximadamente sufrían problemas de dispersión territorial, predominio del vehículo privado, segmentación de usos, destrucción de barrios, inseguridad debido a usos segregados, entre otros. Sin embargo, podemos decir que dichos problemas prevalecen actualmente en los modelos de crecimiento urbano y se han demostrado como ineficaces.

Para esta investigación es de gran interés 2 capítulos del libro "Muerte y Vida de las grandes ciudades" de Jane Jacobs (1961) que son "La peculiar naturaleza de las ciudades" y "Las condiciones para la diversidad urbana". Cada capítulo nos ayudará a entender las diversas condiciones urbanas en la ciudad para proponer el diseño de un proyecto urbano que contemple a la gente como el personaje principal de activación social en la ciudad.

El primer capítulo menciona que las ciudades están compuestas por veredas, parques y barrios. Estos elementos deben cumplir una serie de características para poder ser utilizados de una manera eficiente en la ciudad. Se estudiará a profundidad las veredas y parques como espacios públicos de la ciudad para entender cuál es el rol que cumplen dentro de esta. (Jacobs, 1961) 
Las veredas son un tipo de espacio público, estas son interesantes cuando están activas y la seguridad dependerá de cuán transcurridas sean. Para que una vereda sea segura debe cumplir 3 cualidades relacionadas a lo urbano, arquitectónico y uso de suelo. Primero debe estar muy definido el espacio público del privado; segundo, los edificios no deben dar la espalda a la calle dejándola ciega; y finalmente las veredas deben tener usuarios constantes de la gente que vive en los edificios y de los transeúntes, dando varias miradas durante el día (Jacobs, 1961).

Tomando en cuenta el término ojos en la calle que lo utiliza para aludir a que la seguridad de la calle dependerá de los mismos transeúntes y residentes. En las veredas o parques, el mejor guardián no es el policía sino el peatón, ya que no existe la cantidad necesaria de policías que puedan cubrir el cuidado de todo el espacio público de la ciudad. La seguridad la brinda la gente. La idea de comunidad se refuerza con este principio. Un barrio debe protegerse tanto por los residentes y visitantes sin generar costos adicionales con el uso de guardianes o porteros.

Jacob sostiene que el comercio debe ser de tiendas pequeñas, variadas y no de multinacionales, ya que los comercios pequeños darán trabajo a los residentes de la zona, además que servirán de seguridad al espacio público; por el contrario, el modelo de trabajo de las empresas multinacionales es de adentro hacia afuera, es decir no les interesa que sucede en el entorno. La elección de un comercio barrial fomenta la inclusión social. (Jacobs, 1961).

La presencia de niños en el espacio público tiende a activarlos, ya que no tienen horarios predeterminados, además que atraen miradas de los adultos que están a su cuidado. Si se quiere que la interacción de niños sea de manera continua y espontánea es importante incorporar espacios para ellos en los parques, como un punto central interesante y en las calles, veredas de 9 metros de ancho, ya que el tránsito peatonal los desanimaría a permanecer si las veredas son de menor dimensión. Los cambios de nivel, diversidad de vegetación, aperturas y visuales permiten enriquecer los espacios públicos y crear vínculos con los usuarios (Jacobs, 1961).

Jan Jacobs (1961) en relación a los parques menciona que:

Si el conjunto se capta de un vistazo, como un buen póster, y si todos los sitios del parque son exactamente iguales, y si el usuario se siente más o menos igual en un sitio que en otro cualquiera de ese parque, entonces éste ofrece pocos 
estímulos para todos estos usos y emociones. No habrá muchas razones para volver (Jacobs, 1961, p.134)

Los parques deben contener actividades atractivas y necesarias para el usuario; es importante introducir la vida cultural a este tipo de espacio público, no solo se trata de diseñar parques en áreas libres de la ciudad o pensar que proponer una gran cantidad de parques equivale a calidad. Un parque bien logrado es atractivo cuando permite a los usuarios desarrollar sus actividades; algunas veces el parque no cubre las necesidades del peatón y no es utilizado quedando en abandono como un espacio deprimido, ocasionando peligro, vaciedad y apropiación por usuarios indigentes.

Entonces se puede afirmar que los espacios públicos dependen del funcionamiento del entorno inmediato por lo que en barrios deprimidos y decadentes no llegan a funcionar. Como lo menciona Jane Jacobs (1961):

En las áreas grises las salpicaduras de usos no residenciales no hacen bien y pueden dañar porque estas áreas no están equipadas para manejar a desconocidos (o para protegerlos) ...En distritos animados donde se ha catalizado una abundante diversidad, estos usos no dañan. Al contrario, son necesarios, bien por su directa contribución a la seguridad, el contacto público y los usos divergentes, o porque ayudan a mantener otra diversidad con esos efectos (p. 266).

En el segundo capítulo Jacobs menciona que las ciudades deben tener una diversidad urbana como: combinación de usos primarios y puntos de concentración, para que funcione como un sistema integrado.

La teórica habla de que hay una necesidad de combinar usos en los espacios públicos para atraer gente a la zona por razones específicas. El comercio ambulatorio tiende a mantener las zonas activas, atiende necesidades momentáneas de los usuarios mientras realizan otras actividades en los parques y plazas. La función principal de combinar usos es de aglomerar personas. (Jacobs, 1961)

Asimismo, los puntos de concentración también se dan en hitos urbanos, ya que estos sirven para identificar y definir zonas, además crean vínculos con los habitantes del lugar. Según Jane Jacobs (1961), los hitos son "anunciadores y dignificadores de la diversidad" (p. 423). Estos permiten a las personas ubicar en un mapa mental un área determinada; sin embargo, no se debe abusar de los hitos dentro de las ciudades, ya que tienden a generar competencia. Los hitos son estructuradores de la vida urbana. 
Por otro lado, diseñar espacio público para las personas no es suprimir el transporte vehicular, sino ordenar de tal manera que se reduzca el uso de vehículos particulares y se ordene al transporte pesado. Las calles más transitadas deben de peatonalizarse para generar dinámicas donde los usos se combinen. Es importante que las vías peatonalizadas ofrezcan al usuario áreas de estancia que contengan mobiliario urbano como bancas y sombra. (Jacobs, 1961)

Para que una recuperación urbana sea exitosa depende de cuantos usuarios están en el lugar por voluntad propia. Como lo menciona Jane Jacobs (1961) "Que una rehabilitación tenga éxito implica que haya gente suficiente con apego a su barrio para decidir quedarse en él; y también implica que les sea práctico quedarse” (p. 323).

Finalmente, las teorías de Jane Jacob nos permitirán diseñar un espacio público que contenga diversidad de actividades para garantizar el uso intenso que brinde seguridad y longevidad.

\subsubsection{Teorías de Kevin Lynch}

Kevin Lynch, desde la perspectiva del diseño urbano y la percepción de las personas, realizó estudios acerca de lo que las personas extraen de la realidad física en el espacio urbano. Los resultados dieron origen al libro "La imagen de la ciudad" que aporta la comprensión y transformación de la arquitectura urbana.

Kevin Lynch (1976) menciona que las personas al interactuar con un ambiente particular, forman imágenes mentales de los elementos físicos que son observados.

El paisaje urbano, entre sus múltiples papeles, tiene también el de algo que ha de verse, recordarse y causar deleite. Dar forma visual a la ciudad constituye un tipo especial de problema de diseño; un problema bastante novedoso, dicho sea de paso (p. 8).

Kevin Lynch plantea cinco elementos físicos que conforman la imagen de la ciudad y estos son: Sendas, bordes, barrios, nodos y mojones o hitos. Cabe mencionar que ninguno de los elementos funciona de manera individual, mayormente se integran y se superponen generando una imagen general. (Lynch, 1976)

La percepción genera mapas mentales de la ciudad y las partes que lo componen. Esto ayuda a orientar al observador cuando se traslada de un lugar a otro, ya que le permite establecer puntos de referencia. Sin embargo, la percepción de un objeto puede 
cambiar si las circunstancias de la visión son diferentes. Por ejemplo, una autopista puede ser una senda para el conductor, pero es un borde para el peatón. (Lynch, 1976)

A continuación, se menciona los elementos de la ciudad desde la sensación físicaespacial según Kevin Lynch (1976).

- Sendas: Las sendas son redes que sigue el usuario normalmente. Estas pueden ser las calles, líneas de tránsito, vías vehiculares, canales o líneas de ferrocarril. Mayormente las personas ven a este elemento como predominante en la imagen de ciudad que generan.

- Bordes: Los bordes son elementos lineales que separan una región de otra, pueden ser penetrables o vallas; si bien es cierto que no tienen la función de una senda, también pueden ser organizadores de ciudades. Mayormente los bordes como el agua o murallas configuran el contorno de una ciudad.

- Barrios: Los barrios son conjuntos de tamaño regular-grande, mayormente son reconocidos por el observador por mantener un carácter común de identidad. Son usados como referencia tanto desde el interior y exterior del barrio.

- Nodos: Los nodos son puntos de concentración de un determinado uso o carácter físico. Algunos nodos son las áreas principales de los barrios o puntos de convergencia de varias sendas.

4 Hitos o mojones: Los hitos son puntos de referencia exteriores, mayormente son apreciados de diversos ángulos visuales. Pueden ser naturales o urbanos, usarlos implica seleccionarlos entre diversos elementos que componen la ciudad.

Mayormente para el usuario perceptor son piezas importantes en las ciudades ( $\mathrm{p}$. 61-111).

Estos cinco elementos se interrelacionan para generar una imagen de escala urbana. Mayormente trabajan en parejas y cuando esto sucede perceptualmente uno de ellos tiende a perder el protagonismo. Por ejemplo, un hito ubicado al centro de un barrio podría empequeñecer al barrio dejándolo de lado. Todo dependerá de la ubicación de un elemento respecto a otro. (Lynch, 1976)

Finalmente, el texto "La imagen de la ciudad" se ha convertido en una serie de herramienta proyectual; sin embargo, en el libro no se menciona que a partir de esos 5 elementos se puede formular un proyecto urbano, ya que es un esquema simple y la 
ciudad abarca otros elementos más. Por lo tanto, el teórico propone un lenguaje, una metodología para preguntar a las personas sobre cuál es la percepción que tienen de imagen de la ciudad, cómo les puede servir estos elementos para poder ubicarse en el espacio y no es un libro de elementos proyectuales, ya que el modo en que se realiza el análisis usando estos elementos, afectará al modo en que se diseña una propuesta urbana

\subsubsection{El borde hídrico como articulador urbano}

Los bordes son elementos que componen la morfología urbana de la ciudad y que desde épocas antiguas han marcado y delimitado espacios urbanos. La condición de límite o borde siempre está presente cuando se habla de ciudad, ya que es un espacio donde dos elementos interactúan y hay intercambio. Existen muchas teorías que definen o hacen alusión a los bordes, límites o fronteras. Usaremos las teorías de la arquitectura, la sociología y la planificación urbana de Kevin Lynch, Steven Holl, Josepha Bru y Batty Longley para entender el concepto de borde y su relación con la ciudad.

Los bordes, según Lynch, son: elementos lineales, rupturas lineales de la continuidad que obran como referencias laterales, tienen una forma continua que tiende a fragmentar un territorio. Los bordes adquieren más fuerza si son visibles lateralmente, por ejemplo, un rascacielos frente al Central Park o la transición clara del agua a la tierra en un frente marino, son visualmente impresionantes. (Lynch, 1976)

Asimismo, Lynch propone una división de bordes; los bordes fuertes, son aquellos visualmente prominentes con formas continuas e impenetrables al movimiento transversal. Los bordes fragmentarios; son inaccesibles a los peatones, son visualmente penetrables desde algunos puntos de su totalidad y los bordes aéreos; son elevados y podrían en el futuro ser elementos de orientación (Lynch, 1976). El teórico concluye que las ciudades están formadas por compontes que las caracterizan y que ayudan al observador a ubicarse, uno de ellos son los bordes que si bien es cierto fragmentan las ciudades, no quitan la conexión visual y de movimiento del observador.

Por otro lado, Steven Holl, con una mirada a una nueva construcción de la ciudad, establece que la superficie de una ciudad tiene el potencial para funcionar como un gran imaginario (Holl, 1991). Para Steven Holl, "El borde de la ciudad es una región filosófica donde se superponen paisaje natural y urbano, coexistiendo sin elección ni expectativas. 
Estas zonas llaman a visiones y proyectos que definan una nueva frontera entre lo artificial y lo natural" (Holl, 1991, p. 8)

Estudiar el espacio natural y artificial sirve para entender el fenómeno de creación y dilución de bordes. Si bien es cierto, en la actualidad los bordes resultan ser difícilmente abordables por la complejidad urbana, estos no deben ser proyectados con soluciones generalizadas, al contrario, deben ser diseñados atendiendo cada caso particular y situación individualizada de cada ciudad. Dichos elementos son una oportunidad para tejer redes morfológicas de la ciudad y de esa manera articular. En una visión dinámica los proyectos de bordes adquieren identidad siempre y cuando no continúa el consumo del paisaje por parte de la ciudad.

Para Steven Holl los bordes en la ciudad son espacios con posibilidades de transformación en el que el paisaje natural y urbano se articula. Él aspira a la transformación de una nueva ciudad donde los bordes sean los que definan las nuevas maneras de conexión de la ciudad. Los bordes como elementos urbanos pueden ser mediadores en las zonas urbanas cargadas y pasivas. (Holl, 1991)

Otros teóricos que abarcan el tema de bordes son Michael Batty, Paul Longley, lo hacen desde una perspectiva contemporánea usando la geometría fractal para comprender y planificar la forma física de las ciudades. Este tipo de geometría permite simular ciudades a través de gráficos virtuales. Asimismo, explican cómo las ciudades evolucionan de manera que a primera vista dan la sensación de irregularidad, sin embargo, al utilizar la geometría fractal revelan un orden complejo.

Batty y Longley mencionan que los bordes marcan transiciones entre diferentes formas, controlan y permiten el intercambio entre diversos territorios. Son espacios de conquista y descubrimiento y muestran su estructura a diversas escalas (Batty y Longley, 1994).

Como mencionan los autores, el urbanismo regular ha visto los bordes de "dentro a afuera" como suelos urbanizables sobre no urbanos, sin embargo, el nuevo urbanismo da respuesta a los retos contemporáneos de "afuera a dentro" y a la valoración del paisaje natural frente al urbano. Los bordes, ya sea naturales o artificiales identifican a las ciudades y muchas se están perdiendo por el desarrollo de las ciudades actuales. 
Hablar de bordes nos remite al tema de la ciudad y sus componentes urbanos, si bien es cierto los bordes han existido siempre; es desde la época moderna que se inicia el desarrollo de teorías aplicables a la morfología urbana. Las ciudades están compuestas por bordes naturales y artificiales que les ofrecen su singularidad e identidad. Los bordes tienen que unificar y establecer vínculos entre lo que se propone y lo que existe generando cohesión. No se trata de eliminar los bordes, sino de generar articulación donde el borde sea un espacio de inclusión y no de limitación.

\subsubsection{Lámina de teoría de Diseño urbano}




\section{DISEÑO URBANO}

\section{PAISAJE}

ESPACIO PÚBLICO

INTERPRETACIÓN

BASE CONCEPTUAL

\section{DISEÑO URBANO}

\section{LÁMINA}

\section{FUENTE:}

\section{Libro Muerte y Vida De Las Grandes Ciudades/ Libro La Imagen de la Ciudad

JENKS

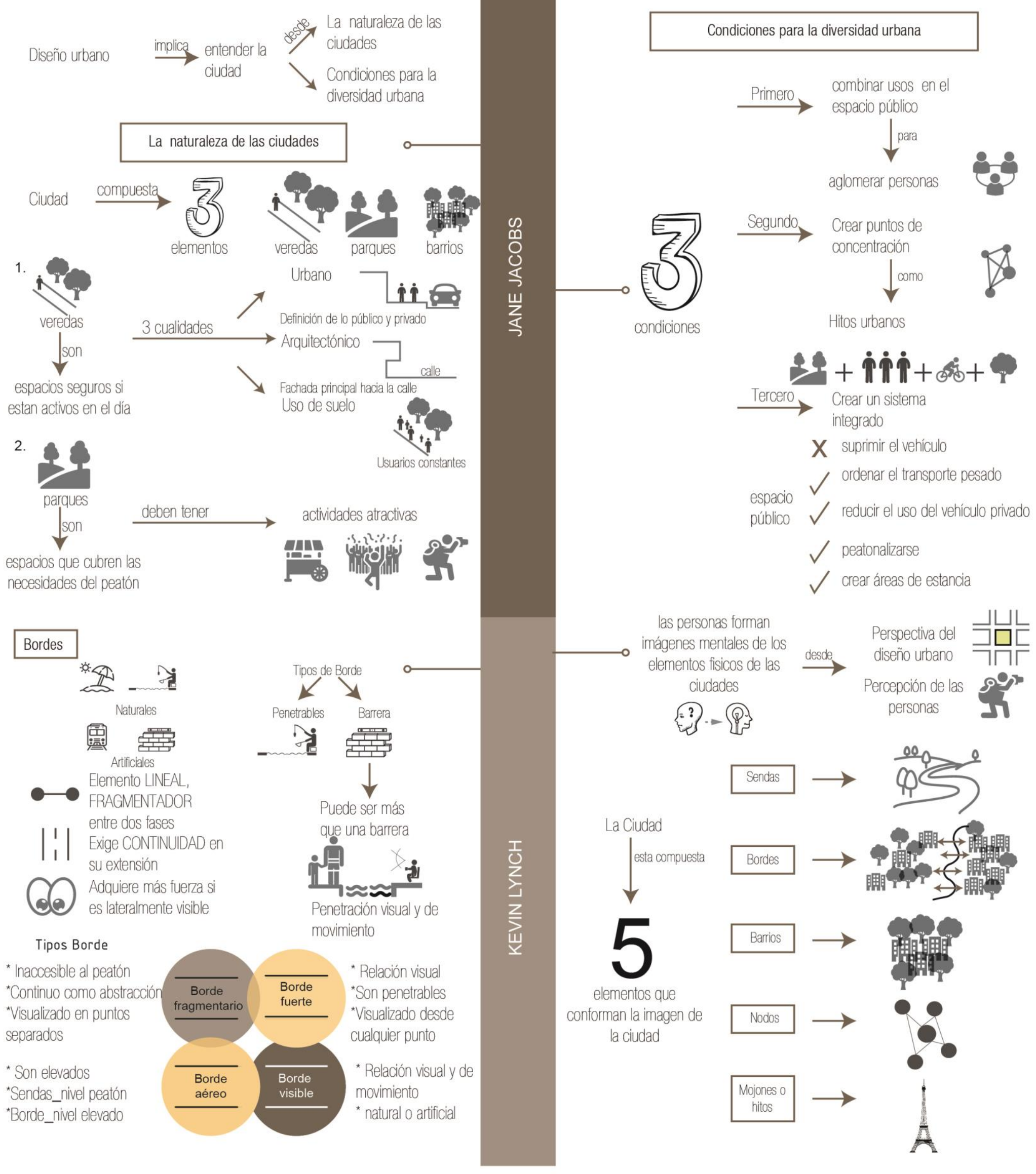




\subsection{La Interpretación como herramienta de educación}

El estudio de la interpretación es un campo extenso a tratar por lo que la presente tesis abarcará aspectos puntuales de la disciplina. Los autores considerados son: Freeman Tilden, Bob Peart, Don Aldridge, Badaracco y Scull., John Veverka, entre otros. En el caso de la selección de teorías en el tema se basa en la consideración conceptual y aplicativa con la propuesta proyectual del Parque Ribereño del Rio Shullcas.

Al inicio del texto se abarcará definiciones que dan una primera aproximación al campo de la interpretación. Para luego hacer referencia a la labor de la planificación interpretativa y poder entender el desarrollo de las áreas internas que garantizan el sentido de la interpretación

\subsubsection{Primeras aproximaciones a la interpretación}

Freeman Tildel, considerado como el padre de la interpretación, realizó la primera definición del término expuesta en el libro "La interpretación de nuestro patrimonio". De la siguiente forma: "Interpretación es una actividad educativa que pretende revelar significados e interrelaciones a través del uso de objetos originales, por un contacto directo con el recurso o por medios ilustrativos, no limitándose a dar una mera información de los hechos" (Tilden, 2006, p. 110-111).

En esta conceptualización, centra la importancia en el objeto como herramienta de comunicación que busca traspasar, difundir el conocimiento mediante la relación del recurso con el receptor. Asimismo, autores como Bob Peart ${ }^{6}$ remarcan la relevancia del objeto como herramienta de interpretación, precisando el sentido de la estimulación del objeto con la siguiente definición:

La interpretación es un proceso de comunicación diseñado para revelar al público significados e interrelaciones de nuestro patrimonio natural y cultural, a través de su participación en experiencias de primera mano con un objeto, artefacto, paisaje o sitio (Peart, 1977, p. 44).

\footnotetext{
${ }^{6}$ Investigador canadiense sobre la conservación y educación de la naturaleza. Ha proporcionado aportes en la disciplina de la interpretación en su escrito Definition of iInterpretation realizado en 1977.
} 
Con ello, se puede inferir que el objeto tiene como función estimular la sensibilidad con la propia vivencia. Asimismo, se requiere señalar la diferencia del término objeto en ambos autores. Por un lado, Tilden hace referencia al objeto como tipo de medio para comunicar mientras Bob Peart alude al objeto como interpretación, es decir a lo que se interpretará.

Don Aldridge, considerado principal impulsador de la interpretación en el ámbito europeo, recalca el valor de la reflexión con respecto a la conservación del medio con las siguientes palabras:

"es el arte de explicar el lugar del hombre en su medio, con el fin de incrementar la conciencia del visitante acerca de la importancia de esa interacción, y despertar en él un deseo de contribuir a la conservación del ambiente." (Aldridge, 1973, p. 22-24)

A partir de la definición anterior el autor menciona que la idea central de la interpretación es el de provocar conciencia, dar a conocer la importancia de la relación entre el visitante y su entorno. No es una conciencia utópica sino de acción con el cuidado, valoración y conservación del recurso.

A modo de conceptualización general de las definiciones expuestas, se comprende que la interpretación es un proceso complejo que involucra varios elementos como el objeto a interpretar, el medio de comunicación y la noción de un receptor, el cual asimila el mensaje de manera propia y experimental para generar reflexión, un cambio de visión y acción sobre lo interpretado.

Por otro lado, no se puede dejar de mencionar la relación entre la interpretación y la educación. Ambas disciplinas proporcionan información, sin embargo, en la interpretación su finalidad es generar una nueva actitud de cambio.

Autores como Morales, reconocido consultor, formador y ex-vicepresidente de la Asociación para la Interpretación del Patrimonio de España, han expuesto en múltiples escritos sobre la concepción de la interpretación. En la jornada de educación ambiental Morales (1983) manifiesta lo siguiente: 
La interpretación no tiene como consigna el de informar, sino de revelar, de despertar la curiosidad, es un modo de educar sin que el público sienta que es objeto de una actividad educativa...la interpretación debe ser recreativa: con ello, se asegura que no haya un rechazo de entrada a la propuesta interpretativa" (p, 214)

Asimismo, expresa que las intenciones de interpretar se concentran en los siguientes cuatro términos: Primero, concebida como una herramienta de cambio de actitud; segundo, instrumento de manejo de recurso; tercero, como herramienta educativa; y finalmente como experiencia recreativa e intelectual. (Morales, 1992)

Finalmente la National Association for Interpretation (2009) formula que "La interpretación es una misión basada en el proceso de comunicación que produce conexiones emocionales e intelectuales entre los intereses del público y los significados inherentes al recurso" (p. 2) De esta forma, se entiende que primero se busca a dar conocer el recurso para luego generar valoración, conciencia, entendimiento y conservación del recurso interpretado a partir de la experiencia generada por el medio de comunicación.

En conclusión, a los distintos puntos de vista en la definición conceptual de la interpretación podemos sostener que la interpretación posee un carácter de concientización que involucra la trasmisión de conocimientos a partir del vínculo emocional y poder generar reflexión a un grupo de personas con respecto a un determinado tema y lugar.

\subsubsection{Proceso de planificación interpretativa}

La planificación interpretativa, es el proceso que analiza necesidades y oportunidades para la interpretación. Al igual que cualquier desarrollo disciplinario se requiere de un manejo sistemático y meteorológico de fases para poder determinar un plan de acción proyectual (Morales, 1992) 
Los autores Badaracco y Scull, considerados pioneros en el tema de la interpretación desarrollaron 3 estrategias básicas a desarrollar en la planificación interpretativa (como se citó en Morales, 1992). Las cuales se harán mención a continuación:

- Recopilación de información sobre el recurso interpretativo y de la distinta área para posteriormente analizarla.

- Desarrollo de estudio sobre el usuario

- Selección y desarrollo de los métodos y medios

Por otro lado autores como Chilman ,reconocido doctor forestal de la Universidad de Michigan ,elaboró una síntesis de 4 fases para el desarrollo del proceso de interpretación (Chilman, 2006). De las cuales se mencionrán a continuación :

- Establecer las necesidades y objetivos y líneas de acción.

- Inventar y recopilar información

- Sintetizar el mensaje y elegir los medios de comunicación adecuados

- Formular las etapas para la realización del plan

Del mismo modo la "Countryside Comission" , postuló que la interpretación se puede definir como un proceso cíclico basado en parte de la elaboración del modelo teórico de los autores Peart y Wood que surge de un sistema de 5 preguntas que responden a los principales componentes del proceso interpretativo y la relación que postula Peart entre las interrogantes y el desarrollo de capítulos en la planificación interpretativa con el fin de determinar las labores en las cada etapas del proceso de planificación.(como se citó en Morales, 1992). A continuación, se presentará las formulaciones que conforman el modelo teórico de Peart y Wood complementado con el desarrollo de áreas de la planificación sostenido por Peart:

- ¿Por qué interpretar? - Lineamientos de interpretación

- ¿Qué se puede interpretar? - Análisis del recurso

\footnotetext{
${ }^{7}$ Antiguo organismo estatuario en Inglaterra y Gales encargado a temas relacionados al campo, actual Comisión de Desarrollo Rural,
} 
- ¿A quién se interpreta? - Análisis de los usuarios

- ¿Cómo, Dónde y cuándo debe interpretarse? - Selección de Medios

- ¿ ¿Y después qué se hará para tener un control? - Evaluación

En conclusión, a partir de las teorías mencionadas de los distintos autores sobre la planificación interpretativa se puede inferir el interés genérico de establecer un sistema secuencial de acciones que busca producir lazos emocionales e intelectuales propiciando un estado de reflexión sobre la idea interpretada.

Asimismo, mencionar la importancia de la recomendación de estratégicas para la elaboración de etapas en la planificación las cuales se resumen en tres pasos base: El primero referente a la recopilación de información; el segundo, el análisis de la información segundo, y el último la selección y desarrollo del tipo de medio para la interpretación.

Finalmente, en relación al modelo teórico del proceso interpretativo se puede determinar que fue pieza clave para el desglose metodológico de los campos para desarrollar en la planificación interpretativa estableciendo 5 pilares.

\subsubsection{Desarrollo de la planificación interpretativa}

Como anteriormente se mencionó, el desarrollo de la planificación interpretativa es primordial para garantizar el objetivo final, sin embargo, la presente tesis se centrará en el aprendizaje de las 4 primeros áreas (objetivos, análisis de recurso, análisis de usuario y selección de medios) debido a la trascendencia y alcance de la información aplicada a la propuesta proyectual de la tesis.

\subsubsection{Lineamientos interpretativos}

Para autores como Veverka (2003), reconocido doctor de interpretación de parques y recreación, determina que la planificación del proceso de interpretación es importante para determinar los objetivos del programa. De este modo el autor clasifica estos en tres tipos. El primero relacionado al aprendizaje; el segundo, al comportamiento; 
y el último, al de las emociones. A continuación, se describirá cada uno de estos objetivos que señala:

- Objetivo de aprendizaje: Son aquellas ideas que hace referencia a la información que se quiere que recuerden o sepan los visitantes.

- Objetivo de comportamiento: Aquello lo que se pretende que el visitante haga. Está relacionado a la acción de los visitantes posterior a la interpretación

- Objetivos emocionales: Son lo que generan impacto en la memoria a largo plazo. Ayuda a determinar la selección de composición de la exhibición para producir sensibilidad

Con lo expuesto, se puede comprender que los objetivos como parte del proceso de interpretación, los objetivos son la base de todo plan de acción. Por lo que es importante tener en cuenta cual es la finalidad de la interpretación con respecto al recurso y la audiencia. Ambos factores se relacionan y no se pueden intervenir uno de ellos sin contemplar al otro.

\subsubsection{Análisis del Recurso}

El proceso de entender el recurso es esencial para poder identificar otras características que pueden ayudar a interpretar mejor. A esta identificación, Morales, lo denomina rasgo interpretativo, que significa "todo objeto, proceso, fenómeno o concepto que merece ser interpretado o que tiene importancia interpretativa" (Morales, 2004)

Por otro lado, Badaracco y Scull, determinan un criterio de evaluación de potenciales interpretativos para constatar su valor sin poner en peligro su integridad. El total de factores a determinar son los diez siguientes. El factor de singularidad, atractivo, resistencia de impacto, acceso, estacionalidad, afluencia del público, disponibilidad de información, facilidad de explicación, pertinencia de contenido, seguridad y facilidad de instalación. A continuación, se explicará a detalle los 7 criterios considerados para la determinación del potencial interpretativo. (Como se cito en Morales, 2004) 
- Singularidad: Está relacionado con el grado de particularidad que presenta en su entorno. Se considera con un gran potencial interpretativo mientras esta cualidad sea más notoria.

- Atractivo: La condición de poder atraer, impacta, generar interés y curiosidad a los visitantes.

- Resistencia al impacto: Refiere a la capacidad del lugar para tolerar la afluencia de los visitantes y la carga de las actividades a realizar. Se determina el grado de sensibilidad del recurso ante la exposición.

- Acceso: Refiere a la condición de los ingresos, caminos del lugar, analiza los tipos y características para determinar si son los más adecuados para los visitantes.

- Afluencia de Público: Se toma en consideración el flujo ya existe de personas que ya visitan el lugar ya sea por el recurso a interpreta $u$ otro elemento aledaño.

- Facilidad de interpretación: alude al grado de facilidad de explicar el elemento a interpretar. El espacio contribuya al proceso de interpretación de comunicación.

- Seguridad: Contempla los riesgos existentes en el lugar en relación a los visitantes.

Con respecto a los criterios mencionados, Morales recomienda una metodología de trabajo para el contraste de información en todos los niveles por medios de planos. Esta información recopilada presenta datos de evolución (Historia), dinámicas del lugar, identificación de recurso, condiciones físicas del lugar, etc. De esta forma se realizar un desarrollo a manera de un listado de criterios puntuales para interpretarlos en planos para su fácil identificación (Morales, 2004).

En conclusión, a partir de los enfoques de análisis del recurso se requiere del conocimiento del recurso a interpretar, ya que para poder transmitir se debe entender todos sus componentes, no solo como un objeto aislado sino también todo lo que se relacione directa o indirectamente y contribuya al objetivo de la interpretación. De este modo los planos son una herramienta importante para la recopilación de información del lugar y de los elementos involucrados con este. 


\subsubsection{Análisis de los usuarios}

El usuario es el elemento motivo con el que se realiza la interpretación. De este modo, es primordial realizar un análisis del público a tratar para garantizar una interpretación adecuada y llegar a conectar con las personas y lograr el objetivo principal de cambio de actuar sobre el tema interpretado. (Morales, 2004)

De forma introductora al estudio de este elemento se puede realizar la pregunta para quién se va a interpretar. La respuesta es amplia y podría variar desde un visitante foráneo hasta el mismo poblador, de modo que es importante determinar el público y realizar un perfil del visitante que posteriormente ayudará a determinar la forma de comunicar. (Morales, 1992)

La organización “Country Commission” determinó 11 aspectos a evaluar en el análisis de usuario actuales o potenciales (Como se cito en Morales, 2004). De los cuales, a continuación, se hará mención de solo 7 indicadores debido a los aportes directos para la elaboración de la propuesta de la tesis a desarrollar:

- Patrones de Visita: Involucra los elementos a proponer en las visitas como horarios, configuración del uso del espacio, flujos.

- Cualidades del grupo: Relacionado a la estructura, tipos y tamaño de los grupos visitantes.

- Características de los visitantes: Tener conocimiento de la composición de los visitantes con respecto a su edad, sexo, procedencia, características socioeconómicas, etc.

- Grupos especiales: Contemplar la presencia de grupos en particular como escolares, científicos, niños, etc.

- Conocimientos previos: Considerar algún grado de relación o estudios previos por los visitantes.

- Intereses: Saber el grado de interés de actividades (recreación, deportes, conocimiento) que el visitante busca desarrollar. 
- Necesidades: Contemplar requerimientos básicos de los visitantes para proporcionar un servicio completo como servicios higiénicos, rampas, proveer comida etc.

Con lo mencionado, se puede concluir que el análisis de usuarios es determínate para la finalidad de la interpretación. Requiere de la identificación particular del visitante para hacer selección óptima del tipo de medio, el cual propicia el vínculo emotivo con el accionar reflexivo. Asimismo, se puede apreciar que cada una de estas pautas relacionadas con el estudio del público contribuye a detectar las maneras posibles de interacción de las personas con el recurso.

\subsubsection{4 . Selección de Medios, programas, técnicas interpretativas.}

La finalidad de los medios de interpretación es de capturar la atención de la persona para provocar un vínculo con el recurso a interpretado para posteriormente generar un estado de reflexión del mensaje. Con ello, el desarrollo de elementos constructivos ayuda al proceso interpretativo al igual que la elaboración de instrumentos de comunicación como panales, construcción de modelos, actividades u otras (Morales, 1992).

Para la identificación práctica de la toma de decisión del tipo de medio interpretativo se requiere de la pregunta cómo, cuándo y dónde se transmite el mensaje de forma óptima. Asimismo, es necesario tomar en cuenta información relacionada al estudio del perfil del público para una elección correspondiente (Morales, 2004)

La clasificación de Pennyfather ${ }^{8}$ sobre los tipos de medios interpretativos se establece por 5 categorías de los cuales el de carácter participativo (categoría que la presente tesis detallará) está compuesto por 13 elementos (Como se citó en Morales, 1992). La elección de esta clasificación al igual que la categoría mencionada es considerada debido a la relación pertinente con el proyecto. A continuanción se hará detalle de los elementos a considerar en el plantemiento de la propuesta:

\footnotetext{
8 Reconocido colaborador del antiguo organismo "Country Commission”.
} 
- Senderos autoguiados en exteriores: Son caminos diseñados para ser recorridos principalmente a pie visitas como horarios, configuración del uso del espacio, flujos.

- Casetas y torres de observación: Construcciones emplazadas estratégicamente que permiten la contemplación puntual del lugar. Es importante señalar que la estructura en si no es interpretativa.

- Binoculares y telescopios: Tener conocimiento de la composición de los visitantes con respecto a su edad, sexo, procedencia, características socioeconómicas, etc.

- Miradores: Espacios integrados al parque con visuales panorámicas.

- Identificador de puntos a distancia: Sistemas que permiten localizar un punto específico en la distancia

- Oportunidades para la participación in situ: Situaciones en donde el usuario puede participar en una actividad interpretativa. Puede ser mediante el uso o manejo de elementos en el paisaje

- Itinerarios autoguiados en interiores: Recorridos internos en una determinada arquitectura.

- Paneles de orientación: Información montada que incorpora mapas o diagramas que permite identificar donde uno se encuentra.

Finalmente podemos concluir que los medios de comunicación determinan la manera, el lugar y el momento adecuado para realizar la interpretación determinándolos como el mecanismo interpretativo para captar la atención del usuario. Asimismo, se puede observar la importancia de la experiencia y la participación activa como estrategia en la interpretación, ya que este tipo de acción permite el vínculo directo del recurso y la persona con el fin de incentivar reflexión sobre lo interpretado.

\subsubsection{Lámina de teoría de interpretación}


DEFINICIONES

TLLDEN

ACTIVIDAD EDUCATIVA $\quad \cdots$ REVELAR

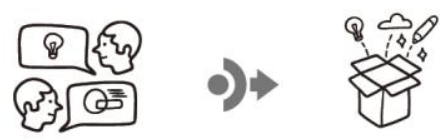

\section{MORALES}

1. REVELAR $\ldots$ LEGADO NATURAL $0 \ldots$ CULTURAL $\ldots$ IN SITU

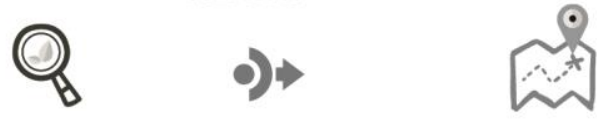

PLANIFICACIÓN INTERPRETATIVA (PI)

PROCESO $\cdots$ NECESIDADESY OPORTUNIDADES

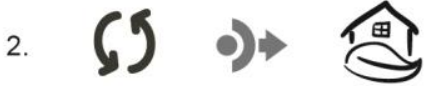

DESARROLLO DEL PI

OBJETIVO

- CONOCIMIENTO:

Dar a conocer al público

- EMOCIÓN:

\section{- COMPORTAMIENTO:}

Acción y actitudes que se adopta

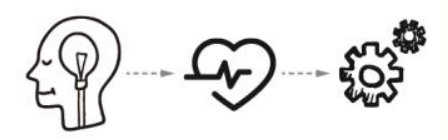

ANALISIS DEL RECURSO

¿Qué merece ser interpetado?

¿Que sitio o sectores tiene un potencial interpretativo?

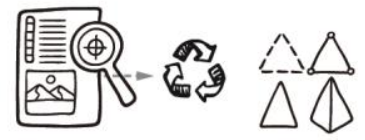

Rasgo interpretativo:

Objeto

\section{थत्रि (C) Proceso}

CRITERIOS

- Accesos:

\section{翼}

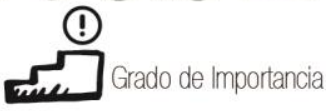

-Singularidad:

- Seguidad

Estacionalidad:

Conserv. 淍巨 Clima

- Infraestructura:
ANÁLISIS DE

AUDIENCIA

\section{¿A quienes va dirigido la interpretación?}

MORALES

Crucial saber las caracteristicas de de la

audiencia para así poder selec ionar la técnica más adecuada

ASPECTOS- COUNTRYSIDE COMMISSION

- Patrones de visita

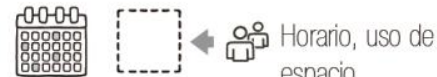

- Tamaño, estructura, tipo del grupo לs

- Perfil del visitantes

- Grupos especiales

- Conocimientos previos \&o

- Intereses

SELECCIÓN MEDIOS DE COMUNICACIÓN

¿Qué médios, programas serán usados?

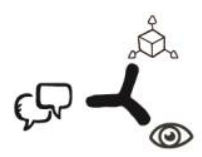

MORALES

Concebidas para inspirar o provocar sentimien
tos.

CONSIDERACIONES - PENNY FATHER

- linerarios

- Casetas y torres de observa-
ción:

- Binoculares y telescopio

- Miradores 䇥

- Identificadores de

(1)

- Particiaciòn in- situ $\longrightarrow$ Uso

- Paneles de orientaciòn

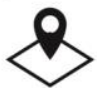

- Itinerarios interiores

$\triangle$ Arquitectura 


\subsection{Base Conceptual}

El Parque Lineal Ribereño Shullcas y CIA Huancayo proponen educar y concientizar a la población sobre el recurso natural del agua del Río Shullcas y el valor del paisaje natural, que son generadores de identidad de la ciudad, usando como herramienta la interpretación en la arquitectura y el paisaje creando un espacio público de integración compuesto por el borde hídrico que plantea articular los distritos de la ciudad de Huancayo.( Lámina 3. 5)

\subsection{Diagrama de Jencks}

Ver (Lámina 3. 6) 


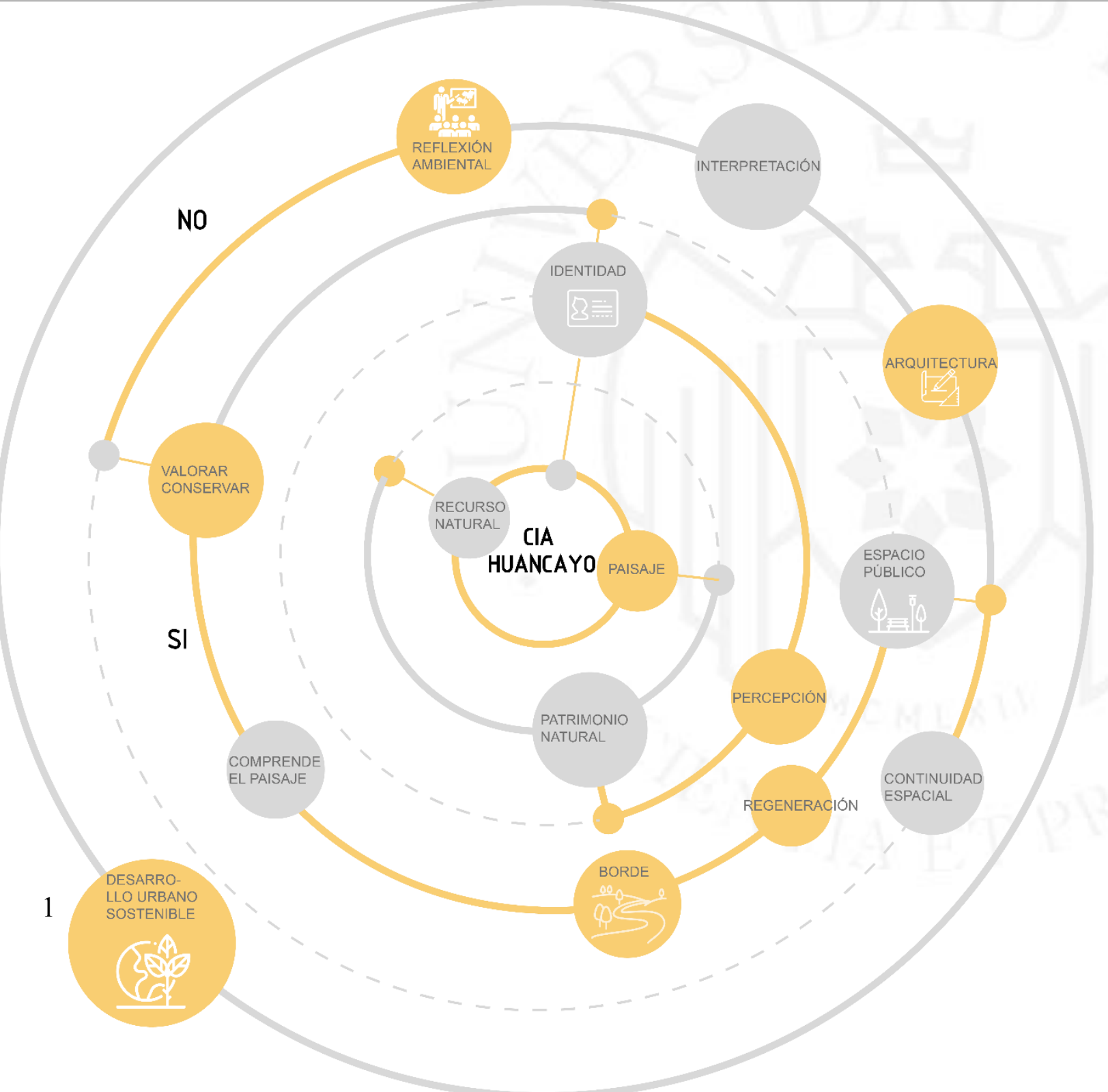

REVALORAF

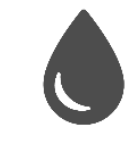

Recurso Natural: Agua del Río Shullcas

\section{ARTICUIAR}

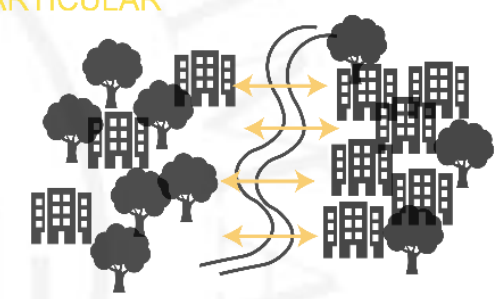

CONCIENTIZAR

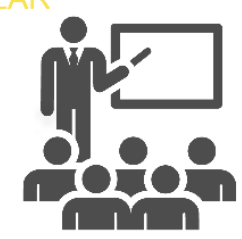

A la población sobre el cuidado, valoración y conservación del agua del

INTEGRAR Y CONECTAR

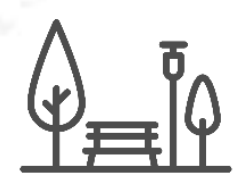

La ciudad con un parque lineal al borde del rio

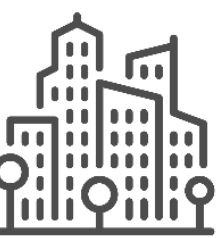

Identidad con su entorno 111

Incremento de espacio úblico

conexión de la ciudad

equipamiento urbano (propuesta) 


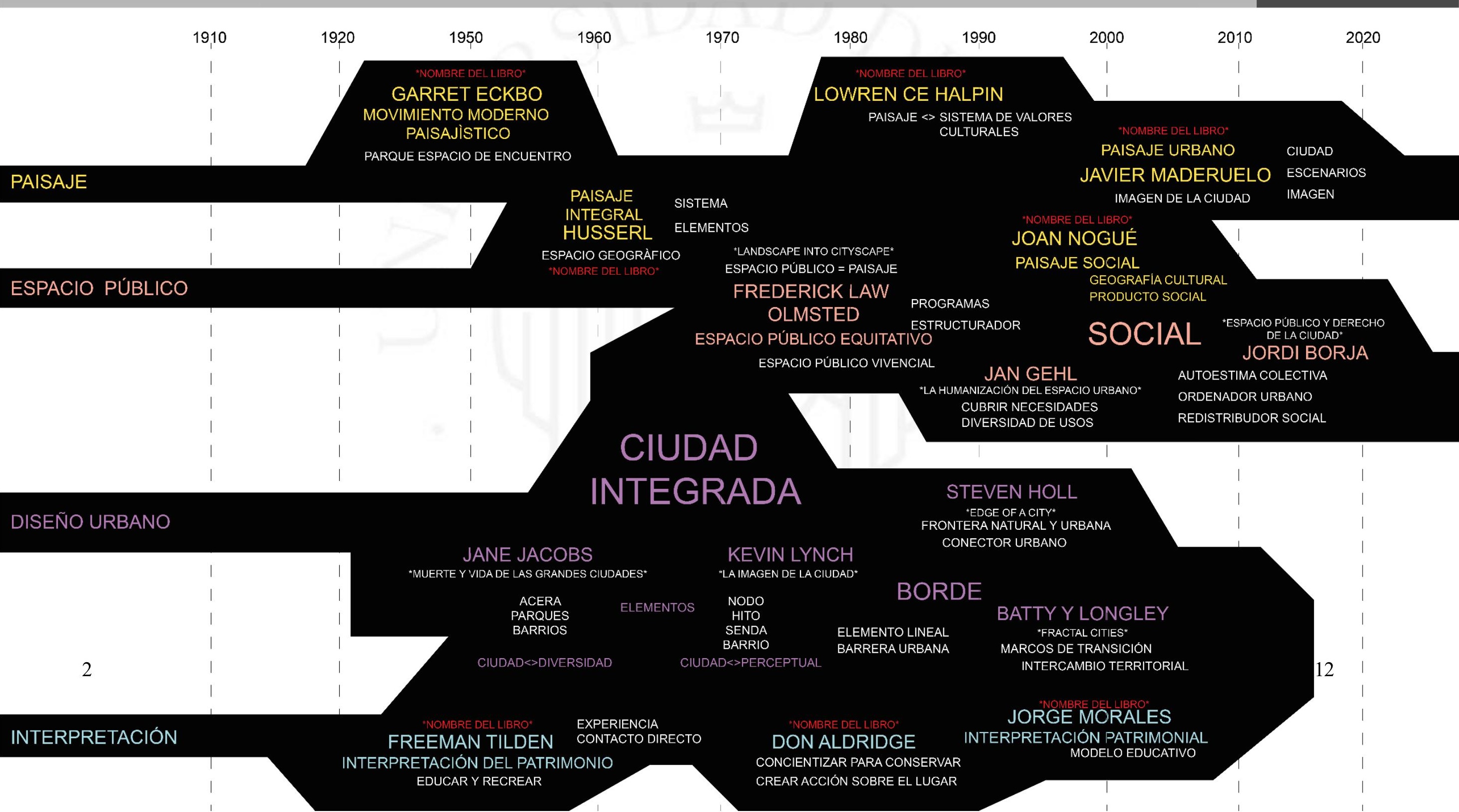




\subsection{Conclusiones parciales}

\subsubsection{Del paisaje}

El concepto del paisaje, como lo sostiene Maderuelo, es una construcción social interpretada en un tiempo específico de carácter mutable. De este modo, el término paisaje urbanos se interpreta como el reflejo físico cultural de la ciudad como lugar que reúne pensamientos, creencias, emociones. A partir de esta idea, podemos sostener que la ciudad de Huancayo es la imagen, el espacio tangible en donde la población se ha manifestado culturalmente a partir de múltiples intervenciones en el territorio.

Las intervenciones en el territorio huancaíno traducidas como composición de los elementos de la ciudad están constituidas por construcciones, vías, plazas, ríos, canales, vegetación y otros de manera aislada entre ellos, ya que espacialmente la ciudad no presenta una imagen integral en donde las unidades compositivas conforman un todo.

La relación de la ciudad de Huancayo y el Río Shullcas es un claro ejemplo de lo mencionado y a pesar de que el río y sus bordes poseen el potencial para ser un espacio contemplativo actualmente son áreas degradadas que no propician una interacción adecuada siendo un espacio aislado de la ciudad .De este modo, se puede acotar que la idea de contemplación de la ciudad a partir de la configuración de escenarios urbanos en las zona próxima al río no aplica debido a la falta de intervenciones que integren estos medios.

Asimismo, la falta de visión sobre una imagen integral de Huancayo dificulta el planteamiento de propuestas y planificaciones que tejan la ciudad integrando las unidades de composición natural y urbana. Además de la falta de consideración de la esencia, del carácter propio del sitio, ya que es la base conceptual de planes que suelen realizar una réplica de modelos de diseño creyendo que se construye una imagen de ciudad cuando realmente el uso y la apropiación del espacio por parte de la población es un indicativo claro de construcción social en el paisaje urbano.

Por otra parte, analizando intervenciones específicas en del Área Central Metropolitana de Huancayo, por medio de las teorías de Garrett Eckbo, podemos identificar dos tipos de medios físicos conformados por los medios urbano y rural De los cuales ha habido múltiples transformaciones en el paisaje. Actualmente en la ciudad (medio urbano), estas intervenciones se traducen en la extensión del asfalto en el territorio 
de manera que no se contempla espacios abiertos en la urbe y permite el desplazamiento de elementos naturales característicos del lugar como la flora, fauna para la expansión del medio urbano generando un desequilibrio territorial entre sí.

De este modo existe una desproporción de espacios abiertos y área edificada que se ve reflejado en el porcentaje de área total destinada para parques y áreas recreativas en la ciudad $^{9}$ y la falta de un espacio recreativo a escala metropolitana que esté al alcance de todos.

Asimismo, el análisis de parque y áreas recreativas contempladas en planes e intervenciones aún no sugieren su implementación como estrategia para la conservación de los recursos naturales en el medio urbano que permitan una imagen integral de elementos naturales y artificiales.

Desde otra escala, también existe un desbalance entre medios (urbano y rural) que se aprecia en el territorio a partir de la configuración de bordes difusos que continúan expandiéndose y degradando las zonas rurales próximas. Un claro ejemplo de esto se parecía en la evolución de la expansión urbana que a través de los años ha generado pérdida de áreas agrícolas, canales, flora y fauna.

A causa de los conflictos territoriales en relación al paisaje se deben considerar la necesidad de plantear intervenciones integradoras que de acuerdo a la escala preserven el medio rural de la expansión en los bordes y creen espacios recreativos (pasivos y activos) que incorporen elementos naturales nativos.

Además, se debe considerar el equilibrio en el diseño de intervención a partir de la proporción entre lo construido y su entono libre., la cual se ha considerado en las distintas escalas el proyecto de tesis.

Finalmente, parte del equilibrio del paisaje se establece por intervenciones de enfoque que buscan potencializar el carácter del lugar estableciendo un vínculo social con el paisaje reforzando la idea de imagen del paisaje como construcción social. De este modo, tanto las intervenciones en el paisaje como el arquitectónico tendrán coherencia

\footnotetext{
${ }^{9}$ Como se menciona en la sección 2.6.4 del capítulo II: Marco Referencial
} 
con la esencia y carácter del lugar prevaleciendo el enfoque en la intervención y no formalidades caprichosas.

\subsubsection{Del espacio público}

El Parque Lineal Ribereño Shullcas será un espacio colectivo que tendrá impacto a nivel de todas las escalas de la ciudad, este debe ser un espacio de equidad social y étnica. Por otro lado, debemos tener en cuenta que la inserción de flora nativa en la propuesta generará identidad al usuario y arraigo al lugar.

El diseño de un proyecto con impacto a escala metropolitana debe estar relacionado a la creación de un sistema que contenga parques, equipamiento y corredores verdes para brindar pluralidad, diversidad de usos y estructura pública a los residentes de la ciudad.

Por otra parte, para que un espacio público funcione se debe considerar al usuario como el actor principal; es decir el espacio debe estar hecho para que los usuarios realicen las actividades que tienen planeadas. De esa manera se evita generar espacios públicos muertos y sin uso. Un espacio público sin activación es perjudicial para el vecindario, ya que permite la aparición de la delincuencia y el peligro.

Es importante direccionar el diseño a mezclar una diversidad de usos para todos los tipos de usuarios, ya que permite el libre desenvolvimiento de nuevas actividades. El espacio público es un sistema que debe tener usos cercanos, los usos deben ser variados, las ciclovías deben ser el medio de transporte de los usuarios y finalmente no debe de existir barreras entre el espacio público y las viviendas aledañas.

La seguridad es un factor primordial en el diseño de espacio público y el impacto que este genera en el entorno inmediato. La sensación de seguridad lo transmiten los mismos usuarios, la generación de una vigilancia por los mismos residentes quiere decir que ha habido una aceptación y sentido de identidad por parte del usuario.

Se debe tomar en cuenta al momento del diseño la incorporación de espacios de recorrido y estancia para usuarios de todas las edades tomando en cuenta las cualidades que presentan. 
El espacio público no solo es físico, sino es social. Es un espacio mixto, colectivo donde se refuerza la relación entre habitantes y entorno. Es un espacio donde se refuerza los lazos comunitarios, donde se expresa dinámicas económicas y relaciones sociales y de poder, por lo tanto, debe contener áreas que permitan estas actividades.

\subsubsection{Diseño urbano}

Cuando se habla de proyectos de escala intermedia, como el Parque Lineal Ribereño Shullcas, definitivamente afectarán el entorno urbano, por lo tanto, se debe considerar el diseño urbano con el objetivo de mejorar el entorno inmediato y la ciudad. Con este objetivo, se ha estudiado a dos expertos en el tema para poder recopilar metodologías de diseño que nos ayudarán a proponer un proyecto urbano integral.

Saber las actividades que realizan los usuarios de la zona nos proporciona información para poder diseñar tanto el espacio público, equipamiento necesario y la articulación que requiere la ciudad. Jane Jacobs nos facilita una clasificación de las actividades que será útil al momento de la proyección.

Por otro lado, diseñar la ciudad implica generar una diversidad urbana; es decir que contenga usos primarios, puntos de concentración, hitos principales y sistemas de transporte integrado. El diseño de un parque lineal ribereño no solo es la creación de un espacio verde, sino es el diseño de un espacio público que contenga elementos que garanticen el uso intenso, además de la seguridad y longevidad.

Finalmente, el diseño urbano también engloba la percepción que tendrá el usuario de la ciudad y las partes que lo componen. Para Kevin Lynch los elementos como las sendas, bordes, hitos, nodo y barrios ayudan al observador a orientarse en el espacio, ya que le permite establecer puntos de referencia. El teórico propone un lenguaje, una metodología para preguntar a las personas sobre cuál es la percepción que tienen de imagen de la ciudad, cómo les puede servir estos elementos para poder ubicarse en el espacio y no es un libro de elementos proyectuales, ya que el modo en que se realiza el análisis usando estos elementos, afectará al modo en que se diseña una propuesta urbana.

De los elementos mencionados por Kevin Lynch, el borde es el que nos interesa en esta investigación, ya que el proyecto se ubica a lo largo del borde natural de Huancayo que es el Río Shullcas. Todos los teóricos coinciden en que el borde es un elemento lineal 
con posibilidades de transformación. Las ciudades están compuestas por bordes naturales y artificiales que les ofrecen su singularidad e identidad. Los bordes tienen que unificar y establecer vínculos entre lo que se propone y lo que existe generando cohesión. No se trata de eliminar los bordes, sino de generar articulación donde el borde sea un espacio de inclusión y no de limitación. Por lo tanto, deben ser vistos como áreas potenciales para el desarrollo de proyectos integradores que conecten y articulen la ciudad.

\subsubsection{De la interpretación}

Los aportes relativos al significado de interpretación han servido como base teórica para la definición propia correspondiente a la intensión de la presente tesis. La interpretación mediante el proceso de comunicación genera sentido de experiencia con la interacción del usuario y la revelación de significados sobre el recurso con el fin de propiciar reflexión, visión y contribución en la conservación de lo interpretado.

Correspondiendo a la propuesta de tesis la interpretación mediante el proceso de comunicación (intervención de diseño paisajístico) genera sentido de experiencia con la interacción de la población huancaína y el paisaje de la Ribera del Shullcas con el fin de propiciar reflexión, visión y contribución en la conservación del patrimonio natural de la ribera.

A partir de la intensión interpretativa del diseño mencionado se puede evidenciar los elementos activos que contribuyen al proceso de interpretación el cual está conformado el recurso (el paisaje de la Ribera del Shullcas), usuario (La población huancaína) y medio (programa de actividades en la propuesta). Esta definición de elementos ayuda a determinar las fases relativas al proceso de planificación las cuales se formularán a continuación de acuerdo a las intenciones y alcances proyectuales pertinentes conformado por los 4 primeros criterios. 
- ¿Por qué interpretar? - Lineamientos de interpretación

Debido a que la ribera del río Shullcas es un área de dominio fluvial considerado como recurso paisajista de interés natural que se encuentra en estado de degradación.

- ¿Qué se puede interpretar? - Análisis del recurso

Los recursos como la flora, fauna, el recurso hídrico y componentes históricos relativos a la ribera Shullcas

- ¿A quién se interpreta? - Análisis de los usuarios

Destinado para los habitantes de Huancayo y en particular al grupo que pertenece al rango de 15 a 59 años de edad.

- ¿Cómo, Dónde y cuándo debe interpretarse? - Selección de Medios

¿Como? A partir de la implementación de distintos programas de interacción directa con el recurso se busca que cubren el interés y vínculo con el recurso ¿Donde? Determinado por el ámbito de intervención en relación próxima a la Ribera del Río Shullcas,

La intensión interpretativa y la definición de las fases en el proceso interpretativo expresados corresponden a la intensión del diseño del Plan Maestro del Parque del Ribereño Shullcas.

En el caso del desarrollo del tramo 1 y del Centro de Interpretaciones del Agua varían los siguientes aspectos relativos al lineamiento de interpretación, análisis del recurso y la selección de medios.

En relación al tramo 1

- ¿Por qué interpretar? - Lineamientos de interpretación

Debido a las consideraciones particulares del tramo 1 en donde existe la pérdida las últimas áreas agrícolas en el casco urbano y del estado de degradación debido a la contaminación de las riberas.

- ¿Qué se puede interpretar? - Análisis del recurso

Los recursos como la flora, fauna, área agrícola y el recurso hídrico pertenecientes a la ribera Shullcas

- ¿Cómo, Dónde y cuándo debe interpretarse? - Selección de Medios 
¿Cómo? A partir de la implementación de distintos programas de interacción directa con el recurso se busca que cubren el interés y vínculo con el recurso Véase lámina

¿Dónde? Determinado por medio Del área de intervención sobre el carácter del paisaje en donde se busca potencializar y conectar con cualidades ambientales.

¿Cuándo? A partir de la programación de turnos

En relación al Centro de Interpretativo de Agua

- ¿Por qué interpretar? - Lineamientos de interpretación

Debido a la relevancia del recurso del agua del Río Shullcas, la cual se encuentra en estado de contaminación

¿Qué se puede interpretar? - Análisis del recurso

El agua, los beneficios que el agua proporciona al desarrollo humano.

- ¿Cómo, Dónde y cuándo debe interpretarse? - Selección de Medios

¿Cómo? Definición del programa arquitectónico específico, la cual se propone relaciones con recurso.

¿Dónde? Elección del terreno en el tramo 1 a partir de cualidades que contribuyen a la relación espacial con el paisaje intervenido.

¿Cuándo? A partir de la programación de turnos

De este modo, por medio de la síntesis del desarrollo del proceso de planificación interpretativa ha servido de apoyo para los primeros esquemas funcionales, programáticos y de cabida para la elaboración de la propuesta integral del Plan Maestro del Parque Ribereño Shullcas, el desarrollo del tramo 1 y la proyección del proyecto piloto del Centro de Interpretación del agua. 


\section{CAPÍTULO IV: MARCO NORMATIVO}

\subsection{Metodologías de intervención en el paisaje}

"La guía metodológica del estudio del paisaje" elaborado por el ayuntamiento de Valenciana - España responde a estrategias de ordenación del territorio y protección del paisaje Por esta razón, el manual fue estableció como herramienta que determine objetivos, principios, estrategias y directrices en el planteamiento de conservación y puesta en valor del paisaje (Muñoz, 2012)

El estudio de paisaje contribuye a la orientación de planteamientos urbanísticos y territoriales, preservando el carácter del medio y en la definición del sistema ecológico del territorio para poner en valor el patrimonio natural. Asimismo, funciona como elemento intermediario que propicia un sentido de identidad a la población sobre el territorio, cohesión social y arraigo a partir de la identificación de los recursos paisajísticos en el medio. (Muñoz, 2012)

De este modo, la guía, para la presente tesis servirá como base de estudio para establecer la propuesta integral del Parque Lineal Riberateño Shullcas y del desarrollo del tramo 1 por medio de la definición de estrategias y directrices urbanísticas y diseño del paisaje que correspondan al territorio de la ciudad de Huancayo. Con ello, se considera parte de la estructura metodológica de la guía de estudio del paisaje que está compuesta por los siguientes puntos:

- Criterios paisajísticos

- Ámbito de estudio: Esta sección presenta el plano la delimitación de intervención y justificación de como se ha establecido

- Unidad de estudio: Compuesto por información relacionada a la evolución y organización del paisaje que considera elementos y conflictos presentes en ella determinado en el ámbito de estudio

- Valoración del paisaje: Presenta la explicación el proceso de valoración a partir de la valoración técnica y visibilidad

- Propuesta: Intenciones enfocadas a los objetivos para una calidad paisajística 


\subsubsection{Estudio del paisaje}

La elaboración del estudio del paisaje es indispensable para la intervención de paisajes debido a los diferentes aportes en relación a la elaboración de planes que sirven de justificación y base normativa del plan a proponer. El estudio se estructura a partir de 6 contenidos, de los cuales debido al alcance de la tesis se desarrollarán los siguientes 5 puntos (Muñoz, 2012).

- Ámbito de estudio: Información del área de intervención

- Caracterización del paisaje: Determinación del carácter del lugar

- Análisis visual: Contribuye al análisis del paisaje a partir de la visualización del territorio

- Valoración del paisaje: Determinación del valor del paisaje y conflictos

- Medidas y acciones: Responden al cumplimiento de los lineamientos de calidad paisajística

Cada uno de estos puntos servirá de base argumentativa en el proceso de intervención en el paisaje de manera que se indicará el aporte de la información en la fase correspondiente.

- Ámbito de estudio: Véase sección 4.1.3

- Caracterización del paisaje: Véase sección 4.1.4

- Análisis visual: Contribuye al análisis del paisaje a partir de la visualización del territorio Véase sección 6.2 y 6.3

- Valoración del paisaje: Véase sección 4.1.5

- Medidas y acciones: Responden al cumplimiento de los lineamientos de calidad paisajística: Véase sección 4.1.6

Como base para la recopilación de información el manual indica la importancia de los tipos de fuentes a considerar. En el caso del proyecto de la presente tesis se ha hecho uso de 5 de ellos establecidos por planes y proyectos en marcha, cartografía del lugar, historia e imagen cultural, reconocimiento del lugar y finalmente el análisis cartográfico. 


\subsubsection{Criterios paisajísticos}

A continuación se presentará los criterios paisajísticos considerados como aportes para la incorporación de nuevas intervención que corresponden estrategias protección, integración, movilidad y ordenación del paisaje (Muñoz, 2012)

Los criterios paisajísticos son los siguientes:

- Respetar la topografía y vegetación del lugar. La topografía es el medio de integración de elementos naturales y urbanos a manera de disfrute de escenarios visuales.

- Definición de bordes urbanos y espacios de transición: Determinar los espacios de transición y bordes urbanos por medio de intervenciones que traten la ambigüedad del área.

- Tratar adecuadamente los accesos: Determinar accesos y vías de comunicación de manera que protejan y ordenen las vistas en dirección al recurso paisajístico estableciendo franjas de protección visual que acompañen el acceso y delimiten el borde urbano.

- Integración paisajística y visual: Integrar paisajísticamente y visualmente las nuevas implantaciones en el territorio a partir de patrones volumetría, materiales y colores del propio lugar.

- Preservar vistas hacia lo paisajes de mayor valor: Se busca garantizar que cualquier tipo de intervención mantenga las condiciones de visibilidad del paisaje de manera que presente una integración paisajística

- Establecer actividades económicas: Se busca intervenir infraestructura en zonas que menor exposición visual creando accesos propios que respeten las franjas de protección visual, el cual proporciona un tratamiento paisajístico.

- Potenciar el suelo no urbanizado: Se valorarán para su inclusión de la infraestructura verde, las áreas que se deben preservar para proteger el patrón ecológico y preservar de la transición de otro tipo de actividades y usos.

- Favorecer el acceso y disfrute a los paisajes en un contexto de movilidad sostenible: La aplicación un modelo de movilidad sostenible mejora la accesibilidad, funcionalidad y visuales al paisaje. 


\subsection{3 Ámbito de estudio}

El ámbito de estudio se define a partir de consideraciones territoriales, paisajísticas y visuales. De manera que se requiere de delimitar el área de extensión del territorio que se va a estudiar e intervenir. (Muñoz, 2012)

\subsubsection{Unidades de paisaje}

Comprende la identificación del carácter del paisaje, descripción, clasificación y delimitación cartográfica de las unidades de paisaje. Para poder entender claramente de la caracterización del paisaje se requiere de análisis de los siguientes 5 puntos. (Muñoz, 2012)

- Evolución del paisaje: Análisis de cambios del paisaje en el pasado, presente y de especulaciones en el futuro de manera de definir los caracteres que el paisaje ha ido adquiriendo.

- Organización del paisaje: Identificación y análisis de rasgos y estructura formal del paisaje definido por factores naturales o humanos que determina el paisaje tenga una imagen en particular por el tipo de relieve, hidrografía y geomorfología. Asimismo, el análisis de la cobertura vegetal compuesta por el sistema de vegetación, implantación humana y láminas de agua son importantes para la definición del paisaje.

- Unidades de paisaje: Identificación de unidades singulares en el paisaje, las cuales poseen una configuración estructural, funcional que es particular para sintetizar e identificar el carácter paisajístico y atender las transiciones y bordes que existen entre los diferentes patrones del paisaje. (Forestales, agroforestales, agrícolas, urbanos y ligados a causes)

- Recursos paisajísticos: Identificación de elementos con valor paisajista, los cuales poseen un valor representativo (visual, ecológico, cultural y o histórico). El recurso de interés ambiental y cultural corresponden a la pertinencia de la tesis por ser la ribera del Shullcas un recurso natural de dominio fluvial en estado frágil debido a actividades incompatibles con el medio. y encontrarse en riesgo ambiental a causa de la contaminación del río y por los elementos de valor histórico y cultural de estructuras agrarias (canales y parcelas) que se están perdiendo. 
- Conflictos paisajísticos: Identificación de aspectos que degradan el paisaje, aquellos que pueden modificar el carácter del paisaje. De manera que se busca determinar los cambios que provocan conflictos paisajísticos que generan consecuencias negativas como la desaparición y degradación de los componentes del paisaje, la fragmentación del territorio (perdida de conectividad física y visual) y la a aparición de nuevos paisajes de baja calidad. A continuación se mencionará algunas tendencias de cambio que perjudican al carácter del lugar: Implantación de infraestructura que provoque degradación y fragmentación al paisaje; introducción de residuos que degradan el medio, presencia de elementos con poca relación al paisaje, implantación de superficies incompatibles en el uso con el paisaje implantación de modelos urbanos y arquitectónicos que no corresponden a lógicas del lugar, Implantación de actividades sin criterio de ordenación y articulación entre ellas y el abandono de zonas agrícolas.

\subsubsection{Valor del paisaje}

Como parte de la elaboración del estudio del paisaje se evalúa los valores (calidad paisajística, valor social y visibilidad del paisaje) y conflictos del paisaje los cuales sirven como data para justificar la determinación de la valoración del paisaje correspondiente al valor representativo (Muñoz, 2012).

De acuerdo a la presente tesis las consideraciones ejecutadas se han establecido por la calidad paisajística y visibilidad del paisaje, a contención se detalla estos criterios (Muñoz, 2012).

- Calidad paisajística: Se determina de acuerdo a 6 criterios de evaluación los cuales se basan en los siguientes: El interés de su conservación correspondiente a la atención de recursos paisajísticos que requieran la necesidad de preservación; la representatividad referido a la capacidad de ser la expresión del carácter de un lugar; la singularidad compuesto por aquellos paisajes particulares que se encuentran en peligro de desaparecer o en estado degradados ; la integridad definidos como espacios que establecen cierto grado de conservación ; la función de un paisaje integral comprendido por su 
caracterización (organización o evolución) que cumplen una función importante en el paisaje y la calidad de escena los que corresponden una expresión singular.

- Visibilidad del paisaje: Se establece de acuerdo al análisis visual que determina las zonas con mayor exposición visual y que por ende son más frágiles

Justificación del valor del paisaje

De acuerdo a los criterios analizamos anteriormente, a continuación, se debe identificar el grado de calidad paisajística el cual ayudará a la determinación del tipo de intervención a realizar.

Figura 4. 1Criterios de valor paisajista

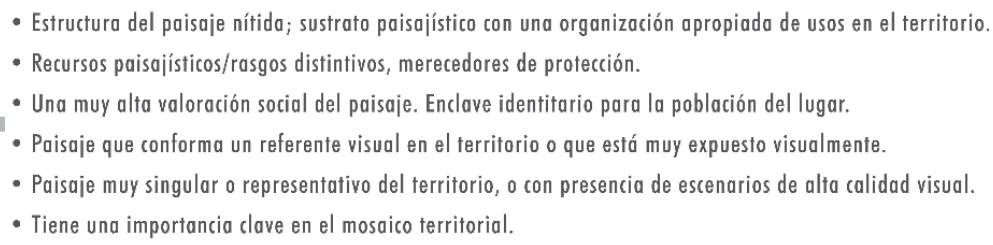

- Estructura del paisaje nítida; sustrato paisajístico con una organización apropiada de usos en el territorio.

- Recursos paisajísticos/rasgos distintivos, merecedores de protección.

- Una muy alta valoración social del paisaje. Enclave identitario para la población del lugar.

- Paisaje que conforma un referente visual en el territorio o que está muy expuesto visualmente.

- Paisaje muy singular o representativo del territorio, o con presencia de escenarios de alta calidad visual.

- Tiene una importancia clave en el mosaico territorial.

- Estructura de paisaje reconocible; el patrón característico todavía es evidente. Cierto aspecto de integridad y coherencia en la organización de los componentes principales.

- Algunos recursos paisajísticos son merecedores de protección.

VALOR ALTO - Paisaje que presenta zonas de alta exposición visual.

- Paisaje de cierta singularidad o representatividad.

- Tiene importancia dentro del mosaico territorial.

- Estructura del paisaje distinguible; el sustrato paisajístico está con frecuencia enmascarado por los usos que se desarrollan.

MEDIO - Pueden aparecer recursos paisajísticos merecedores de protección.

- No tiene una valoración social destacada.

\section{VALOR MUY BAJO- № existen aspectos que presentan interés por la conservación. \\ - En las preferencias de la población se manifiesta una fuerte preocupación sobre la evolución del paisaje.}

Fuente: Guía Metodológica. Estudio del Paisaje

http://www.upv.es/contenidos/CAMUNISO/info/U0670136.pdf 


\section{$\underline{\text { Lineamientos de actuación }}$}

A partir de la determinación de los valores paisajísticos, se debe establecer las líneas estratégicas de acción, las cuales determinan las aspiraciones que se plantean para el paisaje tomando en consideración los valores paisajes y conflictos (Muñoz, 2012)

Con respecto a los fines genéricos que la guía de estudio del paisaje propone y la relación del proyecto Parque Ribereño Shullcas aspira a la conservación del, modificación del paisaje y de gestión del paisaje. A continuación, Se realizará el detalle de cada uno de estos propósitos (Muñoz, 2012).

- Restauración del paisaje: Se establecen medidas enfocadas a la recuperación de los principales valores del paisaje debido a la tendencia de degradación de en la trasformación del territorio.

- Gestión del Paisaje: Considera la introducción de actividades para el manejo del paisaje que conserven el carácter del lugar. Se establece al identificar aspectos en el tiempo que conllevan a la pérdida de valores paisajísticos.

- Modificación el paisaje: Se establece este tipo de intervención cuando se busca cambiar considerablemente el lugar de manera que se modifica la apariencia del territorio que dependerá del grado de acción estableciendo mejoras o de la creación de un nuevo paisaje.

\subsubsection{Propuesta}

De acuerdo a esta sección se elabora las medidas de acción para garantizar la ejecución de los lineamientos trazados. Para la ejecución de las medidas de protección ordenación y gestión se desarrolla cuatro consideraciones que comprenden la infraestructura verde, criterios de catalogación del paisaje, normativa y planteamiento de programa. (Muñoz, 2012)

- Delimitación de la infraestructura verde: Constituido por el conjunto integrado y continuo de espacios libres, recursos ambientales, recursos culturales, recursos visuales, recursos sociales (recreativos), conflictos y las conexiones eclógicas funcionales que las unifica. Esta proposición es fundamental para la integración del paisaje a modo de una red de espacio abiertos y de corredores que se entretejen entre sí para la finalidad de proveer espacios recreativos, proteger hábitats naturales, preservar patrones 
ecológicos, valores culturales y paisajísticos, mejorar el paisaje visual y tratar las zonas de transición físicas (borde del río) y visuales (diferenciación de usos). De acuerdo a lo menciona recomienda 5 puntos a intervenir conformados para proteger los paisajes valiosos, preservar la conexión entre paisajes, mejorar la accesibilidad al paisaje, crear áreas de transición entre usos diferentes y delimitar consideraciones a futuro de nuevas actividades en el medio que no aporten. La infraestructura verde se compone por 3 elementos que corresponden a los espacios de valor natural y cultural, las áreas críticas del territorio que deben quedar libres de urbanización y la red territorial de corredores ecológicos y funcionales que conectan los elementos mencionados.

- Catalogación de los paisajes. Comprende el detalle de los paisajes y elementos de interés ecológicos, patrimoniales, visuales y sociales. Los aspectos a considerar en el catálogo son áreas relevantes (unidades de paisaje o ámbitos paisajistas), elementos de valor (recursos paisajísticos puntuales) y áreas o elementos protegidos por la legislación de protección de espacios naturales.

- Establecimientos de normas de integración paisajística, guías para una adecuada ordenación de paisaje: y preservación del carácter del lugar. Los aspectos que se deben considerase para la regularización en la normativa son la preservación, potencialización de recurso y regulación del sistema de espacios abiertos e infraestructura verde; determinación de los rasgos significativos del carácter del paisaje( topografía, vegetación, visualización y accesos al paisaje) ; directrices para nuevos usos del suelo y regularización de densidades, alturas y volúmenes, tipologías arquitectónicas, morfologías urbanas y empleo de materiales, texturas y colores correspondientes al paisaje ; y rectificación de conflictos paisajísticos y mejora de medios degradados.

- Definición de programas de paisaje: Compuesto por programas que aseguren la preservación y puesta en valor del paisaje, las cuales por la pertinencia de la tesis está relacionada a la valoración natural, cultural que se encuentra en estado de degradación de los bordes del Río Shullcas, por lo que se requiere de una proposición integral El manual establece tipos de programas de los 
cuales se considera 3 tipos para el desarrollo de la propuesta a partir de la proposición de ser un espacio inclusivo; la mejora de espacios degradas que pueden repotenciarse por medio de actividades. ; y la concienciación ciudadana a partir de divulgación de conocimiento acerca del paisaje y sus valores.

Finalmente, la consideración de las fases en el proceso de diseño del paisaje a partir de la guía de estudio del paisaje del ayuntamiento de Valencia servirá de base para la identificación del tipo de intervención en paisaje. Desarrollada en detalle en el marco contextual. 


\subsection{Metodologías de diseño urbano}

Existen diversas metodologías de intervención en espacio público, para esta investigación utilizaremos el texto "La dimensión humana en el espacio público" del Ministerio de vivienda y urbanismo del gobierno de Chile $(2017)^{10}$. Los capítulos que nos servirán como metodología de diseño son: "seis pasos para transformar el espacio público" y “del diseño a la evaluación” (Ministerio de vivienda y urbanismo de Chile [MINVU], 2017).

El espacio público no puede trabajar como un lugar unitario, ya que forma parte de un sistema que en conjunto satisfacen las necesidades de los ciudadanos. El capítulo "Seis pasos para transformar el espacio público" menciona que es recomendable el uso de seis pasos para obtener un adecuado espacio público y estos son: investigar, envisionar, estrategar, diseñar y evaluar; los tres primeros son parte de la planificación y los tres siguientes son parte de la ejecución del proyecto. Para esta tesis utilizaremos cuatro de los seis pasos, ya que no habrá ejecución y evaluación del proyecto (MINVU, 2017).

\footnotetext{
${ }^{10}$ El libro es una guía que recopila herramientas para mejorar la planificación, diseño e implementación de los espacios públicos. Su referente primario es el libro del urbanista Jan Gehl. El libro está basado en el diseñodel espacio para el peatón.
} 
Figura 4. 2 Diagrama que presenta los pasos de gestión del espacio público

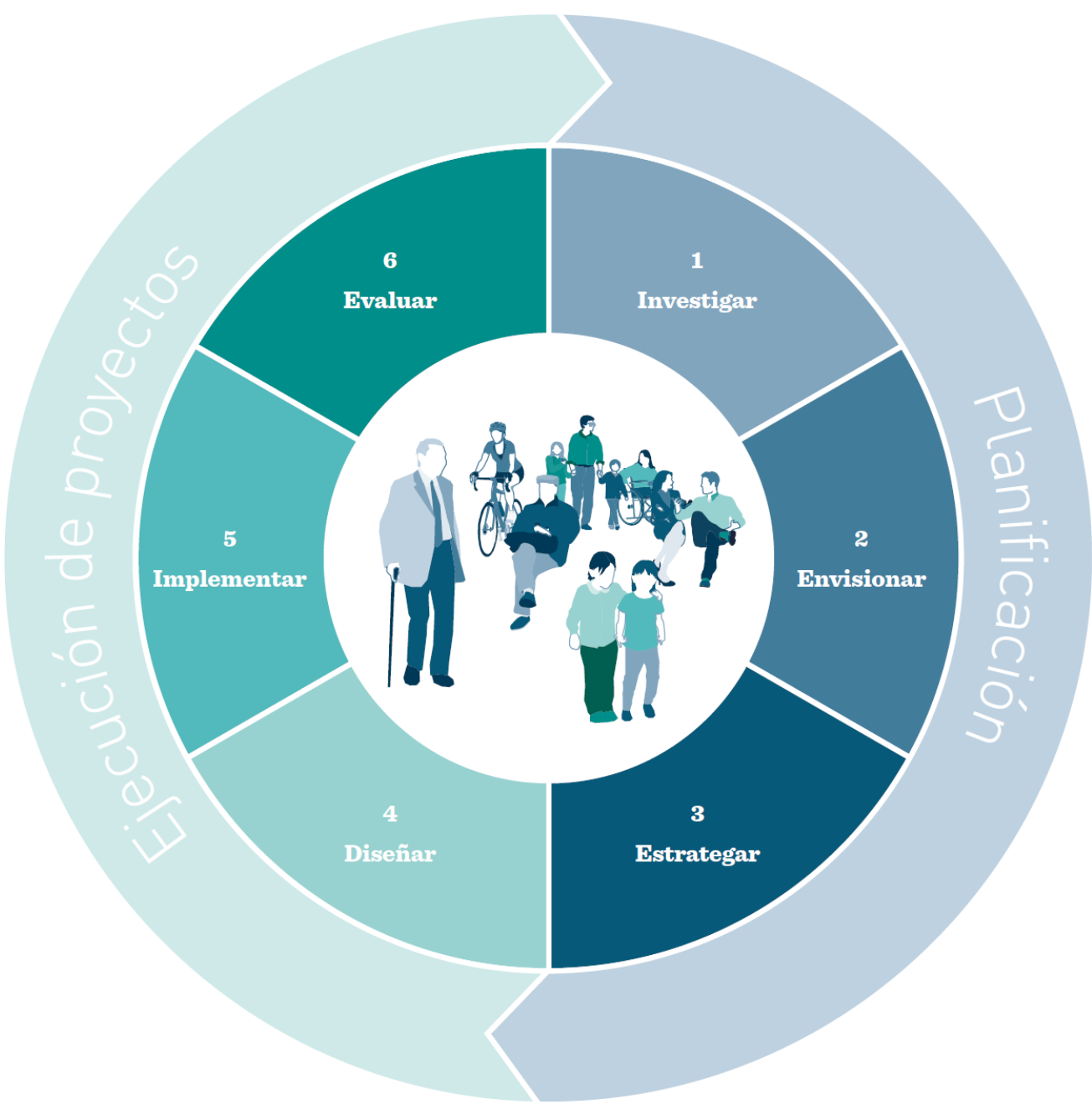

Nota: Diagrama que presenta los pasos de gestión del espacio público. Cada paso genera oportunidades donde el ciudadano es el principal elemento en la toma de decisiones.

Fuente: La dimensión humana en el espacio público (2017)

A continuación, se explicará en que consiste cada paso para un mejor entendimiento de la transformación del espacio público (MINVU, 2017).

\section{$\underline{\text { Investigar }}$}

En esta etapa se analiza los factores existentes con herramientas de medición del funcionamiento del espacio público, además de escuchar al usuario sobre la percepción del espacio, es primordial realizar un mapeo de actores que permite identificar a personas y organizaciones cuya perspectiva pueda fortalecer el análisis de las condiciones actuales 
del lugar. El objetivo principal en esta parte del proceso es contar con una base de evidencias para la toma de decisiones.

Figura 4. 3 Análisis de la vida y espacio público

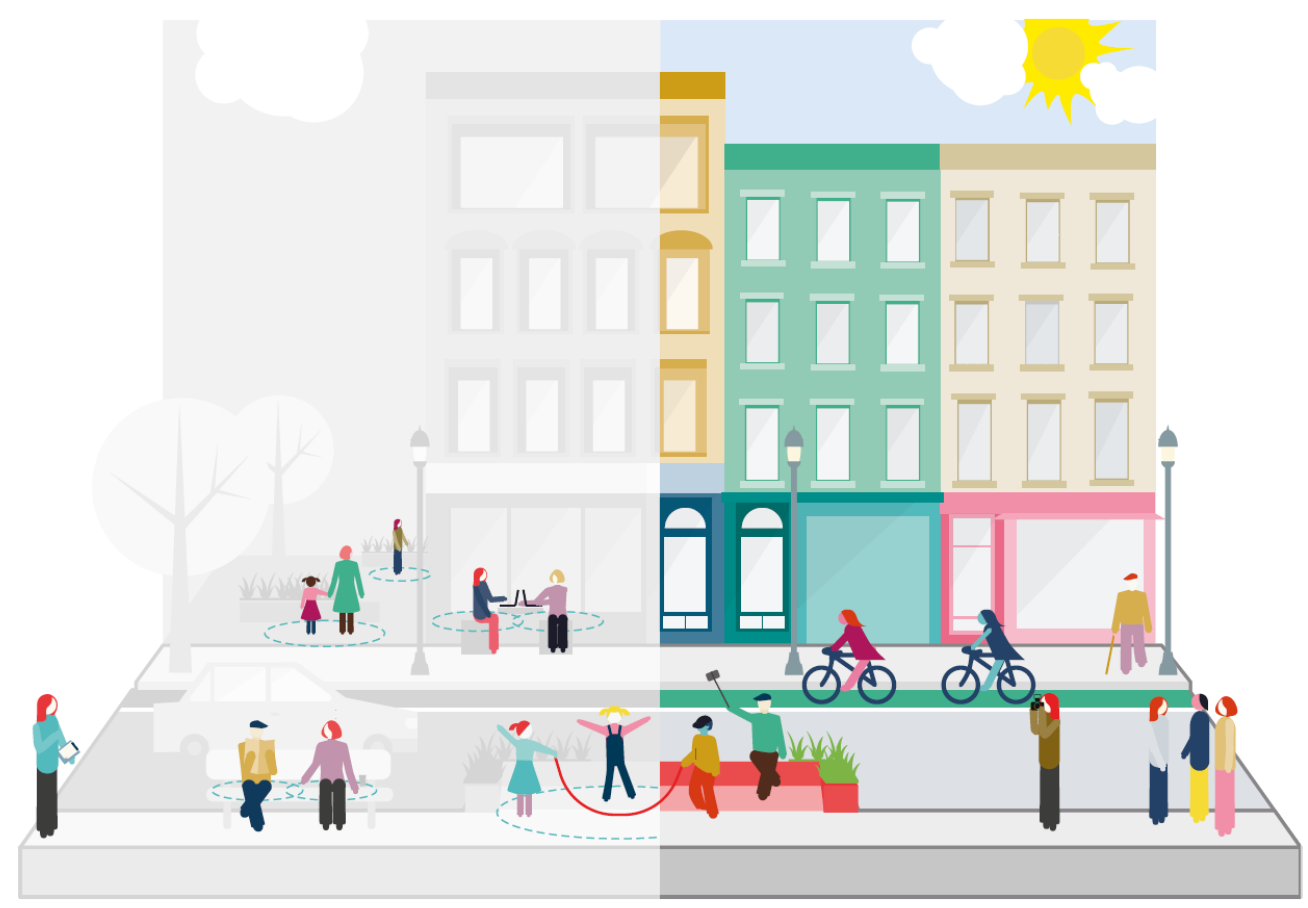

Nota: Observar la vida pública y analizar a los usuarios del espacio público

Fuente: La dimensión humana en el espacio público (2017)

\section{$\underline{\text { Envisionar }}$}

En esta etapa se define la cantidad de proyectos que incluirán a los diversos actores de la ciudad. Es primordial realizar un análisis de oportunidades y desafíos tanto sociales como espaciales para poder enfocar acciones hacia un número limitado de factores. Asimismo, se debe tener en claro cuáles son los problemas a solucionar, ya que no todos los barrios de la ciudad tienen las mismas necesidades. Hay barrios que necesitan de espacio público por condiciones de segregación social, otras porque tienen el reto de conservar recursos o patrimonio natural y otras tienen la necesidad de generar turismo. Los problemas deben ser temas que generen impacto y sean importantes. 
Figura 4. 4 Coordinación para la creación de un plan con visión
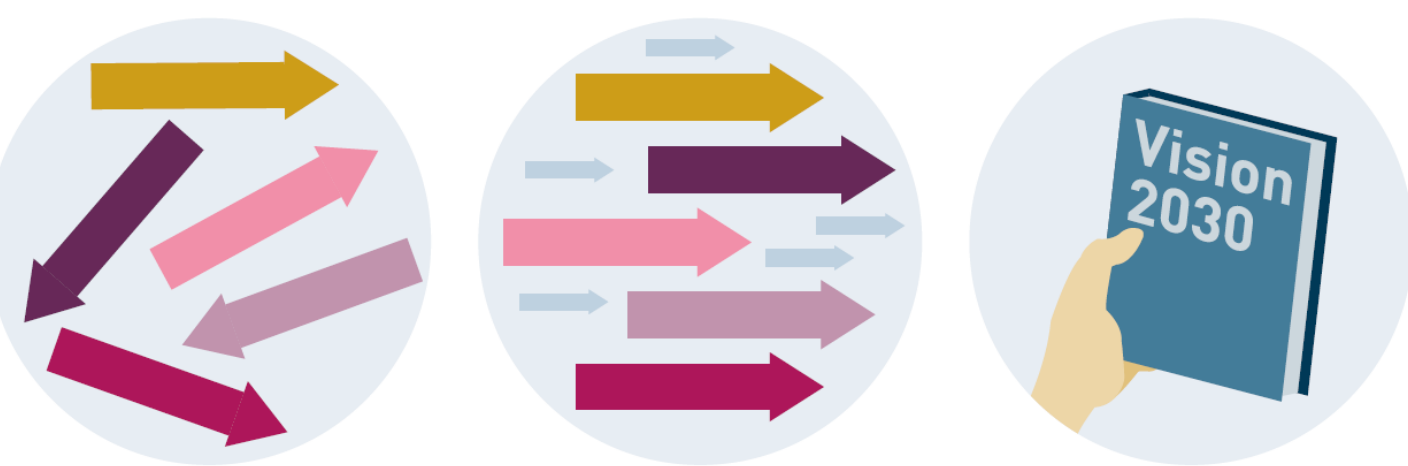

Nota: Trabajar en equipo (gobiernos, municipalidades, ministerios u otros) para generar visión del espacio público en la ciudad

Fuente: La dimensión humana en el espacio público (2017)

\section{Estrategar}

En esta etapa se selecciona los proyectos que necesitan ser desarrollados con prioridad, es necesario la participación ciudadana y si no se utiliza el tema participativo, también hay criterios de equidad donde priorizar englobe factores como la facilidad de implementación, visibilidad de la obra, viabilidad económica y tiempo de ejecución.

Figura 4. 5 Priorización de obras

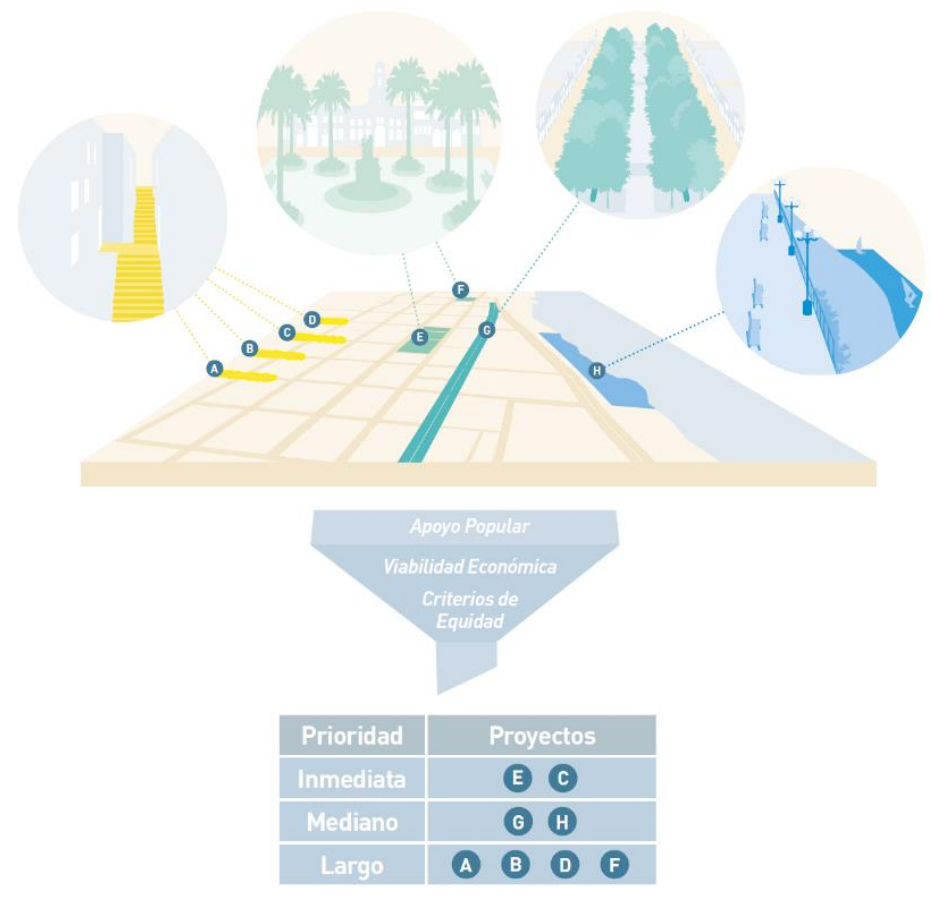

Fuente: La dimensión humana en el espacio público (2017) 


\section{$\underline{\text { Diseñar }}$}

En esta etapa se debe tener en cuenta que diseñar espacio público equivale a la flexibilidad que puede dar el espacio al usuario; es decir no debe estar diseñado con criterios estilísticos, sino de acuerdo a las necesidades y prioridades de los usuarios. La intervención no tiene que ser tan costosa, ya que se puede proyectar de forma progresiva La flexibilidad de un espacio se refiere a que puede ser usado de diversas maneras, cumpliendo funciones y programas diferentes durante el día.

Figura 4. 6 Diseño de espacio público flexible
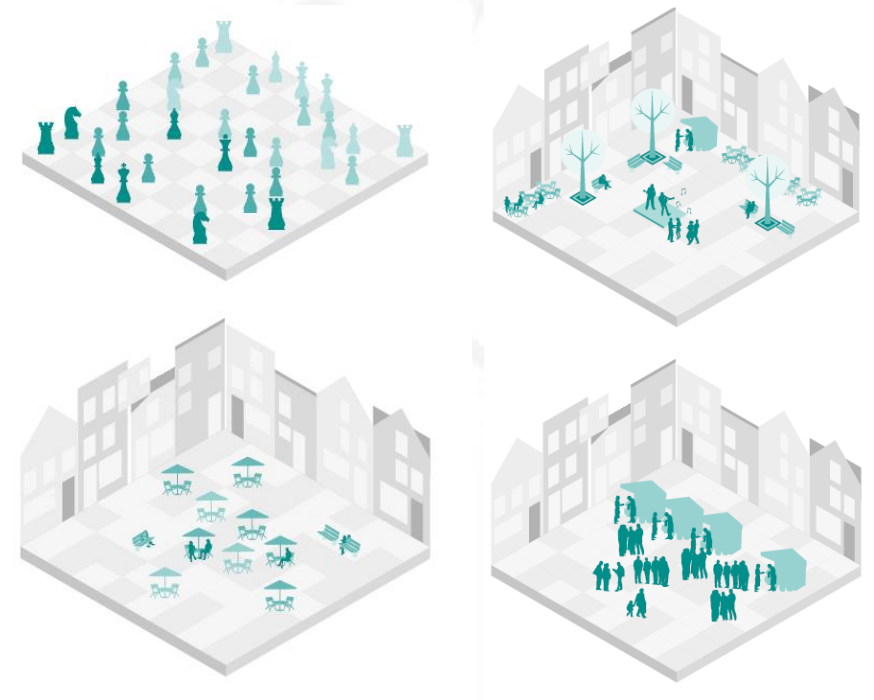

Nota: Al diseñar espacio público, el uso de elementos móviles permite que el espacio pueda ser ocupado con diversas actividades

Fuente: La dimensión humana en el espacio público (2017)

El capítulo "Del diseño a la evaluación" menciona que hay cinco áreas de acción en el diseño del espacio público: Preservación del patrimonio, movilidad sustentable, equidad y diversidad, diseño urbano a la escala humana y fomento económico y cultural. Las cinco áreas de acción conforman un sistema que al trabajar en conjunto mejoran las condiciones urbanas de la ciudad. -

A estas cinco áreas de acción le corresponden cinco ámbitos de actuación que dan al diseño recomendaciones para una mejor intervención del espacio público. La siguiente tabla (Tabla 4.1 y 4.2) muestra la relación y recomendaciones para cada área de acción. 
Tabla 4. 1 Tabla de recomendaciones para cada área de acción

\begin{tabular}{|c|c|c|c|}
\hline Áreas de acción & $\begin{array}{l}\text { Ámbitos de } \\
\text { actuación }\end{array}$ & Concepto & Recomendaciones de diseño \\
\hline \multirow{9}{*}{$\begin{array}{l}\text { Preservación del } \\
\text { patrimonio }\end{array}$} & \multirow{5}{*}{ Biofilía } & \multirow{5}{*}{$\begin{array}{l}\text { Viene del instinto } \\
\text { de conservación } \\
\text { de la diversidad } \\
\text { biológica }\end{array}$} & Conexión de Sistemas Naturales \\
\hline & & & Diseñar con el agua \\
\hline & & & Uso de vegetación autóctona \\
\hline & & & Diseñar para la fauna \\
\hline & & & $\begin{array}{l}\text { Uso de paletas cromáticas inspiradas en } \\
\text { el territorio }\end{array}$ \\
\hline & \multirow{4}{*}{ Genus Loci } & \multirow{4}{*}{$\begin{array}{l}\text { Este término se } \\
\text { refiere a las } \\
\text { características } \\
\text { distintivas de un } \\
\text { lugar }\end{array}$} & Elección de material apropiado del lugar \\
\hline & & & Apreciación local \\
\hline & & & Valorización del patrimonio \\
\hline & & & Alineación con los hechos geográficos \\
\hline \multirow{14}{*}{ Movilidad sustentable } & \multirow{7}{*}{ Accesibilidad } & \multirow{7}{*}{$\begin{array}{c}\text { Es una } \\
\text { posibilidad de } \\
\text { acceder a cierta } \\
\text { cosa o facilidad } \\
\text { de hacerlo }\end{array}$} & $\begin{array}{l}\text { Multimodalidad, uso de diversos tipos de } \\
\text { transporte }\end{array}$ \\
\hline & & & $\begin{array}{l}\text { Integración entre espacio y transporte } \\
\text { público }\end{array}$ \\
\hline & & & $\begin{array}{l}\text { Accesos directos para los peatones y } \\
\text { bicicletas }\end{array}$ \\
\hline & & & $\begin{array}{l}\text { Capacidad de las veredas para personas } \\
\text { y bicicletas }\end{array}$ \\
\hline & & & $\begin{array}{l}\text { Creación de espacios accesibles para } \\
\text { todos }\end{array}$ \\
\hline & & & Estacionamientos para bicicletas \\
\hline & & & Servicios básicos y baños públicos \\
\hline & \multirow{7}{*}{ Circulación } & \multirow{7}{*}{$\begin{array}{l}\text { Movimiento } \\
\text { continuo de las } \\
\text { personas en un } \\
\text { determinado } \\
\text { espacio }\end{array}$} & $\begin{array}{l}\text { Proyecto debe mantener líneas visuales } \\
\text { claras al caminar }\end{array}$ \\
\hline & & & $\begin{array}{l}\text { Mejorar las sendas urbanas creadas por } \\
\text { el peatón para su f"'acil traslado de un } \\
\text { punto a otro }\end{array}$ \\
\hline & & & $\begin{array}{l}\text { Diferenciar áreas de permanencia y } \\
\text { estancia }\end{array}$ \\
\hline & & & $\begin{array}{l}\text { Crear calles de convivencia que son } \\
\text { espacios donde todos los modos circulan } \\
\text { sin necesidad de separación }\end{array}$ \\
\hline & & & Protección del tráfico \\
\hline & & & Crear cruces peatonales seguros \\
\hline & & & $\begin{array}{l}\text { Generar disminución de velocidad de } \\
\text { vehículos cerca al espacio público }\end{array}$ \\
\hline
\end{tabular}

Fuente: La dimensión humana en el espacio público (2017) 
Tabla 4. 2 Tabla de recomendaciones para cada área de acción

\begin{tabular}{|c|c|c|c|}
\hline Áreas de acción & $\begin{array}{l}\text { Ámbitos de } \\
\text { actuación }\end{array}$ & Concepto & Recomendaciones de diseño \\
\hline \multirow{10}{*}{ Equidad y diversidad } & \multirow{5}{*}{ Seguridad } & \multirow{5}{*}{$\begin{array}{c}\text { Sensación total } \\
\text { de confianza de } \\
\text { que no hay } \\
\text { peligro o riesgo }\end{array}$} & Evitar calles y espacios ciegos, sin salida \\
\hline & & & $\begin{array}{l}\text { Crear iluminación a escala de las } \\
\text { personas }\end{array}$ \\
\hline & & & Presencia cívica amigable \\
\hline & & & $\begin{array}{l}\text { Crear espacios activos durante } 18 \text { horas } \\
\text { del día }\end{array}$ \\
\hline & & & Mantener los espacios cuidados \\
\hline & \multirow{5}{*}{ Inclusión } & \multirow{5}{*}{$\begin{array}{l}\text { Crear equidad e } \\
\text { igualdad en los } \\
\text { espacios públicos }\end{array}$} & Mezclar y no segregar por barrios \\
\hline & & & Diseñar para todas las edades \\
\hline & & & Diseñar para todos los géneros \\
\hline & & & $\begin{array}{l}\text { Crear diversidad cultural en el programa } \\
\text { de actividades }\end{array}$ \\
\hline & & & $\begin{array}{l}\text { Crear grados de privacidad en los } \\
\text { diversos espacios }\end{array}$ \\
\hline \multirow{11}{*}{$\begin{array}{l}\text { Diseño urbano a la } \\
\text { escala humana }\end{array}$} & \multirow{6}{*}{ Espacio } & \multirow{6}{*}{$\begin{array}{l}\text { Los espacios se } \\
\text { potencian } \\
\text { apoyándose a la } \\
\text { configuración del } \\
\text { entorno }\end{array}$} & $\begin{array}{l}\text { Crear espacios públicos a escala } \\
\text { humana }\end{array}$ \\
\hline & & & $\begin{array}{l}\text { Crear un perímetro permeable del } \\
\text { espacio público }\end{array}$ \\
\hline & & & Diseñar bordes conectados \\
\hline & & & $\begin{array}{l}\text { Subdividir los espacios en subespacios } \\
\text { que sean a escala humana }\end{array}$ \\
\hline & & & $\begin{array}{l}\text { Crear espacios para parejas, amigos o } \\
\text { personas solitarias }\end{array}$ \\
\hline & & & Evitar cambios de niveles bruscos \\
\hline & \multirow{5}{*}{ Confort } & \multirow{5}{*}{$\begin{array}{l}\text { Condiciones que } \\
\text { proporcionan } \\
\text { bienestar o } \\
\text { comodidad }\end{array}$} & Cobijo contra la interperie \\
\hline & & & $\begin{array}{l}\text { Aprovechar la vegetación para espacios } \\
\text { de sombra }\end{array}$ \\
\hline & & & estimular a la vista, olfato, tacto \\
\hline & & & estimular al oído mitigando los ruidos \\
\hline & & & $\begin{array}{l}\text { Crear espacios para estar parado y } \\
\text { sentado }\end{array}$ \\
\hline \multirow{9}{*}{$\begin{array}{l}\text { Fomento económico } \\
\text { y cultural }\end{array}$} & \multirow{4}{*}{ Comercio } & \multirow{4}{*}{$\begin{array}{l}\text { Actividad que } \\
\text { consiste en } \\
\text { vender y comprar } \\
\text { productos }\end{array}$} & Ecología de comercio \\
\hline & & & Crear comercio que se expanda a la calle \\
\hline & & & Creación de kioskos y tiendas de esquina \\
\hline & & & Ubicación de gastronomía callejera \\
\hline & \multirow{5}{*}{ Recreo } & \multirow{5}{*}{$\begin{array}{l}\text { Diversión o } \\
\text { descanso durante } \\
\text { el tiempo libre }\end{array}$} & Espacios para juegos \\
\hline & & & Espacios para deportes y ejercicios \\
\hline & & & $\begin{array}{l}\text { Crear áreas para la cultura, civismo y } \\
\text { tradición }\end{array}$ \\
\hline & & & Crear áreas de descanso y sociabilidad \\
\hline & & & Crear espacios para la contemplación \\
\hline
\end{tabular}

Fuente: La dimensión humana en el espacio público (2017) 


\subsection{Tipologías de espacio público}

El Plan de Desarrollo Urbano de la ciudad de Huancayo clasifica los parques de acuerdo a las dimensiones e impacto urbano (PDU, 2015). La clasificación es la siguiente:

- Parque Metropolitano: Son espacios que combinan áreas verdes, servicios de diversos tipos destinados a la activación del espacio, asimismo estos parques generan valores paisajísticos y urbanos. Se ubican en regiones metropolitanas con poblaciones mayores al millón de habitantes, el área base para el cálculo de superficie de un parque metropolitano es de $0.4 \mathrm{~m} 2 /$ habitante, y el área mínima de cada parque metropolitano será de 40 ha.

- Parque zonal: Son espacios que combinan áreas verdes y diversos tipos de servicios proporcionan a la ciudad un ambiente natural de características propias, su rango poblacional está orientado a poblacionales urbanas en el rango de los 100,000 a los 300,000 habitantes, el área base para el cálculo de la superficie de un parque zonal es de $0.4 \mathrm{~m} 2 /$ habitante, y el área mínima de cada parque zonal será de 5 ha.

- Parque sectorial: Son espacios que mayormente permiten el desarrollo de actividades pasivas, el rango poblacional está orientado a poblaciones urbanas de 10,000 a los 30,000 habitantes, el área base para el cálculo de la superficie de un parque sectorial es de $2 \mathrm{~m} 2 /$ habitante, y el área mínima de cada parque zonal será de 2 ha.

- Parque local: Son espacios que permiten el desarrollo de actividades de recreación pasiva, se definen en los procesos de habilitación urbana de acuerdo a los porcentajes señalados por la normativa y en Reglamento Nacional de Edificaciones.

- Plaza Cívica: Son espacios públicos delimitados por edificaciones más representativas de la ciudad, son símbolos de poder (religioso o político). Son el centro de la vida urbana. El área base para el cálculo de la superficie de una plaza cívica es de $0.2 \mathrm{~m} 2$ / habitante, y el área mínima de cada plaza cívica es de 1 ha.

Teniendo esta clasificación, podemos inferir que el Parque Lineal Ribereño Shullcas es un parque zonal, ya que está orientado a una población de 100,000 a 300,000 
habitantes, el impacto que generará será a nivel de los distritos principales de la ciudad de Huancayo.

\subsection{Normativa}

En esta sección mencionaremos al marco normativo que gira entorno a la intervención en bordes de río, asimismo mencionaremos la normativa vigente arquitectónica en el Perú. Se mencionará los capítulos y secciones que se tomarán en cuenta en el proyecto al momento del diseño.

Se trabajará con "La propuesta de ley general de desarrollo urbano" del Ministerio de vivienda, construcción y saneamiento [MVCS]. A continuación, se presentará un listado de los capítulos más relevantes que nos ayudarán en el diseño del Parque Lineal Ribereño Shullcas. (Ministerio de Vivienda, Contrucción y Saneamiento [MVCS], s.f.)

Título III: Elementos de soporte urbano

Capítulo I: Sistema de espacios públicos

- Artículo $28^{\circ}$ Definición y clase de espacios públicos

- Artículo $29^{\circ}$ Previsión del espacio público

Capítulo II: Infraestructura urbana

- Artículo $30^{\circ}$ Definición de infraestructura urbana

Capítulo III: Equipamiento urbano

- Artículo $32^{\circ}$ Definición de equipamiento urbano

- Artículo $33^{\circ}$ Previsión de equipamiento urbano

Capítulo V: Paisaje urbano

- Artículo $36^{\circ}$ Definición de paisaje urbano

- Artículo $37^{\circ}$ Previsión de paisaje urbano

Asimismo, se tomará en cuenta el "Reglamento para la delimitación y mantenimiento de las fajas marginales en cursos fluviales y cuerpos naturales y artificiales" de la Autoridad Nacional del Agua [ANA]. A continuación, se presentará un 
listado de los capítulos relevantes que nos ayudarán para diseñar el Parque Lineal Ribereño Shullcas. (Autoridad Nacional del Agua [ANA], 2016)

Título I: Disposiciones generales

- Artículo $4^{\circ}$ Aprobación del ancho mínimo de la faja marginal

- Artículo $5^{\circ}$ Registro de las propiedades aledañas

Título II: Criterios para determinar el límite superior de la ribera y ancho mínimo de las fajas marginales en cauces naturales.

Capítulo I: Criterios para determinar el límite superior dela ribera de cauces naturales

- Artículo $8^{\circ}$ Límite superior de la ribera de cauces naturales

- Artículo $9^{\circ}$ Modelamiento hidráulico

Capítulo II: Criterios para determinar el ancho mínimo de fajas marginales de cauces naturales.

- Artículo $12^{\circ}$ Criterios generales

Por otro lado, el Reglamento Nacional de Edificaciones [RNE] edición 2016. A continuación, se presentará un listado de los capítulos relevantes que nos ayudarán para diseñar el Parque Lineal Ribereño Shullcas y el Centro de Interpretación el Agua. (Colegio de Arquitectos del Peru [CAP], 2016)

Título III.1 Arquitectura

- A.010 Condiciones generales de diseño

- A.090 Servicios comunales

- A.120 Accesibilidad para personas con discapacidad y de las personas adultas mayores

- A.130 Requisitos de seguridad

Finalmente, se usará el manual internacional "Neufert, arte de proyectar en arquitectura" (1975) para complementar la normativa peruana, ya que es muy básico en relación a planes de intervención en bordes de río. A continuación, se mencionará los capítulos que ayudarán para diseñar el Parque Lineal Ribereño Shullcas y el Centro de Interpretación del Agua. (Neufert, 1975) 


\subsection{Instituciones a fines}

\subsubsection{Nacionales}

\section{Ministerio del Ambiente [MINAM]}

Es el ministerio encargado de promover la sostenibilidad ambiental del país, conservando, protegiendo, recuperando y asegurando las condiciones ambientales, los ecosistemas y los recursos naturales.

Según la Resolución Suprema º 189-2012-PCM/MINAM, el objetivo principal es fortalecer la confianza de los ciudadanos en relación al rol del Estado en la protección ambiental, el manejo sostenible de los recursos naturales y la conservación de especies y ecosistemas. Por ello se aprobaron los Ejes Estratégicos de la Gestión ambiental, que son cuatro aspectos que definen la incorporación plena y gradual de la dimensión ambiental en las políticas públicas (Ministerio del Ambiente, 2012)

- Eje 1: Estado Soberano y garante de derechos: Reducir los conflictos socioambientales, elevar el nivel de cultura y ciudadanía ambiental y fortalecer el ejercicio de la función fiscalizadora ambiental.

- Eje 2: Mejora de la calidad de vida con un ambiente sano: Reducir la contaminación de los recursos hídricos en cuencas y en zonas marino costeras, reducir la contaminación del aire, prevenir y detener la degradación y contaminación del suelo, incrementar el conocimiento sobre la disponibilidad del recurso hídrico, reducir la contaminación sonora.

- Eje 3: Compatibilizando el aprovechamiento armonioso de los recursos naturales: Reducir la vulnerabilidad de la población por riesgos de desastres con el ordenamiento territorial $\mathbf{y}$ mantener los servicios ecos sistémicos de las Áreas Naturales.

- Eje 4: Patrimonio Natural Saludable: Elevar la capacidad de adaptación al cambio climático, reducir la deforestación y degradación de los bosques, reducir la emisión de los Gases de Efecto Invernadero (GEI), conservar y poner en valor la diversidad biológica, especialmente las especies amenazadas, preservar la diversidad genética cultivada (en los agro 
ecosistemas) y silvestre y finalmente preservar la integridad de los ecosistemas frágiles.

Para realizar las estrategias mencionadas es importante que ya existan funciones específicas como la adecuada gestión de residuos sólidos, la protección de la calidad del agua, la innovación tecnológica y la información en materia ambiental, ya que actualmente hay una falta de conciencia por la preservación de los recursos naturales.

\section{Ministerio de cultura $[\mathrm{MC}]$}

El Ministerio de Cultura es un organismo, responsable de todos los aspectos culturales del país; es una institución reconocida como eje fundamental del desarrollo sostenible del país, que promueve la ciudadanía intercultural, la integración social y la protección del patrimonio cultural de la nación, facilitando un mayor acceso a la población, a los productos culturales y artísticos y afianzando la identidad peruana.

Las funciones principales del Ministerio son formular, ejecutar y establecer estrategias de promoción cultural de manera inclusiva y accesible, realizar acciones de conservación y protección del patrimonio cultural, fomentar toda forma de expresiones artísticas, convocar y reconocer el mérito de quienes aporten al desarrollo cultural del país, planificar y gestionar con todos los niveles de gobierno actividades que permitan el desarrollo de los pueblos amazónicos, andinos y afroperuanos, todo ello propiciando el fortalecimiento de la identidad cultural y abriendo espacios de participación de todas las culturas.

\section{Autoridad Nacional del Agua [ANA]}

Es un ente nacional que se encarga de administrar, conservar y proteger los recursos hídricos de las diferentes cuencas del Perú, optando por un desarrollo sostenible y una responsabilidad compartida entre el gobierno y la sociedad, incentivando la cultura del agua que reconozca su valor económico, social y ambiental.

La Autoridad Nacional del Agua presentó el plan estratégico que ha sido formulado con el propósito de orientar la gestión del agua del 2011 -2015 .El plan presentó el diagnóstico actual de las cuencas y ríos del Perú, además de los usos que se le da a los ríos como recurso hídrico y la normatividad vigente en relación a la intervención en bordes y fajas marginales de ríos. Estos datos nos permitirán diseñar un 
proyecto que cumpla con los requisitos estratégicos de la organización para no afectar los recursos hídricos y su entorno.

De este plan se utilizarán los parámetros de intervención en bordes de río y fajas marginales, asimismo se extraerá información con respecto a las estrategias de intervención.

\section{Gobierno Regional Junín [GRJ]}

El Gobierno Regional Junín es el encargado de promover y conducir el desarrollo integral sostenible de la Región Junín, con competitividad, enfoque de cambio Climático y gestión de Riesgos, derechos e Igualdad de oportunidad en el marco de la Modernización del Estado. (Gobierno Regional Junin, s.f.)

El proyecto se ubicará en la ciudad de Huancayo departamento de Junín, por lo tanto se utilizará parámetros, información económica, social, cultural, etc. Para el desarrollo del proyecto.

\section{Municipalidad Provincial de Huancayo [MPH]}

La Municipalidad de Huancayo es la encargada de generar condiciones para el desarrollo armónico e integral de la provincia de Huancayo a través de la eficiente prestación de servicios públicos a los ciudadanos con un gobierno local moderno, inclusivo, transparente, sostenible y efectivo (Municipalidad Provincial de Huancayo, 2014)

Del Municipio se extraerá los planos de catastro, zonificación actual, así también se extraerá datos relevantes del Plan de Desarrollo Urbano [PDU] para el proyecto de intervención urbana y arquitectónica que se va a diseñar.

\subsubsection{Internacionales}

\section{ONU- UNEP}

El Programa Medioambiental de las Naciones Unidas es la autoridad ambiental mundial que establece la agenda ambiental global, promueve la implementación coherente de la dimensión ambiental del desarrollo sostenible en el sistema de las 
Naciones Unidas y sirve como defensor autorizado del medio ambiente mundial. (Programa de las Naciones Unidas para el Medio Ambiente \{PNUMA\}, s.f.)

Las labores que desempeña la organización son:

- La evaluación de las condiciones y tendencias ambientales a nivel mundial, regional y nacional

- El desarrollo de instrumentos ambientales internacionales y nacionales

- Fortalecimiento de las instituciones para la gestión racional del medio ambiente

De esta organización se extraerá información concerniente en la evaluación de las condiciones ambientales del Río Shullcas

\section{Banco Internacional del Desarrollo [BID]}

El Programa Ciudades Emergentes y Sostenibles [CES] es un programa de asistencia técnica no-reembolsable que provee apoyo directo a los gobiernos centrales y locales en desarrollo y ejecución de planes de sostenibilidad urbana.

CES emplea un enfoque integral e interdisciplinario para la identificación, organización y priorización en intervenciones urbanas para hacer frente a los principales obstáculos que impiden el crecimiento sostenible de las ciudades emergentes de América Latina y el Caribe. El enfoque se basa en tres pilares: La Sostenibilidad medioambiental y de cambio climático (Banco Internacional de Desarrollo [BID], s.f.)

- La Sostenibilidad Urbana

- La sostenibilidad fiscal y gobernabilidad.

La Ciudad de Huancayo en el 2014 se integró al programa del BID para recibir asesorías en el desarrollo sostenible. De este modo, la municipalidad ha elaborado un informe de sus condiciones actuales que será evaluado por el programa para poder asesorarlos. Todos los datos concernientes y diagnósticos realizados por el CES servirán de apoyo para la elaboración del Marco contextual.

\section{"Consejo Internacional De Museos" [ICOM]}

El Consejo internacional de museos trabaja al servicio de la sociedad y de su desarrollo comprometiéndose a garantizar la conservación y la transmisión de los bienes culturales. Las labores son las siguientes: ("Consejo Internacional del Muesos"[ICOM], s.f.) 
- La lucha contra el tráfico ilícito de bienes culturales

- La gestión de riesgos

- La promoción de la cultura y del conocimiento

- La protección del patrimonio material e inmaterial.

La organización estable regulaciones y normas que se necesitan para poder formar parte de la red de centros de transmisión cultural.

\section{Organismo Mundial de Salud [OMS]}

La Organización Mundial de la Salud tiene como objetivo en construir un futuro mejor y más saludable para las personas de todo el mundo. La organización trabaja junto con los gobiernos y otros asociados para que todas las personas gocen del grado máximo de salud que se pueda lograr. (Organismo Mundial de Salud[OMS], s.f.)

\subsection{Conclusiones parciales}

\subsubsection{De la metodología de intervención del paisaje}

Como se mencionó, anteriormente "La guía metodológica del estudio del paisaje" ha sido de a porte para el desarrollo de estrategias y directrices urbanísticas y de diseño del paisaje para la propuesta integral del Parque Lineal Riberateño Shullcas y el desarrollo del tramo 1 de manera que contribuya al carácter del paisaje integrando la Ribera del Shullcas con el paisaje urbano.

La primera acción previa al contenido metodológico corresponde al estudio del paisaje relacionado a la definición del ámbito de estudio, caracterización del paisaje, valoración del paisaje y medidas y acciones las cuales contribuyen para la metodología a emplear en el análisis del paisaje.

Continuando con las etapas consideradas para la propuesta de la presente tesis, se puede determinar que estas son respuesta del análisis del paisaje a desarrollar. Por lo que, la determinación de los criterios paisajísticos como primera aproximación es la base de cualquier intervención sin aún considerar las peculiaridades de cada paisaje. Las cuales se defienden para la propuesta: respetar la topografía y vegetación del lugar; integración paisajística y visual, establecer actividades económicas, potencializar la ribera del 
Shullcas, tratar la transición de la ribera con el contexto urbano, mejorar los accesos por medio de movilidad sostenible

Finalmente, las conclusiones de las siguientes fases de desarrollo de la guía corresponderán al marco contextual a partir del análisis del paisaje en dos escalas relacionadas a tipo de intervención de la propuesta integral del Parque Ribereño Shullcas a partir del a metodología explicada para el análisis del paisaje local y urbano.

\subsubsection{De la metodología de diseño urbano}

La ciudad está conformada por espacios públicos que constituyen el hábitat de todo ciudadano. Esta necesita ordenarse para poder brindar al peatón espacios de calidad. El ordenamiento tiene que ser de las diversas áreas de acción de la ciudad como el patrimonio, movilidad, diversidad, diseño urbano a escala humana y el fomento cultural.

Las instituciones del estado, a nivel Sudamérica, han mostrado un interés en mejorar las ciudades, Chile es uno de ellos, en el manual de "La dimensión humana en el espacio público" propuesto por el Ministerio de vivienda y urbanismo de Chile, se genera recomendaciones de diseño, así como lineamientos y estrategias para poder intervenir en la ciudad.

Las recomendaciones responden a ámbitos de actuación dependiendo de las áreas de acción. Son 80 recomendaciones de diseño que permiten mejor el espacio público para dar al usuario áreas donde puedan desarrollar sus actividades.

\subsubsection{De la normativa e instituciones a fines}

A partir del "La propuesta de ley general de desarrollo urbano" podemos determinar que la intervención es un plan de ordenamiento metropolitano ya que solucionará temas de ordenamiento urbano continuidad física en una gestión conjunta entre gobiernos distritales.

Asimismo, esta norma nos ayudará a definir los diversos elementos de soporte urbano conformado por espacio público, infraestructura urbana, equipamiento urbano y paisaje urbano para proponer un proyecto integral a escala metropolitana. En la ciudad 
de Huancayo, el espacio público se determina por ser natural como el Río Shullcas o creado por el hombre como los parques y plazas.

En relación a la infraestructura urbana en Huancayo, está determinada por las redes de alcantarillado que actualmente se encuentran expuestas al borde de río, siendo estas consideradas para la intervención en el Parque Lineal Ribereño.

La incorporación de nuevo equipamiento urbano, en la ciudad de Huancayo dependerá de la dotación, uso y conservación. De modo que el Centro de Interpretación de Agua de acuerdo a la ley está definido como un equipamiento para conservación.

El paisaje urbano hace referencia a que se debe preservar el paisaje natural, es decir que las edificaciones cerca de áreas naturales no deben alterar su condición ni romper la armonía de este.

Por otro lado, el "Reglamento para la delimitación y mantenimiento de las fajas marginales en cursos fluviales y cuerpos naturales y artificiales" nos permitirá definir las distancias de la faja marginal respecto al eje del Río Shullcas, la cual se debe considerar que al tener un tramo de río con baja pendiente (menor a $1 \%$ ) cerca al cruce con el Río Mantaro el ancho mínimo de la faja será de 6 a 10 metros

El Reglamento Nacional de Edificaciones nos proporciona una normativa referente a la arquitectura que nos será útil en el diseño de interpretación del agua para hacer de este un equipamiento inclusivo, con espacios que permitan al usuario desarrollarse de manera óptima. Asimismo, se usará el manual internacional "Neufert" como herramienta de diseño arquitectónico para la ejecución del Centro de Interpretación del Agua. 


\section{CAPÍTULO V: MARCO OPERATIVO}

\subsection{Metodología}

Para comprender mejor como intervenir en los bordes del Río Shullcas, se realizará un análisis de tres referentes mundiales que han tenido impacto en las ciudades donde han sido ejecutadas. Asimismo, se analizará a tres referentes de centros de interpretación para poder proponer el proyecto piloto del CIA-Huancayo

A continuación, se describirá las variables de análisis que se utilizarán para comprender los proyectos.

- Ficha del Proyecto presentará los datos relevantes del proyecto como el año, equipo de trabajo, cliente, periodo histórico, datos de la ciudad donde se ubica y descripción.

- Historia y Toma de partido una línea del tiempo se encargará de mostrar el tiempo de planificación, diseño y ejecución del proyecto, ubicará los momentos más relevantes de su contexto histórico. Por otro lado, mediante gráficos y esquemas se presentará las ideas y conceptos que cada arquitecto tuvo para el diseño.

- Ubicación mediante mapas se mostrará el emplazamiento del proyecto, la ubicación exacta y el impacto en el entorno inmediato y accesos.

- Programa se muestra los paquetes programáticos, el cuadro de áreas, el organigrama espacial con gráficos, la zonificación espacial y relación espacial con planos necesarios.

- Espacio se analizará los diversos tipos de espacio dentro del proyecto según el área, aforo y ratio

- Tecnología se analizará los diversos sistemas constructivos y materiales utilizados_en el proyecto

- Impacto social se muestra los radios de impacto de la edificación, se describe el rol de la cultura e identidad de cada proyecto. 
Finalmente, se realizará cuadros comparativos de los casos análogos para culminar en una ficha resumen que sintetice la información relevante a tomar en cuenta para el diseño del Parque Lineal Ribereño Shullcas y el Centro de Interpretación del Agua.

El mapa (Figura 5.1) muestra la ubicación de los proyectos análogos de este capítulo Figura 5. 1 Mapa de ubicación de proyectos análogos

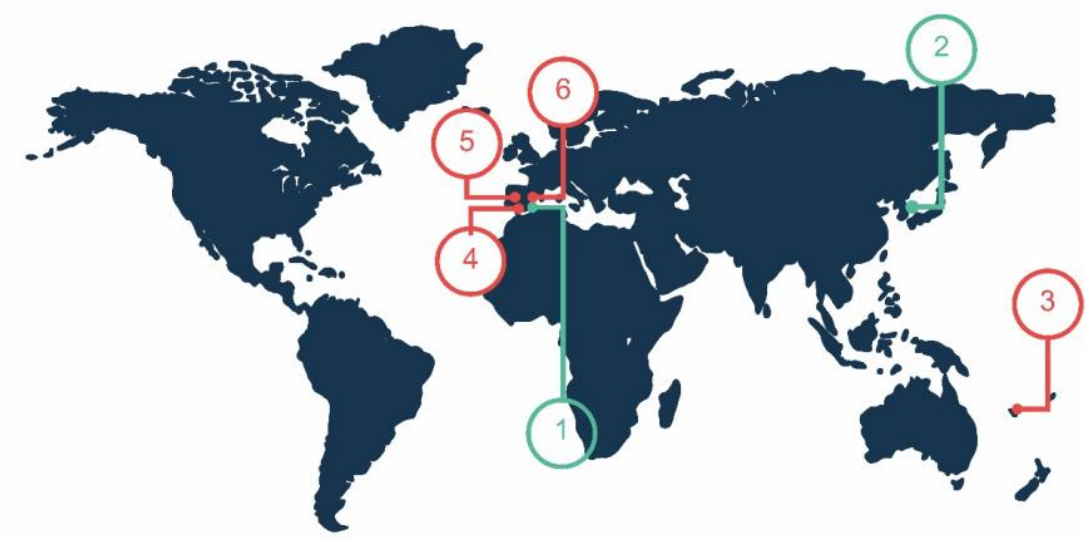

Rio Manzanares - Madrid, España

2. Rio Cheonggyecheon - Seúl, Corea del Sur

3. Centro Cultural Jean Marie Tjibaou - Noumea

4. Centro de interpretación y acogida de visitantes de La Antigua - España

5. Centro de interpretación de la Naturaleza de los humedales-Salburủa, España

6. Centro de interpretación de los Rios - Benavente, España

Fuente: Elaboración propia

\subsection{Estudios de casos}

\subsubsection{Regeneración de bordes de río}

5.2.1.1 Regeneración Urbana de los bordes del Río Manzanares - España 


\section{REGENERACIÓN URBANA RÍO MANZANARES MADRID,ESPAÑA}

HISTORIA

TECNOLOGÍA
UBICACIÓN

IMPACTO SOCIAL

PROGRAMA

\section{ESPACIO}

IMÁGENES DELAUTOR EN BASEA :

Web: Madrid Río/ Metropolis "2015 (jttp//www.metropolis.org/es/premios/5a edicion-2014/madrid-rio)

Libro: Paisajes en la ciudad Madrid Río: Geografía, infraestructura y espacio público (Fernández Villanueva, 2015)

Texto: Plan especial Río Manzanares estudio de incidencia ambiental ( Coordinaci y Singulares, n.d)

AÑO 2005-2011

EQUIPO

Equipo de diseño de superficie

Burgos y Garrido Arquitectos

Porras la Casta Arquitectos

Rubio y Alvarez Sala Arquitectos

CLIENTE

PERIODO HISTÓRICO

Ayuntamiento de Madrid

DATOS DE LA CIUDAD

Periodo contemporáneo

Ciudad: Madrid, España

Población: 5 millones

Área: 400 km2
FICHA

5.1

OPERACIÓN URBANA

Longitud del parque: $6.7 \mathrm{~km}$

Superficie del parque: $110 \mathrm{Ha}$.

Superficie de otros usos: $10 \mathrm{Ha}$.

Superficie total: $120 \mathrm{Ha}$.

Periodos de planificación: 2003-2008

Periodos de construcción: 2004-2011

Presupuesto de obra en superficie: 500 millones de dólares

Presupuesto total: 5000 millones de dólares
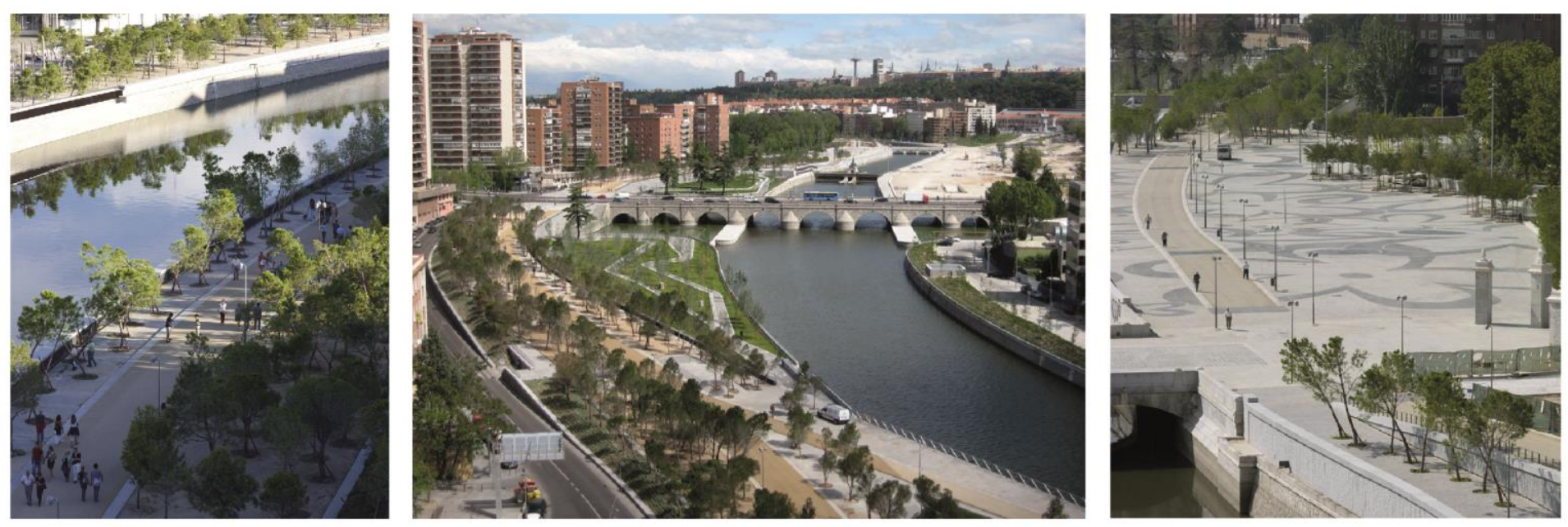


\section{REGENERACIÓN URBANA RÍO MANZANARES MADRID,ESPAÑA}

FICHA DEL PROYECTO

ESPACIO
HISTORIA

TECNOLOGÍA
UBICACIÓN

PROGRAMA

\subsection{1}

FICHA

IMPACTO SOCIAL

IMÁGENES DEL AUTOR EN BASE A

Web: Madrid Río/ Metropolis "2015 (jttp//www.metropolis.org/es/premios/5a edicion-2014/madrid-rio)

Libro: Paisajes en la ciudad Madrid Rio: Geografia, infraestructura y espacio público (Fernández Villanueva, 2015)

Texto: Plan especial Río Manzanares estudio de incidencia ambiental ( Coordinaci y Singulares, n.d)

\section{PERIODO HISTÓRICO}

Madrid durante muchos años del siglo XIX tuvo cambios muy repentinos respecto al crecimiento desordenado, en esta época la ciudad crecía entorno al río y se contruyó el ferrocarril de circunvalación en la margen izquierda incentivando el crecimiento desordenado.

El Río Manzanares, se había convertido en el vertedero de residuos de la capital, sus aguas negras manifestaban un deterioro alarmante, desde el punto de vista de higiene y era necesario reparar.

La canalización y saneamiento de las aguas del río era inaplazable. En el siglo XX cuando llegó la primera intervención de obras, la huella horrorosa del río empezó a cambiar y se sustituyó por un trazo geométrico ordenado en la actualidad. La obra fue producida por el ingeniero Fungairiño, quién solo se limitó a la canalización y saneamiento del agua como factores principales.

La idea de entender el borde del río como un episodio urbano que ordene y limite el crecimiento de la ciudad en su entorno quedó postergada con urgencia.

\section{PLANES URBANOS}

Es así que en 1925 al término de las obras de canalización aparece un proyecto para urbanizar los márgenes del Río Manzanares, fue la primera visión conjunta donde se integraba la industria con la vivienda obrera por un gran parque lineal; sin embargo, la realidad permaneció ajena y las márgenes del río seguían padeciendo el crecimiento acelerado y desordenado. Hubo una contradicción entre intentos de planificación y realidad.

Acontinuación se presentan los cuatro planes urbanos que tuvo Manzanares antes del concurso de regeneración urbana en borde de ríos.

Plan Bidagor

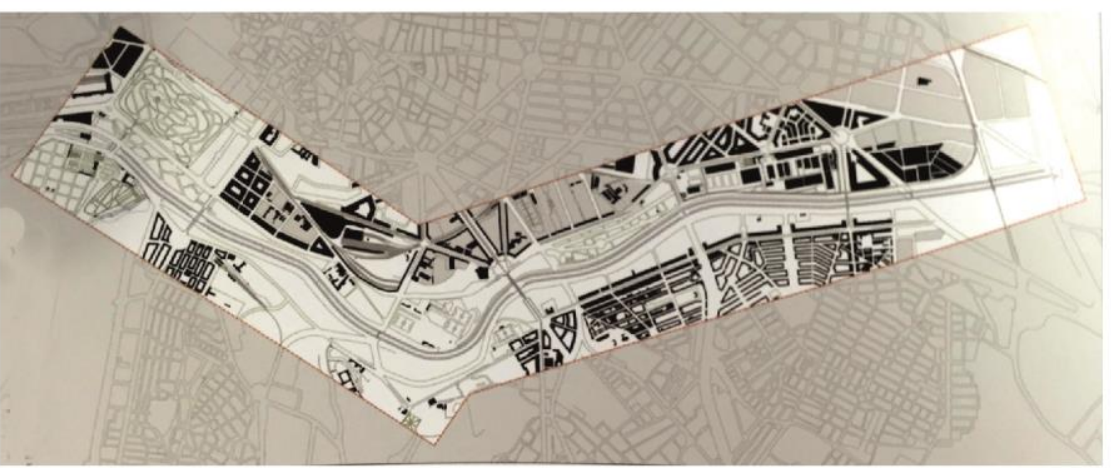

- Manzanares debía recuperar la idea de zócalo verde

- El río debía ser el eje ordenador natural

entre el paisaje cerrano y boscoso 
REGENERACIÓN URBANA RIOO MANZANARES MADRID,ESPAÑA

SECCIÓN

\subsection{1}

FICHA DEL PROYECTO

ESPACIO

\section{HISTORIA}

\section{UBICACIÓN}

TECNOLOGÍA
PROGRAMA

FICHA

5.3

IMÁGENES DEL AUTOR EN BASE A :

Web: Madrid Río/ Metropolis "2015 (jttp//www.metropolis.org/es/premios/5a edicion-2014/madrid-rio)

Libro: Paisajes en la ciudad Madrid Rio: Geografía, infraestructura y espacio público (Fernández Villanueva, 2015)

Texto: Plan especial Rio Manzanares estudio de incidencia ambiental ( Coordinaci y Singulares, n.d)

\section{IMPACTO SOCIAL}

Plan Mendoza

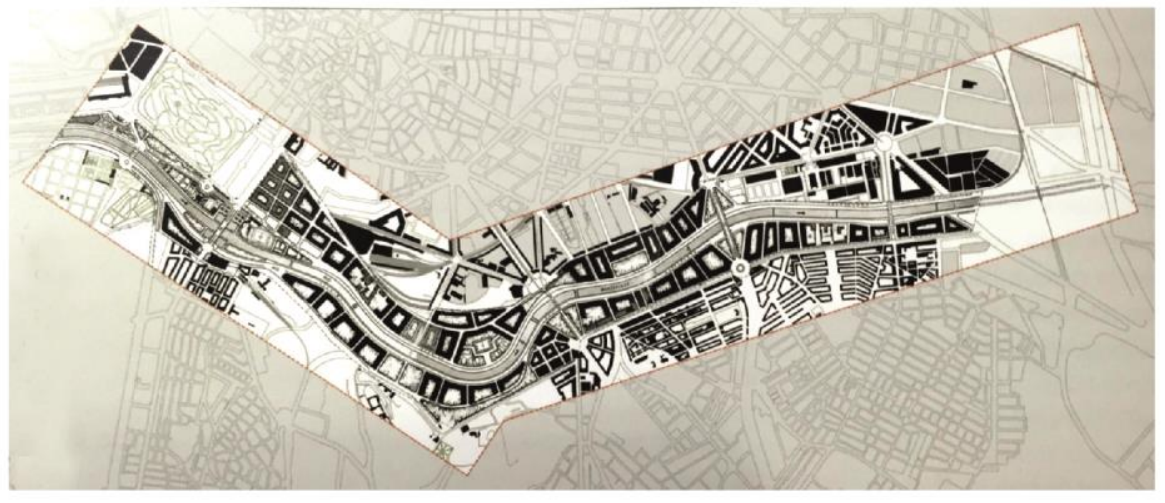

Plan Perpiña

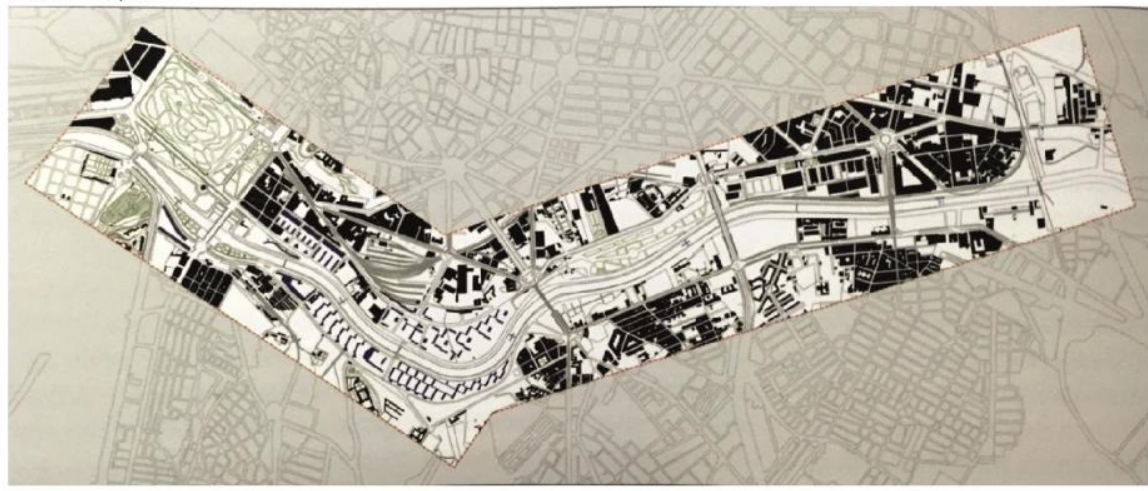

Plan 2000

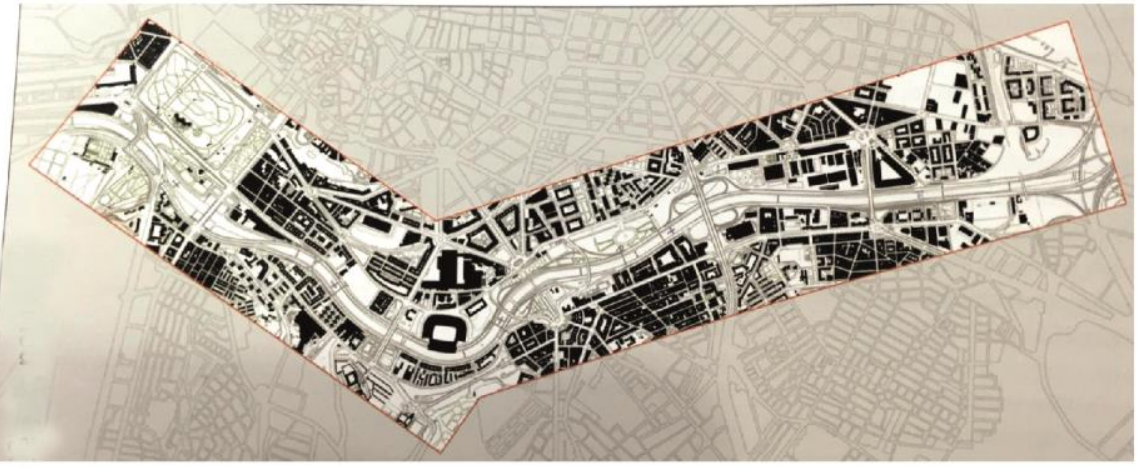

- Reforma y mejora urbana a cambio de un aprovechamiento privado

- Aplicación de los mecanismos clásicos de especulación totalmente indiferente a la singularidad del lugar.

- Propone para el tramo de los puentes Segovia y Toledo en lugar de una ciudad jardín, varios bloques en altura para vivienda.

- Propone enfatizar en la conexión de una ciudad fragmentada por medio de autopistas que se ubiquen a lo largo del río para facilitar conexiones vehículares 


\section{REGENERACIÓN URBANA RÍO MANZANARES MADRID,ESPAÑA}

\begin{abstract}
-ICHA DEL PROYECTO
\end{abstract}
ESPACIO

\section{HISTORIA}

UBICACIÓN

\section{2 .1}

\section{FICHA}

IMPACTO SOCIAL

IMÁGENES DEL AUTOR EN BASE A:

Web: Madrid Rio/ Metropolis "2015 (jttp//www.metropolis.org/es/premios/5a edicion-2014/madrid-rio)

Libro: Paisajes en la ciudad Madrid Rio: Geografia, infraestructura y espacio público (Fernández Villanueva, 2015)

Texto: Plan especial Río Manzanares estudio de incidencia ambiental ( Coordinaci y Singulares, n.d)

\section{4}

\section{TOMA DE PARTIDO}

\section{EL CONCURSO DE REGENERACIÓN URBANA DE BORDE DE RÍO}

En el año 2005 , el ayuntamiento de Madrid organizó un concurso de ideas para urbanizar los bordes del río, ya que era necesario porque la ciudad presentaba varios problemas

Durante la organización del concurso no hubo oposición política, ni resistencia respecto al tema, no fue como con otras obras, por ejemplo cuando se realizaron los túneles viales hubo oposición por diversos partidos políticos.

El proceso de regeneración de los bordes del río tuvo una duración aproximada de siete años y durante ese periodo ningún partido político estuvo en contra, ni realizó acciones al
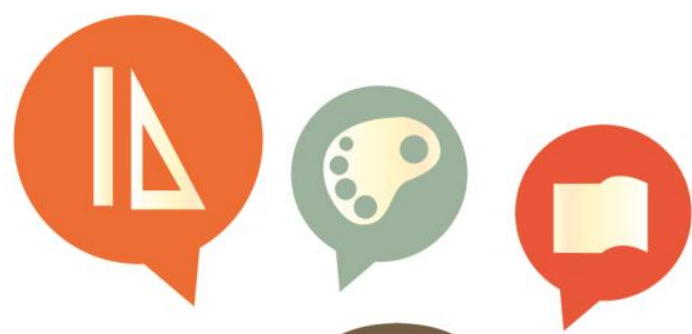
respecto.

El concurso tenía tres objetivos principales:

Recuperación de la margen del río con acciones y propuestas para:

\section{OBJETVO 1}

- Incrementar el área verde y conectar los espacios existentes

- Mejorar los bordes del río y proponer continuidad en las márgenes

- Regenerar la trama urbana de la ciudad

- Poner en valor a los edificios históricos, monumentos, edificios contemporáneos de la ciudad

- Dar valor al paisaje y generar un plan de desarrollo sostenible para el parque lineal

- Tratamiento de la superficie liberada tras el soterramiento de la M-30

Estudio del sistema dotacional existente, buscando

- Forma de tratamiento del río y el entorno, puesta en valor del agua

- Optimización de los espacios como Matadero y el mercado de frutas - Aprovechamiento del cauce del río para usos deportivos y de entretenimiento

- Creación de nuevos ejes peatonales y sendas de ciclovías y el enlace con las sendas ya existentes.

Estudio del sistema de trasporte existente, buscando:

- Reorganización del tráfico actual, predominio del transporte público y preponderancia del peatón

- Tratamiento a los túneles y accesos

- Oportunidades de introducción de nuevos elementos de transporte público de caracter interior 


\section{REGENERACIÓN URBANA RÍO MANZANARES MADRID,ESPAÑA}

\subsection{1}

FICHA DEL PROYECTO

ESPACIO
HISTORIA

TECNOLOGÍA
UBICACIÓN

IMPACTO SOCIAL
FICHA

5.5

IMÁGENES DEL AUTOR EN BASE A :

Web: Madrid Río/ Metropolis "2015 (jttp//www.metropolis.org/es/premios/5a edicion-2014/madrid-rio)

Libro: Paisajes en la ciudad Madrid Rio: Geografía, infraestructura y espacio público (Fernández Villanueva, 2015)

Texto: Plan especial Río Manzanares estudio de incidencia ambiental ( Coordinaci y Singulares, n.d)

\section{PROBLEMA}

Después de la canalización de Manzanares no tuvo otra intervención urbana, lo que ocasionó la aparición de problemas más grandes. Estos fueron:
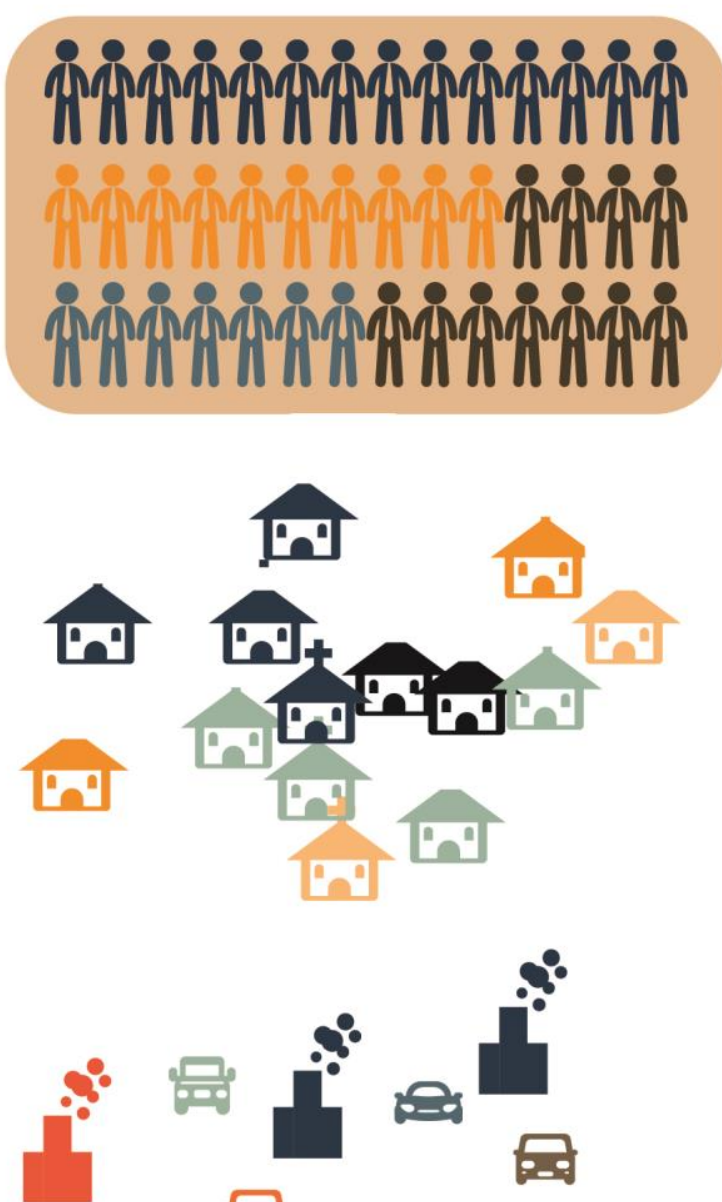

电
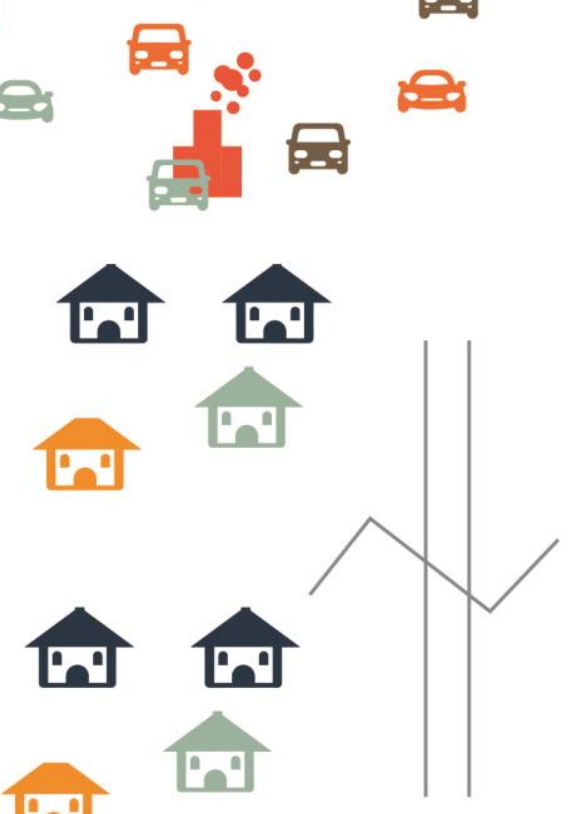

Crecimiento acelerado de la población, causó deterioro higiénico de los bordes, además que las personas optaron por vivir en las fajas marginales del río.

Crecimiento desordenado de la ciudad hacia el río por la construcción del ferrocarril y circunvalación a la margen izquierda (1851) y por el derribo del muro de Felipe IV

Contaminación del cauce del Río Manzanares y los bordes debido a la presencia industrial, así también por los desagües de las viviendas. Estos estaban direccionados con salida al río y el incremento de vehículos de transporte

Desconexión de territorios de forma lineal y pérdida del valor histórico, ya que perdió la forma de su estado natural por la metrópoli 


\section{REGENERACIÓN URBANA RÍO MANZANARES MADRID,ESPAÑA}

\section{HISTORIA}

UBICACIÓN
PROGRAMA

IMPACTO SOCIAL

\section{ESPACIO}

TECNOLOGIA

\section{2 .1}

IMÁGENES DEL AUTOR EN BASE A :

Web: Madrid Río/ Metropolis "2015 (jttp//www.metropolis.org/es/premios/5a edicion-2014/madrid-rio)

Libro: Paisajes en la ciudad Madrid Río: Geografía, infraestructura y espacio público (Fernández Villanueva, 2015 )

Texto: Plan especial Río Manzanares estudio de incidencia ambiental ( Coordinaci y Singulares, n.d)

TOMA DE PARTIDO

BURGOS Y GARRIDO, PORRAS DE LA CASTA, RUBIO Y ALVAREZ-SALA CON WEST B

\section{EL RÍO ES MÁS GRANDE}

En primer lugar se partió de la idea que el río no es un accidente de la ciudad, por el contrario es un elemento importante propio de la cuenca fluvial, ya que gracias a la presencia de este elemento nace la ciudad. Por lo tanto, la propuesta del Río Manzanares tomó como partido actuar desde una posición geografica que negocia con un continuo biológico, es decir intervenir en sus 69 km de recorrido longitudinal descomprimiéndose, naturalizándose y generando una continuidad de áreas verdes para los habitantes.

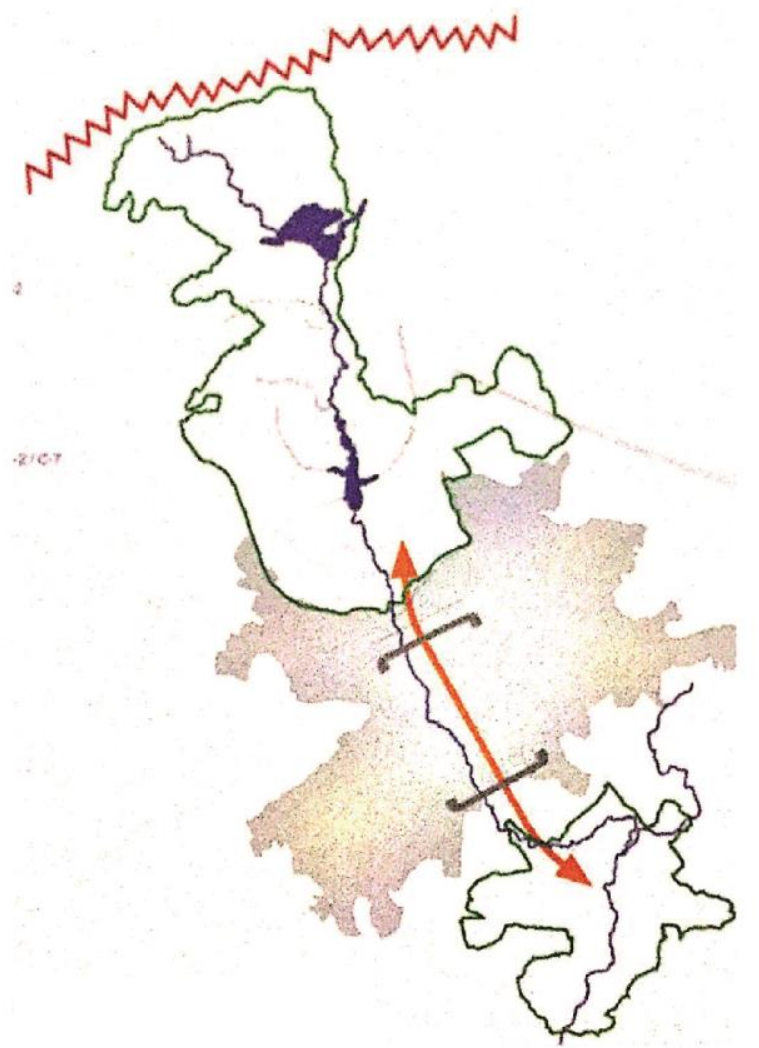

MADRID TAPÓN

Madrid no ha sido capaz de dar comunidad a sus áreas naturales norte-sur, es imprescindible la unión y continuidad del parque natural de la cuenca alta y el parque natural del sureste.

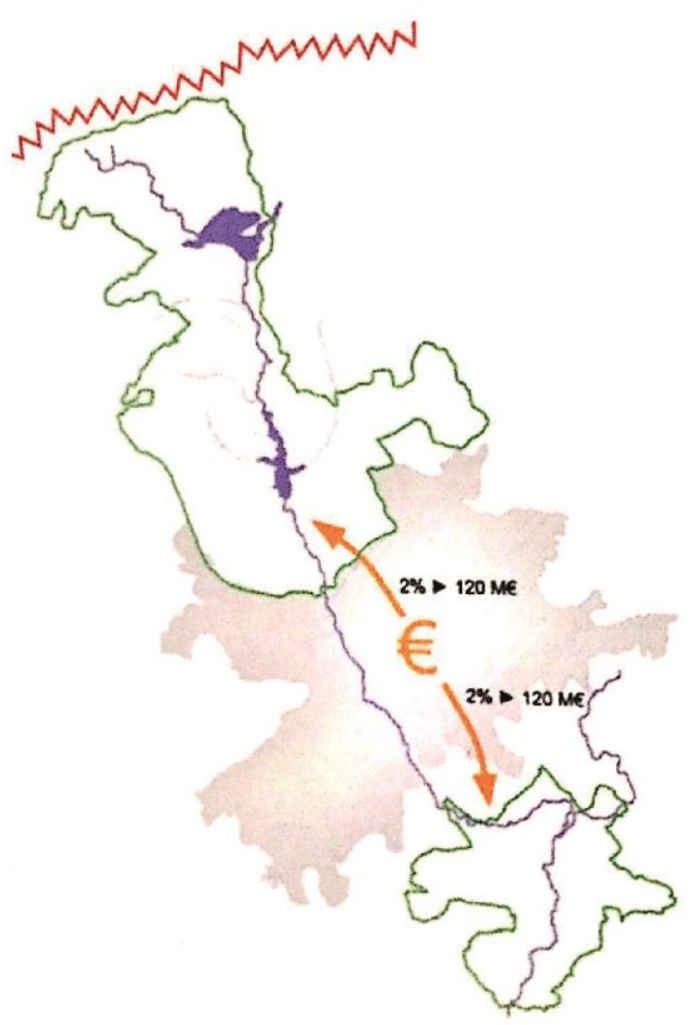

INVERTIR EN RESCATAR EL RÍO

La inversión en el río tiene sentido cuando se recupera en su totalidad. Restaurar el área verde y espacio público puede servir para regenerar la ciudad. 


\section{REGENERACIÓN URBANA RÍO MANZANARES MADRID,ESPAÑA}

FICHA DEL PROYECTO

ESPACIO
HISTORIA

TECNOLOGIA
UBICACIÓN

IMPACTO SOCIAL

\section{2 .1}

\section{FICHA}

5.7

\section{TOMA DE PARTIDO}

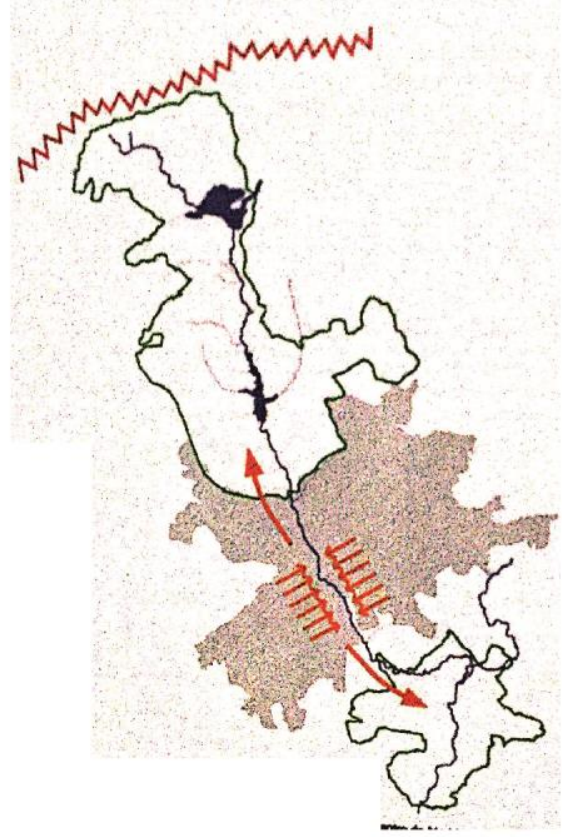

EL RÍO SALIDA NATURAL DE MADRID

Se podrá salir en bicicleta o a pie desde el centro de Madrid en ambos sentidos

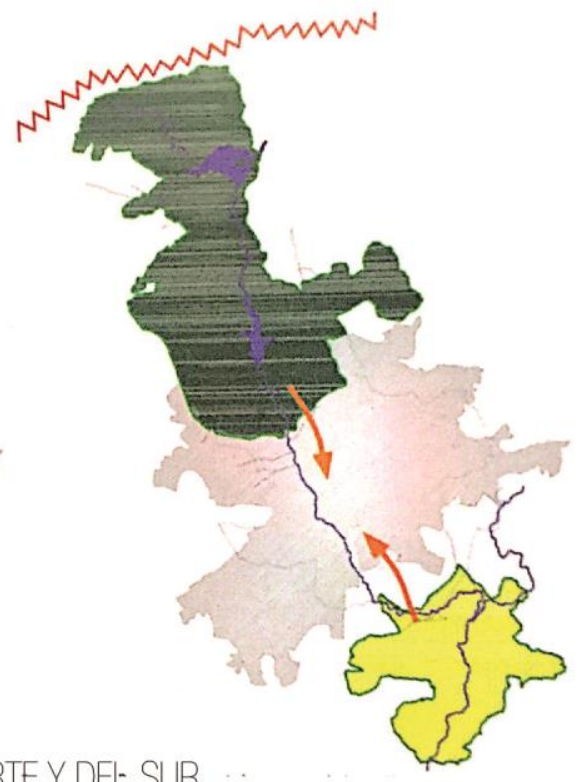

DEL NORTEY DEL SUR

Generar un paisaje dentro de la ciudad que permita unificar el área natural a lo largo del río

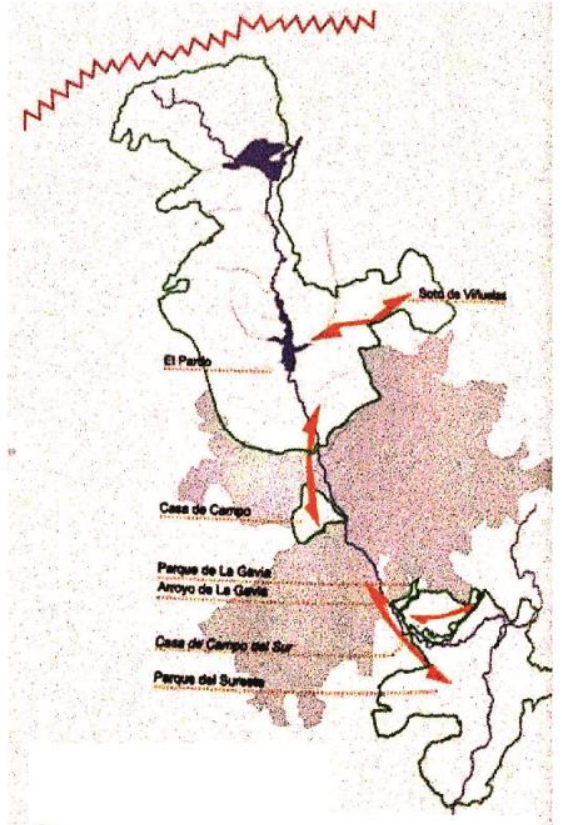

ENLAZAR ÁREAS NATURALES

El territorio fragmentado se puede convertir en una unidad con la intervención del Río Manzanares. Recuperando una continuidad natural perdida.

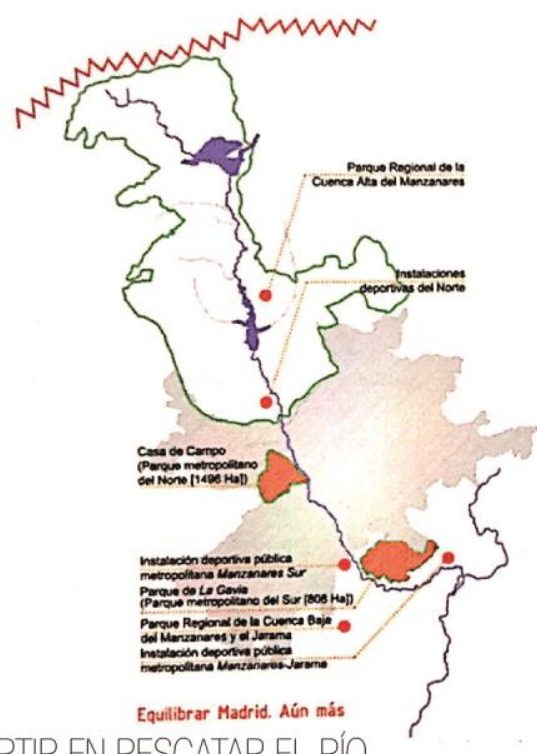

INVERTIR EN RESCATAR EL RÍO

Auque el caudal es casi ridículo y tiende a secarse en ciertas épocas del año, tranformará la ciudad colocándola en el centro y le devolverá al río la inversión realizada. 


\section{REGENERACIÓN URBANA RÍO MANZANARES MADRID,ESPAÑA}

SECCIÓN

FICHA DEL PROYECTO

ESPACIO

\section{HISTORIA}

UBICACIÓN
PROGRAMA

IMPACTO SOCIAL

\section{2 .1}

FICHA

5.8

IMÁGENES DEL AUTOR EN BASE A :

Web: Madrid Rio/ Metropolis "2015 (jttp//www.metropolis.org/es/premios/5a edicion-2014/madrid-rio)

Libro: Paisajes en la ciudad Madrid Río: Geografía, infraestructura y espacio público (Fernández Villanueva, 2015)

Texto: Plan especial Río Manzanares estudio de incidencia ambiental ( Coordinaci y Singulares, n.d)

\section{TOMA DE PARTIDO}

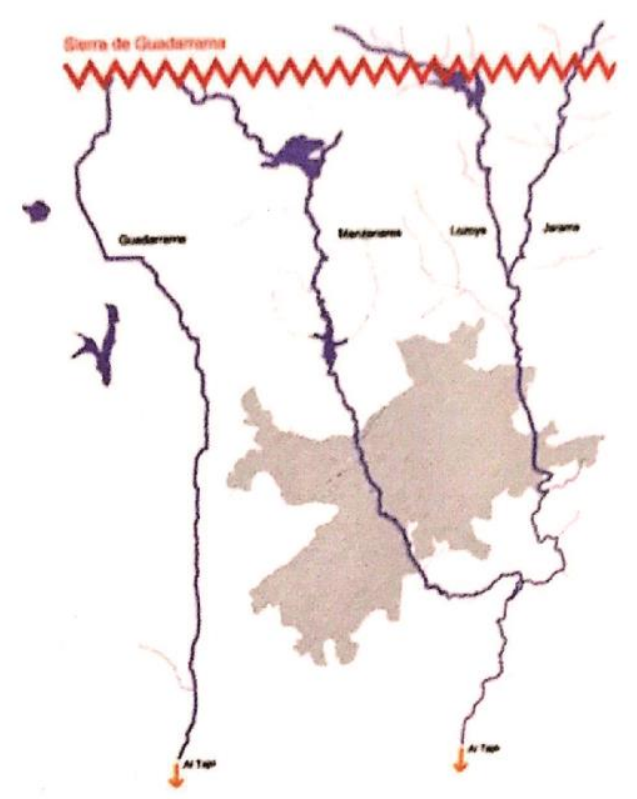

EL TERRITORIO ES LA FIGURA Y NO EL FONDO

Se podrá salir en bicicleta o a pie desde el centro de Madrid en ambos sentidos

LÍNEA DEL TIEMPO

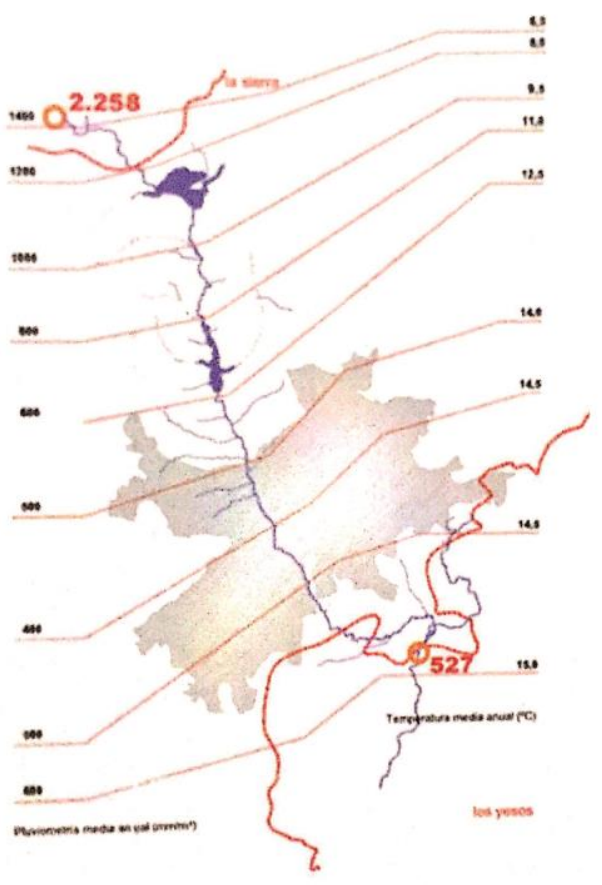

DEL CABO NORTE A TARIFA

El territorio fragmentado se puede convertir en una unidad con la intervención del Río Manzanares recuperando la continuidad natural perdida.

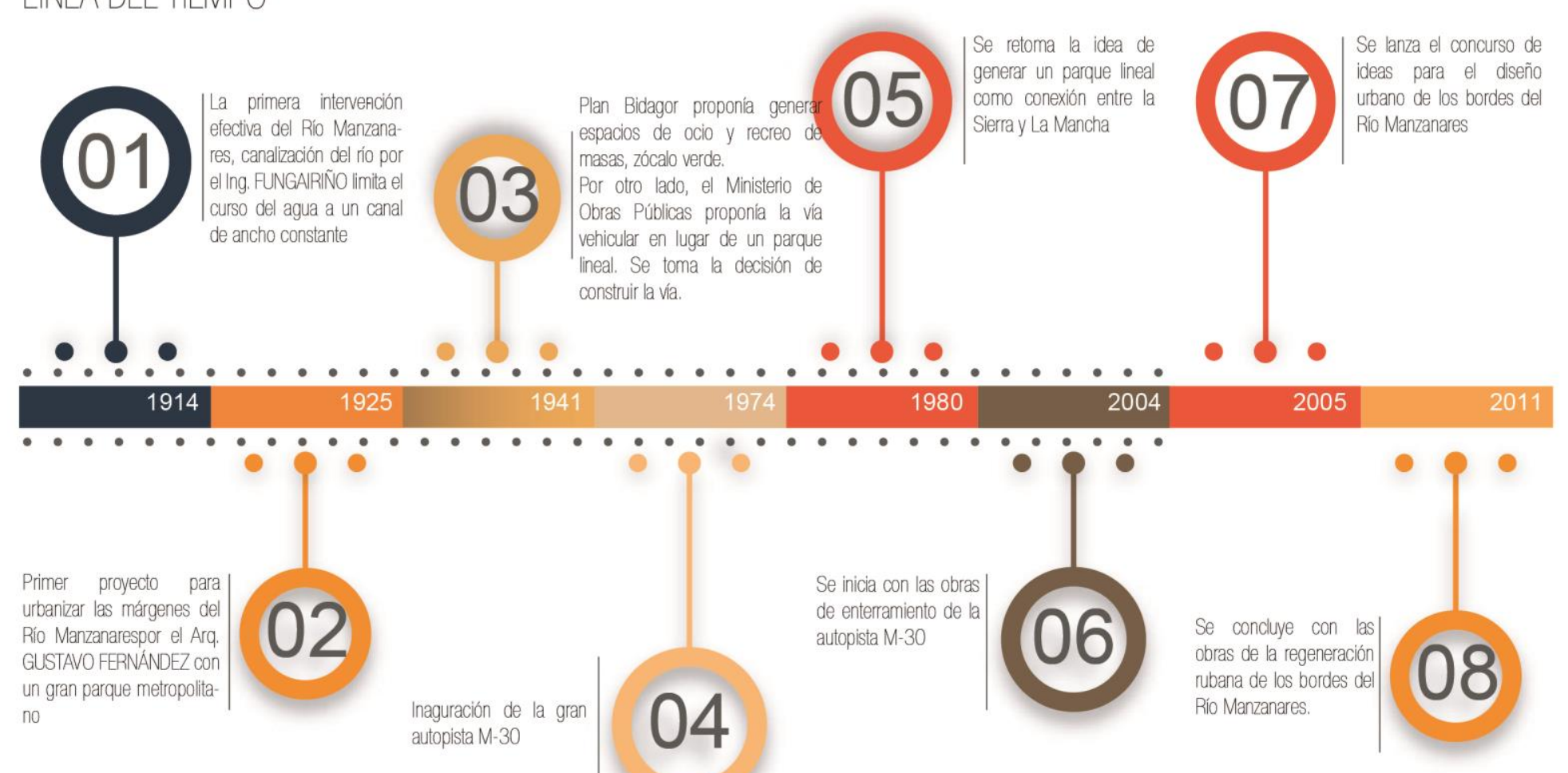




\section{REGENERACIÓN URBANA RÍO MANZANARES MADRID,ESPAÑA}

PROGRAMA

\section{ESPACIO}

\section{TECNOLOGÍA}

IMPACTO SOCIAL

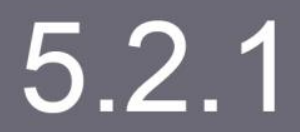

FICHA

5.9

IMÁGENES DEL AUTOR EN BASEA :

Web: Madrid Río/ Metropolis "2015 (jttp//www.metropolis.org/es/premios/5a edicion-2014/madrid-rio)

Libro: Paisajes en la ciudad Madrid Río: Geografia, infraestructura y espacio público (Fernández Villanueva, 2015)

Texto: Plan especial Río Manzanares estudio de incidencia ambiental ( Coordinaci y Singulares, n.d)

UBICACIÓN MACRO

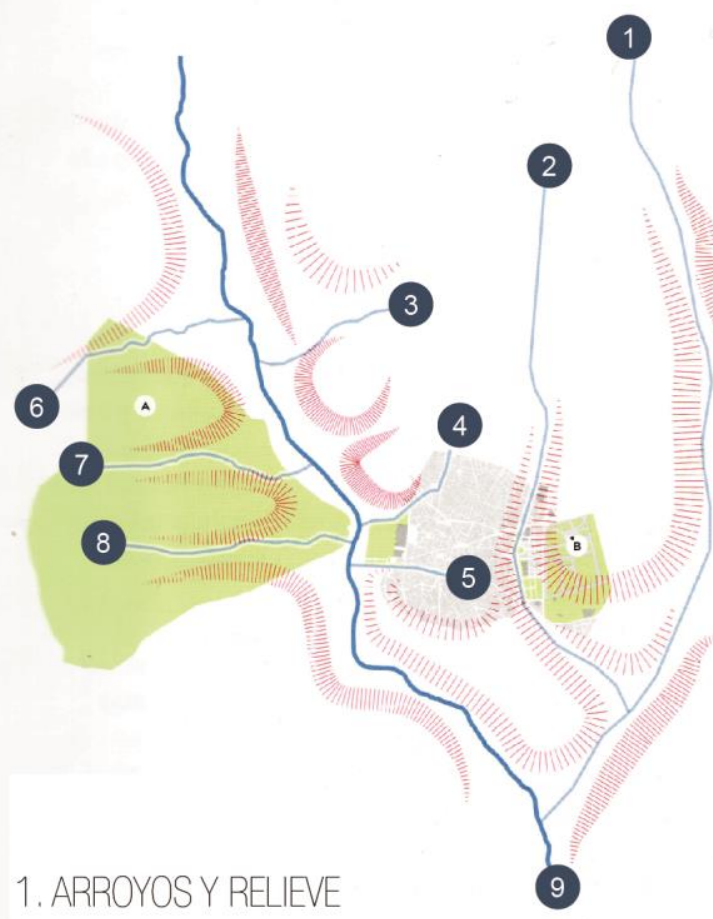

\section{ZONAS VERDES}

A. CASA DE CAMPO

B. PARQUE DEL RETIRO

- TOPOGRAFIA

PRINCIPAL

1. ARROYO DE ABROÑIGAL 2. ARROYO DE LA FUENTE CASTELLANA

3. ARROYO DE CANTARANAS

4. ARROYO DE LEGANITOS

5. ARROYO DE SAN PEDRO

6. ARROYO DE ANTEQUINA

7. ARROYO DE VALDEZA

8. ARROYO DE MEAQUES

9. RIO MANZANARES
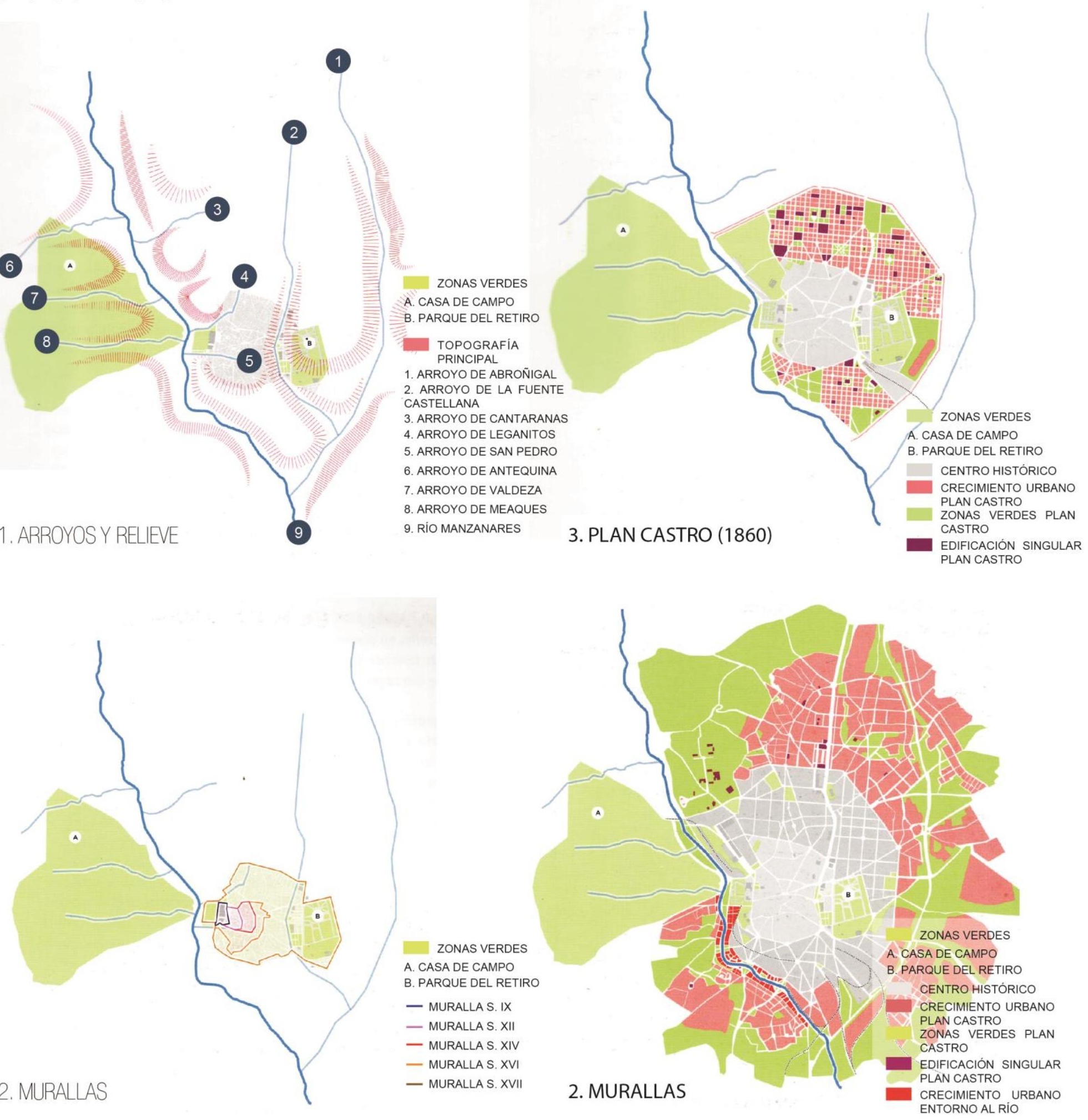


\section{REGENERACIÓN URBANA RÍO MANZANARES MADRID,ESPAÑA}

\section{UBICACIÓN}

\section{2 .1}

PROGRAMA

IMPACTO SOCIAL

\section{FICHA}

IMÁGENES DEL AUTOR EN BASE A :

Web: Madrid Río/ Metropolis "2015 (jttp//www.metropolis.org/es/premios/5a edicion-2014/madrid-rio)

Libro: Paisajes en la ciudad Madrid Rio: Geografia, infraestructura y espacio público (Fernández Villanueva, 2015)

Texto: Plan especial Río Manzanares estudio de incidencia ambiental ( Coordinaci y Singulares, n.d)

PLANO CON ENTORNO INMEDIATO

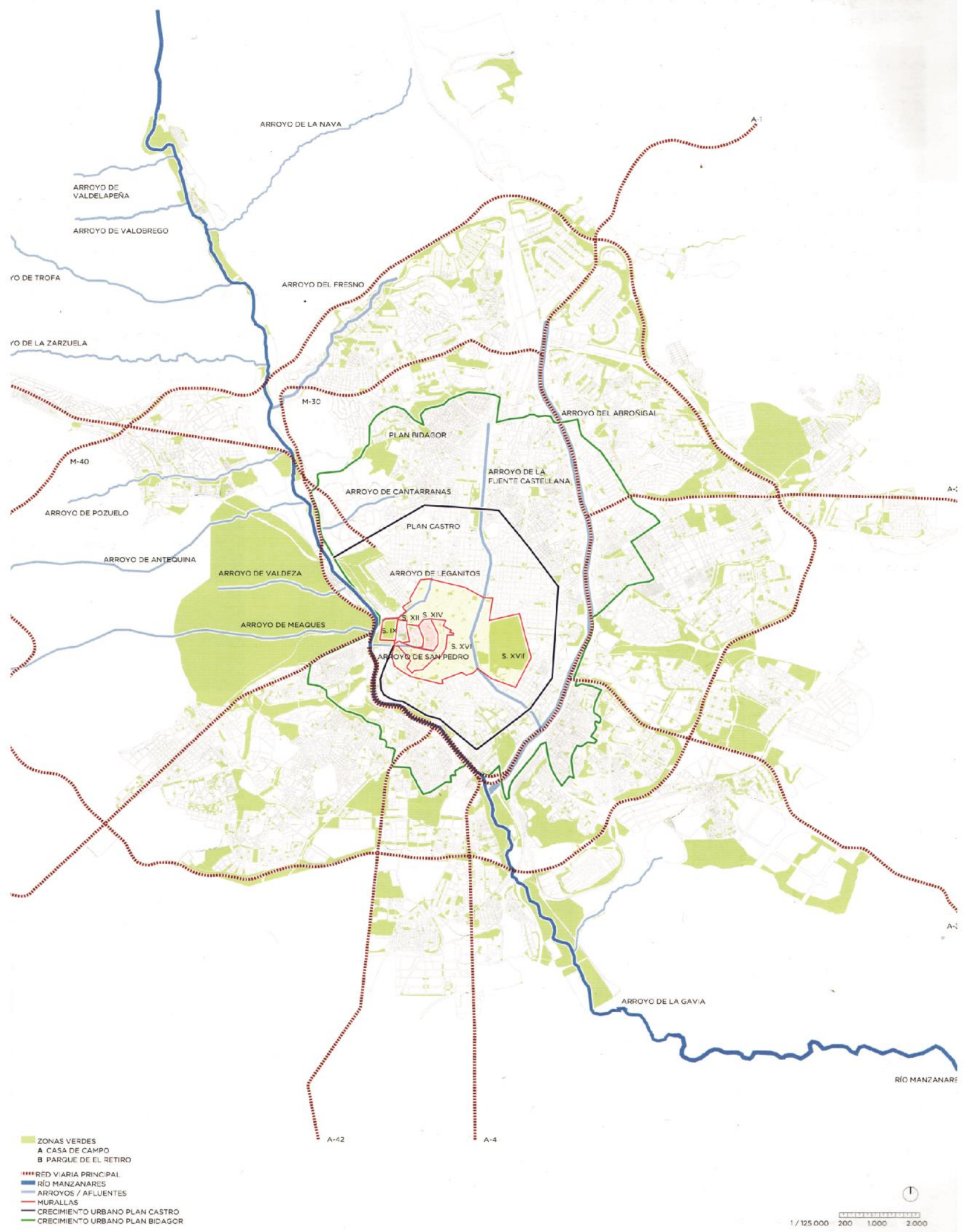




\section{REGENERACIÓN URBANA RÍO MANZANARES MADRID,ESPAÑA}

\section{FICHA DEL PROYECTO}

\section{UBICACIÓN}

\section{2 .1}

PROGRAMA

\section{ESPACIO}

IMPACTO SOCIAL

\section{FICHA}

5.11

\section{IMÁGENES DEL AUTOR EN BASE A :}

Web: Madrid Río/ Metropolis "2015 (jttp//www.metropolis.org/es/premios/5a edicion-2014/madrid-rio)

Libro: Paisajes en la ciudad Madrid Río: Geografía, infraestructura y espacio público (Fernández Villanueva, 2015) Texto: Plan especial Río Manzanares estudio de incidencia ambiental ( Coordinaci y Singulares, n.d)

VÍA M-30 EN SUPERFICIE

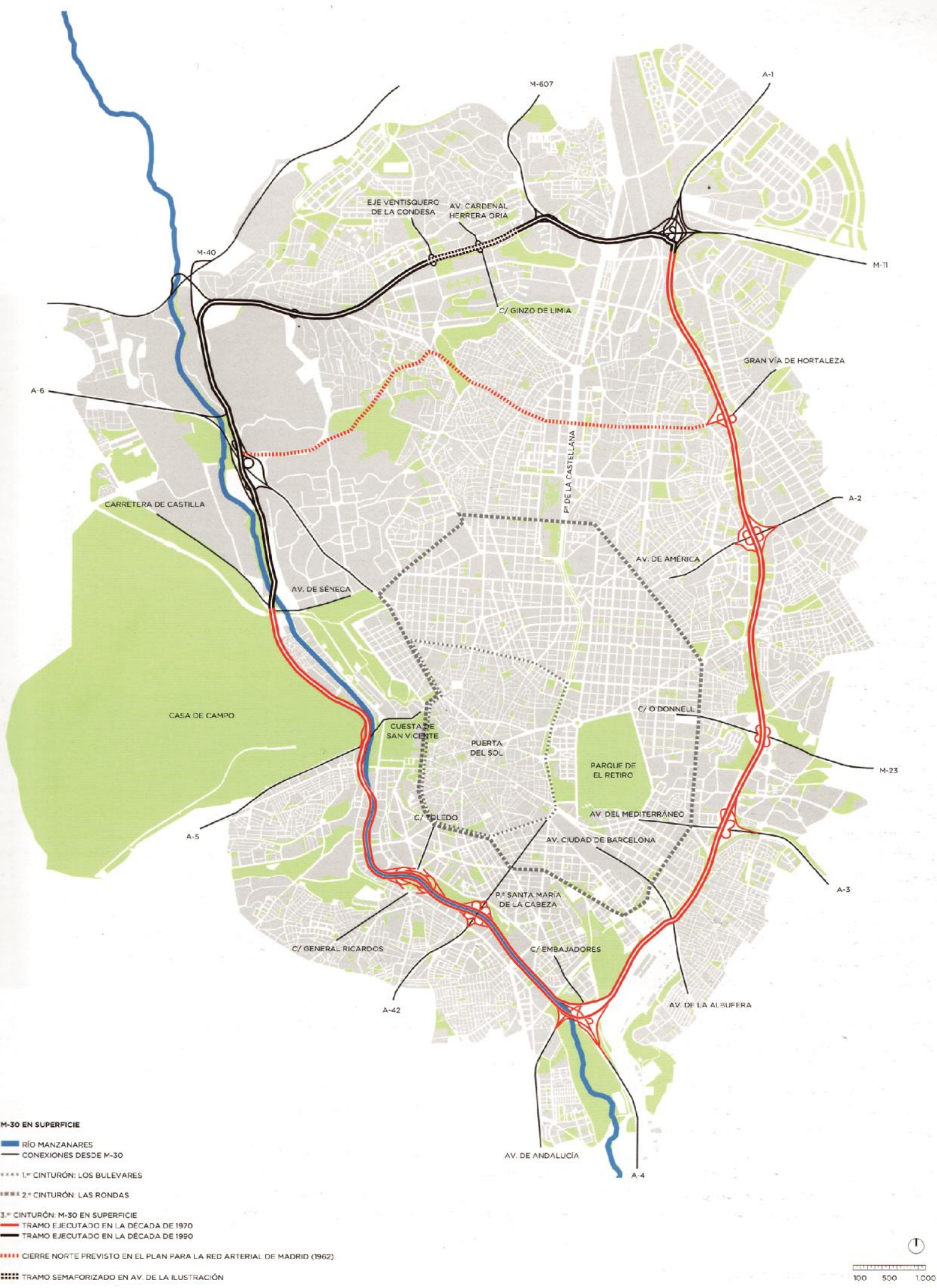




\section{REGENERACIÓN URBANA RÍO MANZANARES MADRID,ESPAÑA}

UBICACIÓN

TECNOLOGÍA
PROGRAMA

IMPACTO SOCIAL

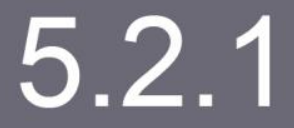

FICHA

5.12

IMÁGENES DEL AUTOR EN BASE A :

Web: Madrid Río/ Metropolis "2015 (jttp//www.metropolis.org/es/premios/5a edicion-2014/madrid-rio)

Libro: Paisajes en la ciudad Madrid Rio: Geografía, infraestructura y espacio público (Fernández Villanueva, 2015)

Texto: Plan especial Río Manzanares estudio de incidencia ambiental ( Coordinaci y Singulares, n.d)

ACCESOS PÚBLICOS PEATONALES

\section{PROPUESTA}

Análisis recorridos de ocio y puntos de interés

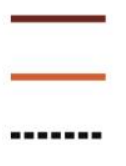

ITINERARIOS PEATONALES Y CICLISTAS

ITINERARIOS PEATONALES

ITINERARIOS PEATONALES DE ACOMPAÑA-

MIENTO

CONEXIONES PEATONALESY CICLISTAS

1 PARQUE LINEAL MANZANARES NORTE

2 CASA DE CAMPO

3 PARQUE LINEAL MANZANARES SUR

CONEXIONES TRANSVERSALES PEATONA-

LES

4 HACIA EJE COMERCIAL

5 P DE EXTREMADURA

6 HACIA EJE COMERCIAL LA LATINA

9 HACIA CARABANCHEL

10 HACIA EL EJE CULTURAL CASTELLANA

11 HACIA PAU CARABANCHEL

12 HACIA EJE COMERCIAL PUENTE

DELICIAS

13 HACIA CIUDAD DE LOS ÁNGELES

14 PARQUE ENRIQUE TIERNO GALVÁN

PUNTO DE INTERÉS CULTURAL/DEPORTIVO

15 PISTAS DE PADEL

16 ERMITA VIRGEN DEL PUERTO

17 PISTAS DEPORTIVAS

18 ESTADIO VICENTE CALDERÓN

19 PISTAS DEPORTIVAS

20 PLAYA

21 PISTAS DE FÚTBOL

22 PISTAS DE PÁDEL

23 SKATE PARK

24 CENTRO DE INTERPRETACIÓN DEL RÍO

MANZANARES

25 MATADERO

26 PISTAS DEPORTIVAS

27PISTAS BMX

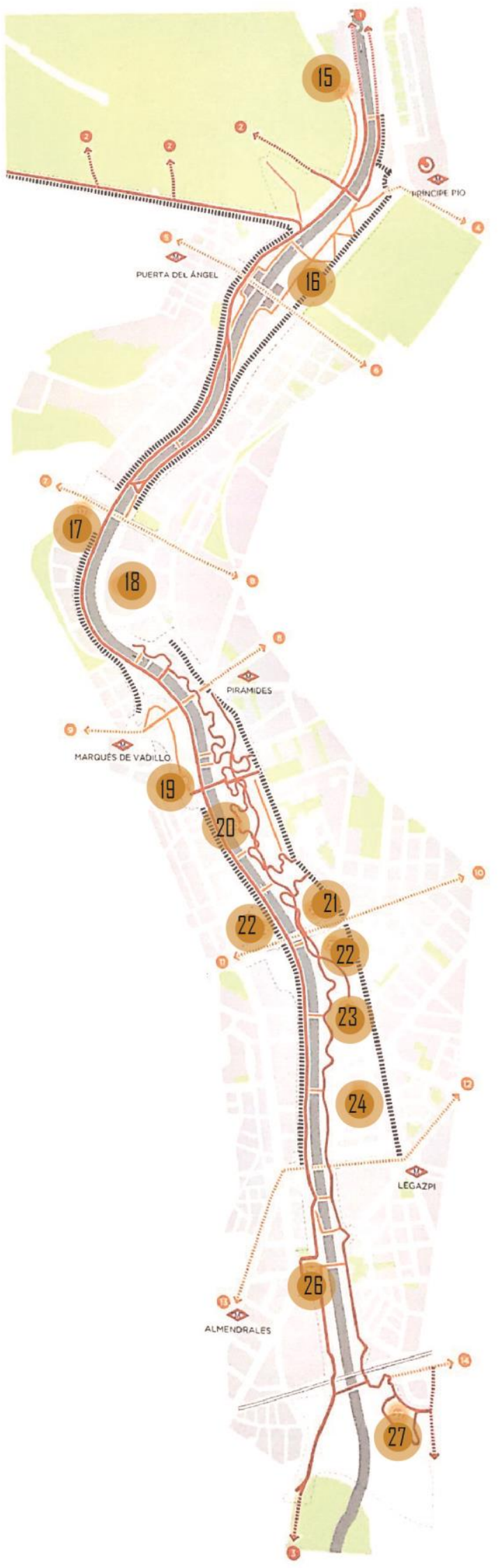




\section{REGENERACIÓN URBANA RÍO MANZANARES \\ MADRID,ESPAÑA}

UBICACIÓN

TECNOLOGIA
PROGRAMA

IMPACTO SOCIAL

\section{2 .1}

\section{FICHA}

5.13

IMÁGENES DEL AUTOR EN BASE A :

Web: Madrid Río/ Metropolis "2015 (jttp//www.metropolis.org/es/premios/5a edicion-2014/madrid-rio)

Libro: Paisajes en la ciudad Madrid Río: Geografía, infraestructura y espacio público (Fernández Villanueva, 2015)

Texto: Plan especial Río Manzanares estudio de incidencia ambiental ( Coordinaci y Singulares, n.d)

\section{ESTACIONES Y MEDIOS DE TRANSPORTE}

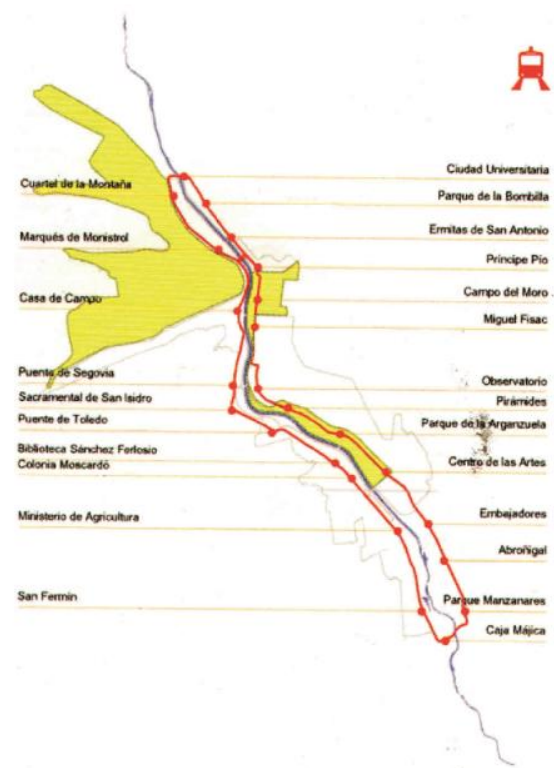

\section{TRANSPORTE PÚBLICO}

La propuesta contiene una lineal bidireccional de tranvía. Esta infraestructura liga los barrios longitudinalmente, además de ser un componente panorámico ligado al recreo y turismo.

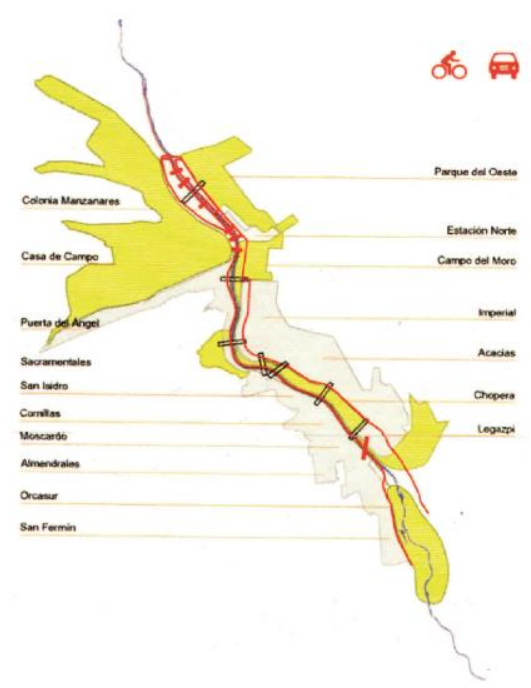

\section{CONECTIVIDAD ENTRE BARRIOS}

La mejora en la red de puentes, el tratamiento selectivo que arroja el tráfico y la propuesta de una red lenta local configura el sistema que mejora la accesibilidad de los barrios. Los nuevos puentes permiten la conexión transversal de los barrios de la ciudad.

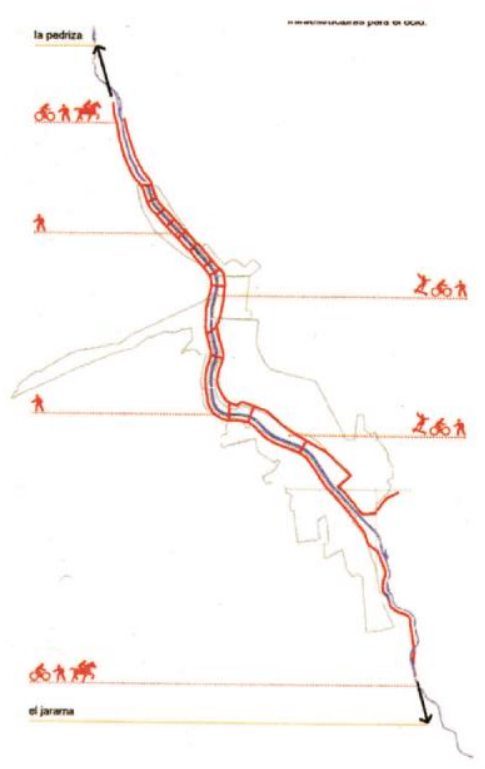

\section{MOVILIDAD PLURIMODAL}

Los circuito de movilidad componen una red como barrera al sistema de movilidad vehicular. Se ha diseñado un sistema de senderos continuos en toda la longitud del río, además de enlazar los barrios con espacios de recreación.

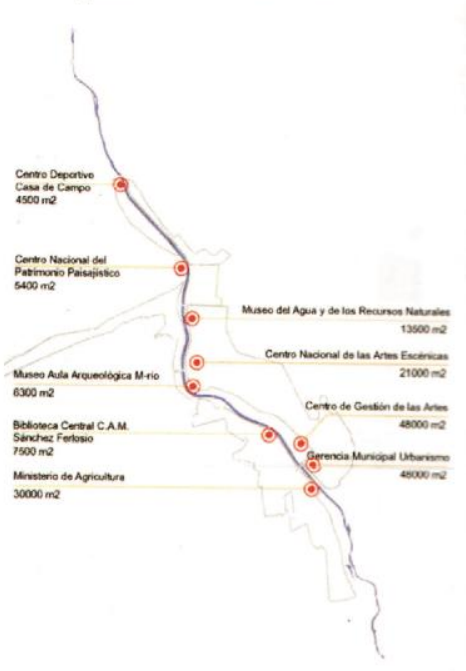

POTENCIAL DE USOS COLECTIVOS

La condición central-lineal resulta de la interacción del río y la ciudad. El río es un eje en el que convivirán un sinfin de dotaciones que aportan un carácter institucional al centro urbano. 


\section{REGENERACIÓN URBANA RÍO MANZANARES MADRID,ESPAÑA}

FICHA DEL PROYECTO

ESPACIO
HISTORIA

TECNOLOGIA

\section{UBICACIÓN}

PROGRAMA

IMPACTO SOCIAL
5.2 .1

FICHA

5.14

IMÁGENES DEL AUTOR EN BASE A :

Web: Madrid Rio/ Metropolis "2015 (ittp//www.metropolis.org/es/premios/5a edicion-2014/madrid-rio)

Libro: Paisajes en la ciudad Madrid Río: Geografia, infraestructura y espacio público (Fernández Villanueva, 2015)

Texto: Plan especial Río Manzanares estudio de incidencia ambiental ( Coordinaci y Singulares, n.d)

\section{VÍAS PRINCIPALES}

PUENTES Y PASARELAS

$\square$

EXISTENTES

RESTAURADOS

NUEVOS

CONEXIONES CON LAS VIIAS

VÍAS LONGITUDINALES

1 ANCETO MARINAS

2PUENTE DE LA FLORIDA

3 AV. DEL PORTUGAL

4 P. VIERGEN DEL PUERTO

5 AV MANZANARES

6 P DE YESERÍAS

7 AV DEL MANZANARES

8 P DE LA CHOPERA

9 CALLE MAESTRO ARBOS

4..... VÍAS DE CONEXIÓN TRANSVERSAL

10 HACIA PLAZA DE ESPAÑA

11 P DE EXTREMADURA

$12 \mathrm{~A}-5$

13 CALLE SEGOVIA

14 PUENTE DE LA ERMITA DEL SANTO

15 PUENTE DE PONTONES

16 CALLE TOLEDO

17 CALLE GENERAL RICARDO

18 PISTA DE LA CABEZA

19A-42 TOLEDO

20 HACIA ATOCHA

21 AV. CORDOBA

22 A. ANDALUCÍA

23 PUENTE DE LAS DELICIAS

M-30 EN SUPEREICIE

- RÍO MANZANARES
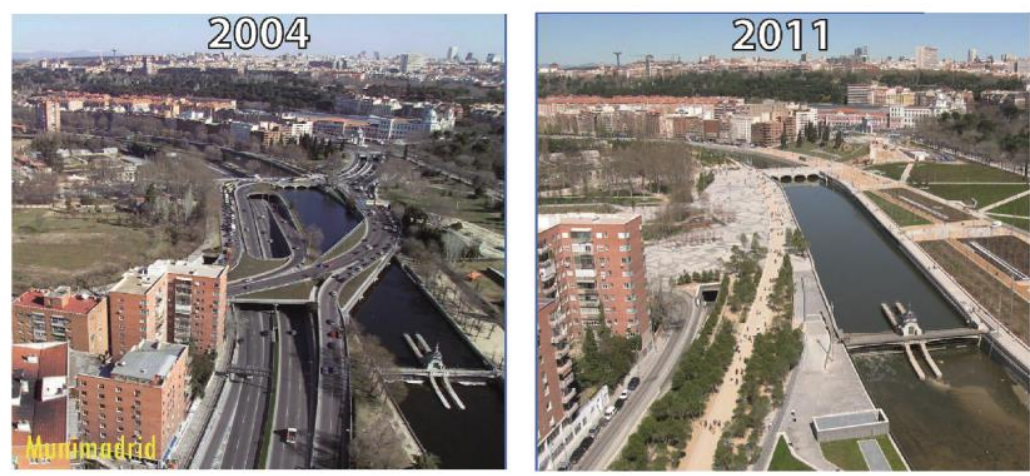

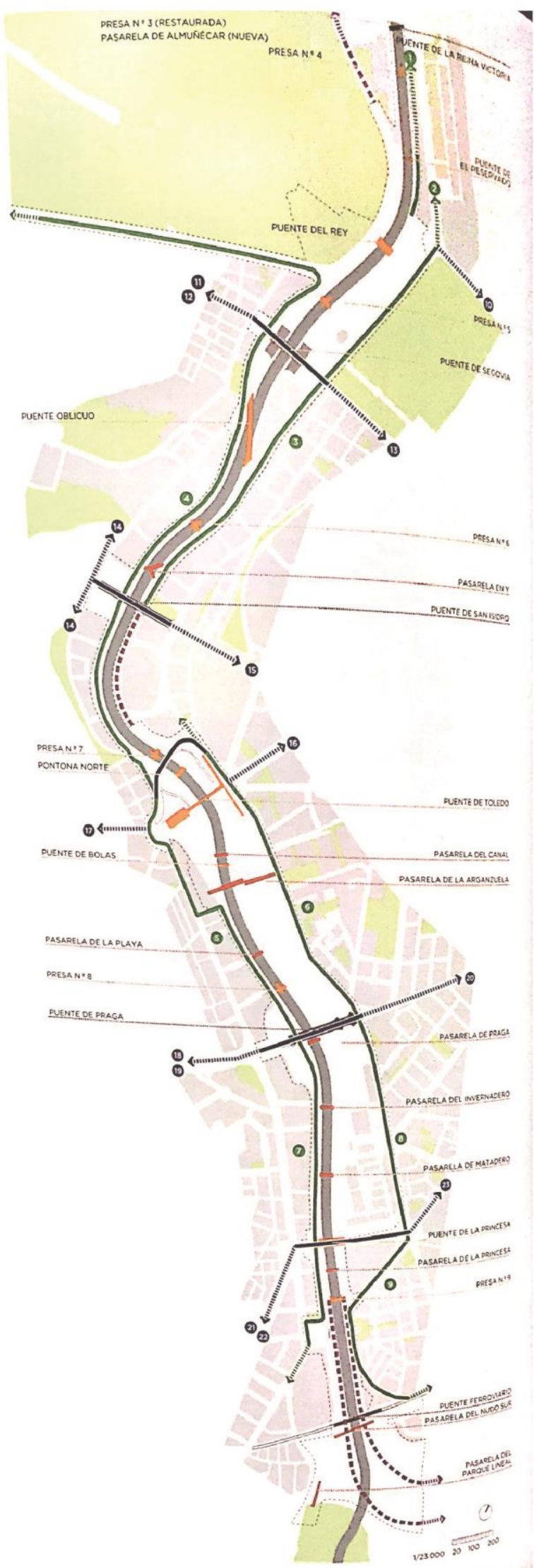


REGENERACIÓN URBANA RÍO MANZANARES

MADRID,ESPAÑA

SECCIÓN

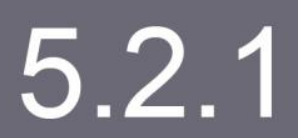

FICHA DEL PROYECTO

HISTORIA

UBICACIÓN

PROGRAMA

ESPACIO

TECNOLOGÍA

IMPACTO SOCIAL

FICHA

5.15

IMÁGENES DEL AUTOR EN BASEA

Web: Madrid Río/ Metropolis "2015 (jttp//www.metropolis.org/es/premios/5a edicion-2014/madrid-rio)

Libro: Paisajes en la ciudad Madrid Rio: Geografia, infraestructura y espacio público (Fernández Villanueva, 2015)

Texto: Plan especial Río Manzanares estudio de incidencia ambiental ( Coordinaci y Singulares, n.d)

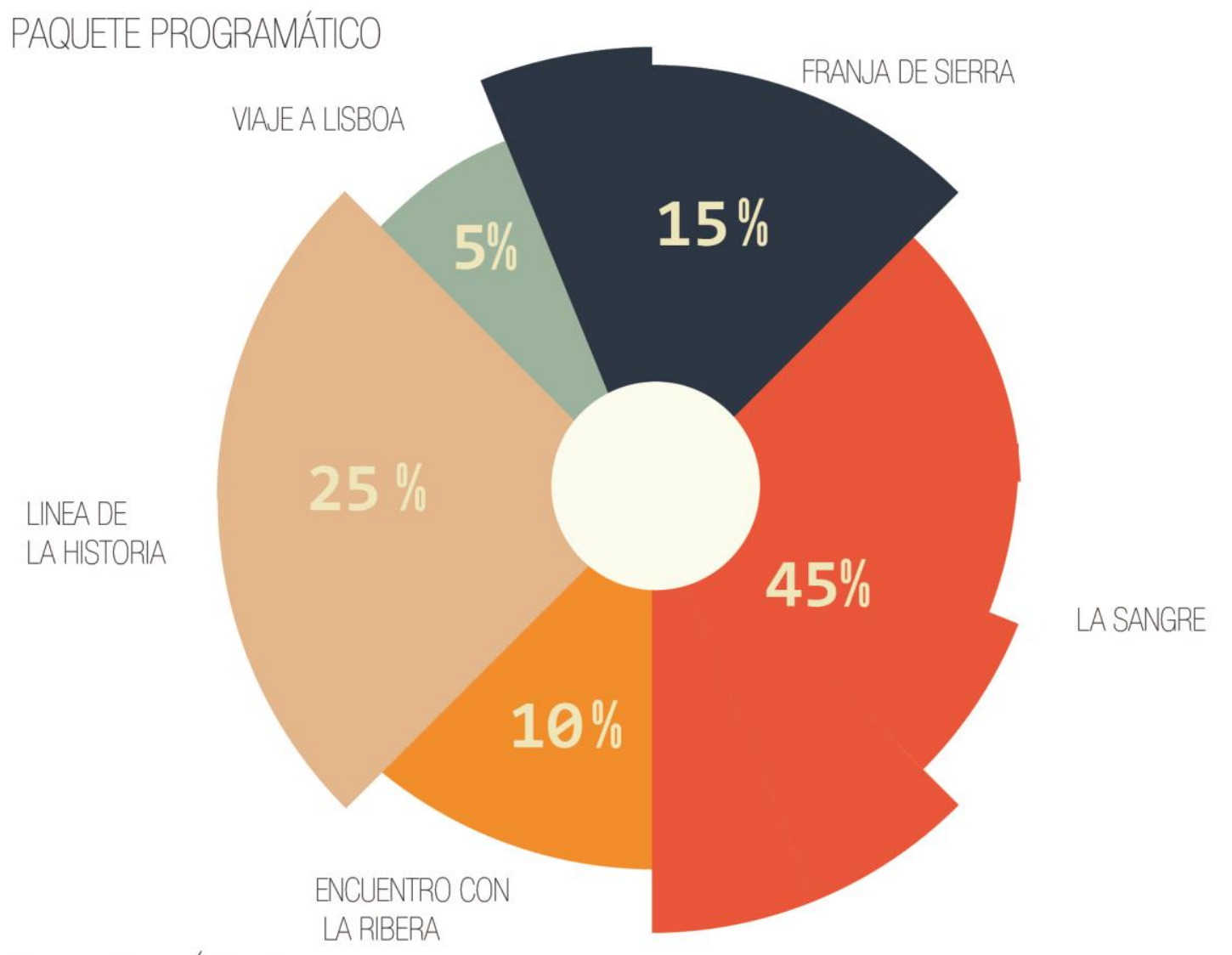

CUADRO DE ÁREAS

\begin{tabular}{c} 
FRANJA DE \\
SIERRA \\
$\begin{array}{c}\text { Juegos infantiles } \\
100 \mathrm{~m} 2\end{array}$ \\
Rehabilitación de \\
presas \\
$42 \mathrm{~m} 2$ \\
Pasarela de \\
Almuñecar \\
$47.50 \mathrm{~m} 2$ \\
Pabellón de \\
escalada \\
$480.33 \mathrm{~m} 2$ \\
\hline Jardínes de \\
San Isidro \\
$319.67 \mathrm{~m} 2$
\end{tabular}

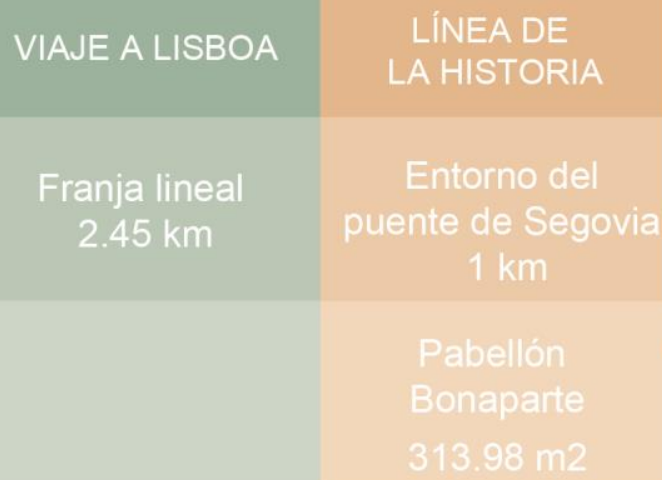

Puente del rey

$40 \mathrm{~m} 2$

Fuentes de las lavanderas

$113.40 \mathrm{~m} 2$

Huerta de la partida

$313.98 \mathrm{~m} 2$

USUARIOS

입

- Discapacitados

. $\curvearrowright$ Estudiantes

Niños

|ำ กำ

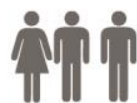

1 Estudiantes

- Discapacitados

Ancianos

แ่

Familias

인

Personal capacitado Empleados

del área de limpieza, servicio,

administrativo, etc

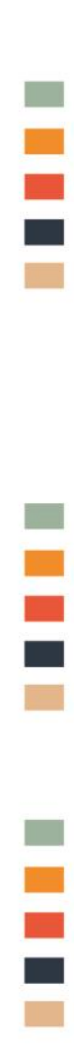




\section{REGENERACIÓN URBANA RÍO MANZANARES MADRID,ESPAÑA}

FICHA DEL PROYECTO

ESPACIO
HISTORIA

TECNOLOGÍA

\section{PROGRAMA}

IMPACTO SOCIAL

IMÁGENES DEL AUTOR EN BASE A :

Web: Madrid Río/ Metropolis "2015 (jttp//www.metropolis.org/es/premios/5a edicion-2014/madrid-rio)

Libro: Paisajes en la ciudad Madrid Río: Geografía, infraestructura y espacio público (Fernández Villanueva, 2015)

Texto: Plan especial Río Manzanares estudio de incidencia ambiental (Coordinaci y Singulares, n.d)

\section{FICHA}

\subsection{6}

\section{PAQUETE PROGRAMÁTICO}

A partir del análisis del contexto se encontró seis unidades diferentes que responden a seis situaciones urbanas y pertenecen a escenarios distintos de Madrid, pero que finalmente comprenden un solo proyecto.

Son seis paisajes que tienen componentes naturales y artificiales que resultan de la interpretación, apropiación, adaptación y transformación de la ciudad.

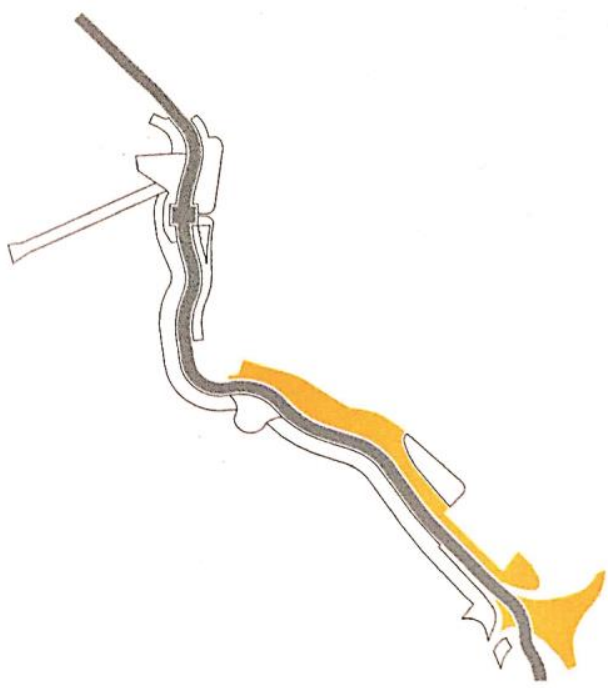

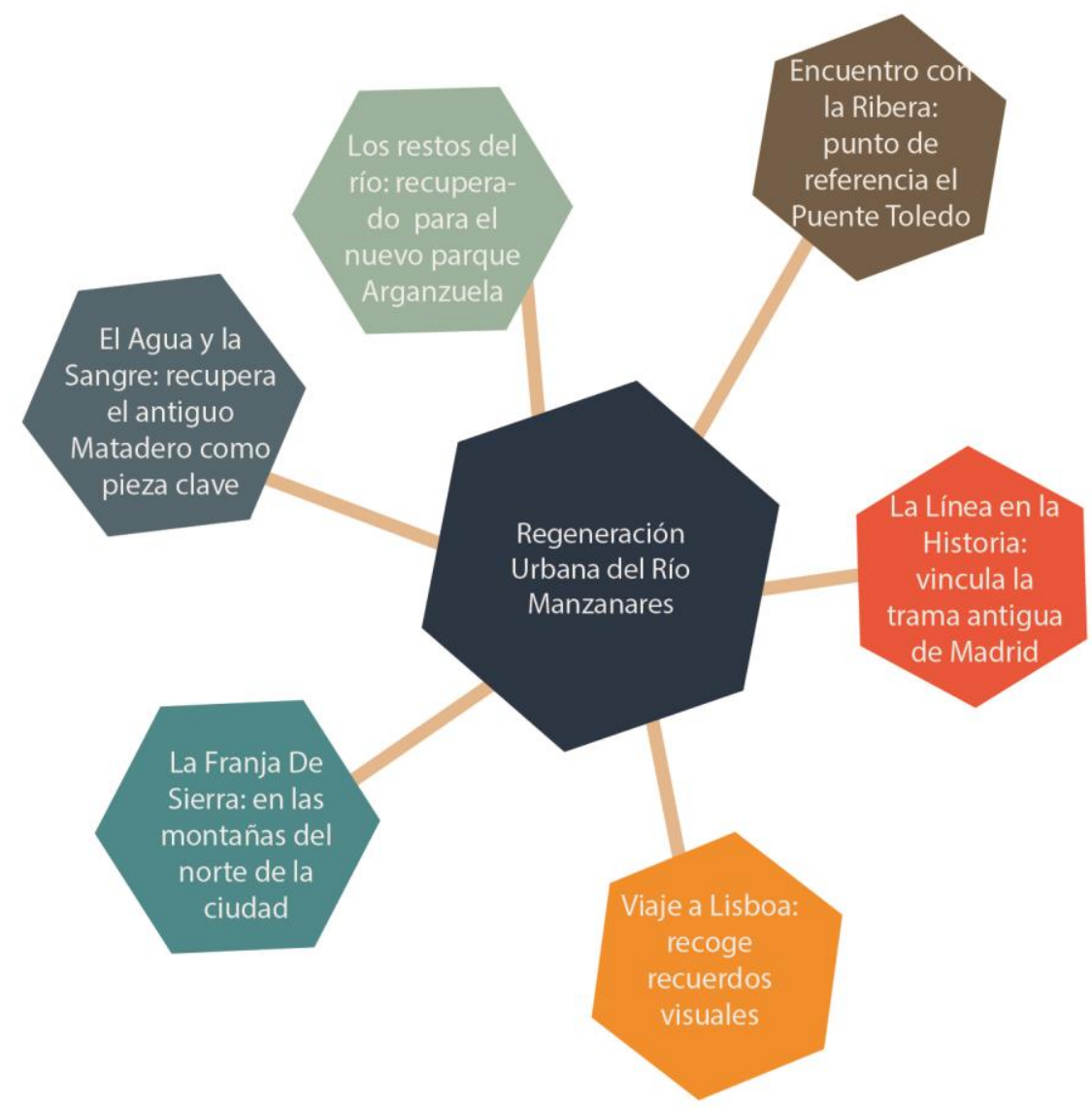

A continuación analizaremos uno de los seis tramos de proyecto para poder entender el impacto que tuvo en la regeneración de la ciudad

\section{RESTOS DEL RIO}

\section{PARQUE LAARGANZUELA}

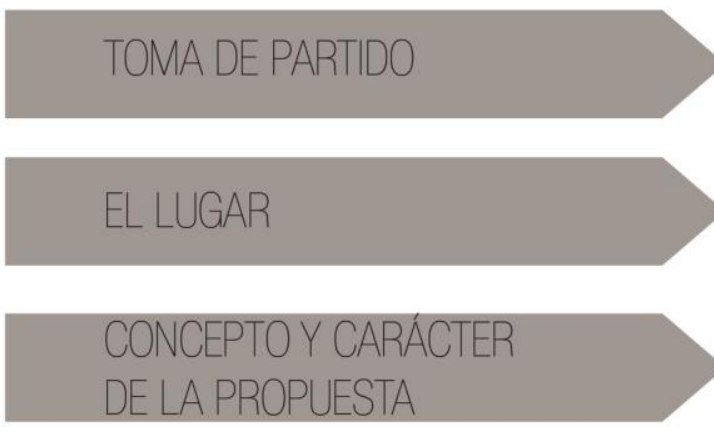

PAISAJEY CIUDAD

\section{DESCRIPCIÓN DEL PAISAJE}

SOLUCIÓN TÉCNICA

MATERIALES Y ELEMENTOS 


\section{REGENERACIÓN URBANA RÍO MANZANARES MADRID,ESPAÑA}

FICHA DEL PROYECTO

ESPACIO
HISTORIA

UBICACIÓN

\section{PROGRAMA}

IMPACTO SOCIAL

\section{2 .1}

\section{FICHA}

IMÁGENES DEL AUTOR EN BASEA :

Web: Madrid Rio/ Metropolis "2015 (jttp//www.metropolis.org/es/premios/5a edicion-2014/madrid-rio)

Libro: Paisajes en la ciudad Madrid Rio: Geografia, infraestructura y espacio público (Fernández Villanueva, 2015)

Texto: Plan especial Río Manzanares estudio de incidencia ambiental ( Coordinaci y Singulares, n.d)

\section{PAQUETE PROGRAMÁTICO}

1. RESTOS DEL RÍO

\section{TOMA DE PARTIDO}

Se trata de una pieza de casi $30 \mathrm{Ha}$. El límite noroeste es el estadio del Attético de Madrid y el límite sureste finaliza en un complejo nudo conocido como el Nudo Sur.

La ubicación es un tema clave para la toma de partido, ya que el terreno se encuentra en un área densamente edificada de la ciudad en la que apenas existen ciertos vacíos.

Asimismo, El tamaño justifica una propuesta unitaria diferente al resto de los paisajes.

\section{EL LUGAR}

La Arganzuela fue un espacio libre municipal donde se pastaban los rebaños siglos atrá, la aparición de la industria y el transporte hicieron que cambie la zonificación, convirtiéndose en vías de conexión de la ciudad.

Durante muhos años fue utilizado para la proyección de parques, plazas, etc. Y ya en el siglo XXI tuvo dos efectos opuestos sobre el área. Por un lado, se desapareció los autos para ampliar la superficie libre y por otro lado, el proceso de obra produjo la devastación de suelos.

\section{CONCEPTO Y CARÁCTER} DE LA PROPUESTA

Idea de construir un parque con los restos del cauce del río como material figurativo

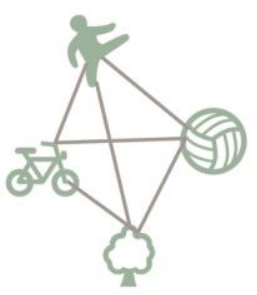

Se buscó proponer líneas longitudinales, actividades urbanas, conectividad, agua y vegetación. Estas son herramientas que hacen el nuevo organismo verde para la ciudad

Margen izquierda del Río Manzanares, al sur del puente Toledo

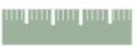

Franja libre de 2,200 metros de largo por 150 metros de ancho

Orientada en sentido noroeste-sureste y sus límites Iongitudinales son el Río Manzanares y por el otro lado el eje urbano. 


\section{REGENERACIÓN URBANA RÍO MANZANARES MADRID,ESPAÑA}

FICHA DEL PROYECTO

ESPACIO
HISTORIA

UBICACIÓN

TECNOLOGÍA

\section{PROGRAMA}

IMPACTO SOCIAL

IMÁGENES DEL AUTOR EN BASEA

Web: Madrid Rio/ Metropolis "2015 (jttp//www.metropolis.org/es/premios/5a edicion-2014/madrid-rio)

Libro: Paisajes en la ciudad Madrid Río: Geografía, infraestructura y espacio público (Fernández Villanueva, 2015)

Texto: Plan especial Río Manzanares estudio de incidencia ambiental ( Coordinaci y Singulares, n.d)

\section{FICHA}

5.18

\section{RESTOS DEL RÍO}

\section{DESCRIPCIÓN DEL PAISAJE

ARROYO Y FUENTES

- ARROYO SECO

- FUENTE TIPO S

- FUENTE TIPO M

- $=$ FUENTE TIPO L

= FUENTE TIPO XL

- PLAYA

- FUENTE HELECHOS

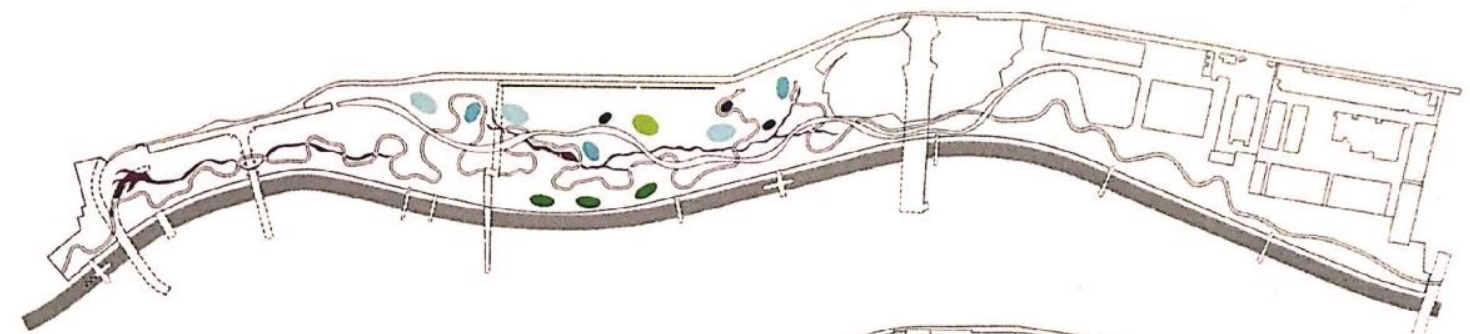

VEGETACIÓN

- BOSQUE MEDITERRÁNEO

- BOSQUE ATLÁNTICO

- BOSQUE DE RIBERA

- VEGETACION ARBUSTIVA JUNTO

= PLÁTANOS

- TAPIZANTES AROMÁTICAS ARB

-
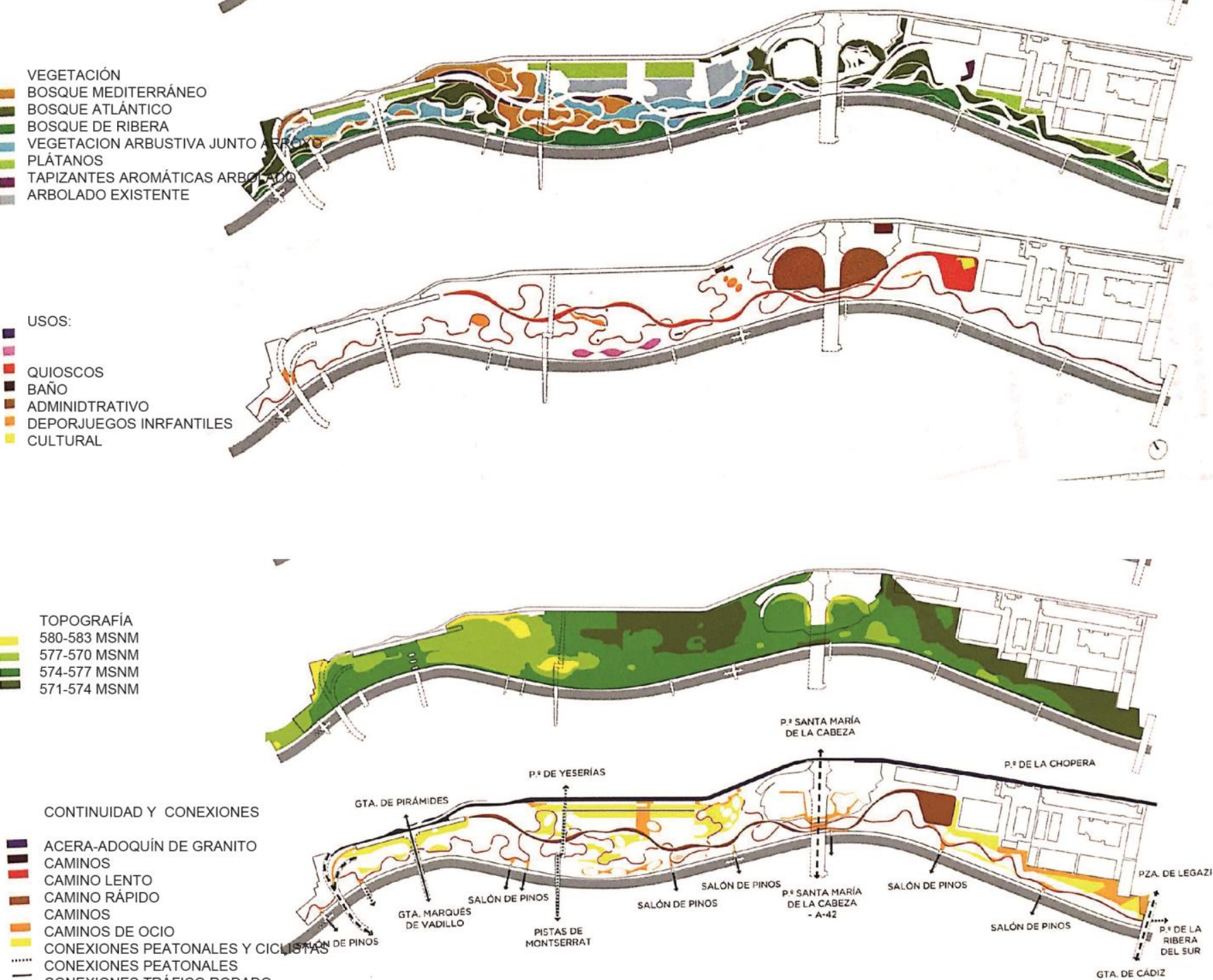

CONTINUIDAD Y CONEXIONES

- ACERA-ADOQUIN DE GRANITO

- CAMINOS

- CAMINO LENTO

- CAMINO RÁPIDO

- CAMINOS

- CONEXIONES PEATONALES Y CICLIITKASS DE PINOS

..... CONEXIONES PEATONALES

- CONEXIONES TRÁFICO RODADO 


\section{REGENERACIÓN URBANA RÍO MANZANARES MADRID,ESPAÑA}

\section{2 .1}

FICHA DEL PROYECTO

ESPACIO
HISTORIA

UBICACIÓN

PROGRAMA

FICHA

5.19

Web: Madrid Río/ Metropolis "2015 (jttp//www.metropolis.org/es/premios/5a edicion-2014/madrid-rio)

Libro: Paisajes en la ciudad Madrid Río: Geografía, infraestructura y espacio público (Fernández Villanueva, 2015)

Texto: Plan especial Río Manzanares estudio de incidencia ambiental ( Coordinaci y Singulares, n.d)

PAQUETE PROGRAMÁTICO

PAISAJE Y CIUDAD
El parque se ha convertido en un área de esparcimiento con impacto metropolitano, ha dejado atrás su dimensión local y su carácter de barrio para ser el eje de esparcimiento estructurante de Madrid.

Tiene una doble condición, parque urbano y parque fluvial por el modo que está construído. El agua, la vegetación, la topografía u otros son elementos que dan una mirada al naturalismo en todo sentido.

\section{El nuevo parque de la Arganzuela}
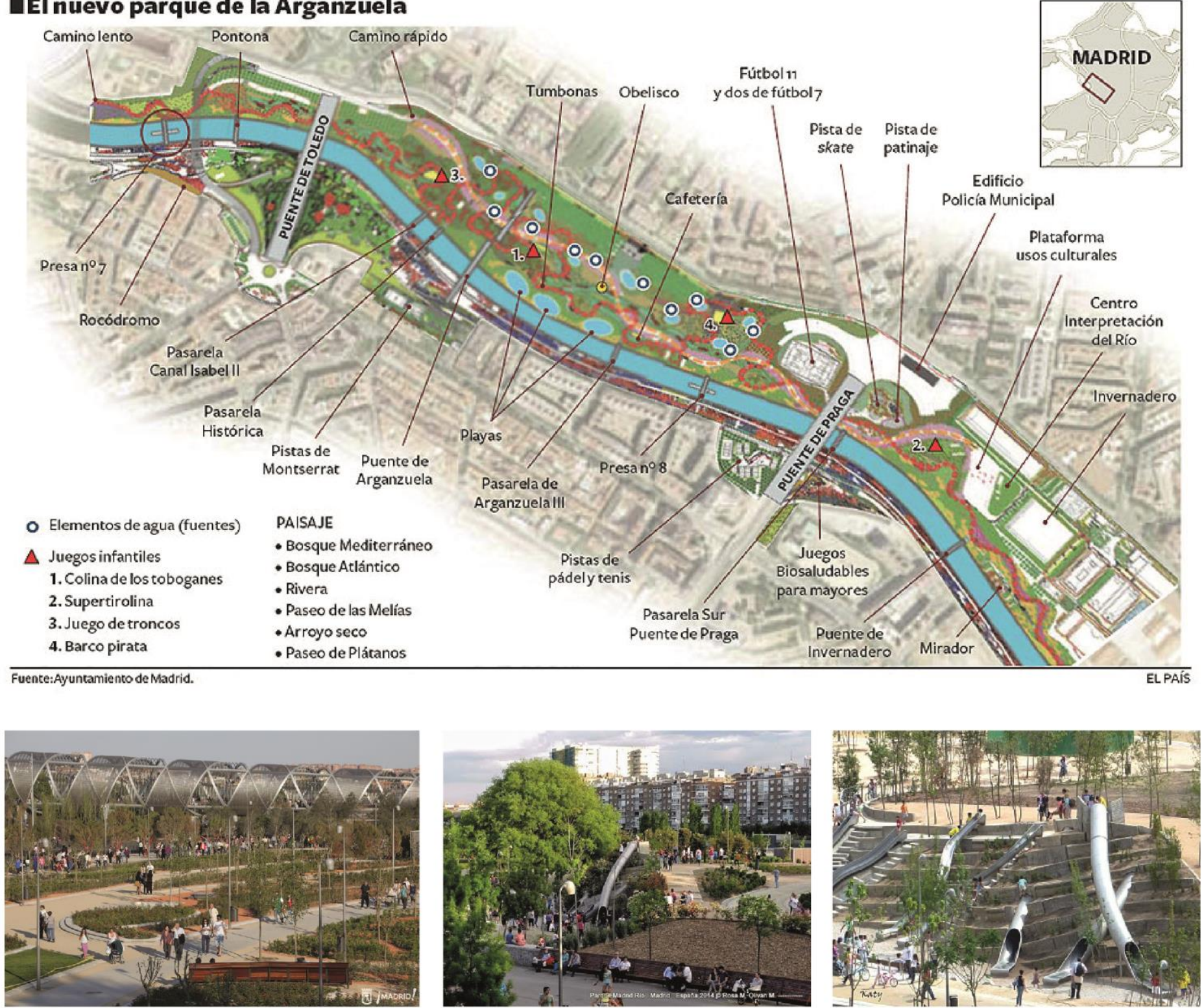


\section{REGENERACIÓN URBANA RÍO MANZANARES} MADRID,ESPAÑA

SECCIÓN

\section{2 .1}

FICHA DEL PROYECTO

ESPACIO
HISTORIA

UBICACIÓN

PROGRAMA

TECNOLOGÍA
FICHA

5.20

Web: Madrid Río/ Metropolis "2015 (jttp//www.metropolis.org/es/premios/5a edicion-2014/madrid-rio)

Libro: Paisajes en la ciudad Madrid Río: Geografía, infraestructura y espacio público (Fernández Villanueva, 2015) Texto: Plan especial Río Manzanares estudio de incidencia ambiental ( Coordinaci y Singulares, n.d)

FLUJO Y CIRCULACIÓN

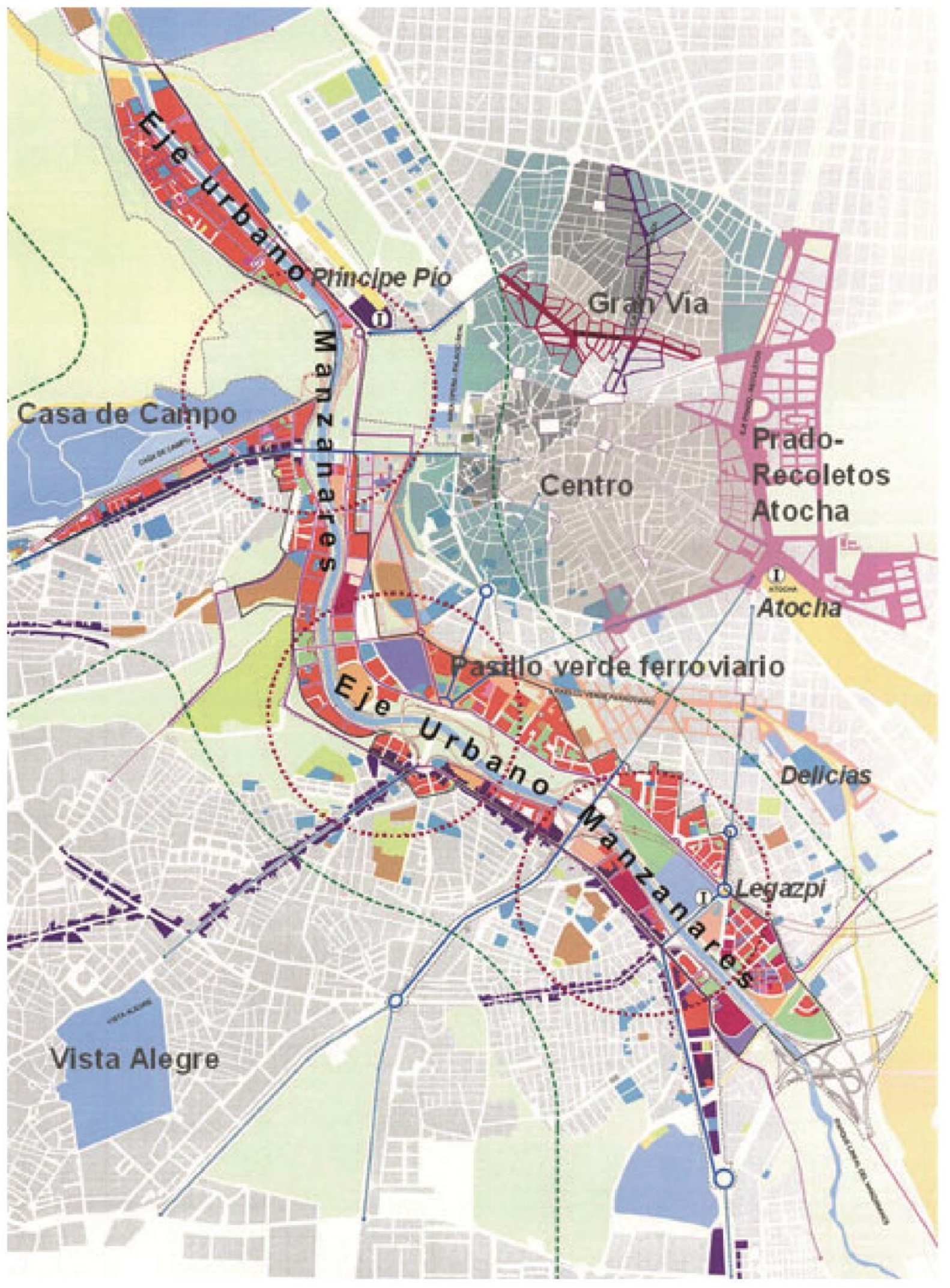

ÁREA CONSTRUIÍDA

ÁREA LIBRE

ÁREA CONSTRUIDA

$10 \mathrm{Ha}$

ÁREA LIBRE

$110 \mathrm{Ha}$

PÚBLICO

SEMIPÚBLICO

PRIVADO

PÚBLICO

$85 \%$

$20 \%$

PRIVADO

$5 \%$

FLUJOS Y

CIRCULACIONES 


\section{REGENERACIÓN URBANA RÍO MANZANARES MADRID,ESPAÑA}

FICHA DEL PROYECTO

$$
\text { HISTORIA }
$$

UBICACIÓN

ESPACIO
TECNOLOGÍA

TECNOLOGÍA

IMPACTO SOCIAL

\section{IMÁGENES DEL AUTOR EN BASE A}

Web: Madrid Río/ Metropolis “2015 (jttp//www.metropolis.org/es/premios/5a edicion-2014/madrid-rio)

Libro: Paisajes en la ciudad Madrid Río: Geografía, infraestructura y espacio público (Fernández Villanueva, 2015)

Texto: Plan especial Río Manzanares estudio de incidencia ambiental ( Coordinaci y Singulares, n.d)

\section{MATERIALES}

La utilización de materiales está basado en el diálogo entre los espacios de tránsito, espacios lineales y los entornos que son el resultado de los cruces, curvas y vacíos que aparecen como respuesta a los desplazamientos.

Los materiales rememoran a la ciudad, ya que proceden de los entornos naturales del río y son utilizados en todos los caminos, sendas y ciclovías del proyecto.

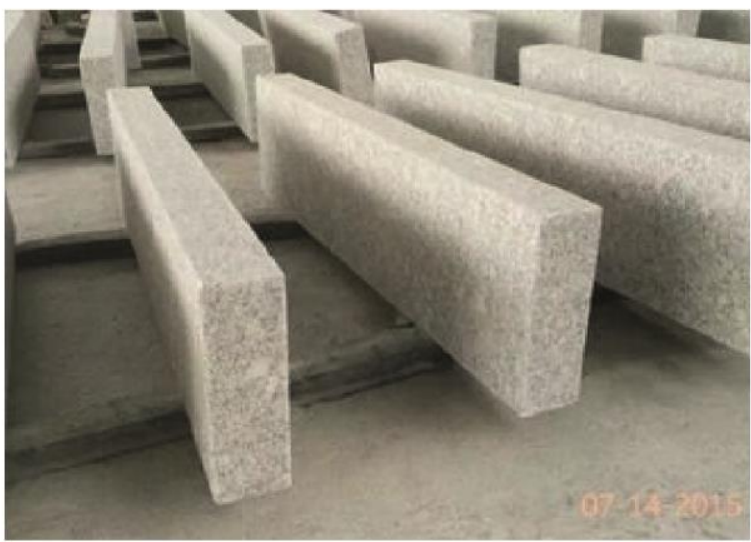

Encintado de granito

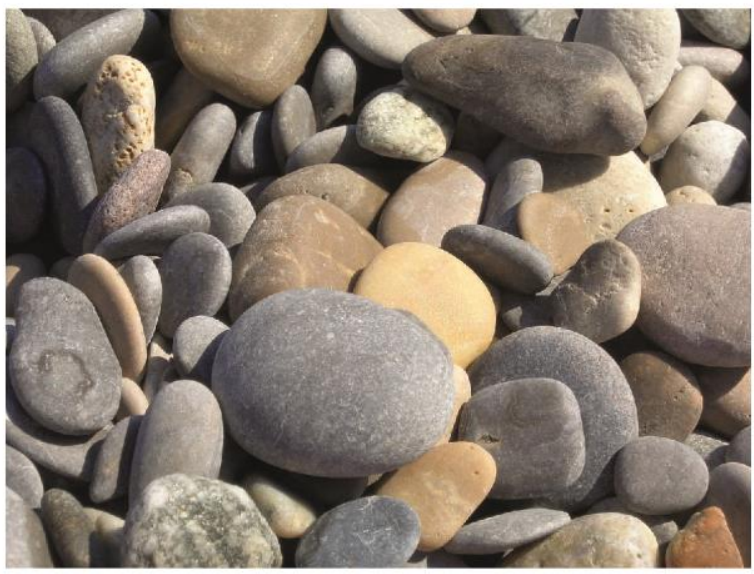

Bolos de granito procedentes de las montaña de Madrid norte

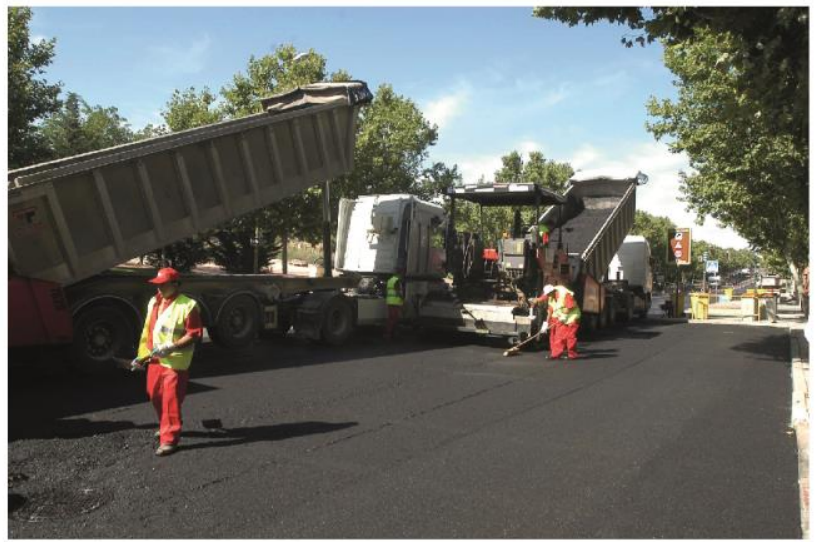

Aglomerado asfáltico

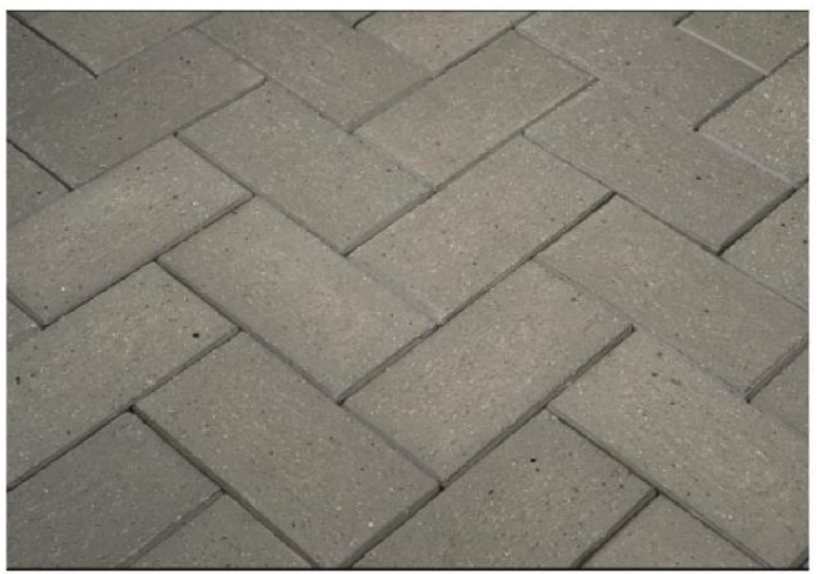

Adoquines de concreto con textura
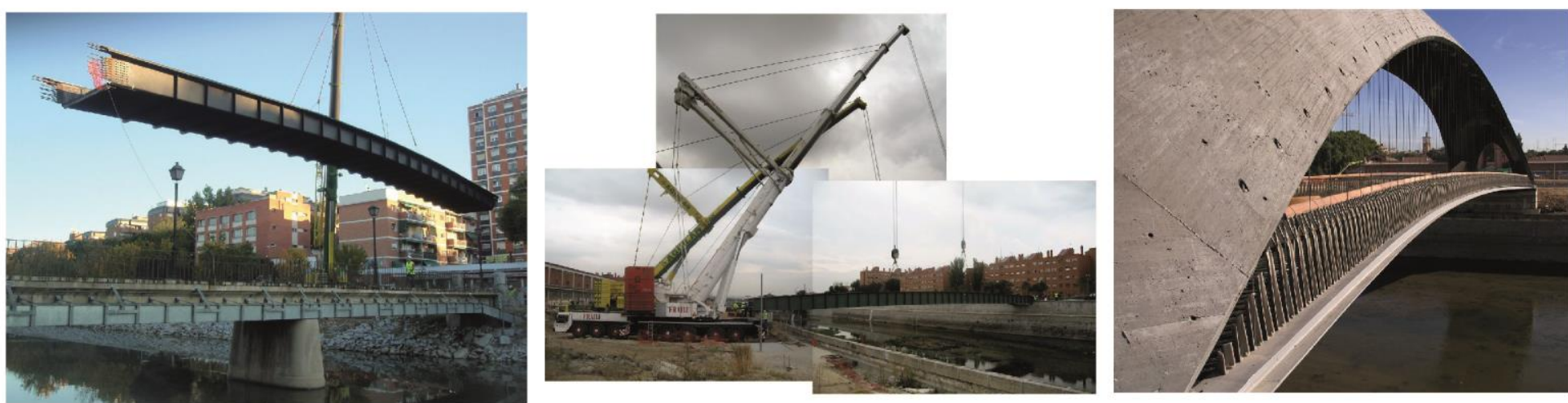
REGENERACIÓN URBANA RÍO MANZANARES MADRID,ESPAÑA
SECCIÓN

$$
5.2 .1
$$

5. 22

IMÁGENES DEL AUTOR EN BASE A

Web: Madrid Río/ Metropolis “2015 (jttp//www.metropolis.org/es/premios/5a edicion-2014/madrid-rio)

PROGRAMA

Libro: Paisajes en la ciudad Madrid Río: Geografia, infraestructura y espacio público (Fernández Villanueva, 2015)

Texto: Plan especial Río Manzanares estudio de incidencia ambiental ( Coordinaci y Singulares, n.d)

SISTEMA CONSTRUCTIVO

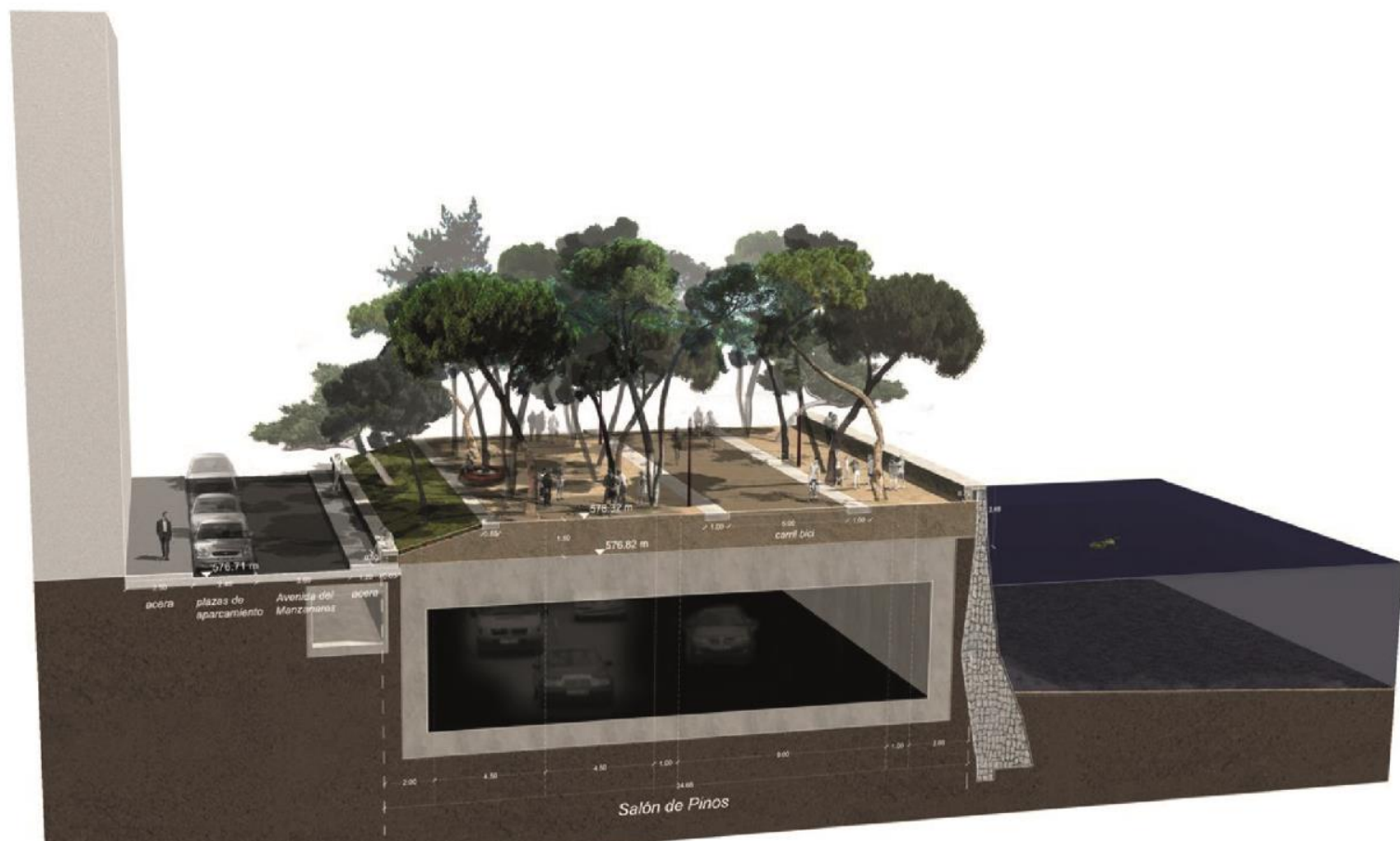

SECCIÓN DE LAALAMEDA DE MANZANARES

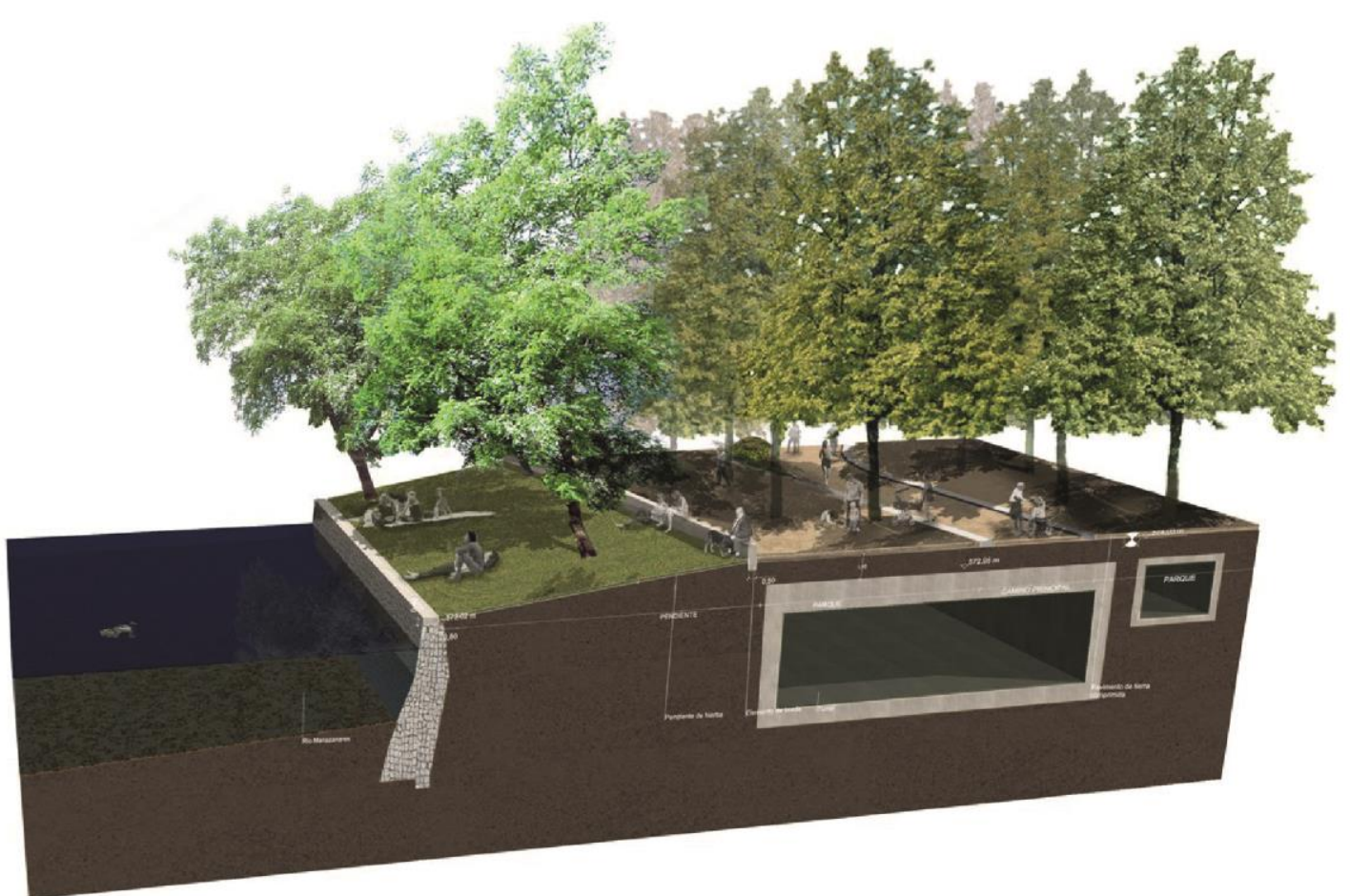


REGENERACIÓN URBANA RÍO MANZANARES MADRID,ESPAÑA
FICHA DEL PROYECTO

ESPACIO
HISTORIA

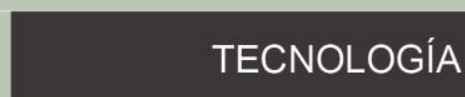

PROGRAMA

IMPACTO SOCIAL
FICHA

5. 23

IMÁGENES DEL AUTOR EN BASE A

Web: Madrid Rio/ Metropolis "2015 (jttp//www.metropolis.org/es/premios/5a edicion-2014/madrid-rio)

Libro: Paisajes en la ciudad Madrid Rio: Geografía, infraestructura y espacio público (Fernández Villanueva, 2015)

Texto: Plan especial Río Manzanares estudio de incidencia ambiental ( Coordinaci y Singulares, n.d)

CAMINO A MATADERO

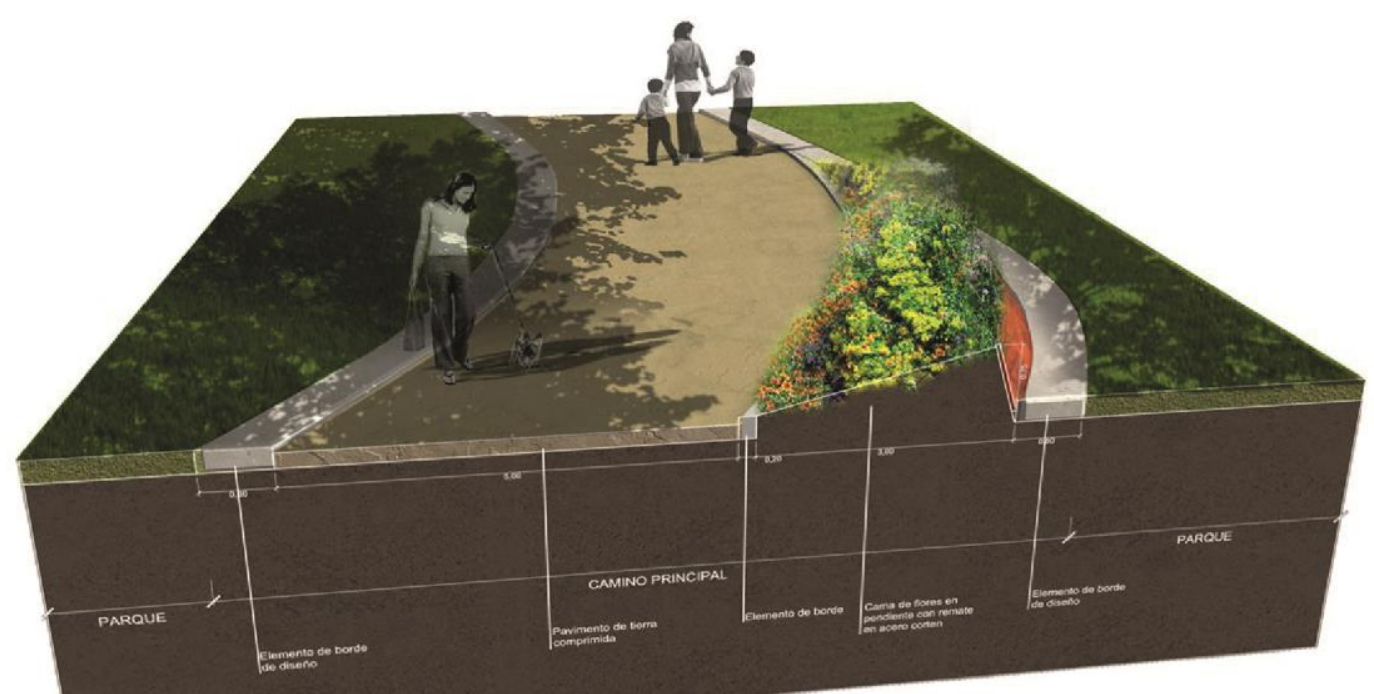

SECCIÓN RÍO SECO

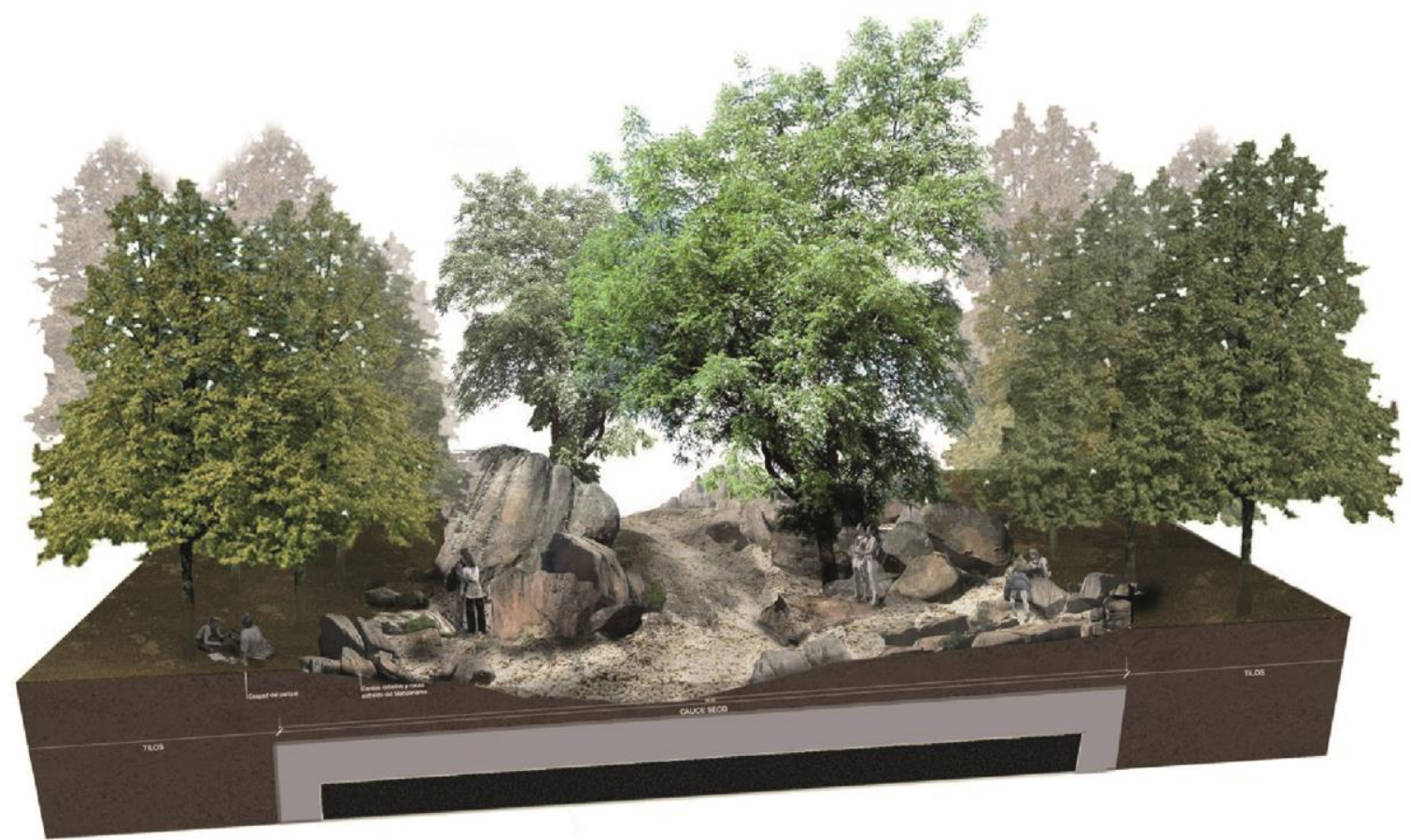




\section{REGENERACIÓN URBANA RÍO MANZANARES MADRID,ESPAÑA}

SECCIÓN

\subsection{1}

FICHA DEL PROYECTO

\section{ESPACIO}

\section{HISTORIA}

\section{TECNOLOGÍA}

PROGRAMA

\section{IMPACTO SOCIAL}

IMÁGENES DEL AUTOR EN BASE A

Web: Madrid Río/ Metropolis "2015 (jttp//www.metropolis.org/es/premios/5a edicion-2014/madrid-rio)

Libro: Paisajes en la ciudad Madrid Rio: Geografia, infraestructura y espacio público (Fernández Villanueva, 2015) Texto: Plan especial Río Manzanares estudio de incidencia ambiental ( Coordinaci y Singulares, n.d)

Muro de concreto armado para la

canalización

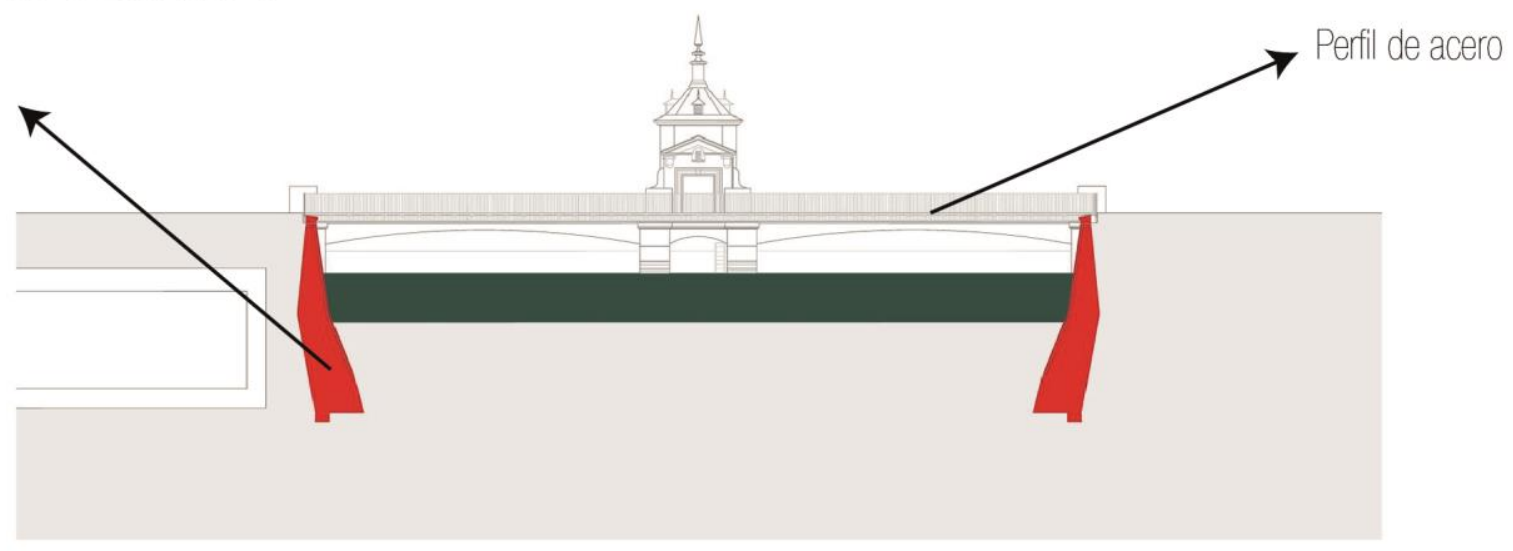

Muro de concreto armado para la canalización

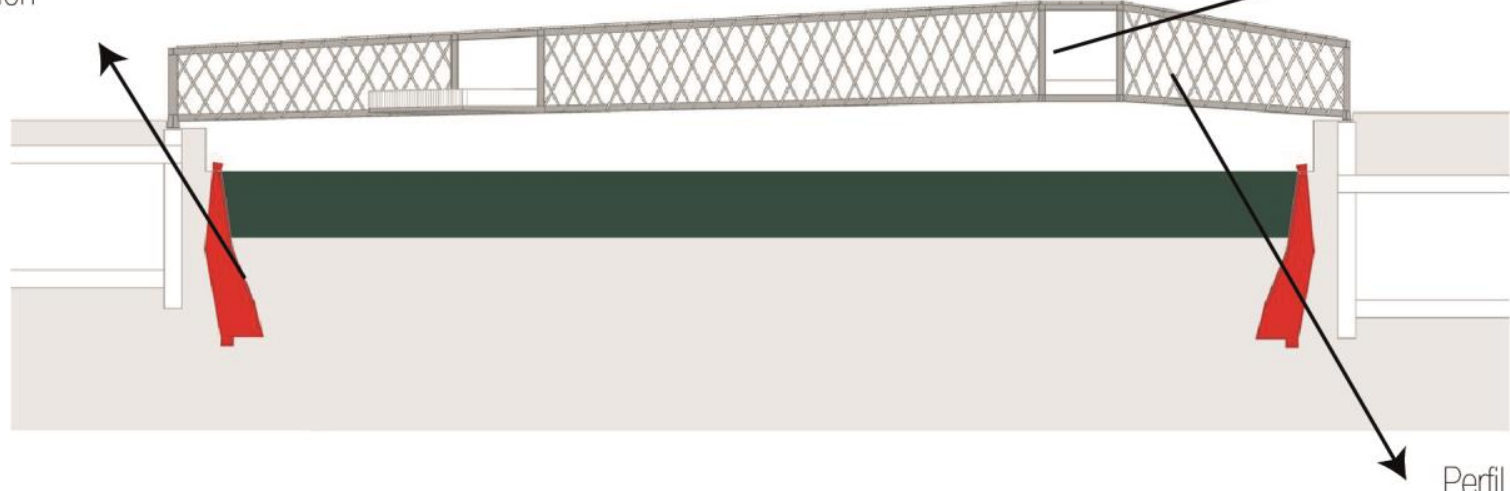

Perfil de acero en

forma de $\mathrm{H}$

DETALLE CONSTRUCTIVO DE PASARELAS DE CONEXIÓN TRANSVERSAL

Perfil de acero en forma de rectangular

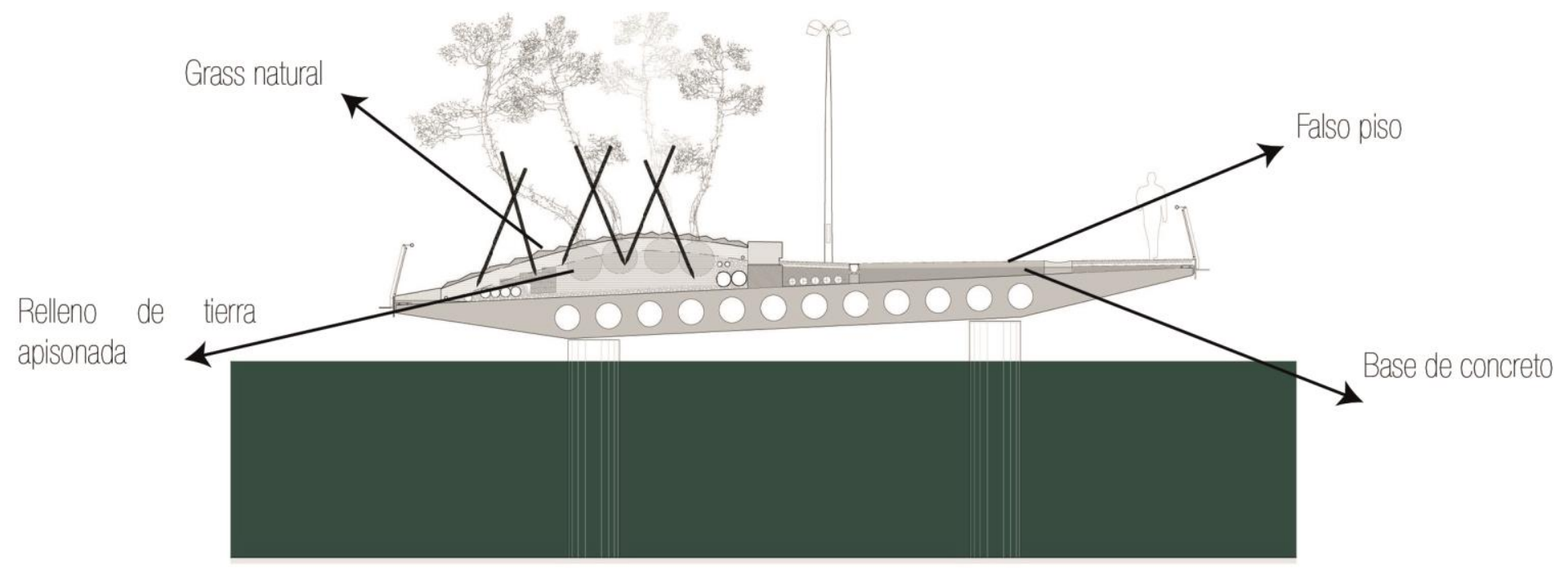




\section{REGENERACIÓN URBANA RÍO MANZANARES MADRID,ESPAÑA}

FICHA

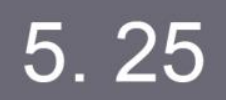

RADIO DE INFLUENCIA

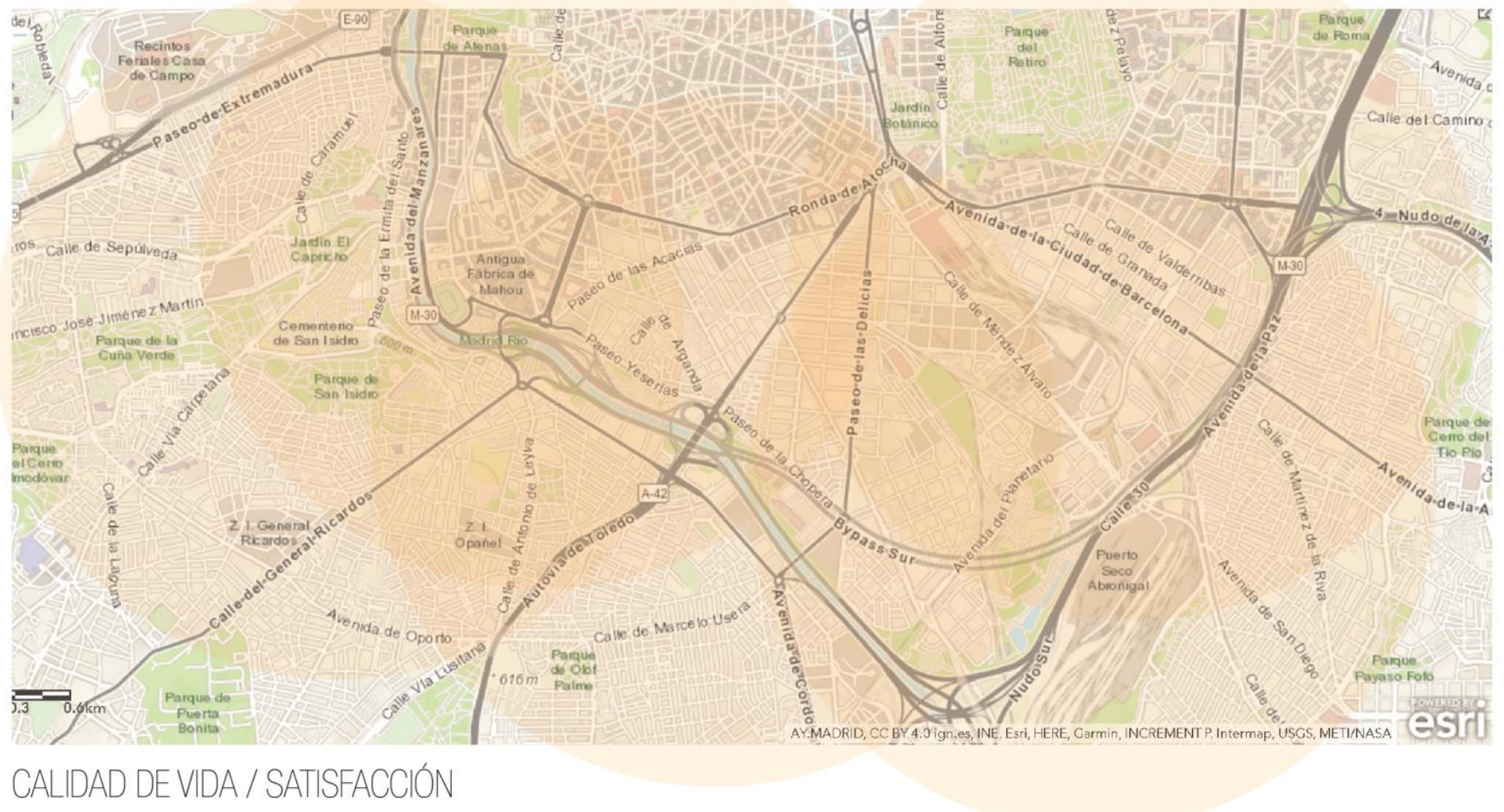

El proyecto ha tenido un impacto social a escala metropolitana. En primer lugar ha generado un cambio radical en la disminución del uso del automóvil proponiendo nuevos sistemas de transporte no contaminantes; en segundo lugar, el entorno del Río Manzanares se ha convertido en un gran espacio de encuentro a nivel metropolitano, cambiando su antigua zonificación en la que era un parque barrial, incluyendo toda clase social, cultural y económica de la población; en tercer lugar, al poseer nuevas dotaciones de servicio público contemporáneo y mejorando los que se encontraban en mal estado ha generado la inclusión de la población de diversas edades; en cuarto lugar ha habido una mejora de los barrios respecto a la integración con el centro histórico, el norte y sur de la ciudad generando nuevas conexiones longitudinales y transversales; finalmente, se han propiciado criterios de sostenibilidad con respecto a la integración social, accesibilidad inclusiva y paisaje urbano.

A escala metropolitana los recursos históricos como puentes, edificios, monumentos que forman parte del pasado de Madrid han sido rehabilitados y se les ha dado un nuevo valor cultural para facilitar su accesibilidad y configurar un gran eje histórico cultural en la ciudad.

A escala urbana, la incorporación de equipamiento peatonal como las pasarelas de cruce sobre el Río Manzanares fueron rehabilitadas y diseñadas para facilitar el acceso al peatón desde cualquier lugar en el que se encuentre.

A escala local, las imágenes de los vecinos se han incorporado en la ornamentación artística de nuevas pasarelas con mucha pertenencia y carácter de espacio común.

El soterramiento de la M-30 y el posterior ajardinamiento ha incrementado la eficiencia energética y funcional, reduce la emisión de gases de efecto invernadero y su corolario de ahorro a usuarios y ciudad. Puede constatarse el incremento de actividad económica en el área de influencia, asimismo el valor del suelo se ha incrementado tanto de terrenos privados y comerciales, asimismo hay un incremento del interés de los propietarios porrehabilitar sus viviendas y negocios. 


\section{REGENERACIÓN URBANA RÍO MANZANARES MADRID,ESPAÑA}

CAUSAS

1. Crecimiento acelerado de la población, causó deterioro higiénico de los bordes, las personas optaron por vivir en las fajas marginales del río

2. Contaminación del cauce del Río Manzanares y los bordes debido a la presencia industrial, así también por los desagües de las viviendas Incremento de vehículos de transporte.

3. Desconexión de territorios de forma lineal y pérdida del valor histórico, ya que perdió la forma de su estado natural por la metrópoli

\section{ESTRATEGIAS}

1. Regenerar la trama urbana de la ciudad

2.Aprovechamiento del cauce del río para usos deportivos y de entretenimiento

3.Dar valor al paisaje y generar un plan de desarrollo sostenible para el parque lineal.

4. Tratamiento de la superficie liberada tras el soterramiento de la M-30

5. Reorganización del tráfico actual, predominio del transporte público y preponderancia del peatón.

6. Tratamiento a los túneles y accesos

7.Oportunidades de introducción de nuevos elementos de transporte público de caracter interior

8. Optimización de los espacios como Matadero y mercado de frutas.

9. Creación de nuevos ejes peatonales y sendas de ciclovias y el enlace con las sendas ya existentes.

9.Poner en valor a los edificios históricos, monumentos, edificios contemporáneos de la ciudad

\section{CONSECUENCIAS}

1. El entorno del Río Manzanares se ha convertido en un espacio de encuentro a nivel metropolitano, cambiando su antigua zonificación en la que era un parque barrial, incluyendo toda clase social, cultural y económica de la población.

2. Ha habido una mejora de los barrios respecto a la integración con el centro histórico, norte y sur de la ciudad generando nuevas conexiones longitudinales y transversales

3. Ha generado la disminución del uso del automóvil proponiendo nuevos sistemas de transporte no contaminantes

4. El soterramiento de la M-30 y el posterior ajardina miento ha incrementado la eficiencia energética y funcional, reduce la emisión de gases de efecto invernadero y su corolario de ahorro a usuarios y ciudad.

5. la incorporación de equipamiento peatonal como las pasarelas de cruce sobre el Río Manzanares fueron rehabilitadas y diseñadas para facilitar el acceso peatón desde cualquier lugar en el que se encuentre.

6. las imágenes de los vecinos se han incorporado en la ornamentación artística de nuevas pasarelas con mucha pertenencia y carácter de espacio común.
La tasa general de accidentes cayó casi al 50\%, lo que puede estimarse como un ahorro de 770 millones de euros en términos de cuantías de seguros, impuestos, etc.

Al ampliar la capacidad de la M30 y mejorar conexiones Se estima un ahorro anual de 4,4 millones de euros, en términos de horas de trabajo.

Medioambientales

Disminución de la contaminación acústica

Disminución de tráfico, y como consecuencia, menores emisiones de gases de efecto invernadero.

Sociales

a M-30 era una línea divisoria entre Madrid y sus vecinos. Después de completarse el proyecto, se conectaron zonas residenciales y se establecieron nuevos puntos de encuentro. En general, la calidad de vida ha mejorado.

Las líneas de autobuses se han trazado nuevamente, siendo más eficientes ahora, lo que ha sido posible, gracias al soterramiento de una parte de la vía que rodea como un anillo a la ciudad.

El plan de renovación de la M-30 y su gestión integrada, transformó la vía en una infraestructura moderna y segura, reduciendo la accidentalidad

DESVENTAJAS

1. El mayor problema es el de las "zonas verdes" Es decir, hay dificultades propias del subsuelo, ya que los árboles no pueden alcanzar el nivel freático o no tienen la suficiente cantidad de suelo para e regadío

2. Al realizarse el proyecto sobre el soterramiento de la M30, en muchos tramos, la proximidad a las losas impide plantaciones adecuadas, encallejona el río y deja poca libertad en el diseño paisailistico de los márgenes. 


\section{2 .1}

FICHA DEL PROYECTO

ESPACIO

IMÁGENES DEL AUTOR EN BASE A :

(Seoul Metropolitan facilities Management Corporation, n.d.)

About UNEP. (n.d.). Retrieved from http://www.unep.org/about/
FICHA

5.27
CUDAD

POBLACIÓN
Seúl

24,5 mil Habitantes

$17.200 \mathrm{Hab} / \mathrm{Km} 2$

$600 \mathrm{Km} 2$

Cheonggyecheon

$5.8 \mathrm{Km} 2$

LONGITUD

Gobierno Metropolitano de Seul

OPERACIÓN URBANA

$5.8 \mathrm{Km}$

PROMOTOR

$37 \mathrm{Ha}$.

LONG.DEL PARQUE

$40 \mathrm{Ha}$.

SUP. DEL PARQUE

SUPERFICIE TOTAL

$2002-2003$

P.PLANIFICACION

2003-2005

P.CONSTRUCIÓN

PRES. OBRA

120 millones de dólares

380 millones de dólares

PRES.TOTAL

EQUIPO DE DISEÑO

Diseñadores principales

Arquitectura Contemporánea

Arquitecto paisajista

Proyecto
Cheongsuk Ingenieros

Saman Ingenieros

: Dongmyung Ingenieros

: SeoAhn Total Landscape

Mikyoung Kim Design
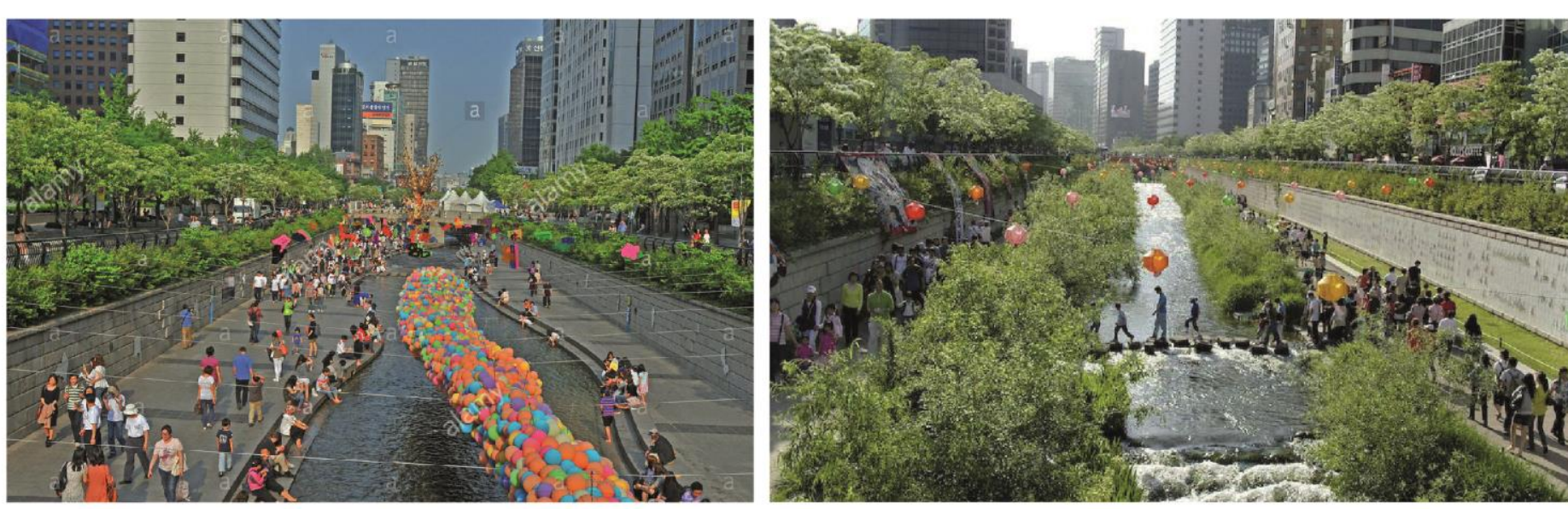


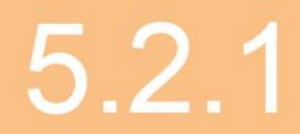

FICHA DEL. PROYECTO

ESPACIO
HISTORIA
UBICACIÓN
FICHA

IMÁGENES DEL AUTOR EN BASE A :

TECNOLOGIA

IMPACTO SOCIAL

5.28

(Seoul Metropolitan facilities Management Corporation, n.d.)

About UNEP. (n.d.). Retrieved from http://www.unep.org/about/

\section{PERIODO HISTÓRICO}

\section{Intervención contemporánea}

Gran parte de la expansión territorial se da por medio de las migraciones que se originaron a mitad del siglo XX. Los inmigrantes se asentaron en las orillas del Río Cheong Gye Cheon de manera precaria. La consecuencia de esto fue el deterioro con gran rapidez, la basura, los sedimentos y la cantidad de residuos que transportaba lo convirtió en una cloaca a cielo abierto, con el consiguiente riesgo para la salubridad pública.

La propuesta de cubrir el río se realizó en 1957 con una gran losa de hormigón. Luego de los años sesenta, tras la necesidad de espacio por el tráfico en el centro de la ciudad, se llevó la construcción de una autopista de doble nivel sobre el antiguo cauce finalizándose en 1976. Este cambio en Seúl fue el símbolo del desarrollo económico y de la "modernidad" que estaba adquiriendo Corea del Sur.

El resultado de la construcción de la autopista generó varios problemas, acentuando la congestión de tráfico, la polución y el ruido. La propia autopista tendría problemas constructivos y tuvo que limitar el peso de los vehículos que circulaban por ella y el centro de la ciudad se convirtió en un lugar inhóspito para los ciudadanos.

\section{PROBLEMA}

La zona presentaba problemas de deterioro, inseguridad, mala calidad de aire y altos costos de mantenimiento en los sótanos, debido a la humedad y el hacinamiento. Otro impacto que generó fue la fragmentación urbana y social.

Dentro de los periodos de 1975-1995, la población en la zona disminuyó en un 52\%, Asimismo, el tipo de vivienda era de baja calidad, en su mayoría alquilados o invadidos. El porcentaje de este tipo de viviendas representa el 35\% de las viviendas del centro.
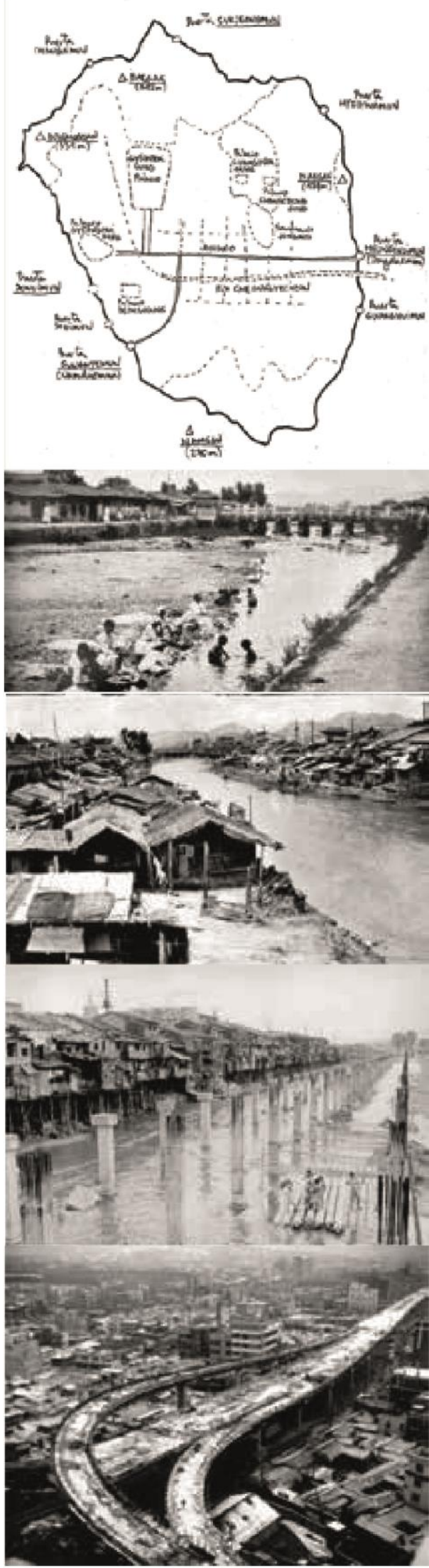


\section{TOMA DE PARTIDO}

La propuesta nace de la necesidad de reparar las fallas estructurales de la autopista elevada sobre el cauce del río. Sin embargo, se planteó un proyecto urbano llamado "El proyecto de Restauración de Cheonggyecheon". El fin del proyecto era demoler la autopista para restaurar el flujo del río y crear un parque de cinco millas, 1000 acres que bordean el nuevo curso de agua.

El objetivo del plan fue la reorganización sistemática de la zona Cheonggyecheon y el desarrollo a largo plazo de la zona centro. Los puntos a trabajar fueron:

\section{Estrategias para el desarrollo del centro}

Los planes urbanos para la zona Cheonggyecheon y otras zonas de destinos principales

La revitalización de las industrias del centro

A partir de estos objetivos para la mejora de la ciudad, las estrategias puntuales de propuesta se basaron:

Mejorar las condiciones ambientales en la zona del centro para crear un punto focal de importancia histórica y estéti-

ca

Activar el crecimiento económico a largo plazo mediante la atracción de turistas e inversores

Ayudar en la toma de Seúl como centro financiero y comercial de la región de Asia Oriental

De este modo el plan maestro incluye medidas especíicas para restaurar el entorno natural del Cheonggyecheon y crear un espacio público más orientado al ser humano mediante planes para restaurar el paisaje, los recursos de agua seguros, el tráfico, construir puentes, restaurar bienes históricos y gestionar conflictos sociales.

\section{TOMA DE PARTIDO PUNTUAL}

La propuesta paisajistica del borde del río tiene como punto de partida:

* Formación de una zona verde de oeste que une Deoksugung (Palacio), el Cheonggyecheon, el ungnangcheon (arroyo ) y el Hangang (río)

* Formación de una zona verde de norte-sur que unirá a Jongmyo (capilla real), Seun Arcade, y Namsan (Mt)

* La prevención de inundaciones

* La plena utilización de los espacios disponibles y conservación de la naturaleza

* Fomentar un ecosistema estable mediante la siembra de plantas nativas y árboles

* Seguridad en canales para la libre circulación de la vida silvestre

* Expansión de las zonas verdes

* Estos puntos nacen con la finalidad de formar un entorno natural para los habitantes asegurando la identidad 
REGENERACIÓN URBANA RÍO CHEONGGYECHEON-SEÚL

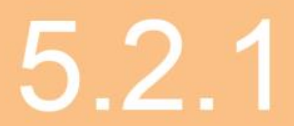

FICHA DEL PROYECTO HISTORIA

UBICACIÓN

FICHA

ESPACIO

TECNOLOGIA

5.30

IMÁGENES DEL AUTOR EN BASE A :

(Seoul Metropolitan facilities Management Corporation, n.d.)

About UNEP. (n.d.). Retrieved from http://www.unep.org/about/

MAPA MACRO
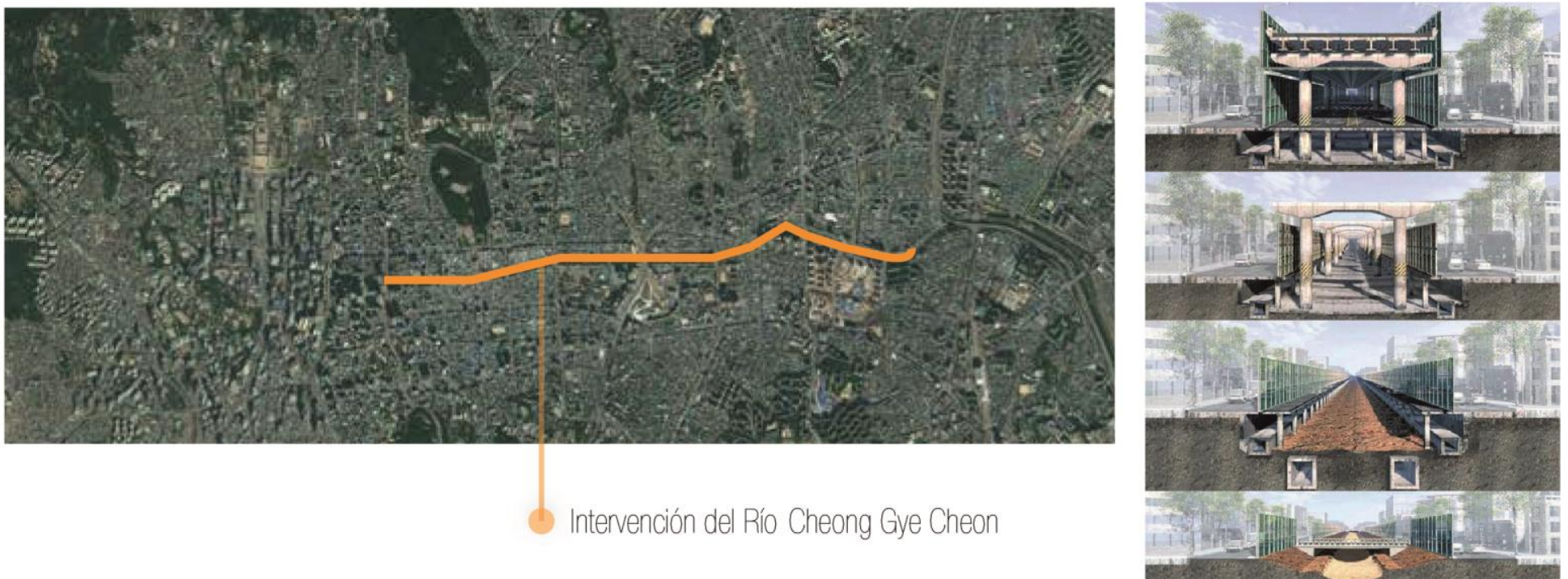

El río Cheonggyecheon, unos de los más de 20 afluentes del Río Han , se encuentra ubicado en el nucleo historico de Seúl y es uno de los afluentes del Rió Han
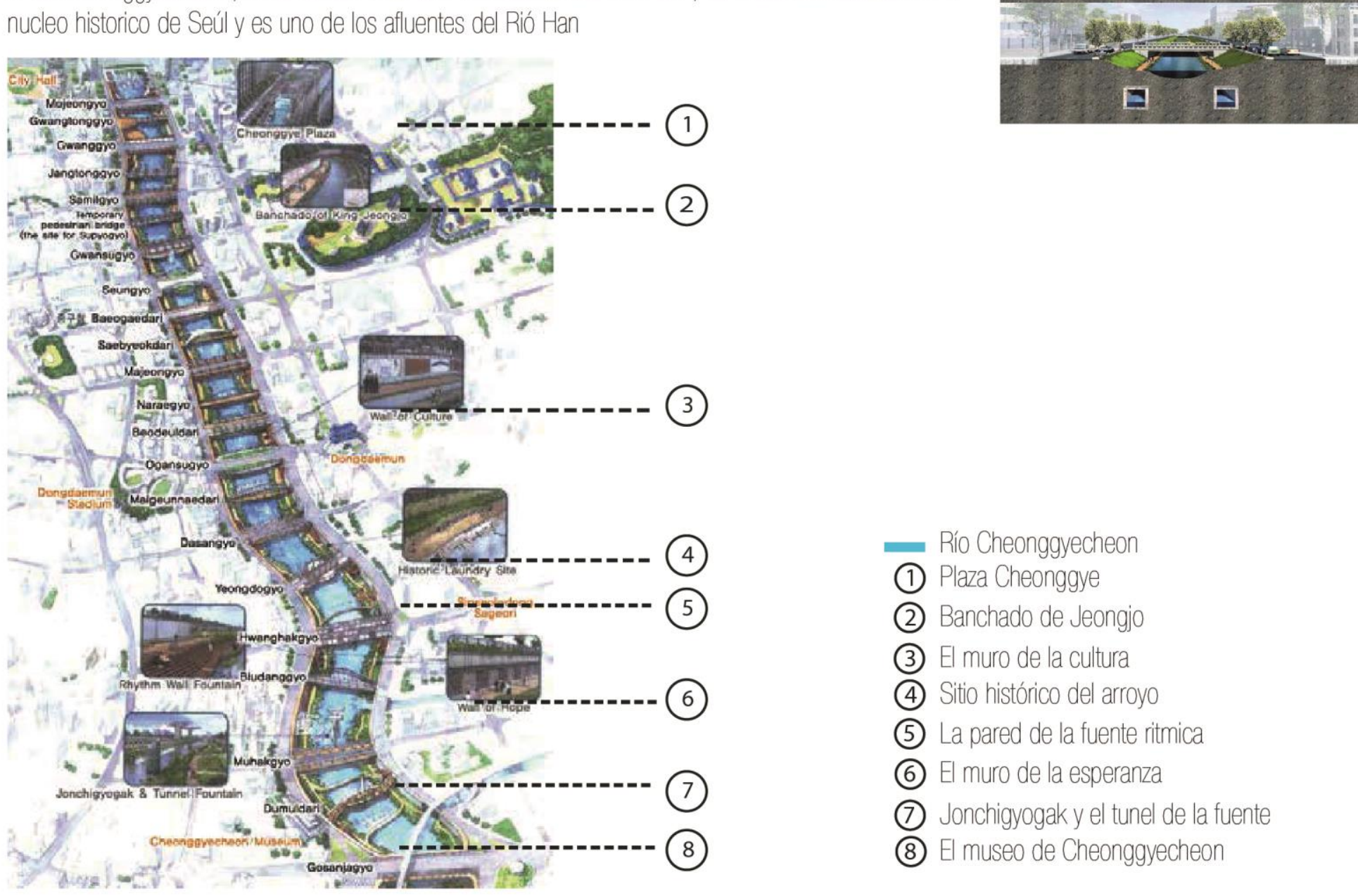
- Río Cheonggyecheon
(1) Plaza Cheonggye
(2) Banchado de Jeongjo
(3) El muro de la cultura
(4) Sitio histórico del arroyo
(5) La pared de la fuente ritmica
(6) El muro de la esperanza
(7) Jonchigyogak y el tunel de la fuente
(8) El museo de Cheonggyecheon 


\section{2 .1}

FICHA DEL PROYECTO

ESPACIO

HISTORIA

UBICACIÓN

PROGRAMA

FICHA

5.31

IMÁGENES DEL AUTOR EN BASE A :

(Seoul Metropolitan facilities Management Corporation, n.d.)

About UNEP. (n.d.). Retrieved from http://www.unep.org/about/

VÍAS PRINCIPALES Y ESTACIONES DE TRANSPORTE

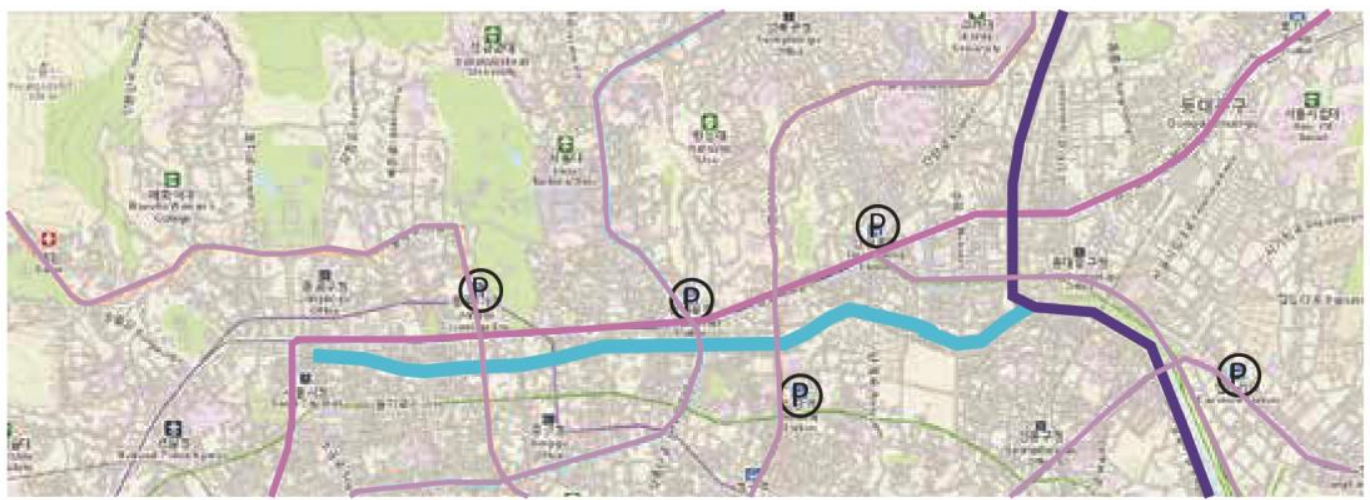

\begin{tabular}{ll} 
Vías Principales \\
Autopista Orense \\
\hline P Vías de transporte público \\
Paradero
\end{tabular}

\section{ACCESOS PÚBLICOS PEATONALES}

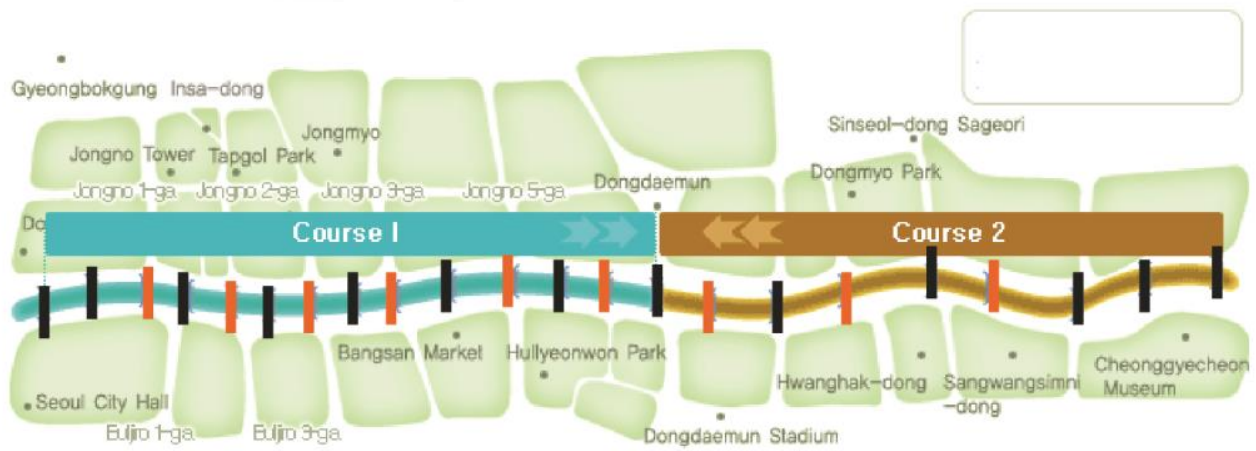

I Puentes peatonales

I Puentes peatonales $\mathrm{y}$ autos

Los planificadores del proyecto tomaron varias medidas destinadas a minimizar la congestión del tráfico en este centro y aseguraron la infraestructura de transporte adecuada en ausencia de la autopista . A ambos lados de la corriente, 13,5 millones se destinaron para dar cabida a las aceras; de dos carriles, caminos bidireccionales; y las zonas de carga / descarga. Los límites del sistema de tráfico de nuevo diseño giros a la izquierda y giros en $U$ en un esfuerzo para evitar retrasos en el tráfico y proteger el medio ambiente de las emisiones de automóviles. Un total de 22 nuevos puentes se construyeron sobre el Cheonggyecheon, 5 de los cuales son los puentes peatonales y 17 son puentes vehiculares. 
FICHA DEL PROYECTO HISTORIA

ESPACIO

\section{IMÁGENES DEL AUTOR EN BASE A :}

(Seoul Metropolitan facilities Management Corporation, n.d.)

About UNEP. (n.d.). Retrieved from http://www.unep.org/about/

\section{UBICACIÓN}

IMPACTO SOCIAL

\section{FICHA}

5.32

\section{CORTES ESQUUEMÁTICOS}

La relación con el río se da por medio de espacios públicos que han sido recuperados con la regulación de alturas entorno al Cheonggyecheon.

Asimismo, se formularon espacios de permanencia a manera de terrazas proximas al agua. Para la realización de estos espacios se requirio del estudios del caudal y de zonas indundables, ya que era la mejor manera de determinar la factibilidad y la forma de las terrazas.

Los cortes esquemáticos muestran la relación de espacio público y el río en diferentes puntos del proyecto
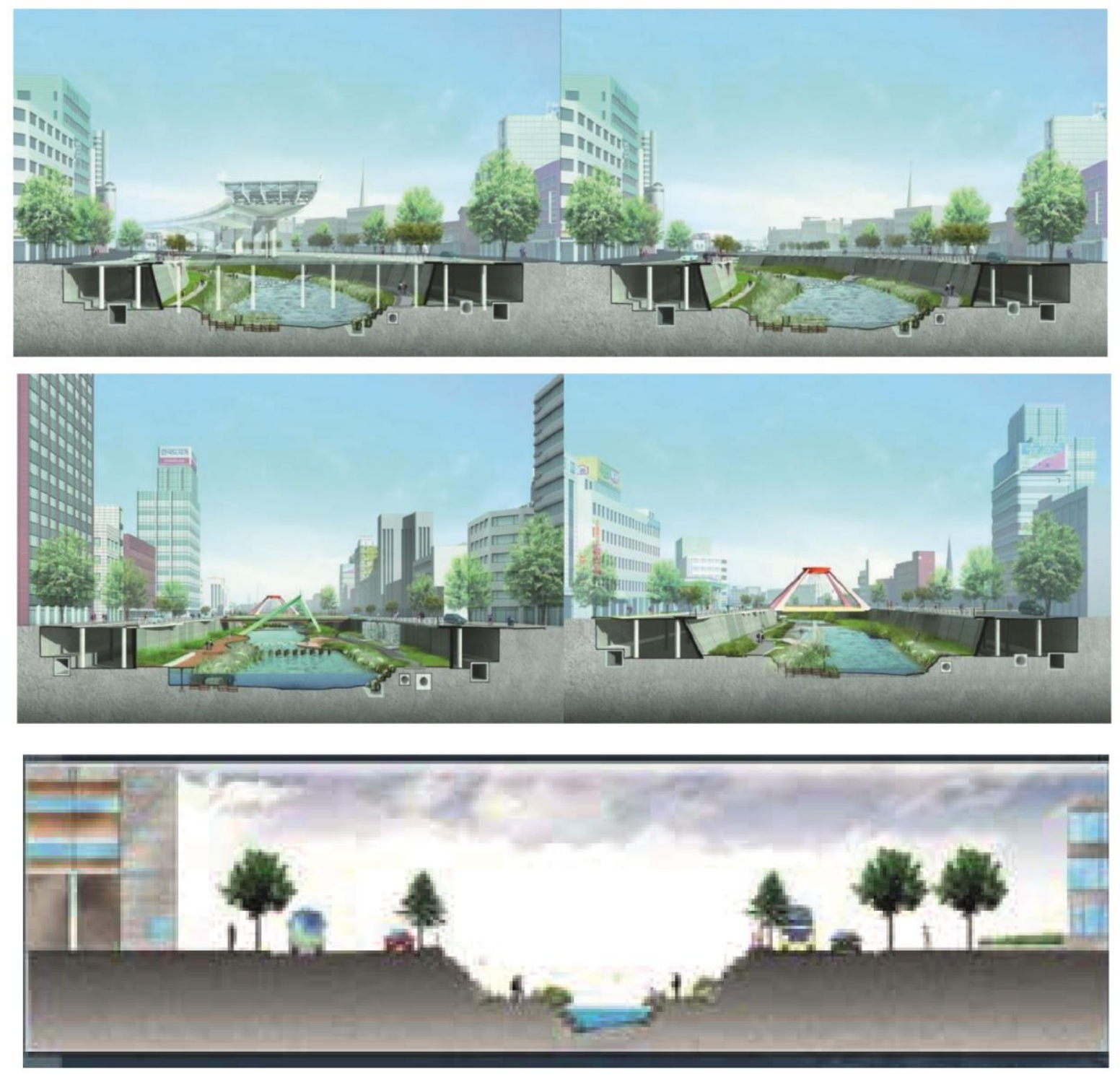
FICHA DEL PROYECTO

ESPACIO

HISTORIA

UBICACIÓN

TECNOLOGIA

\section{PROGRAMA}

FICHA

5.33

IMÁGENES DEL AUTOR EN BASE A :

(Seoul Metropolitan facilities Management Corporation, n.d.)

About UNEP. (n.d.). Retrieved from http://www.unep.org/about/

\section{PERIÓDO HISTÓRICO}

Se creó programas turísticos para que las personas disfruten del patrimonio histórico y cultural que hay en la zona. De modo que Seúl desarrolló un plan de gestión urbana para regular parámetros como la altura del edificio, la construcción de ratio de cobertura, la densidad de desarrollo y las normas de estacionamiento para mantener o generar un carácter en particular a la zona.

El Plan del 2004 dividió el área alrededor de Cheonggyecheon en 22 bloques y los clasificó en zona de conservación, nuevo desarrollo, renovación voluntaria y reorganización integral de acuerdo con sus características, patrón de uso del suelo e historia. Las zonas de reurbanización y mejora se desarrollarían activamente para reforzar sus propias características.

Por otra parte, las zonas de conservación están destinadas a preservar la identidad mientras se adaptan a los cambios. Por ejemplo, en Gwancheol-dong, designada como zona de preservación, se desarrolló a mayor escala para proteger la identidad espacial. Asimismo, se propuso el uso comercial para la revitalización de la calle en los pisos inferiores y así crear un entorno orientado al peatón.

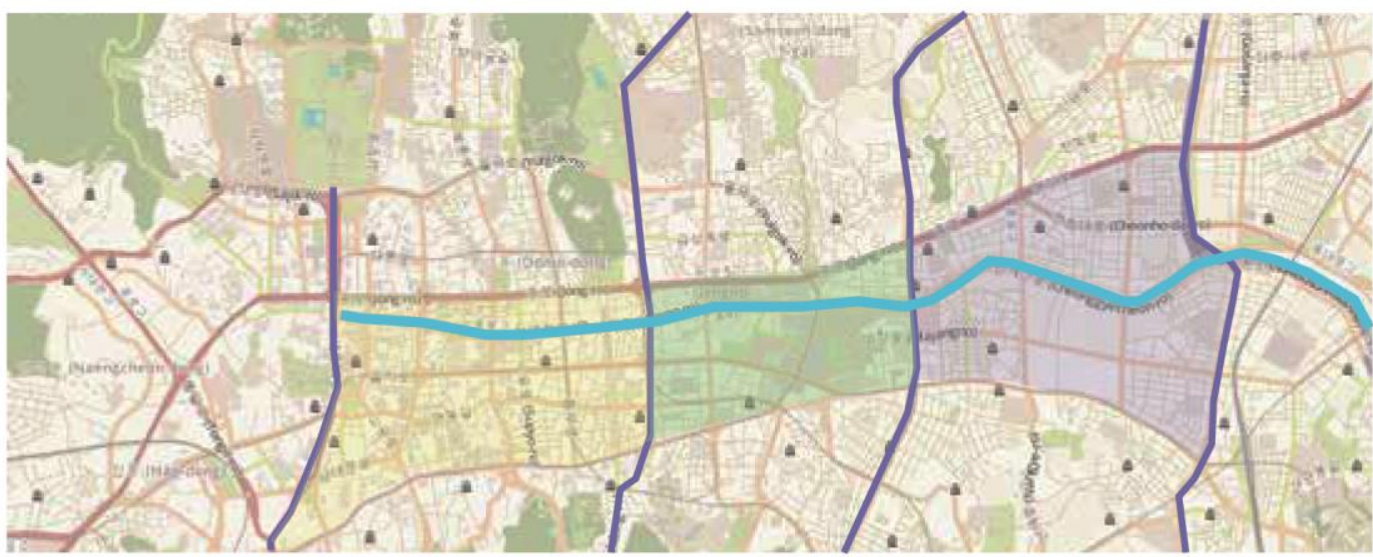

Río Cheonggyecheon

Ecológico

Cultural

Histórico

\section{ZONIFICACIÓN}

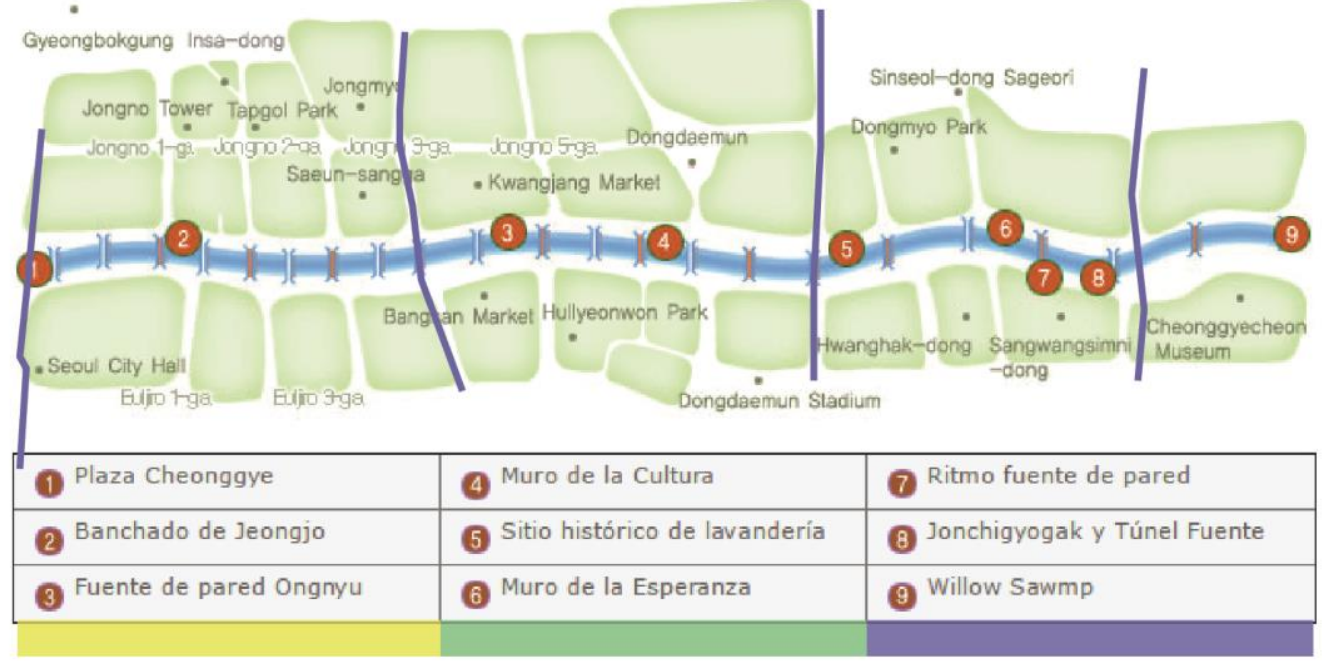

Puentes peatonales

Puentes peatonales y autos 
FICHA DEL PROYECTO

ESPACIO

IMÁGENES DEL AUTOR EN BASE A :

(Seoul Metropolitan facilities Management Corporation, n.d.)

About UNEP. (n.d.). Retrieved from http://www.unep.org/about/

\section{PROGRAMA}

PAQUETE PROGRAMÁTICO

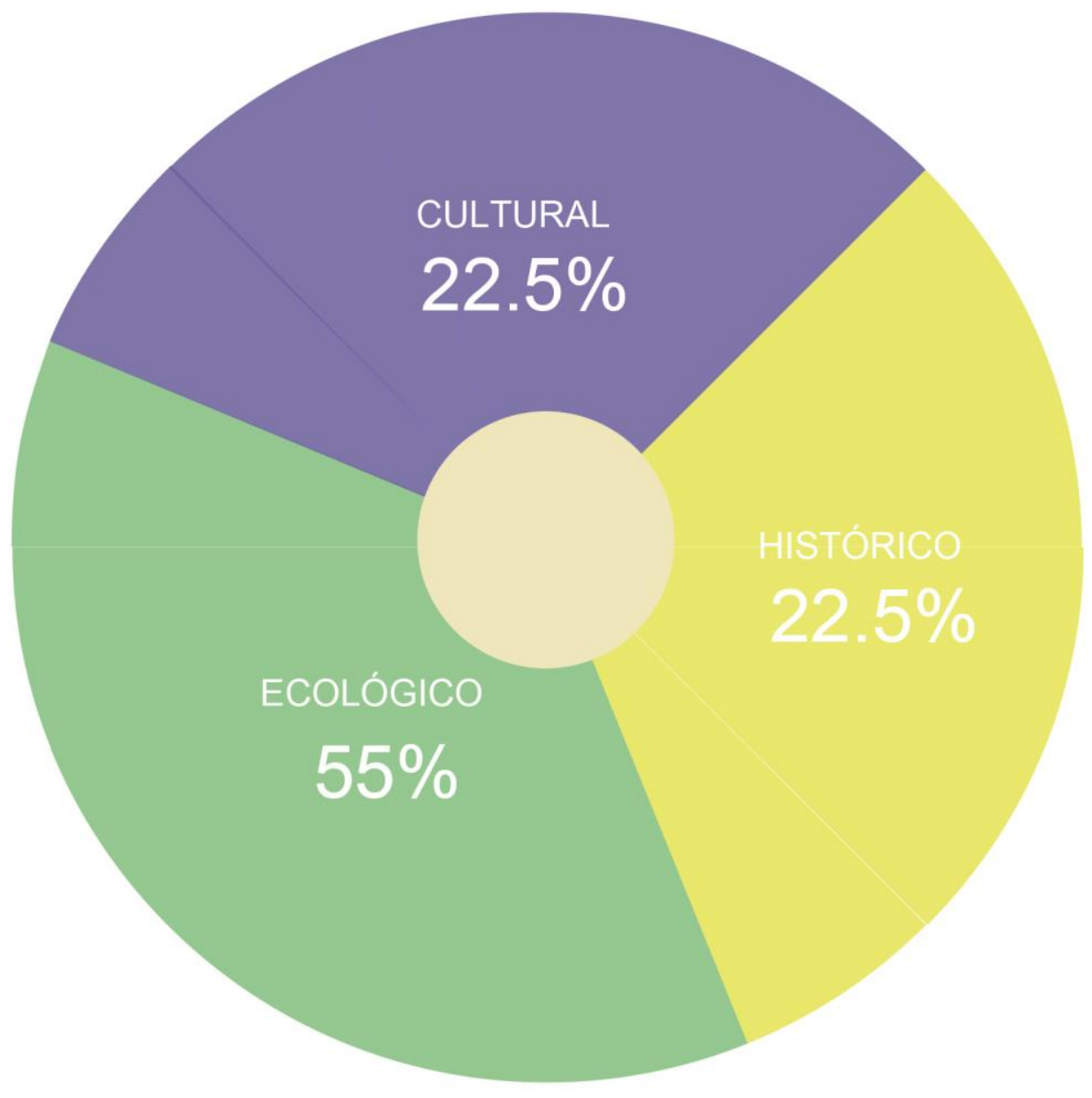

CUADRO DE ÁREAS

\section{USUARIOS}

蚥

$\begin{array}{ll} & \text { Ancianos } \\ \text { - Discapacitados }\end{array}$

11 Estudiantes

Niños

Niños

滛

ڤึก Estudiantes

- Turistas

\# Discapacitados

Ancianos

"ִamilias

Personal capacitado Empleados

del área de limpieza, servicio, administrativo, etc.
Ecológico

Cultural

Histórico

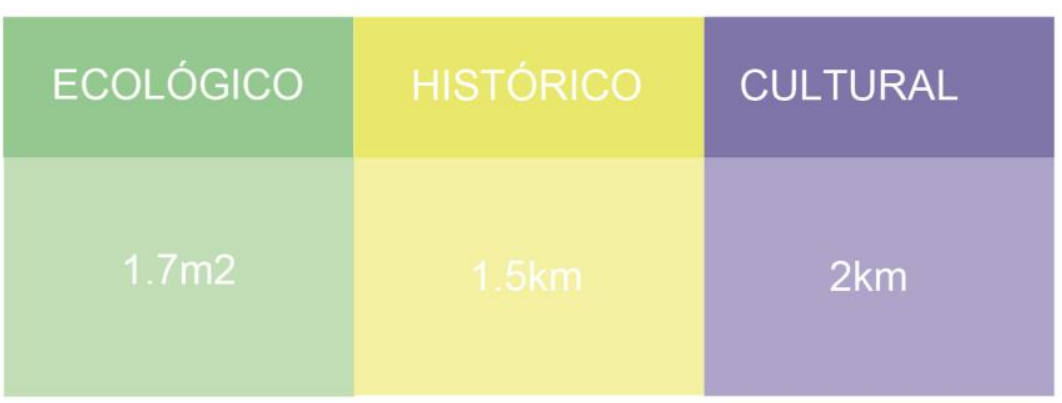




\section{2 .1}

FICHA DEL PROYECTO

ESPACIO

IMÁGENES DELAUTOR EN BASE A :
UBICACIÓN

TECNOLOGIA

IMPACTO SOCIAL

(Seoul Metropolitan facilities Management Corporation, n.d.)

About UNEP. (n.d.). Retrieved from http://www.unep.org/about/
FICHA

\section{ESPACIALIDAD}

Las estrategias de diseño planteadas en relación a caminos en las márgenes del río se basan en lo siguiente:

* Utilzar materiales eco- amigables y sostenibles

* Las dimensiones de ancho son para paseos 3 metros, mientras que las aceras solo para uso peatonal van de 0.90 metros hasta 2.5 metros

Los caminos de acceso al rio deben de ser de fácil ubicación; sin embargo, se debe tomar en cuenta las zonas de inundaciones para así garantizar el uso, función y estética con la propuesta de la regeneración.

En relación a las veredas, de ambas márgenes, que se encuentran delante de un edificio son de 3 metros de ancho; mientras que, para los de estacionamientos de vehículos son de 2 metros y finalmente, para las aceras cerca de la corriente son de 1.5 metros.

\section{DEFINICIONES}

El proyecto es la secuencia lineal de espacios públicos que se encuentran al borde del río. Las áreas de recorrido poseen una temática turística. De este modo garantizan la conexión completa promedio de caminos transversales

ESQUEMAS
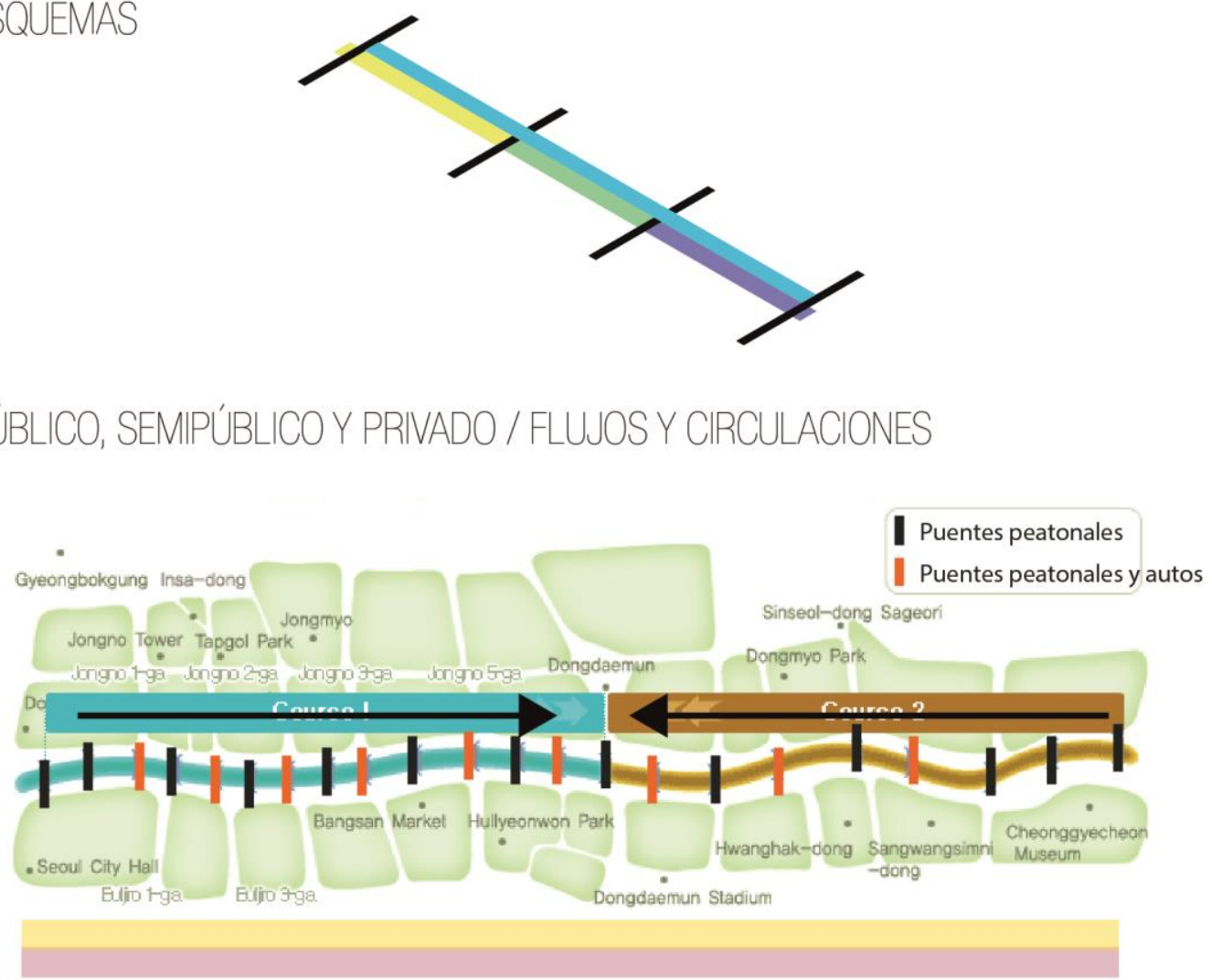

LEYENDA DE FLUJOS Y CIRCLLACIONES Circulación Total

$\checkmark$ Flujo

LEYENDA PÚBLICO, SEMIPÚBLICO

Recorrido

Espacio Público

Acceso Restringido $0 \%$

Acceso Libre 
FICHA DEL PROYECTO

ESPACIO

TECNOLOGIA
UBICACIÓN

PROGRAMA

\section{IMPACTO SOCIAL}

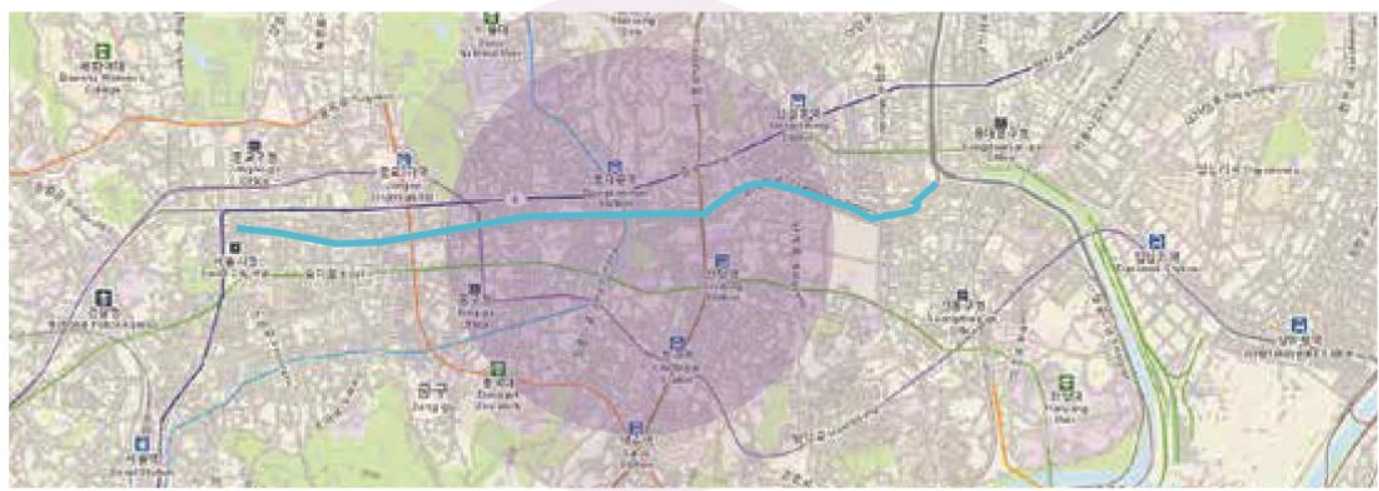

Espacio Público /Área verde

- Centro de Interepretaciones

Radio de influencia

Un punto importante es el cambio en la conciencia de los ciudadanos ya que se buscaba la valorización del entorno natural. Incluso antes del proyecto de restauración, las personas ya tenían interés en el medio natural y la aspiración para una mejor Cheonggyecheon.

Después de presenciar la corriente restaurada y el entorno, el reconocimiento de la gente sobre el valor aumentó aún más.

De acuerdo con una encuesta de la voluntad de los ciudadanos a pagar por una corriente natural antes y después del proyecto de restauración, el valor económico anual de un arroyo natural apreciado por los ciudadanos saltó de 20.226 a 37.724 KRW por hogar.

La encuesta confirmó que los ciudadanos de Seúl colocan un valor más alto en el medio natural después de experimentar el Cheonggyecheon restaurado. ("Seoul Urban Renewal: Cheonggyecheon Stream Restoration," n.d.)

- La reducción del efecto de isla de calor

El efecto de isla de calor en el centro de la ciudad se ha reducido. La temperatura de la zona de Cheonggyecheon antes de la restauración fue de 2,2 ${ }^{\circ} \mathrm{C}$ superior a la media de Seúl, pero se redujo a 1,3 ${ }^{\circ} \mathrm{C}$ después de la restauración, dejando caer de un $8 \%$ a 18\%. La temperatura del punto verde dentro de la corriente fue de $0,9^{\circ} \mathrm{C}$ menor que el área vecina.

-Mejor calidad del aire

E cambio físico y el volumen de tráfico reducido en la zona de Cheonggyecheon redujo la concentración de polvo fino (PM-10), NO2, compuestos orgánicos volátiles (COV) y otros contaminantes Asimismo se estableció corredor de viento y la creación de la corriente afectada entorno al vecino.

- La restauración del medio natural

El ecosistema también se restauró. Hubo incremento de especies como aves, insectos y plantas. Por otro lado, el aumento de espacio público mejoró el medio ambiente para los peatones.

Estas mejoras han ocasionado un impacto positivo en la población flotante y turistas, ya que la población flotante, en dias laborables y fines de semana, registró visitas continuas. Sin embago, el aumento fue mayor en los días laborables, lo que significa que los ciudadanos visitan la corriente a menudo.

En la encuesta de 2013, el 89\% de los encuestados estaban satisfechos con la ruta de senderos a lo largo de la corriente. Fueron particularmente satisfechos con la singularidad del lugar en sí. Sin embargo, mostraron un menor nivel de satisfacción en la accesibilidad, ya que el acceso desde el nivel del suelo al río fue limitado debido a la poca anchura de la corriente. Desde la perspectiva de los ciudadanos, la mayor contribución de la restauración fue la creación de un lugar para relajarse. En la encuesta de 2013, el 59.6\% de los encuestados indicó que Cheonggyecheon se ha convertido en el lugar de celebración de diversos eventos culturales: 259 eventos fueron recibidos en el periodo 2005-2007, posicionando firmemente al río como un lugar para la cultura y la recreación.

Finalmente, el control de inundaciones es un factor importante que ha tenido cambios óptimos. Cheonggyecheon es la zona de más baja altitud con una amplia cuenca para recaudar el agua de lluvia que se puede llegar a convertir en una corriente altamente propensa a las inundaciones.

De este modo, el área de descarga de la corriente fue restaurado y se presentó libre de daños de inundación. ("Seoul Urban Renewal: Cheonggyecheon Stream Restoration," n.d.). 


\section{RESUMEN}

\section{CAUSAS}

1. La congestión vial que sufrían los usuarios de la carretera

2. Elevados índices de contaminación acústica y aire por la polución

3. Proplemas constructivos de la autopista que cubría el río

4. E centro de la ciudad se convirtió en un lugar peligroso, inhóspito e insalubre

5.Mala calidad de aire y altos costos de mantenimiento en los sótanos, debido a la humedad y el hacinamiento

6. Fragmentación urbana y social.

About UNEP. (n.d.). Retrieved from http://www. unep.org/about

\section{ESTRATEGIAS}

1. Creación de una zona verde de oeste que une Deoksugung (Palacio), el Cheonggyecheon, el ungnangcheon (arroyo ) y el Hangang (río).

2. Creación de una zona verde de norte-sur que unirá a Jongmyo (capilla real), Seun Arcade, y Namsan (Mt).

3. Utilización de los espacios disponibles para la conservación de la naturaleza

4. Fomentar un ecosistema estable mediante la siembra de plantas nativas y árboles

5. Seguridad en canales para la libre circulación de la vida silvestre

6.Rompimiento de la autopista que cubría el río para dar al peatón áreas de estancia que sirvan para el desarrollo de sus acividades.

7. Creación de puentes y pasarelas para combatir el problema de fragmentación urbana

\section{CONSECUENCIAS}

1. Incremento de turismo, hasta la actualidad se registra un aproximado de 70 millones de visitas

2. Incremento del valor del suelo, tanto residencial y comercial

3. La movilidad alrededor de Seúl ha mejorado con cerca de 170,000 viajes menos en automóvil cada día, el aumento del $4,3 \%$ y $1,4 \%$ en usuarios de metro y autobús respectivamente, y la creación de itinerarios peatonales.

4. Mejora de la calidad del aire, se muestra en la reducción de partículas pequeñas en el aire de 74 a 48 microgramos por metro cúbico.

5. El espacio público se ha convertido en destino para actividades recreativas y culturales, y la Sociales

mejora de la zona ha creado un lugar propicio Hubo un considerable impacto en la regeneración para las actividades económicas.

\section{Económicas}

Incremento de zonas comerciales y empresas cerca a la intervención urbana

Incremento del valor del suelo de las edificaciones aledañas.

\section{Medioambientales}

Disminución de las temperaturas de los suelos y superficies cercanas al nuevo canal, ya que presentan un promedio de $3.6^{\circ} \mathrm{C}$ menos que en zonas a 400 metros de distancia del proyecto. Los ríos son climatizadores naturales, enfrian la capital durante los veranos más calurosos.

Aumento de la velocidad de vientos, aproximadamente en un 50\% más. urbana de los barrio que bordea el canal

\section{DESVENTAJAS}

1. Se ha producido una dura gentificación en el área, desplazando a una gran masa de población de sus lugares de origen. 


\section{CENTRO CULTURAL Y DE INTEPRETACIÓN}

JEAN MARIE TJIBAOU

\section{FICHA DEL PROYECTO}

ESPACIO
HISTORIA

TECNOLOGÍA
UBICACIÓN

IMPACTO SOCIAL

Página web del Centro CulturalJuan Marie TjibaouArchDaily

Texto: Architecture and the representation of culture: The Tjibaou cultural center in New Caledonia- Lisa Findley

ARQUITECTO:

AÑ :

EQUIPO:

Renzo Piano

1991-1998

- Arquitecto Renzo Piano

- Arquitecto Paul Vincente

- Antropólogo Alban Bensa

CLIENTE: Gobierno Francés- Francois Mitterand

\section{PERIODO HISTÓRICO}

DESCRIPCIÓN:
Periodo contemporáneo

El Centro Cultural ubicado en Nouméa, capital de Nueva Caledonia, colonia Francesa y archipiélago de Oceanía situado en la Melanesia a $1500 \mathrm{~km}$ al Este de Australia, es un conjunto de edificaciones semejante a un pueblo con diferentes funciones y recorrido, exhibe elementos de la vida de los Kanako (Una de las culturas primitivas de Nueva Caledonia) y revive sus antiguas ceremonias. Las edificaciones, Renzo piano las describe como: "Son estructuras curvadas semejantes a las cabañas construidas con vigas y nervios de madera; son recipientes arcaicos cuyo interior está equipado con la mejor tecnología" (Timber \& Burdeos, 2001). El propósito del proyecto fue largo y complejo, ya que existía un conflicto histórico entre los Kanak y los gobernantes de descendencia europea de Nueva Caledonia. La isla de gran extensión que fue colonizada por los franceses en el siglo XIII-XIX había soportado durante muchos siglos la explotación de sus recursos y largos periodos de esclavización Kanak. En este contexto se propone un proyecto como reconocimiento a la cultura marginada y fue financiada por el gobierno francés.

Después de la construcción del centro cultural la transformación económica de la ciudad es totalmente notable, ya que se convierte en un ícono para la isla y la arquitectura internacional obteniendo nuevas oportunidades de negocio. (Langdon, 2016).
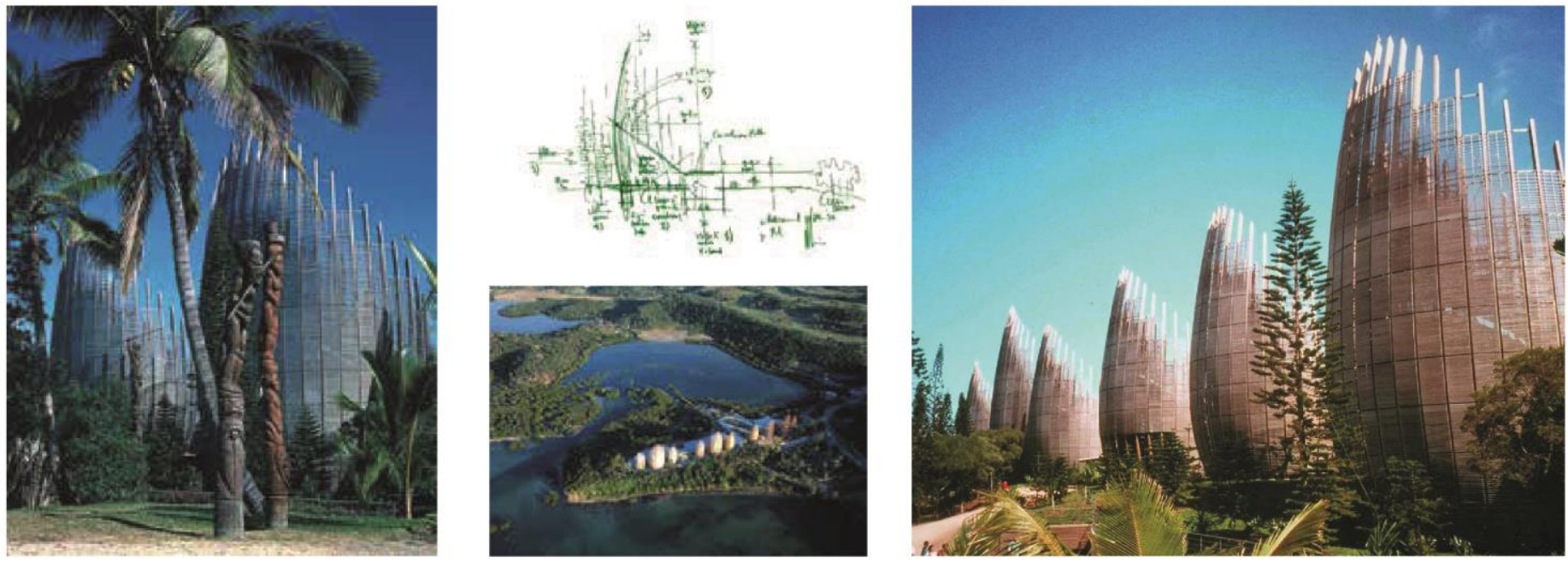


\section{CENTRO CULTURAL Y DE INTEPRETACIÓN JEAN MARIE TJIBAOU}

\begin{abstract}
FICHA DEL. PROYECTO
\end{abstract}
ESPACIO

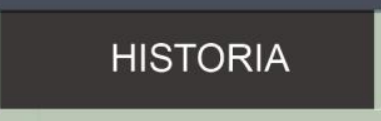

TECNOLOGIA

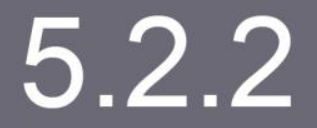

UBICACIÓN

PROGRAMA

IMÁGENES DEL AUTOR EN BASE A :

Texto: Tjibaou cultural center case of study- Harvard University

texto: Architecture and the representation of culture, The Tjibaou Cultural Center in New Caledonia

web: Plataforma de Arquitectura
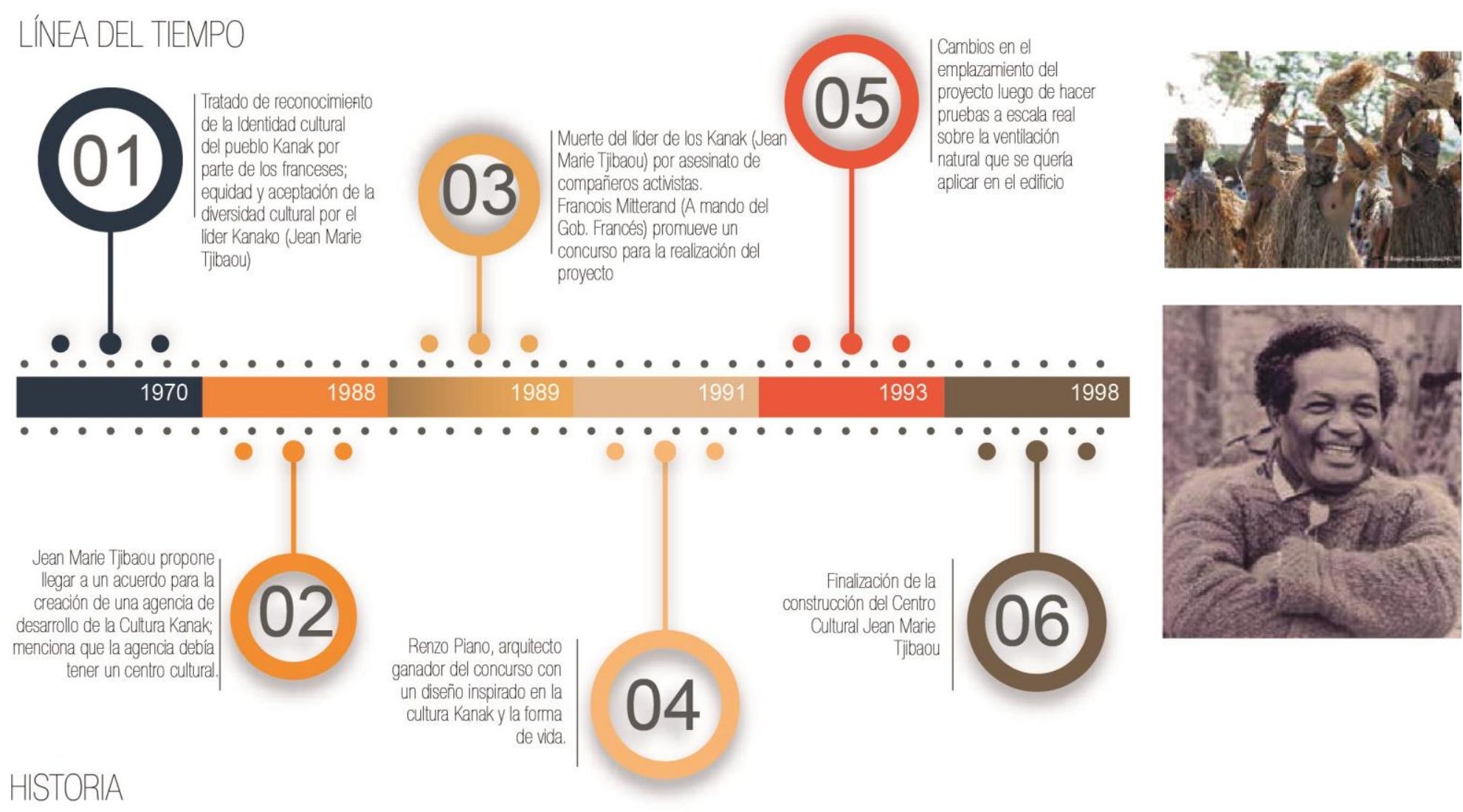

FICHA

IMPACTO SOCIAL

\subsection{9}

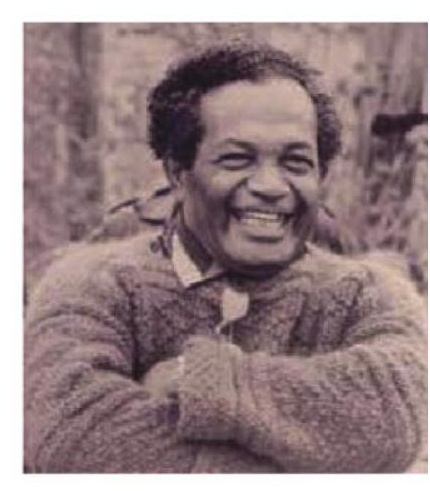

Nueva Caledonia, es un territorio francés ubicado en una isla de 480 kilómetros de largo, contiene varias islas en la periferia. Cuando los franceses \|legaron, aproximadamente en el siglo XVII, había 27 pueblos indígenas con diferentes idiomas. La comunidad más grande era los Kanak. La historia de la conquista fue vergonzosamente similar a las historias de indígenas conquistadas en todo el mundo. Durante la conquista hubo destrucción cultural de los objetos y tradiciones implantando la nueva cultura francesa como símbolo de superioridad.

Los Kanak son una comunidad de tradición guerrera; por lo tanto, no fueron blancos fáciles de conquistar. Los recursos de la isla fueron explotados por los conquistadores durante muchos años.

Durante el siglo XIX un grupo de colonos franceses llegó a la isla y la situación de los Kanak empezó a mejorar en cierto modo, ya que les dieron oportunidades económicas con trabajos como jardineros, mineros, etc. Pero les impusieron el idioma, la imitación de la cultura francesa, el comportamiento, las actividades, etc. Destruyendo el paisaje, idioma, espacios culturales u otros.

Aproximadamente en 1860, en el discurso de los derechos civiles, los líderes de la comunidad Kanak protestaron exigiendo sus derechos contra la marginalidad política y cultural por la que estaban pasando, ya que la transformación de Nueva Caledonia fue completamente exterior a los Kanak. La líder para ese entonces era Jean Marie Tjibaou, que pedía la liberación del pueblo Kanak y la valoración de su cultura. En 1988 hubo un brote de violencia entre la comunidad indígena y los franceses, pero esto fue evitado por una firma de acuerdo en el mismo año. Jean Marie Tjibaou fue quien estuvo al tanto de dicho acuerdo y mencionó que: "La cultura es la capital de una ciudad, es lo que da conocimiento en la vida" (Findley, n.d., p. 421).

Después del acuerdo tomado se creó la agencia de desarrollo de la Cultura Kanak y Tjibaou fue firme en mencionar que la agencia debía de tener un centro cultural y que debería estar ubicado en el centro de Nouméa (donde se inició la cultura Kanak). El centro debía ayudar a la recuperación de la cultura (danzas, lenguaje, música, arte), asimismo debía permitir el desarrollo e interacción con otras islas del Paćfico y el mundo. 


\section{CENTRO CULTURAL Y DE INTEPRETACIÓN JEAN MARIE TJIBAOU}

FICHA DEL PROYECTO

ESPACIO

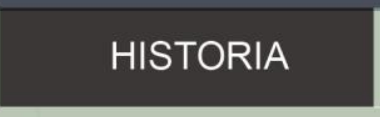

TECNOLOGIA
UBICACIÓN

IMPACTO SOCIAL

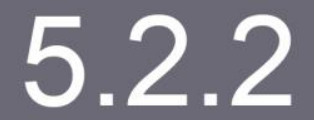

IMÁGENES DEL AUTOR EN BASE A :

Texto: Tjibaou cultural center case of study- Harvard University

texto: Architecture and the representation of culture, The Tjibaou Cultural Center in New Caledonia

web: Plataforma de Arquitectura

Un año después del acuerdo, Jean Marie Tjibaou fue asesinada por un grupo de extremistas de su misma cultura, este hecho demostró la necesidad inmediata de gestionar la paz. En 1989 el Gobierno Francés con su presidente Francois Mitterand y el comité cultural incluyeron el centro cultural Kanak de la isla de Nueva Caledonia en la lista de los principales proyectos de construcción que serviría como un legado de su gobierno. La construcción de un edificio cultural para una colonia, en el perfil internacional, sería vista como una grandiosa gestión del gobierno francés.

En 1991 se lanza el concurso para la realización del centro cultural, el ganador fue Renzo Piano con su proyecto Inspirado en las cabañas tradicionales del pueblo Kanako, haciendo uso de la vegetación del lugar, además de la orientación para obtener en ciertos espacios del proyecto una ventilación natural favorable. A continuación, se explicará detalladamente el análisis del proyecto. (Findley, n.d.)

\section{TOMA DE PARTIDO}

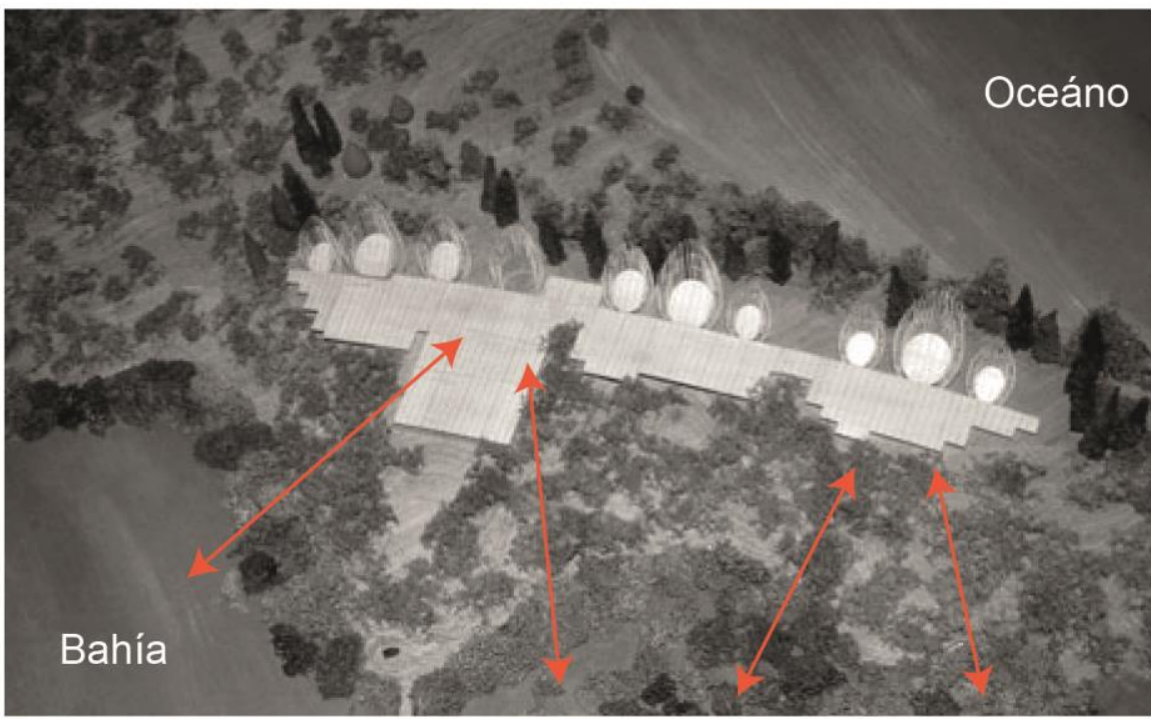

Contacto directo con la bahía y el oceáno

Pacífico, respetando el área natural

Por otro lado genera contraste entre la

naturaleza y el edificio

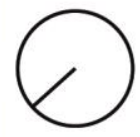

La forma responde a las viviendas vernáculas de la Cultura Kanak, el material para su construcción es con palmeras de la isla

caballete

$$
\text { emparillado larguero }
$$

horizontal intermedio

zacate

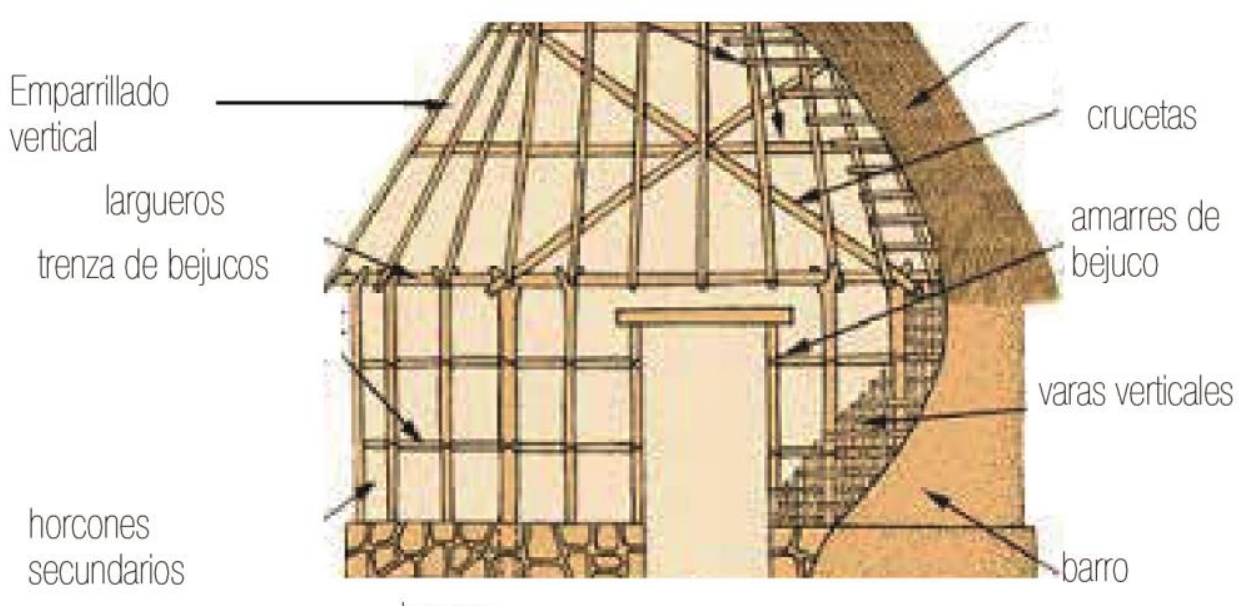

horcon 


\section{CENTRO CULTURAL Y DE INTEPRETACIÓN \\ JEAN MARIE TJIBAOU}

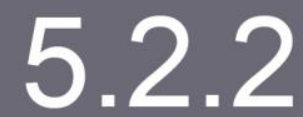

FICHA DEL PROYECTO

ESPACIO
HISTORIA

TECNOLOGÍA

\section{UBICACIÓN}

IMPACTO SOCIAL

IMÁGENES DEL AUTOR EN BASE A :

Texto: Tjibaou cultural center case of study- Harvard University

texto: Architecture and the representation of culture, The Tjibaou Cultural Center in New Caledonia

web: Plataforma de Arquitectura

La madera vertical toma como referente a los

horcones que utilizan los Kanak al construir

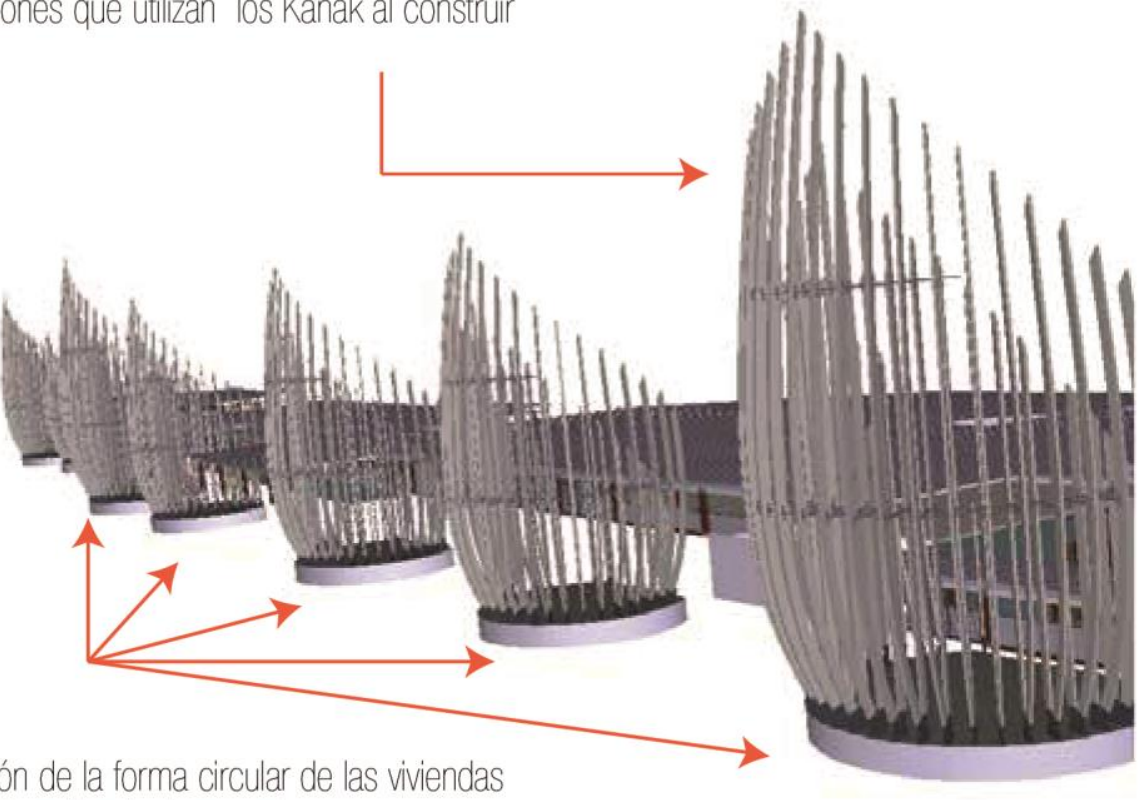

Aplicación de la forma circular de las viviendas

de la cultura Kanak al proyecto

Inspirada en: Viviendas de la cultura Kanak
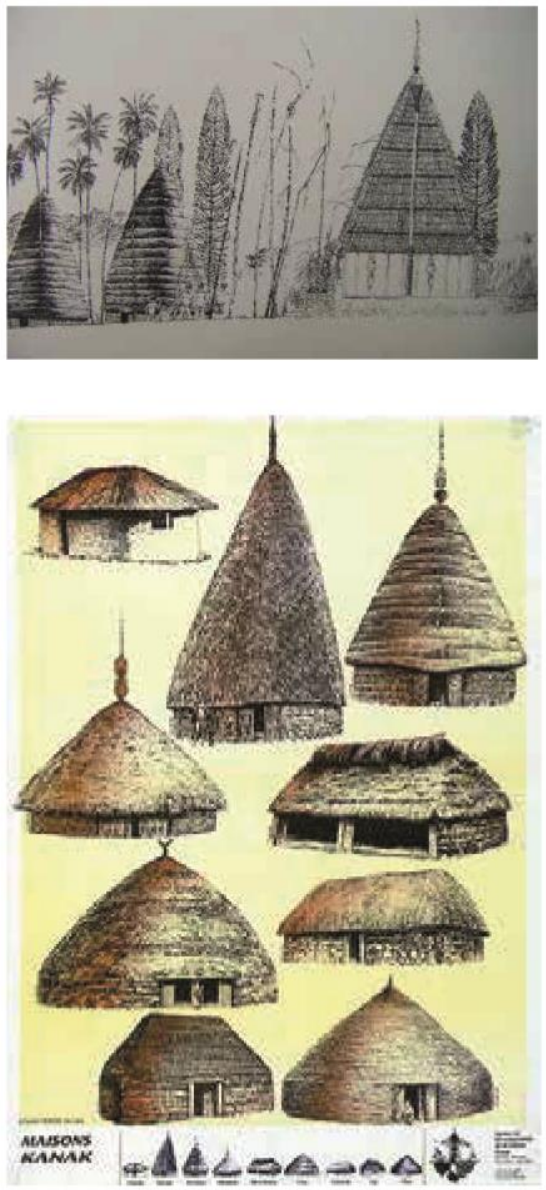

Cada casco presenta una doble capa

de madera vertical
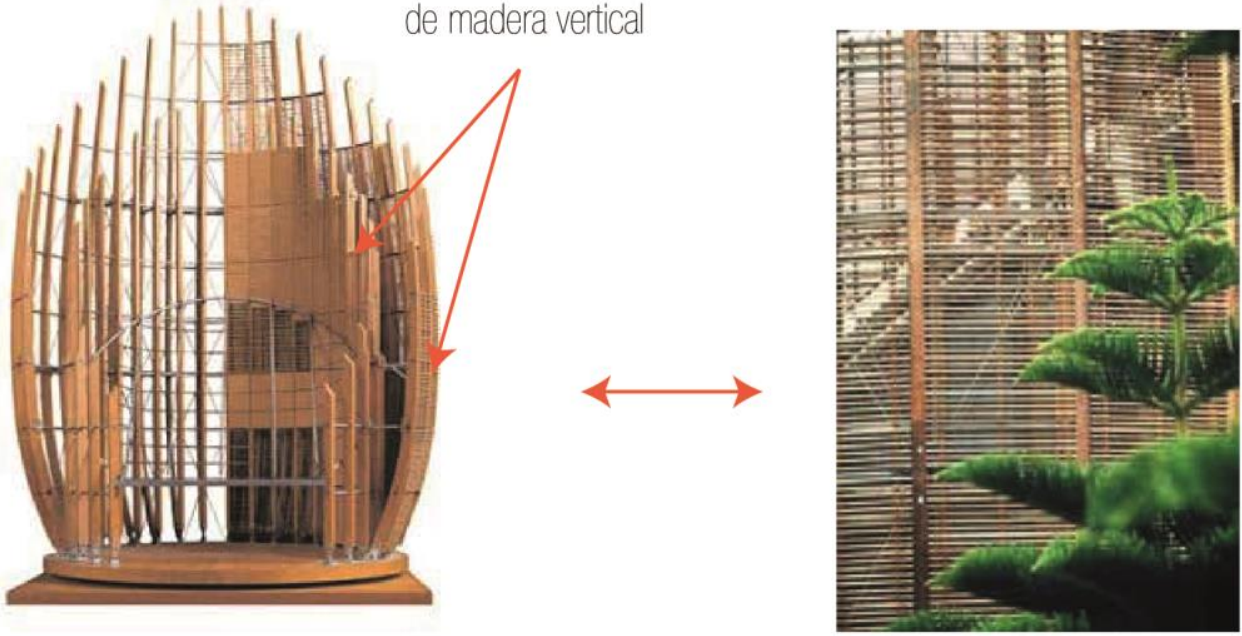

En la parte inferior tienen un teijido de protección y estructura como las viviendas de los Kanak 
CENTRO CULTURAL Y DE INTEPRETACIÓN JEAN MARIE TJIBAOU

SECCIÓN

\section{2 .2}

HISTORIA
UBICACIÓN

TECNOLOGÍA

\section{PROGRAMA}

FICHA

5.42

IMÁGENES DEL AUTOR EN BASE A:

IMPACTO SOCIAL

Texto: Tjibaou cultural center case of study- Harvard University

texto: Architecture and the representation of culture, The Tjibaou Cultural Center in New Caledonia

web: Plataforma de Arquitectura

La forma lineal responde a la ventilación y a las corrientes

de viento más intensas que vienen del Oceáno

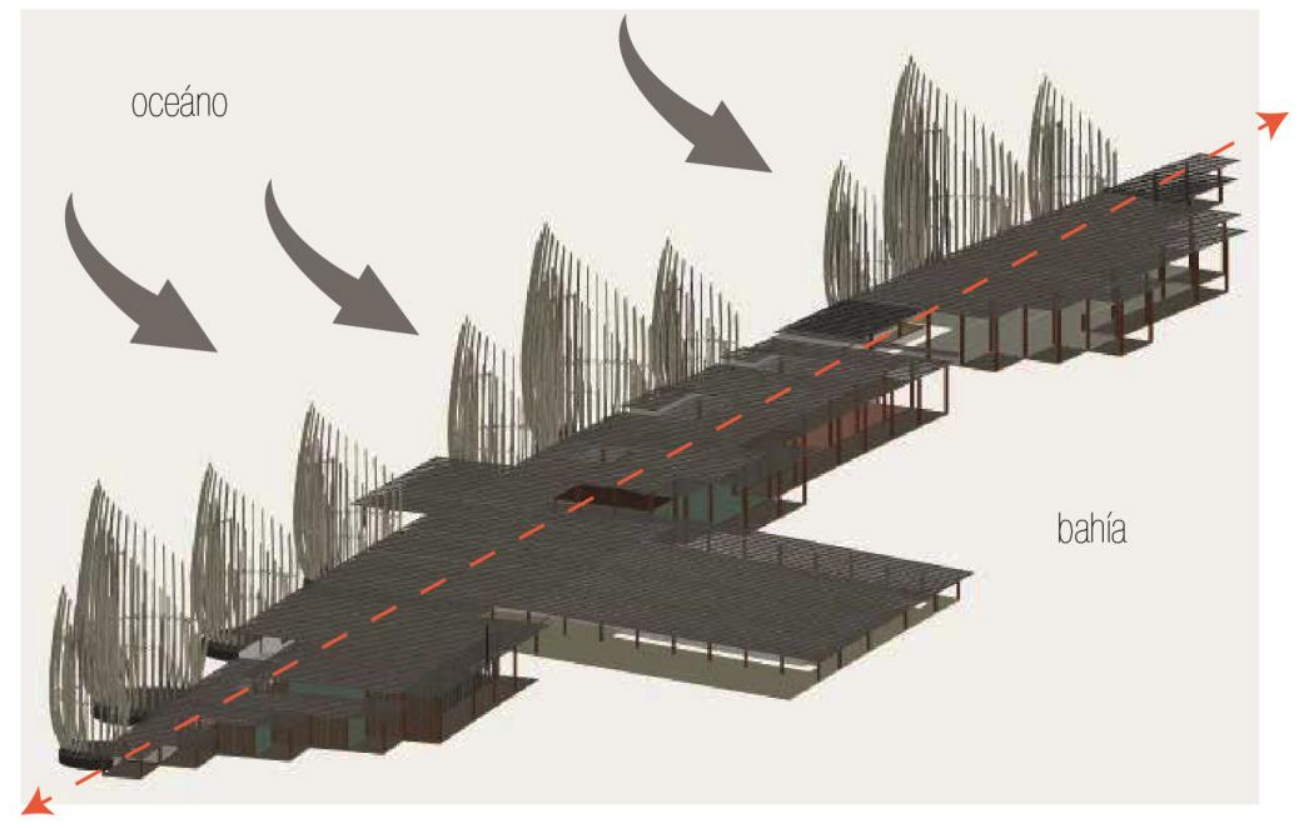

La forma delantera de los cascos es de un solo nivel, totalmente ortogonal

para favorecer por medio de los patios la ventilación cruzada
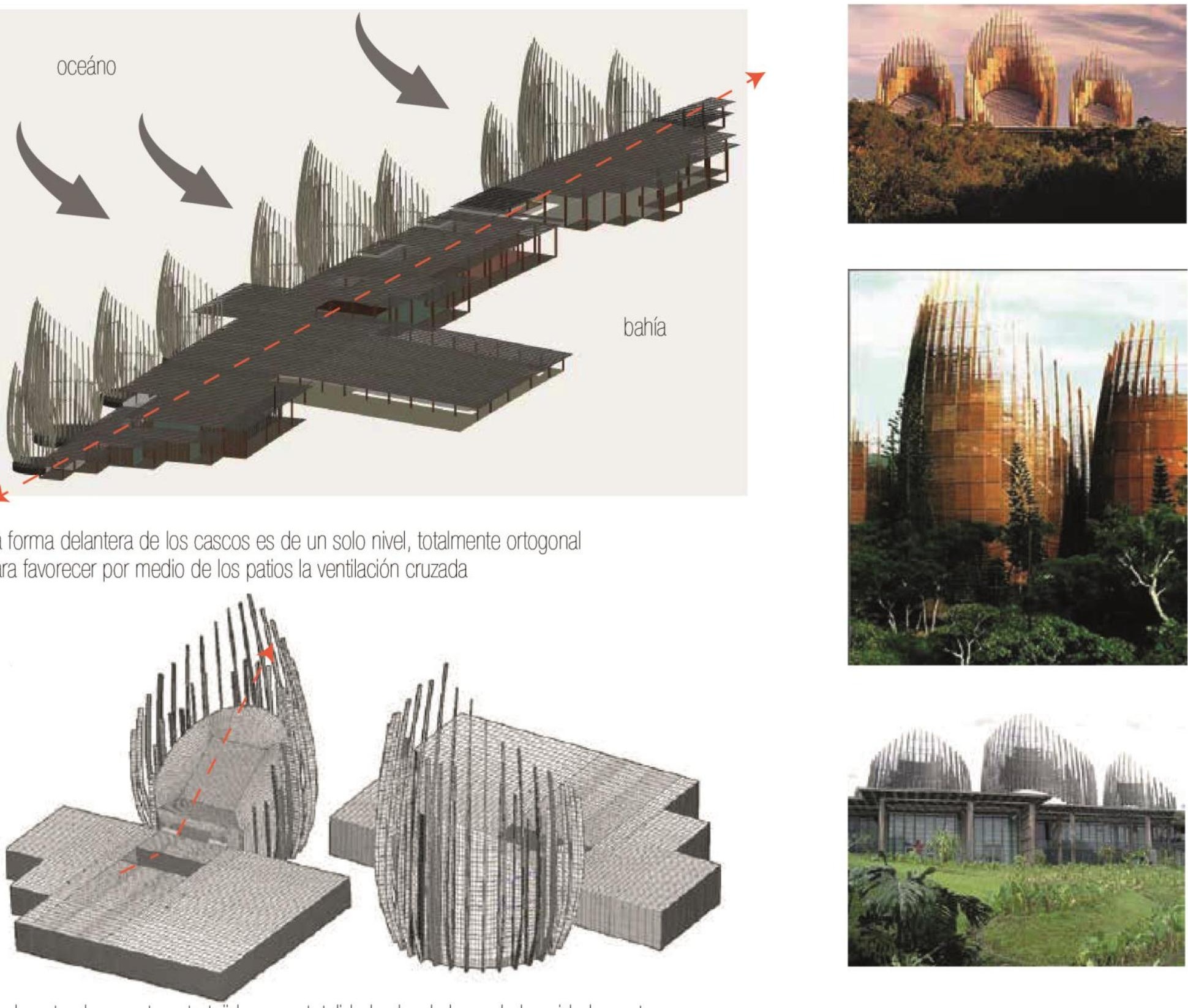

Finalmente el proyecto esta tejido en su totalidad sobre la base de la unidad, mante

niendo un orden con los elementos, para lograr Unidad en la FORMA utiliza los elemen -

tos repetitivos logrando un carácter unificado

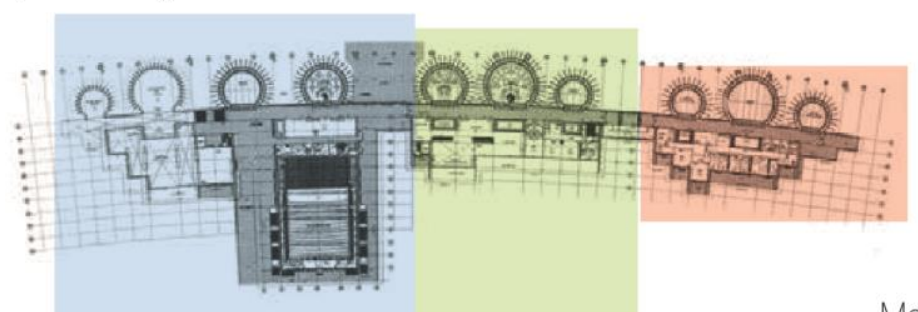




\section{CENTRO CULTURAL Y DE INTEPRETACIÓN JEAN MARIE TJIBAOU}

SECCIÓN

FICHA DEL PROYECTO HISTORIA UBICACIÓN

ESPACIO

TECNOLOGÍA

IMPACTO SOCIAL

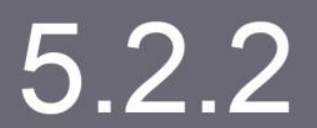

IMÁGENES DEL AUTOR EN BASE A :

Texto: Tjibaou cultural center case of study- Harvard University

texto: Architecture and the representation of culture, The Tjibaou Cultural Center in New Caledonia web: Plataforma de Arquitectura

\section{UBICACIÓN}

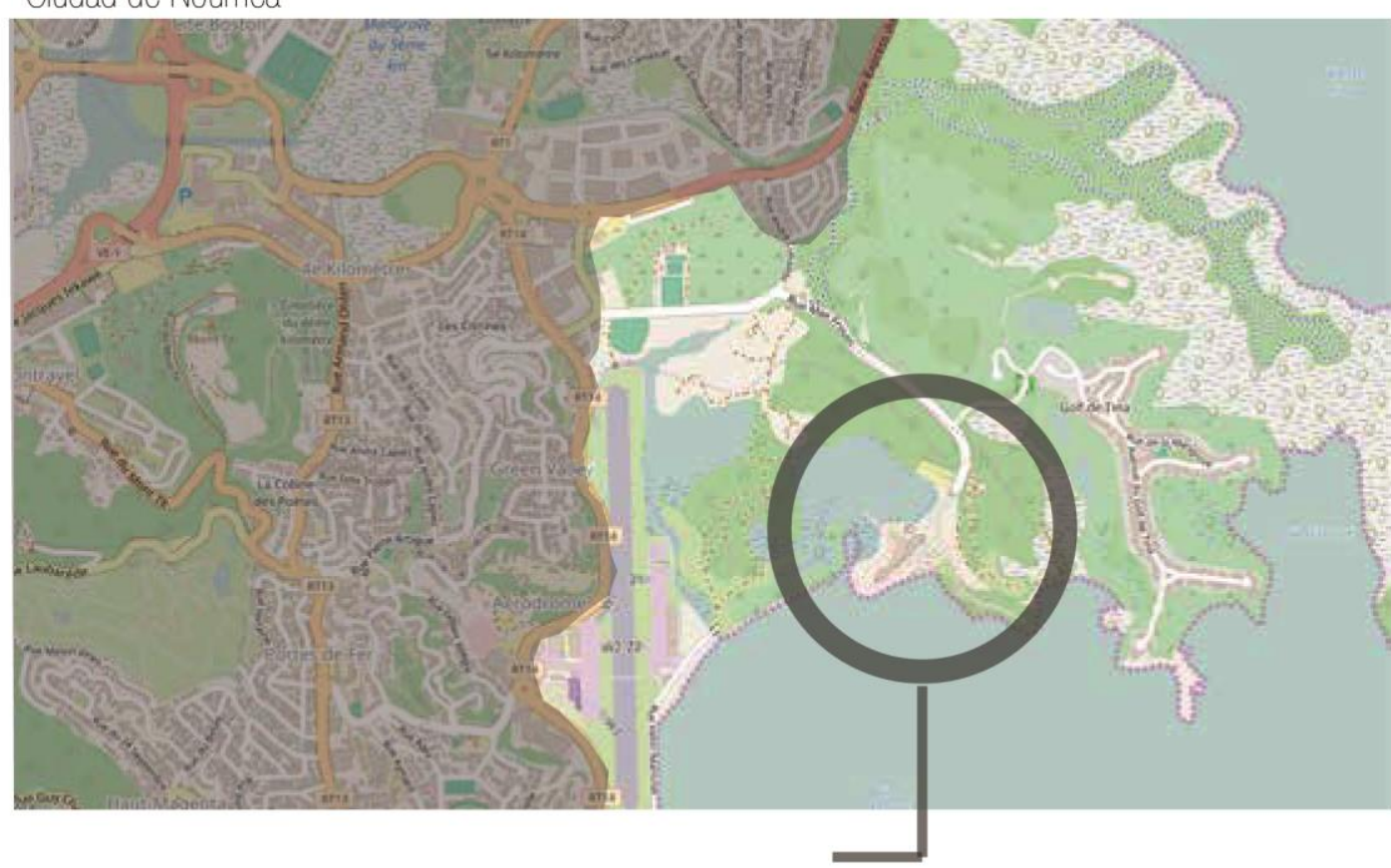

El Centro Cultural Jean Marie Tjibaou se encuentra a unos $10 \mathrm{~km}$ del centro de la ciudad de Nouméaen la Penísula Tina rodeada por tres lados con agua en la capital de Nouméa, Nueva Caledonia, que es una colonia Francesa y archipiélago de Oceanía situado en la Melanesia a 1500 km al este de Australia.

\section{PLANO CON ENTORNO INMEDIATO}

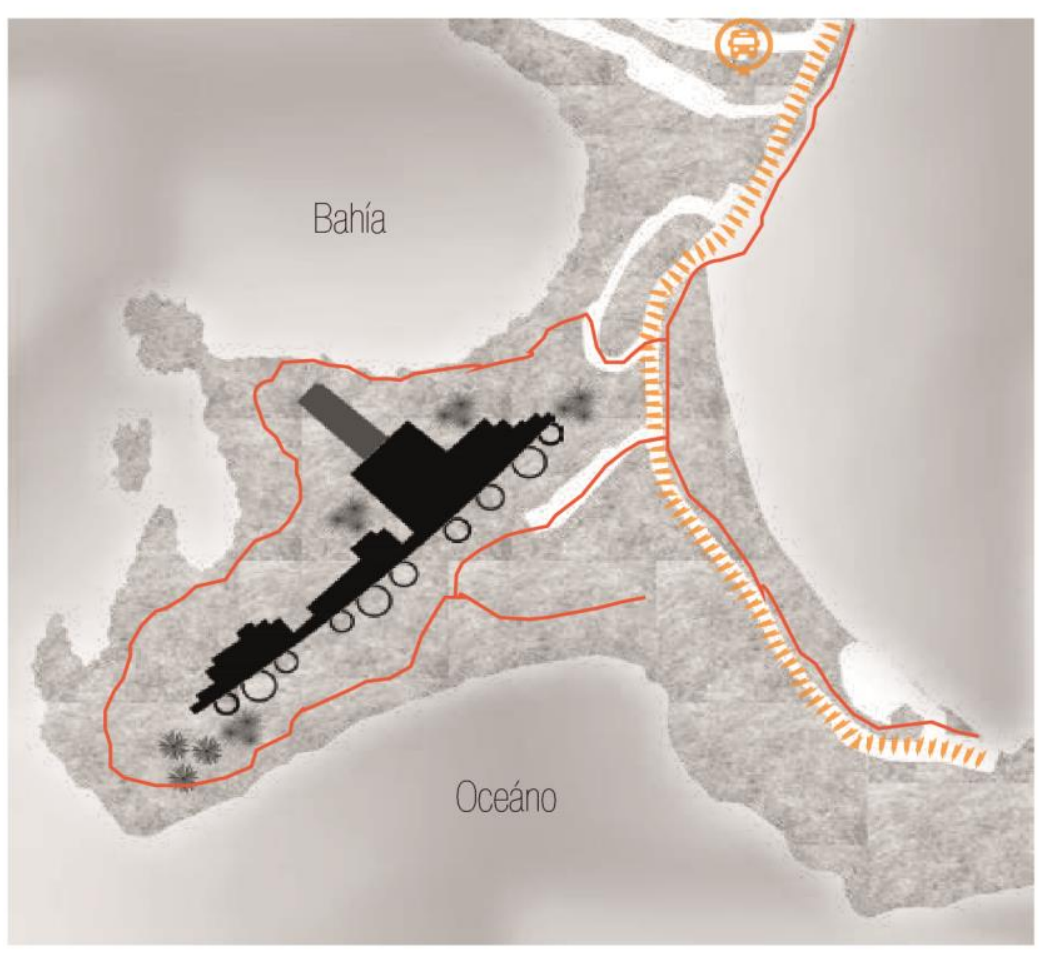

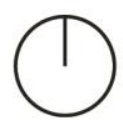

nombre de la calle: Rue Des Accords de Matignon

ङ Ciclovías

Y Vías peatonales

(日) Paradero más cercano al proyecto nombre: Centre Couturel

Tiempo estimado de llegada desde el centro de Nouméa (10 km)

Fen Vehículo particular

16 minutos.

7-a Transporte público

25 minutos

강 Bicicleta

50 minutos

Y Caminando

1 hora 30 minutos

paradero más cercano al Centro Cultural Jean Marie Tjibaou

$$
\text { Y. Caminando } 5 \text { minutos }
$$

El terreno asignado al proyecto se encuentra entre la laguna y bahía del oceáno. La laguna posee densos manglares en el borde del agua. 


\section{CENTRO CULTURAL Y DE INTEPRETACIÓN JEAN MARIE TJIBAOU}

\section{2 .2}

FICHA DEL PROYECTO

ESPACIO
HISTORIA

UBICACIÓN

TECNOLOGÍA

IMPACTO SOCIAL
FICHA

5.44

IMÁGENES DEL AUTOR EN BASE A

Texto: Tijibaou cultural center case of study- Harvard University

texto: Architecture and the representation of culture, The Tjibaou Cultural Center in New Caledonia

web: Plataforma de Arquitectura

ACCESOS PÚBLICOS PEATONALES

ESTACIONES DE TRANSPORTE

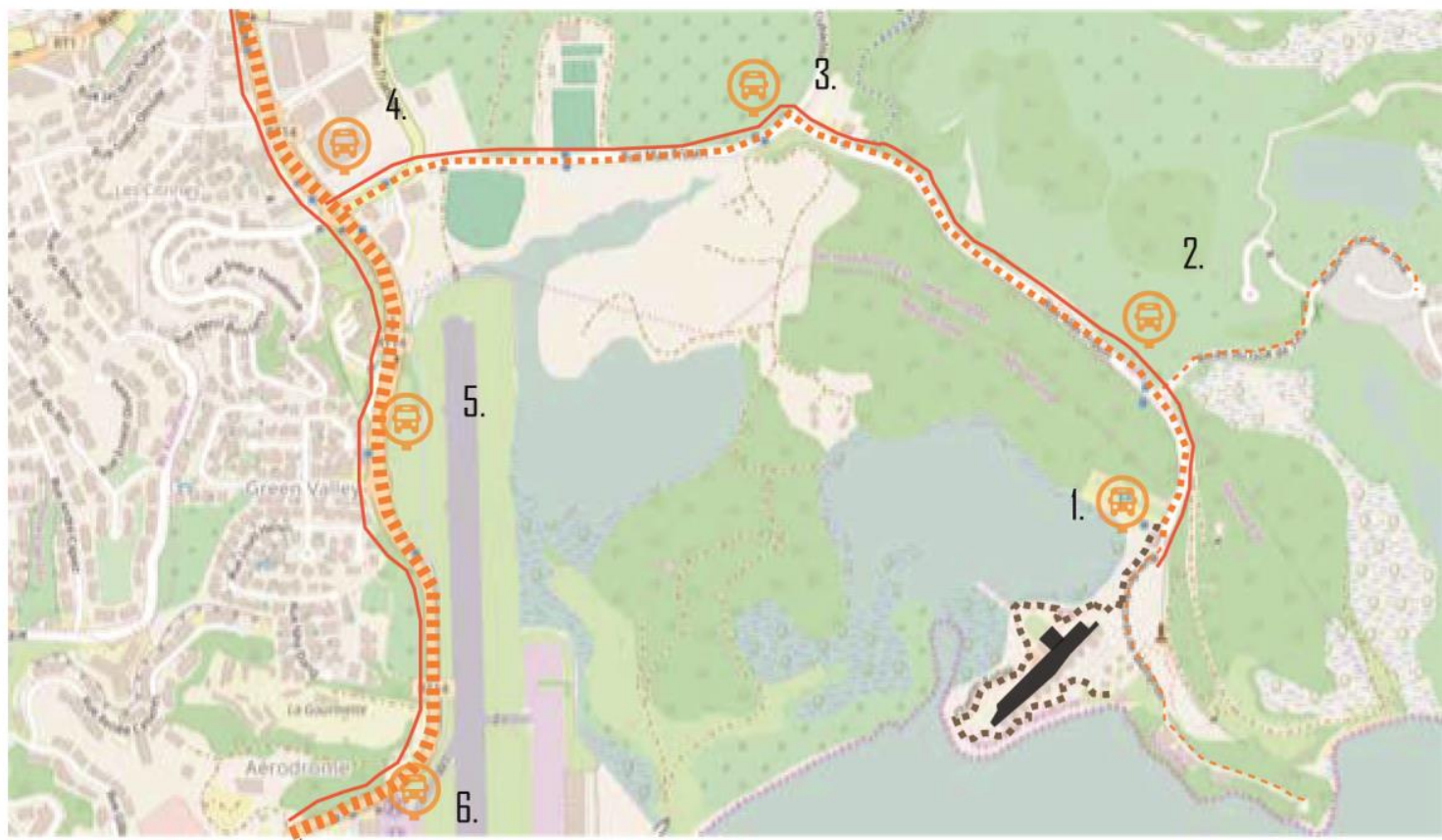

CORTES ESQLUEMÁTICOS
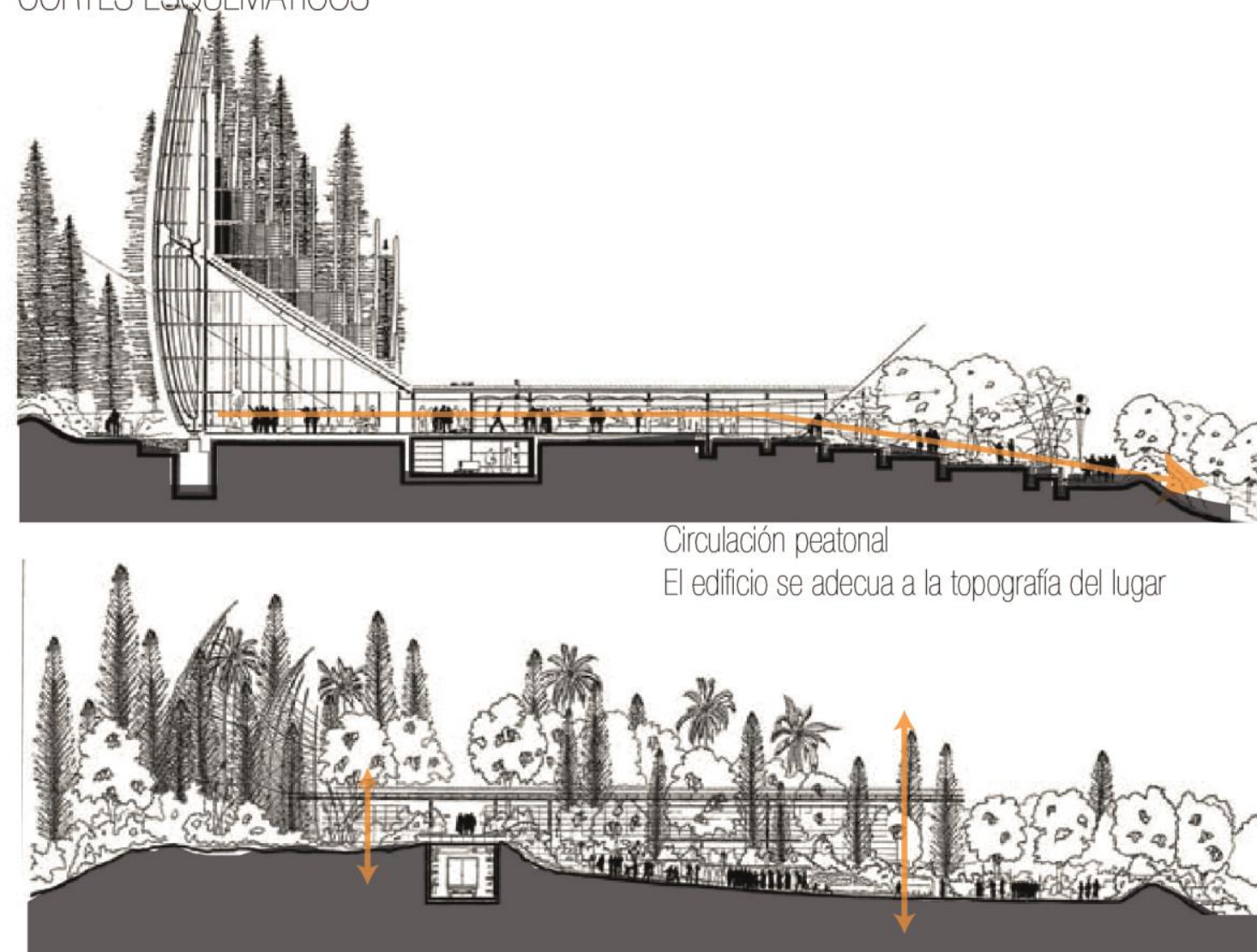

El edificio se pierde en la naturaleza, por el material que utiliza y por la altura del edificio

Circulación peatonal

El edificio se adecua a la topografía del lugar
VÍAS PRINCIPAL ES

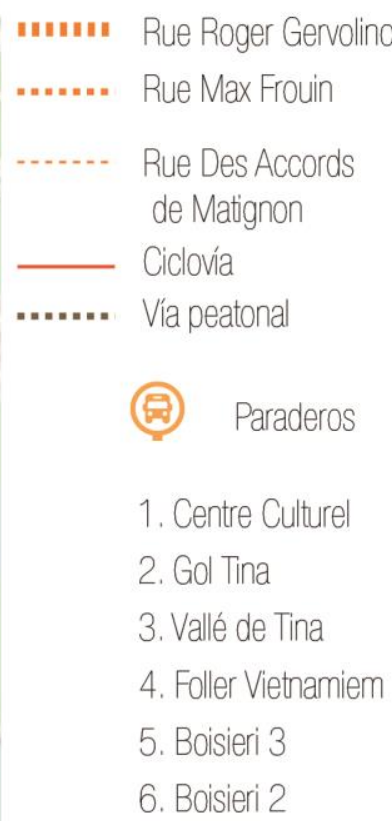

El acceso vehicular es hasta el estacionamiento del Centro Cultural, que se encuentra a 200m. del ingreso principal del edificio donde el acceso es peatonal.

E Centro Cultural Jean Marie Tjibaou esta ubicado cerca al Golf de Tina, la comunidad de los Kanak, desde sus inicios del proyecto no estuvieron de acuerdo con el emplazamiento, ya que el lugar no rememoraba el origen de la cultura 


\section{CENTRO CULTURAL Y DE INTEPRETACIÓN} JEAN MARIE TJIBAOU

SECCIÓN

\section{2 .2}

FICHA DEL PROYECTO ESPACIO
HISTORIA

UBICACIÓN
PROGRAMA

IMPACTO SOCIAI
FICHA

5.45

IMÁGENES DEL AUTOR EN BASE A :

Texto: Tjibaou cultural center case of study- Harvard University

texto: Architecture and the representation of culture, The Tjibaou Cultural Center in New Caledonia

web: Plataforma de Arquitectura

PAQUETES PROGRAMÁTICOS

CUADRO DEÁREAS

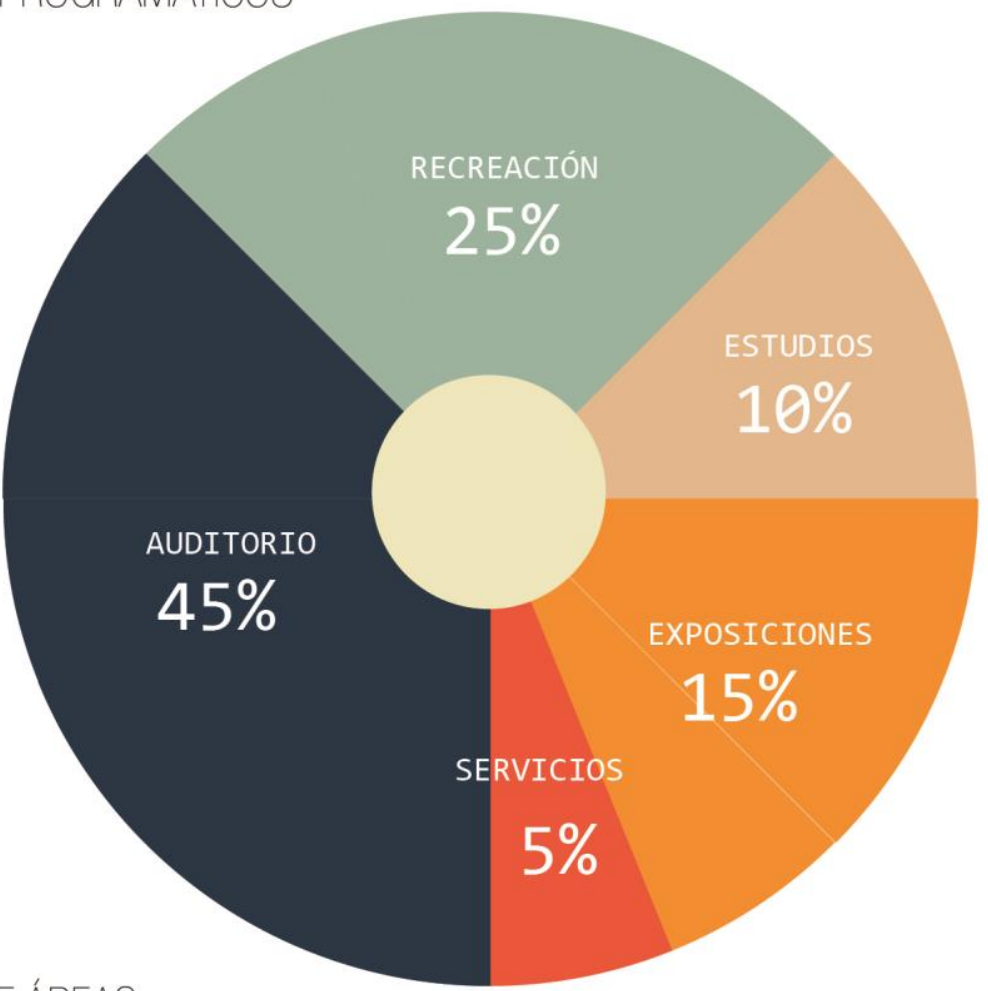

\begin{tabular}{|c|c|c|c|c|}
\hline AUDITORIO & RECREACIÓN & ESTUDIOS & EXPOSICIONES & SERVICIOS \\
\hline TEATRO & $\begin{array}{l}\text { NFITEATRO AL AIRE } \\
\text { LIBRE }\end{array}$ & $\begin{array}{l}\text { LABORES DE } \\
\text { INVESTIGACIÓN }\end{array}$ & $\begin{array}{l}\text { GALERIA ZONA A } \\
\text { EXPOSICION } \\
\text { PERMANENTE }\end{array}$ & CAFÉ \\
\hline $1200 \mathrm{~m} 2$ & $600 \mathrm{~m} 2$ & $63 \mathrm{~m} 2$ & $63 \mathrm{~m} 2 / 95 \mathrm{~m} 2 / 140 \mathrm{~m} 2$ & 95 m2 \\
\hline $\begin{array}{c}\text { SALA DE } \\
\text { CONFERENCIAS }\end{array}$ & TERRAZA 1 & 2 BIBLIOTECAS & $\begin{array}{l}\text { ESPACIO DE } \\
\text { MUESTRAS } \\
\text { TEMPORALES }\end{array}$ & ADMINISTRACIÓN \\
\hline \multirow[t]{3}{*}{$150 \mathrm{~m} 2$} & 300 m2 & $140 \mathrm{~m} 2 / 140 \mathrm{~m} 2$ & $300 \mathrm{~m} 2$ & $63 \mathrm{~m} 2$ \\
\hline & $\begin{array}{r}\text { SALA DEE USOS } \\
\text { MÚLTIPLES }\end{array}$ & SALÓN DE CLASE & GALERÍA ZONA B & BAÑOS \\
\hline & $250 \mathrm{~m} 2$ & $63 \mathrm{~m} 2$ & $250 \mathrm{~m} 2$ & $40 \mathrm{~m} 2$ \\
\hline
\end{tabular}

\section{SALÓN DE \\ COMPUTO \\ $63 \mathrm{~m} 2$}

HALL DE

LECTURA

$95 \mathrm{~m} 2$

\section{USUARIOS}

ถุำ

- Discapacitados

I. Estudiantes

Niños

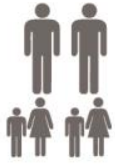

幅 Niños

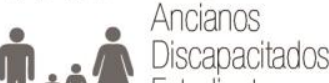

Estudiantes

Familias

10 Turistas

Personal capacitado

Empleados del área

de limpieza

servicio, administrativo, etc. 


\section{CENTRO CULTURAL Y DE INTEPRETACIÓN JEAN MARIE TJIBAOU}

FICHA DEL PROYECTO

ESPACIO
HISTORIA

UBICACIÓN

PROGRAMA

MPACTO SOCIAL

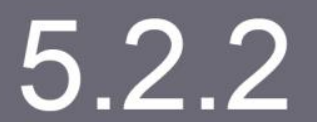

FICHA

5.46
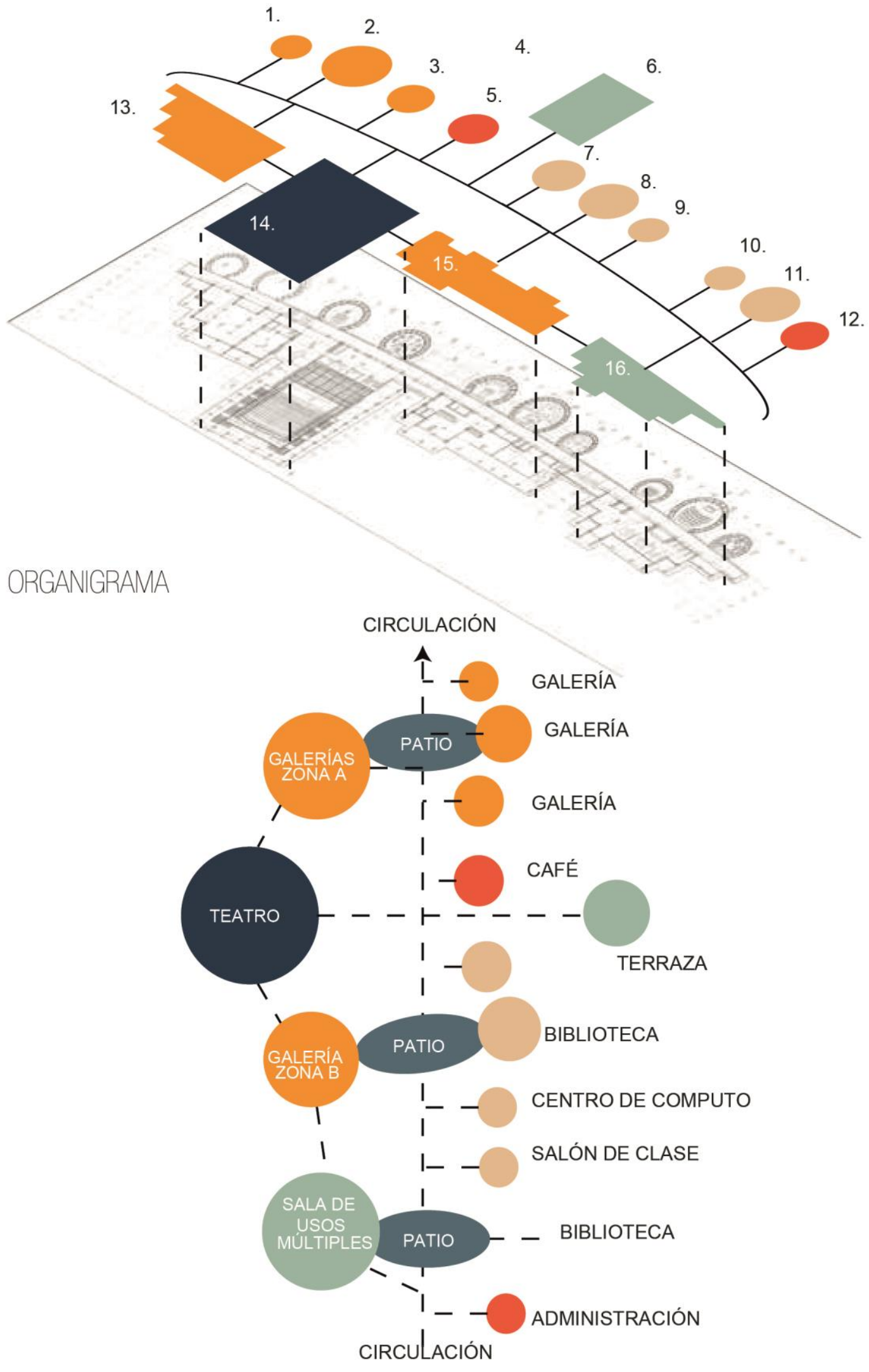

Leyenda de zonificación

1.Galería de exposición Permanente

2.Galería de exposición Permanente

3.Galería de exposición Permanente

4.Anfiteatro al aire libre

5.Café

6. Terraza 1

7. Hall de lectura

8. Biblioteca

9. Centro de computo

10. Salón de clase

11. Biblioteca 2

12. Administración

13. Galerías zona a

14. Auditorio/teatro

15. Galería zona b

16. Sala de usos múltiples 


\section{CENTRO CULTURAL Y DE INTEPRETACIÓN JEAN MARIE TJIBAOU}

\section{PROGRAMA}

ESPACIO

TECNOLOGÍA

IMPACTO SOCIAL

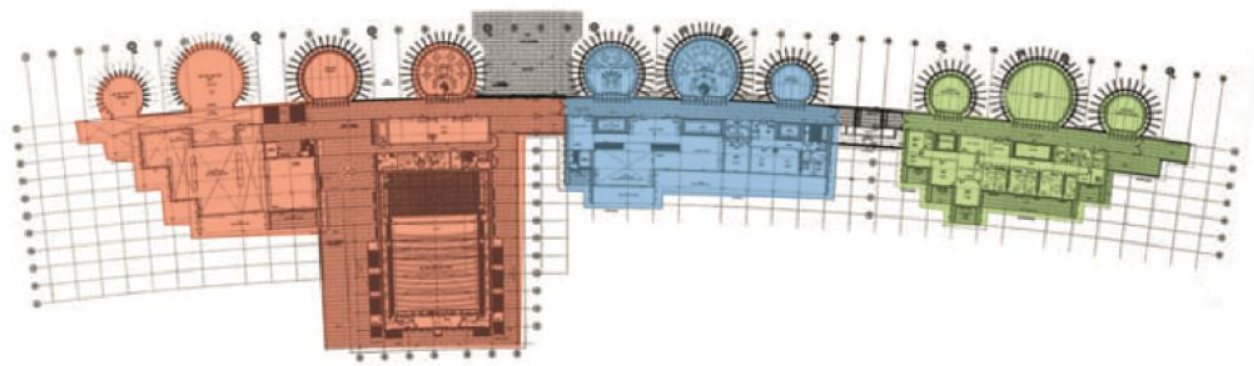

PAQUETE 1

PAQUETE 2

PAQUETE 3

Galería de exposición permanente Espacio de muestras temporales Auditorio

Anfiteatro al aire libre
Glabores de investigación Sala de conferencias Biblioteca

Hall de lectura
Sal a de usos múltiples

Salón de clase

Salón de computo

Administración Terrazas
RELACIÓN ESPACIAL
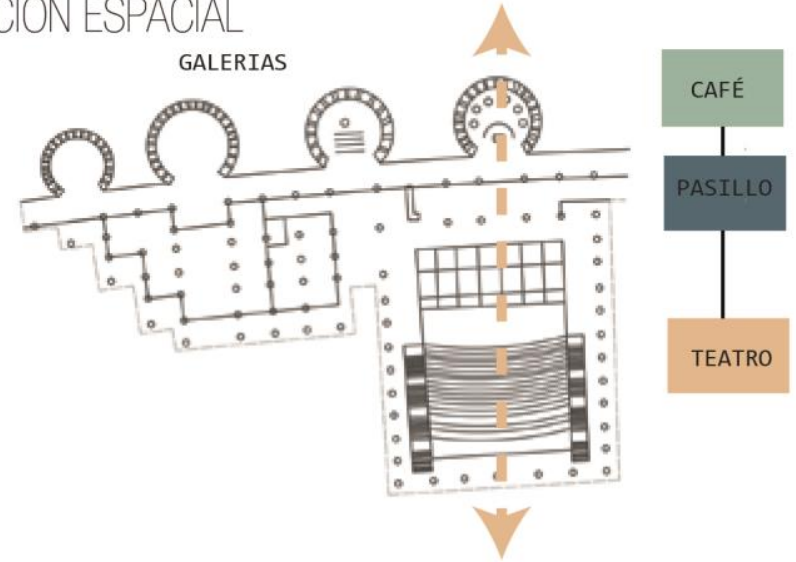

RELACIÓN ESPACIAL: YUXTAPOSICI6N

En este tipo de relación espacial hay una

comunicación entre dos o más espacios por medio de un pasillo

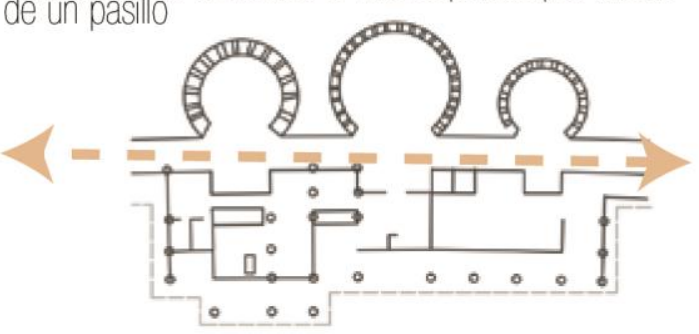

RELACIÓN ESPACIAL: INDEPENDIENTE

En este tipo de relación espacial solo existe una conexion general y cada uno tiene un acceso independiente

\begin{tabular}{l|l|l|l|}
$\begin{array}{l}\text { HALL DE } \\
\text { LECTURA }\end{array}$ & \multicolumn{2}{|c|}{ BIBLIOTECA } & $\begin{array}{r}\text { SALA DE } \\
\text { LECTURA }\end{array}$ \\
\hline & & & \\
\hline
\end{tabular}

FICHA

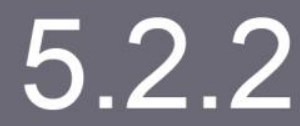

5.47 


\section{CENTRO CULTURAL Y DE INTEPRETACIÓN JEAN MARIE TJIBAOU}

\section{2 .2}

FICHA DEL PROYECTO

\section{ESPACIO}

HISTORIA

UBICACIÓN

PROGRAMA

TECNOLOGÍA
IMPACTO SOCIAL
FICHA

5.48

IMÁGENES DEL AUTOR EN BASE A :

Texto: Tjibaou cultural center case of study- Harvard University

texto: Architecture and the representation of culture, The Tjibaou Cultural Center in New Caledonia

web: Plataforma de Arquitectura

\section{DEFINICIÓN}

Una organización lineal consiste esencialmente en una serie de espacios. Estos espacios pueden estar interrelacionados directamente, o bien estar enlazados por otro espacio lineal independiente y distinto, asimismo una organización lineal suele estar compuesta por espacios lineales repetidos que son similares en tamaño, forma y función. También puede a lo largo de su longitud distribuir un conjunto de espacios de diferente tamaño.

Aquellos espacios que sean importantes, funcionales o simbólicamente dentro del centro cultural, pueden ocupar cualquier lugar en la secuencia lineal y mostrar la relevancia mediante sus dimensiones y forma.

Así también, las organizaciones lineales marcan una dirección y producen la sensación de movimiento, de extensión y de crecimiento. Para detener este crecimiento es correcto recurrir a la conclusión de organizaciones lineales con un espacio o una forma dominante, a la articulación de un acceso 0 a la conexión con otra forma constructiva o topográfica de emplazamiento.

El centro cultural según su temática de exposición está orientado a la historia de la cultura Kanak, al ámbito etnográfico de la comunidad y a difundir la diversidad cultural que existe en la ciudad, cuenta con una organización lineal, secuencial que muestra las costumbres e identidad de la cultura más grande de Nouméa-Nueva Caledonia.

\section{ESQUEMAS}

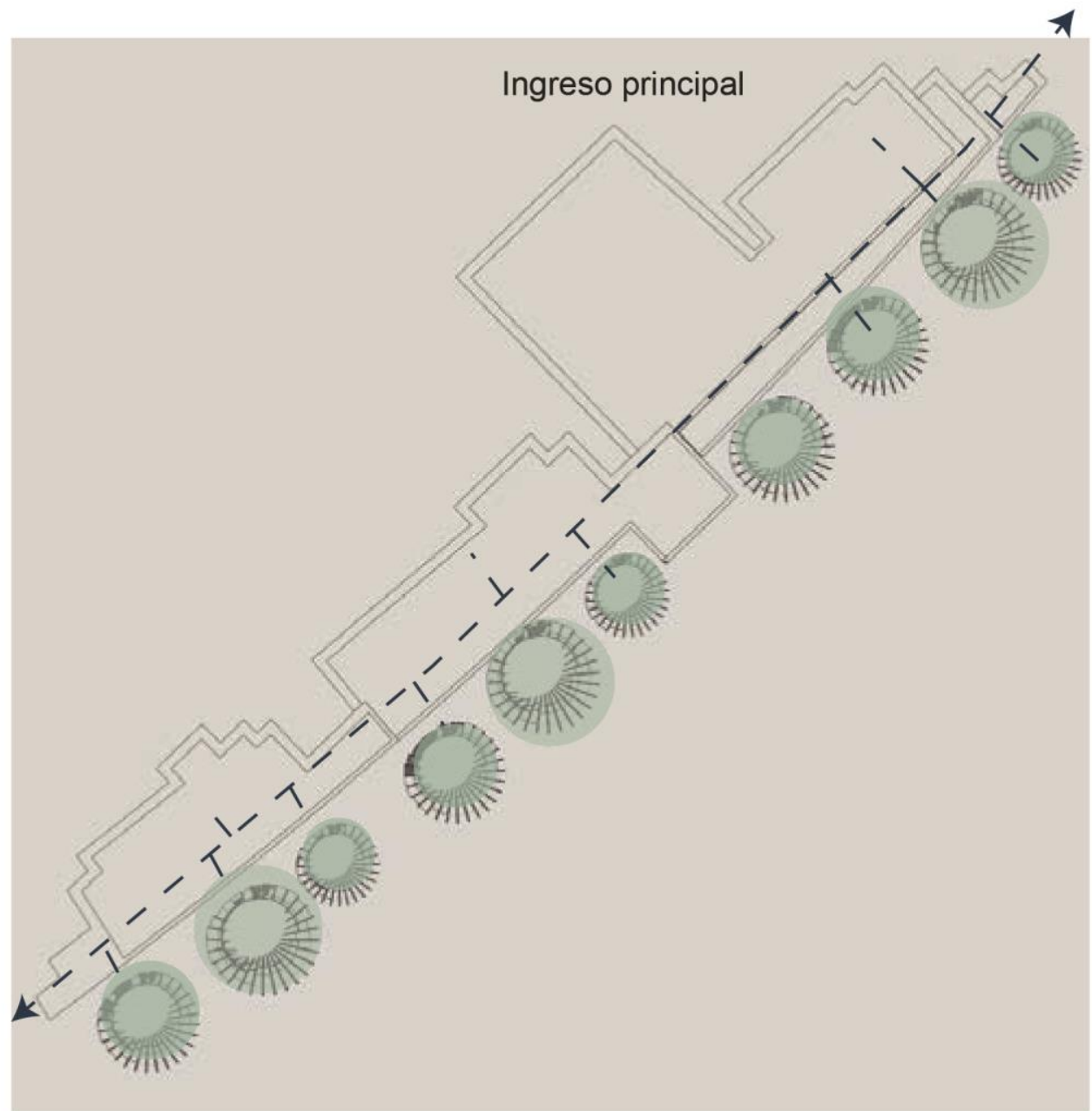

\section{Pasillo de circulación lineal}

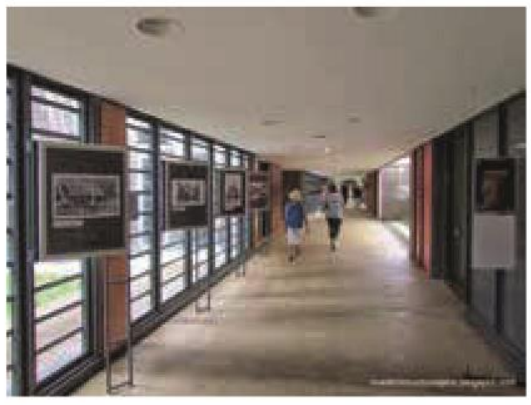

Sala de exhibición permanante acceso por medio del pasillo

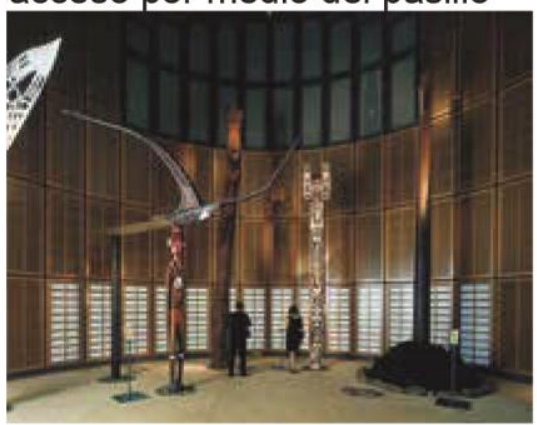

TEMÁTICA

HISTORIA

ETNOGRÁFICO 


\section{CENTRO CULTURAL Y DE INTEPRETACIÓN JEAN MARIE TJIBAOU}

SECCIÓN

\section{2 .2}

HISTORIA

UBICACIÓN

PROGRAMA

ESPACIO
TECNOLOGÍA

IMPACTO SOCIAL
FICHA

5.49

\section{IMÁGENES DEL AUTOR EN BASE A :}

Texto: Tjibaou cultural center case of study- Harvard University

texto: Architecture and the representation of culture, The Tjibaou Cultural Center in New Caledonia

web: Plataforma de Arquitectura

PÚBLICO-SEMIPÚBLICO-PRIVADO

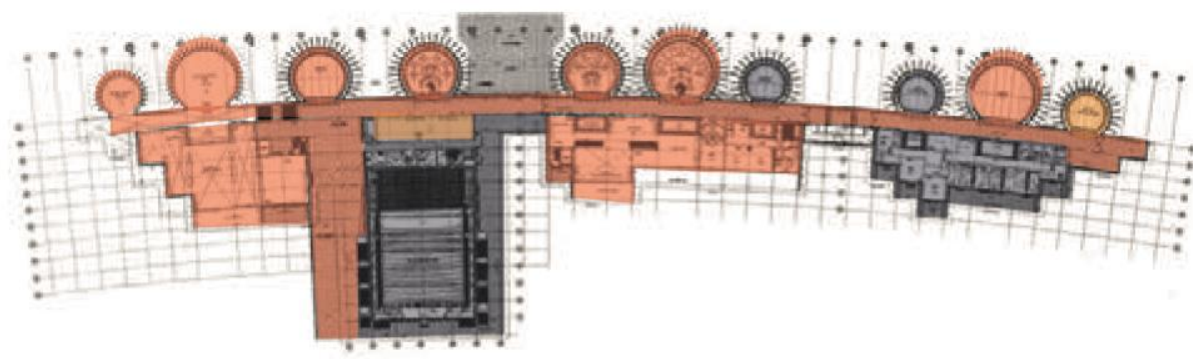

- SEMI-PÚBLICO

$5 \%$ ESPACIO PRIVADO

$\mathbf{2 0 \%}$ ESPACIO SEMI PÚBLICO

$\mathbf{8 5}$ \% ESPACIO PÚBLICO

NOLLY
PRIVADO

\section{FLUJOS Y CIRCULACIONES}

$12 \%$ CIRCULACIÓN

ÁREA CONSTRUIIDAÁREA LIBRE

ACCESO RESTRINGIDO

$15 \%$

ACCESO LIBRE

$85 \%$

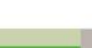

ÁREA CONSTRIIÍDA

8100 m2

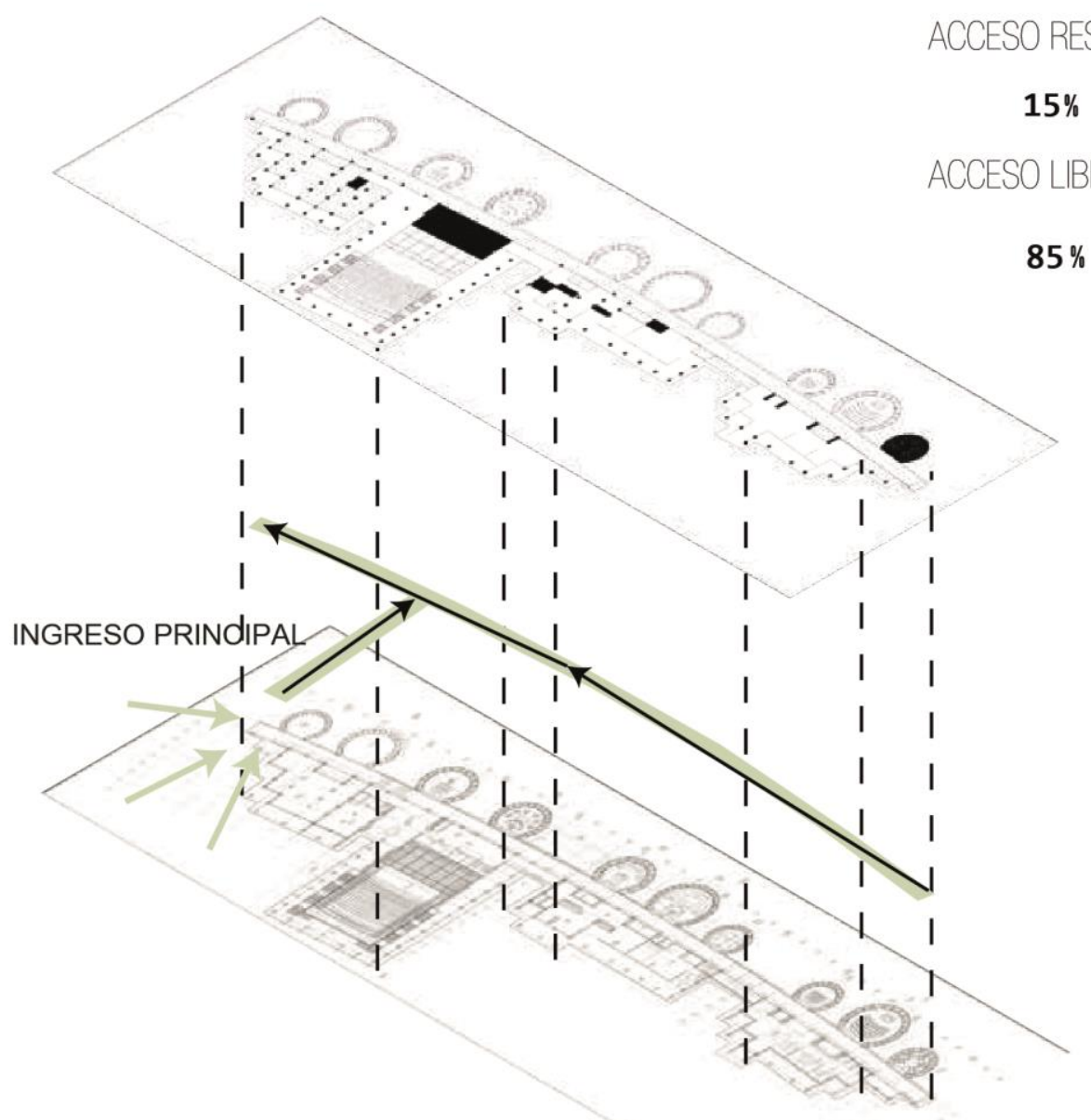

ÁREA LIBRE DEL EDIFICIO

450 m2

ÁREA TOTAL DEL EDIFICIO

8550 m2

ÁREA LIBRE PROTEGIDA

$20,000 \mathrm{~m} 2$

LEYENDA DE FLUJOS

Y CIRCULACIONES

Pasillos de circulación

Flujo de circulación 
CENTRO CULTURAL Y DE INTEPRETACIÓN JEAN MARIE TJIBAOU

SECCIÓN

\section{2 .2}

FICHA DEL PROYECTO ESPACIO
HISTORIA

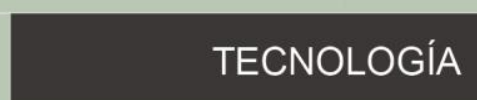

UBICACIÓN

IMPACTO SOCIAL
FICHA

5.50

IMÁGENES DEL AUTOR EN BASE A

Texto: Tjibaou cultural center case of study- Harvard University

texto: Architecture and the representation of culture, The Tjibaou Cultural Center in New Caledonia web: Plataforma de Arquitectura
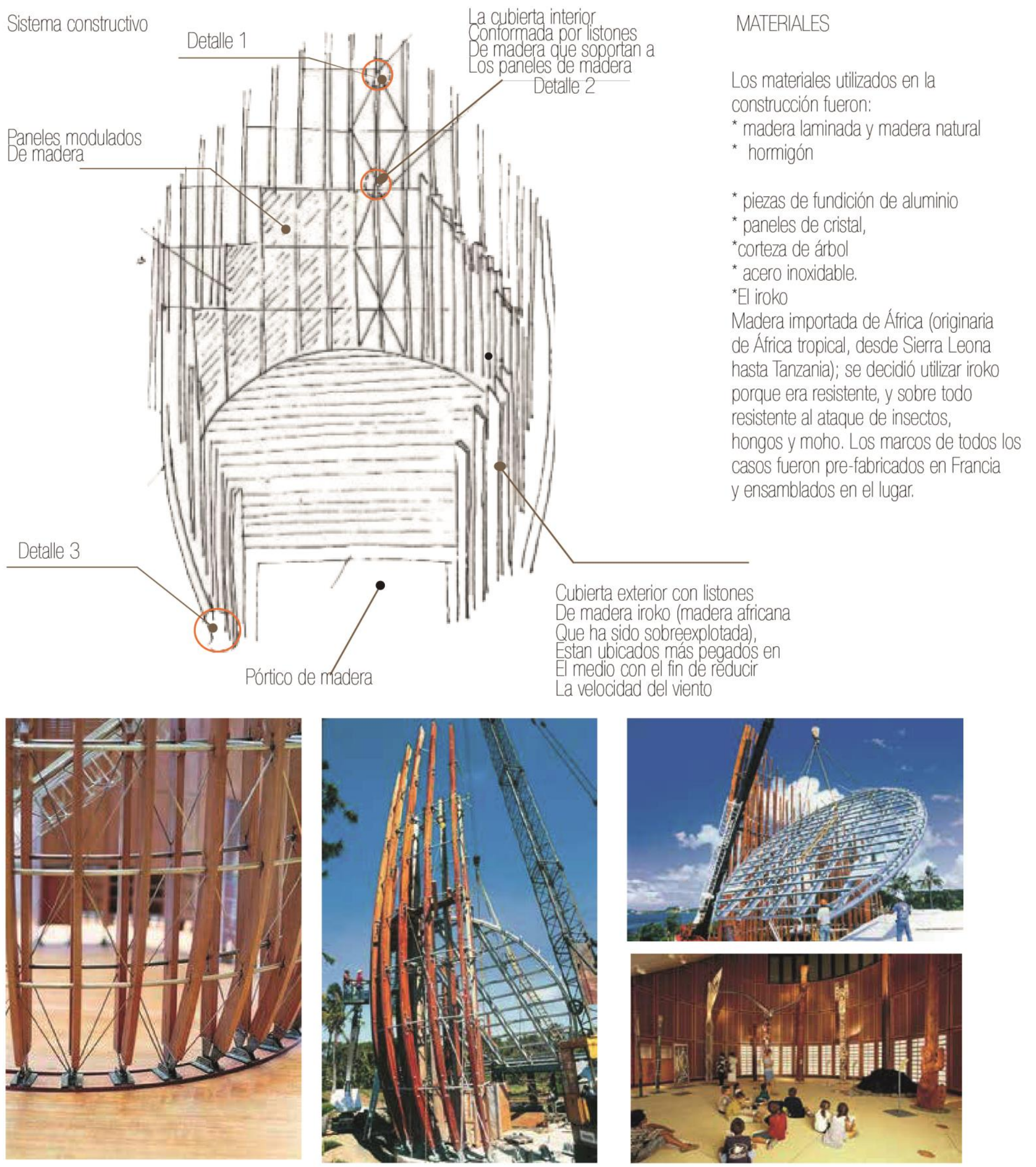
CENTRO CULTURAL Y DE INTEPRETACIÓN JEAN MARIE TJIBAOU
SECCIÓN

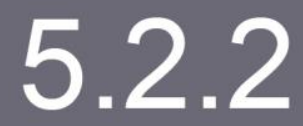

FICHA DEL PROYECTO

ESPACIO
HISTORIA

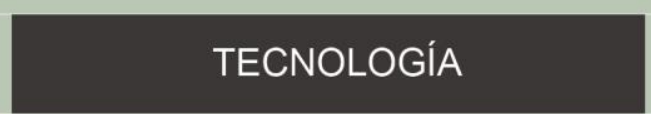

PROGRAMA

IMPACTO SOCIAL
FICHA

5.51

IMÁGENES DEL AUTOR EN BASE A :

Texto: Tjibaou cultural center case of study- Harvard University

texto: Architecture and the representation of culture, The Tjibaou Cultural Center in New Caledonia web: Plataforma de Arquitectura

SISTEMA CONSTRUCTIVO

DETALLE 1
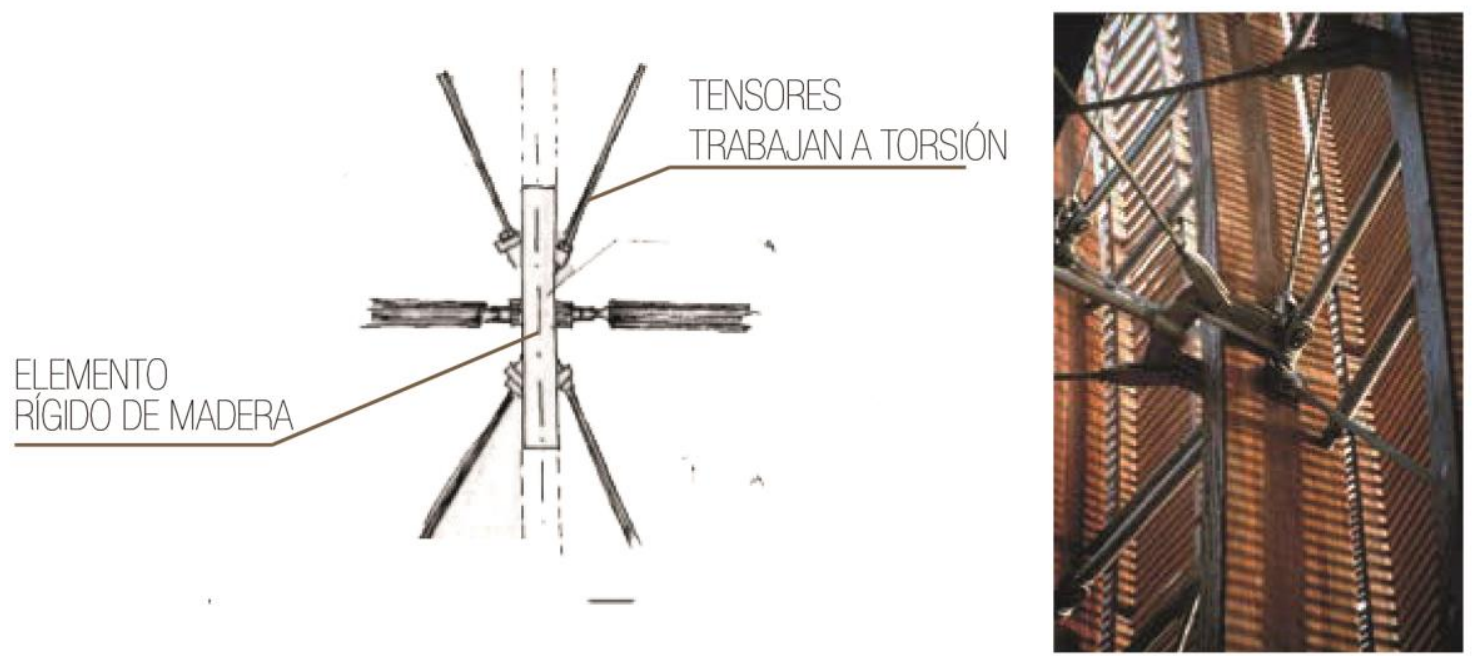

DETALLE 2

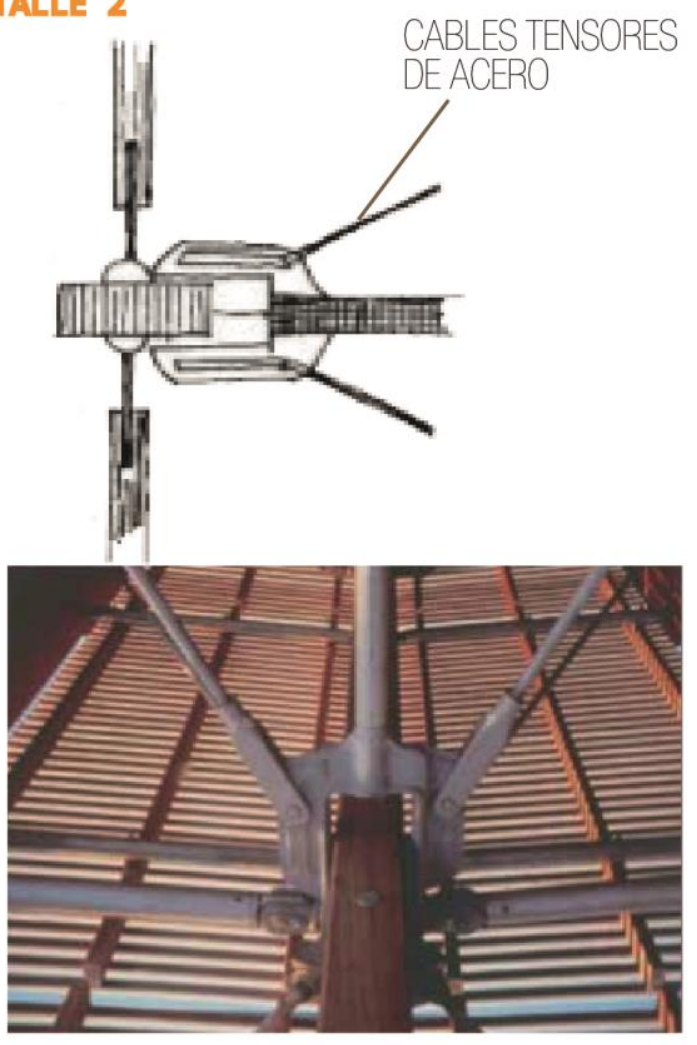

DETALLE 3
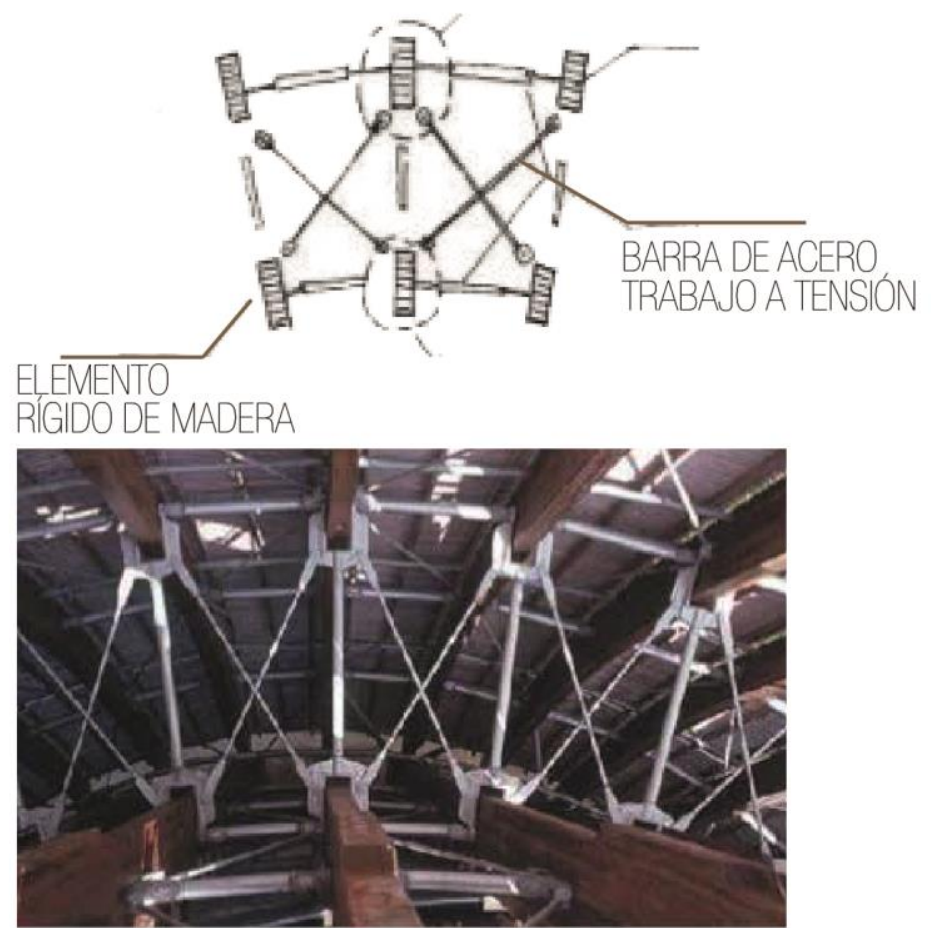

MATERIALES

La madera utilizada en la construcción fue la IROKO (por su gran durabilidad). Esta madera es proveniente del África y actualmente se encuentra sobrexplotada, la comunidad de los Kanak menciona que debieron haber utilizado la madera que ellos utilizan para la construcción de sus casas que son las palmeras jóvenes. 


\section{CENTRO CULTURAL Y DE INTEPRETACIÓN JEAN MARIE TJIBAOU}

\section{2 .2}

FICHA DEL PROYECTO

HISTORIA

UBICACIÓN

PROGRAMA

\section{ESPACIO}

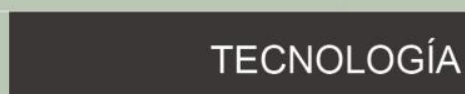

\section{IMPACTO SOCIAL}

FICHA

5.52

IMÁGENES DELAUTOR EN BASE A :

Texto: Tjibaou cultural center case of study- Harvard University

texto: Architecture and the representation of culture, The Tjibaou Cultural Center in New Caledonia

web: Plataforma de Arquitectura

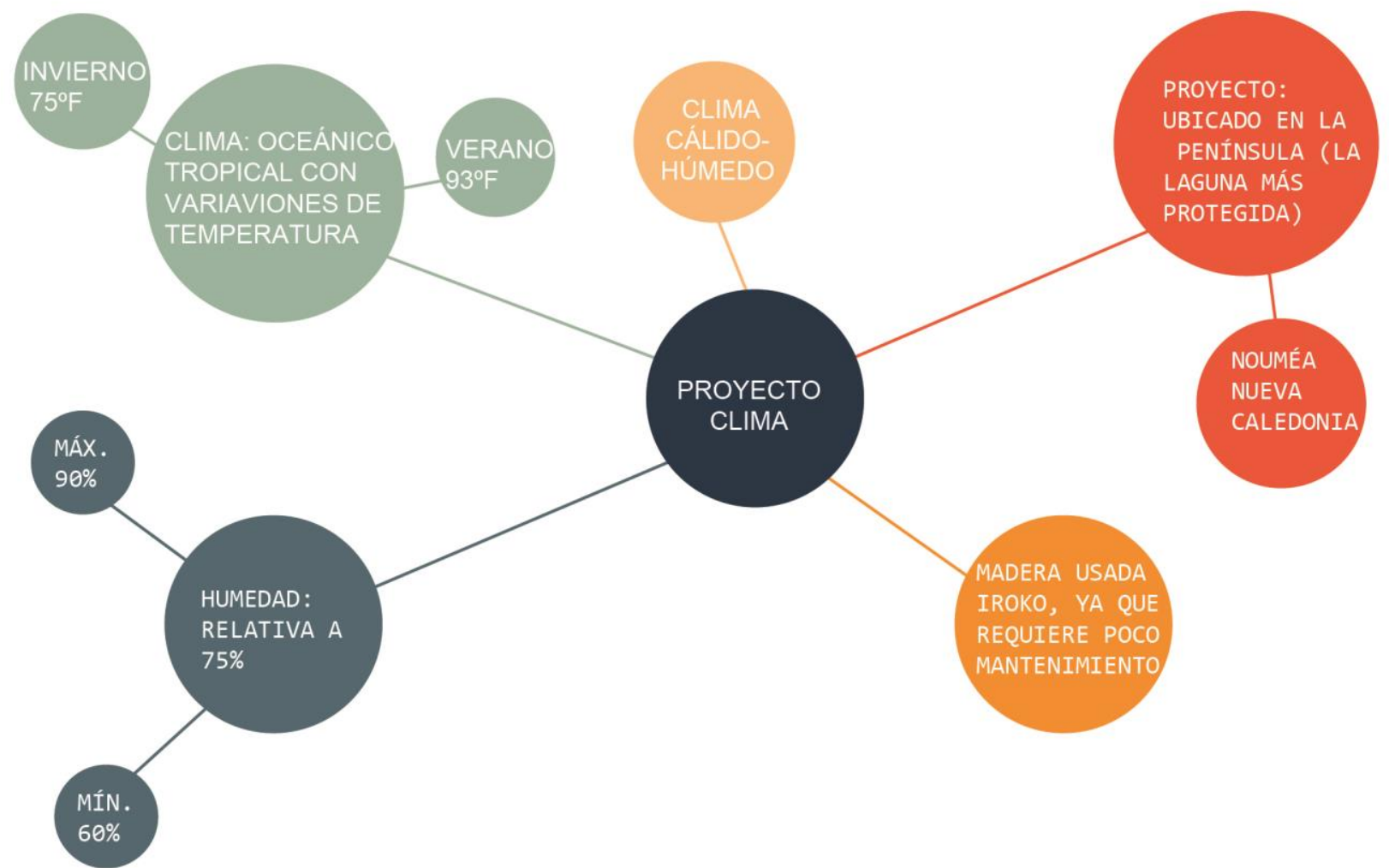

El Centro Cultural Jean Marie Tjibaou ubicada en la Penísula Tina utiliza en el diseño un sistema de ventilación natural para aminorar el uso de recursos artificiales, este sistema tiene dos principios que se mostrarán a continuación.

Principio de apilación: (ventilación canalizada o entubada) es aquella donde la tasa de ventilación se puede aumentar mediante la distancia vertical entre la entrada y salida.

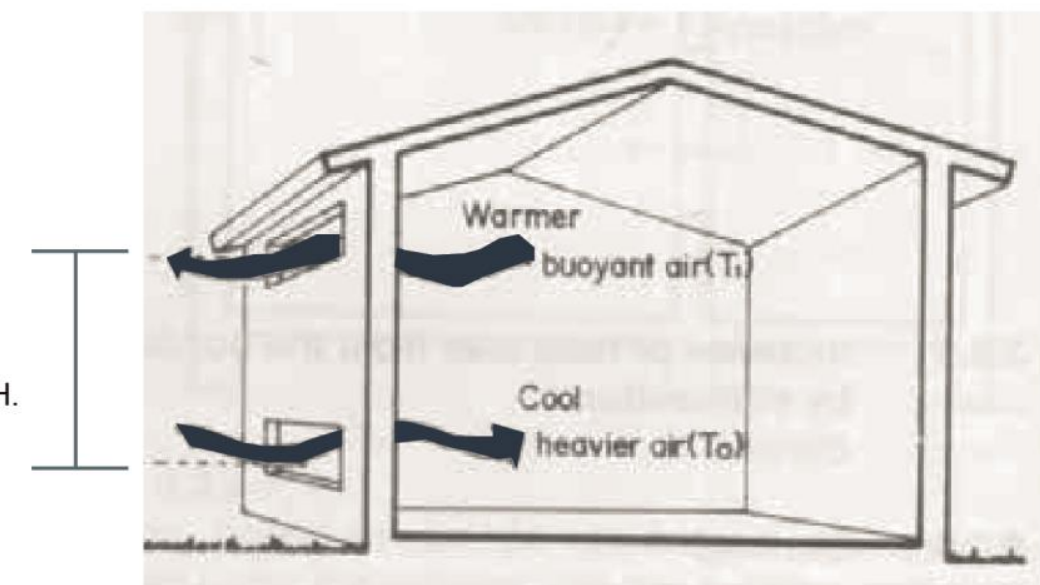




\section{CENTRO CULTURAL Y DE INTEPRETACIÓN JEAN MARIE TJIBAOU}

\section{2 .2}

FICHA DEL PROYECTO

ESPACIO
HISTORIA

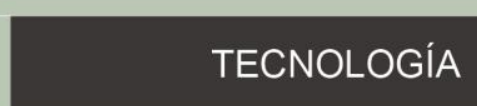

UBICACIÓN

IMPACTO SOCIAL
FICHA

5.53

IMÁGENES DEL AUTOR EN BASE A :

Texto: Tjibaou cultural center case of study- Harvard University

texto: Architecture and the representation of culture, The Tjibaou Cultural Center in New Caledonia web: Plataforma de Arquitectura
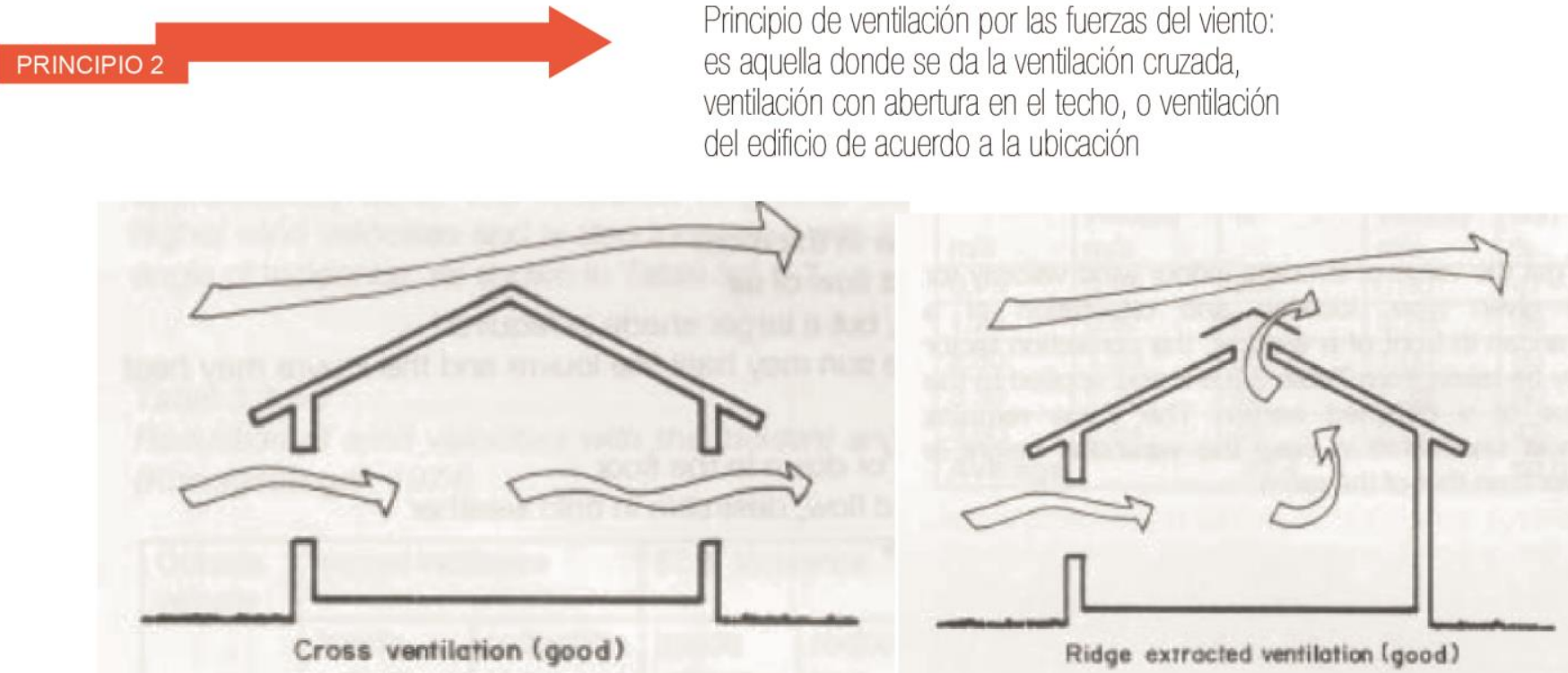

Ambos principios son utilizados en el diseño del edificio, el sistema de ventilación natural es eficiente cuando hablamos de los cascos de madera individualmente, pero en conjunto es un sistema que no funciona;por ejemplo la sala de computación y el auditorio que son ambientes que generan más calor necesitan aire acondicionado porque el sistema de ventilación natural no abastece las necesidades

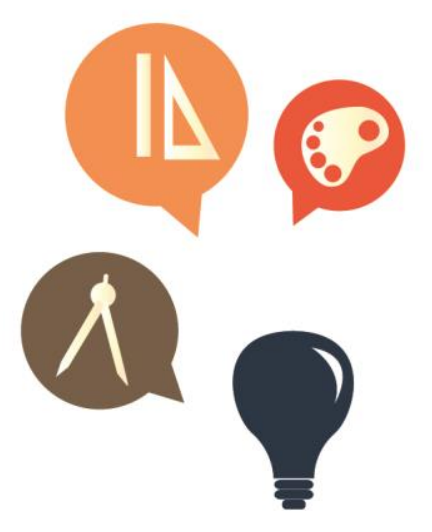

La idea inicial del edificio planteaba los cascos de madera en ambos sentidos algunos abiertos y otros cerrados supuestamente para lograr una mejor ventilación dentro de el edificio, ya que los cascos tenían aberturas hacia el barlovento ( a lado del mar) y sotavento (a lado de la bahía).

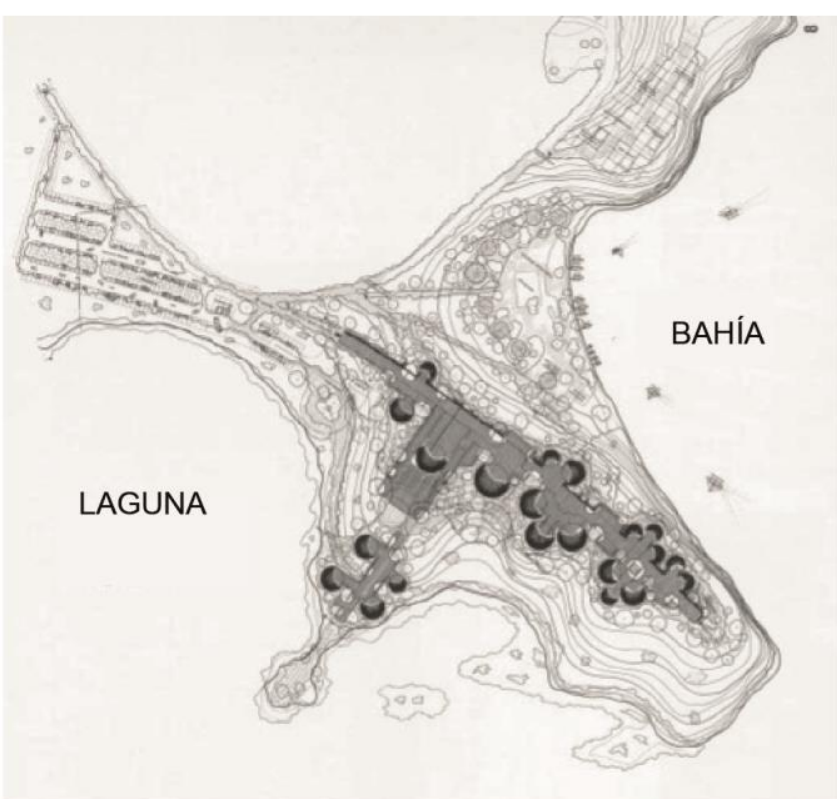




\section{CENTRO CULTURAL Y DE INTEPRETACIÓN JEAN MARIE TJIBAOU}

\section{2 .2}

FICHA DEL PROYECTO

ESPACIO
HISTORIA UBICACIÓN PROGRAMA

TECNOLOGÍA
IMPACTO SOCIAL
FICHA

5.54

IMÁGENES DEL AUTOR EN BASE A :

Texto: Tjibaou cultural center case of study- Harvard University

texto: Architecture and the representation of culture, The Tjibaou Cultural Center in New Caledonia web: Plataforma de Arquitectura

Al momento de realizar las pruebas de viento a escala real se dieron cuenta que la distribución de los cascos no favorecía a la ventilación natural al interior del edificio, es así que reordenan los cascos y los ubican de forma lineal, de tal manera que sirvan como palas eólicas.

Sin embargo a todo el dificio en conjunto no abastecía la ventilación natural, pero sí lo hacia a los cascos individualmente.

$3 \mathrm{~m} / \mathrm{s} \quad 6 \mathrm{~m} / \mathrm{s} \quad 10 \mathrm{~m} / \mathrm{s} \quad 15 \mathrm{~m} / \mathrm{s}$ ciclón inverso
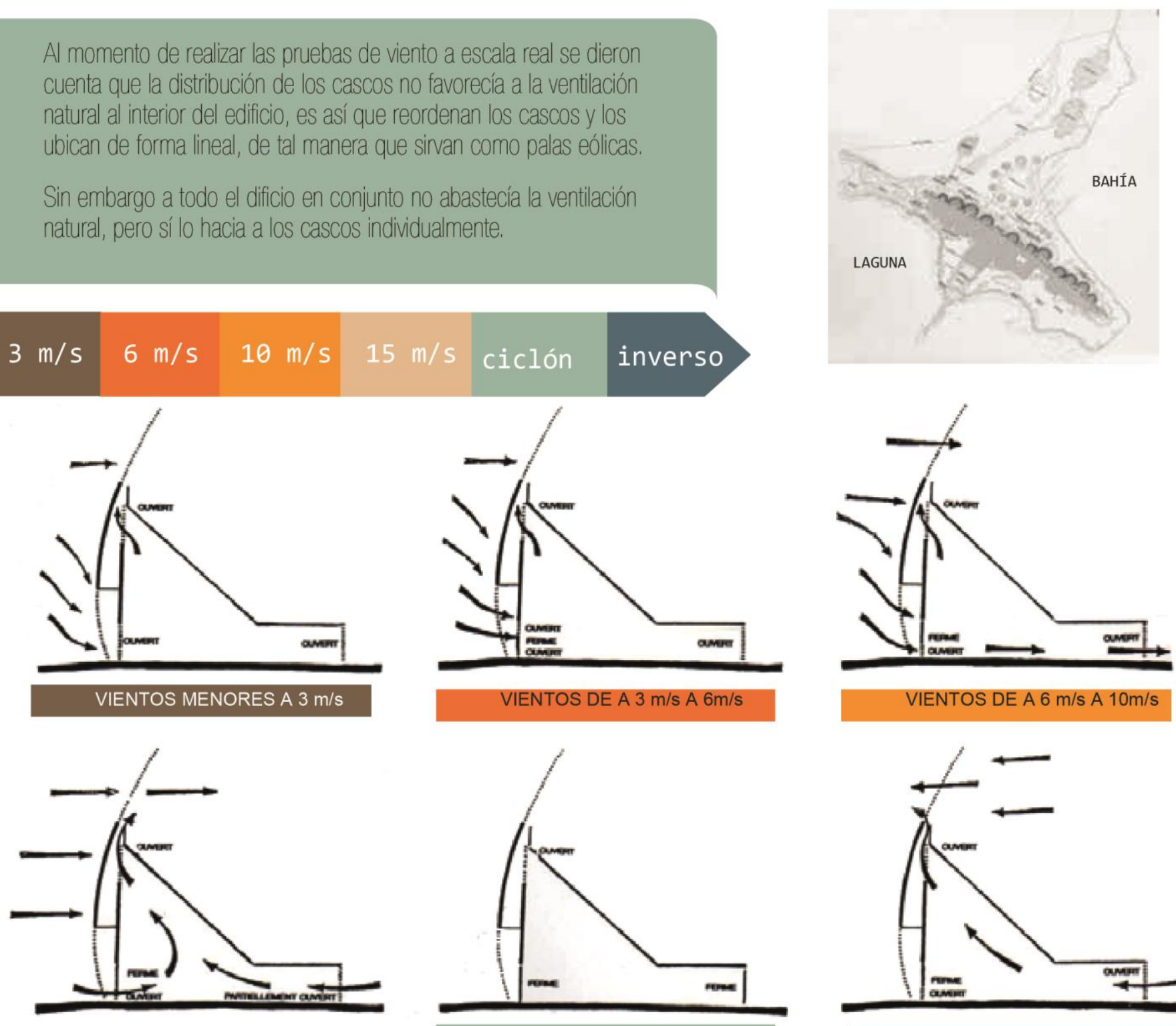

VIENTOS DE A $10 \mathrm{~m} / \mathrm{s}$ A $15 \mathrm{~m} / \mathrm{s}$
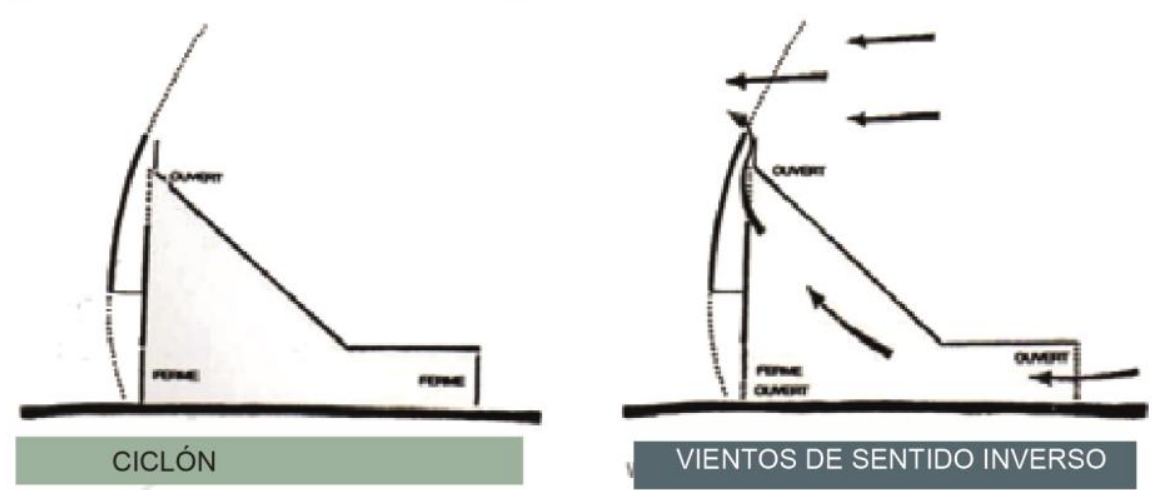

VIENTOS DE SENTIDO INVERSO

La cobertura del edificio controla las diferentes fuerzas del viento, ya que contiene unas rejillas computarizadas que permiten

el acceso del viento de acuerdo a la velocidad que tiene, como vemos en la imagen superior

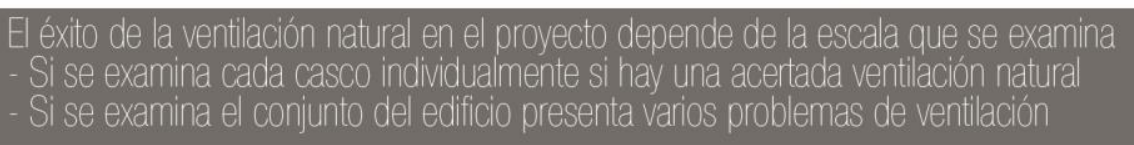

La repetición del sistema de ventilación no es favorable para el proyecto, ya que varios

espacios como la sala de computo y el auditorio no funcionan con este tipo de ventilación, ya

que poseen características especiales que necesitan otro tipo de tratamiento 


\section{CENTRO CULTURAL Y DE INTEPRETACIÓN JEAN MARIE TJIBAOU}

\section{FICHA DEL PROYECTO}

ESPACIO
HISTORIA

UBICACIÓN

PROGRAMA

\section{2 .2}

ESPACIO TECNOLOGIA IMPACTO SOCIAL
IMÁGENES DEL AUTOR EN BASE A:
Texto: Tjibaou cultural center case of study- Harvard University
texto: Architecture and the representation of culture, The Tjibaou Cultural Center in New Caledonia
web: Plataforma de Arquitectura

FICHA

5.55
MEMORIA Y TRADICIONES

CALIDAD DE VIDASSATISFACCIÓN

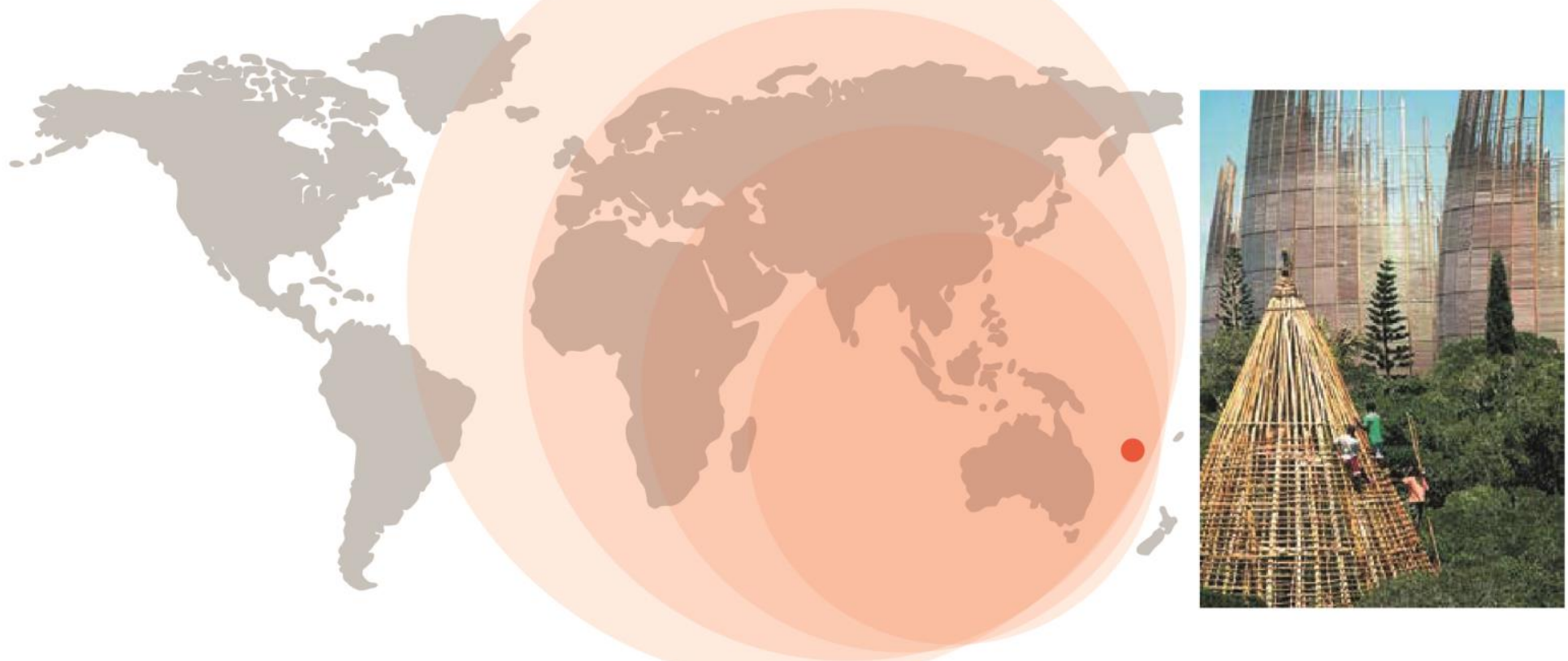

El Centro Cultural Jean Marie Tijbaou tiene un impacto a nivel internacional, ya que la innovación con un edificio aparentemente sencillo, pero en realidad con una técnica arquitectónica compleja llama mucho la atención. Asimismo, el centro cultural posee características positivas frente al movimiento arquitectónico de su época porque no cae en formalismos superficiales, es decir no pretende imitar una historia, ni tampoco recrearla, la relata, la investiga y presenta a la cultura Kanak en un objeto arquitectónico.

La intervención arquitectónica no puede dejar de lado la historia, la tradición, el contexto construido. Es la arquitectura un aspecto de transformación y un actor directo de este proceso, reinventándose con el vivir de la ciudad y la sociedad, y que hoy en día ha ido perdiendo poco a poco ese carácter de identidad que ha cargado durante años con la cultura de los pueblos. Todo está ligado a un contexto y más aún a una realidad humana heterogénea en el planeta.

Arquitectónicamente el proyecto genera un gran impacto social en el mundo, ya que atrae turismo a gran escala, la economía de Nouméa-Nueva Caledonia ha crecido con la presencia de este nuevo objeto arquitectónico; en relación a la Cultura Kanak el impacto social estuvo relacionado a la conservación de la diversidad cultural, de la identidad y que no haya una pérdida del idioma, música, danza u otros factores culturales de la cultura Kanak.
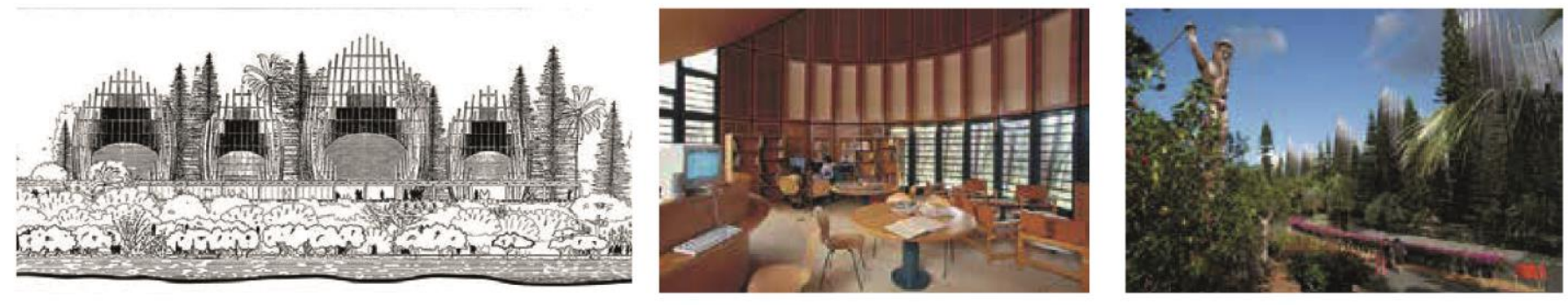


\section{LAANTIGUA}

FICHA DEL PROYECTO

ESPACIO
HISTORIA

TECNOLOGIA
UBICACIÓN

IMPACTO SOCIAL
FICHA

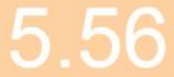

IMÁGENES DEL AUTOR EN
Imágenes del autor en base a:

Página web: https://www.archdaily.pe/pe/774570/centro-de-interpretacion-y-acogida-de-visitantes-de-la-antigua-

ventura-plus-llimona

Página web: https://assets.master-builders-solutions.basf.com/shared\%20documents/pdf/spanish\%20

(spain)/mbs-centro-interpretacion-la-antigua.pdf

ARQUUTECTO: Renzo Piano

AÑo:

2014

EQUIPO:

- $\quad$ Arquitecto Kaoru Fujii

- $\quad$ Arquitecto Yoshihide Kobanawa

- $\quad$ Arquitecta Gloria Busquets

- $\quad$ Arquitecta Mónica Sánchez.

- Museóloga Anna Escarpanter Llandrich

- Museóloga Ana Galdós Monfort.

- $\quad$ Ingeniero Civil Blázquez Guanter, cosultora estructural S.L.P

Ayuntamiento De Zumarrága (Zumarraga Lantzen S. A. U.)

DESCRIPCIÓN:

El proyecto se encuentra ubicado en Beloki Hiribidea, 20700, Lumárraga - España fue realizado por el estudio de arquitectura "Ventura Limona Taller de arquitectura y diseño". La finalidad del proyecto es poner en valor La antigua Ermita de Santa María de Zumárraga (La antigua) que forma parte de la ruta de los Tres Templos de Tierra Ignaciana en conjunto con los santuarios Loyola y Arantzasu.

El edificio propone mimetizarse al paisaje y toma como modelo el bosque vasco, la infraestructura cuenta con tres salas de exposición que dan a conocer la evolución histórica de la ciudad con respecto a la ermita; además contiene un bar-restaurante y un vestibulo que también son usados como mirador. Los espacios están abiertos hacia la calle para aprovechar el máximo de luz. El proyecto ha tratado de recuperar todos los elementos naturales de su entorno e introducirlos en el edificio, es así que el diseño toma en cuenta los accesos de luz natural, aprovecha las visuales, moldea las paredes como si de un negativo de troncos se tratara, toma en cuenta el paisaje del bosque para el emplazamiento (Archdaily, 2015).

PERIODO HISTÓRICO:
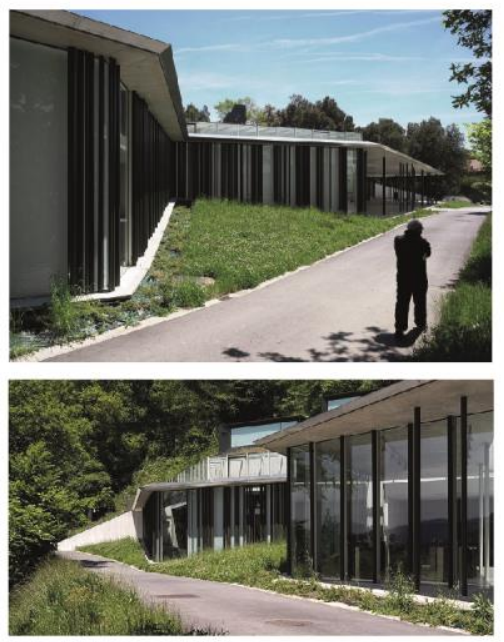

Periodo contemporáneo

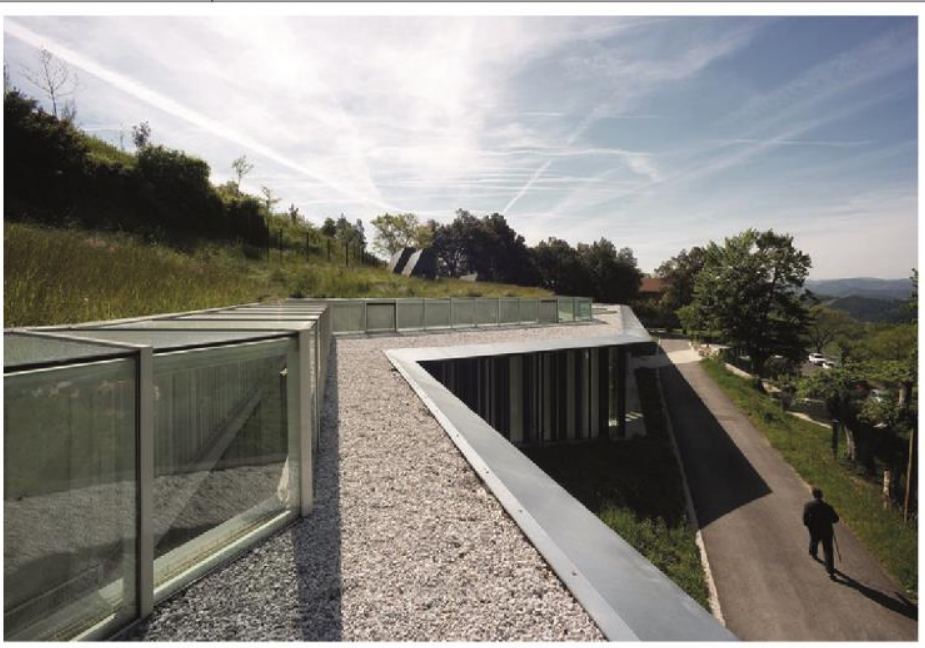

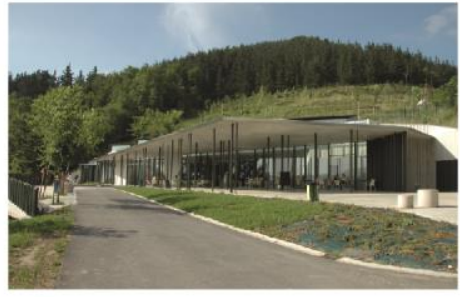

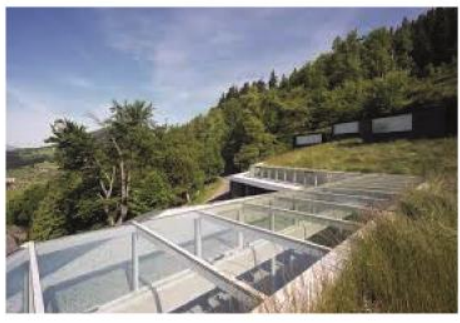


IMÁGENES DEL AUTOR EN BASE A :

Página web: https://www.archdaily.pe/pe/774570/centro-de-interpretacion-y-acogida-de-visitantes-de-la-antigua-

\section{LÍNEA DEL TIEMPO}

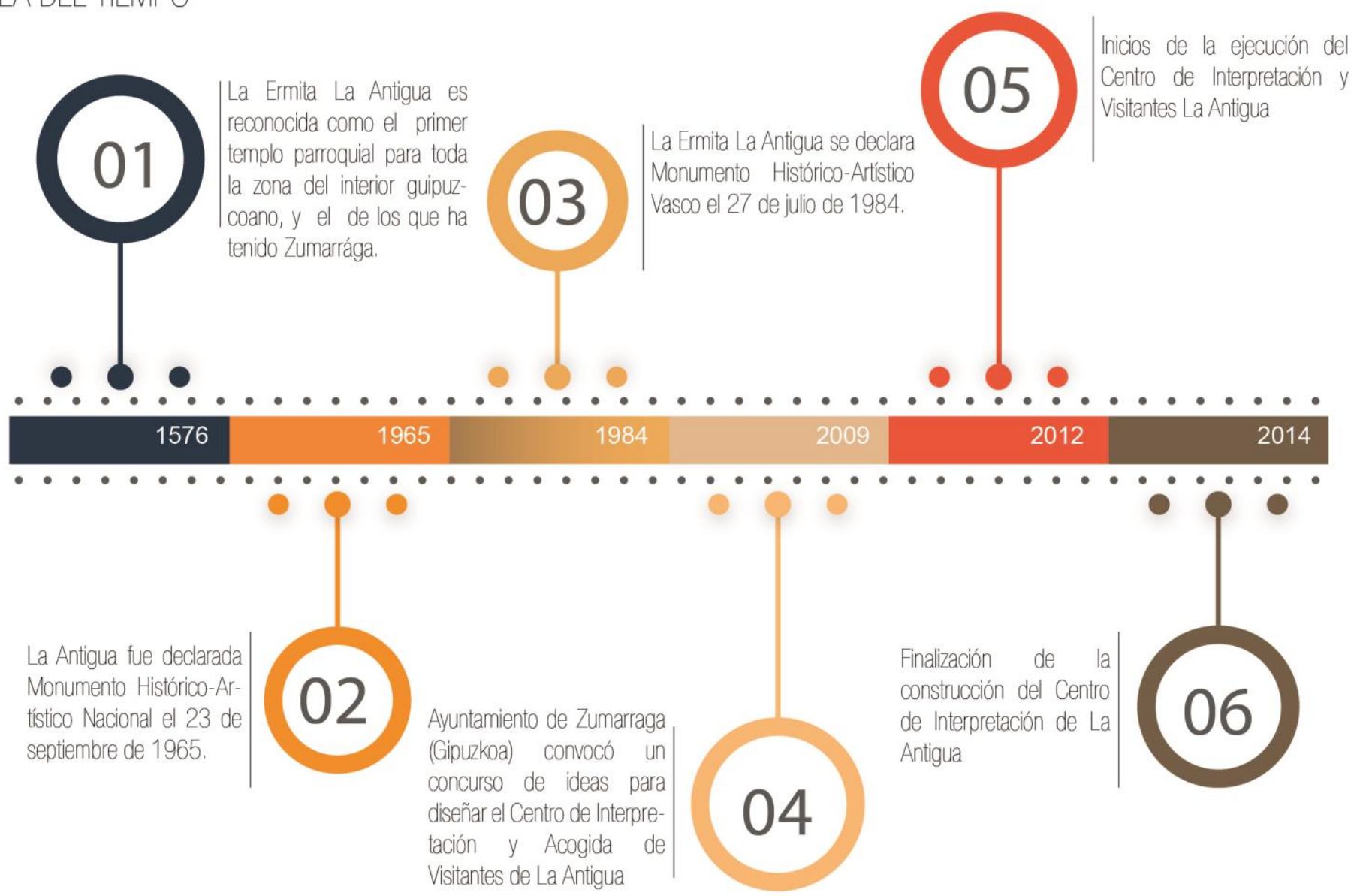

\section{HISTORIA}

En febrero de 2009, el ayuntamiento de Zumárraga, municipio de la provincia de Guipúzcoa, en la comunidad autónoma del País Vasco, España convocó a un concurso para el diseño del Centro de Interpretación y Visitantes de La Antigua, donde se encuentra la Ermita Románica.

La Ermita Románica es el primer templo parroquial documentado en el Municipio de Zumarrága, 1576. Los documentos pasados indican que la Ermita era de un tamaño inferior al actual y era el punto de peregrinación al que acudían comunidades distintas de distancias de 15 km. aproximadamente.

El edificio, durante la historia, ha tenido muchas intervenciones y restauraciones, fue declarada Monumento Histórico-Artístico Nacional el 23 de Setiembre de 1965.

El ganador del concurso es el estudio de arquitectos "Ventura Limona Taller de arquitectura y diseño" quien presenta un proyecto, en un terreno contiguo a la ermita románica de La Antigua, conocida también como "la Catedral de las ermitas vascas" y de gran potencial turístico, de baja escala, ya que su intención era no irrumpir el paisaje, ni superar la altura de la ermita, pero teniendo en cuenta que tenía que ser un edificio atractivo para los visitantes; es por ello que diseñan un edificio que se mimetiza al entorno, ya que esta soterrado en un 65\% minimizando el impacto visual y compensando con la aportación de energía geotérmica. 


\section{LAANTIGUA}

Página web: https://www.archdaily.pe/pe/774570/centro-de-interpretacion-y-acogida-de-visitantes-de-la-antigua-

Un factor clave para la museografía es la acogida y recibimiento, que se proyectó como espacio principal en el centro de visitantes con un gran vestíbulo cubierto que acoge a los visitantes y además les genera visuales del entorno. Bajo el diálogo de museografía y arquitectura se diseñó todas las áreas del proyecto que se encuentran trazadas para el uso y pensadas para funcionar independientemente del resto del equipamiento.

Por otro lado, el diseño transmite el planteamiento de conceptos. Por ejemplo, la composición vertical del material tubular que simboliza el bosque y la importancia que la metalurgia ha tenido en Zumarraga. Asimismo, se diseñó los elementos expositivos que aportan exclusividad, personalidad y calidad. El Centro de interpretación y visitantes La Antigua se ha concebido con un objetivo: la unidad entre el continente y contenido.
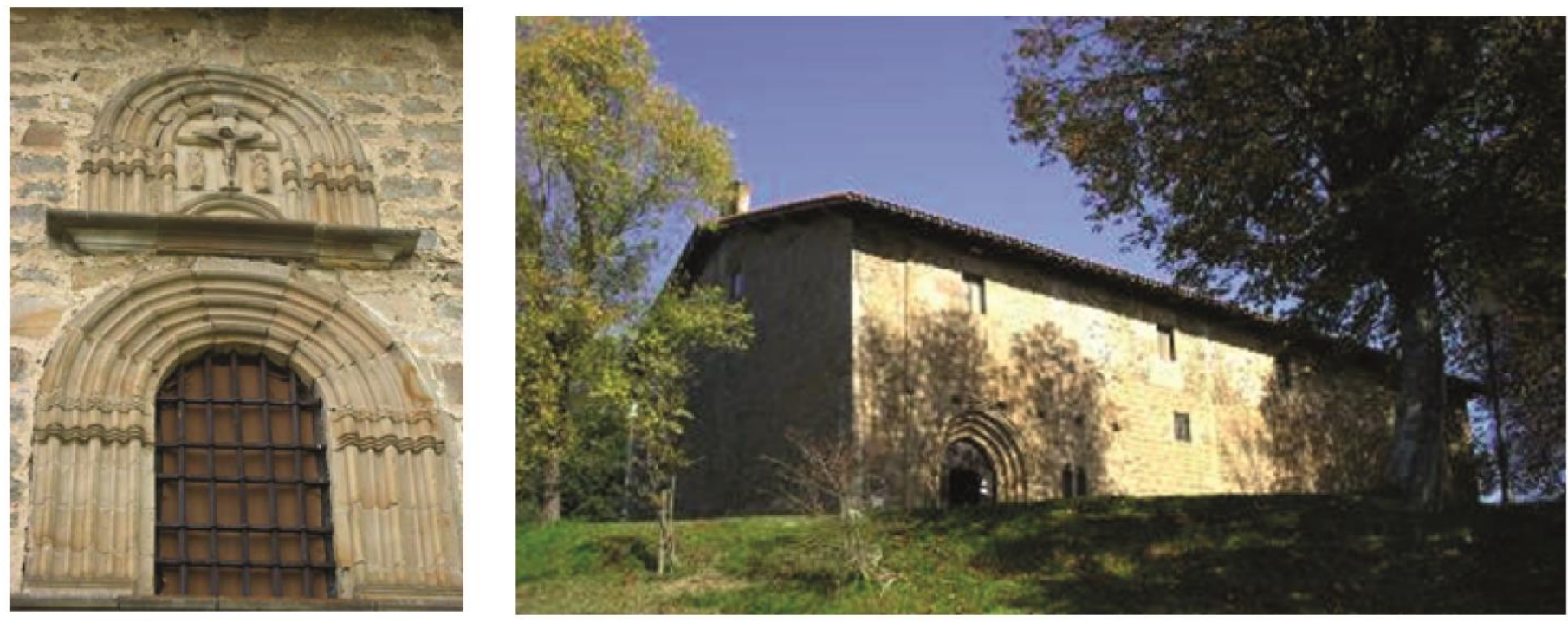

\section{TOMA DE PARTIDO}

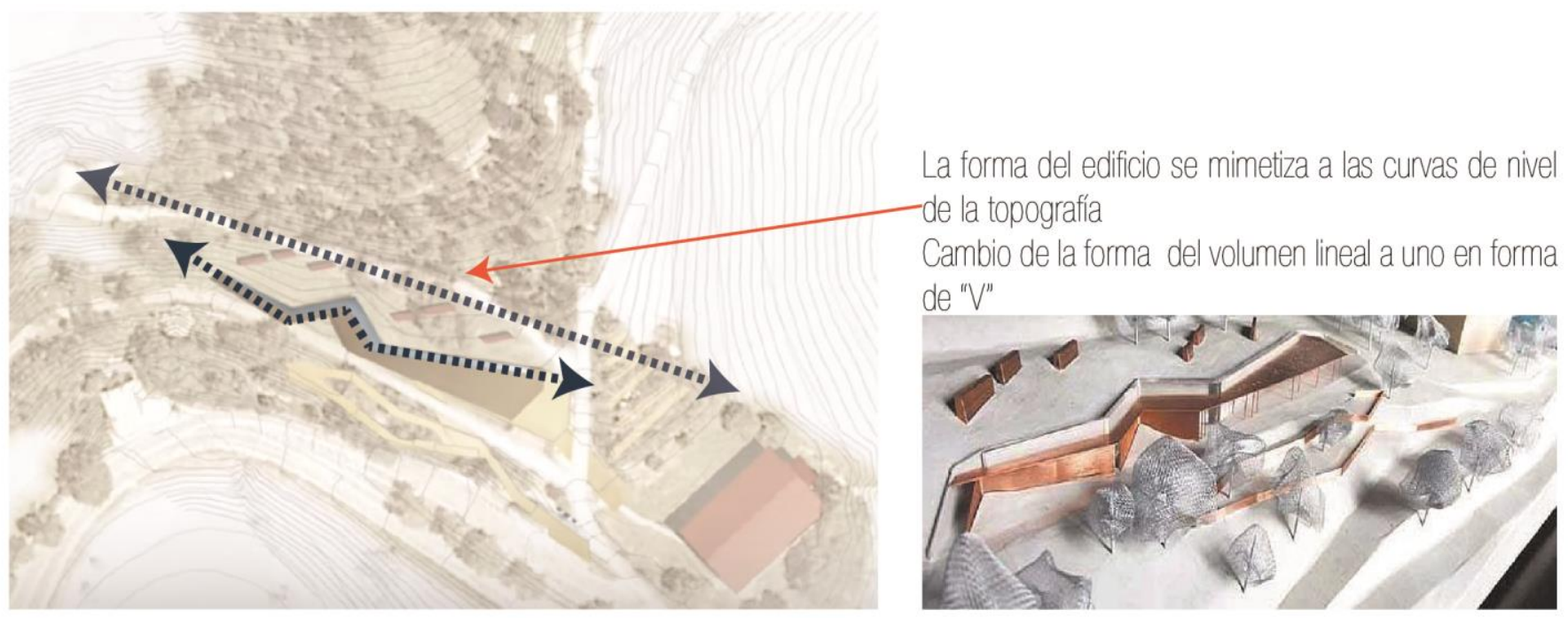


IMÁGENES DEL AUTOR EN BASE A :

Imágenes del autor en base a:

UBICACIÓN

IMPACTO SOCIAL
FICHA

Página web: https://www.archdaily.pe/pe/774570/centro-de-interpretacion-y-acogida-de-visitantes-de-la-antigua-

ventura-plus-llimona

Página web: https://assets. master-builders-solutions.basf.com/shared\%20documents/pdf/spanish\%20

(spain)/mbs-centro-interpretacion-la-antigua.pdf

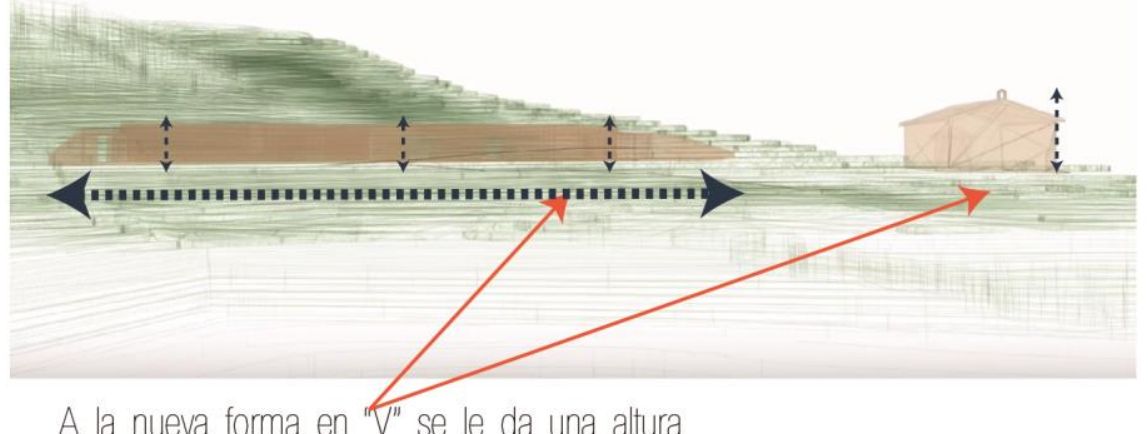

mínima (1 nivel) para pasar desapercibida con

respecto a La Ermita

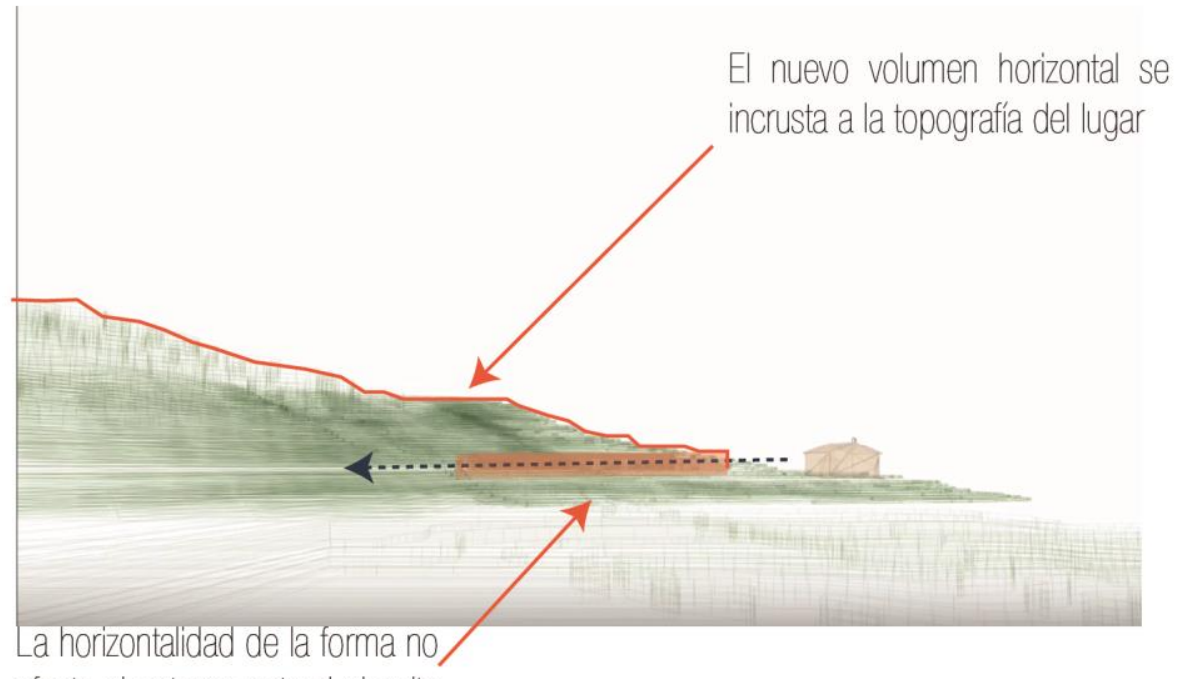

afecta al entorno natural ni quita

protagonismo a La Ermita

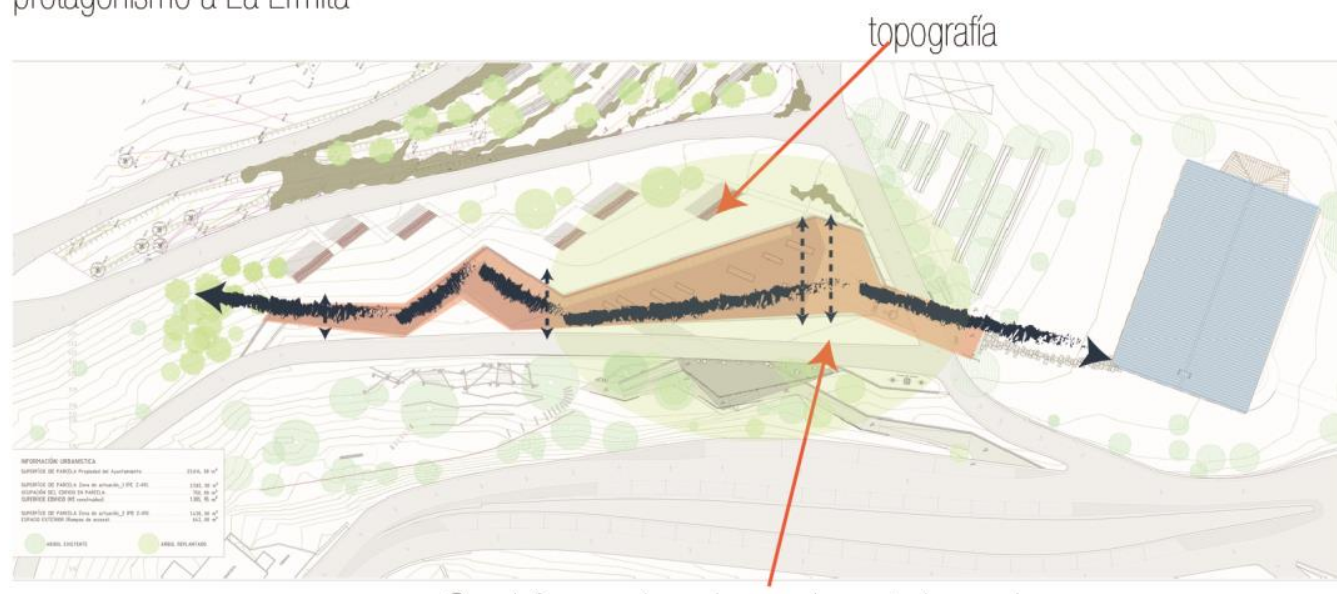

Se deforma el volumen incrustado en la

topografía dándole mayor dimensión al lado

del ingreso principal para generar un recibidor
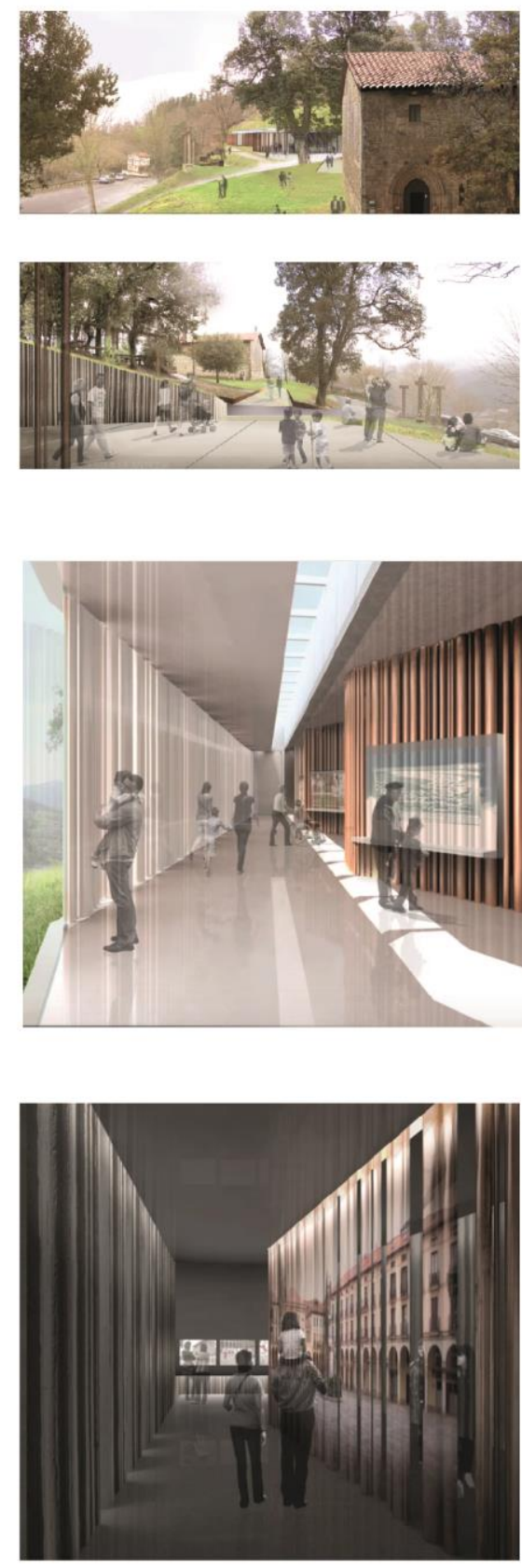
IMÁGENES DEL AUTOR EN BASE A :

Imágenes del autor en base a:

Página web: https://www.archdaily.pe/pe/774570/centro-de-interpretacion-y-acogida-de-visitantes-de-la-antigua-

\section{UBICACIÓN}

Ciudad De Zumarrága

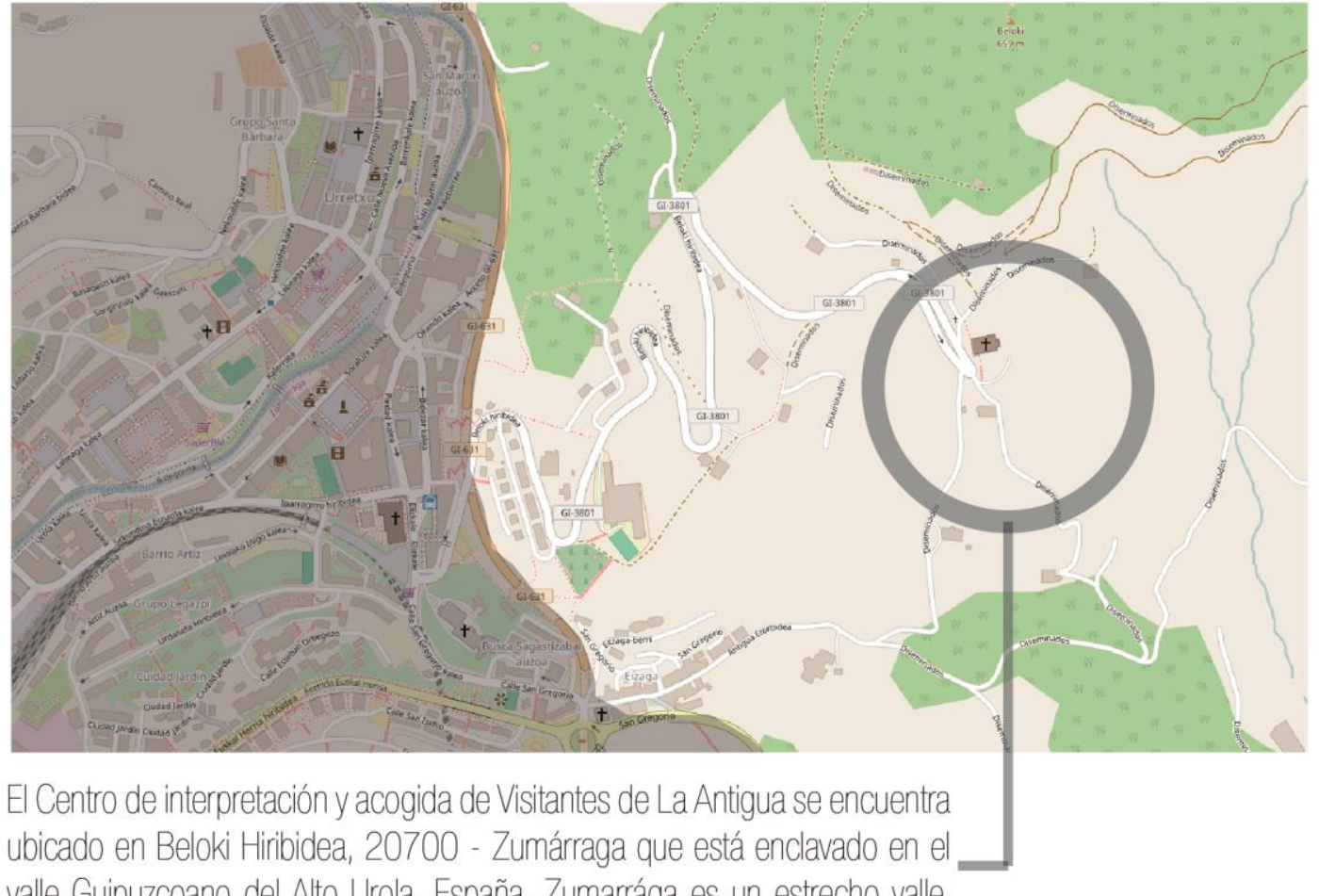

valle Guipuzcoano del Alto Urola, España. Zumarrága es un estrecho valle,

con una anchura de unos $3 \mathrm{~km}$. Y limita por el oeste, el río Urola que la separa

de su vecina Urrechu, con la que forma un mismo casco urbano.

\section{PLANO CON ENTORNO INMEDIATO}

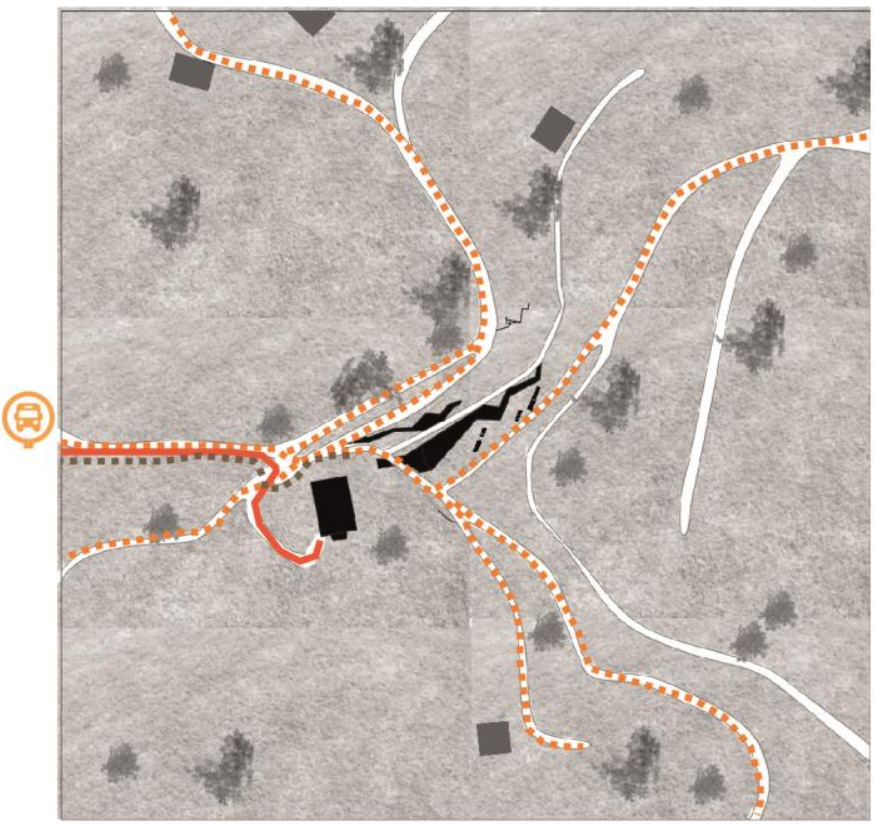

(-o

Vía Vehicular más cercana al proyecto

nombre de la calle:Diseminados Bareiatua

ब大 Ciclovias

Y Vías peatonales

(8) Paradero más cercano al proyecto nombre: Centre Couturel

Tiempo estimado de llegada desde el Ayuntamiento de Zumarrága

Vehículo particular
6 minutos.

\section{Transporte público}

3 minutos

G?

3 minutos

20 minutos

Fु Bicicleta

16 minutos

\section{Caminando}

30 minutos

Tiempo estimado de llegada desde el paradero más cercano al Centro Cultural Jean Marie Tjibaou

Caminando

20 minutos 
ESPACIO

TECNOLOGIA
FICHA

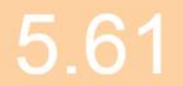

IMÁGENES DEL AUTOR EN BASE A :

Imágenes del autor en base a:

Página web: https://www.archdaily.pe/pe/774570/centro-de-interpretacion-y-acogida-de-visitantes-de-la-antigua-

ventura-plus-llimona

Página web: https://assets.master-builders-solutions.basf.com/shared\%20documents/pdf/spanish\%20

(spain)/mbs-centro-interpretacion-la-antigua.pdf

ACCESOS PÚBLICOS PEATONALES

ESTACIONES DE TRANSPORTE

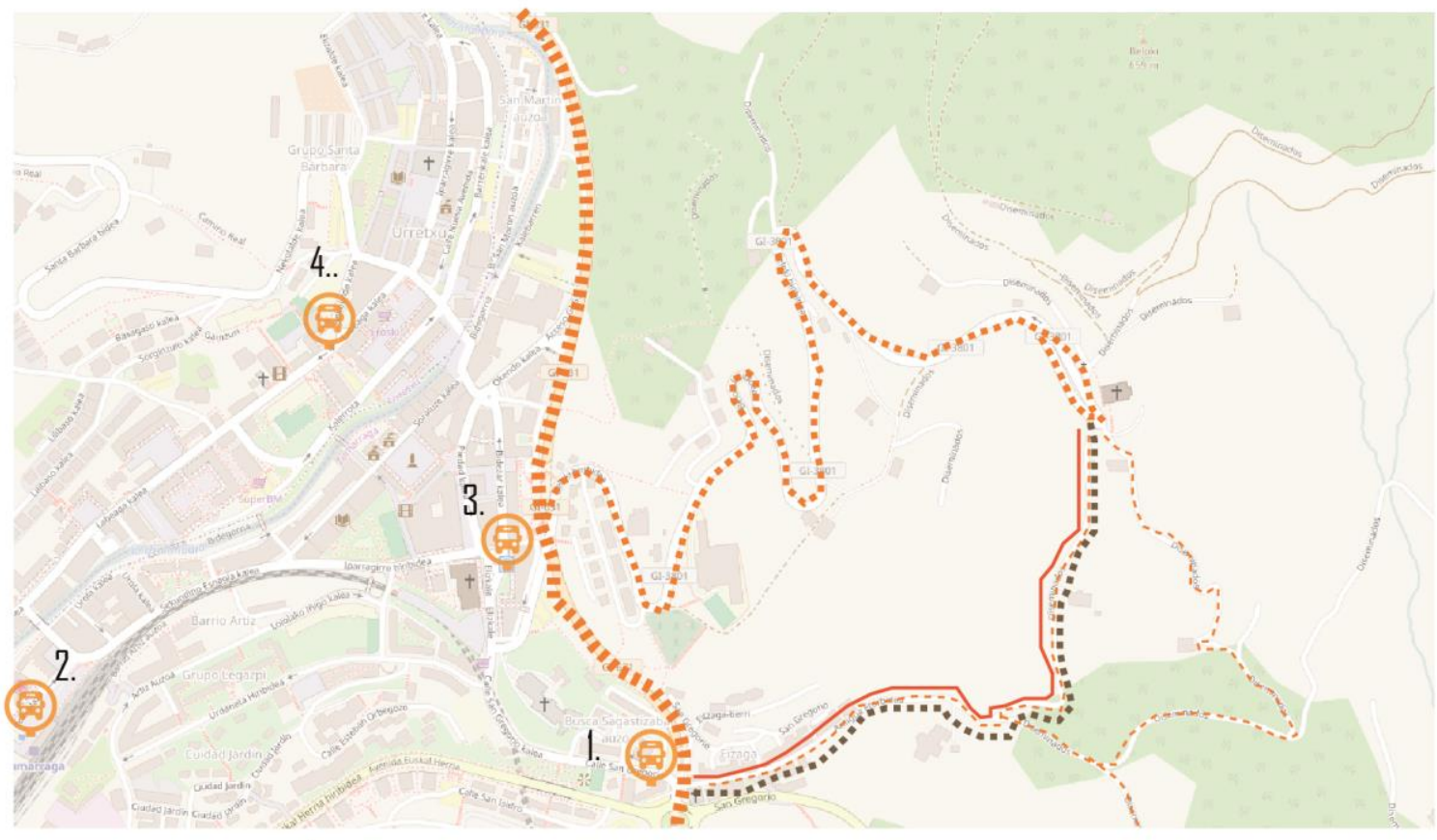

\section{CORTES ESQUEMÁTICOS}

Se mimetiza al paisaje generando

techos verdes y se incrusta an la

topografía del lugar.

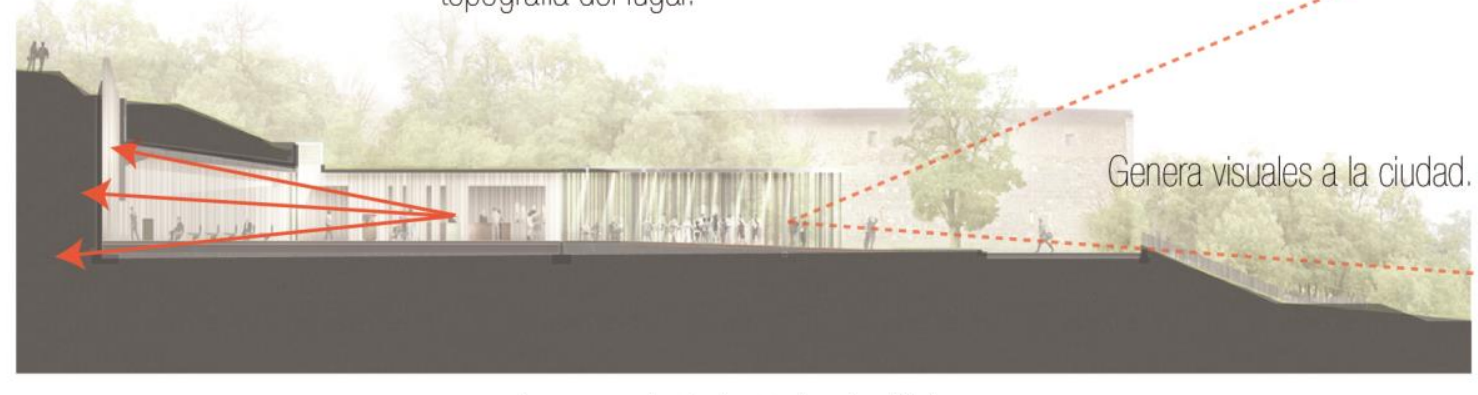

Acceso principal a todo el edificio

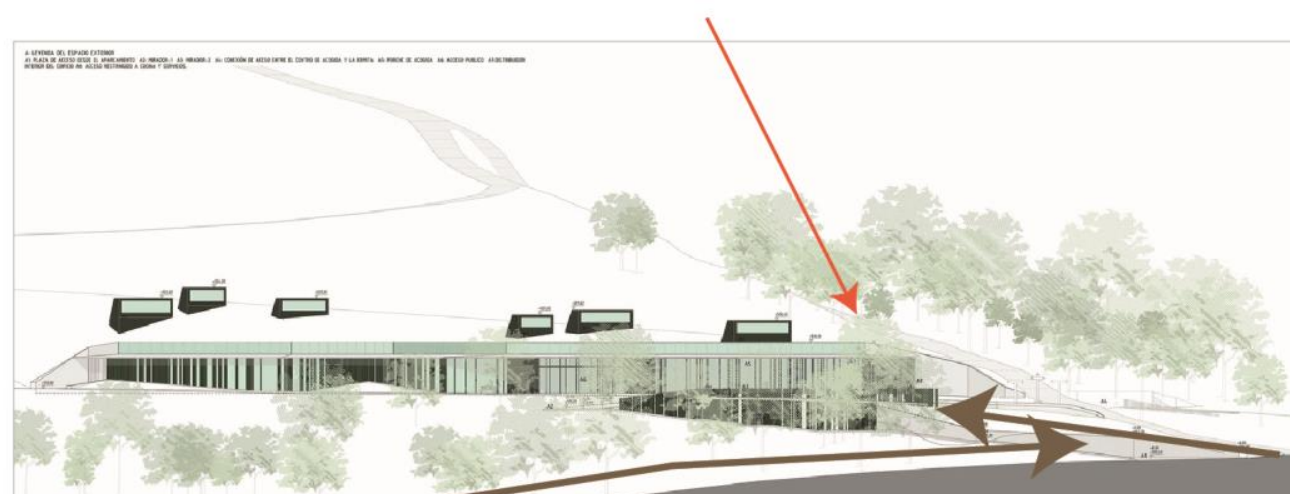

Se ha anulado la visualización de aparcamiento desde el vestibulo de acogida y el centro, soterrado en $65 \%$, se adentra el monte minimizando el impacto visual y favoreciendo la sostenibilidad del edificio compensado con aportación de energía geotérmica. 


\section{LAANTIGUA}

FICHA DEL PROYECTO

ESPACIO

IMÁGENES DEL AUTOR EN BASE A :

\section{PROGRAMA}

HISTORIA UBICACIÓN

TECNOLOGIA
IMPACTO SOCIAL
PAQUETES PROGRAMÁTICOS

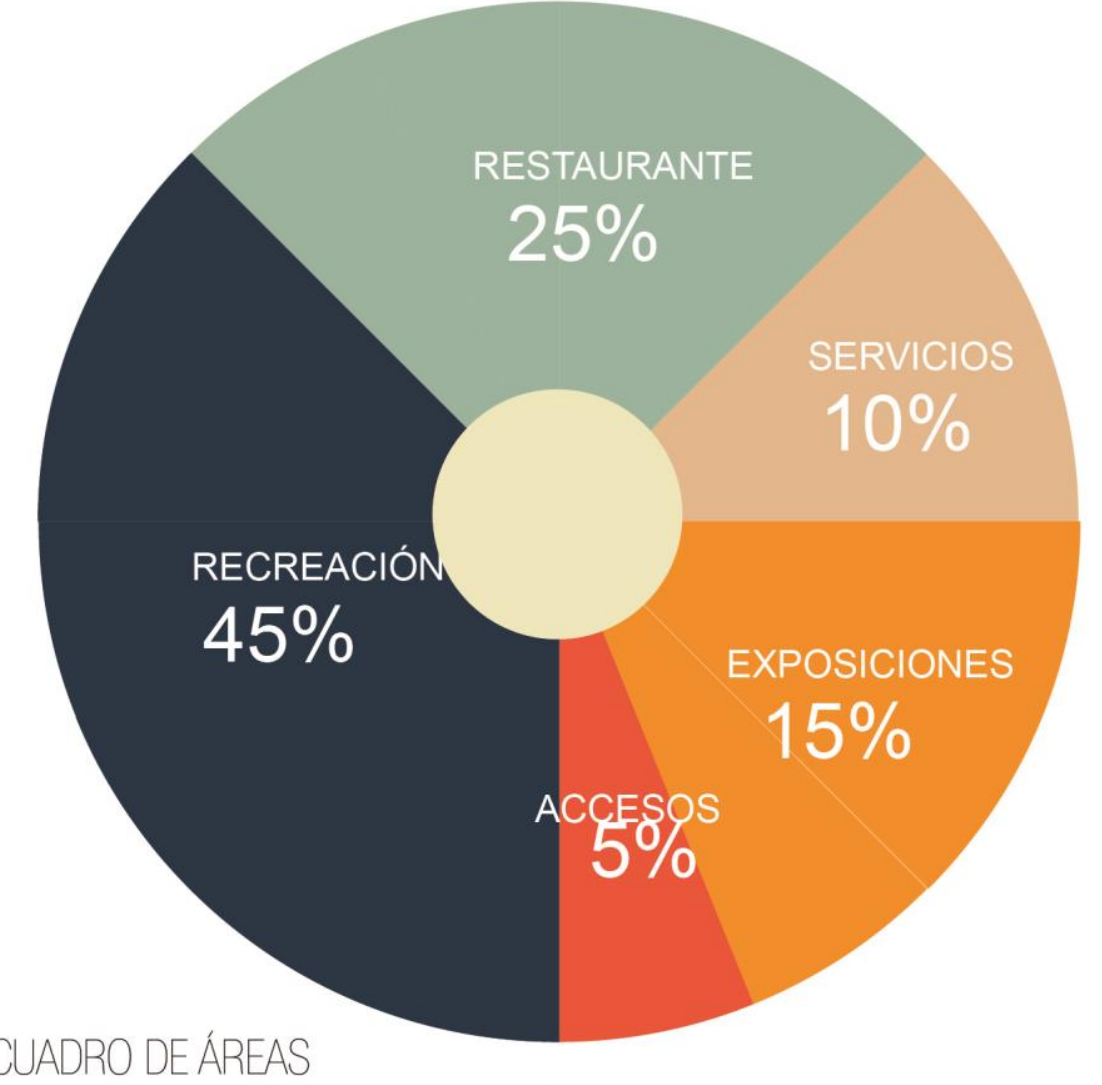

\section{USUARIOS}

ஸึ่

Ancianos
Discapacitados

i) Estudiantes

Niños

II Turistas 滛

Personal capacitado

Empleados del área de limpieza,

servicio, administrativo, etc.

\begin{tabular}{|c|c|c|c|c|}
\hline RECREACIÓN & RESTAURANTE & SERVICIOS & EXPOSICIONES & ACCESOS \\
\hline $\begin{array}{l}\text { PLAZA DE ACCE- } \\
\text { SOS DESDE EL } \\
\text { APARCAMIENTO } \\
\qquad 100 \mathrm{~m} 2\end{array}$ & BAR & $\begin{array}{l}\text { RECEPCIÓN } \\
15 \mathrm{~m} 2 \\
\text { TIENDA } \\
30 \mathrm{~m} 2\end{array}$ & $\begin{array}{l}\text { SALA } \\
\text { EXPOSICIÓN } \\
\text { PERMANENTE } \\
120\end{array}$ & $\begin{array}{l}\text { HAL DE DISTRIBU- } \\
\text { CIÓN EL EDIFICIO } \\
20 \mathrm{~m} 2\end{array}$ \\
\hline $\begin{array}{l}\text { MIRADOR } 1 \\
85 \mathrm{~m} 2\end{array}$ & $\begin{array}{l}\text { RESTAURANTE } \\
\text { AREA DE } \\
\text { COMENSALES } \\
200 \mathrm{~m} 2\end{array}$ & $\begin{array}{l}\text { SERVICIOS } \\
\text { HIGIENICOS } \\
40 \mathrm{~m} 2 \\
\text { ALMACENES } \\
15 \mathrm{~m} 2\end{array}$ & $\begin{array}{l}\text { SALA DE CONFE- } \\
\text { RENCIAS Y ESP. } \\
\text { PEDAGOGICO } \\
60 \mathrm{~m} 2\end{array}$ & $\begin{array}{l}\text { HALL DE } \\
\text { ENTRADA } \\
15 \mathrm{~m} 2\end{array}$ \\
\hline $\begin{array}{c}\text { MIRADOR } 2 \\
55 \mathrm{~m} 2\end{array}$ & & $\begin{array}{l}\text { COCINA BAR } \\
15 \mathrm{~m} 2 \\
\text { SERV. DEL } \\
\text { BAR-RESTAURANTE } \\
15 \mathrm{~m} 2\end{array}$ & $\begin{array}{l}\text { SALA DE EXPOSI- } \\
\text { CION TEMPORAL } \\
50 \mathrm{~m}^{2}\end{array}$ & $\begin{array}{c}\text { ACCESO A LA } \\
\text { ERMITA } \\
20 \mathrm{~m} 2\end{array}$ \\
\hline $\begin{array}{l}\text { VESTÍBULO DE } \\
\text { ACOGIDA } \\
250 \mathrm{~m} 2\end{array}$ & & $\begin{array}{c}\text { SERVICIO } \\
\text { HIGIÉNICOS } \\
20 \mathrm{~m} 2 \\
\text { COCINA } \\
20 \mathrm{~m} 2\end{array}$ & & \\
\hline
\end{tabular}

ALMACEN 2 


\section{LAANTIGUA}

ESPACIO

TECNOLOGIA

IMPACTO SOCIAL

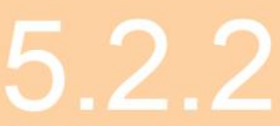

IMÁGENES DEL AUTOR EN BASE A :

Imágenes del autor en base a:

Página web: https://www.archdaily.pe/pe/774570/centro-de-interpretacion-y-acogida-de-visitantes-de-la-antigua-

ventura-plus-llimona

Página web: https://assets.master-builders-solutions.basf.com/shared\%20documents/pdf/spanish\%20

(spain)/mbs-centro-interpretacion-la-antigua.pdf

ZONIFICACIÓN A NIVEL MACRO

1.

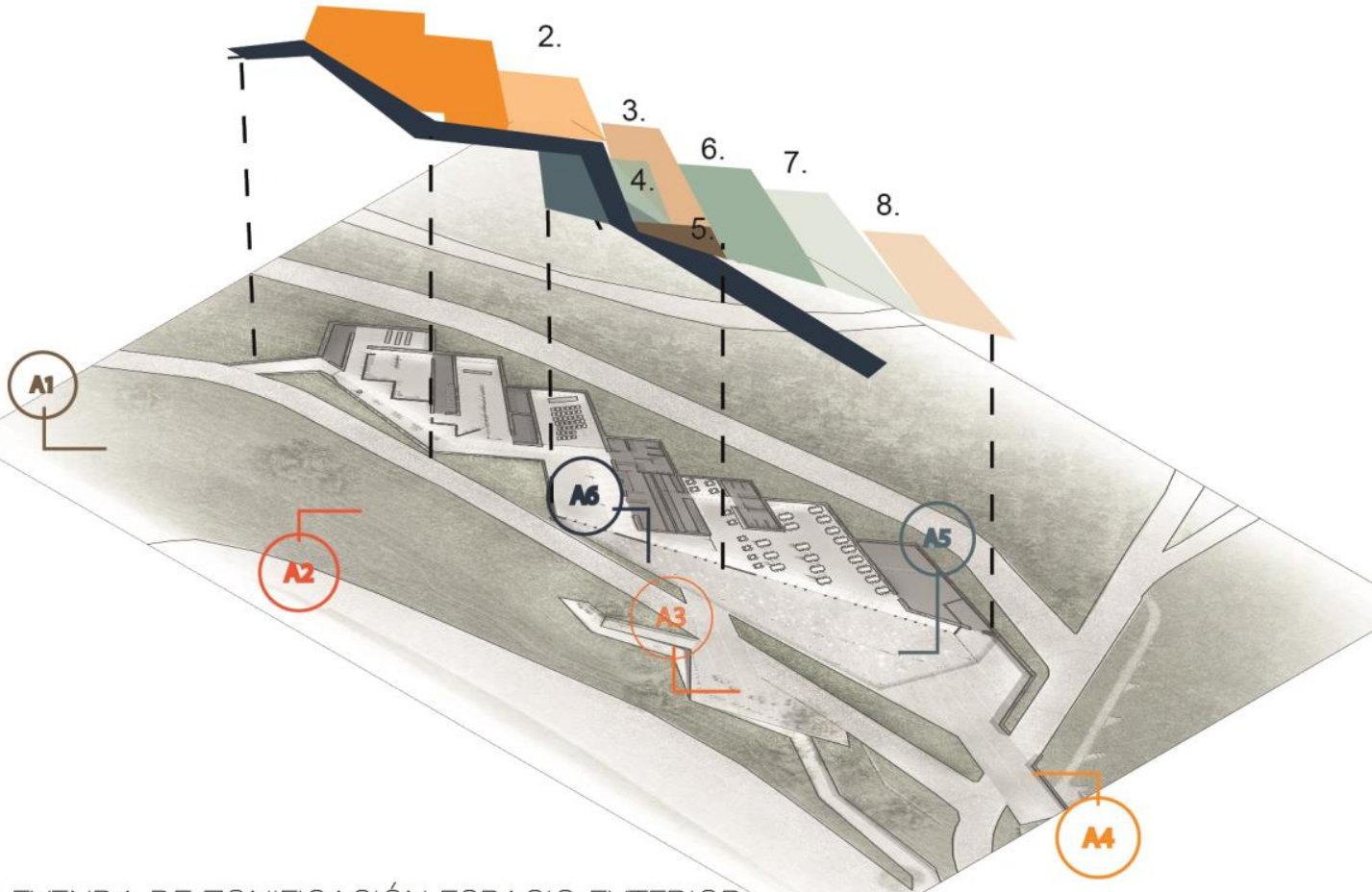

Leyenda de zonificación

1.Sala de exposición

Permanente

2. Sala de conferencias

3.Zona de servicios

4.Sala de exposición

Temporal

5.Hall de distriución

Deledificio

6. Bar

7. Restaurante

8. Cocina del restaurante

LEYENDA DE ZONIFICACIÓN ESPACIO EXTERIOR

\begin{tabular}{llllll|}
\hline A1:PLAZA DE & & & & \\
ACCESO DESDE & A2: & A3: & A4: ACCESO A & A5:VESTÍBULO DE & A6:HALL DE \\
ESTACIONAMIENTO & MIRADOR & MIRADOR & LA ERMITA & ACOGIDA & DISTRIBUCIÓ \\
\hline
\end{tabular}

ORGANIGRAMA

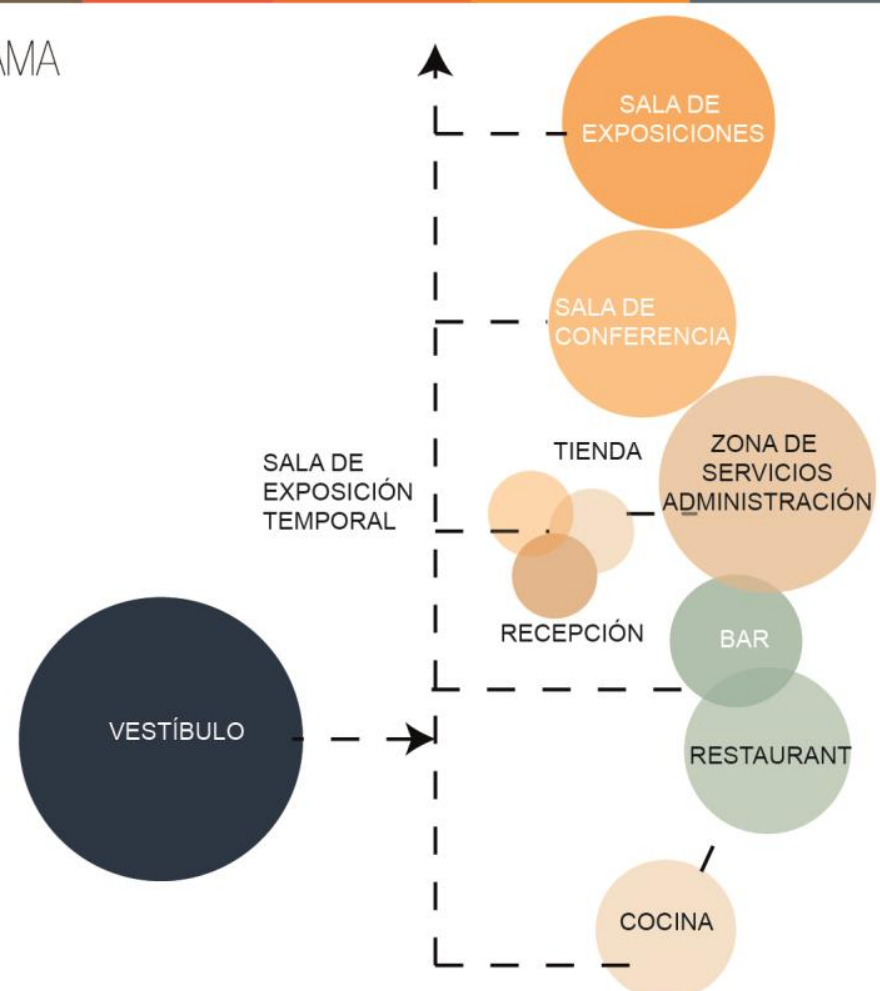


IMÁGENES DEL AUTOR EN BASE A :

Página web: https://www.archdaily.pe/pe/774570/centro-de-interpretacion-y-acogida-de-visitantes-de-la-antiguaventura-plus-llimona

Página web: https://assets.master-builders-solutions.basf.com/shared\%20documents/pdf/spanish\%20(spain)/ mbs-centro-interpretacion-la-antigua.pdf

web: Las Relaciones espaciales-Luis Ismael Pérez

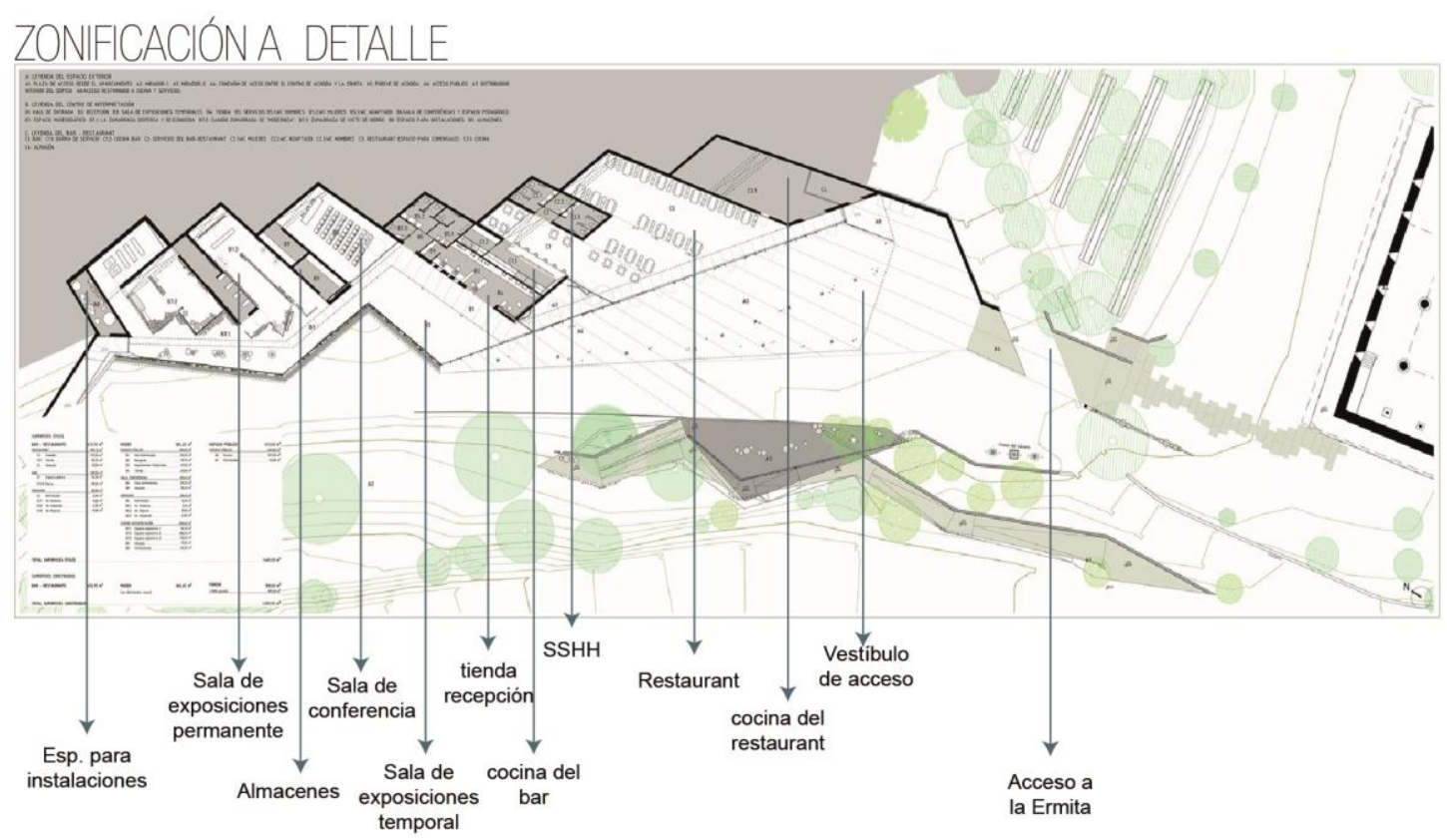

\section{RELACIÓN ESPACIAL}

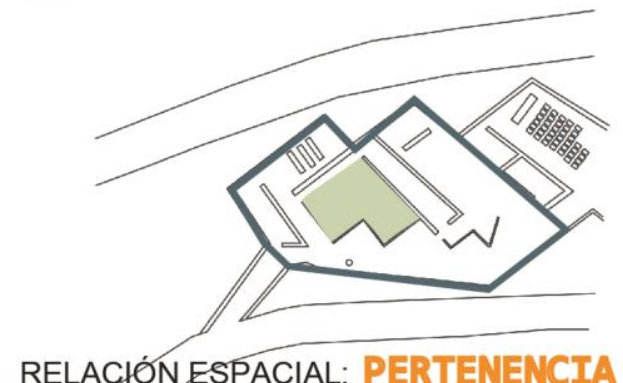

En este tion de relación espacial un espacio

tiene la capacidad de contener a otro
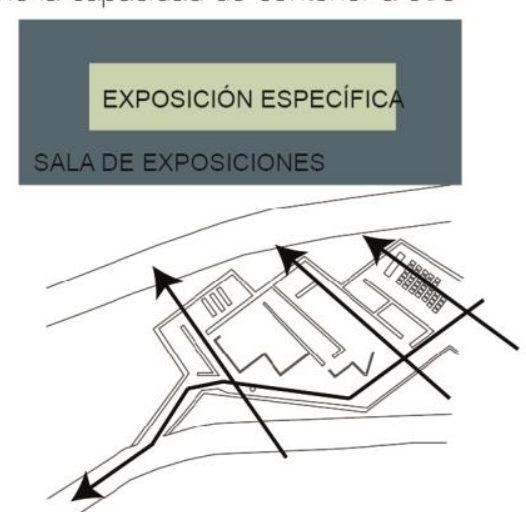

RELACIÓN ESPACIAL: INDEPENDIENTE

En este tipo de relación espacial cada espacio

Tiene ingreso independiente y en común solo tienen

la circulación

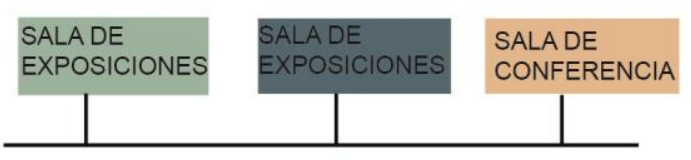

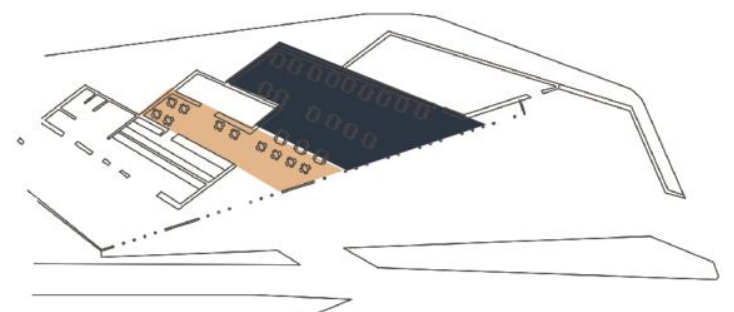

RELACIÓN ESPACIAL: INTERSECCION

En este tipo de relación espacial dos espacios se intersectan, sin embargo el espacio intersectado sigue perteneciendo a uno de los dos

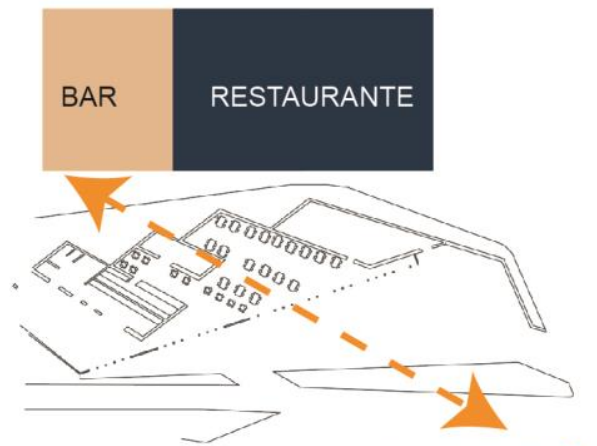

RELACIÓN ESPACIAL: YUXTAPOSICIÓN En este tipo de relación espacial hay una Comunicación de dos o más espacios por medio de un pasillo 


\section{ESPACIO}

TECNOLOGIA IMPACTO SOCIAL

IMÁGENES DEL AUTOR EN BASE A :

web: Plataforma de Arquitectura

web: Las Relaciones espaciales-Luis Ismael Pérez

texto: La sinergia entre museografia y arquitectura es posible: El Centro de Interpretación y Visitantes de La Antigua

Zumarraga-Anna Escarpanter

\section{DEFINICIÓN TIPOLOGÍA}

Una organización lineal consiste esencialmente en una serie de espacios. Estos espacios pueden estar interrelacionados directamente, o bien estar enlazados por otro espacio lineal independiente y distinto.

En el centro de interpretación y acogida de visitantes La Antigua los espacios se encuentran agrupados a lo largo de una línea, este tipo de organización soluciona las condiciones de desplazamiento, ya que es en una sola dirección y mayormente de forma horizontal.

Esta tipología espacial conecta todo lo que se dispone en la longitud generando espacios independientes, encierra todo el programa en un campo espacial de fácil recorrido.

\section{ESQUEMAS}

Circulación horizontal
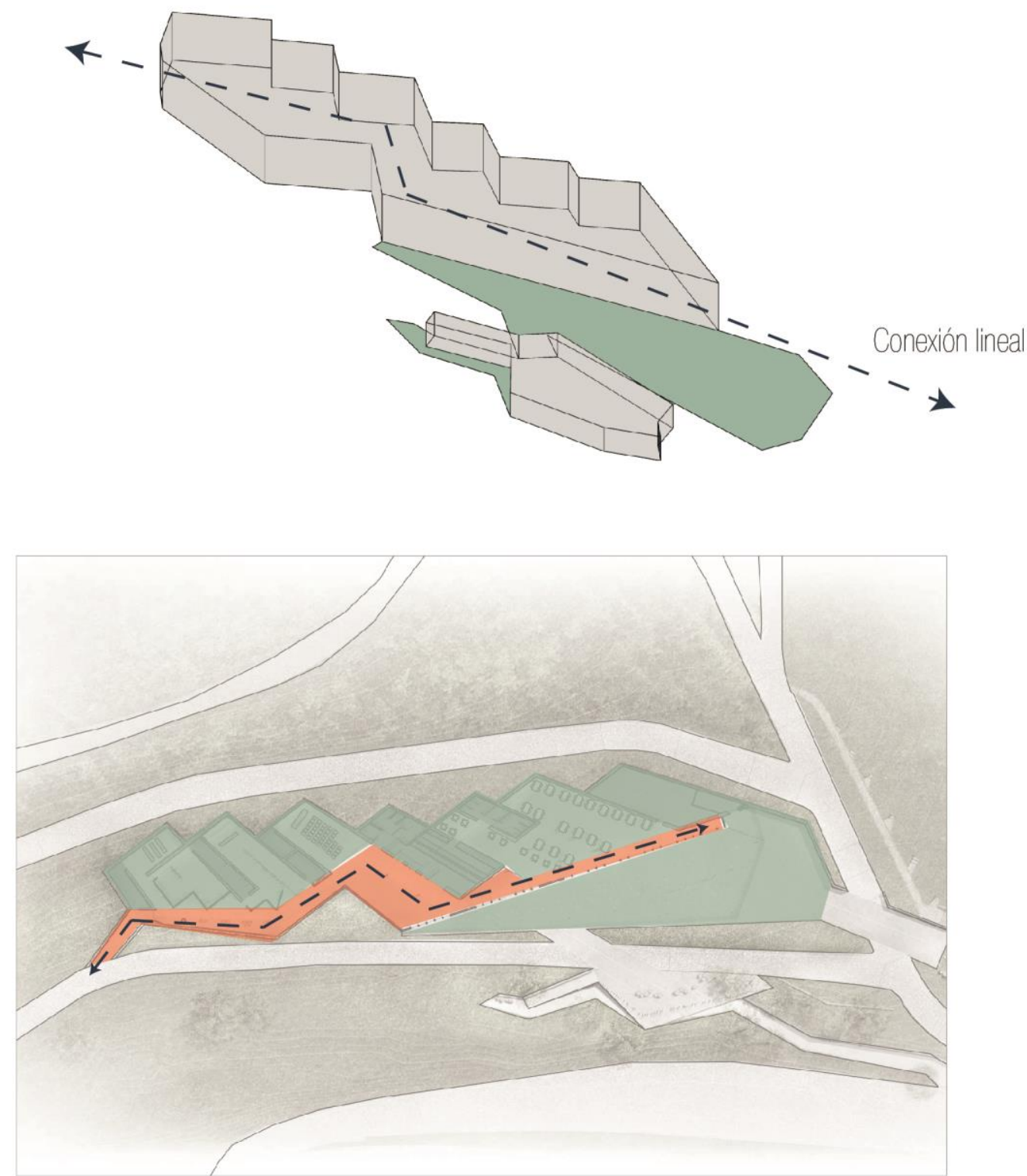

Corredor con vista a la sala de conferencia

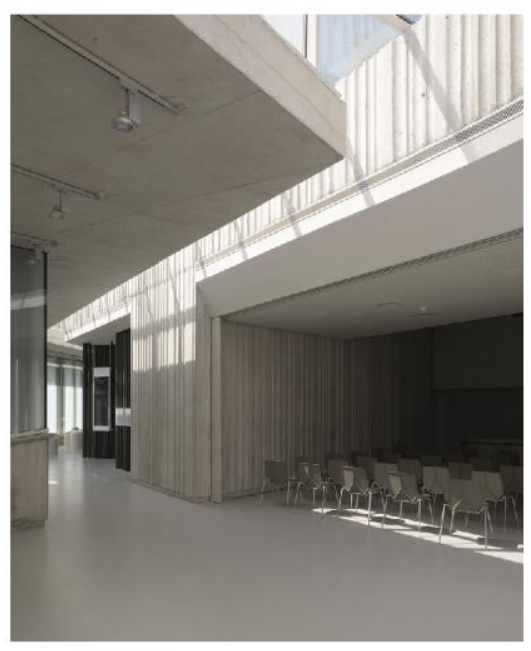

Corredor de circulación

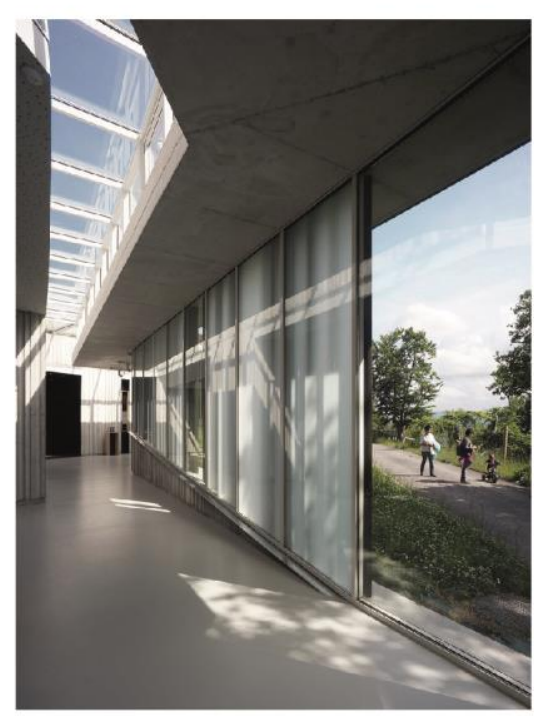

TEMÁTICA

PAISAJE

HISTORIA 


\section{ESPACIO}

\section{TECNOLOGIA}

\section{IMPACTO SOCIAL}

FICHA

5. 68

IMÁGENES DEL AUTOR EN BASE A :

web: Plataforma de Arquitectura

web: Las Relaciones espaciales-Luis Ismael Pérez

texto: La sinergia entre museografia y arquitectura es posible: El Centro de Interpretación y Visitantes de La Antigua

Zumarraga-Anna Escarpanter

\section{PÚBLICO-SEMIPÚBLICO-PRIVADO}

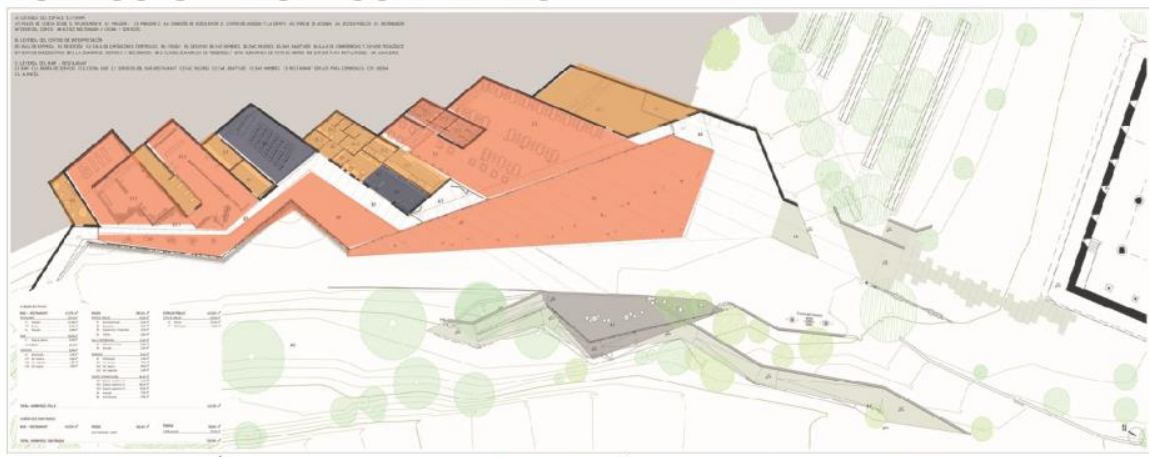

SEMI-PÚBLICO

$10 \%$ Espacio privado

20\% Espacio semi público

70 \% Espacio público

NOLLY

\section{PRIVADO}
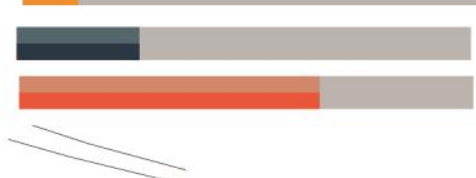

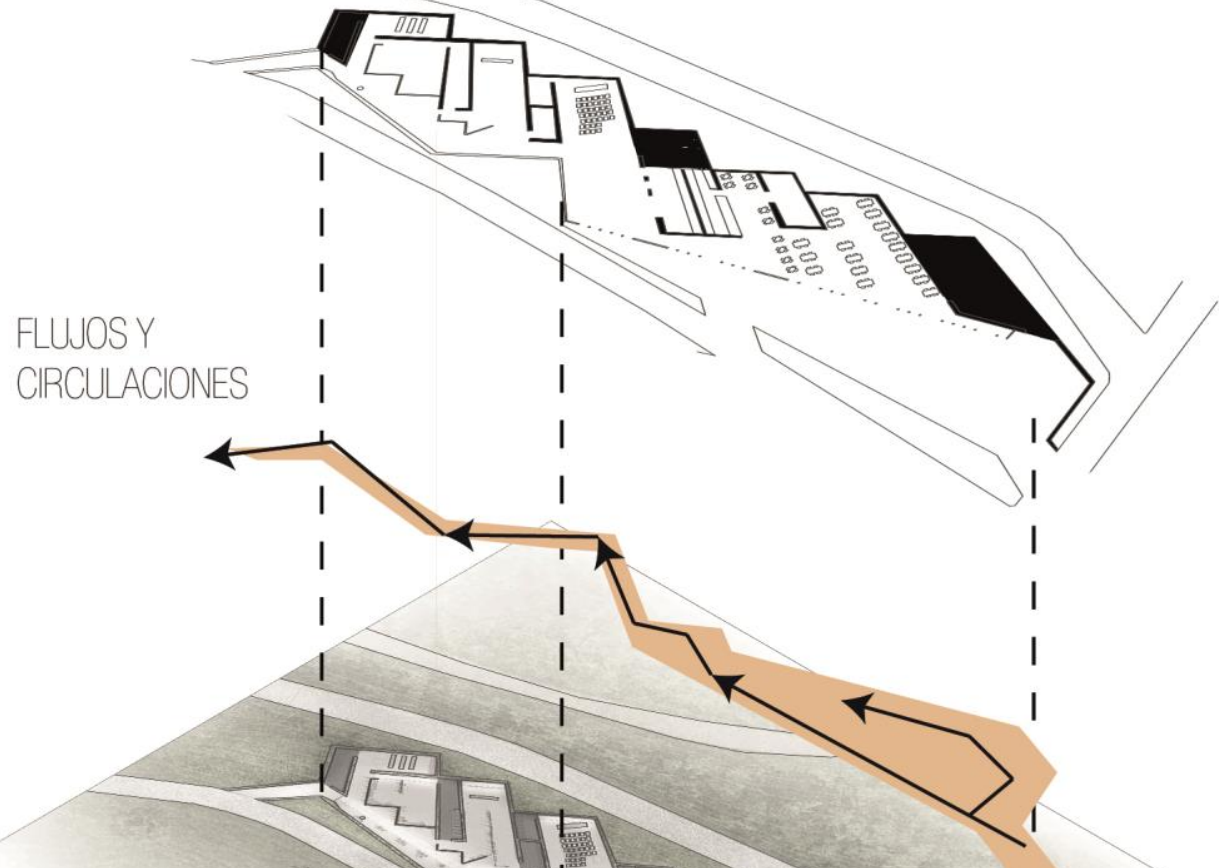

ÁREA CONSTRUIDA-ÁREA LIBRE

ÁREA CONSTRUIDA

$1300 \mathrm{~m} 2$

ÁREA LIBRE DEL EDIFICIO

$197.70 \mathrm{~m} 2$

ÁREA dDE CIRCLLACIÓN DEL EDIFICIO

$91.75 \mathrm{~m} 2$

ÁREA DEL TERRENO PARA EL EDIFICIO

$3270.00 \mathrm{~m} 2$

ÁREA TOTAL DEL EDIFICIO

$1397.70 \mathrm{~m} 2$

ÁREA LIBRE PROTEGIDA

$31400.00 \mathrm{~m} 2$

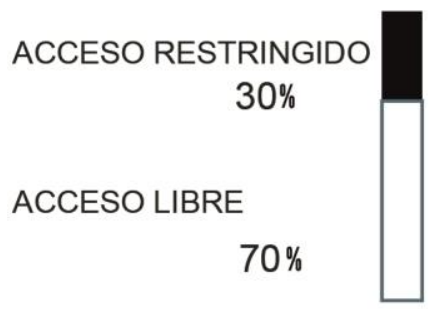

FLUJOS Y CIRCULACIONES

15 \% CIRCULACIÓN 


\section{ESPACIO}

\section{TECNOLOGÍA}

IMPACTO SOCIAL

\section{IMÁGENES DEL AUTOR EN BASE A :}

web: Plataforma de Arquitectura

web: Las Relaciones espaciales-Luis Ismael Pérez

texto: La sinergia entre museografia y arquitectura es posible: El Centro de Interpretación y Visitantes de La Antigua

Zumarraga-Anna Escarpanter

\section{SISTEMA CONSTRUCTIVO}

El sistema constructivo utilizado en este centro de interpretación se basa en el uso de hormigón armado, ya que tiene que soportar cargas de los techos verdes que propone el proyecto.

Por otro lado, la fachada esta compuesta por una celosía metálica vertical haciendo memoria a la ciudad herrera que era Zumarrága en la antigüedad.

Tanto el diseño del edificio como los materiales constructivos son una interpretación de los recursos naturales de la zona: madera, piedra y hierro, economías de subsistencia de La Antigua y de Zumarraga.
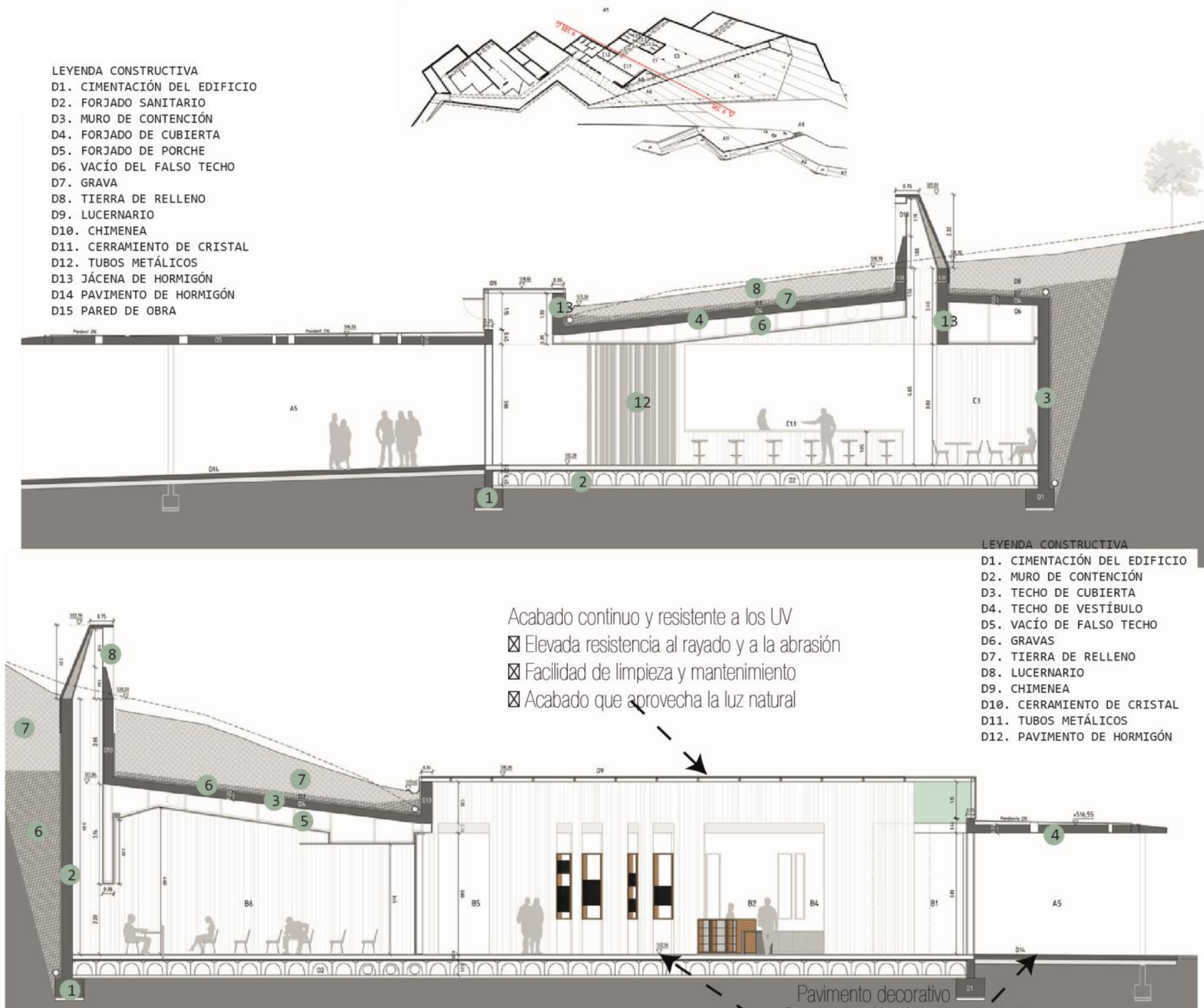

Acabado continuo y resistente a los UV

\Elevada resistencia al rayado y a la abrasión

\ Facilidad de limpieza y mantenimiento

\Acabado que zerovecha la luz natural

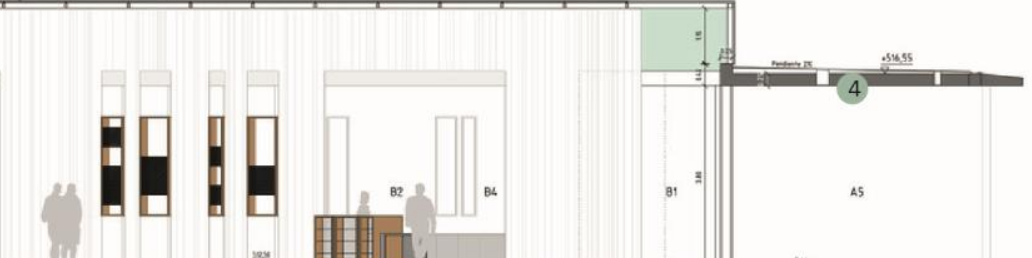

D1. CIMENTACIÓN DEL EDIFICIO

D2. MURO DE CONTENCIÓN

D3. TECHO DE CUBIERTA
D4. TECHO DE VESTÍBULO

D5. VACÍO DE FALSO TECHO

D6. GRAVAS

D7. TIERRA DE RELLENO

D8. LUCERNARIO

D9. CHIMENEA

D10. CERRAMIENTO DE CRISTAL

D11. TUBOS METÁLICOS

D12. PAVIMENTO DE HORMIGÓN 


\section{ESPACIO}

\section{TECNOLOGÍA}

IMPACTO SOCIAL

FICHA

\section{IMÁGENES DEL AUTOR EN BASE A :}

web: Plataforma de Arquitectura

web: Las Relaciones espaciales-Luis Ismael Pérez

texto: La sinergia entre museografia y arquitectura es posible: El Centro de Interpretación y Visitantes de La Antigua

Zumarraga-Anna Escarpanter

\section{MATERIALES}

* Tubos metálicos

* concreto armado

* vidrio

* planchas de acero

*Perfiles metálicos
*grava
*perfiles de aluminio
* pletinas metálicas

\section{DETALLE CONSTRUCTIVO}

\section{DETALLE 1}

DETALLE DE FACHADA

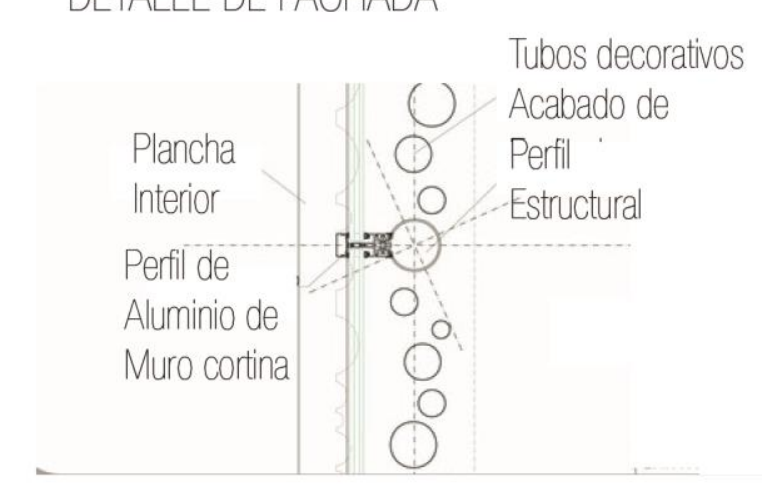

DETALLE 2

DETALLE DE COLUMNA CON MURO

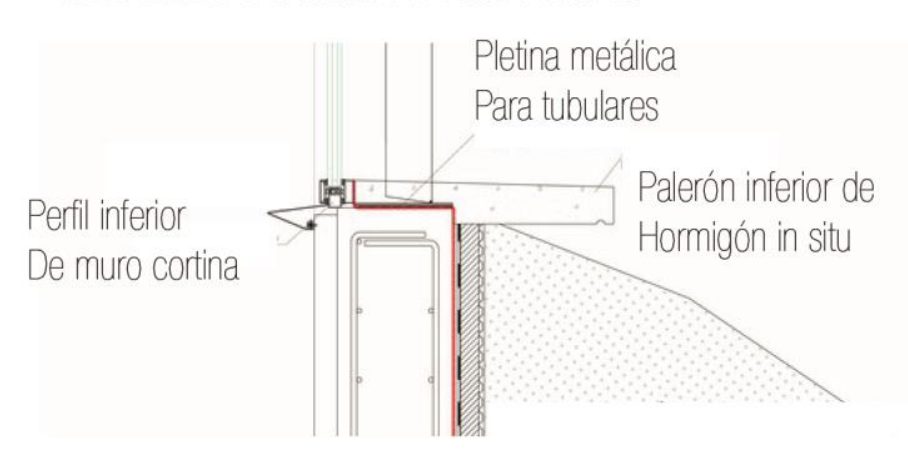

DETALLE 3

DETALLE 1
* cubierta de polietileno

*canaletas

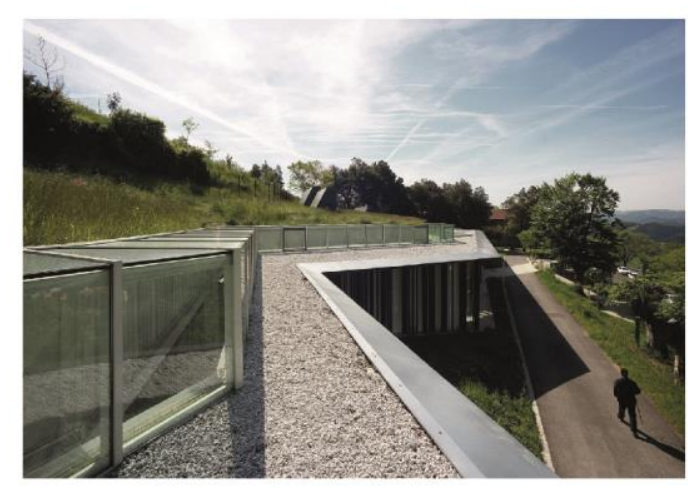

DETALLE DE ALERO SUPERIOR DE LOSA
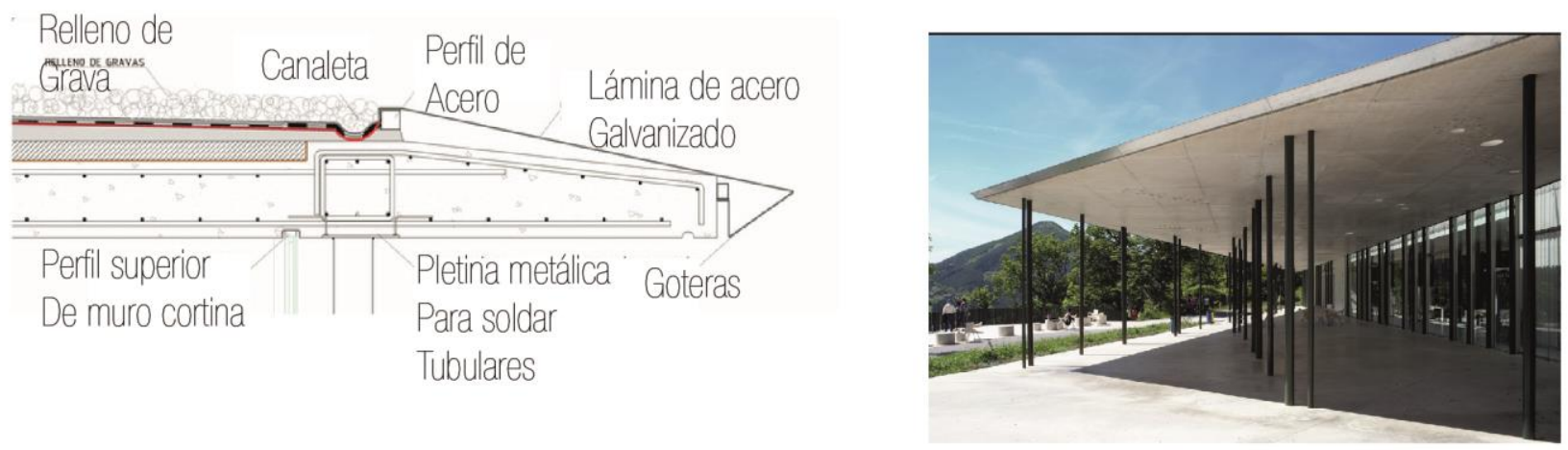


\section{LAANT}

\section{ESPACIO}

\section{TECNOLOGÍA}

IMPACTO SOCIAL

IMÁGENES DEL AUTOR EN BASEA:

web: Plataforma de Arquitectura

web: Las Relaciones espaciales-Luis Ismael Pérez

texto: La sinergia entre museografia y arquitectura es posible: El Centro de Interpretación y Visitantes de La Antigua

Zumarraga-Anna Escarpanter

\section{IMPACTO AMBIENTAL}

El proyecto del Centro de Interpretación y Acogida de Visitantes La Antigua nace de la tierra, del entorno de valle y montes en el que está situado, se articula con el entorno, la topografía y se mimetiza en la naturaleza cubriendo una parte del edificio con techos verdes que permiten mantener el interior totalmente fresco por la geotérmica.

Esta construcción ha tenido un impacto ambiental muy notorio, ya que desde la toma de partido tuvo la idea de no irrumpir el paisaje, ni tampoco superar la altura a La Ermita.

Sin bien es cierto al hablar de sostenibilidad, habrá muchos factores que el edificio no toma en cuenta, por ejemplo la materialidad, ya que los materiales utilizados son importados de otras ciudades, por lo tanto esto genera mayor gasto de energía.

Con respecto a la iluminación y ventilación natural, tampoco hay un ahorro de energía, ya que es artificial debido a que la gran parte del edificio se encuentra soterrado. 


\section{LAANTIGUA}

RADIO DE INFLUENCIA

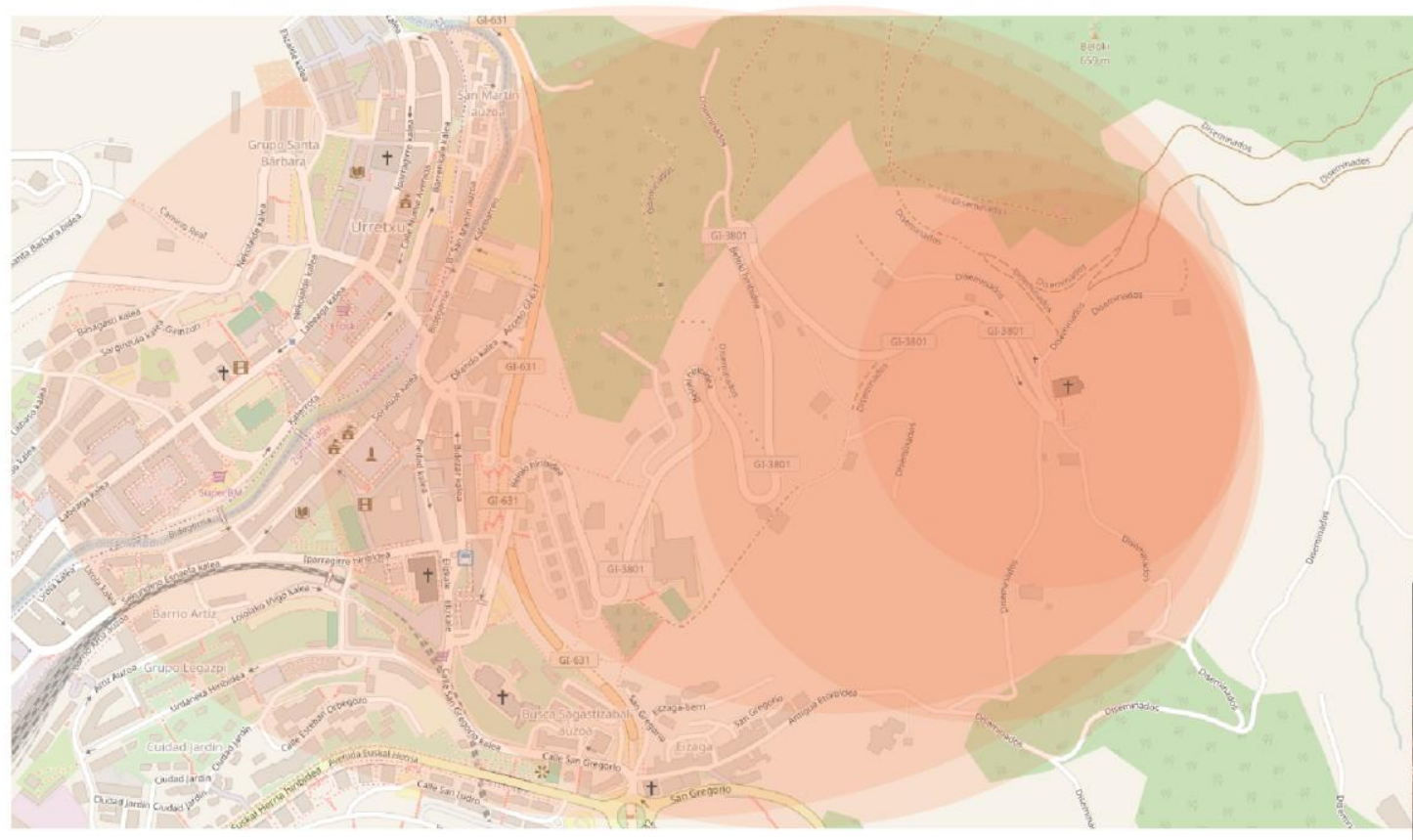

\section{CALIDAD DE VIDASSATISFACCIÓN}

El Centro de Interpretación y Acogida de Visitantes La Antigua ha tenido un impacto a nivel de la ciudad de Zumarrága, ya que se ha convertido en el ícono representativo de la ciudad y esto fue por dos razones que generaron un gran impacto social.

La primera, porque está ubicado al costado de La Ermita La Antigua que es el primer templo parroquial documentado para toda la zona del interior guipuzcoano, y hasta 1576, el primero de los que ha tenido Zumarrága, además la Ermita es de gran importancia porque parece una construcción románica. En relación cronológica se sitúa en el periodo gótico de Euskadi, pero teniendo en cuenta que fue construida con elementos arcaizantes para la época en la que se edificó. De esa manera La Antigua permite contemplar, en cierta medida, como pudieron ser los antiguos templos románicos de Gipuzkoa, techados en madera, con tallas, y sobrios en la decoración.

Asimismo, lo más destacable del interior es el carácter rural del mismo, ya que recuerda, tanto en la estructura como en la decoración, a los caseríos o a la arquitectura rural de Euskadi. Así, uno de los elementos más importantes del templo se encuentra en la ornamentación utilizada en la madera.

En segundo lugar, durante los días festivos que tiene la ciudad, el centro de interpretación es un punto de concentración de la población, ya que La Ermita La Antigua posee a la Virgen Santa María y en las cercanías del templo se realiza una romería en la fiesta patronal.

Por otro lado, el centro de interpretación tiene salas de exposición con temática de la historia de Zumarrága, esto atrae a los visitantes y turistas que visitan la ciudad y desean conocer.
POBLACIÓN ACTUAL

10,324 habitantes.
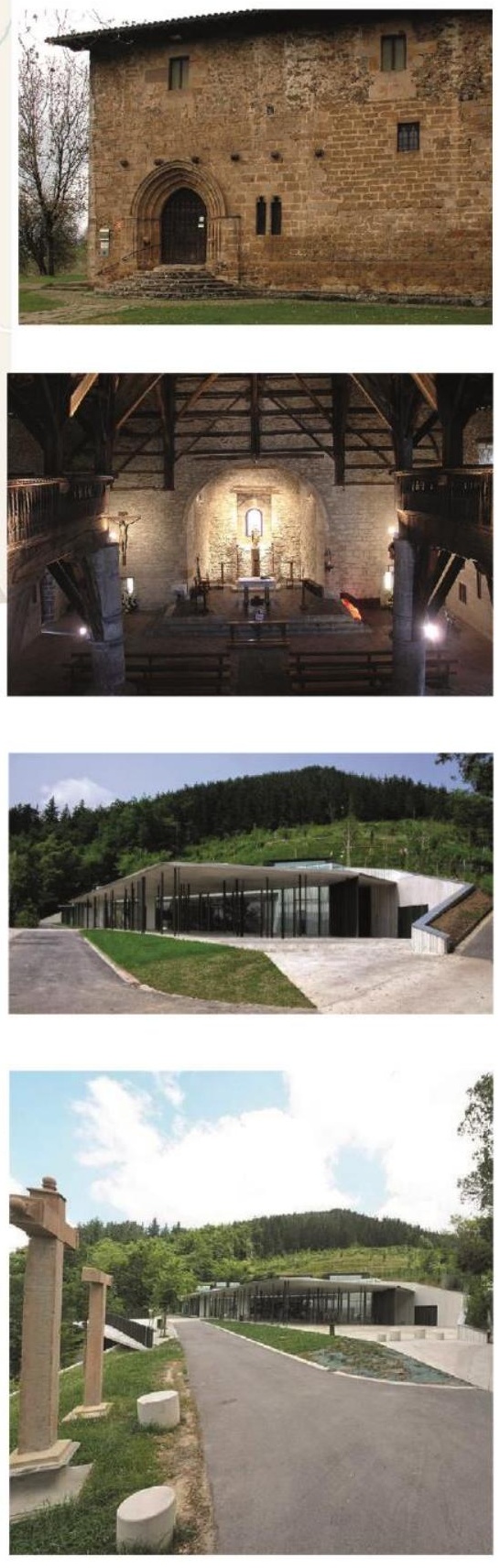
FICHA DEL PROYECTO

ESPACIO
HISTORIA

TECNOLOGIAA
UBICACIÓN

PROGRAMA

FICHA

5.71

\section{IMÁGENES DEL AUTOR EN BASE A :}

ATARIA. (n.d.). Ataria, Centro de interpretación de la Naturaleza.

Retrieved from http://www.estudioataria.com/ataria.html

ARQUUTECTO

- José María García del Monte

- Ana María Montiel Jiménez

- Fernando García Colorado

EQUIPO

- José Luis Fernández Cabo - Especialista estructural en Madera

- Rafael Valín Alcocer - Fase del diseño

- José Luis Montoya Y Luis Alberto Martínez De Sarriá - Técnicos en Obra

- GEA.S.L. - Instalaciones

AÑO

2006-2008

Centro de Estudio Ambiental del Ayuntamiento de Victoria

Se encuentra ubicado al norte del Parque de Salburúa en el distrito de Victoria -Gasteiz.

El proyecto como el umbral del parque está compuesto por dos niveles que dan un total de 1600 $\mathrm{m}^{2}$, los cuales son espacios de promueven la educación y actividades relacionadas a la puesta en valor y cuidado del ecosistema de los humedales. (ATARIA, n.d.)

El diseño del proyecto se realizó por QVE Arquitectos. La propuesta se basa en seis pórticos a modo de crujilla. El material principal a trabajar fue la madera como elemento de mediación con la naturaleza. (ATARIA, n.d.)
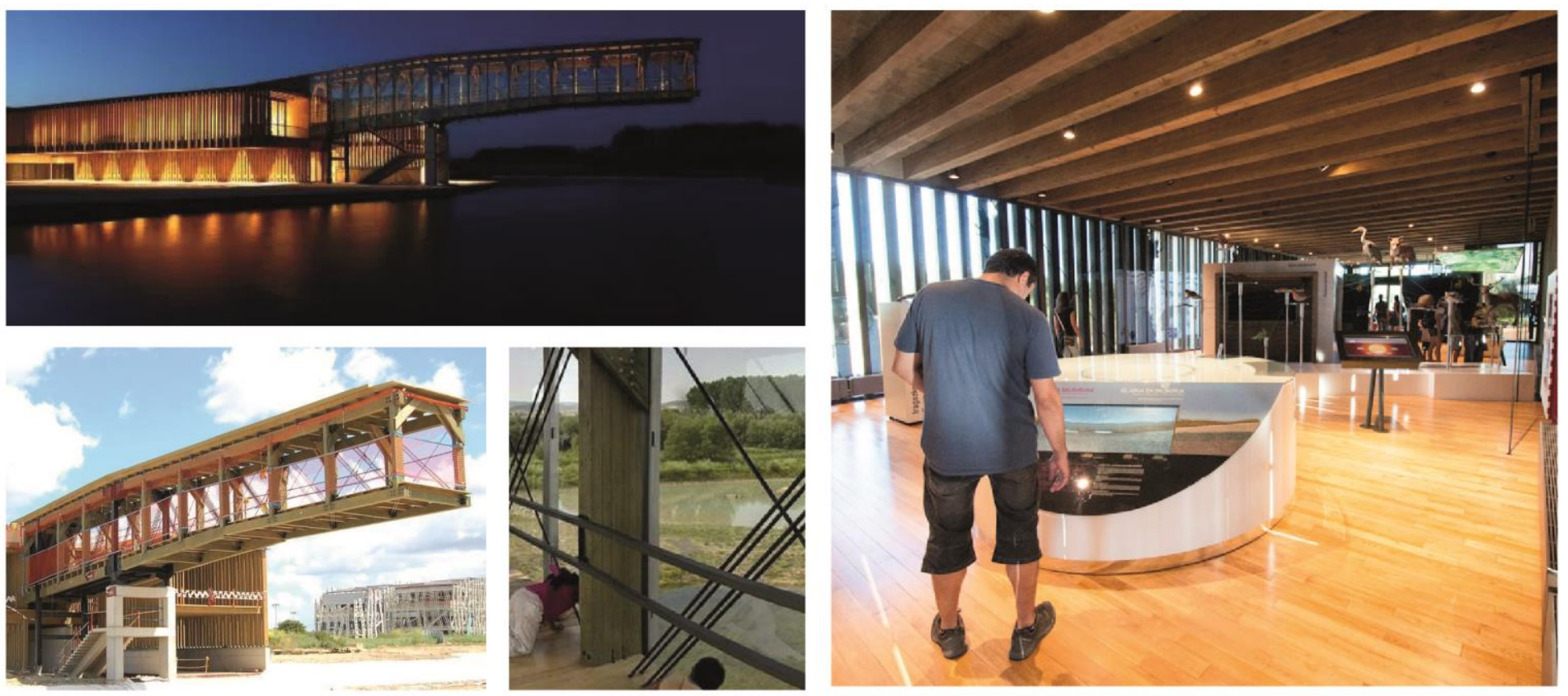
ATARIA. (n.d.). Ataria, Centro de interpretación de la Naturaleza.

Retrieved from http://www.estudioataria.com/ataria.html

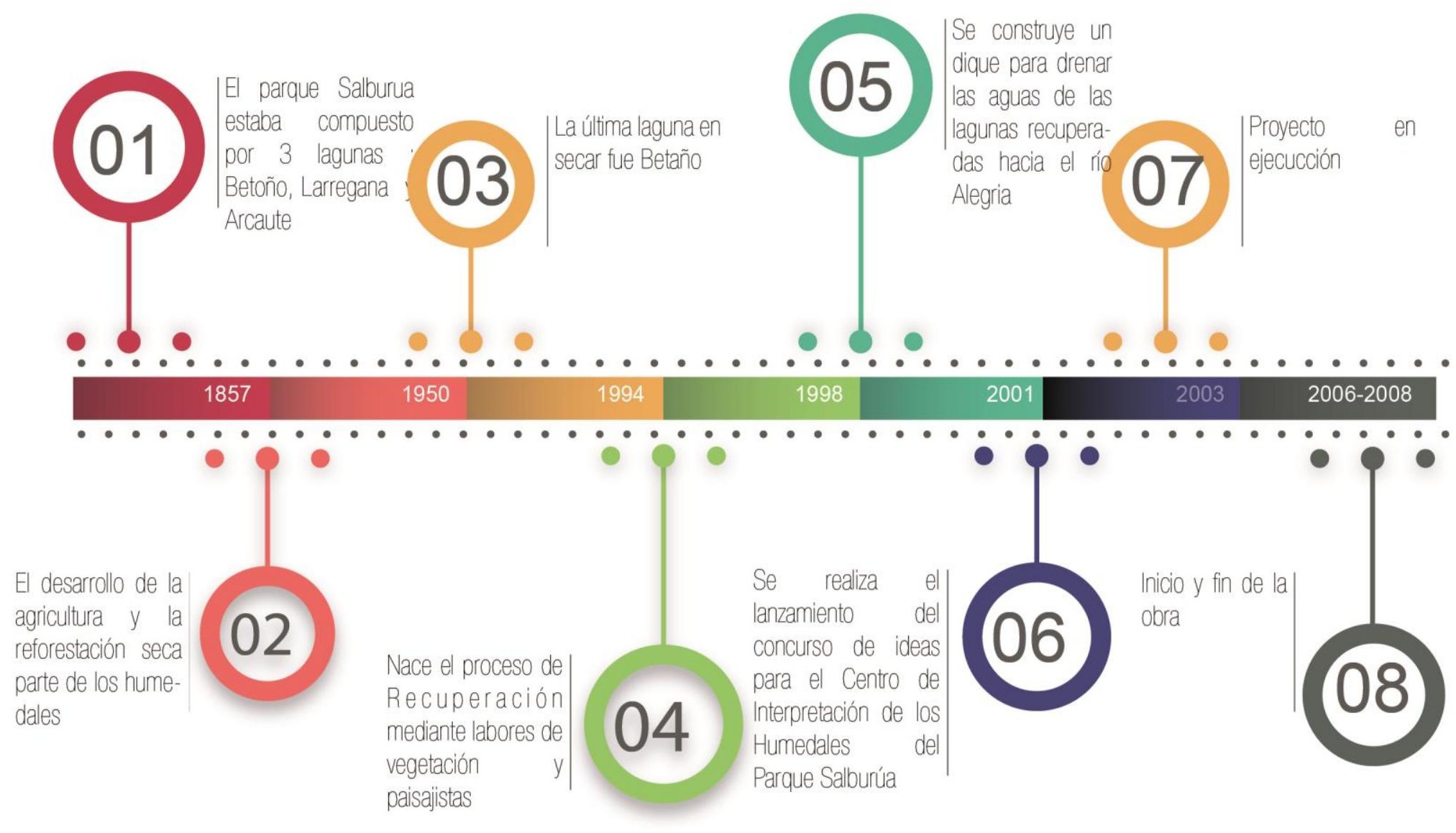

HISTORIA

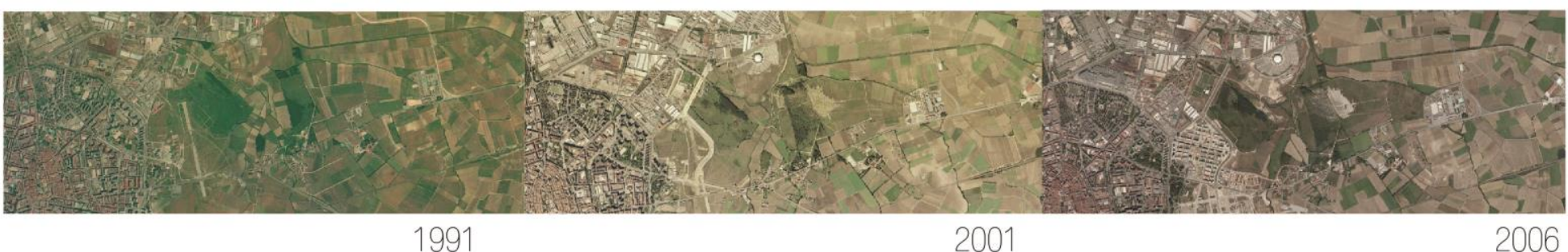

Los humedales de Salburúa han sido formados por aguas subterráneas del "Acuífero Cuaternario de Vitoria", que es una bolsa de agua y se extiende bajo la Llanada Alvesa. Originalmente los humedales estaban conformados por tres lagunas principales (Betoño, al oeste; Larregana, al norte y Arcaute, al sureste) que con el tiempo han ido desapareciendo.

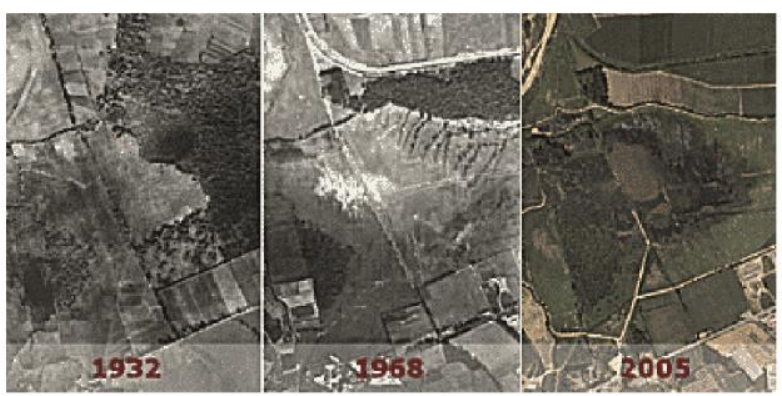


FICHA DEL PROYECTO

ESPACIO

\section{HISTORIA}

TECNOLOGIA

\section{UBICACIÓN}

IMPACTO SOCIAL
FICHA

\subsection{3}

IMÁGENES DELAUTOR EN BASE A :

ATARIA. (n.d.). Ataria, Centro de interpretación de la Naturaleza.

Retrieved from http://www.estudioataria.com/ataria.html

\section{TOMA DE PARTIDO}

La idea de proyectar un edificio que vaya más allá de los límites fue el concepto principal de diseño de los arquitectos, que vuele sobre el agua para dar al visitante un espacio privilegiado dentro del parque. Surge la idea de crear un mirador de 21 metros de largo.
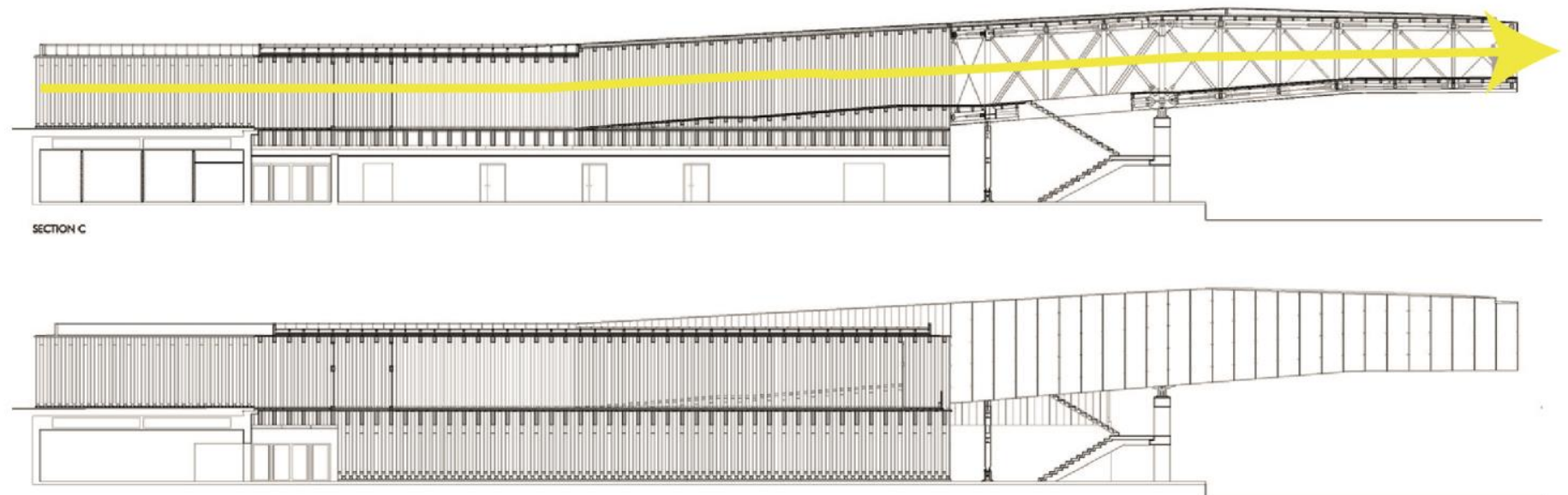

SECTIOND

Por otro lado, la elección del material fue un punto de partida , ya que al ubicarse en un parque natural lo que se buscaba era no alterar el paisaje. La dificultad del proyecto fue encontrar un sistema de construcción que permita hacer tangible las ideas. La madera y el metal fueron seleccionados para la ejecución.

Asimismo, la sostenibilidad fue otro punto de partida, el uso de energías naturales dentro del edificio, es por eso se diseña un centro de interpretación que genera sombra y use ventilación cruzada.
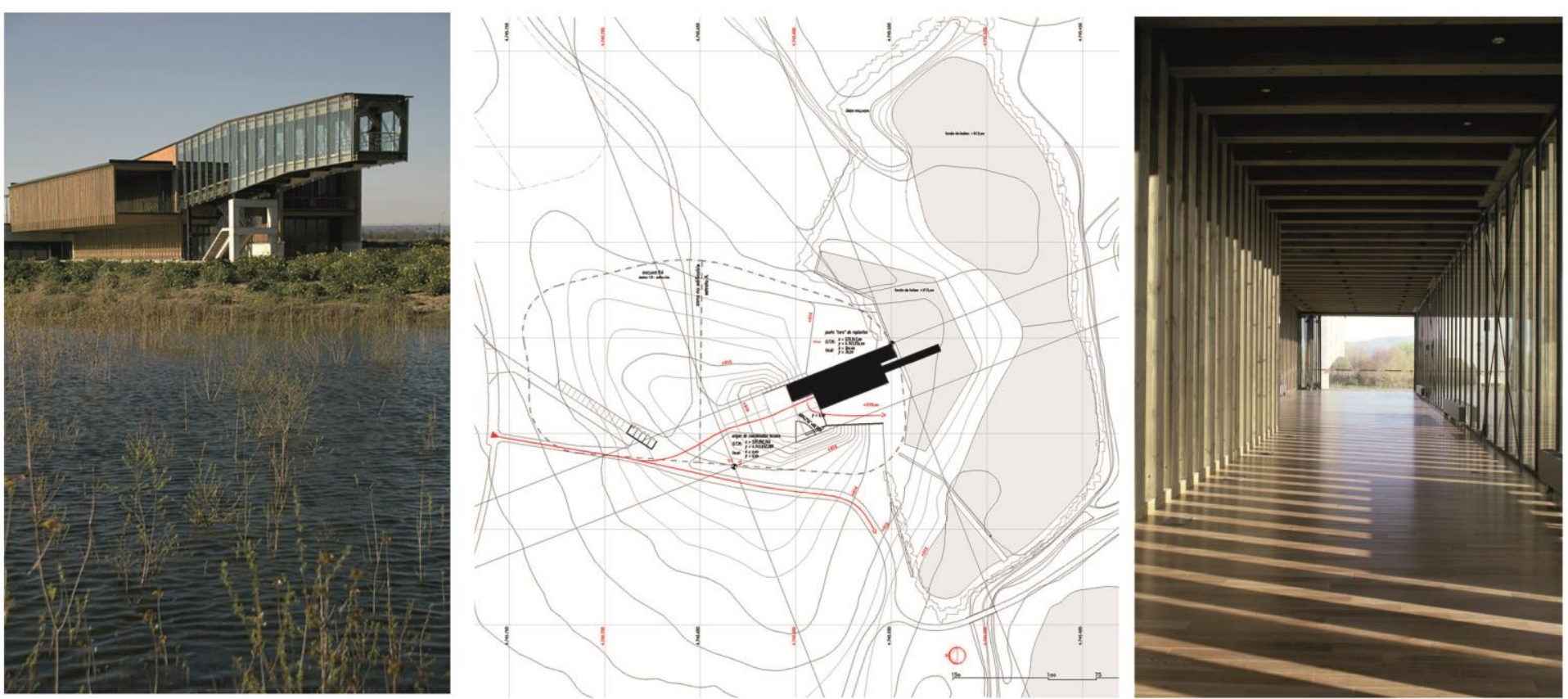


\section{SALBURÚA, ATARIA}

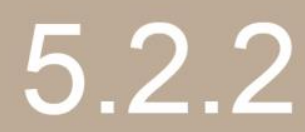

FICHA DEL. PROYECTO

ESPACIO
HISTORIA

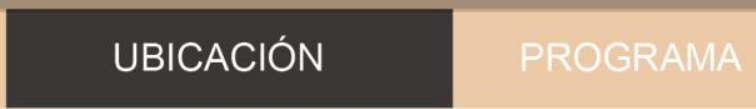

IMPACTO SOCIAL
FICHA

\section{IMÁGENES DELAUTOR EN BASE A :}

ATARIA. (n.d.). Ataria, Centro de interpretación de la Naturaleza.

Retrieved from http://www.estudioataria.com/ataria.html

UBICACIÓN

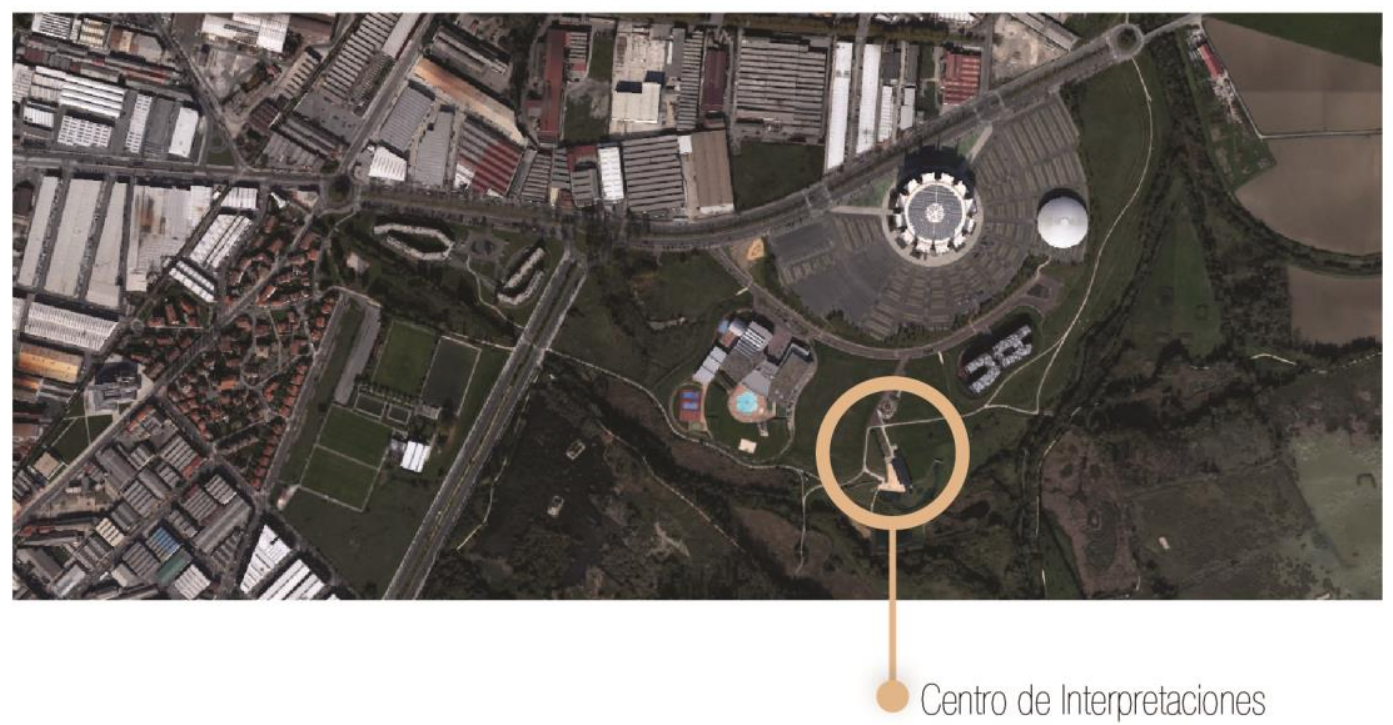

Se encuentra ubicado al norte del Parque de Salburua en el distrito de Victoría -Gas-

teiz en la Comunidad Autónoma de Vasco

PLANO CON ENTORNO INMEDIATO / VIAS PRINCIPALES / ESTACIONES DE TRANSPORTES

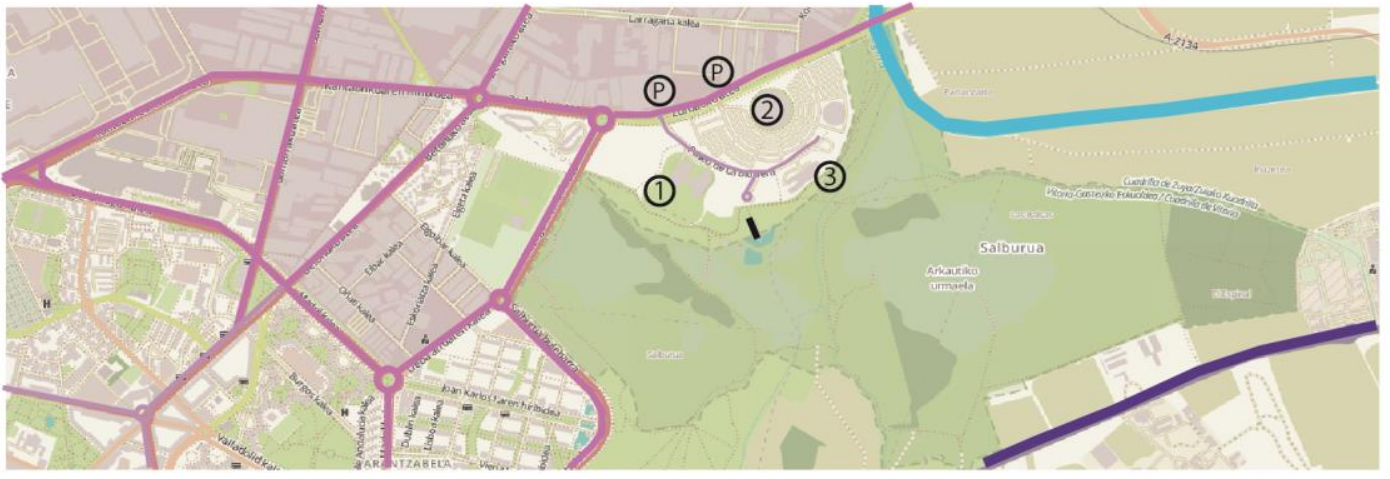

El centro de interpretación se encuentra a las afueras de la ciudad. El entorno inmediato esta compuesto por un área protegida que lo conforman el conjuto de humedales y el equipamiento deportivo del Bakh y el Pabellón Buesa Arena. Asimismo, próximo al proyecto se encuentra Río Alegre que conforma parte del ecosistema del lugar.

Con respecto a la conexión, esta se encuentra interconectada adecuadamente.

Las distancias de viaje son cortas. Por ejemplo, vía transporte privado y bicicleta la distancia es 13 minutos, tomando como punto de partida el centro de la ciudad. La distancia más larga fue mediante el transporte público (30 minutos) llegando al paradero más cercano al parque.
Zona Urbanizada
Parque
Bosque
Laguna
Humedal
Río Alegre

Zona Urbanizada
Parque
Bosque
Laguna
Humedal
Río Alegre

Zona Urbanizada
Parque
Bosque
Laguna
Humedal
Río Alegre

Zona Urbanizada
Parque
Bosque
Laguna
Humedal
-Río Alegre

Zona Urbanizada
Parque
Bosque
Laguna
Humedal
Río Alegre

Río Alegre

(2) Pabellón Buesa Arena

(3) El Edificio Vital

(P) Paraderos

- Vías Principales

- Autopista N-104

_ Vías Secundarias

— Centro de Interpretaciones

- Vehículo Particular (C) $13 \mathrm{~min}$

Transporte Público $30 \mathrm{~min}$

Bicicleta $13 \mathrm{~min}$

(C)

4 Peatona 
 \\ SALBURUA, ATARIA}

FICHA DEL PROYECTO

ESPACIO

\section{UBICACIÓN}

\section{2 .2}

\section{IMÁGENES DEL AUTOR EN BASE A :}

\section{TECNOLOGIA}

IMPACTO SOCIAL
FICHA

5.75

ATARIA. (n.d.). Ataria, Centro de interpretación de la Naturaleza.

Retrieved from http://www.estudioataria.com/ataria.html

\section{PLANO CON ENTORNO INMEDIATO/ ACCESOS PEATONALES}
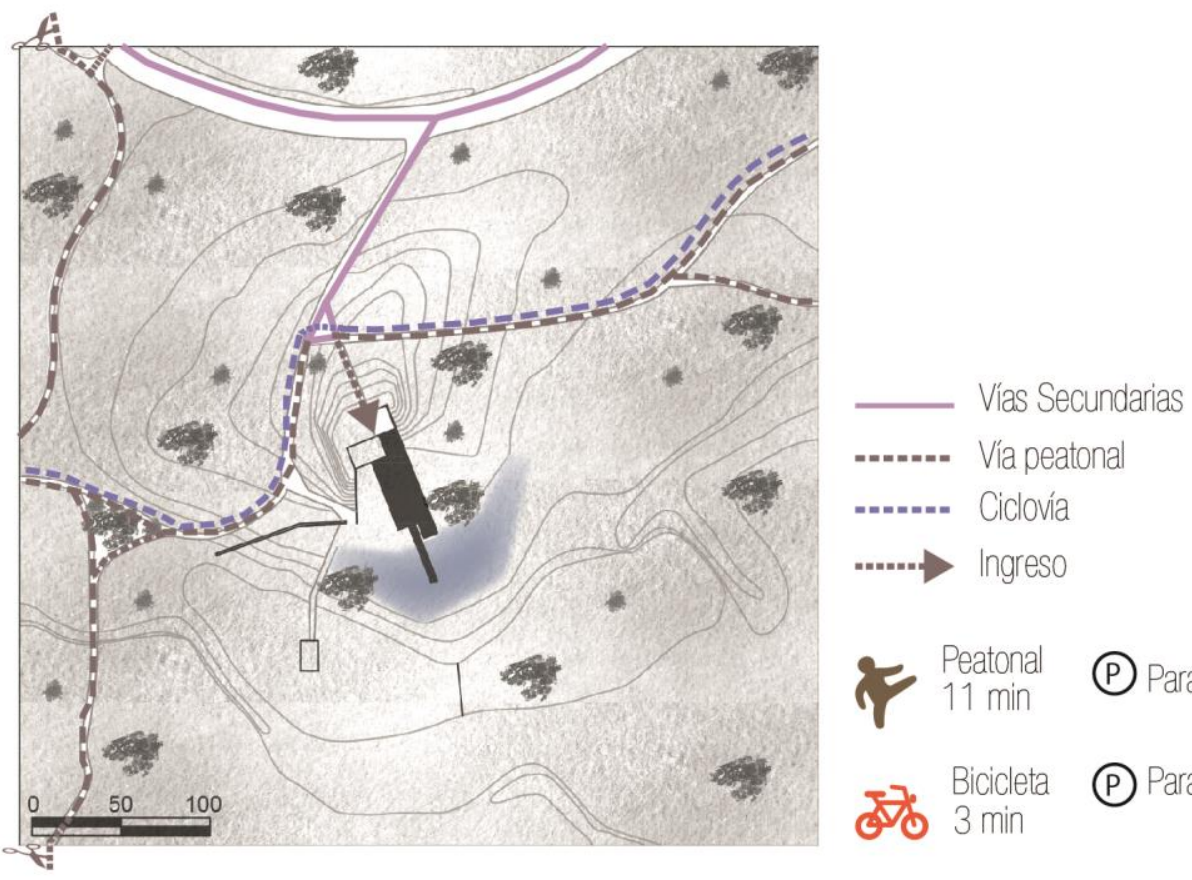

El Ingreso al centro de interpretación es peatonal, por lo que requiere de un traslado de 11 minutos a pie del paradero más cercano (ubicado al frente del pabellón). Por otro lado, existe un área de aparcamiento que se encuentra a 3 min de la entrada. Finalmente, desde el centro de la ciudad el tiempo estimado de traslado caminando es de 46 minutos aproximadamente.

\section{APORTES}

Mediante el análisis del lugar y el emplazamiento del Centro de Interpretaciones podemos indicar que se encuentra alejado de la ciudad. Cerca al lugar se ubican 2 paraderos, aproximadamente a 11 minutos y 13 minutos. Asimismo, dentro de la zona se encuentran ciclovías que permiten llegar al centro de interpretación desde el paradero más cercano en un tiempo estimado de 3 minutos.

\section{CORTES ESQUEMÁTICOS}

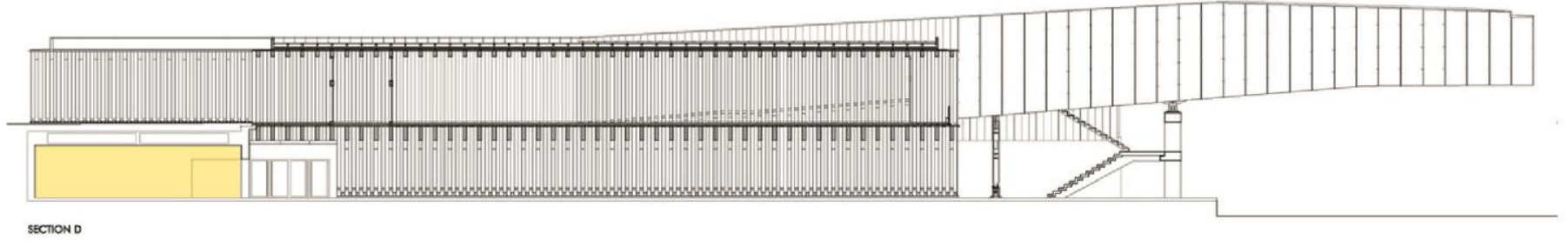

La relación del entorno y el ingreso es semi directa, debido a la existencia de un patio que sirve como preámbulo o antesala del proyecto. 
CENTRO DE INTERPRETACIÓN DE LA NATURALEZA DE SALBURÚA, ATARIA

\section{ESPACIO}

IMÁGENES DEL AUTOR EN BASE A :

ATARIA. (n.d.). Ataria, Centro de interpretación de la Naturaleza.

Retrieved from http://www.estudioataria.com/ataria.html

\section{USUARIOS}

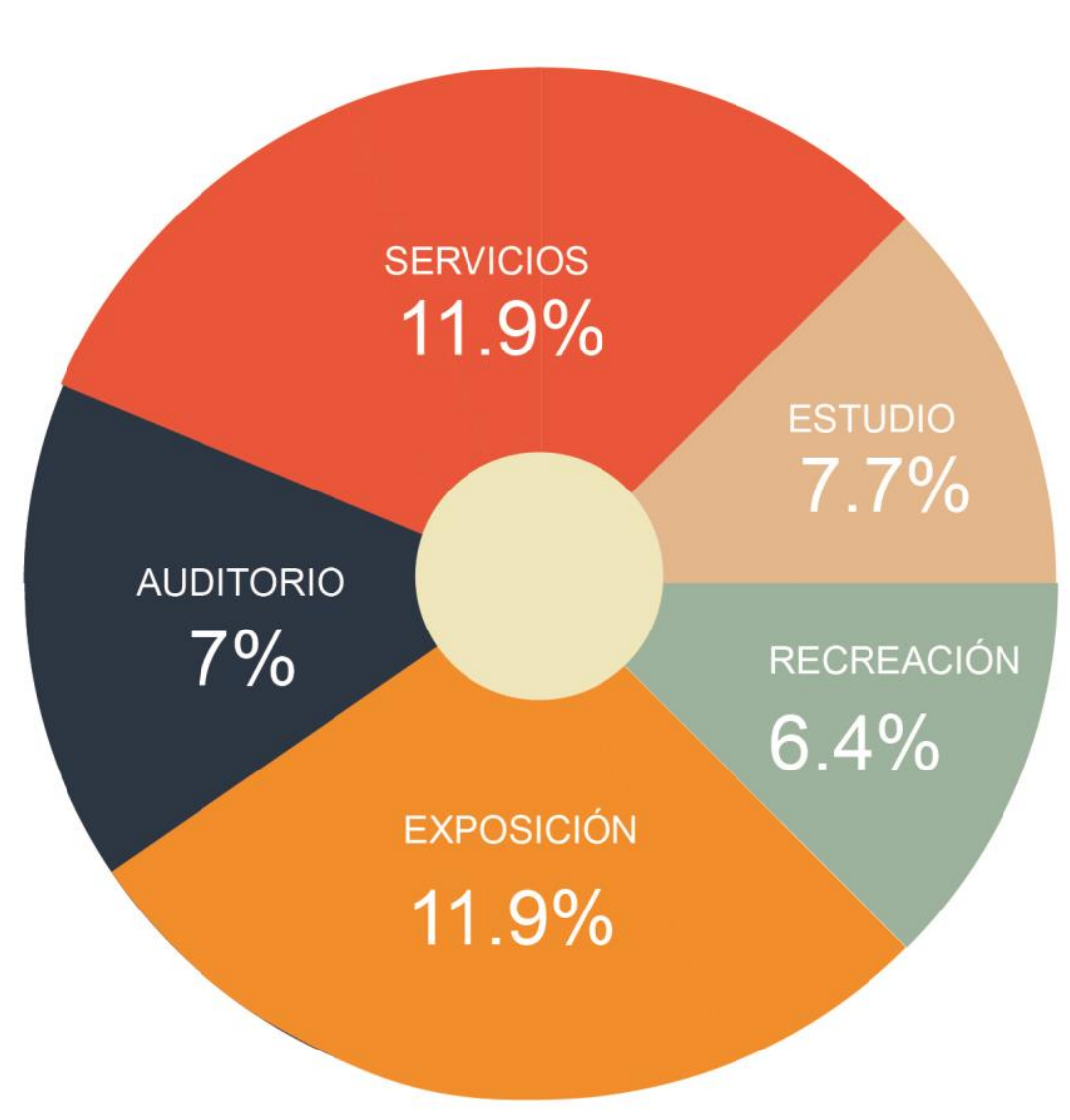

PAQUETES PROGRAMÁTICOS
101 Turistas
FICHA

\subsection{6}

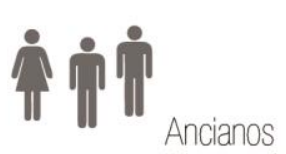

- Discapacitados

Niños

กั่

Personal capacitado

Empleados del área

de limpieza,

servicio, administrativo, etc.

CUADRO DE ÁREAS

\begin{tabular}{|c|c|c|c|c|}
\hline AUDITORIO & RECREACIÓN & ESTUDIOS & EXPOSICIONES & SERVICIOS \\
\hline $\begin{array}{c}\text { SALA DE ACTOS } \\
127 \mathrm{~m} 2\end{array}$ & $\begin{array}{l}\text { MIRADOR } \\
25 \mathrm{~m} 2\end{array}$ & $\begin{array}{l}\text { LABORATORIO } \\
64.5 \mathrm{~m} 2\end{array}$ & $\begin{array}{l}\text { SALA EXP. } \\
\text { PERMANENTE } \\
216 . \mathrm{m} 2\end{array}$ & $\begin{array}{l}\text { CAFETERÍA } \\
106 \mathrm{~m} 2\end{array}$ \\
\hline & $\begin{array}{l}\text { SALA DE ESTAR } \\
92 \mathrm{~m} 2\end{array}$ & $\begin{array}{l}\text { OFICINAS } \\
70 \mathrm{M} 2\end{array}$ & $\begin{array}{l}\text { SALA EXP. } \\
\text { TEMPORAL } \\
132.5 \mathrm{~m} 2\end{array}$ & $\begin{array}{l}\text { SERVICIOS } \\
\qquad 38 \mathrm{~m} 2\end{array}$ \\
\hline & & & & $\begin{array}{l}\text { ADMINISTRACIÓ } \\
146.5 \mathrm{~m} 2\end{array}$ \\
\hline
\end{tabular}




\section{ESPACIO}

TECNOLOGÍA

IMÁGENES DEL AUTOR EN BASE A :

ATARIA. (n.d.). Ataria, Centro de interpretación de la Naturaleza.

Retrieved from http://www.estudioataria.com/ataria.html

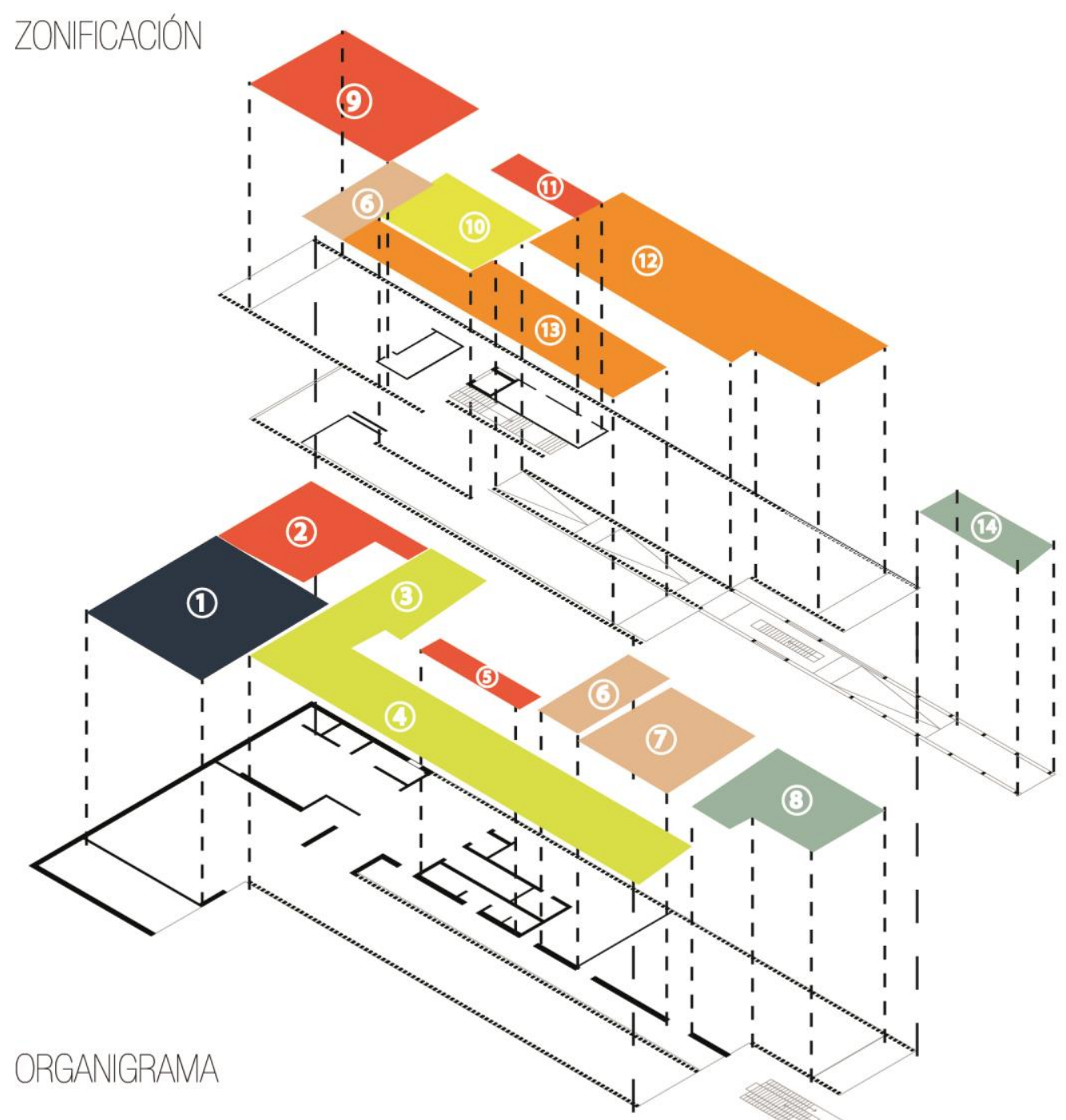

Segundo Nivel

Primer Nivel
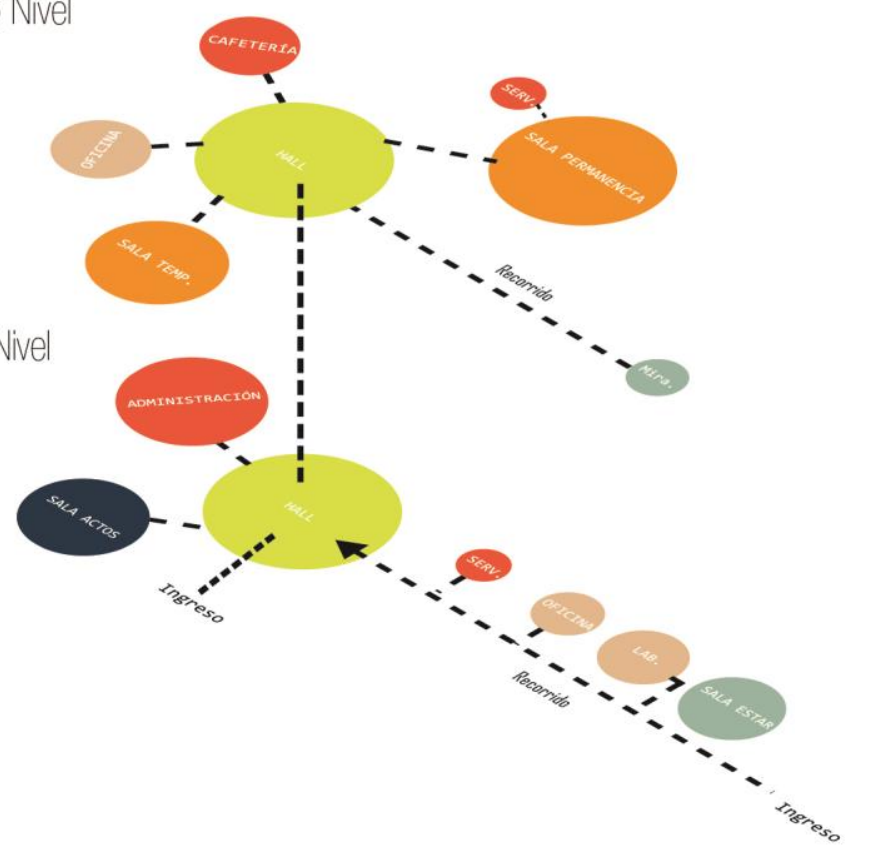

FICHA

5.77

\section{Exposición}

Servicios

\section{Estudio}

Conferencia

Recreación

Recorrido

(1) Sala de Actos

(2) Administración

(3) Hall

(4) Recorrido

(5) Baños

(6) Oficinas

(7) Laboratorio

(8) Sala de estar

(9) Cafetería

(10) Hall

(11) Baño

(12) Sala de Exp.Permanente

(13) Sala de Expo. Temporal

(14) Mirador 
HISTORIA

UBICACIÓN

PROGRAMA

\section{ESPACIO}

TECNOLOGÍA

IMPACTO SOCIAL
FICHA

5.78

IMÁGENES DEL AUTOR EN BASE A :

ATARIA. (n.d.). Ataria, Centro de interpretación de la Naturaleza.

Retrieved from http://www.estudioataria.com/ataria.html

\section{DEFINICIONES DE TIPOLOGÍA}

El Centro de interpretacion de los humedales presenta una tipología lineal. La conformación del recorrido y el hall que distribuye a los espacios determinan la volumetría

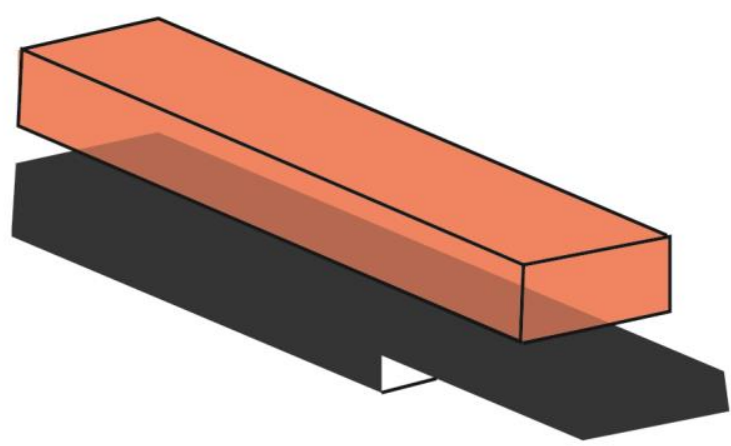

\section{PÚBLICO-SEMIPÚBLICO-PRIVADO}

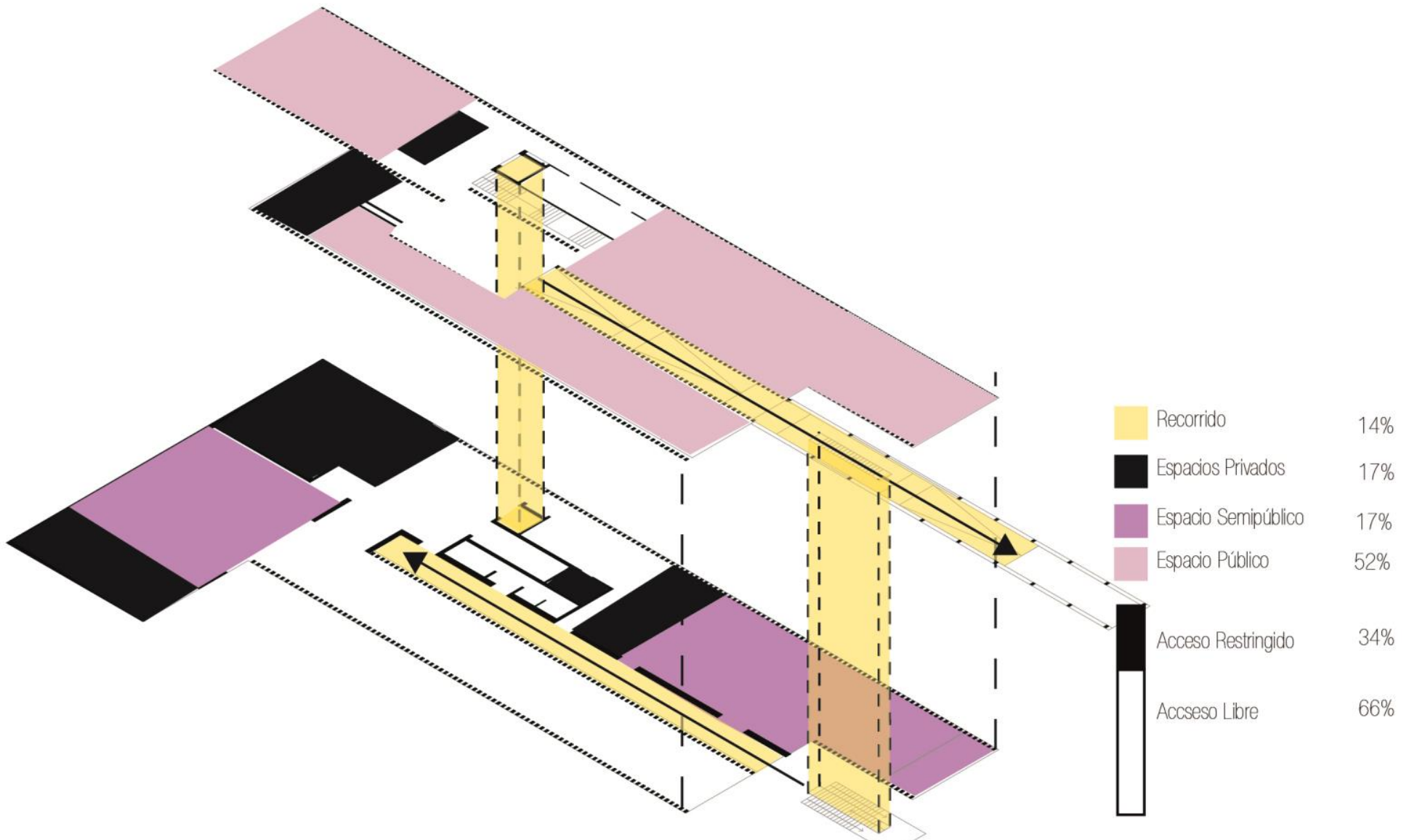




\section{ESPACIO}

\section{TECNOLOGÍA}

IMPACTO SOCIAL

IMÁGENES DEL AUTOR EN BASE A :

ATARIA. (n.d.). Ataria, Centro de interpretación de la Naturaleza.

Retrieved from http://www.estudioataria.com/ataria.html

\section{FLUJOS Y CIRCULACIONES}

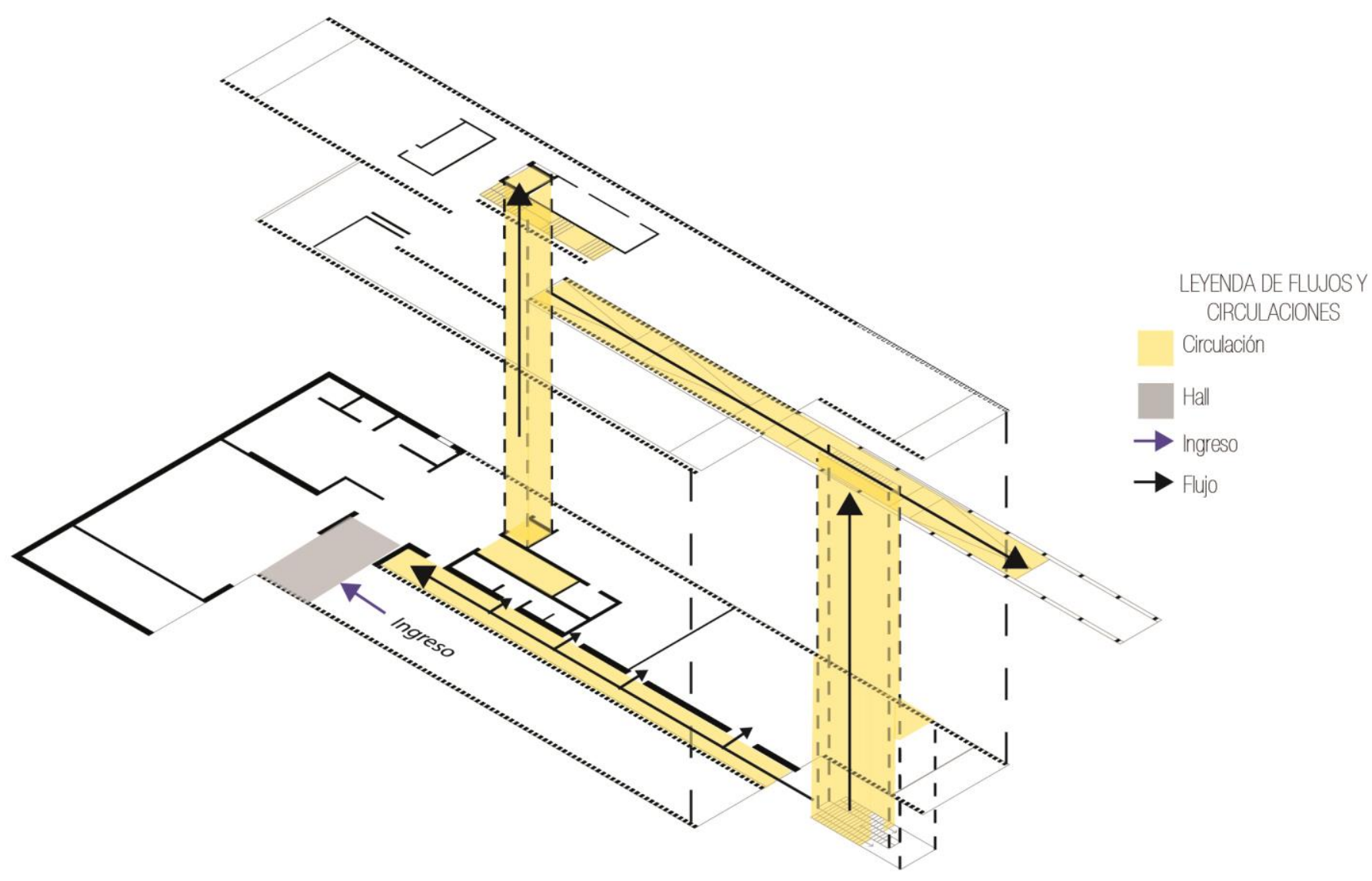

ÁREA CONSTRUIDA-ÁREA LIBRE

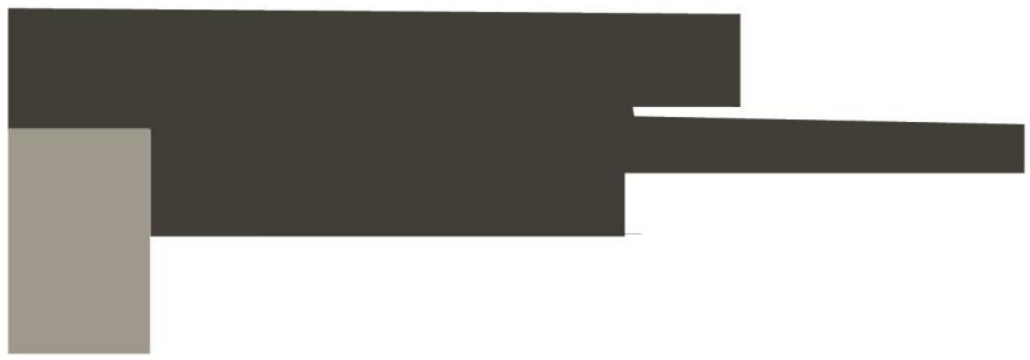

Área construída

Área libre del edificio

Área total del edificio

Área libre protegida

Área total intervención
$1800 \mathrm{~m} 2$

$0 \mathrm{~m} 2$

$1800 \mathrm{~m} 2$

$5400 \mathrm{~m} 2$

$7200 \mathrm{~m} 2$ 


\section{TECNOLOGÍA}

\section{IMPACTO SOCIAL}

FICHA

5.80

IMÁGENES DEL AUTOR EN BASE A :

ATARIA. (n.d.). Ataria, Centro de interpretación de la Naturaleza.

Retrieved from http://www.estudioataria.com/ataria.html

\section{ESPACIALIDAD}

La relación entre espacios interiores, en el caso del centro de interpretación de los humedales de Salburúa se da de dos maneras. La primera es relación de pertenencia, esta conexión se da por medio del hall que permite contener y conectar con los demás espacios. Otro caso es la relación por yuxtaposición que se da por el recorrido central y lineal que distribuye a los diferentes programas.

\section{RELACIÓN HORIZONTAL}

La relación espacial horizontal del proyecto, se genera a través बelel ecorrido central que llega a un hall que reparte a todos los espacios

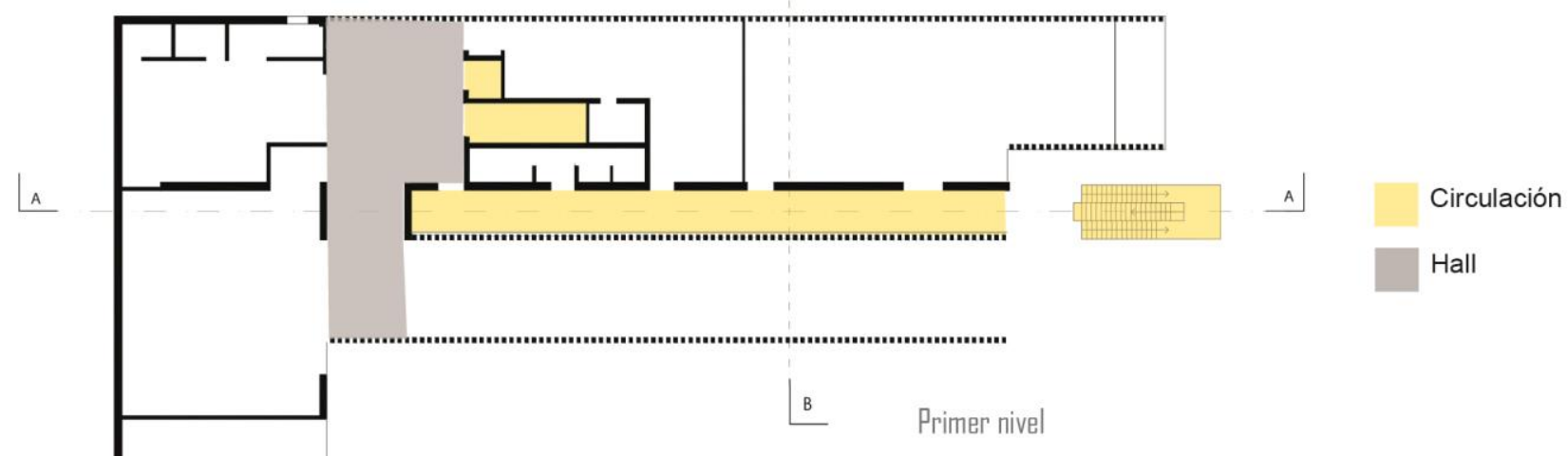

B

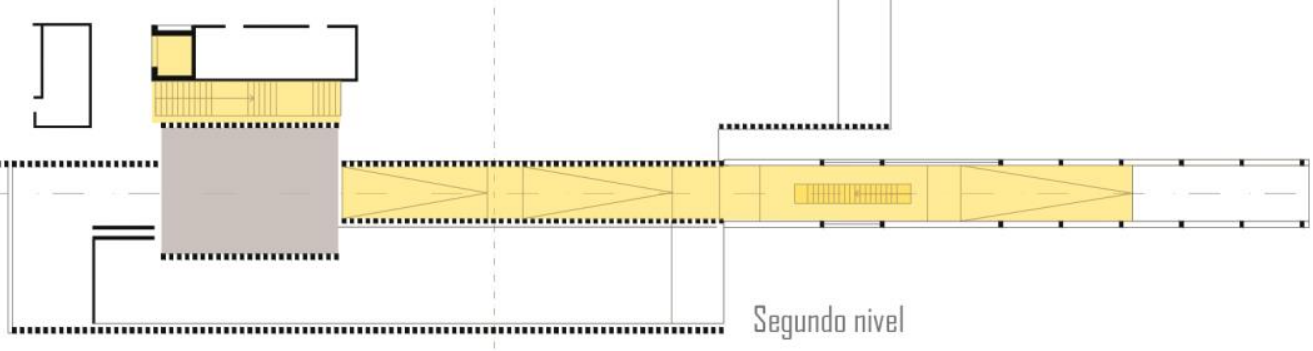

B

\section{RELACIÓN VERTICAL}

La relación vertical se establece con el entorno. La materialidad del proyecto que permite la permeabilidad logra que el edificio este observando todo a su alrededor.

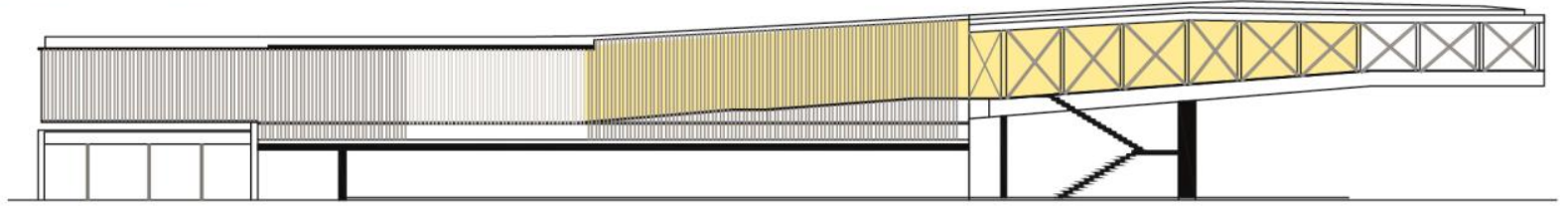

Corte AA

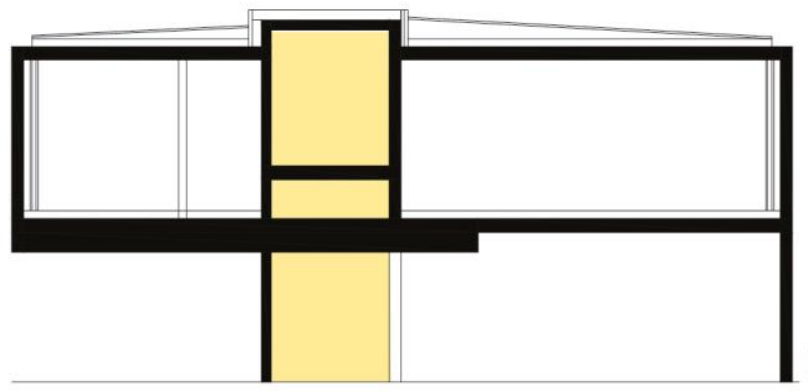




\section{ESPACIO}

\section{TECNOLOGÍA}

IMPACTO SOCIAL

ATARIA. (n.d.). Ataria, Centro de interpretación de la Naturaleza.

Retrieved from http://www.estudioataria.com/ataria.html

\section{MATERIALES}

El material con el que se trabajó es la madera y acero, ya que por el diseño necesitan ser resistentes y estructurantes.

Por otro lado, la cimentación de la estructura está conformada por zapatas y cimiento corrido que permiten el anclaje de la estructura de madera y acero

\section{SISTEMA CONSTRUCTIVO}

El proyecto al ser el ingreso principal al parque natural tuvo como propósito ser un umbral. Este concepto de diseño con la toma de partido del material tiene como resultado el sistema constructivo de pórticos de madera consecutivos uno del otro configurando los espacios intermedios.

\section{DETALLE CONSTRUCTIVO}

El primer paso en la construcción es el soporte estructural. Este está compuesto por concreto que permite el anclaje de los pórticos de madera al suelo con la finalidad de evitar el contacto con el suelo húmedo.

Para el diseño de los pórticos fue preciso definir un ritmo de distancia de 20x 20 en fachada y en vigas de 80x80.

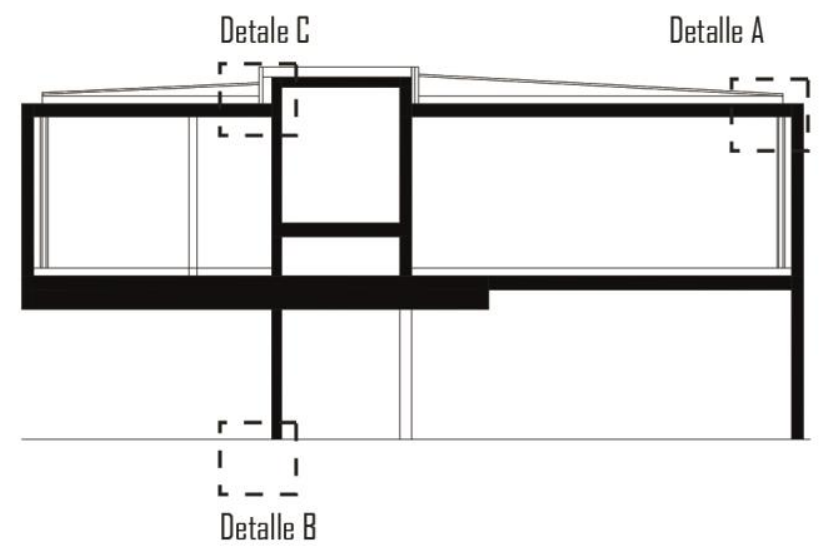

Detalle de canaletas

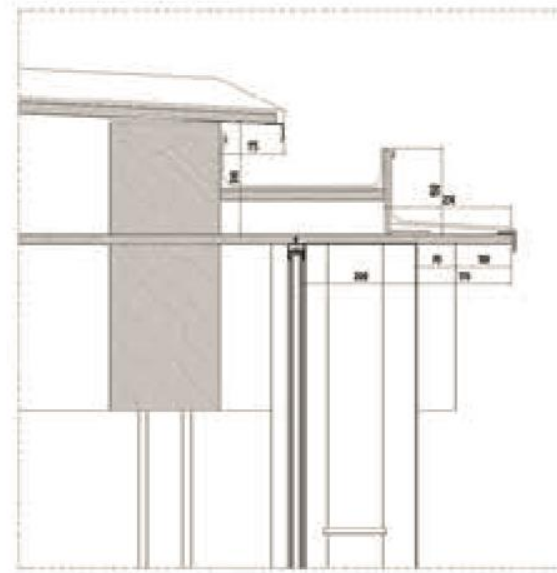

DETALLEA
Detalle de anclaje de la estructura de madera

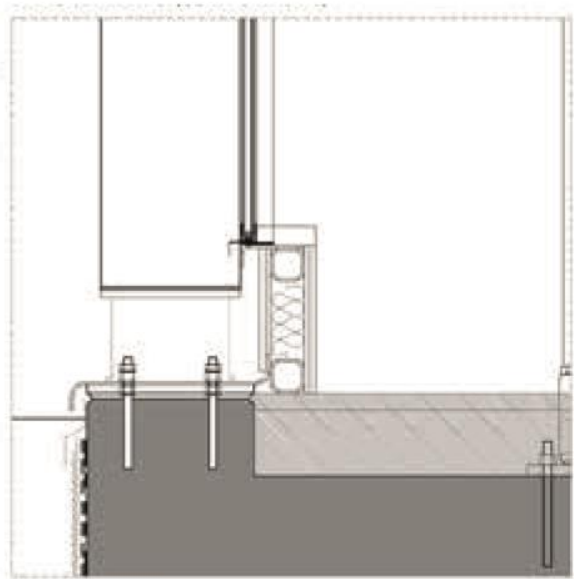

DETALLEB
Detalle de clarabolla

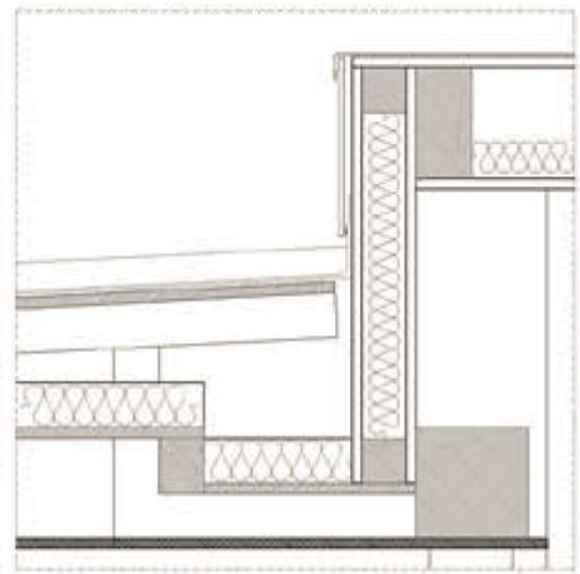

DETALLEC 


\section{2 .2}

FICHA DEL PROYECTO

ESPACIO

HISTORIA

UBICACIÓN

PROGRAMA

IMPACTO SOCIAL
FICHA

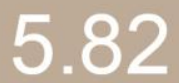

\section{IMÁGENES DELAUTOR EN BASE A :}

ATARIA. (n.d.). Ataria, Centro de interpretación de la Naturaleza.

Retrieved from http://www.estudioataria.com/ataria.html

\section{RADIO DE INFLUENCIA}

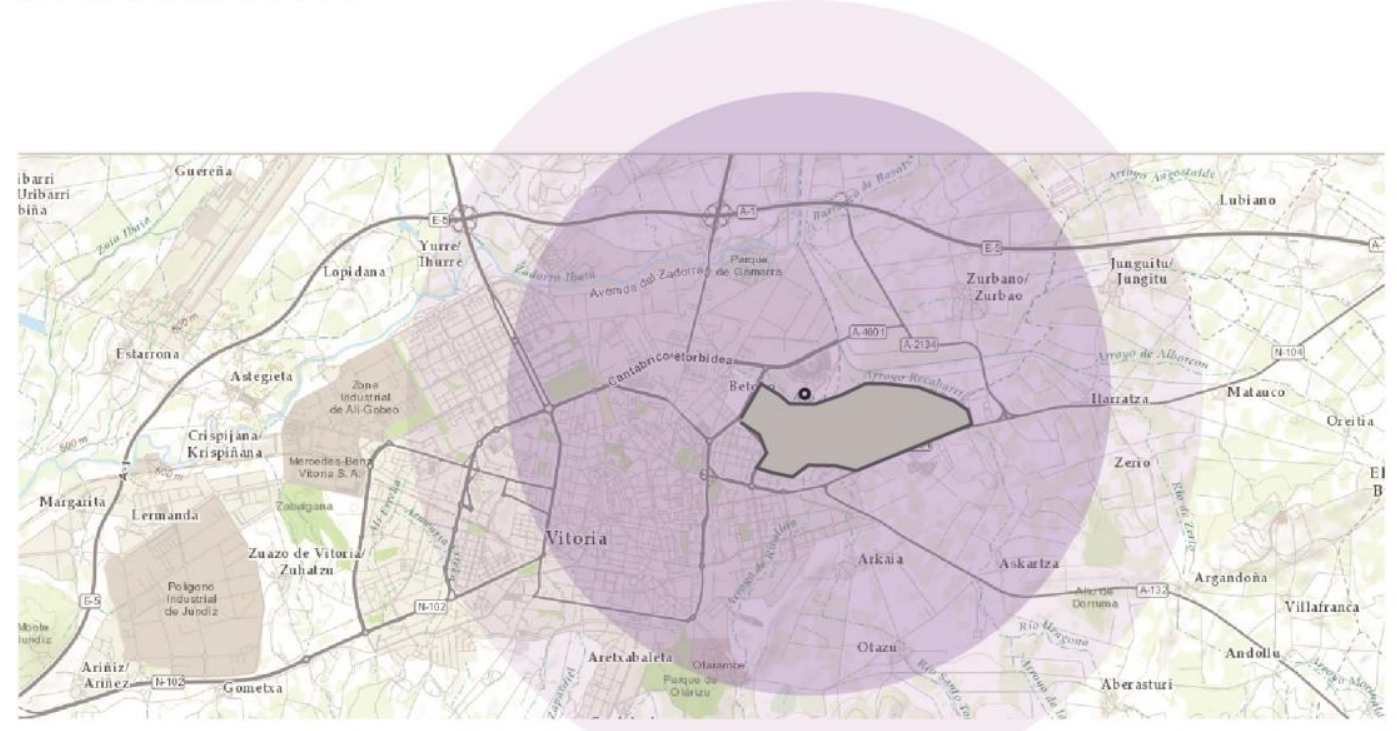

Humedales de Salburúa

- Centro de Interepretaciones

Radio de influencia

El proyecto se ubica en el parque de humedales de Salburúa a las fueras de la ciudad. El centro forma parte del anillo verde y genera un impacto a nivel local.

En relación al aspecto ecológico, se genera un impacto regional, ya que los humedales tienen un rol importante en el proceso de migración de aves. En consecuencia, existe la necesidad de preservar el paisaje.

Por lo tanto, el centro de interpretación es un proyecto transmisor de educación ambiental y tiene un impacto directo con la ciudad al establecer programas con escuelas de la zona.

\section{CALIDAD DE VIDASSATISFACCIÓN}

La recuperación de los humedales y la iniciativa del proyecto ha causado un bienestar ambiental, económico y social a la comunidad. En el aspecto ambiental, la recuperación del ecosistema ha ocasionado la mejora de la calidad del entorno y el incremento de especies de fauna. En lo social, el centro de interpretación se ha convertido en un espacio de atracción y recreación que permite el turismo y la aglomeración de visitantes, ya que proporciona actividades de descanso, paseo, y distracción. Finalmente en lo económico, hay un incremento de visitas nacionales e internacionales, además de la generación de trabajo para la conservación y mantenimiento del lugar.

\section{MEMORIA Y TRADICIONES}

La zona intervenida por el centro de interpretación es parte de la memoria colectiva de la población, ya que ha sido un lugar de aprovechamiento para el cultivo. Sin embargo, tras secarse los humedales se perdió gran parte del recurso natural y del paisaje. De este modo, la iniciativa del proyecto fue la búsqueda de la revaloración del patrimonio natural e insignia de la Ciudad de Victoria. 
HISTORIA

UBICACIÓN

PROGRAMA

ESPACIO

TECNOLOGÍA

IMPACTO SOCIAL

\section{FICHA}

\subsection{3}

ARQUTECTO

EQUPO

AÑO

CLIENTE

DESCRIPCIÓN
- José Juan Barba

- Concha Llorden - Diseño 2005-2008

Proyecto Unión Europea

Se encuentra ubicado en el terreno del Parque de la Pradera en la ciudad de Benavente, España. El proyecto pertenece al programa INTEREG IIIA, encargada de crear una serie de infraestructuras medioambientales en la Unión Europea. El centro parte de la interpretación de los ríos como un elemento que riega al territorio de manera natural y que además es recurso manipulado por el hombre. (Diputación de Zamora, 2014, p. 12) (Ayuntamiento de Benavente, 2011, p. 25).

El proyecto contiene cinco salas y dos patios, los cuales están rodeados por la circulación.
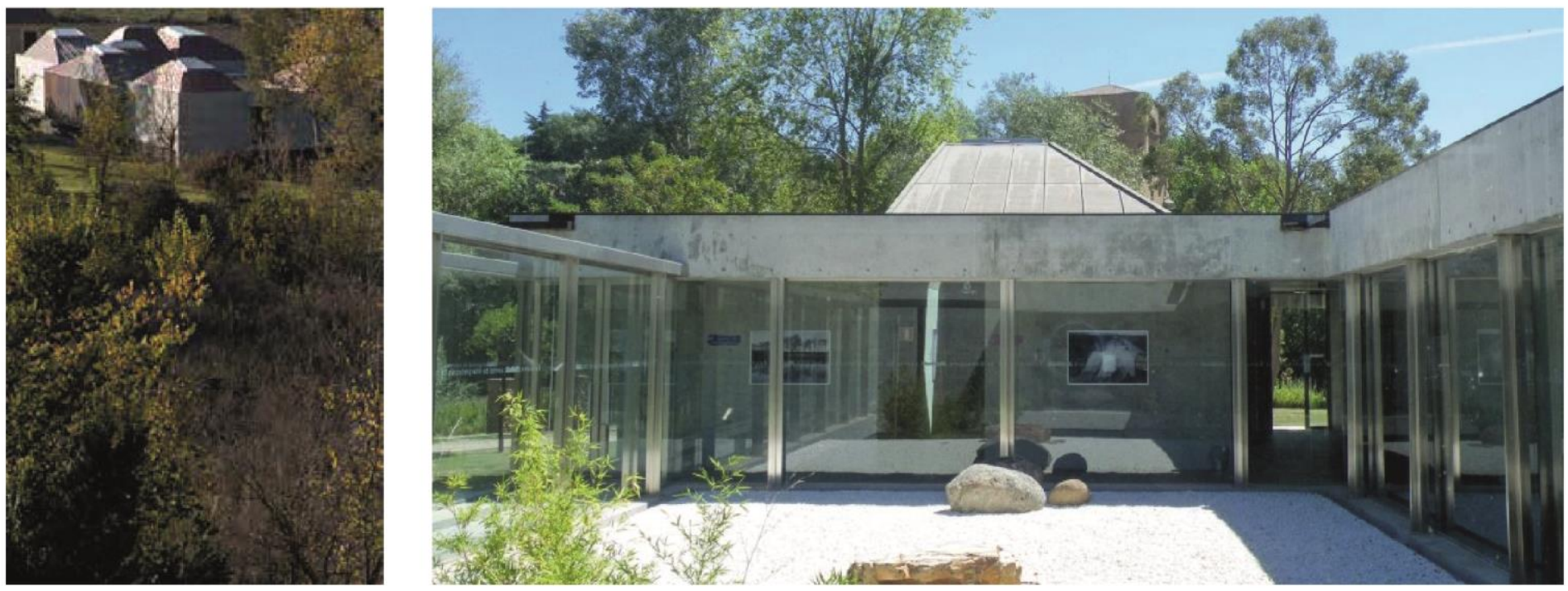
HISTORIA

TECNOLOGÍA
UBICACIÓN

IMPACTO SOCIAL
PROGRAMA

\section{FICHA}

IMÁGENES DEL AUTOR EN BASE A:

Archdaily. (2010). Centro de Investigación e Interpretación de los ríos / José Juan Barba | ArchDaily Perú.

Retrieved from http://www.archdaily.pe/pe/02-43932/centro-de-investigacion-e-interpretacion-de-los-rios-jose-juan-barba

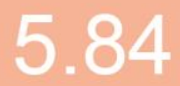

\section{HISTORIA}

Pertenece al programa INTERREG de desarrollo transfronterizo para superar los problemas resultantes del aislamiento. El objetivo del programa es desarrollar polos económicos y sociales transfronterizos y estrategias comunes de desarrollo territorial.

El proyecto surge como medio para poder acercar al público al mundo de los ríos, mostrando la fragilidad ecológica de los mismos y la necesidad de tomar medidas para la conservación.

\section{TOMA DE PARTIDO}

El Centro de Interpretación de los Ríos se desarrolla a partir de tres aspectos: el lugar, programa y percepción del espacio.

Lugar: Se encuentra emplazado cerca a la intersección de ríos Tera y Esla. La ubicación es estratégica para remarcar la condición del río como recurso natural que ha sido manipulado por el hombre. La estrategia está en ubicar al centro cerca de la zona inundable para que el usuario pueda interpretar la importancia del patrimonio natural.

Programa: La propuesta de programa está relacionada a la temática y factores involucrados al ecosistema de los ríos. En el proyecto se observa cinco salas con temáticas diferentes. Por ejemplo, la sala del agua, sala de la tierra, sala de flora, sala de fauna y la sala del hombre.

Perceptual: El planteamiento de la relación con el exterior es clave para establecer un vínculo entre naturaleza y espacio de exposición, lo cual se ve reflejado en el uso de materiales y forma del proyecto.
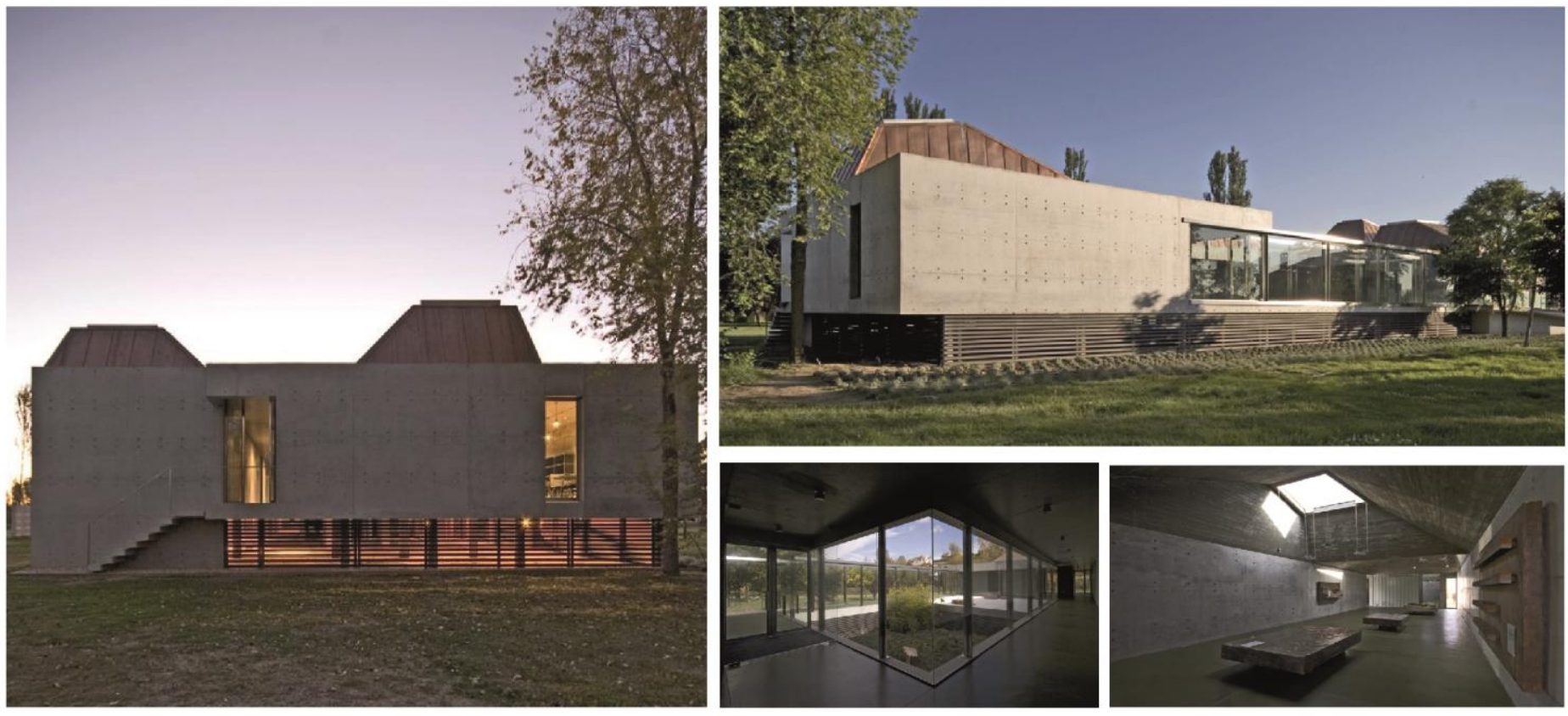


\section{2 .2}
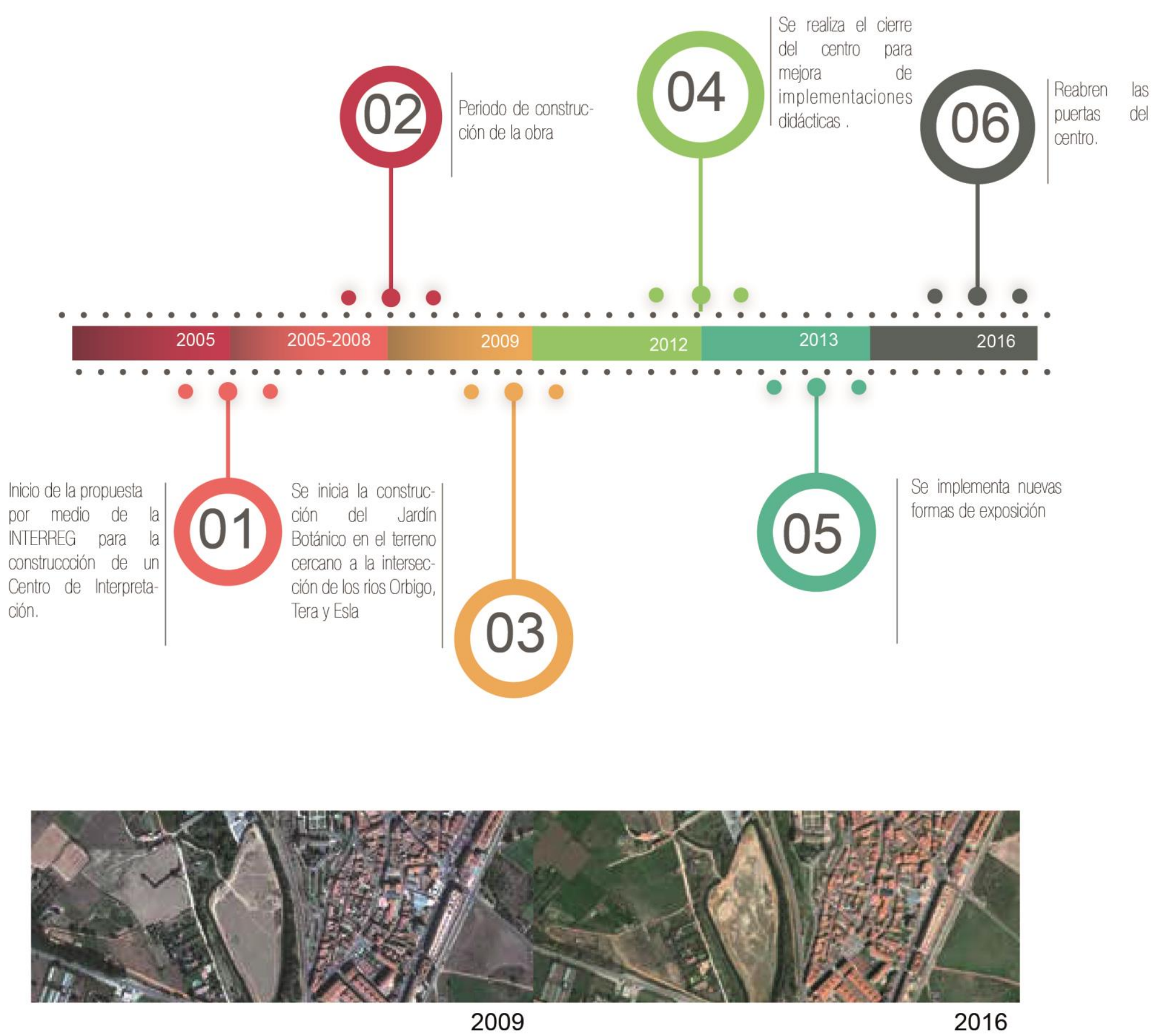


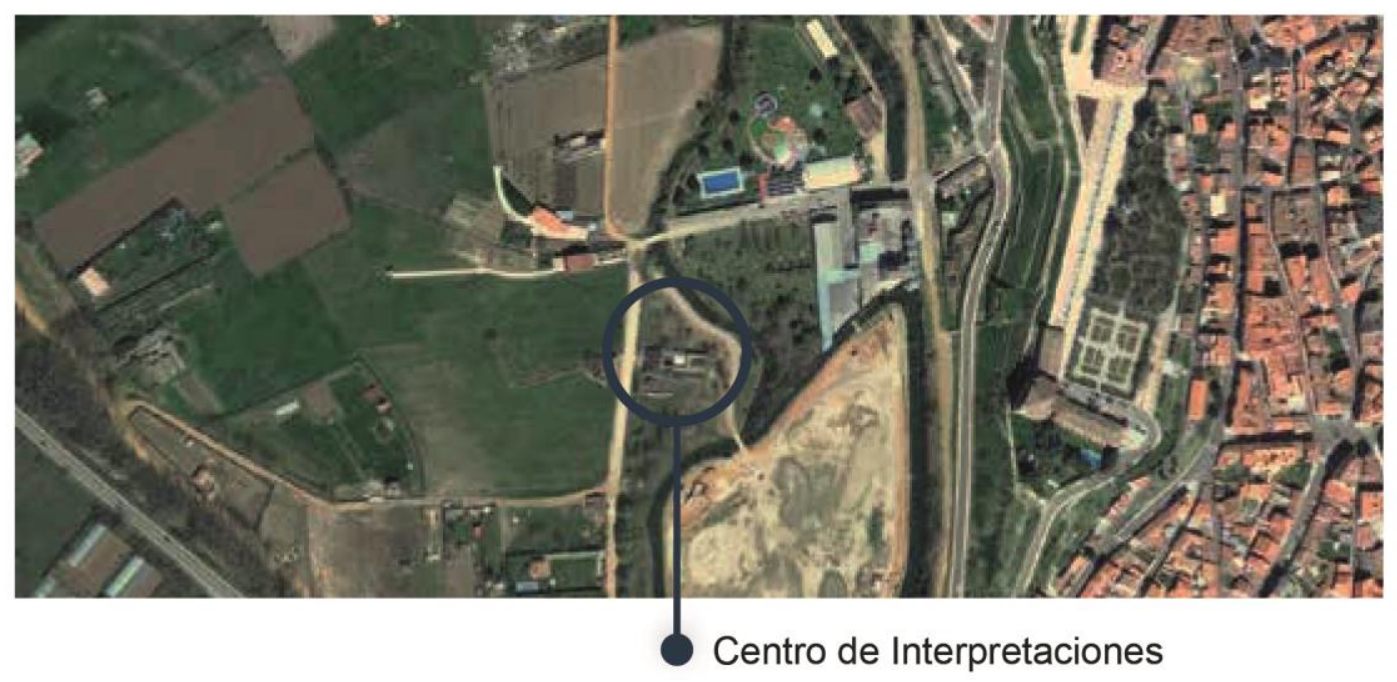

Se encuentra en el valle del Órbigo, en la ciudad de Benavente, Zamora,

España. Está localizado en zona agrícola a las afueras del casco de la ciudad.

PLANO CON ENTORNO INMEDIATO / VIAS PRINCIPALES /

ESTACIONES DE TRANSPORTES

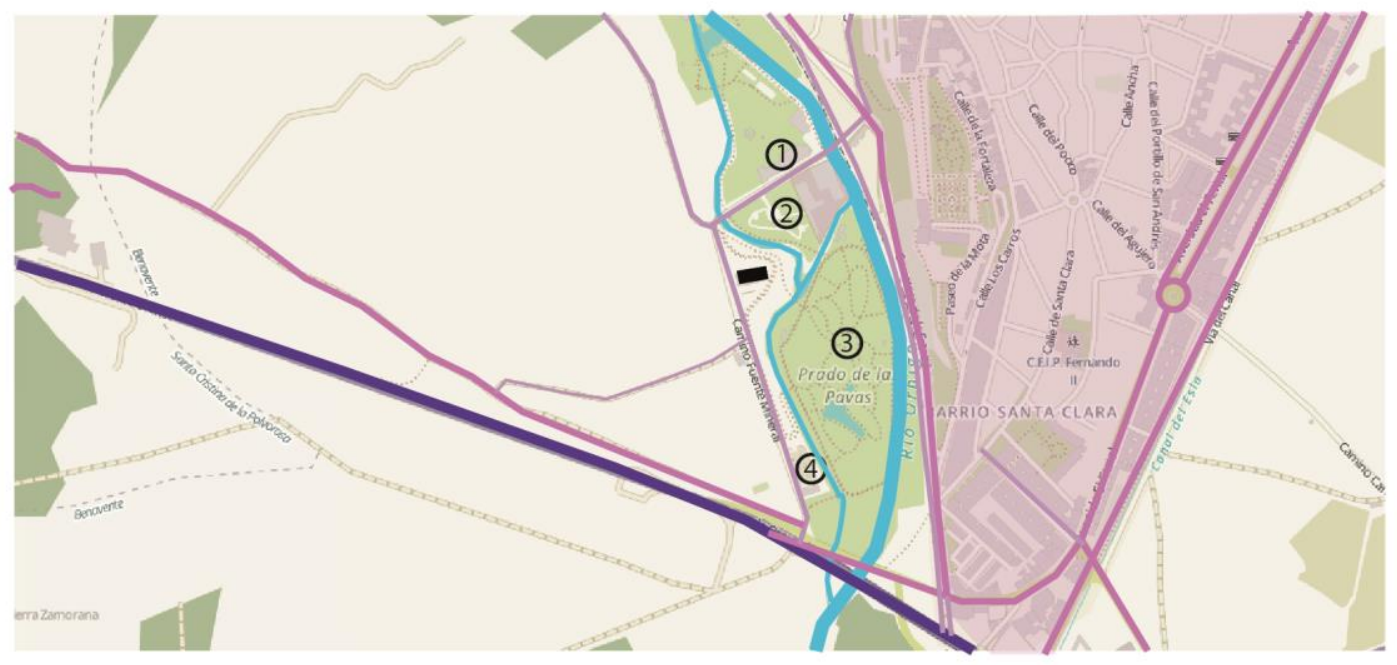

El centro de interpretación se encuentra a las afueras de la ciudad. El entorno inmediato está compuesto por el parque de La Pradera, Jardín botánico Prado de las Pavas y la piscina municipal. No se encuentra en una zona urbanizada sino en medio de zona agrícola

Con respecto a la conexión con la ciudad, el proyecto no cuenta con paraderos cercanos, por lo tanto, la llegada al lugar es solo con transporte privado, bicicleta o caminando. El tiempo estimado de llegada al centro desde el centro de la ciudad es de $5 \mathrm{~min}$ en auto , 6 min en bicicleta y 15 min caminando.

Zona Urbanizada

Parque

Centro de Interpretaciones Laguna

Río Orbigo

_Río Tera y Esla

(1) Pisninas Municipal

(2) Parque Entrecanos

(3) Jardín Botánico Prado de las Pavas

(3) Centro didactico de seguridad vial

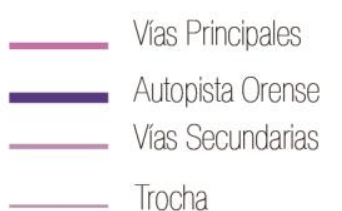

Vehículo Particular (C) 강 6 min 
ACCESOS PÚBLICOS PEATONALES
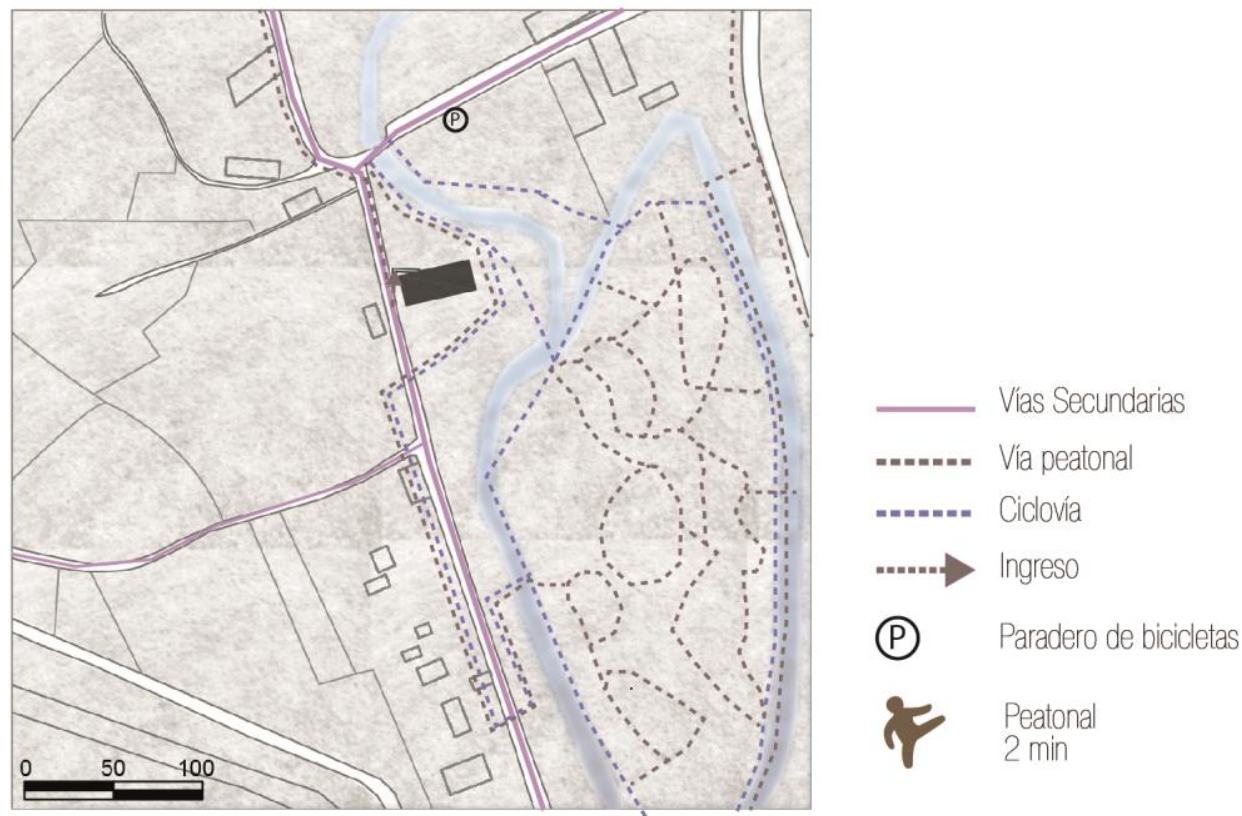

El Ingreso al centro de interpretación es peatonal, no se ha encontrado paraderos de autobuses cercanos a la zona. Sin embargo, existe un paradero de bicicletas cerca de las piscinas municipales. El tiempo de caminata desde este paradero hasta el centro de interpretación es de 2 minutos aproximadamente.

APORTES

Mediante el análisis del lugar y el emplazamiento del centro de interpretación podemos indicar que se encuentra a las afueras de la ciudad y el tiempo de llegada es corto. Sin embargo, al no existir un adecuado sistema de transporte público, ocasiona pocas visitas de la población.

\section{CORTES ESQUEMÁTICOS}

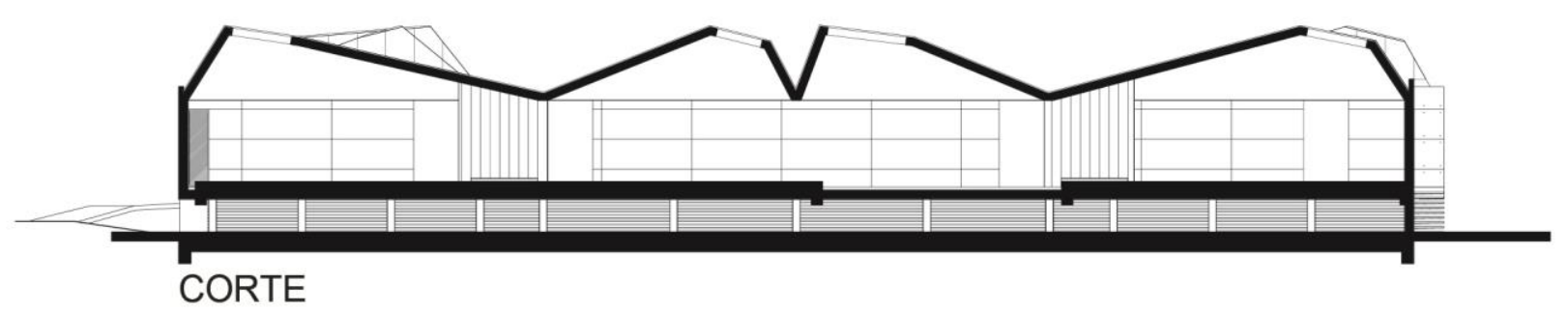

La relación con el entorno y el ingreso es semi directa, debido a que la estructura no posa en el suelo sino está elevada por ser área inundable. 


\section{PROGRAMA}

ESPACIO

TECNOLOGÍA

IMPACTO SOCIAL

FICHA

PAQUETES PROGRAMÁTICOS

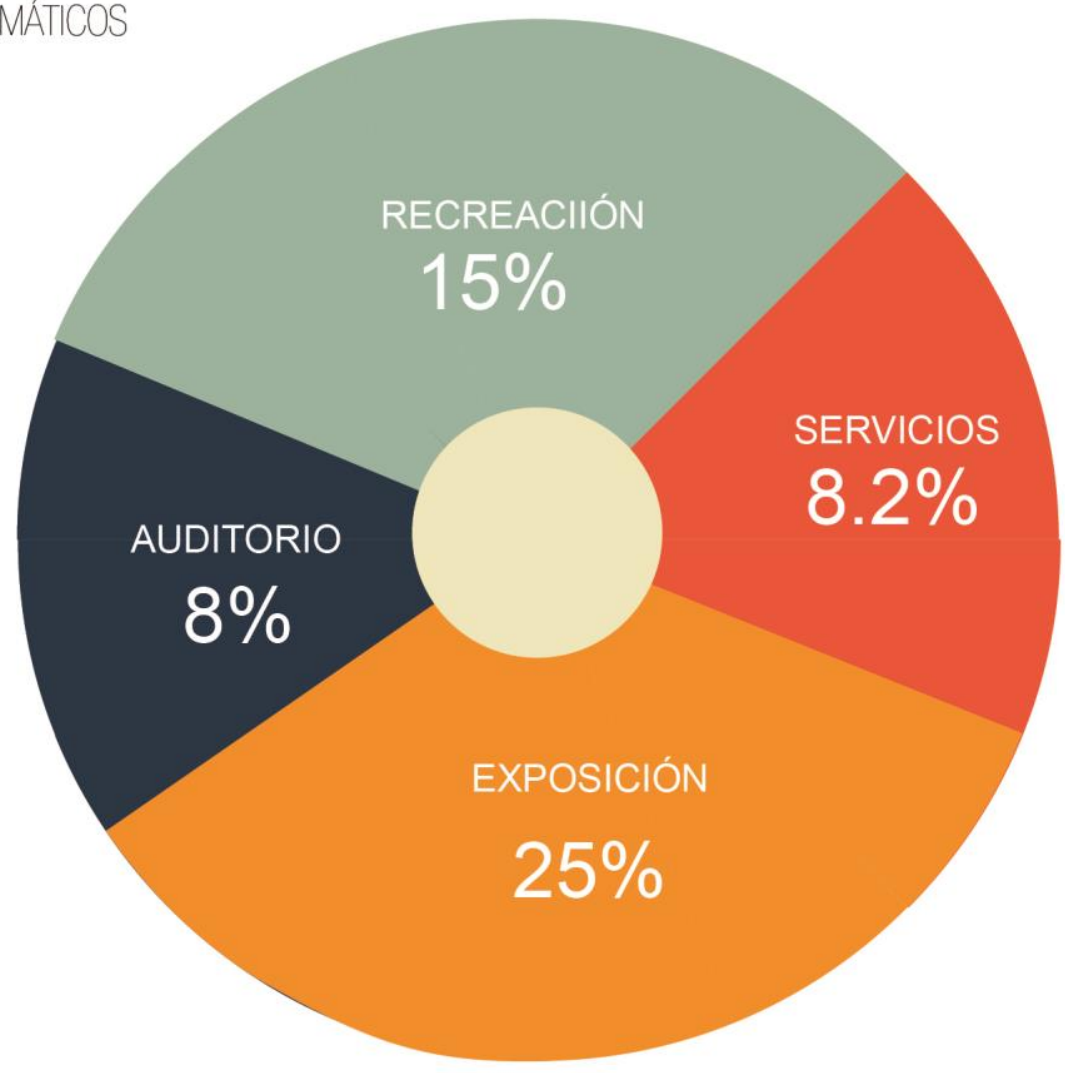

USUARIOS
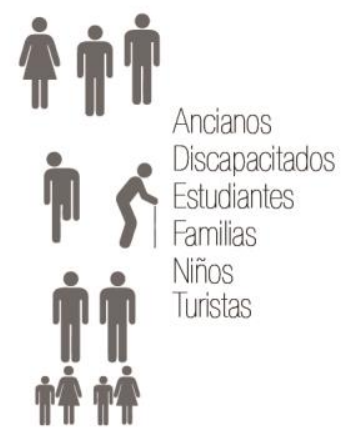

Personal capacitado Empleados del área de limpiezz servicio, administrativo, etc.

CUADRO DE ÁREAS

\begin{tabular}{|c|c|c|c|}
\hline AUDITORIO & RECREACIÓN & EXPOSICIONES & SERVICIOS \\
\hline $\begin{array}{l}\text { SALA DE } \\
\text { AUDIOVISUALES }\end{array}$ & PATIO JAPONES & SALA DEL AGUA & BAÑOS \\
\hline \multirow[t]{7}{*}{$72 \mathrm{~m} 2$} & $68 \mathrm{~m} 2$ & $42 \mathrm{~m} 2$ & $106 \mathrm{~m} 2$ \\
\hline & PATIO LA RIBERA & SALA DE LA TIERRA & ADMINISTRACIÓN \\
\hline & $68 \mathrm{~m} 2$ & $48 \mathrm{~m} 2$ & $32 \mathrm{~m} 2$ \\
\hline & & SALA DE LA FLORA & \\
\hline & & $48 \mathrm{~m} 2$ & \\
\hline & & SALA DE LA FAUNA & \\
\hline & & $40 \mathrm{~m} 2$ & \\
\hline
\end{tabular}

SALA DE LA HOMBRE

Y ELAGUA 


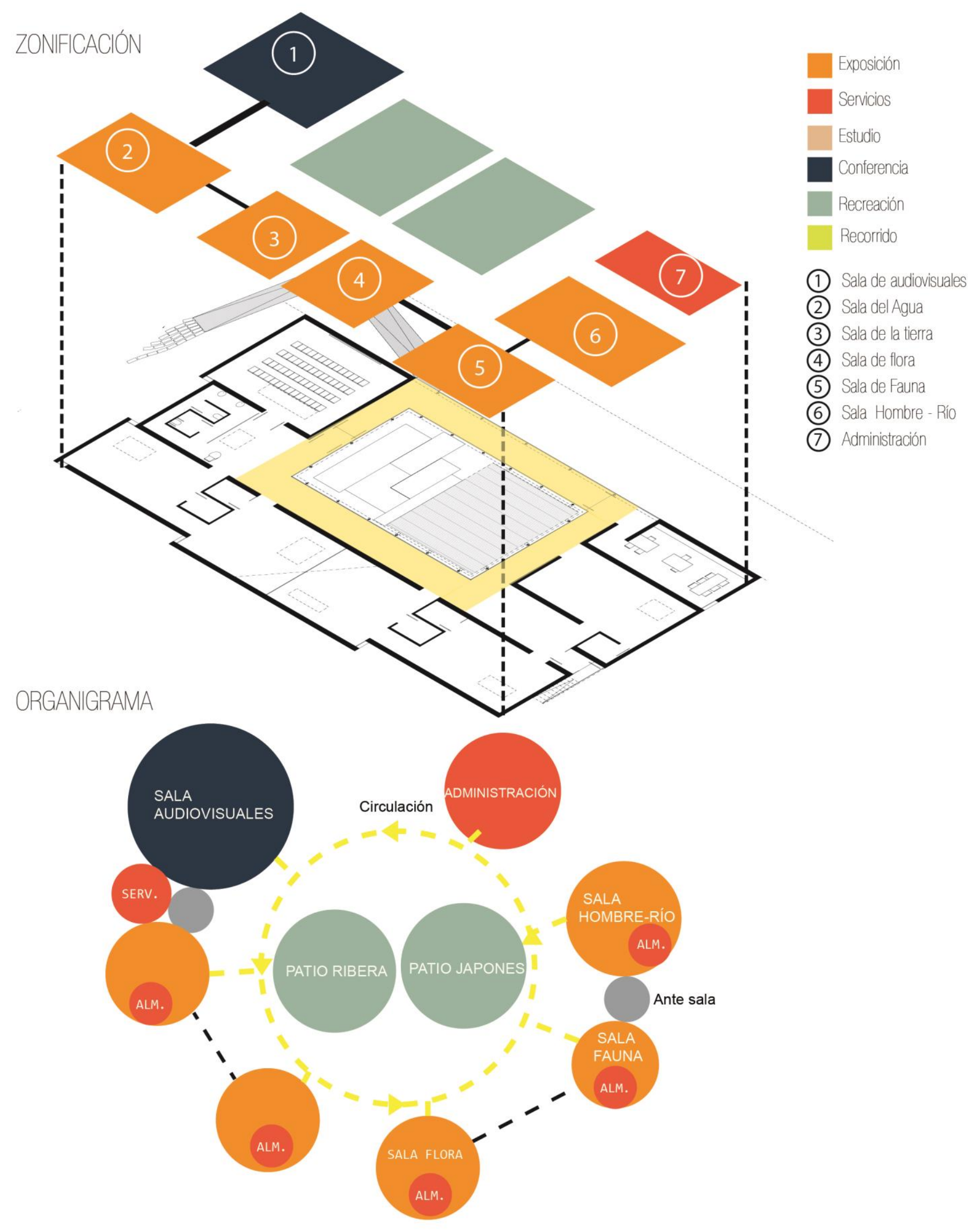




FICHA DEL PROYECTO HISTORIA UBICACIÓN
ESPACIO
TECNOLOGÍA

\section{DEFINICIONES}

El Centro de Interpretación de los Ríos presenta una tipología central. La suma de espacios conforma el bloque y estos crean un espacio central que esta compuesto por el recorrido y patios internos .

\section{ESQUEMAS}

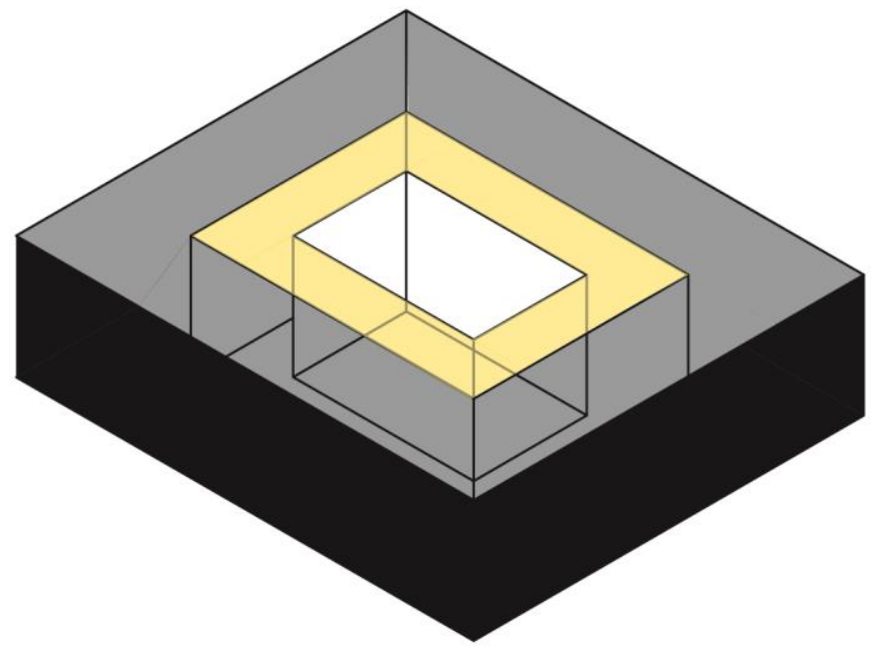

PÚBLICO-SEMIPÚBLICO-PRIVADO
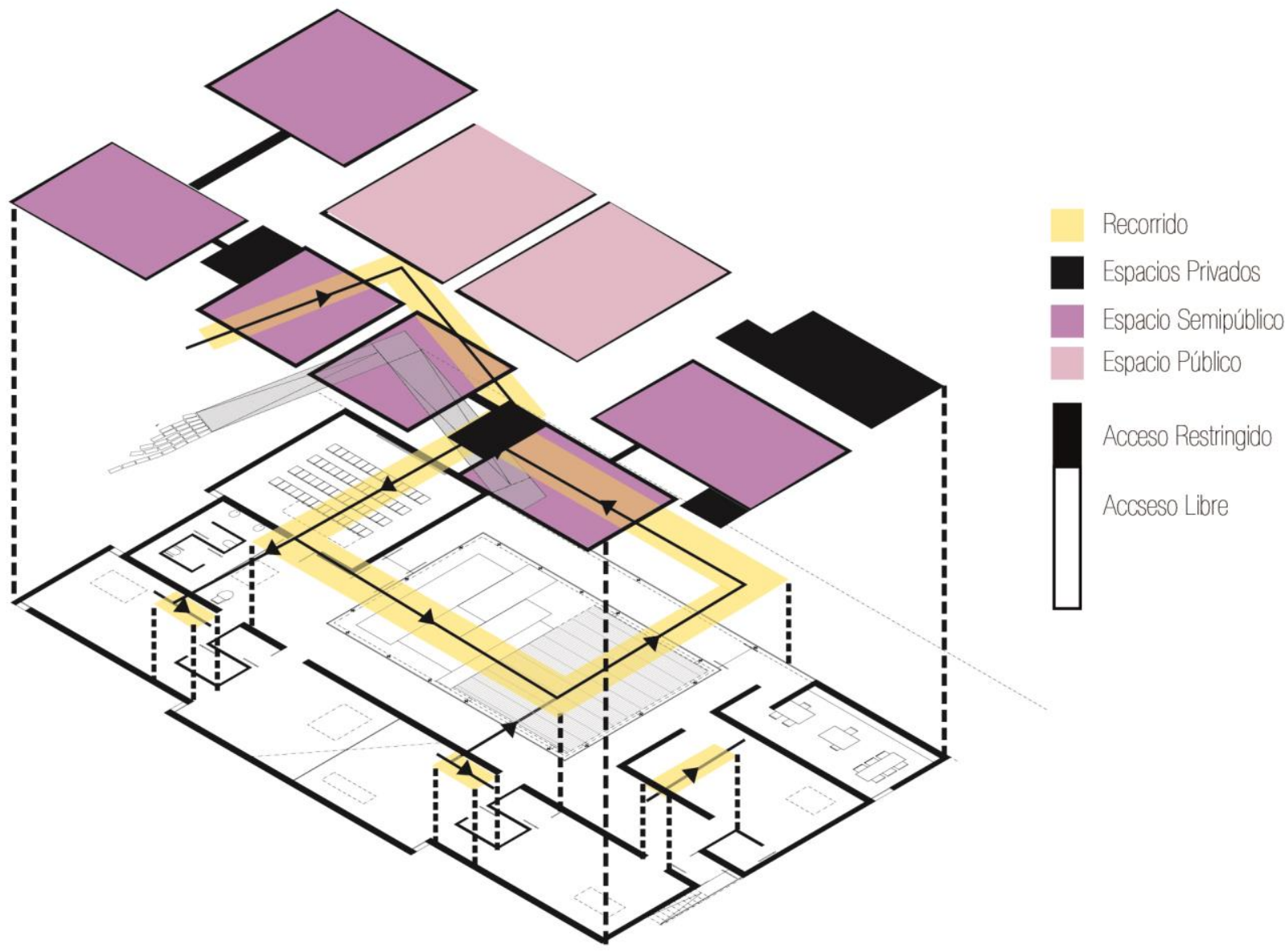


\section{ESPACIO}

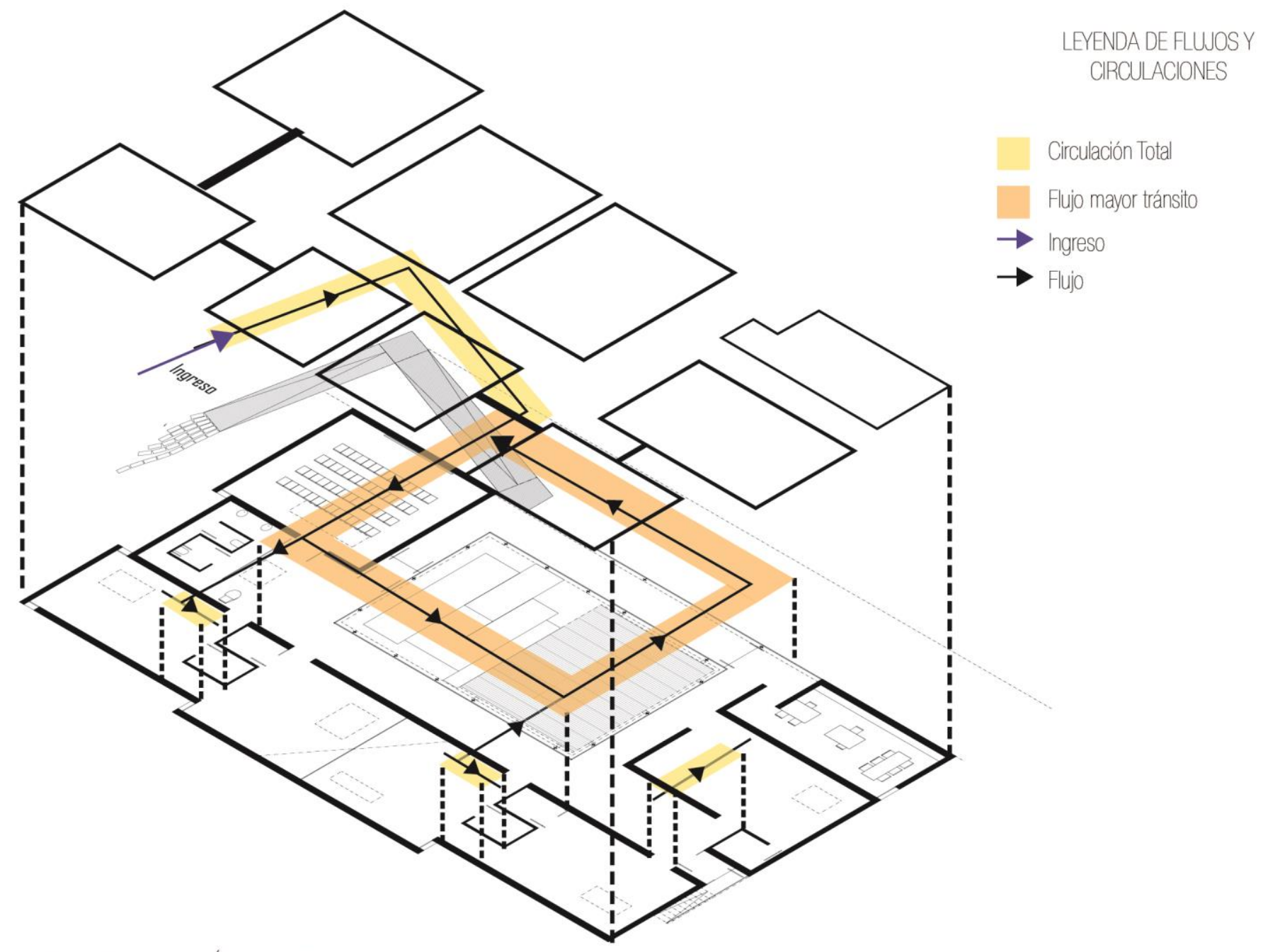

ÁREA CONSTRUIDA-ÁREA LIBRE

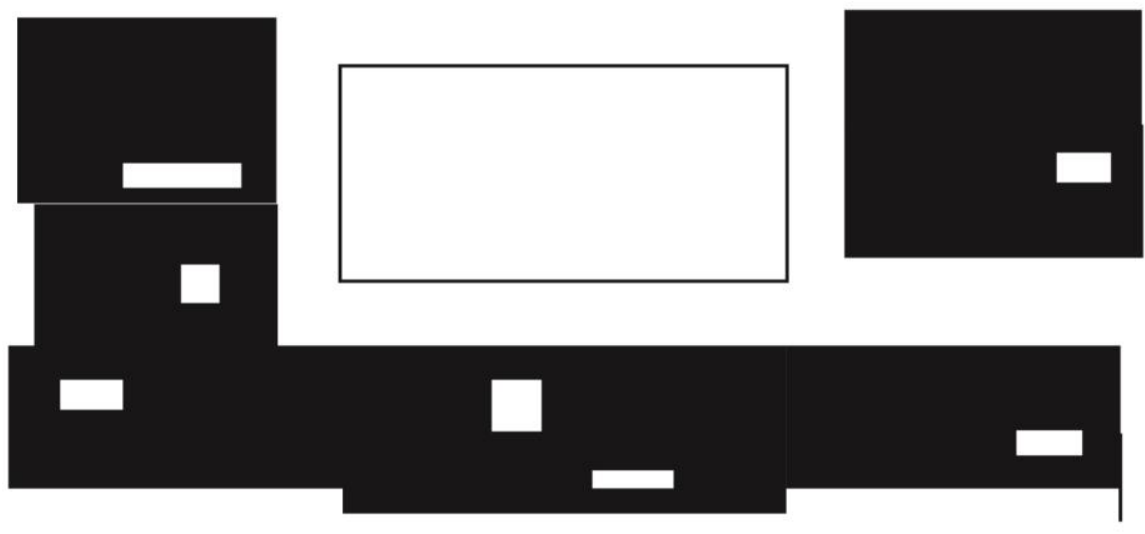

Techado 83.5\%

$\square$ Sin techo $\quad 16.5 \%$

Área construída

Área libre del edificio

Área total del edificio

Área libre protegida

Área total intervención
$21 \%$

$12 \%$
$750 \mathrm{~m} 2$

$150 \mathrm{~m} 2$

$900 \mathrm{~m} 2$

19100m2

$20000 \mathrm{~m} 2$ 


\section{ESPACIALIDAD}

La relación entre espacios se da por pertenencia, es decir los patios están contenidos por el programa. Asimismo, se da por yuxtaposición a partir del recorrido de pasillos internos que conectan una sala con otra.

\section{RELACIÓN HORIZONTAL}

La relación espacial horizontal, se genera a través del recorrido. La disposición de los espacios genera una secuencia cíclica.

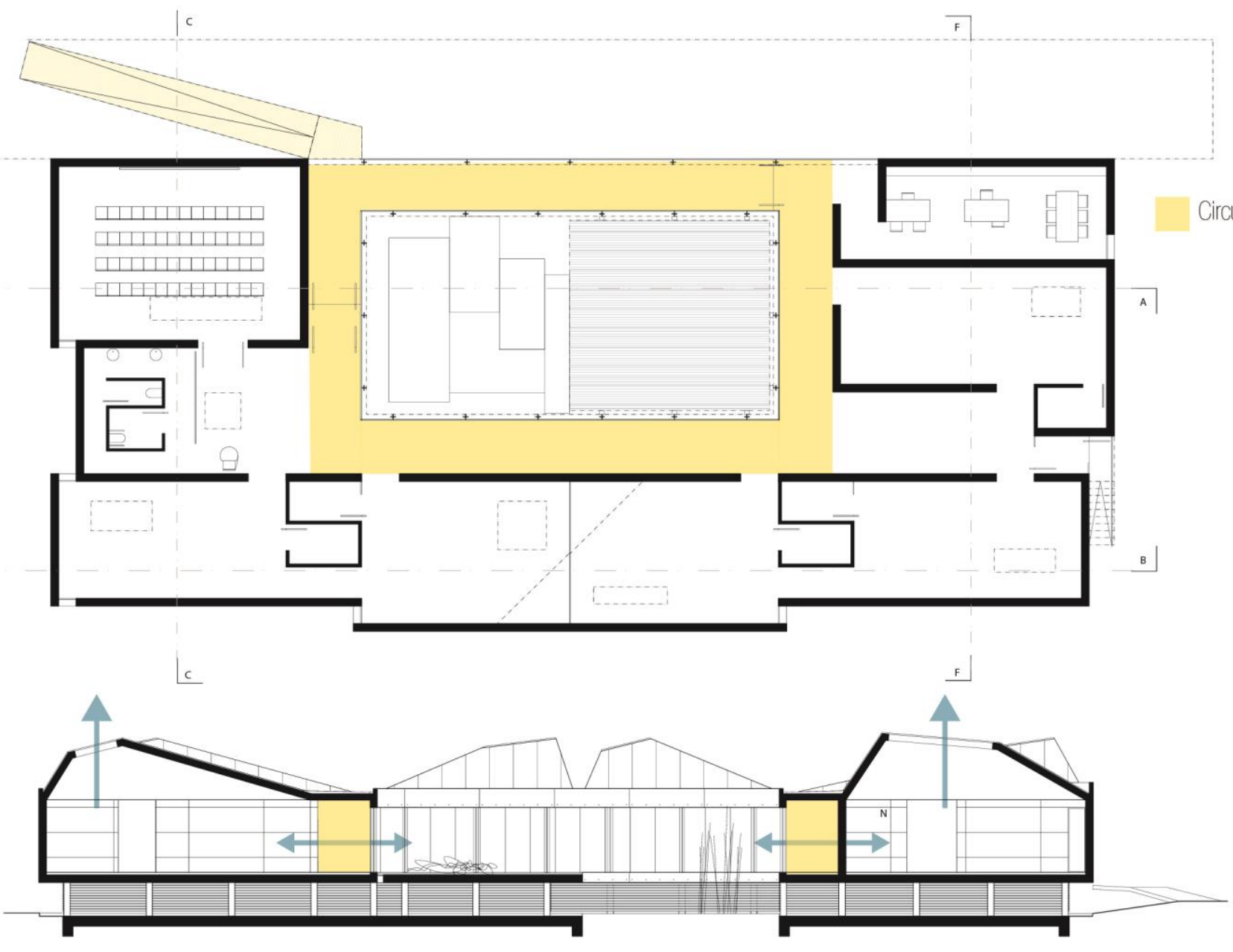

CORTEAA E 1:250

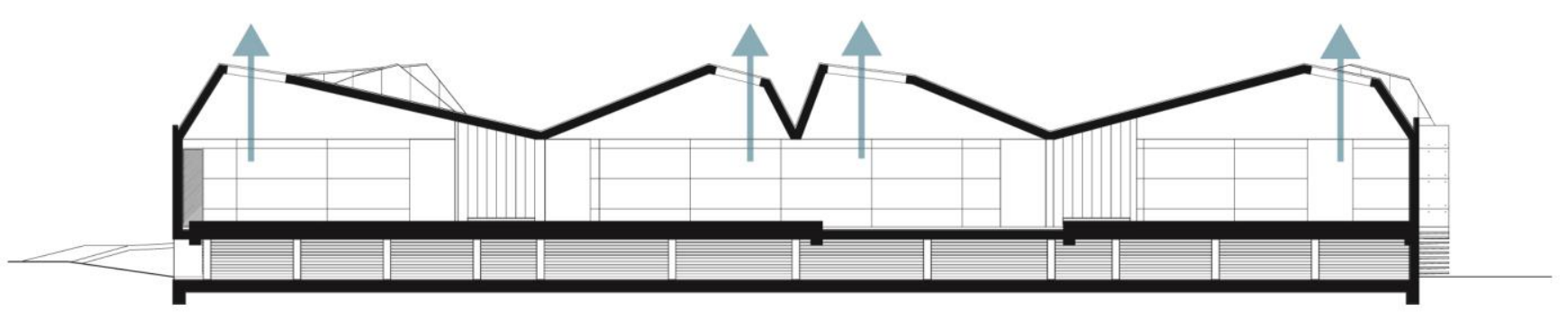




\section{ESPACIALIDAD}

\section{RELACIÓN VERTICAL}

La relación vertical se establece por medio de lucernarios que permiten una conexión con la naturaleza. Las entradas de luz y la forma de los techos le dan la cualidad al espacio de dilatarse hacia el cielo.
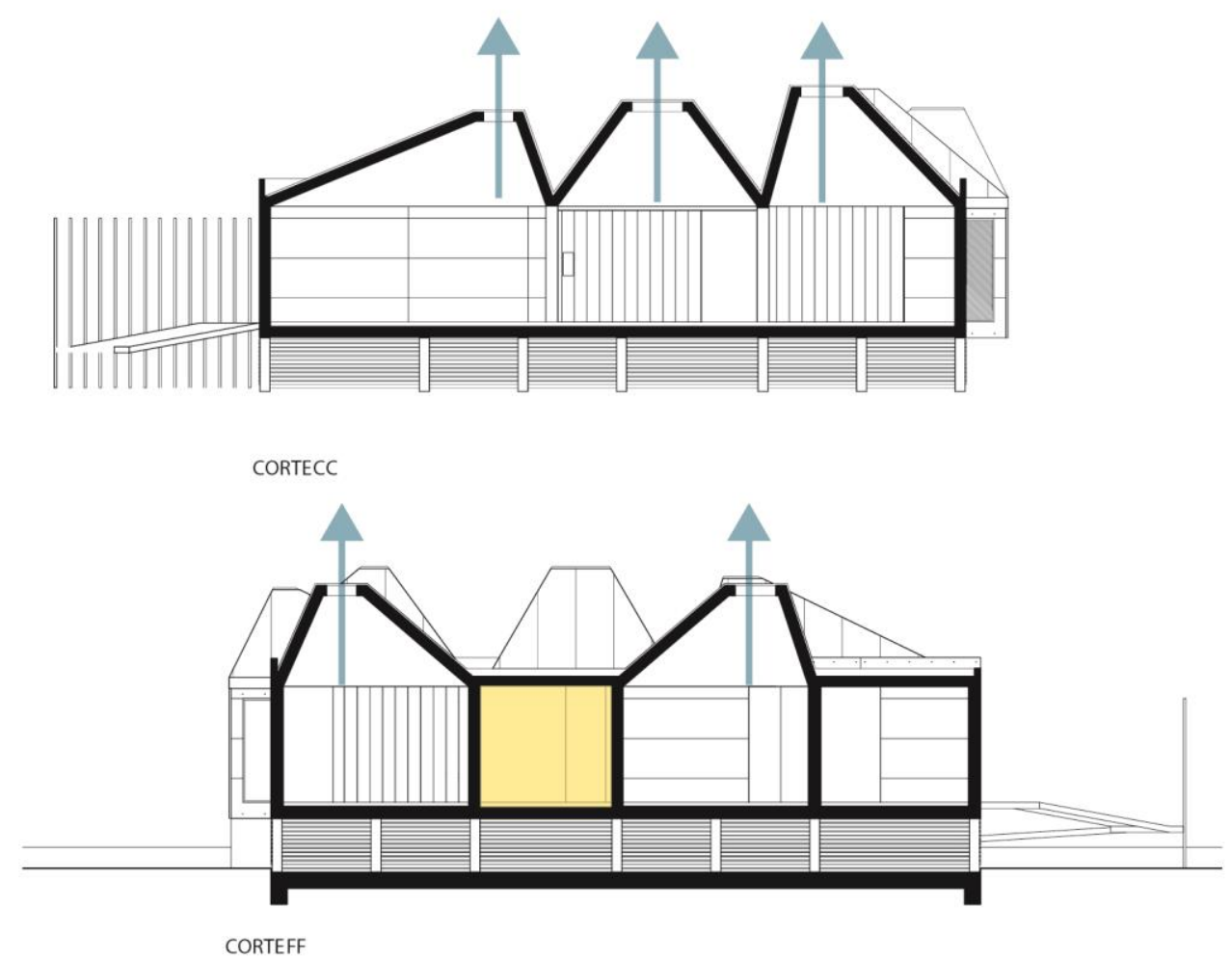

\section{MATERIALES}

Los materiales a utilizar fueron hormigón armado expuesto. Las cubiertas y partes de la fachada poseen revestimiento de cobre. En los pilares se utilizó acero inoxidable y vidrio; los patios poseen barandillas de acceso de acero inoxidable y los servicios tienen pavimento de hormigón, resinas pigmentadas y acero galvanizado.

\section{SISTEMA CONSTRUCTIVO}

El proyecto se encuentra elevado 1.35 metros por un sistema de pilares que cargan una losa de concreto armado, además que toda la estructura es de concreto armado.

\section{IMPACTO AMBIENTAL}

La construcción de concreto armado genera un impacto negativo en el medio ambiente por utilizar materiales no renovables. Además, el uso de concreto demanda cantidades de agua mayores que otro sistema constructivo. 


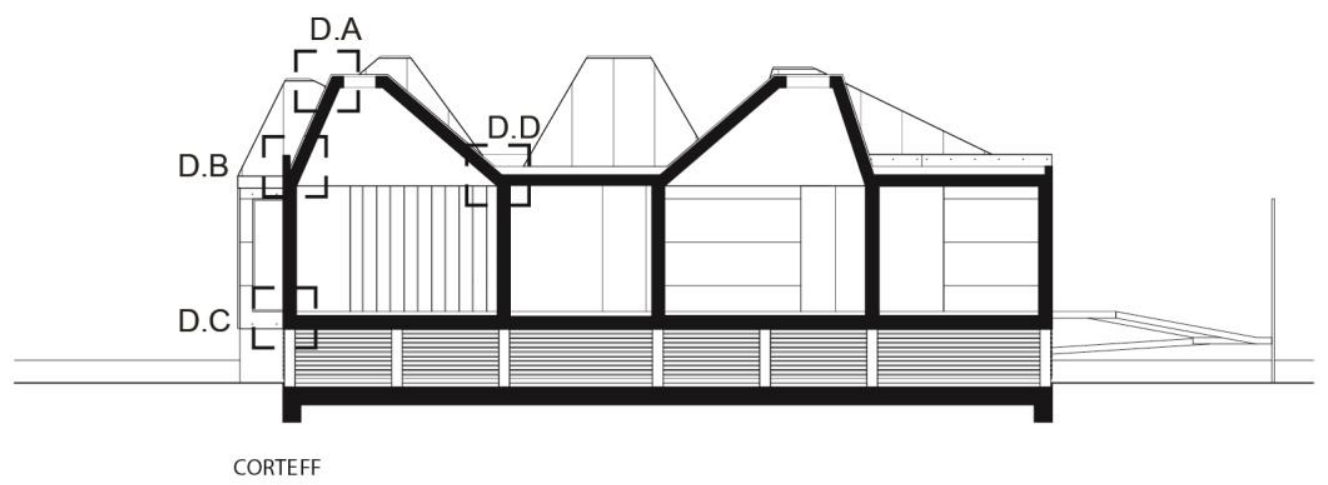

\section{DETALLEA}

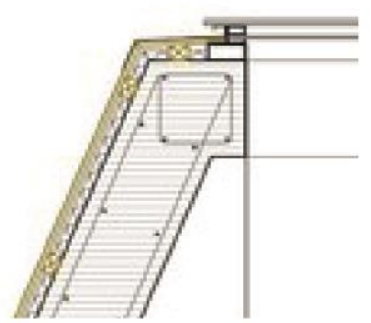

Cubierta de cobre enchapado de $0.8 \mathrm{~mm}$ de espesor. Fijación al tablero mediante pastillas de anclaje

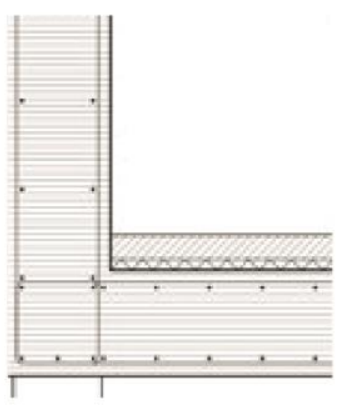

DETALLE C

Tablero anglomerado de $10 \mathrm{~mm}$ espesor Sobre rastrel $50 \times 30$ cada 500 m

\section{DETALLE B}

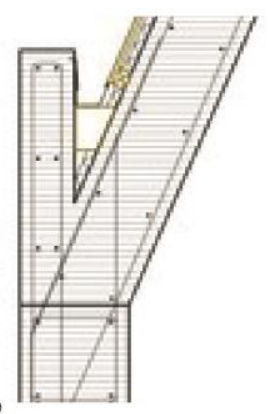

Losa hormigón armado inclinada de $25 \mathrm{~cm}$ espesor

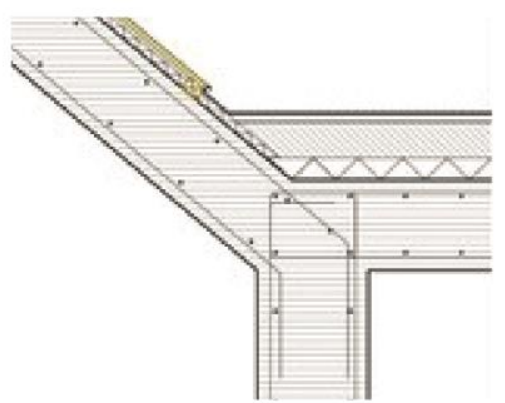

DETALLE D
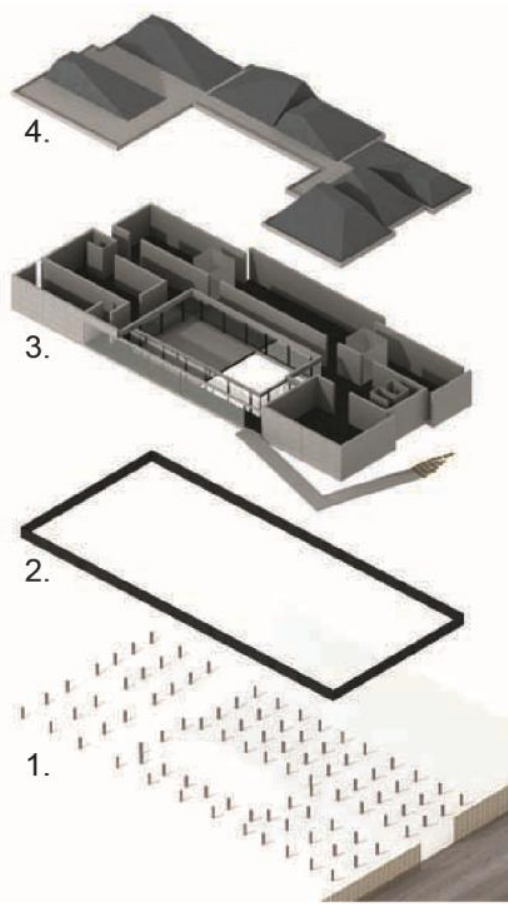

1. Pilotes de 1.35 metros

2. Losa de cimentación

3. Muros de concreto armado

4. Cubiertas de concreto armado 
RADIO DE INFLUENCIA

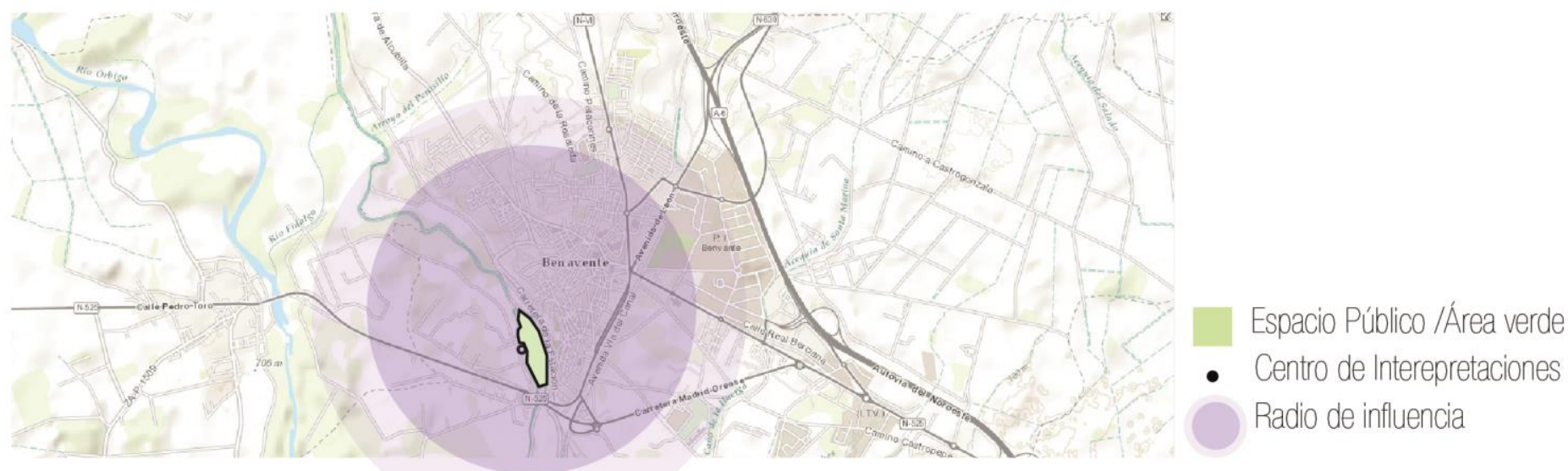

El proyecto se encuentra en fueras inmediatas de la ciudad en una zona donde se realiza la actividad agricola. El centro de interpretaciones se localiza entre parques que se han planteado en anteriormente o posteriores como el Jardín botánico. El impacto que ha querido obtener el Centro de interpretaciones es a nivel educativo de la zona es decir . El centro ha recibido visitas de particulares, además, de alumnado de los colegios e institutos locales, de Cruz Roja en el marco del programa de Paseos Saludables, de grupos de la Tercera Edad de La Coruña, de alumnos y profesores de la escuela taller y del taller de empleo municipales y también de trabajadores de la Empresa Aquagest de toda la región de Castilla y León. Para el diseño de los pórticos fue preciso definir un ritmo de distancia de 20x 20 en la fachada y en la vigas una secuencia de $80 \times 80$

\section{CALIDAD DE VIDASSATISFACCIÓN}

Muchas críticas ha habido con respecto al planteamiento y a la ejecución del proyecto.

En relación al impacto social, este en un inicio obtuvo acogida, sin embargo con la falta de implementación de mobiliarios, paneles, maquetas e información que contribuyen a la transmisión de la información empezó a disminuir el porcentaje de visitas.

Sin embargo cabe señalar que la construcción del proyecto ha ido de la mano con la implementación de educación ambiental estableciéndola con la campaña de Aula educacional ambiental (espacio que busca crear actividades de juego en conjunto de la enseñanza. Lo cual hasta cierto punto se puede señalar que el CIR (Centro de Interpretación de los Ríos fue construido como medio y herramienta para la transmisión del cuidado y valorización del patrimonio natural. En la actualidad se trata de implementar actividades para asegurar la actividad del centro. (Ayuntamiento Benavente, n.d.)

\section{MEMORIA Y TRADICIONES}

La zona intervenida por el centro de interpretaciones es un área que busca ser pontencia por la intersección de los ríos Tera y Esla, La puesta del proyecto en ese lugar no se basa en particular por hechos que sean parte de la memoria colectiva de la comunidad sino más bien se basa en el aprovechamiento del terreno como potencial para llegar a tranmitir y educar ala población sobre la tématica de los ríos.

\section{IMPACTO ECONÓMICO}

El proyecto ha sido objeto de crítica y en algunos casos catalogado como un proyecto despropósito. Se le atribuye a la gestión de mal realizada debido a los gastos por encima de los previstos con una inicial de 300000 Euros y finalmente termino costando 2000000 Euros. Del mismo modo, el centro no ha generado cambios de crecimiento turístico, por lo que no ha habido laguna mejora económico (Zamoradigital, 2009) 


\section{CUADRO COMPARATIVO DE REGENERACIÓN URBANA DE RIOS}

RIO MANZANARES - RIO CHEONGGYECHEON

FICHA

\section{FUENTE: :}

Elaboración propia en base a láminas de la sección 5.2.1 y 5.2.2 de la presente tesis

\section{RIOO CHEONGGYECHEON \\ SEÚL-KOREA \\ RIOCHEONGGYECHEON}

\section{RÍO MANZANARES MADRID-ESPAÑA}

: Madrid

Ciudad

Población

Densidad

Área

Río

Longitud
: 5 millones habitantes

$5334.77 \mathrm{Hab} / \mathrm{Km} 2$

$400 \mathrm{Km} 2$

Manzanares

$6.7 \mathrm{~km}$

\section{Ciudad}

Población

Densidad

Area

Río

Longitud

\section{Seúl}

: 24,5 mil Habitantes

17.200 Hab/ Km2

$600 \mathrm{Km} 2$

:Cheonggyecheon

$8.00 \mathrm{~km}$
1. Crecimiento acelerado de la población, causó deterioro higiénico de los bordes, las personas optaron por vivir en las fajas marginales del rio.

2. Contaminación del cauce del Río Manzanares y los bordes debido a la presencia industrial, asi también por los desagües de las viviendas. Incremento de vehículos de transporte.

3. Desconexión de territorios de forma lineal y pérdida del valor histórioo, ya que perdió la forma de su estado natural por la metrópoli
1. La congestión vial que surfían los usuarios de la carretera

2. Elevados índioes de contaminación acústica y aire por la polución

3. Proplemas constructivos de la autopista que cubría el río

4. El centro de la ciudad se convirtió en un lugar peligroso, inhóspito e insalubre.

5.Mala calidad de aire y altos costos de mantenimiento en los sótanos, debido a la humedad y el hacinamiento 6. Fragmentación urbana y social.

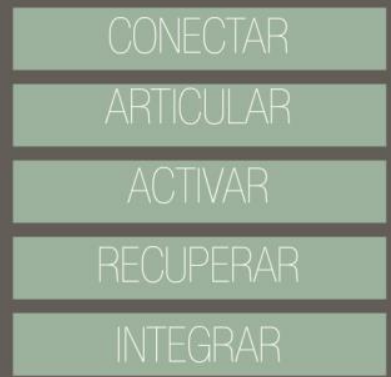

1. Regenerar la trama urbana de la ciudad

2.Aprovechamiento del cauoe del río para usos deportivos y de entretenimiento 3.Dar valor al paisaje y generar un plan de desarrollo sostenible para el parque lineal.

4. Tratamiento de la superficie liberada tras el soterramiento de la M-30 5. Reorganización del tráfico actual, predominio del transporte público y preponderancia del peatón.

6. Tratamiento a los túneles y accesos

\begin{tabular}{|l}
\hline CONECTAR \\
\hline ARTICULAR \\
\hline ACTIVAR \\
\hline RECUPERAR \\
\hline CONSERVAR \\
\hline
\end{tabular}

1. Creación de una zona verde de oeste

2. Creación de una zona verde de norte-sur

3. Utilización de los espacios disponibles para la conservación de la naturale 4. Fomentar un ecosistema estable mediante la siembra de plantas nativas árboles

5. Seguridad en canales para la libre circulación de la vida silvestre 6. Rompimiento de la autopista que cubría el río para dar al peatón áreas de estancia que sivan para el desarrollo de sus acividades. 7. Creación de puentes y pasarelas para combatir el problema de fragmenta ción urbana 


\section{CUADRO COMPARATIVO DE REGENERACIÓN URBANA DE RIOS}

\section{FUENTE: :}

Elaboración propia en base a láminas de la sección 5.2.1 y 5.2.2 de la presente tesis

\section{RÍO CHEONGGYECHEON SEÚL-KOREA}

RÍO MANZANARES

MADRID-ESPAÑA
Puentes: 9

Pasarelas: 13

\section{PARQUE LA ARGANZUELA}

- CONTINUIDAD Y CONEXIONES

- acera-ADOQUIN DE GRANITO

- CAMINOS

- CAMINO LENTO

CAMINO RÁPIDO

CAMINOS

- CAMINOS DE OCIO

... CONEXIONES PEATONALES Y CICLISTAS

- CONEXIONES PEATONALES

- - CONEXIONES TRÁFICO RODADO

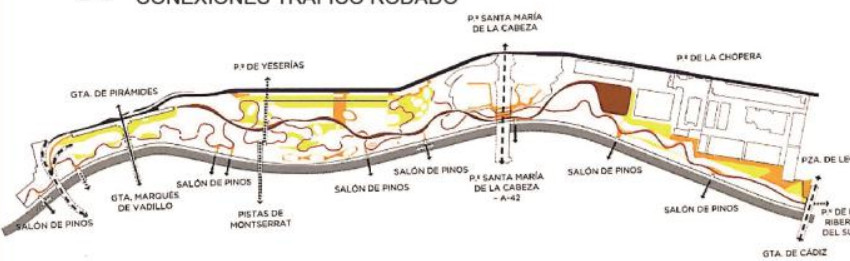

Puentes: 12

Pasarelas: 21
I puentes Peatonales

PUENTES PEATONALES Y AUTOS

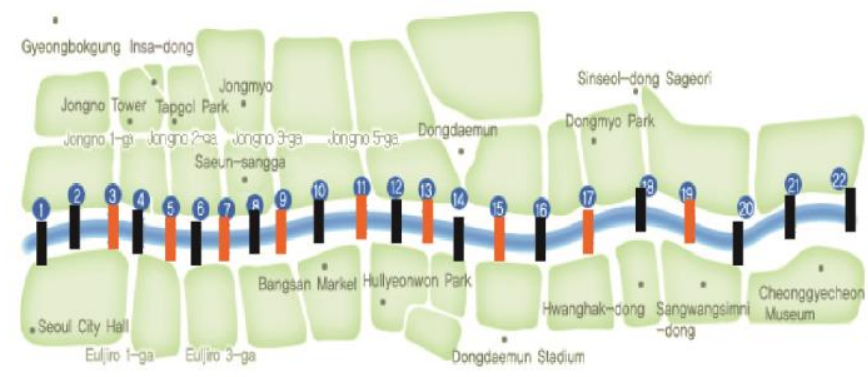

\begin{tabular}{|c|c|c|c|c|}
\hline (1) Mojeongyo & $\begin{array}{l}\text { 6 Temporary pede } \\
\text { strian bridge (the sit } \\
\text { e for Supyogyo) }\end{array}$ & (1) Majeongyo & (1) Dasangyo & (2) Dumuldari \\
\hline 2 Gwangtonggyo & $\boldsymbol{D}^{\text {Gwansugyo }}$ & (2) Naraegyo & (1) Yeongdogyo & (2) Gosanjagyo \\
\hline (3) Gwanggyo & (8) Seungyo $^{-1}$ & (3) Beodeuldari & (2) Hwanghakgyo & \\
\hline $0^{\text {Jangtonggyo }}$ & (9) Baeogaedari & (1) Ogansugyo & (1) Biudanggyo & \\
\hline 5 Samilgyo & (1) Saebyeokdari & (5) Malgeunnaedari & (1) Muhakgyo & \\
\hline
\end{tabular}

- QUIOSCOS

- ADMINIDTRATIVO

- DEPORJUEGOS INRFANTILES

CULTURAL 


\section{CUADRO COMPARATIVO DE REGENERACIÓN URBANA DE RIOS}
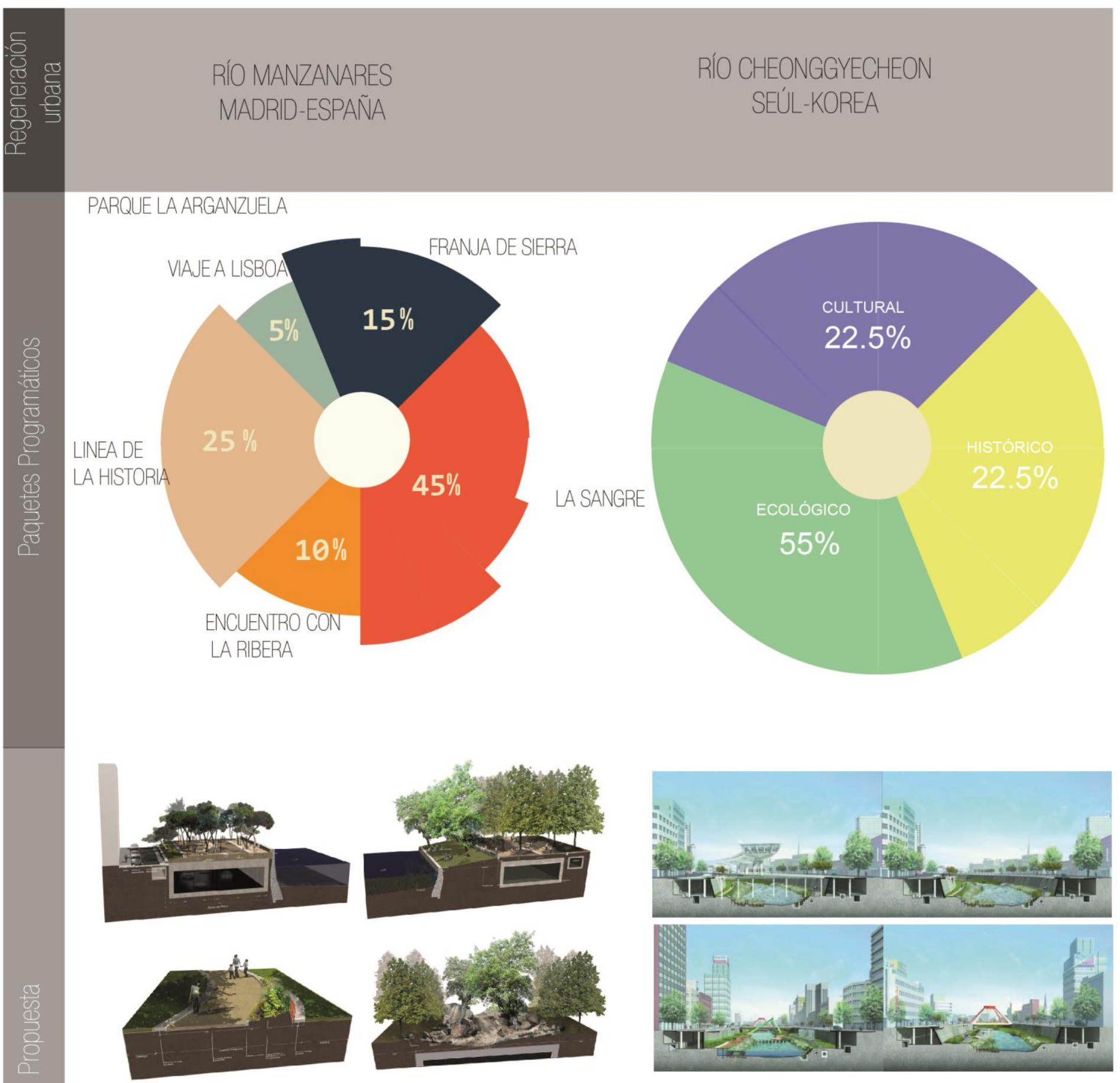

El soterramiento de la M-30 permite la creación de espacio público en la ribera del Río Manzanares.

El rompimiento de la vía sobre el río permite la creación de espacio público en una zona decadente.

La regeneración urbana del río se da a nivel de las calles y vías principales

La regeneración del río se da a un nivel inferior a las calles y vías principales; sin embargo tiene un impacto positivo como espacio público. 


\section{CUADRO COMPARATIVO DE REGENERACIÓN URBANA DE RÍOS}

RIO MANZANARES - RIOO CHEONGGYECHEON

\section{FUENTE:}

Elaboración propia en base a láminas de la sección 5.2.1 y 5.2.2 de la presente tesis

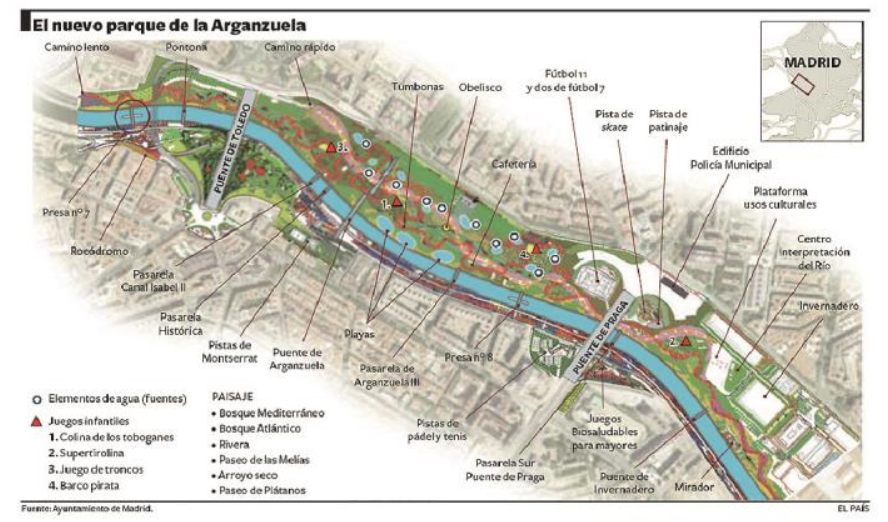

1. El entorno del Río Manzanares se ha convertido en un espacio de encuentro a nivel metropolitano, cambiando su antigua zonificación en la que era un parque barrial, incluyendo toda clase social, cultural y económica de la población.

2. Ha habido una mejora de los barrios respecto a la integración con el centro histórico, norte y sur de la ciudad generando nuevas conexiones longitudinales y transversales

3.Ha generado la disminución del uso del automóvil proponiendo nuevos sistemas de transporte no contaminantes

4. El soterramiento de la M-30 y el posterior ajardinamiento ha incrementado la eficiencia energética y funcional, reduce la emisión de gases de efecto invernadero y su corolario de ahorro a usuarios y ciudad.

5. la incorporación de equipamiento peatonal como las pasarelas de cruce sobre el Río Manzanares fueron rehabilitadas y diseñadas para facilitar el acceso al peatón desde cualquier lugar en el que se encuentre.

6. las imágenes de los vecinos se han incorporado en la ornamentación artística de nuevas pasarelas con mucha pertenencia y carácter de espacio común.

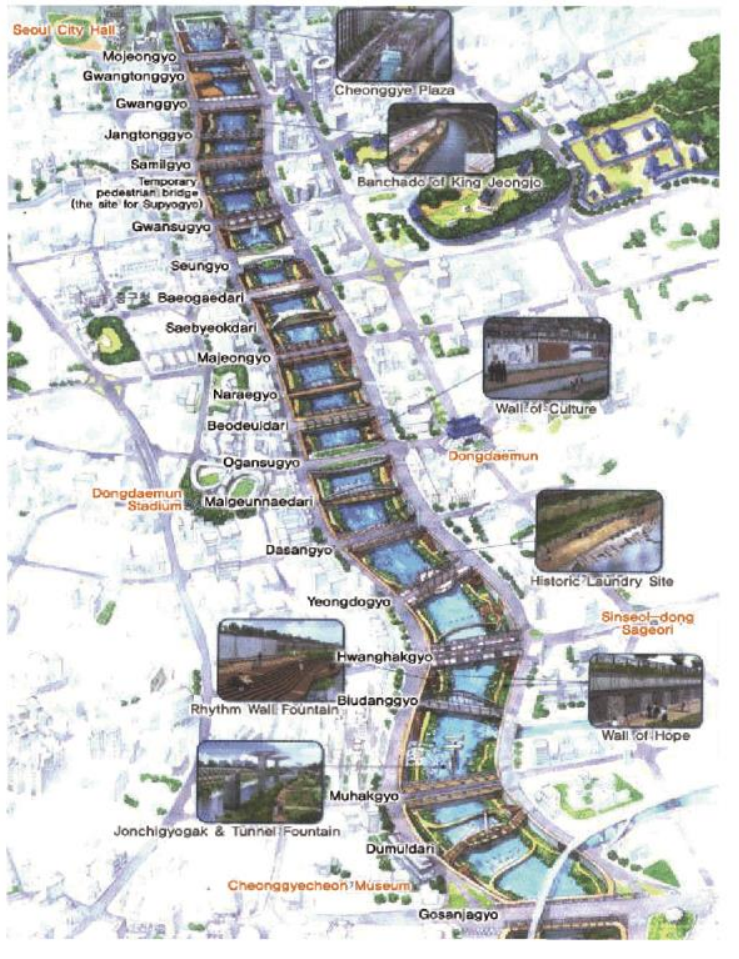

1. Incremento de turismo, hasta la actualidad se registra un aproximado de 70 millones de visitas

2. Incremento del valor del suelo, tanto residencial y comercial.

3. La movilidad alrededor de Seúl ha mejorado con cerca de 170,000 viajes menos en automóvil cada día, el aumento del $4,3 \%$ y $1,4 \%$ en usuarios de metro y autobús respectivamente, y la creación de itinerarios peatonales.

4. Mejora de la calidad del aire, se muestra en la reducción de partículas pequeñas en el aire de 74 a 48 microgramos por metro cúbico.

5. El espacio público se ha convertido en destino para actividades recreativas y culturales, y la mejora de la zona ha creado un lugar propicio para las actividades económicas. 
CENTRO DE INTERPRETACIÓN JEAN MARIETJIBAOU
CENTRO DE INTERPRETACIÓN LA ANTIGUA
CENTRO DE INTERPRETACIÓN DE LOS HUMEDALES DE SALBURÚA

CENTRO DE INTERPRETACIÓN DE LOS RÍOS

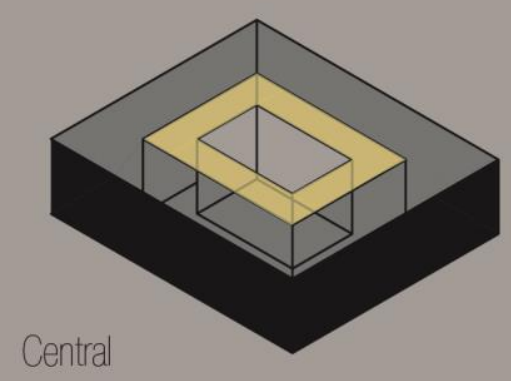

HSTORIA
ETNOGRÁFICO
CULTURAL

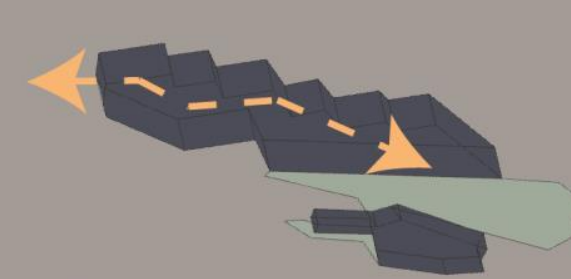

Lineal

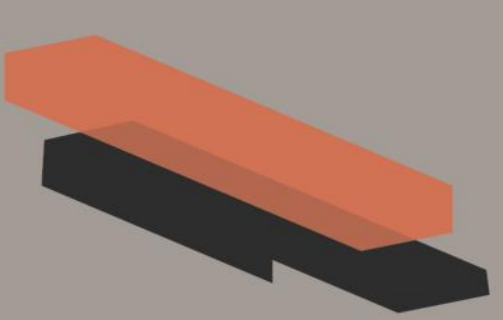

Lineal

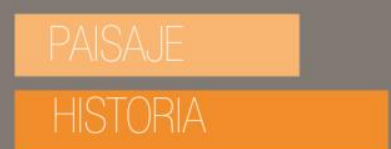

PAISAJE

AGUA 


\section{CENTRO DE INTERPRETACIÓN JEAN \\ MARIETJIBAOU}

CENTRO DE INTERPRETACIÓN LA ANTIGUA
CENTRO DE INTERPRETACIÓN DE LOS HUMEDALES DE SALBURÚA

\begin{tabular}{|c|c|c|c|}
\hline Área construida & $8,100 \mathrm{~m} 2$ & Área construida & $1,300 \mathrm{~m} 2$ \\
\hline Área libre del edificio & $450 \mathrm{~m} 2$ & $\begin{array}{l}\text { Area iliore del ealicio } \\
\text { Area de circulación del edificio }\end{array}$ & $\begin{array}{l}197.70 \mathrm{~m} 2 \\
01.75 \mathrm{~m}^{2}\end{array}$ \\
\hline Área total del edificio & $8,550 \mathrm{~m} 2$ & Área del terreno para el edificio & $3,270.00 \mathrm{~m} 2$ \\
\hline Área libre protegida & $20,000 \mathrm{~m} 2$ & $\begin{array}{l}\text { Area total del edificio } \\
\text { Área libre protegida }\end{array}$ & $\begin{array}{l}1,397.70 \mathrm{~m} 2 \\
31,400.00 \mathrm{~m} 2\end{array}$ \\
\hline
\end{tabular}

$\begin{array}{ll}\text { Area construida } & 1,800 \mathrm{~m} 2 \\ \text { Areal libre del edificio } & 0 \mathrm{~m} 2 \\ \text { Area total del edificio } & 1800 \mathrm{~m} 2 \\ \text { Area libre protegida } & 5,400 \mathrm{~m} 2 \\ \text { Area total intervención } & 7,200 \mathrm{~m} 2\end{array}$

Área construida

Área libre del edificio Área total del edificio Área libre protegida Área total intervención
$750 m 2$
$150 m 2$
$900 m 2$
$19,100 m 2$
$20,000 m 2$

\section{ACCESO RESTRINGIDO}

$15 \%$

ACCESO LIBRE

$85 \%$
ACCESO RESTRINGIDO

$30 \%$

ACCESO LIBRE

$70 \%$
ACCESO RESTRINGIDO

$34 \%$

ACCESO LIBRE

$66 \%$
ACCESO RESTRINGIDO

$13.9 \%$

ACCESO LIBRE

$86.1 \%$ 
CENTRO DE INTERPRETACIÓN JEAN MARIE TJIBAOU
CENTRO DE INTERPRETACIÓN LA ANTIGUA
CENTRO DE INTERPRETACIÓN DE LOS

HUMEDALES DE SALBURÍA
CENTRO DE INTERPRETACIÓN DE LOS RIOS
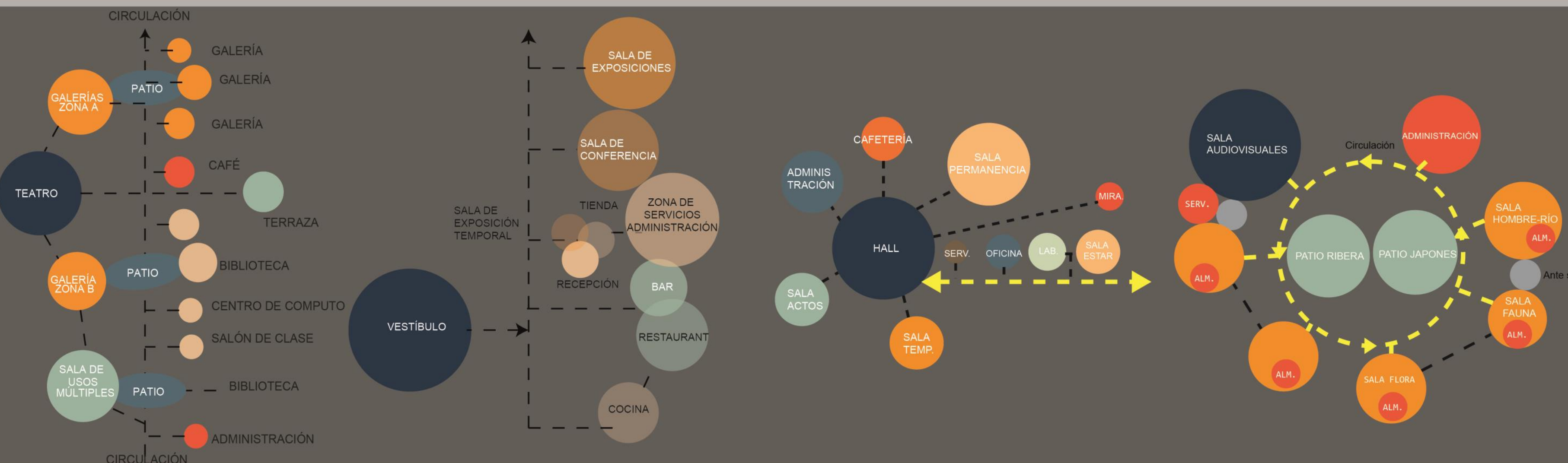
CENTRO DE INTERPRETACIÓN LA ANTIGUA
CENTRO DE INTERPRETACIÓN DE LOS HUMEDALES DE SALBURÚA
CENTRO DE INTERPRETACIÓN DE LOS RÍOS MARIE TJIBAOU

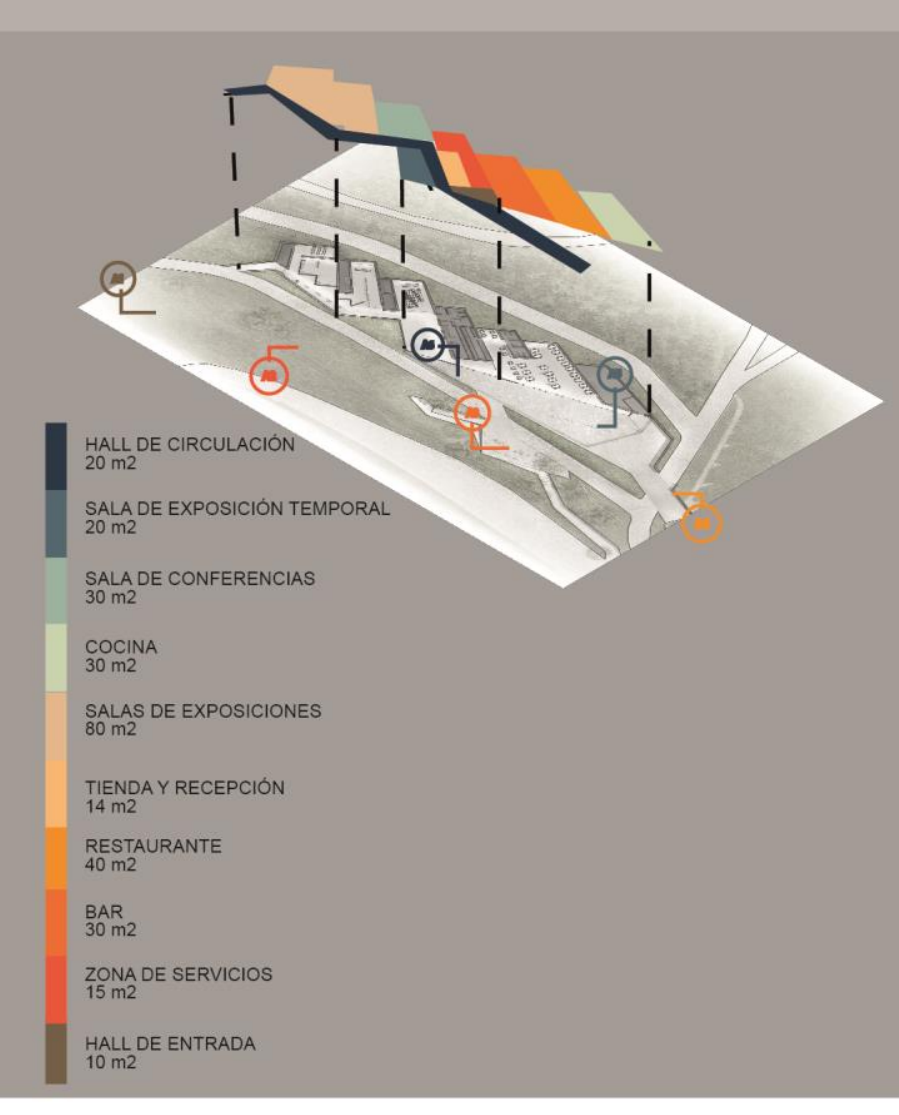

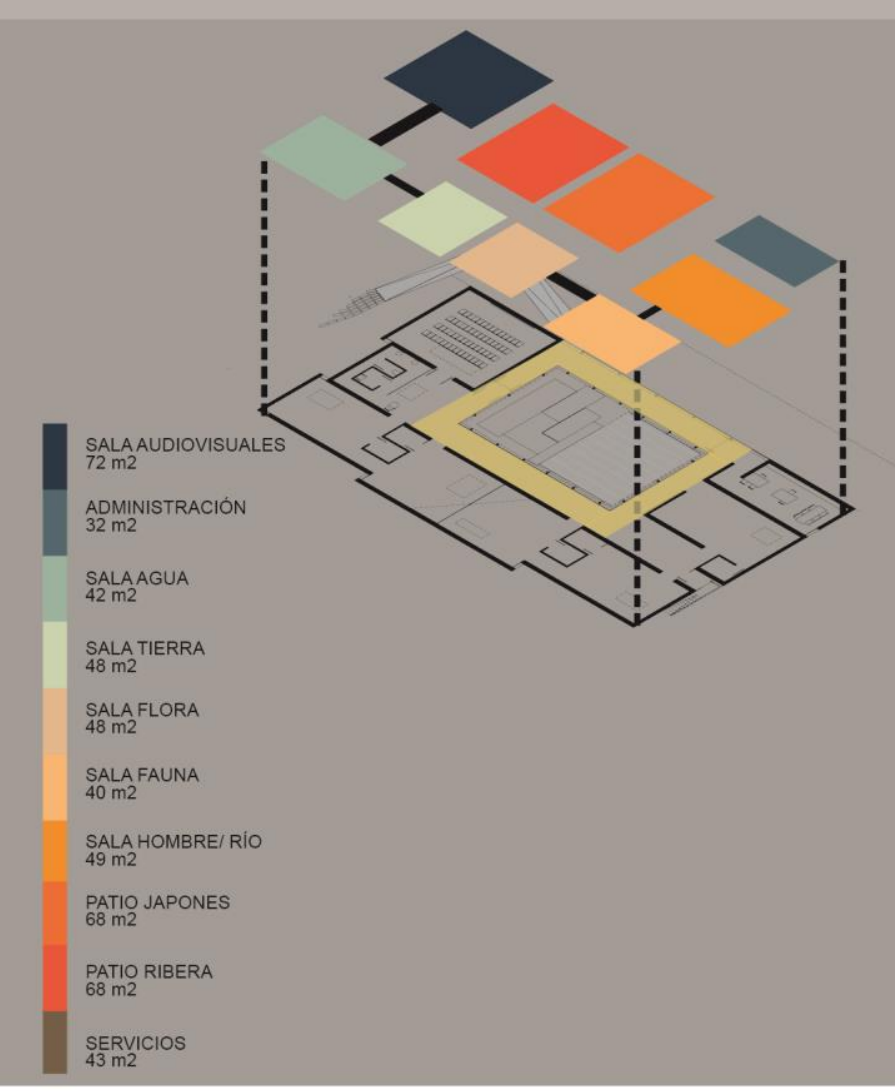


CENTRO DE INTERPRETACIÓN JEAN MARIETJIBAOU
CENTRO DE INTERPRETACIÓN LA ANTIGUA
CENTRO DE INTERPRETACIÓN DE LOS HUMEDALES DE SALBURÚA
CENTRO DE INTERPRETACIÓN DE LOS RIOS

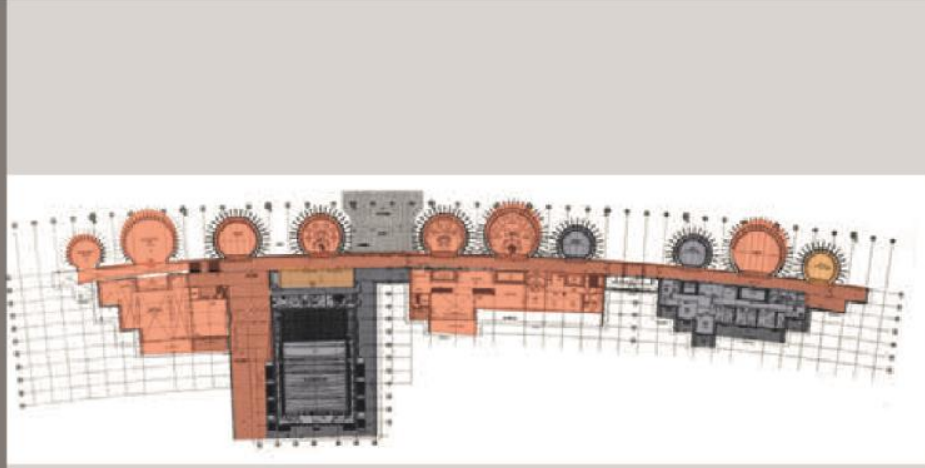

SEMI-PÚBLICO

—- PÚвLICO

PRIVADO

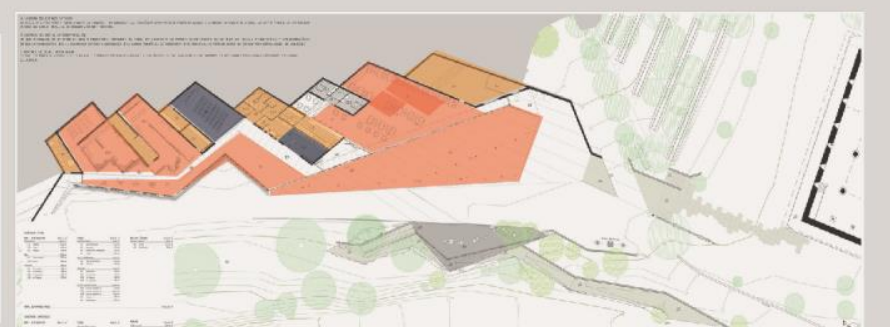

- SEMI-PÚBLICO

[. PÚBLICO

PRIVADO

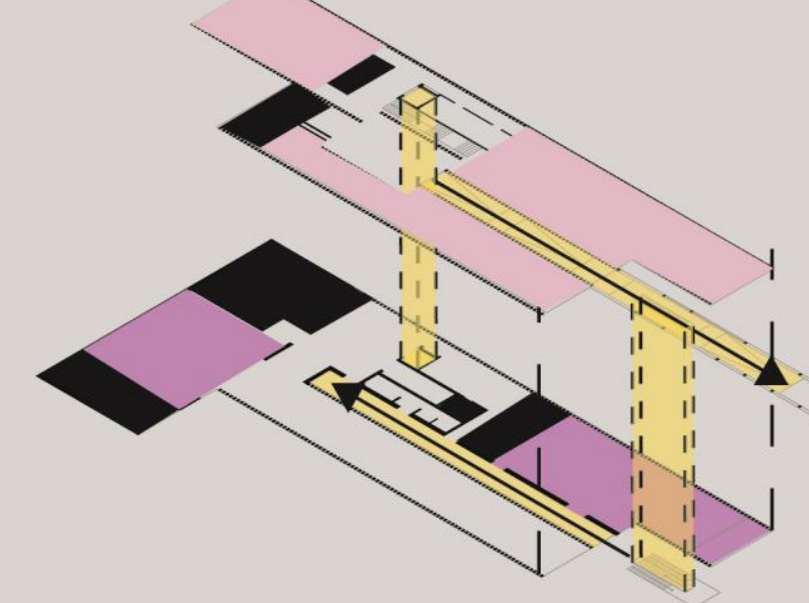

5\% Espacio Privado

20\% Espacio Semi Público

85\% Espacio Público

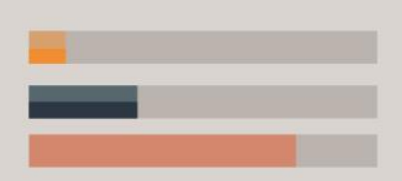

10\% Espacio Privado

20\% Espacio Semi Públco

70\% Espacio Público
Recorrido

$14 \%$

—Espacios Privados $\quad \mathbf{1 7 \%}$

- Espacio Semipúblico 17\%

Espacio Público $\quad \mathbf{5 2 \%}$

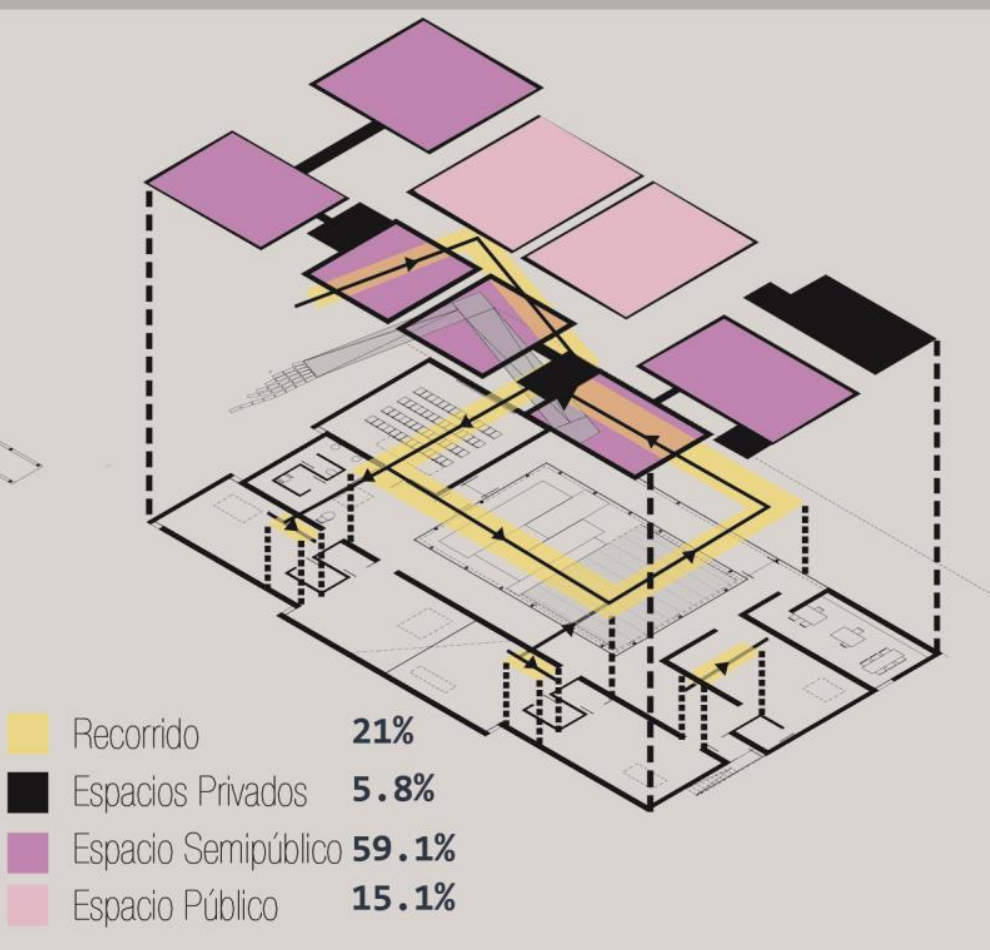




\section{CUADRO RESUMEN}

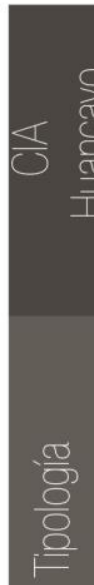

\section{RESULTADO DEL ANÁLISIS DE CENTRO} DE INTERPRETACIÓN

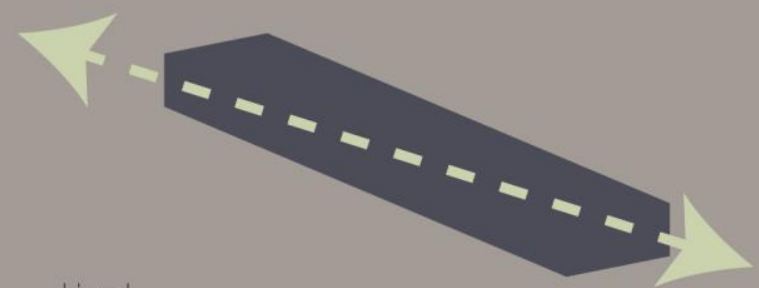

Lineal

\section{PAISAJE}

De los casos análogos, la temática de paisaje es la más común, será tomada en cuenta al momento del desarrollo del CIA-Huancayo

Área construida

$2,500 m 2$

Área total

$5,000 m 2$
ACCESO RESTRINGIDO

क
83
8
8

\section{ACCESO LIBRE}

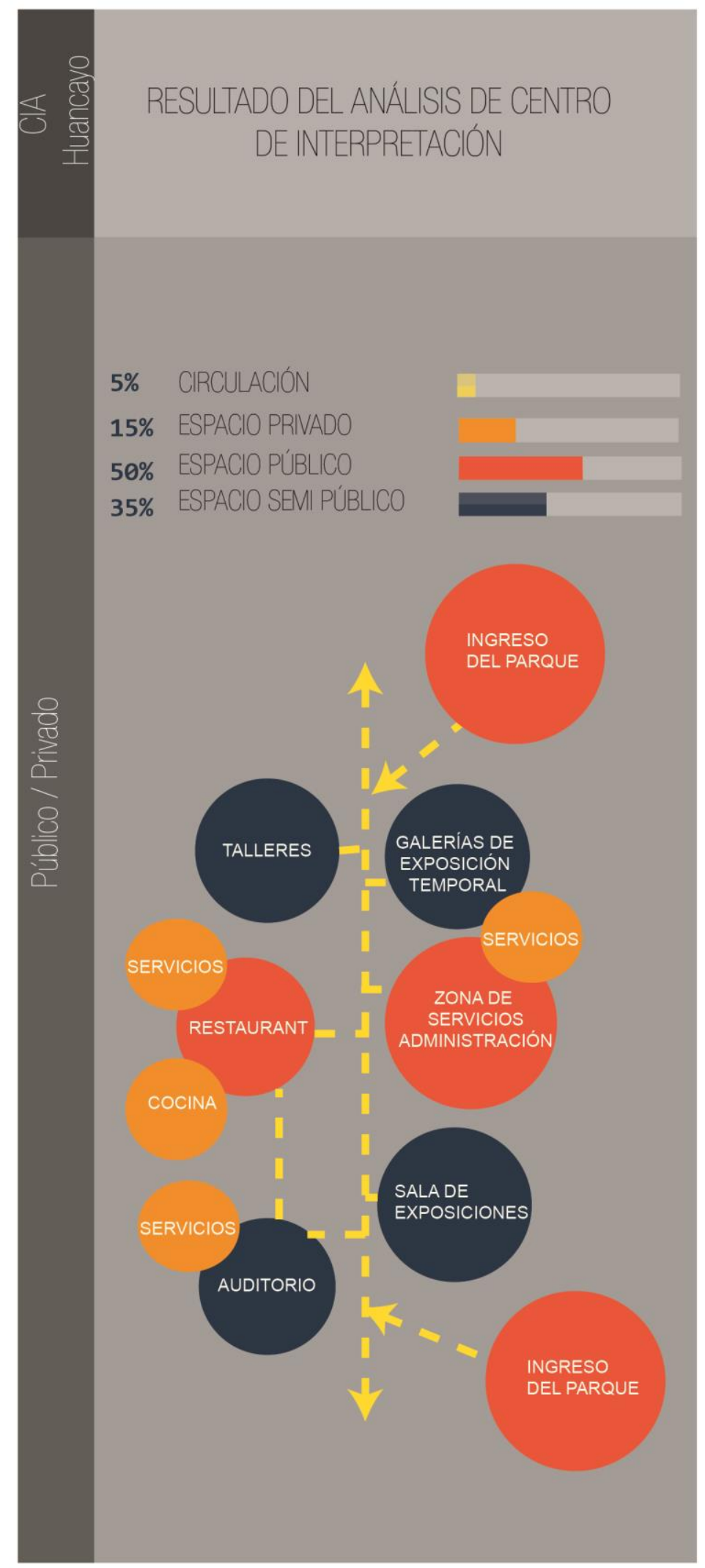




\section{3 .3}

RÍO MANZANARES - RÍO CHEONGGYECHEON

FICHA

\subsection{6}

Elaboración propia en base a láminas de la sección 5.2 .1 y 5.2.2 de la presente tesis

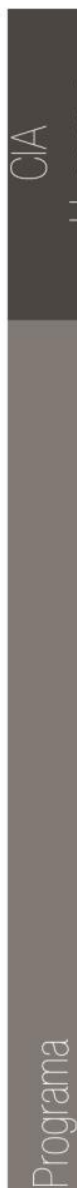

RESULTADO DEL ANÁLISIS DE CENTRO DE INTERPRETACIÓN

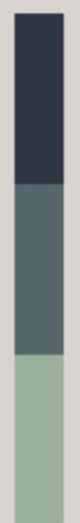

SALAS DE EXPOSICIÓN PERMANENTES $553.6 \mathrm{~m} 2$

GALERÍAS DE EXPOSICIÓN TEMPORAL $550.23 \mathrm{~m} 2$

ADMINISTRACIÓN

$190.00 \mathrm{~m} 2$

MIRADORES

$64.5 \mathrm{~m} 2$

RESTAURANTE

$80.00 \mathrm{~m} 2$

AUDITORIO

$380.00 \mathrm{~m} 2$

TALLERES

$220.00 \mathrm{~m} 2$

SERVICIOS

$38 \mathrm{~m} 2$

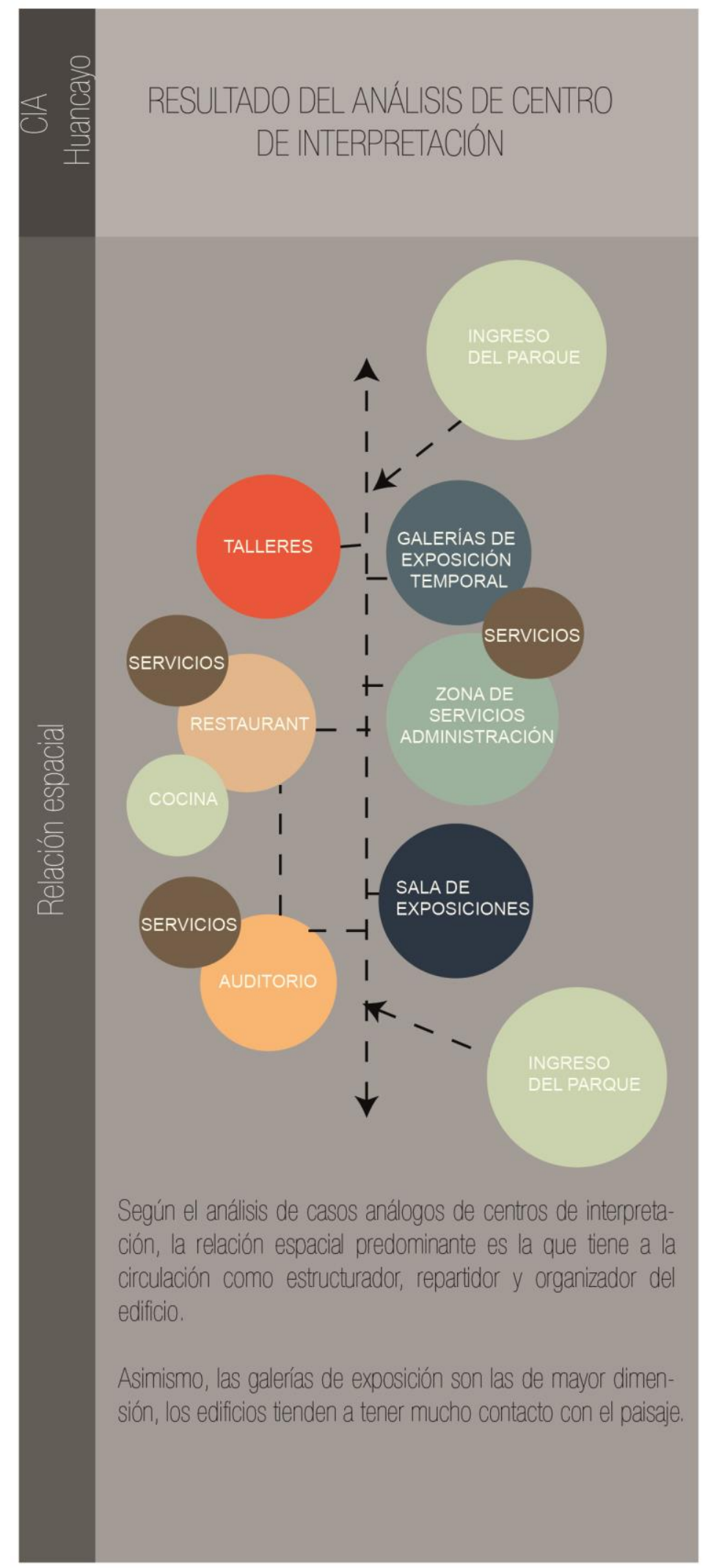




\subsection{Conclusiones parciales}

\subsubsection{De intervenciones de regeneración de bordes de ríos}

Después del análisis de los referentes de regeneración urbana de bordes de río se concluye que los proyectos presentan problemas como desconexión de territorios, pérdida del patrimonio natural, altos índices de contaminación, transporte no planificado, fragmentación urbana, entre otros. En consecuencia, surge una preocupación del estado por regenerar los bordes del río para mejorar la calidad de vida de la población.

La acción de regenerar está relacionada a la mejora de un elemento deteriorado, en este caso los bordes de los ríos Manzanares y Cheonggyecheon.

En el siguiente cuadro (Tabla 5.1) se muestra los objetivos y estrategias que han aplicado los casos de estudio para solucionar los diferentes problemas que encontraron en la ribera del río.

Tabla 5. 1 Cuadro de objetivos del intervennciones de regeneración de bordes de río

\begin{tabular}{|c|c|c|}
\hline & Río Manzanares & \begin{tabular}{|l} 
Río Cheonggyecheon \\
\end{tabular} \\
\hline Objetivos & Estrategias & Estrategias \\
\hline \multirow{4}{*}{ Conectar } & Soterramiento de la M30 & \multirow{2}{*}{$\begin{array}{l}\text { Construcción de puentes y } \\
\text { pasarelas cada } 100 \text { metros }\end{array}$} \\
\hline & Creación de ciclovías & \\
\hline & $\begin{array}{l}\text { La tranvía como transporte } \\
\text { público }\end{array}$ & $\begin{array}{l}\text { Restructuración del tránsito } \\
\text { vehicular }\end{array}$ \\
\hline & $\begin{array}{l}\text { Creación de puentes y pasarelas } \\
\text { para conectar barrios }\end{array}$ & $\begin{array}{l}\text { Creación de camino peatonal } \\
\text { bidireccionales paralelas al río }\end{array}$ \\
\hline \multirow[b]{3}{*}{ Activar } & Creación de parques diversos & \multirow{2}{*}{$\begin{array}{l}\text { Creación de nodos focales a } \\
\text { partir de la historia }\end{array}$} \\
\hline & Creación de programas & \\
\hline & $\begin{array}{l}\text { Incrementar equipamiento: } \\
\text { Matadero, Centro de } \\
\text { Interpretación, museo del agua u } \\
\text { otros. }\end{array}$ & $\begin{array}{l}\text { Creación de temáticas turísticas } \\
\text { en eje lineal del río conformado } \\
\text { por ecológicas, históricas y } \\
\text { culturales. }\end{array}$ \\
\hline \multirow{2}{*}{ Recuperar } & $\begin{array}{l}\text { Reciclar edificaciones con valor } \\
\text { patrimonial para dar nuevos usos }\end{array}$ & $\begin{array}{l}\text { Siembra de planta y árboles } \\
\text { nativos }\end{array}$ \\
\hline & Uso de la fauna nativa en parques & $\begin{array}{l}\text { Restauración de bienes } \\
\text { históricos del entorno inmediato }\end{array}$ \\
\hline Integrar & Creación de boulevard verdes & Creación de ejes verdes \\
\hline
\end{tabular}

Fuente: Elaboración propia basada en el libro Madrid Río y Seul Metropolitan Facilities Management Corporation 
Para el desarrollo del Parque Lineal Ribereño Shullcas, tendremos en cuenta las metodologías de intervención de los referentes estudiados, ya que después de lo analizado podemos inferir que un plan maestro de borde de río cuenta con una cartera de proyectos que se desarrollan a corto, mediano y largo plazo. Por lo tanto, el Parque Lineal Ribereño Shullcas, al ser un plan maestro de borde de río, deberá contener proyectos que activen el eje y entorno inmediato del río. El objetivo de las estrategias de intervención es mantener un flujo constante de usuarios que active el parque durante el día, ya que, sin aglomeraciones de personas, este puede convertirse en un lugar inseguro y peligroso.

Asimismo, un plan maestro pretende incrementar equipamiento, espacio público, transporte integrado que ordene la ciudad y mejore la calidad de vida de los habitantes. Por lo tanto, el espacio público debe contener áreas que permitan al usuario realizar sus actividades. Así como los referentes proponen temáticas en el recorrido. Estudiaremos la caracterización del eje del Río Shullcas para proponer temáticas que atraigan al usuario.

La conexión y articulación por medio de puentes y pasarelas nos ayudará a solucionar los problemas de ruptura de trama urbana. Asimismo, la creación de sistemas de transporte integrado y sostenible de manera longitudinal, como en el Río Manzanares, tejerá los diversos sectores de la ciudad de Huancayo por medio del Río Shullcas.

\subsubsection{De centros de interpretación}

En el análisis de centros de interpretación estudiamos cuatro referentes. Respecto a las ubicaciones todas coinciden en encontrarse en áreas verdes y a las afueras inmediatas del casco urbano de la ciudad, Esto se debe a que la temática del centro está relacionada al paisaje natural. Sin embargo, no se encuentra desconectada del casco urbano, ya que cuentan con paraderos, sistemas de ciclovías, autobuses que facilitan el acceso a los usuarios. Por lo tanto, la ubicación de un centro de interpretación puede ser dentro o fuera del casco urbano, solo dependerá que se encuentre conectado con sistemas viales que faciliten el acceso y acorten los viajes de los usuarios.

Respecto a la tipología, la mayoría de los centros de interpretación analizados coinciden en la forma lineal, la ventaja de esta tipología es que la circulación se convierte en el eje estructurante del edificio, esto permite la independencia de salas. En algunos casos existe un remate al final del eje lineal, siendo el espacio jerárquico o principal. En 
el Centro de Interpretación del Agua, la tipología lineal nos permitirá estructurar el edificio y conectar a los caminos del Parque Lineal Ribereño Shullcas para que el peatón al recorrer el parque no sienta que el edificio es una pieza diferente.

El programa de los centros coincide en contener galerías de exposición y conservación, miradores, talleres, administración, restaurante y áreas de servicio. Mayormente los espacios tienen conexiones horizontales entre ellos y verticales con el paisaje. Considerando lo analizado, el Centro de Interpretación del Agua contará con los espacios necesarios que proporcionen al usuario una experiencia única para poder educar y concientizar.

Los materiales utilizados en los centros de interpretación analizados son de la zona y otros importados, lo recomendable para que no exista un gasto de energía innecesario sería utilizar materiales de la zona que proporcionen al usuario el confort térmico necesario para la estancia. Por lo tanto, el CIA Huancayo usará materiales de la zona y el sistema constructivo dependerá de los materiales a utilizar. La estructura expuesta es una estrategia de diseño que se podría aplicar al CIA Huancayo.

Los centros de interpretación estudiados no alteran el paisaje natural, se ubican de tal manera que se mimetizan o se posan. El CIA Huancayo usará una de las dos estrategias dependiendo del tipo de suelo del lugar a emplazarse y de los factores de riesgo como inundaciones, ya que el terreno está en la ribera del Río Shullcas. 


\section{CAPÍTULO VI: MARCO CONTEXTUAL}

\subsection{Metodología}

El análisis del paisaje se establece en relación al desarrollo del estudio del paisaje de " $L a$ guía metodológica del estudio del paisaje”, explicada en el marco normativo, y el análisis de componentes del paisaje como instrumento de argumentación para la intervención de la propuesta.

La presente tesis propone el planteamiento del Plan Maestro del Parque Lineal Ribereño Shullcas para posteriormente desarrollar el Tramo 1 de la propuesta. De este modo la metodología se desarrollará para ambas intervenciones considerando algunas variaciones en el análisis de componentes del ámbito de estudio a razón de la diferencia de escalas de los proyectos.

A continuación, se indicará el orden de las fases consideradas en el estudio de " $L a$ guía metodológica del estudio del paisaje". Además del análisis de los componentes del paisaje incorporado en esta metodología adoptada, considerando los alcances y limitaciones de la presente tesis.

- Ámbito de estudio

- Análisis de componentes del paisaje

- Caracterización del paisaje

- Valoración del paisaje

- Medidas y acciones:

\subsection{Plan Maestro Parque Llineal Ribereño Shullcas (Paisaje local)}

Como se mencionó anteriormente la metodología se desarrollará a partir de las 5 fases definidas en paralelo con el análisis de componentes de la ciudad, determinados por siete criterios (crecimiento urbano, topografía y agua, espacios libres e infraestructura ecológica, movilidad peatonal, vehicular, equipamientos, riesgos y contaminación). 


\subsection{1 Ámbito de estudio}

El área de estudio está definida por la ribera del Río Shullcas y el entorno inmediato a este. El ámbito de estudio (Lámina 6.1) inicia, desde el cruce con el Río Mantaro hasta las cercanías de la urbanización Las Retamas de San Luis y abarca transversalmente un aproximado de 4 cuadras paralelas al río.

\subsubsection{Análisis de componentes del paisaje local}

A continuación, se presenta láminas de análisis de los componentes del paisaje conformado por: crecimiento urbano, topografía y agua, espacios libres e infraestructura ecológica, movilidad peatonal, vehicular, equipamientos, riesgos y contaminación. 


\section{SECCIÓN}

\section{2 .1}

FUENTE:

Plan de Desarrollo Urbano Huancayo 2015-2025/ Enciclopedia Departamental Junín

\section{LÁMINA 6.1}

DEFINICIÓN DEL ÁMBITO DE ESTUDIO

El área de estudio está definida por la Ribera del Shullcas y la trama urbana próxima al río, el cual se encuentra conformado por los siguientes tipos de espacios:

\section{Espacio público disponible}

2. Viviendas precarias asentadas en zonas de riesgo

3. Terrenos con usos no compatibles a la zonificación

4. Zona de protección (fajas marginales) en ambos bordes.

5. Equipamientos

\section{ÁREAS DEL ÁMBITO}

Área de fajas marginales: 25.4 ha

Área de bordes: 264.6 ha

\section{LEYENDA DEFINICIÓN DEL ÁMBITO}

Área del ámbito de estudio

Zona de intervención

Fajas marginales
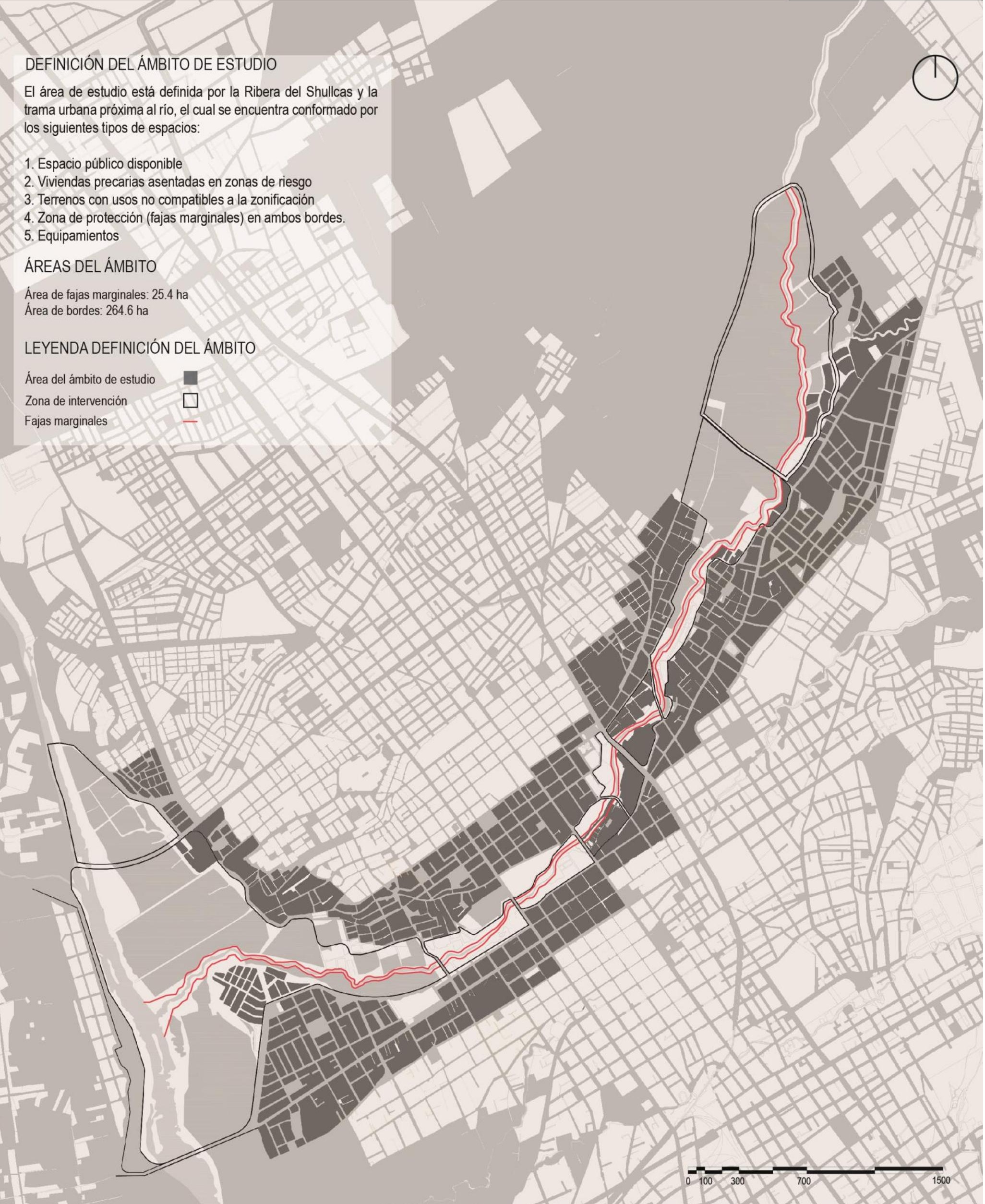


\section{CRECIMIENTO URBANO}

\section{SECCIÓN}

\subsubsection{1}

FUENTE:

Plan de Desarrollo Urbano Huancayo 2015-2025/ Enciclopedia Departamental Junín

\section{LÁMINA 6.2}

\section{DEFINICIÓN DEL ÁMBITO DE ESTUDIO}

La Ciudad de Huancayo tiene una extensión de $4,673.60 \mathrm{Ha}$. aproximadamente, donde la consolidación de la trama urbana es reflejo de las distintas etapas de la ciudad. Un claro ejemplo de esto es el Centro Histórico que presenta una trama ortogonal mientras existen otras áreas con configuraciones distintas

\section{LEYENDA CRECIMIENTO URBANO}

\section{Trama histórica 1532-1572}

Trama de expansión en 1800

Trama de expansión 1900

Trama de expansión 2001

Trama de expansión 1960-1970 Trama de expansión 2006

Trama de expansión 1980

- Trama de expansión 2007

Trama de expansión 1990

Zona De Intervención

Trama de expansión 2000-2002

Fajas Marginales

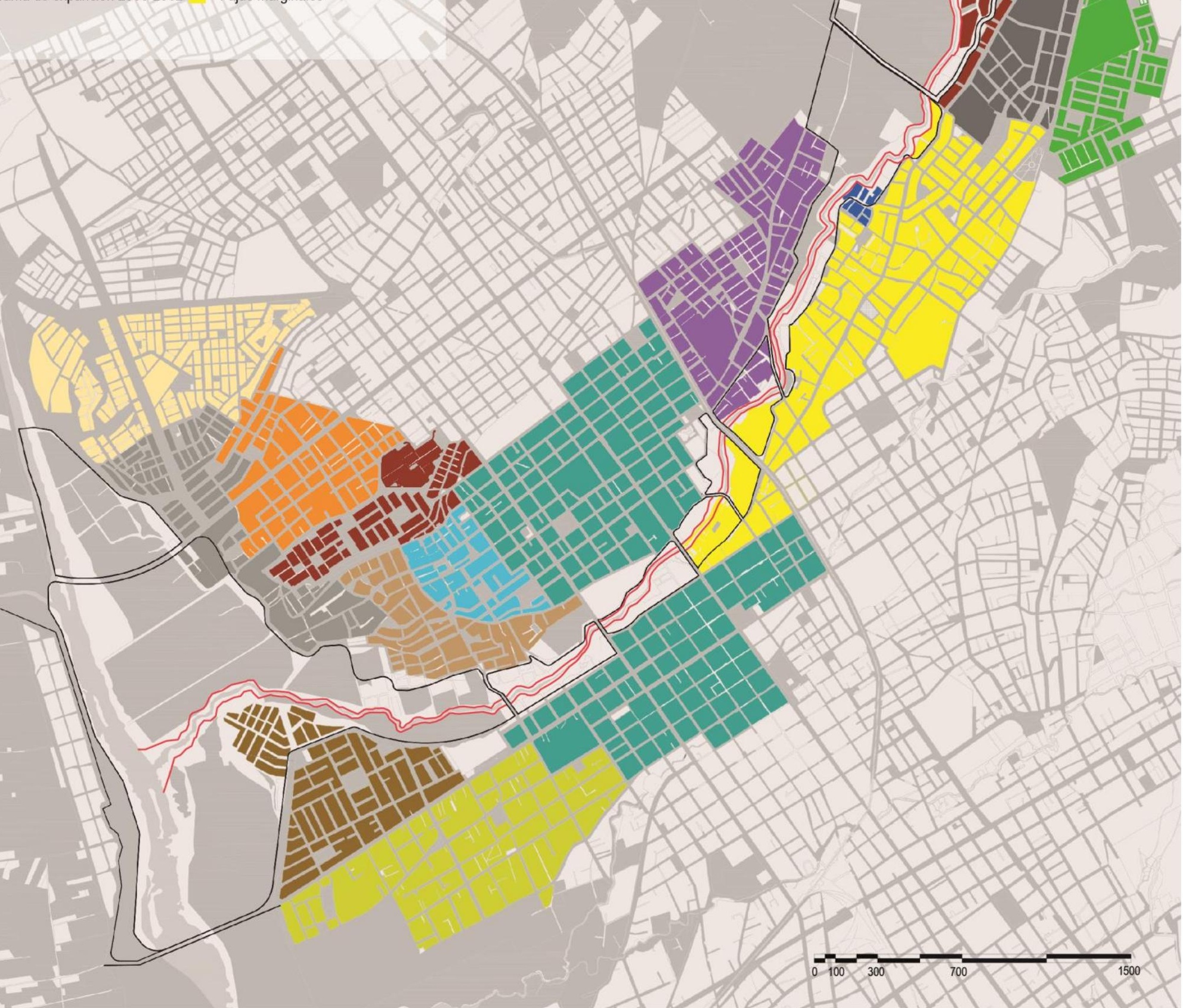




\section{CIUDAD AGUA Y TOPOGRAFÍA}

\section{SECCIÓN}

6.2 .2 .2

FUENTE:

Plan de Desarrollo Urbano Huancayo 2015-2025/ Enciclopedia Departamental Junín

\section{LÁMINA 6.3}

\section{CIUDAD AGUA Y TOPOGRAFÍA}

La cuenca principal de la Ciudad de Huancayo y del Valle del Mantaro es el Río Mantaro.

Esta compuesta por subcuencas como el Río Shullcas, Cunas, Chilca y diversos canales, siendo el Shullcas de mayor importancia para la ciudad por ser el abastecedor principal de agua potable de los distritos con mayor población en la ciudad ( Tambo y Huancayo)

\section{LEYENDA AGUAY TOPOGRAFÍA}

Río Mantaro

Afluentes y canales

Topografia

Zona de intervención

Fajas marginales 


\section{LÁMINA 6.5}

DEFINICIÓN DEL ÁMBITO DE ESTUDIO

El flujo peatonal se da de manera transversal y longitudinal. Sin embargo, se observa que no hay una conexión directa con el Rio Shullcas. Las viviendas ubicadas en la ribera dan la espalda al río generando una fragmentación entre distritos

\section{MOVILIDAD PEATONAL Y PUNTOS DE INTERÉS} CONEXIÓN TRANSVERSAL

1. Hacia Parque Industrial

2. Hacia Universidad Nacional del Centro del Perú

3. Hacia Hospital Regional ESSALUD

4. Hacia Distrito De Pilcomayo

5. Hacia Real Plaza Huancayo

6. Hacia Mecado Mayorista de la Región

7. Municipalidad de Huancayo/ Plaza Huamanmarca

8. Hacia Distrito de Sapallanga

9. Hacia Coliseo Huanca

10. Hacia Distrito de Huayucachi

CONEXIÓN LONGITUDINAL

11. Hacia Nevado Huaytapallana

12. Hacia Ribera del Rio Mantaro

13. Hacia zona de Protección ecológica

Puntos de Interés Salud/Educación / Cultura / Comercio

14. Colegio Nacional La Asunción de Palian

15. UPLA

16. Universidad Continental

17. Parque De La Identidad Huanca

18. Colegio Nacional Santa Isabel

19. Discoteca Maxxo

20. Terminal Terrestre de buses de la Selva Central

21. Open Plaza Huancayo

22. Plaza Constitución

23. Colegio MariaAuxiliadora

24. Colegio Salesiano Santo Rosa

1) 25. Colegio Salesiano Técnico

26. Cementerio General

27 Hospifal Regional Daniel Alcides Carrión

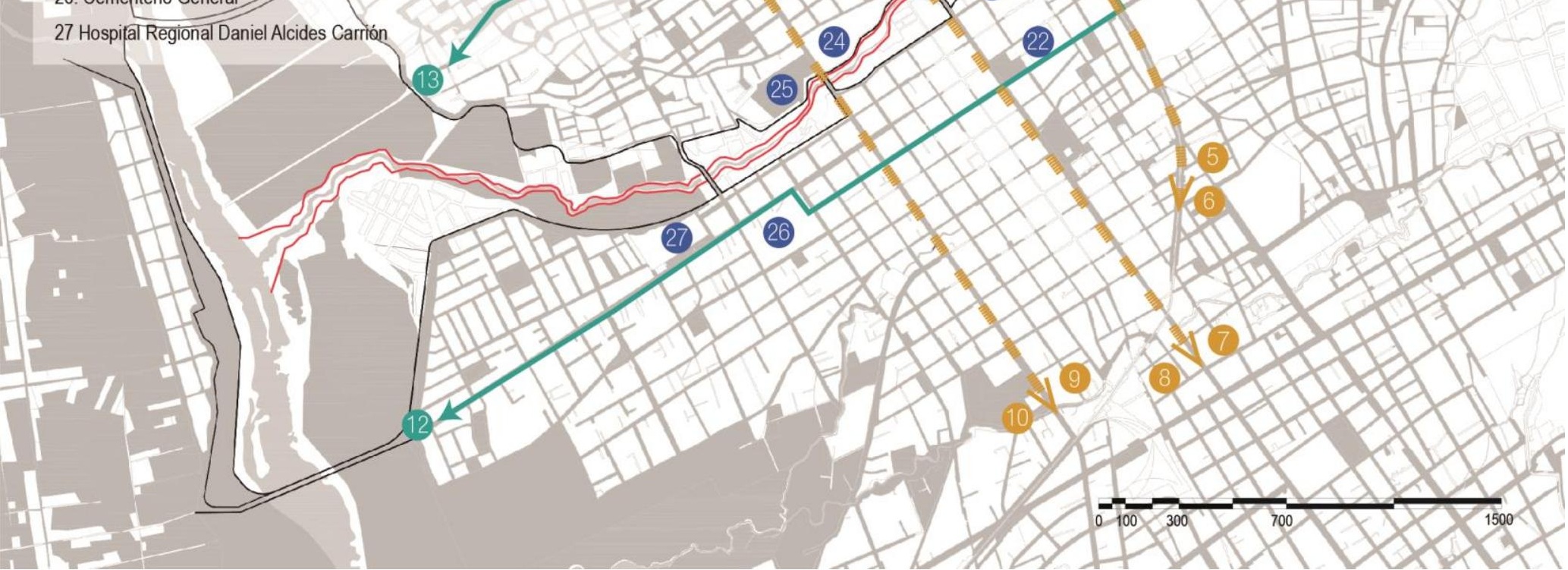




\section{LÁMINA 6.6}

DEFINICIÓN DEL ÁMBITO DE ESTUDIO

Debido a la configuración de la trama urbana las conexiones longitudinales en relación a la Ribera del Shullcas son vías discontinuas y las conexiones transversales se encuentran ubicadas en la zona central sur mientras que al norte solo está el Puente San Agustin. Por otro lado, existe un proyecto de vía transversal llamada Evitamiento que está prevista construirse en el 2020.

\section{LEYENDA MOVILIDAD VEHICULAR}

CONEXIONES TRANSVERSALES -

\section{Puente Carrión}

2. Puente Huancavelica

3. Puente Real

4. Puente Amazonas

5. Puente Ferrocarril

6. Puente Los Alamos

7. Puente San Agustin

CONEXIONES LONGITUDINALES -

\section{Av. Evitamimiento}

2. Av. Daniel A. Carrión $\uparrow \downarrow$

3. Av. Cusco

4. Av.Puno

5. Av. Deutsua

6. Av. Ayacucho

7. Av. San Carlos

8. Av. Trujillo

9. Av. Calmell del Solar $\uparrow$ ।

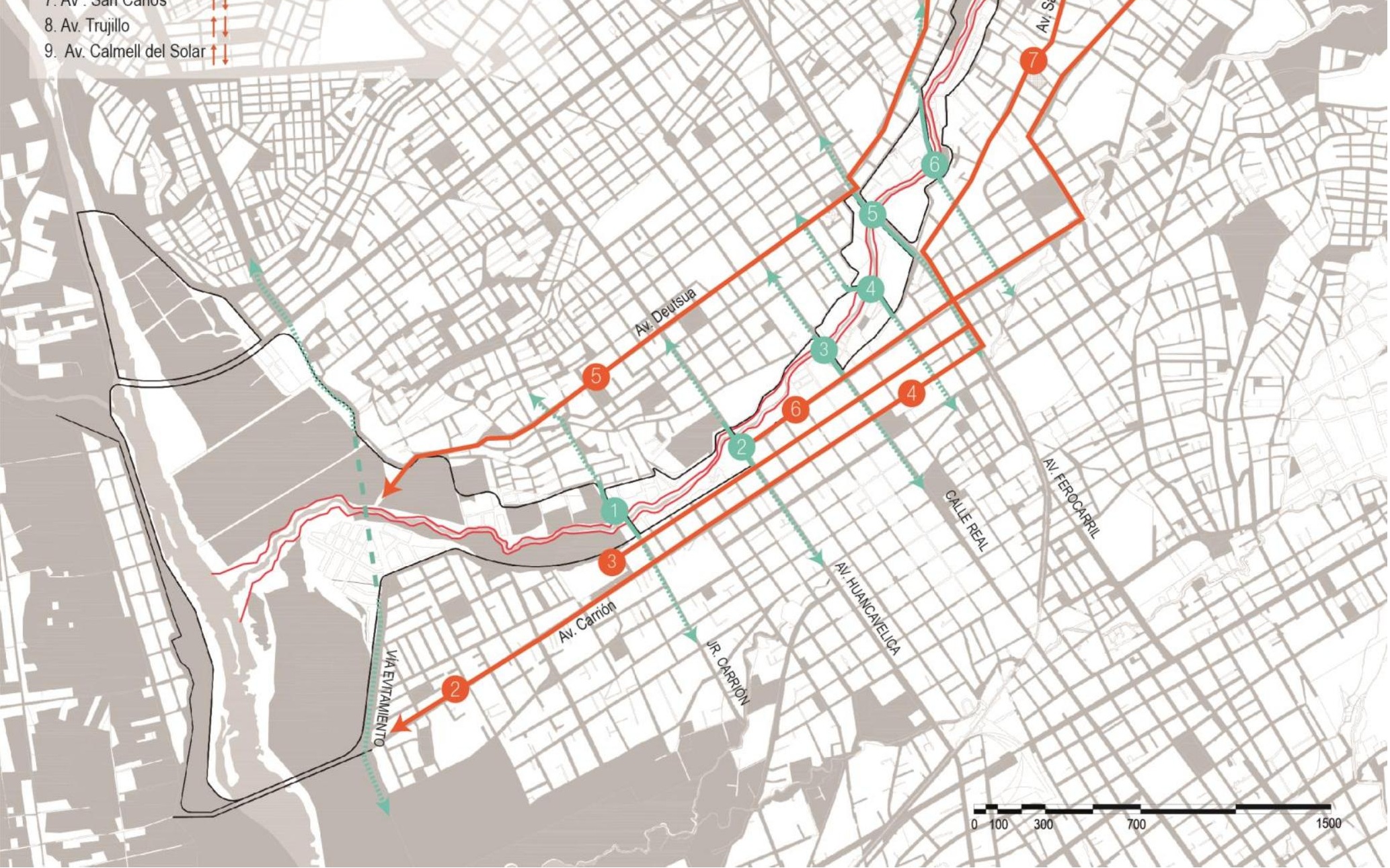




\section{SECCIÓN}

\section{2 .2 .6}

FUENTE:

Plan de Desarrollo Urbano Huancayo 2015-2025/ Enciclopedia Departamental Junín

\section{LÁMINA 6.7}

\section{DEFINICIÓN DEL ÁMBITO DE ESTUDIO}

El equipamiento predominante en la Ciudad de Huancayo es el comercio (centros comerciales, mercados y comercio calle real), seguido por la educación y siendo más específicos la educación básica es la predominante.

\section{PORCENTAJE AREADE EQUIPAMIENTOS}

\section{$3.3 \%$ Salud \\ $2.2 \%$ Cultural \\ $11.2 \%$ Recreativo}

\section{LEYENDA EQUIPAMIENTO}

EDUCACIÓN SUPERIOR

1. ISTP Santiago Antúnez de Mayolo

2. UPLA Universidad Peruana Los Andes

3. Universidad Continental

4. Instituto Continental

EDUCACIÓN BÁSICA

5. Colegio Nacional La Asunción de Palián

6. Colegio Nacional Santa Isabel

7. Colegio Claretiano

8. Colegio Andino

9. Colegio Técnico Inmaculada

10. ICPNA

11. Colegio María Auxiliadora

12. Colegio Nacional Rosario

14. Colegio Gelicich

15. Colegio Ingenería

16. Golegio Salesiano Santa Rosa

17. Colegio Salesiano Técnico

18. Colegio NacionałPolitécnico

19. Jardin Particular San Pedro EQUIPAMIENTO ESPECIAL COMERCIOMETROPOEITANO 20. Mercado El Tambo

21. Open Plaza

22. Real Plaza

23. Mercado Mayorista

24. Comercio Calle Real

25. Tienda Maestro

26. Super Plaza Vea

RECREACIÓN

EQUIPAMIENTO DE SALUD

27. Hospital El Carmen

28. Clinica Ortega

29. Hospital Regional Daniel Alcides Carión

\author{
$0 / 7$
}

$\sqrt{47}$
$32.8 \%$ Educación

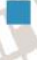 \\ (}

I.

lián

$4 \times$

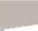




\subsubsection{Caracterización del paisaje}

Se determina el carácter del paisaje a partir de la identificación de patrones en el territorio correspondientes al ámbito de estudio. En el caso de la ribera del Shullcas se analiza la transición del borde del río con el medio urbano estudiando los siguientes aspectos (evolución, organización, patrones, recursos paisajísticos y conflictos paisajísticos).

\section{$\underline{\text { Evolución }}$}

Se realiza un análisis de las trasformaciones del paisaje en el tiempo. De esta manera se puede determinar (Lámina 6.2) como la ciudad se ha ido expandiendo con el asentamiento de viviendas y equipamiento a lo largo del Río Shullcas convirtiendo al río en el nuevo eje estructurador de la ciudad. El estudio, presenta las diversas tramas existentes que se han configurado en el territorio desde la fundación de la ciudad hasta el año 2017.

\section{Organización}

Se determina por el estudio de la estructura formal del paisaje (topografía e hidrografía). Además de la identificación y análisis de la cobertura vegetal (Sistema vegetal, cuerpos de agua y plantaciones humanas). En el caso del ámbito de la ribera del Shullcas, la hidrografía (Lámina 6.3) está compuesta por la subcuenca del Shullcas que oscila entre 3200 y3310 msnm. Por otro lado, la cobertura vegetal (Lámina 6.4) está definida por suelo agrícola y área verde de la ciudad conformado por parques y ejes de vías.

\section{$\underline{\text { Unidades (Patrones) }}$}

Surge de la identificación de patrones en el paisaje que determinan la configuración del territorio de manera particular para saber intervenir de manera óptima. En el área de estudio existe tres tipos de unidades de paisaje (Lámina 6.9) conformados por el medio urbano, suelo agrícola y el Río Shullcas.

\section{$\underline{\text { Recurso paisajístico }}$}

Se determina mediante la identificación de elementos con valor representativo. La ribera del Shullcas presenta recursos de interés ambiental y cultural. Este recurso natural de dominio fluvial se encuentra en estado frágil debido a actividades incompatibles con el 
medio y a causa de la contaminación (Lámina 6.8). Por otro lado, existen elementos de valor histórico y cultural compuestos por construcciones de estructuras agrarias (canales y parcelas) y patrimonio religioso (Capilla la Merced) (Lámina 6.7).

\section{Conflictos paisajísticos}

Identificación de aspectos que no contribuyan o generen cambios en el carácter del paisaje por medio de consecuencias perjudiciales que implique la degradación o desaparición de los componentes del territorio.

En el ámbito de estudio, se aprecia fragmentación del territorio relacionada a la perdida de conectividad física y visual (Lámina 6.5) por la presencia de viviendas e infraestructura que bloquean el paso y la visual de la ribera. Asimismo, se encuentran residuos sólidos que degradan el medio; presencia de elementos con poca relación al paisaje (Puente Santa Isabel se emplaza en una de las secciones más angostas del río generando un espacio fuera de proporción con el contexto), implantación infraestructura (Industrial) incompatibles con el uso del paisaje, Creación de áreas recreativas dispersas sin criterio de ordenación y articulación entre ellas y finalmente el abandono de zonas agrícolas para la lotización y construcción en ellas. Al extremo sur oeste de la ribera del Shullcas se ha mantenido, en mínimo grado, algunas parcelas y el extremo norte a pesar de contar con mayor área agrícola, también se encuentra amenazado por la venta y construcción. 
CARACTERIZACIÓN DEL PAISAJE LOCAL_"

A partir del análisis de los componentes la ciudad establecido por el criterio de siete aspectos (trama urbana, topografia 'y agua, espacios libres e infraestructura ecológica, movilidad peatonal, vehicular, equipamientos, riesgos y contaminaciôn), como herramienta conclusiva de información y justificativa para Jă toma de decisiones de cualquier intervención a proponer, la esstructura del ámbito de estudio conformada por la ribera y entorno inmediato ha permitido reconocer la relación de la ciudad con la ribera como una barrera urbana que presenta caracteristicas partioulares en deteterminados sectores a lo largo del Rio Shullcas.

La caracterización está determinada por 5 sectores definidos por los límites entre el medio urbano -rural y la propia ciudad. Los extremos longitudinales se definen por ecológico y natural, ubicando el primero cerca a la desembocadura del Río Mantaro y. el segundo, el natural, en dirección al Huaytapallana. Ambos determinados por el análisis de infraestructura ecológica. Las tres áreas restantes que componen la extensión del Río Shullcas ubicados en el medio urbano se encuentran conformados por zona histórica, ambiental y educativo-residencial. La determinación de las características se basa en el análisis de equipamiento, conexiones y contaminación

\section{LEYENDA}

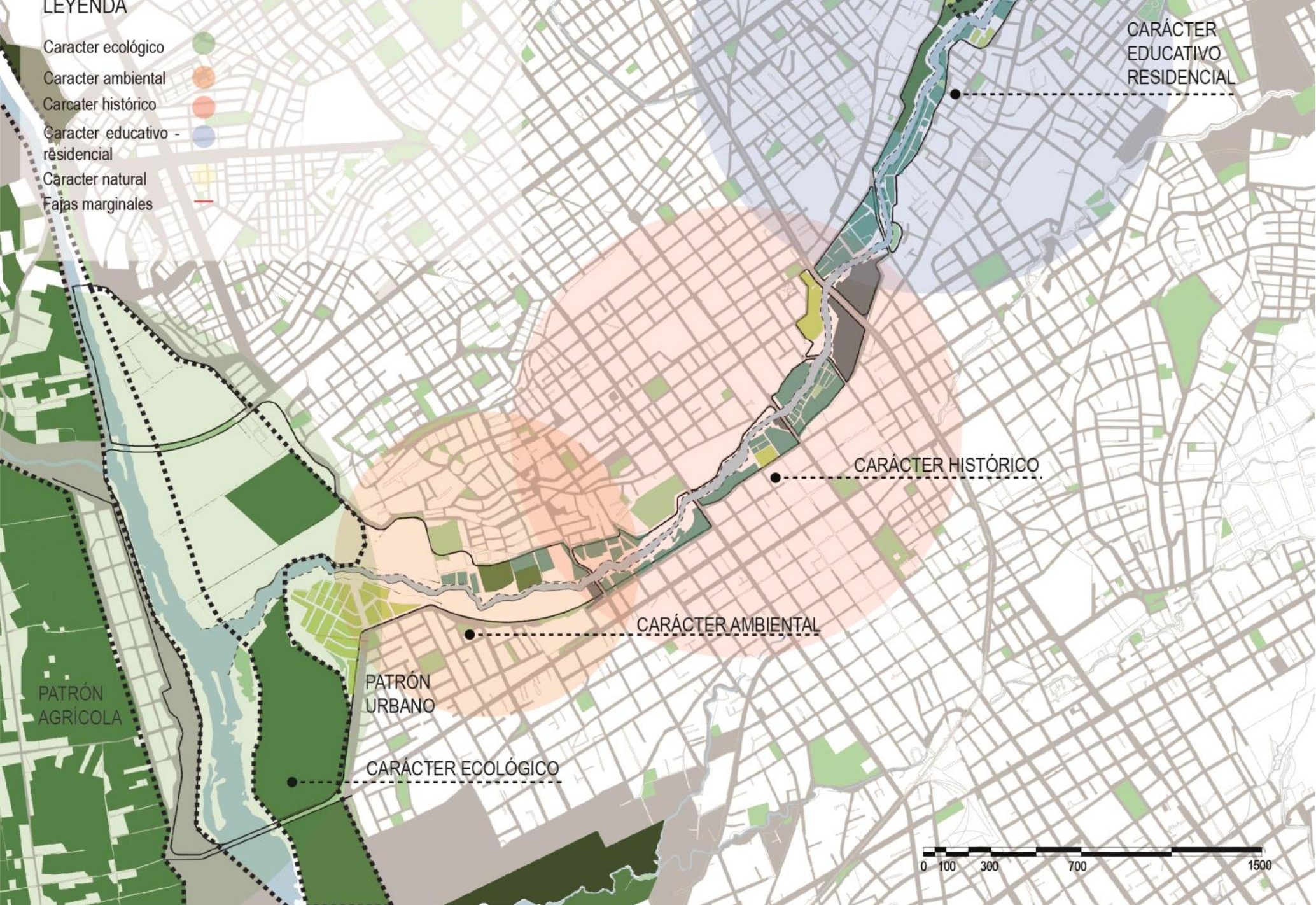




\subsubsection{Valoración del paisaje}

Esta fase determina el valor de la calidad paisajística y visibilidad del paisaje, además de las consideraciones de los conflictos del territorio.

$\underline{\text { Calidad paisajista }}$

- Interés de conservación: El Río Shullcas al ser considerado como dominio público, recurso paisajístico de interés natural y fuente de abastecimiento de agua potable de la ciudad de Huancayo, actualmente se encuentra en estado de degradación a causa de la contaminación y fragmentación urbana. Por lo tanto, requiere de la preservación. Asimismo, del cuidado como espacio intermedio entre el recurso natural y la ciudad.

- La representatividad: Las condiciones actuales de la ribera son lamentables, se ha perdido el carácter del lugar a causa de la parcelación de áreas agrícolas en los bordes. Las últimas áreas agrícolas son las del extremo sur y norte. Actualmente la ribera del Shullcas, no es un elemento representativo que la población identifique dentro de la ciudad.

- La singularidad: La existencia de las parcelas en una mínima parte de la ribera en el ámbito de estudio del medio urbano debería considerarse como un elemento que requiere de atención especial como estrategia de intervención. Sin embargo, la condición y peligro de desaparición no son favorables.

- La integridad: El área de estudio no está integrado, todo se ha transformado por acción del hombre y asentamiento al borde de la ribera.

- La función: Al ser el Río Shullcas el nuevo eje de crecimiento de la ciudad, la ribera presenta una oportunidad como estrategia para el ordenamiento paisajístico de la ciudad, asimismo actuará como medio conector e integrador entre las unidades de paisaje agrícola urbana, además de incorporar un sistema de espacios públicos interconectados con la ribera. Actualmente, las áreas libres en la ribera se encuentran desoladas y sin cuidado, así como los espacios públicos que parecen ser elementos aislados de la ciudad.

- Calidad de escena. Debido a las condiciones de la ribera y el río no se aprecia visuales representativas, sin embargo, con el tratamiento de los bordes se pude establecer lugares con interés estético. 


\section{$\underline{\text { Justificación del valor del paisaje }}$}

De acuerdo a los criterios analizados anteriormente se identifica el grado de calidad paisajística. La ribera del Shullcas, como materia de intervención, presenta grado de valor bajo, que corresponde a una estructura de paisaje degradado, con organización poco legible.

Existe poco interés del recurso paisajístico por parte del estado, además de otros factores en el que suelo agrícola ha perdido valor para remplazarlo por medio urbano, de esta manera no existe reflejo de apreciación de la ribera y el río por parte de la población.

\section{Propósito de actuación}

De acuerdo a la determinación del valor paisajístico, se define ejes estratégicos de acción como intenciones que buscan considerar en el paisaje. De este modo el proyecto del Parque Lineal Ribereño Shullcas aspira a la modificación del paisaje y gestión del mismo, ya que para establecer una estructura y configuración del paisaje claramente definida se requiere la modificación e intervención del aspecto físico del territorio para establecer la mejora del paisaje considerando las características del contexto urbano.

\subsubsection{Medidas y acciones}

La determinación de medidas y acciones sirven para garantizar las directrices trazadas. A partir de ellas se establecen tres formulaciones que ayudan al desarrollo de la tesis de acuerdo a los alcances. Estas comprenden infraestructura verde y definición de programas del paisaje.

\section{$\underline{\text { La infraestructura verde }}$}

Se define a partir de la integración y continuidad de espacios libres, recursos ambientales, culturales, visuales, sociales y conexiones ecológicas funcionales que las integre entre sí a modo de un sistema de espacios abiertos y corredores De este modo la metodología recomienda aspectos a considerar en la intervención:

- Proteger los paisajes valiosos: Proteger la ribera y el Río Shullcas, preservar patrones ecológicos (la composición de la ribera como sistema de espacio público recreativo) 
- Preservar la conexión entre unidades: Establecer la ribera del Shullcas como medio conector entre las unidades de suelo agrícola, forestal y rural los cuales se encuentran en los extremos de este.

- Mejorar la accesibilidad: Por medio de la creación de espacios recreativos en la infraestructura verde.

- Crear áreas de transición entre usos y actividades: El tratamiento de las áreas de transición física de unidades de paisaje (borde del río y el medio urbano) como espacio que atenúa de la diferenciación de usos y actividades (ciudad y ribera- como espacio intermedio del contraste entre un medio acelerado y un espacio de contemplación)

De este modo, la infraestructura verde se define por los espacios de valor natural (ribera y Río Shullcas), las áreas de riesgo que deben quedar libres de urbanización (áreas de la ribera vulnerables a inundación) y la red de corredores ecológicos -funcionales que conectan todos los elementos entre sí

\section{Definición de programas de paisaje}

Está definido por objetivos que aseguran la preservación y la puesta en valor del paisaje concerniente al Río Shullcas que se encuentra en estado de degradación. Los programas a proponer se establecen de acuerdo a los siguientes criterios considerados pertinentes para la presente tesis:

- Mejora de un espacio sensible: En relación a la intervención de los bordes de la ribera considerando estrategias de potencializar el paisaje por medio de actividades.

- Propuesta de uso público: El recurso paisajístico como espacio público que mejora la accesibilidad, contemplación y disfrute de ella.

- Conciencia de la población: Por medio de la trasmisión de conocimiento acerca de la ribera del Shullcas y los valores en el paisaje.

\subsection{Elección del tramo a intervenir}

Para la elección del terreno se analiza 17 criterios (Lámina 6.10, 6.11) de los cuales se considera a la caracterización del paisaje como factor determinante. 


\section{ELECCIÓN DEL TERRENO}

\section{CAPÍTULO}

6.3

\section{FUENTE:}

Plan de Desarrollo Urbano Huancayo 2015-2025/ Enciclopedia Departamental Junín

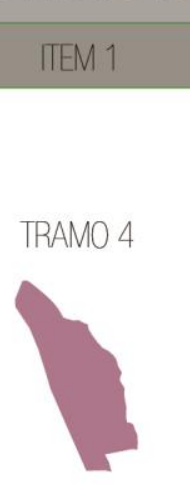

ITEM 3
Ubicación

CRITERIO 4

CRonificación 5

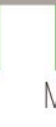

Rivera cerca al cruce del Río Shullcas y Mantaro, Huancayo Junín

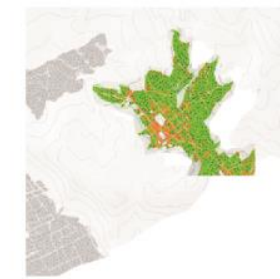

CRITERIO 7

Accesibilidad FRENTES

Los frentes son de VÍAS

FORMA DE LA TRAMA

Sin trama/ área rural

CARACTERIZACIÓN

Natural

6

3

6

TRAMO 2

Rivera cerca al cruce del Río Shullcas y Mantaro, Huancayo Junín

$1.50 \mathrm{Ha}$

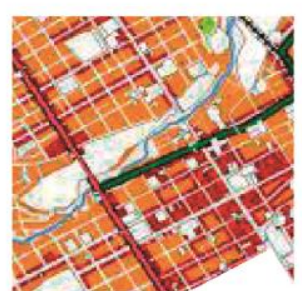

FORMA DE LA TRAMA

trama histórica área rural, ya que no hay ciudad CERCANÍA Se encuentra a $1 \mathrm{hmin}$ Solar y se toma un caminando/20 min en desvío hacia la margen carro partiendo de la izquierda del Río P.Constitución 4

FRENTES

Sus frentes son La calle La vía de acceso es la Real (principal e histórica Avenida Calmen Del de Huancayo), el Río Solar y se toma un Shullcas como frente desvío hacia la margen CARACTERIZACIÓN perpendicular a la Real. izquierda del Río Histórico CERCANÍA se encuenta a 13 min al Distrito de Cochas caminando/3mir en Chico carro

64

\section{FORMADE LA}

TRAMA

TRAM0 1 Rivera cerca al cruce del Río Shullcas y Mantaro, Huancayo Junín

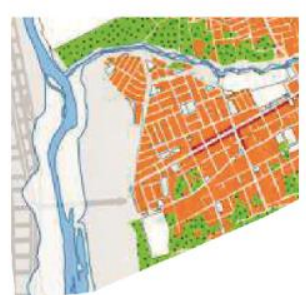

$2.8 \mathrm{Ha}$

tama de expansión

CARACTERIZACIÓN

Ambiental

6

FRENTES

Tiene frente a la ciudad al Río Shullcas y Río Mantaro, ya que se encuentra ubicado en la intersección de estos ríos.

CERCANÍA

se encuentra a $30 \mathrm{~min}$ caminando/10 min en carro

\section{LÁMINA 6.10} Shullcas

\section{CRITERIO 8}

Vías de acceso

VÍAS
Shullcas con dirección

\section{CRITERIO 9}

Percepción

VISUALES

área agrícola

CONTAMINACIÓN

Si hay presencia de contaminación de agua del río

6

VISUALES

Río Shullcas y el puente de la Calle Real CONTAMINACIÓN

contaminación sonora y vehicular en horas

punta

7

VÍAS Las vías de acceso son la Calle Breña y Daniel Alcides Carrión partiendo desde pla plaza constitución
VISUALES

Intersección de los ríos

Shullcas, Mantaro y Cunas

CONTAMINACIÓN

contaminación de

agua, borde y fajas marginales de los ríos

\section{CRITERIO 10}

Consideraciones ambientales

CLIMA

El clima en la zona nor-este de la ciudad es templado variable con temperatuas de $22^{\circ} \mathrm{CA}$ $-10^{\circ} \mathrm{C}$, ya que se encuentra a 3700
CLIMA de la ciudad es templado variable con temperatuas de $24^{\circ} \mathrm{C}$ A $-8^{\circ} \mathrm{C}$, ya que se encuentra a 3250 msnm

\section{CRITERIO 11} Infraestructura y servicio

Si posee un sistema de agua y desagüe cercano no cuenta con pavimento, y sist. de recolección de residuos.

3

Si posee un sistema de agua y desagüe, cuenta con pavimento, alumbrado y sist. de recolección residuos.

6

CLIMA

El clima al oeste de la ciudad es templado variable con temperatuas de $24^{\circ} \mathrm{C} \mathrm{A}-8^{\circ} \mathrm{C}$ presenta

una

humedad relativa por la cercanía a los ríos.
Si posee un sistema de agua y desagüe, cuenta con pavimento, alumbrado y sist. de recolección de residuos. 
ELECCIÓN DEL TERRENO

CAPÍTULO

6.3

FUENTE:

Plan de Desarrollo Urbano Huancayo 2015-2025/ Enciclopedia Departamental Junín

\section{CRITERIO 12}

Riesgos

TIPO DE SUELO

En la parte inferior grava

pobremente gradado y

en la superior grava bien

gradado

VULNERABLIIDAD

deslizamiento de tierra y caída

TIPO DE SUELO

CRITERIO 13

Características de las construcciones de

la zona

\section{ENTORNO INMEDIATO}

Las edificaciones más cercanas al terreno son

de área rural y material

noble

5

ENTORNO INMEDIATO

TRAMO 2

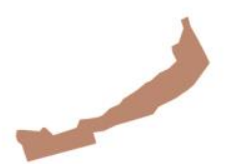

En la parte inferior grava Las edificaciones más pobremente gradado, en la cercanas al terreno en superior grava bien gradado y su mayoría son de en la parte media grava y limo ladrillo.

\section{VULNERABLIDAD}

deslizamiento de tierra y caída
ENTORNO INMEDIATO

TIPO DE SUELO En la parte inferior grava las edificaciones más pobremente gradado, en la cercanas al terreno en

TRAM0 1 en la parte media grava y limo ladrillo.

VULNERABILIDAD fajas marginales, solo se puede

intervenir con espacio público en la zona de riesgo muy alto superior grava bien gradado y su mayoría son de

Puntos de inundaciones en las

CRITERIO 14

Equipamiento próximo

No hay equipamiento cercano, ya que pertenece a una ciudad no consolidada

(1)

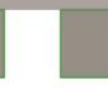

CRITERIO 15

Revaloración

Patrimonial agrícola y que este no se gran variedad de pierda con el tiempo. tubérculos , maíz y Agua como fuente de vegetales vida de I cuenca del río

Shullcas
Valorizar el patrimonio siembra y cultivo de una

\section{LÁMINA 6.11}

En la mayoría el equipamiento encontrado en esta zona esta ligado a la educación, comercio y puntos de interés más conocidos.
Valorización de la historia no hay presencia de de la ciudad (tejido vegetación a excepción urbano) y el patrimonio del área forestal natural del Río Shullcas

\section{CRITERIO 17}

Evaluación de Inversión
Poca probabilidad de afiliación de alguna empresa privada por su lejanía, etc.
Alta probabilidad de inversión de empresas privadas y públicas por la cercanía al equipamiento del centro de la ciudad. 


\subsection{Proyecto piloto tramo 1 (Paisaje urbano)}

Se desarrollará a partir de las 5 fases definidas en conjunto con el análisis de componentes de la ciudad, están determinadas por diez criterios (percepción, topografía y agua, clima, espacios libres e infraestructura ecológica, movilidad peatonal, vehicular, parámetros y zonificación, riesgos y contaminación), los cuales son la base para el desarrollo del ámbito de estudio, la caracterización del paisaje, el análisis visual, la valoración del paisaje, medidas y acciones.

\subsection{1 Ámbito de estudio}

El área de estudio está definida por la propuesta del tramo 1 del Parque Lineal Ribereño Shullcas y de las zonas próxima a este debido a la influencia directa de la intervención. El ámbito de estudio (Lámina 6.12) parte desde la vía evitamiento hasta el puente Daniel Alcides Carrión, aproximadamente 4 cuadras.

\subsubsection{Análisis de componentes del paisaje urbanos}

A continuación, se presentará las láminas del análisis de componentes del proyecto piloto llamado tramo 1 a escala barrial conformado por los criterios percepción, topografía y agua, clima, espacios libres e infraestructura ecológica, movilidad peatonal, vehicular, parámetros y zonificación, riesgos y contaminación. 


\section{FUENTE:}

Plan de Desarrollo Urbano Huancayo 2015-2025/ Enciclopedia Departamental Junin

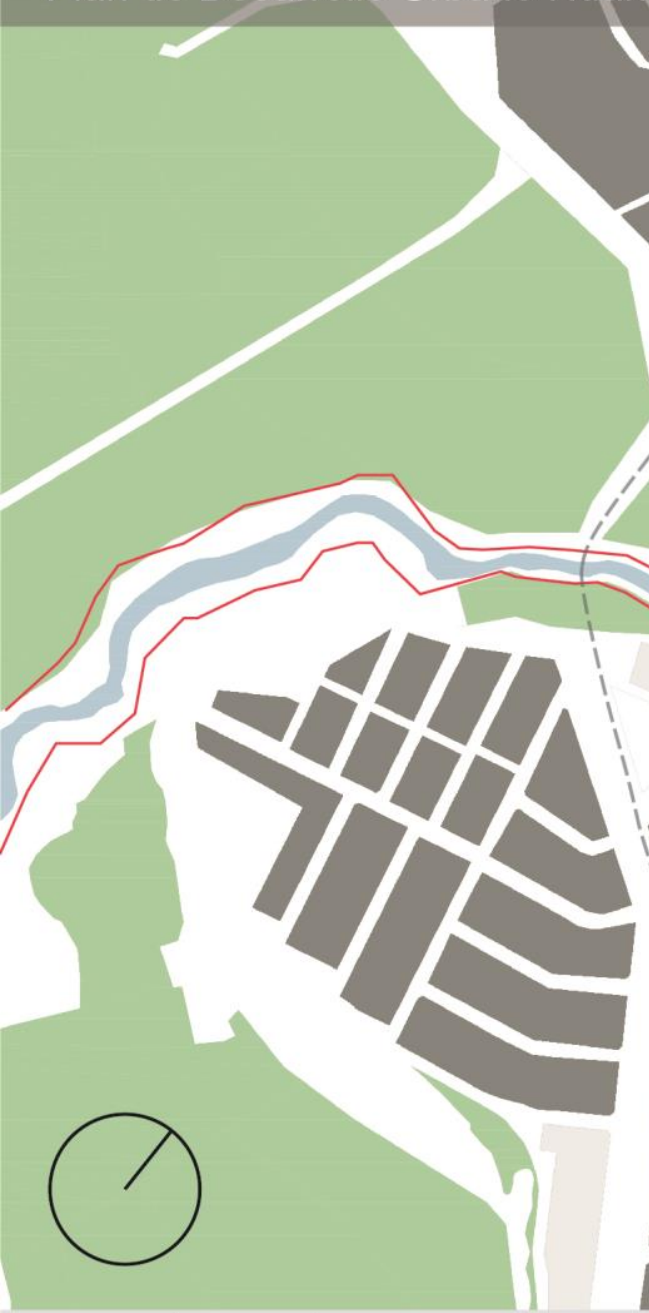

DEFINICIÓN DEL ÁMBITO DE ESTUDIO

El área de estudio está determinada por el tramo 1 de la propuesta 1 .Viviendas precarias asentadas en zonas del Parque Lineal Ribereño Shullcas. La escala de estudio contribuye de riesgo

al análisis puntual a nivel barrial, de las áreas próximas. Las edifica- $\quad 2$. Construcciones con usos no compatibles ciones del entorno inmediato se componen por los siguientes tipos a la zonificación

La margen izquierda del Río Shullcas pertenece al distrito de Huancayo, zona urbana consolidada con viviendas aledañas en su mayoría de dos a tres niveles; mientras la margen derecha pertenece al distrito de El Tambo, conformado por un área semiurbana de viviendas en su mayoría en proceso de consolidación y áreas de cultivo.
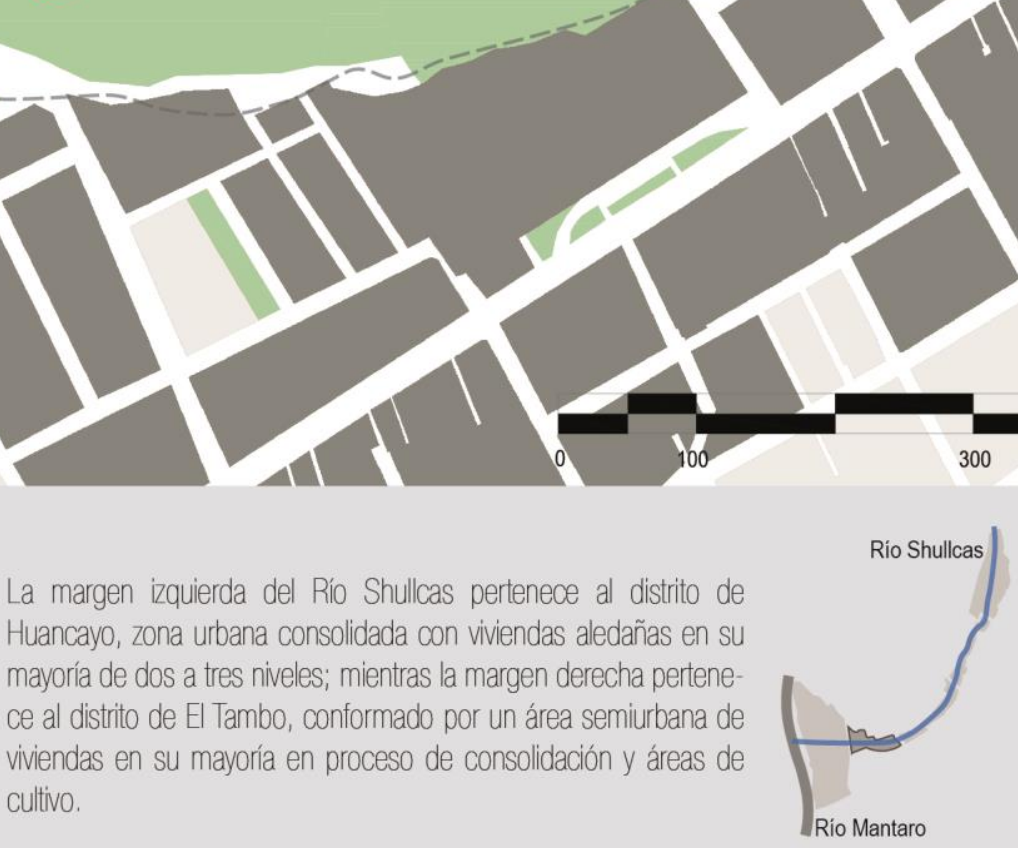

LEYENDA DEFINICIÓN DEL ÁMBITO

Area del ámbito de estudio Zona de intervendín Fajas marginales

ÁREAS DEL ÁMBITO Area ámbito de estudio : 130 ha Longitud del ribera en el ámbito de estudio : 


\section{FUENTE:}

Plan de Desarrollo Urbano Huancayo 2015-2025/ Enciclopedia Departamental Junín

LÁMINA 6.14

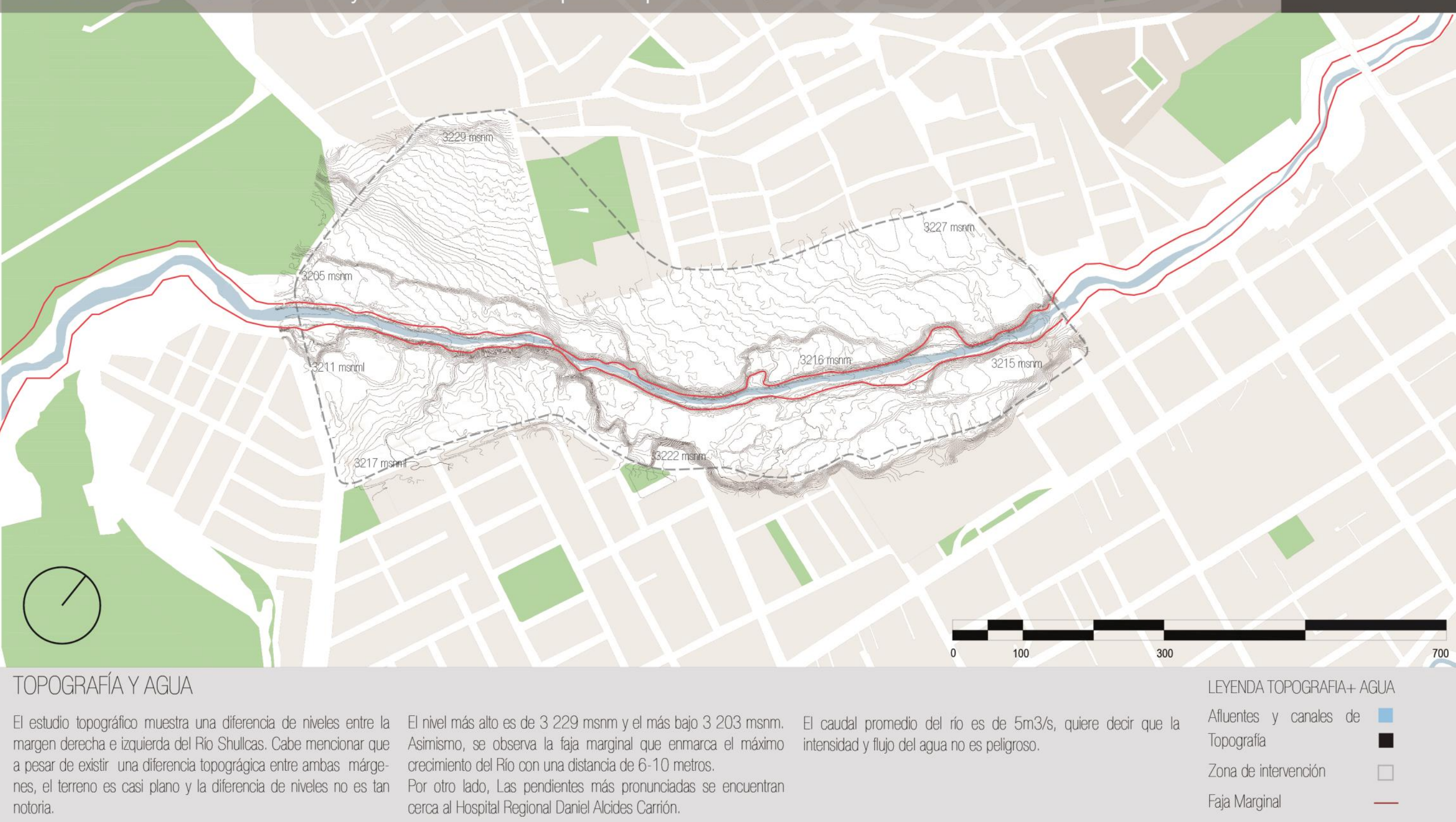




\section{ÁREA LIBRE E INFRAESTRUCTURA ECOLÓGICA}

FUENTE:

Plan de Desarrollo Urbano Huancayo 2015-2025/ Enciclopedia Departamental Junín

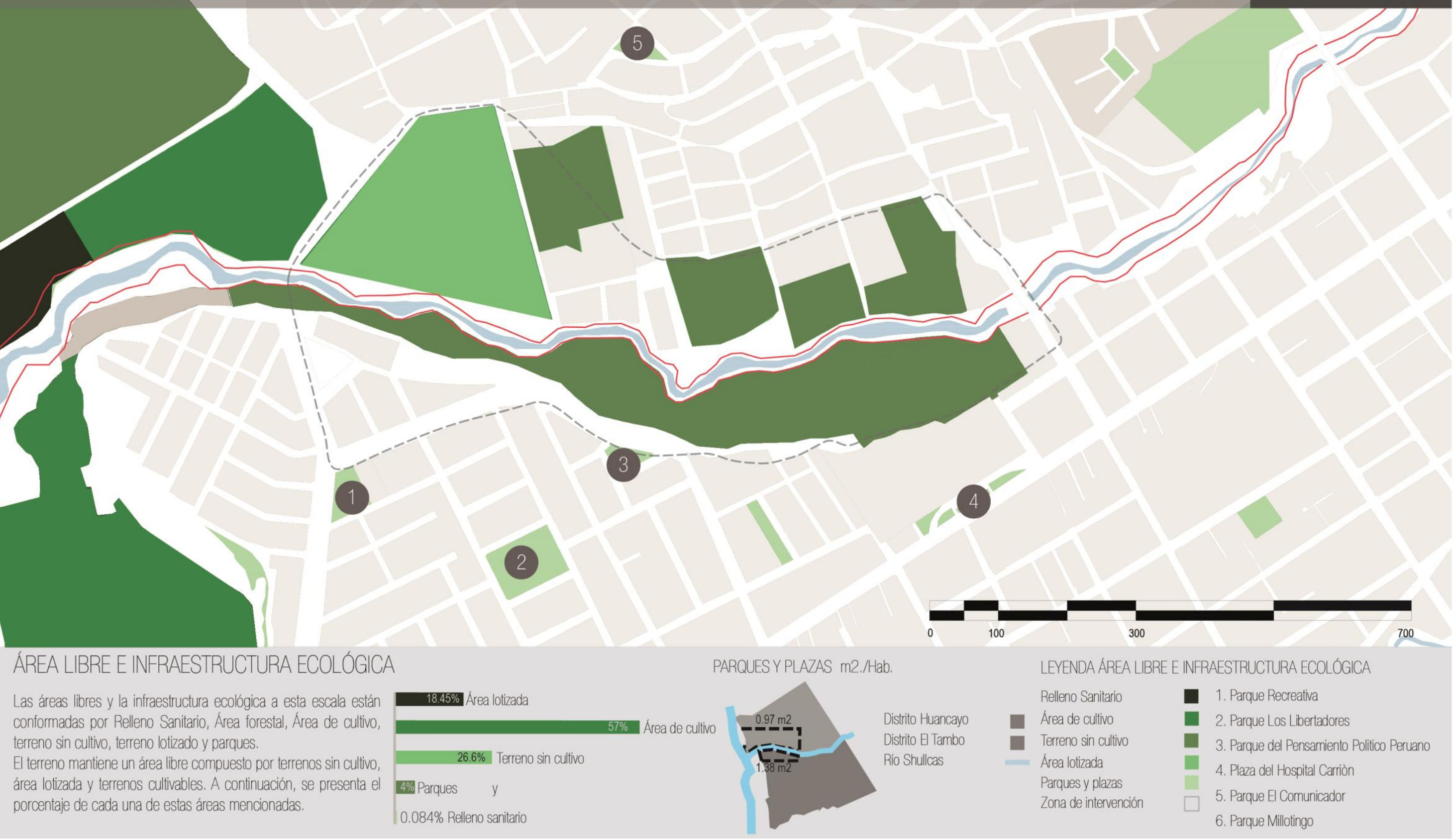




\section{FLUJO PEATONAL}

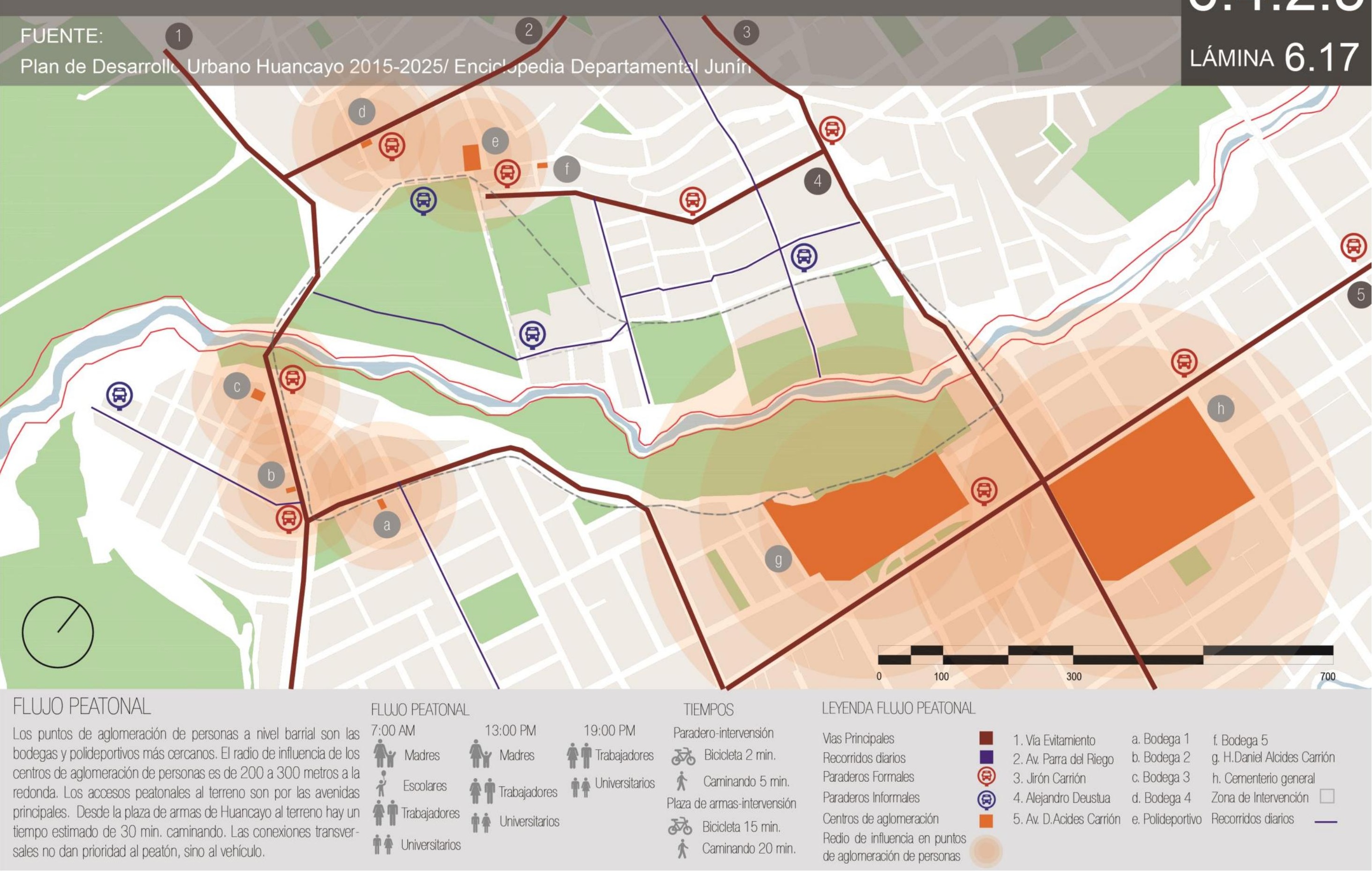

6.4 .2 .5 LÁMINA 6.17

SECCIÓN 


\section{FLUJO VEHICULAR}

\section{FUENTE:}

Plan de Desarrollo Urbano Huancayo 2015-2025/ Enciclópedia Departamental Junín

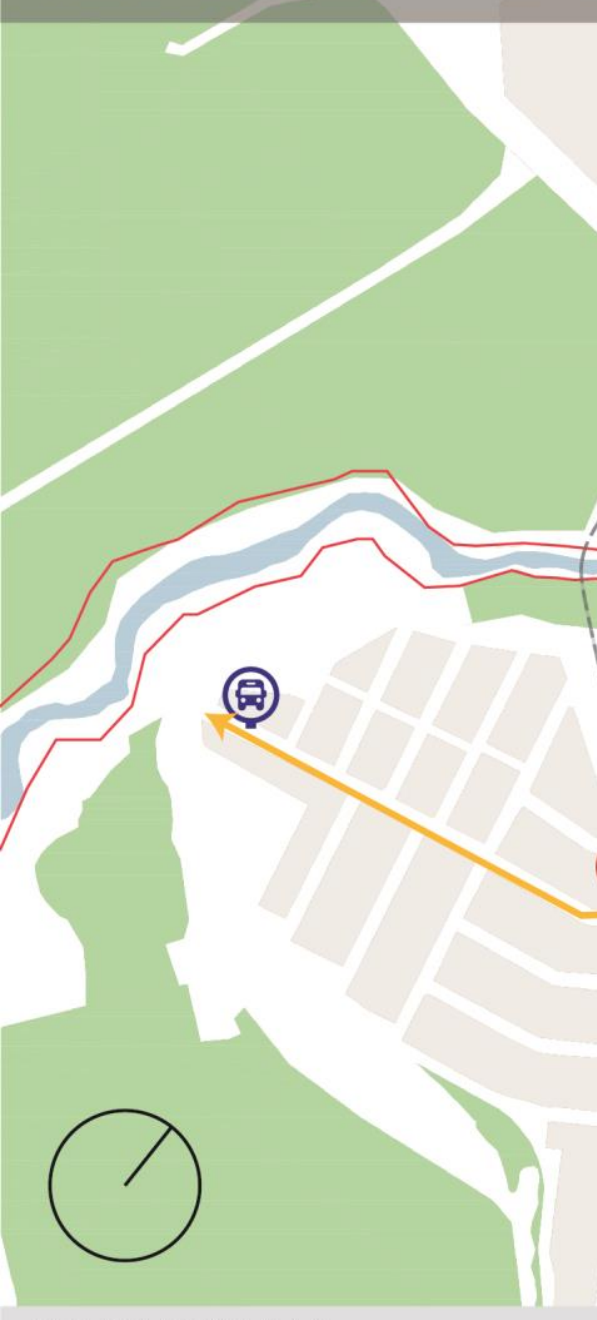

FLUJO VEHICULAR

Las lineas de transporte público tienen horario propio, por lo tanto, no es un transporte formal. De todos los tipos de automóviles, el

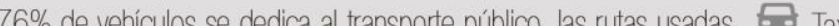
son por las vías principales de la ciudad. El terreno cuenta con 4 rutas de transporte público como conexión con el centro de la ciudad. El tiempo estimado en vehículo particular desde la plaza de armas es de 15-20 minutos.

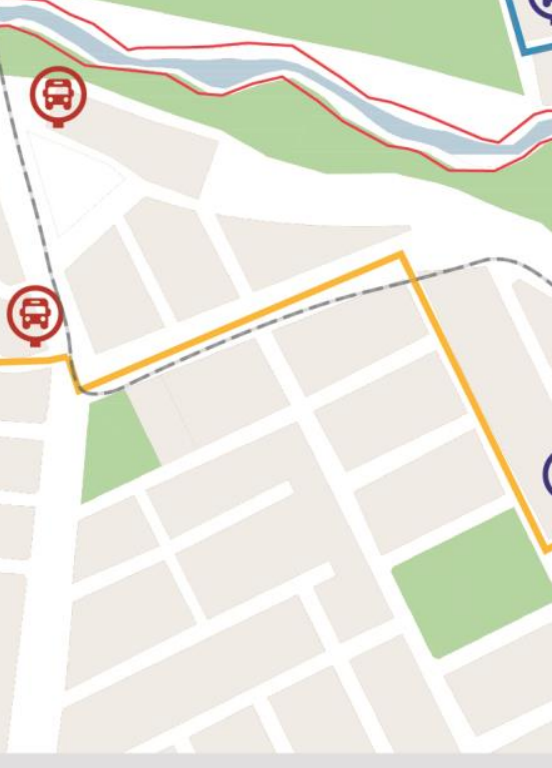

TIPOS DE TRANSPORTE

Privado $83 \%$ 뭉 Público $7 \%$ MODALIDAD DE VIAJE Colectivo 38\% Camioneta rural 38\%

(20)

\section{(a)}

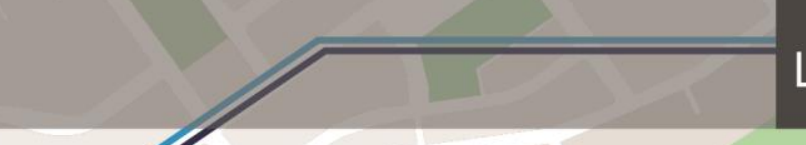

LÁMINA 6.18

(a)

PROPÓSITOS DE VIAJES

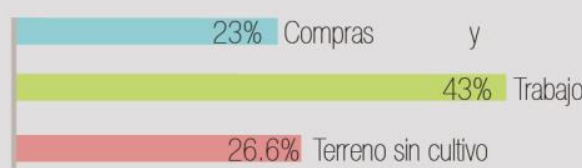

9\% Paseo

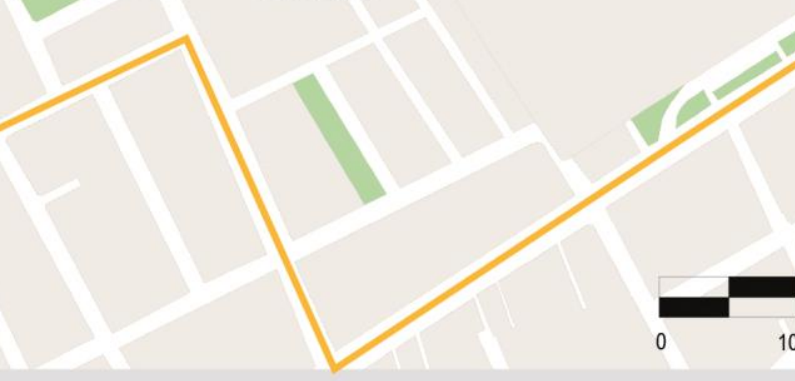

LEYENDA

Paraderos formales Paraderos informales Zona de intervención Transporte privado desde el centro de la ómnibus 13\% Vehículos menores 2\% Taxi $4 \%$

RUTAS DE TRANSPORTE PÚBLICO

(2) Ruta nro 15

(2) TR-0074 E.T. Pio Pata S.A. TC-15 Ruta nro 20 TR-0074 E.T. Pio Pata S.A. TC-20 Ruta nro 05

TR-0074 E.T. Pio Pata S.A. TCE-05 TR-0074 E.T. Pio Pata S.A. TCE-07 


\section{FUENTE:}

Plan de Desarrollo Urbano Huancayo 2015-2025/ Enciclopedia Departamental Junín

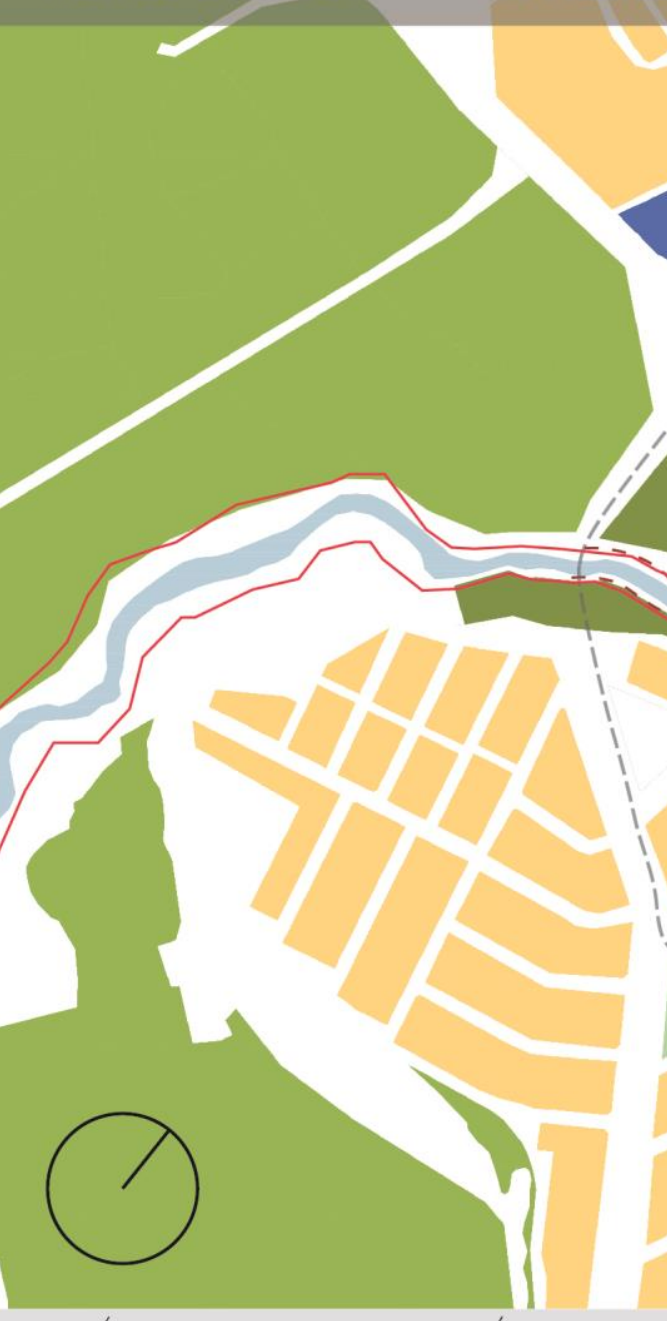

PARÁMETROS Y ZONFICACIÓN

El análisis de parámetros de zonificación establecida por la Municipalidad de Huancayo determina que la zona aledaña al río es de tipo parque zonal.

Parque zonal es la combinación de área verde y diversos tipos de servicios asignados al desarrollo de actividades recreativas que proporcionan a la ciudad un ambiente natural.
El parámetro de este uso establece que el cálculo de superficie del parque zonal es de $0.4 \mathrm{~m} 2$ por habitante con un área mínima de 5 Ha. Los parques zonales están orientados a poblaciones urbanas entre 100000 a 300000 habitantes Z. DE HAB. EN RIBERAS DE RIOS

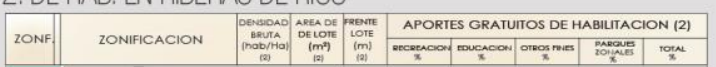

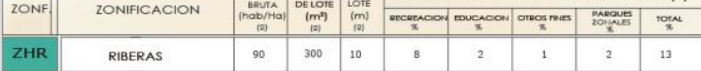

afrentes y canales de agua normativa indica que las alturas oscilan Zona de intervención entre 3 a 5 pisos con un coeficiente de Faja Marginal edificación 2.5 , de área libre de 30\% y LEYENDA DE ZONFICACIÓN establecimiento de 1 estacionamiento cada 10 personas.
Residencial densidad atta

Residencial densidad media Residencial densidad media
LÁMINA 6.20 


\section{FUENTE:}

Plan de Desarrollo Urbano Huancayo 2015-2025/ Enciclopedia Departamental Junín LÁMINA 6.21

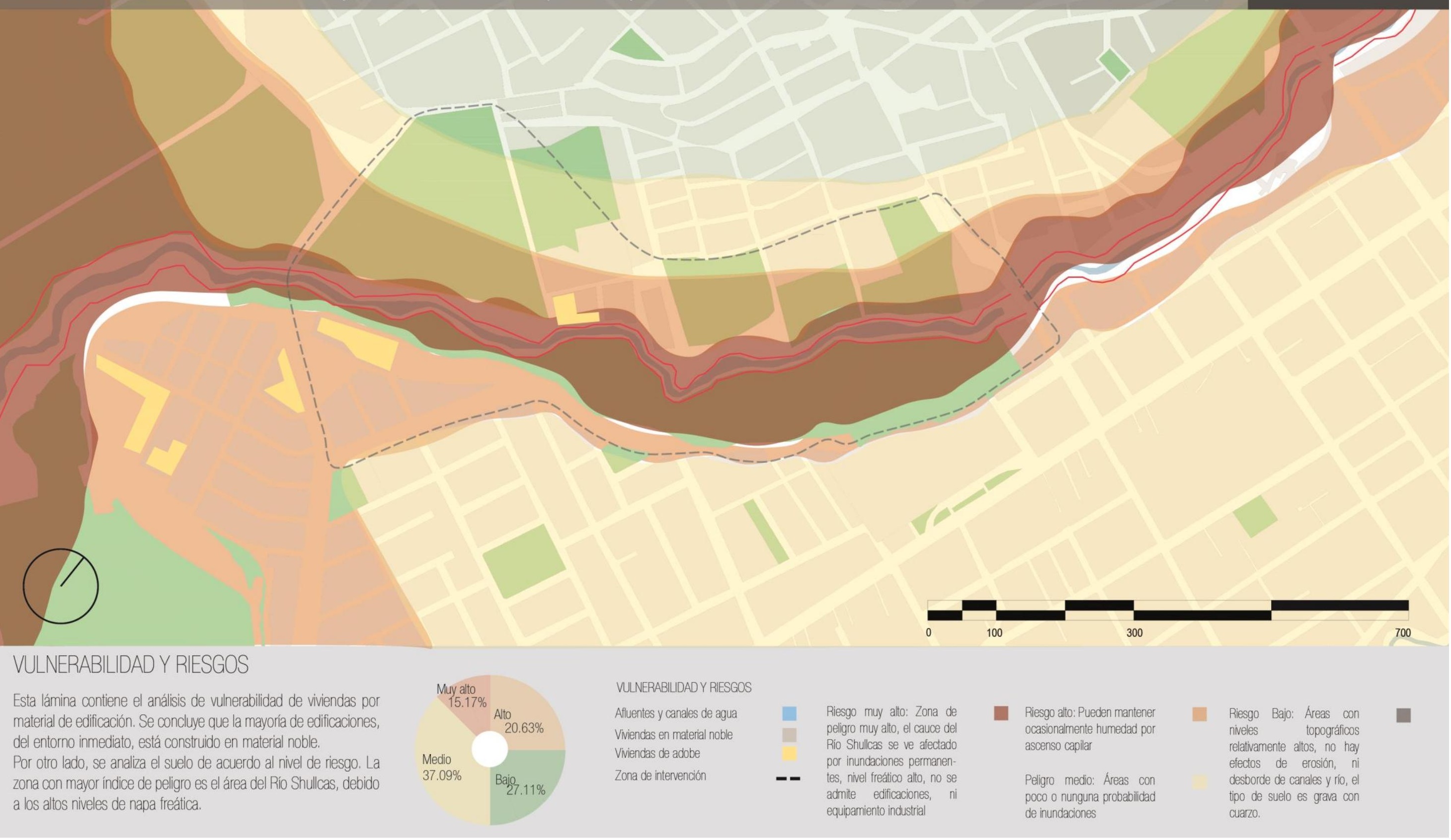




\subsubsection{Caracterización del paisaje}

Se determina el carácter del paisaje a la identificación de patrones en el territorio correspondiente al ámbito de estudio. En el tramo 1 se analiza la transición del borde del río y el medio urbano a escala barrial considerando los aspectos de evolución, organización, patrones, recursos paisajísticos y conflictos paisajísticos.

\section{Evolución}

Se realiza un análisis de las trasformaciones del paisaje en el tiempo. De manera que se determina como las viviendas han ido asentándose a lo largo del borde del Río Shullcas propiciando, en ese sector, la pérdida de suelo agrícola con la lotización y habilitación residencial en la ribera. El estudio, presenta los cambios de la trama urbana que se ha generado desde el 2011 hasta la actualidad.

\section{$\underline{\text { Organización }}$}

Se determina a partir del estudio de la topografía e hidrografía. Además de la identificación y análisis de la cobertura vegetal relacionada al sistema vegetal, y plantaciones humanas. En el caso del tramo 1, la topografía (Lámina 6.14) presenta la sección del Río Shullcas niveles distintos en ambos márgenes, las cuales oscilan entre 3205 y3227 de altitud. La cobertura vegetal se compone por algunas áreas agrícolas y la existencia de área verde de parques y ejes de vías.

\section{$\underline{\text { Unidades (Patrones) }}$}

Surge de la identificación de patrones en el tramo 1 que determinan la configuración del territorio para definir la caracterización del paisaje. Se puede determinar tres tipos de unidades de paisaje (Lámina 6.23) conformados por el medio urbano, suelo agrícola y la sección de la ribera.

\section{$\underline{\text { Recurso paisajístico }}$}

Se determina mediante la identificación de elementos con valor representativo. El tramo 1 ámbito presenta el recurso de interés ambiental por medio de las parcelas y tipo de vegetación, además del valor cultural que en ambos casos se encuentran en estado del tipo frágil debido a actividades incompatibles con el medio y de presentar riesgo ambiental a causa de la contaminación del río. 


\section{$\underline{\text { Conflictos paisajísticos }}$}

Son los aspectos que no contribuyen o generan cambios en el carácter del que implica la degradación o eliminación de los componentes del territorio. En el ámbito de estudio, se encuentran residuos sólidos que degradan el medio; presencia de elementos con poca relación al paisaje (invasión de viviendas en el borde de la ribera), la implantación infraestructura (Industrial) incompatibles con el uso, la ubicación (Áreas recreativas) sin criterio de ordenamiento y articulación y finalmente el abandono de zonas agrícolas para la lotización y construcción en ellas. En esta sección existen algunas parcelas que se encuentran amenazadas para la venta y construcción. 


\section{$\underline{\text { Recurso paisajístico }}$}

Se determina mediante la identificación de elementos con valor representativo. El ámbito presenta el recurso de interés ambiental y cultural en estado frágil debido a actividades incompatibles con el medio, además de encontrarse en riesgo ambiental a causa de la contaminación del río.

\section{Conflictos paisajísticos}

Son los aspectos que no contribuyen o generan cambios en el carácter del que implica la degradación o eliminación de los componentes del territorio. En el ámbito de estudio, se encuentran residuos sólidos que degradan el medio; presencia de elementos con poca relación al paisaje (invasión de viviendas en el borde de la ribera), la implantación infraestructura (Industrial) incompatibles con el uso, la ubicación (Áreas recreativas) sin criterio de ordenamiento y articulación y finalmente el abandono de zonas agrícolas para la lotización y construcción en ellas. En esta sección existen algunas parcelas que se encuentran amenazadas para la venta y construcción.

\subsubsection{Valoración del paisaje}

La valoración del pasaje en la presente tesis está conformada por la determinación del valor de calidad paisajística y de la visibilidad del paisaje además de las consideraciones de los conflictos del territorio.

\section{$\underline{\text { Calidad paisajista }}$}

- Interés de conservación: El tramo 1 como parte del plan maestro se considera como recurso paisajístico de interés de tipo natural, sin embargo, se encuentra en estado de degradación a lo largo de su recorrido y en mayor grado de contaminación en el cruce con el Río Mantaro. Por ello se requiere de la preservación del recurso y del tratamiento del espacio entre el recurso natural y la ciudad.

- La representatividad: Las condiciones actuales del tramo 1 son lamentables, ha perdido el carácter del lugar debido a la parcelación de áreas agrícolas en los bordes, este anteriormente considerado como espacio de mitigación de 
transición de medio urbano y el río. Por otra parte, la población, no percibe a este recurso como un elemento representativo de la zona.

- La singularidad: En la ribera del tramo 1, las parcelas deberían considerarse como un elemento que requiere de atención especial como estrategia de intervención. Sin embargo, su condición y peligro de desaparición no son favorables

- La integridad: El área no se encuentra integrada, se aprecia en la fractura urbana entre el medio urbano y el recurso de la Ribera del Shullcas.

- La función: No existe elemento claro que estructure el paisaje, sin embargo, la existencia de algunas parcelas podría considerarse como espacio público conector entre el río y la ciudad. Actualmente, parte de estas áreas se encuentran $\sin$ uso y $\sin$ cuidado

- Calidad de escena. Debido a las condiciones de la ribera y el río no se aprecia visuales representativas, sin embargo, con el tratamiento de los bordes se pude establecer visuales con interés estético.

\section{Visibilidad del paisaje}

A partir del análisis visual se observa (Lámina 6.21) el estado de degradación causado por la contaminación y la pérdida del carácter de suelo agrícola determinándola como zona frágil.

\section{Justificación del valor del paisaje}

De acuerdo a los criterios analizados anteriormente se identifica el grado de calidad paisajística; el tramo 1 como materia de intervención presenta el valor de muy bajo, el cual que corresponde a una estructura de paisaje dañado por la distorsión de usos que se desarrolla., no existe aspectos que preserven el interés de conservación del suelo agrícola y la valoración social.

\section{Propósito de actuación}

Por medio de la determinación del valor paisajístico, se define los ejes estratégicos de acción De este modo el plan piloto del tramo 1 aspira a la modificación del paisaje y gestión del mismo, ya que el sector como espacio agrícola ha perdido el carácter y la valoración social. Con ello se propone establecer una estructura y configuración del 
paisaje definido que contribuya y corresponda a las condiciones y las necesidades del medio urbano.

\subsubsection{Medidas y acciones}

Se determina las directrices que garantizan el desarrollo del propósito, las cuales se establecen por tres formulaciones que corresponden a la infraestructura verde,

\section{$\underline{\text { La infraestructura verde }}$}

Se define a partir de la integración y continuidad de espacios libres, recursos ambientales, culturales, visuales, sociales y conexiones ecológicas funcionales que las integre entre sí a partir de ejes y espacios verdes. De este modo los siguientes aspectos para la intervención.

- Proteger los paisajes valiosos: Preservar los espacios de interés ambiental y social que conforma el borde de la ribera del tramo 1 como espacio público que contribuya a la conservación y estado del río)

- Preservar la conexión entre unidades: Establecer el tramo 1 como el espacio conector inmediato entre las unidades del medio urbano y la ribera del Shullcas.

- Accesibilidad: Por medio de la creación de una gran variedad de espacios recreativos en la infraestructura verde para el disfrute y uso del espacio como la creación de plazas, losas deportivas, áreas de juego, jardín botánico y pozas naturales.

- Creación de áreas de transición entre usos y actividades: El tratamiento de las áreas de transición entre unidades de paisaje en relación al tramo 1 que parten de la creación de espacios intermedios que atenúan los distintos usos y actividades formado por el medio de la ribera y la ciudad.

De este modo, la infraestructura verde se define por los espacios de valor natural y patrimonial conformado por los bordes del tramo 1 y el río Shullcas, la consideración de áreas vulnerables a inundación que deben quedar libres de urbanización y, finalmente, la red de corredores verdes y funcionales que conectan todos los elementos entre sí

\section{Definición de programas de paisaje}

Está definido por objetivos que aseguren la preservación y la puesta en valor del paisaje concerniente a la valoración natural y el estado de degradación del tramo 1 de la ribera 
del Shullcas. De manera que los programas a proponer se establecen de acuerdo a los siguientes criterios considerados pertinentes para la presente tesis:

- Mejora de un espacio sensible: La propuesta se basa en la intervención de los bordes de la ribera a partir de estrategias de activación del paisaje como la creación de espacio público que propicia actividades de interacción con el paisaje, recreación, cultural En relación a la intervención de los bordes de la ribera considerando estrategias de potencializar el paisaje por medio de actividades.

- Consideración de uso público: Se establece mediante la implementación de accesos estratégicos al paisaje, creación de caminos que generen diferentes situaciones al usuario como contemplación y disfrute.

- Conciencia de la población: Se establece por medio de la creación de equipamiento cultural ambiental (CIA) que busca generar espacios de encuentro que propicien la trasmisión de conocimiento acerca del paisaje de la ribera y los valores del entorno.

\subsection{Conclusiones parciales}

El estudio contextual del lugar parte del análisis del paisaje local y urbano pertinente para la propuesta integral del Parque Lineal Ribereño Shullcas y el plan piloto del tramo 1. Con ello, el estudio ha contribuido a la identificación del carácter del paisaje con la intención de integrar la Ribera del Shullcas con el entorno urbano desde un ámbito macro y particular.

Las características del paisaje de la ciudad de Huancayo establecido por los aspectos de evolución, organización, unidades, recursos y conflictos paisajísticos son reflejo de una trama urbana discontinua ya que presenta consolidación en el centro de la ciudad a diferencia de los extremos que se encuentran en etapa de expansión informal.

Asimismo, el ámbito de estudio presenta pendientes pronunciadas en la zona centro a diferencia de los extremos. En relación al espacio abierto e infraestructura ecológica el $70.5 \%$ es área rural agrícola sin embargo el porcentaje del espacio público es de $0.2 \%$ estableciendo un déficit de áreas recreativas públicas por el ciudadano 
Por otro lado, la movilidad peatonal y vehicular presentan un mayor flujo en tres avenidas transversales al río que se encuentran en el centro de la ciudad, esto se debe a que gran parte de los puntos de interés se encuentran focalizados en el centro histórico de Huancayo. Del mismo modo, las conexiones paralelas al río no son continuas debido a una aglomeración urbana. Además de la falta de conexiones del centro de la ciudad y el centro poblado de Huamancaca ubicado al frente del Río Mantaro.

Huancayo posee un carácter comercial debido a que más del $50 \%$ de equipamiento está destinado al uso comercial, seguido por la educación con un 32.8\%. La ubicación del comercio y de educación básica se encuentra en el centro de la ciudad, mientras que la educación superior se ubica en la zona norte margen izquierda del río. El equipamiento ubicado en la ribera es en su mayoría no compatible con el uso de suelo establecido.

El ámbito de estudio está conformado por zonas de peligro del tipo muy alto, alto y medio. Esta clasificación se da a partir de factores geológicos, hidrográficos y de contaminación, siendo la desembocadura del Río Shullcas la zona con mayor peligro. Por otro lado, la ribera contiene viviendas emplazadas en zonas de riego muy alto que ocasionan fragmentación entre el patrimonio natural y la ciudad.

El análisis de ambos casos a través de las fases mencionada anteriormente (evolución, organización, definición de patrones paisajísticos, recursos paisajísticos y conflictos urbanos) ha permitido el entendimiento del paisaje y así determinar la caracterización del paisaje y evaluar el grado de calidad paisajística en la que se encuentra la ribera del Shullcas estableciéndose en el ámbito de estudio a escala local con 5 zonas de carácter conformados por natural, educativo-residencia, histórico, ambiental y ecológico.

De este modo, teniendo en cuenta las consideraciones de la ribera del Shullcas se puede establecer el tipo de acción a intervención, el cual en este caso se considera el de "modificar" el paisaje que contempla el cambio del aspecto físico del territorio para establecer una estructura y configuración clara de la ribera y se aprecie un paisaje integral. Con ello, se busca que la ribera, suelo agrícola y medio urbano por medio del plan maestro Parque Lineal Ribereño Shullcas se plantee como una secuencia de intervenciones a largo plazo para lograr una conectividad ambiental transversal por medio del espacio público. Finalmente, el Plan Piloto tramo 1 se entiende como un proyecto que busca desarrollarse de manera óptima por factores de acceso, percepción, infraestructura, 
servicio, consideraciones ambientales, revaloración patrimonial, equipamiento próximo, riesgos, vegetación, ubicación y gestión para generar una reacción inmediata de la ciudad.

Para la elección del tramo a intervenir se tuvo en cuenta los criterios mencionados y como resultado de análisis técnico, el tramo se caracteriza como un sector en óptimas condiciones de ser intervenido y transformado como una zona de carácter ambiental.

Con la misma lógica de análisis del Parque Lineal Ribereño Shullcas, el ámbito del estudio del tramo 1 presenta características de paisaje a nivel barrial delimitado transversamente por la vía Evitamiento y Puente Alcides Carrión. La ribera del río contiene viviendas precarias asentadas en zona de riego además de usos no compatibles a la zonificación. En la zona, la topografía presenta diferencia de niveles en ambas márgenes siendo la más pronunciada la margen izquierda.

Otro factor a considerar es el clima, el cual mantiene una temperatura de 10 a 25 grados con vientos predominantes en dirección suroeste y noroeste. La infraestructura ecológica y área libre con mayor presencia son las de cultivo con un 57\% y con relación al espacio público $4 \%$ del total.

Las vías de mayor tránsito son ejes transversales al río conformado por el Puente Alcides Carrión, asimismo, el transporte privado de tipo taxi colectivo es el de uso predomínate por los habitantes generando la existencia de paraderos informales.

Los parámetros urbanos de la ciudad de Huancayo clasifican al ámbito de estudio como parque zonal y el uso actual predomínate en el entorno inmediato es residencial mientras que en la zona de intervención terreno sin cultivo.

La ribera del Río Shullcas presenta altos niveles de napa freática, así como una alta contaminación de agua y suelo causado por el alcantarillado y la presencia de residuos sólidos

Finalmente, la intervención del tramo 1 requiere de la modificación del paisaje para lograr una transición del medio urbano, del área libre y del área de protección ecológica. 


\section{CAPÍTULO VII: CONCLUSIONES FINALES}

El crecimiento urbano de Huancayo en las últimas décadas ha generado la formación de un nuevo eje ordenador territorial en la longitudinalidad del Río Shullcas. Sin embargo, este no presenta una lógica territorial de expansión ni de ordenamiento, en donde la ribera sea concebida como un espacio a intervenir por su rol urbano paisajístico, sino que más bien este es percibido como una barrera urbana que fractura la ciudad y solo cumple el rol como abastecedor de agua para la población

Asimismo, la lógica de desarrollo de la población asociada al tránsito y cambio como modernidad, contempla el futuro sin considerar el carácter del territorio. Con ello, la ciudad no tiene un sentido de identidad en relación al entorno, el cual es claramente notable con el desinterés de preservar elementos propios del medio físico tanto natural como cultural.

Por otro lado, los bordes del Río Shullcas presenta problemas relacionados con el asentamiento de viviendas informales en las zonas de vulnerabilidad alta; la presencia de descargas de aguas residuales y contaminación de residuos sólidos en las fajas del río. Además de problemas urbanos relacionados a la fragmentación urbana; falta de espacio público y equipamiento cultural, las cuales podrían compensarse con el tratamiento e intervención de la ribera del Shullcas.

Como se mencionó anteriormente la existencia de problemas territoriales como desarticulación general del paisaje, problemas urbanos y la degradación de la ribera propician la intervención de los bordes del Río Shullcas como espacio público que contemple espacios abiertos, incorporación de equipamiento cultural, deportivo y recreativo con el propósito de integrar el paisaje, mejorar las condiciones de la ciudad y valorar el río como elemento natural en el medio urbano

De este modo la presente tesis busca establecer la propuesta por medio del sustento de objetivos y estrategias proyectuales del desarrollo teórico de los términos de paisaje, espacio público, diseño urbano, bordes e interpretación. 
Los aportes con respecto al paisaje definido por Maderuelo y Garrett sostienen la idea como el reflejo físico de la idiosincrasia social compuesto por elementos urbanos y naturales, resultado de múltiples transformaciones por la acción del hombre y de la naturaleza. Al igual, la ciudad de Huancayo esta constituido por construcciones, vías, plazas, ríos, canales, vegetación y otros, sin embargo, esta no se concibe como una imagen integral del territorio a razón de la composición aislada de los elementos mencionados entre sí, esto puntualmente visible con la relación de la ciudad, el río y ribera.

A pesar de que el que el río y sus bordes poseen el potencial para ser un espacio de integración son áreas degradadas y aisladas que no propician una interacción adecuada con la población. Con ello, la acotación de Maderuelo sobre la contemplación del paisaje urbano, como la imagen perceptual que se concibe de este, se da por medio de la configuración de escenarios urbanos. Así en el contexto de la ribera del Shullcas es un espacio de situaciones y de dinámicas urbanas de baja calidad por el estado de degradación, de este modo la contemplación, admiración o valoración de este medio es nulo. Por ello, la intervención por medio de la propuesta del Parque Lineal Ribereño Shullcas busca configurar esta área como medio conector, integrador del paisaje que propicie situaciones urbanas de contemplación.

En relación con los aportes de Garrett Eckbo sobre la integración del paisaje proporcionan estrategias que corresponden al equilibrio en el territorio, en el caso de la tesis, en dos tipos de escala. El primero, entre el medio urbano y rural, la desproporción se da a causa de la expansión urbana que genera bordes difusos y proporciona la degradación de las zonas rurales y perdida de suelo agrícola; y el segundo, entre los espacios libres (parque, plazas) y o elementos naturales (Río Shullcas, canales, flora, fauna) con respecto a lo edificado en el paisaje urbano. Esto claramente notorio en el porcentaje por debajo del estándar del área total existente de parques y áreas recreativas en la ciudad, además de la falta de un espacio recreativo a escala metropolitana al alcance de todos que considere la integración de elementos naturales en ella.

Asimismo, Eckbo menciona que el equilibrio se establece por medio del estudio del paisaje para poder organizar, manejar las unidades que lo componen y crear una imagen integral de este. Con ello, la intervención parte del entendimiento del paisaje integral de Huancayo, poder definir el medio urbano y rural de manera que la expansión 
de la ciudad no degrade o elimine suelo agrícola, además de incorporar elementos naturales en la urbe para la integración del paisaje urbano.

Por otra parte, Eckbo también destaca la necesidad de potencializar el carácter del lugar y generar un vínculo social con el territorio. Por ello, la propuesta del Parque Lineal Ribereño Shullcas y el Centro de Interpretación del Agua se define de manera coherencia con el lugar prevaleciendo este enfoque y reforzando, así, la percepción de paisaje a partir de la construcción social establecida.

Desde otro punto, la idea de espacio público a partir de las teorías de Jordi Borja y Jan Gehl, permiten contemplar la propuesta del parque ribereño como espacio colectivo de impacto en el área metropolitana y sectorial de la ciudad, en donde se busca promover equidad social.

En relación a la contribución de Frederick Law Olmsted en la lógica del espacio público, esta debería partir de un sistema de parques, equipamientos y corredores verdes que brinden pluralidad, diversidad de usos y estructura pública para beneficio de los residentes de la ciudad. De modo, la propuesta imparte una red de espacios públicos que articula la ciudad y confluye en la ribera del Shullcas como espacio jerárquico.

Con respecto a la teoría del diseño urbano se establece, en la propuesta, por medio de la consideración de la diversidad urbana que implica la incorporación de usos primarios, puntos de concentración, hitos principales y sistemas de transporte integrado. Así, la intervención no solo sea la creación de un espacio verde, sino sea el diseño de un espacio público que con los elementos propuestos garanticen el uso constante, propicie seguridad y beneficios para la población de Huancayo.

La base teórica de bordes, importante por la ubicación de la propuesta en la ribera del Shullcas como borde natural, proporciona el entendimiento de la singularidad e identidad que proporciona este elemento a la ciudad. Además de la posibilidad funcional de la ribera de unificar y establecer vínculos entre el entorno existente y la propuesta. Con ello, la intervención no trata de eliminar los bordes o delimitar la ciudad, sino de articular este espacio con el parque lineal potencializando la ribera como espacio integrador que conecte y articule la ciudad.

Por otro parte, establecer una propuesta integral, conlleva la necesidad de concientizar a la población sobre el cuidado de los elementos naturales de la ciudad, es 
decir el río, la flora, fauna entre otros. De este modo, el parque y el Centro de Interpretación del Agua buscan por medio de herramientas de interpretación propiciar un vínculo de identidad y valoración con estos elementos.

Con ello, la interpretación asiste a la propuesta como proceso de comunicación a partir de la experiencia entre el usuario y el recurso con el fin de posibilitar reflexión, visión y conservación de lo interpretado. Por ello, la intervención se define por medio del diseño paisajístico generando sentido de experiencia con la interacción directa entre la población huancaína y el paisaje de la Ribera del Shullcas a fin de propiciar reflexión y conservación del medio y el río.

Asimismo, está disciplina además de contribuir a la justificación de para que se interpreta, contribuye al estudio del recurso, al cálculo de usuarios y a la selección de actividades a establecer, ya que en todo proceso de interpretación se requiere del entendimiento de lo interpretado, es decir, el estudio del paisaje de la ribera, la noción del tipo usuario quien va dirigido la interpretación ,definido en este caso por la población de Huancayo; y por último, la selección del tipo de programa de actividades a configurar en la propuesta los cuales conecten con la población y propicien conciencia sobre el cuidado y valoración de la ribera y el río

De este modo, el motivo de interpretación que responde al parque ribereño se establece al considerar a la ribera Shullcas como recurso paisajístico de interés natural el cual se encuentra en estado de degradación. Del mismo modo, el desarrollo del tramo 1 se genera por medio de la de pérdida de área agrícola en el casco urbano, además de ser el sector más crítico de contaminación de la ribera y por último, la interpretación del agua se argumenta con el Centro de Interpretación del agua el cual busca recuperar el valor del recurso del Río Shullcas actualmente contaminado.

Con el entendimiento de cada una de las teorías mencionadas en relación al paisaje, espacio público, diseño urbano, bordes e interpretación, estos han servido como base y sustento en la elaboración de estrategias para la propuesta integral del Parque Lineal Ribereño Shullcas y el Centro de interpretación del agua.

Asimismo, la consideración de la normativa es indispensable para la ejecución de la propuesta. Por lo que se ha considerado estándares o metodologías de intervención para el caso del paisaje elaborado por el ayuntamiento de ayuntamiento de Valenciana 
que permiten establecer estrategias de ordenación del territorio y protección del paisaje, las cuales se aplican en el estudio del paisaje. Asimismo, la contemplación de la metodología de diseño urbano asistido por el Ministerio de vivienda y urbanismo de Chile nos proporciona bases para el ordenamiento de espacios públicos para brindar al ciudadano espacios de calidad, los cuales el radio de acción, relevante para la tesis, está relacionada a la movilidad, al diseño urbano a escala humana y fomento de cultura para la aplicación de estas en la configuración de objetivos y del diseño.

El manejo de la normativa y estudio de instituciones afines permite entender los alcances de los reglamentos implicados en la intervención del Parque ribereño como soporte urbano definido como espacio público por estar conformado por el Río Shullcas y creación de parques y plazas. La infraestructura urbana ,comprende la intervención del parque lineal a través de la actuación de las redes de alcantarillado, actualmente expuestas al borde de río; asimismo, la configuración del equipamiento urbano, está conformado por la propuesta del Centro de Interpretación de Agua que de acuerdo a la ley se define como equipamiento para la conservación, además de considerarse por la necesidad de este tipo de servicios en la ciudad razón de la baja dotación de este; y, finalmente, el paisaje urbano, el cual determina la preservación del paisaje natural ante cualquier desarrollo urbano que afecte o rompa con la armonía integral del paisaje, de este modo la propuesta busca integrar ambos medios urbano y rural como la integración del paisaje territorial de Huancayo.

Con lo que respecta al estudio de los casos referenciales de intervención en bordes de ríos y de centros de interpretación, permite el planteamiento de estrategias claves que solucionen conflictos encontrados en la ciudad, además de mejoras en la valoración por parte de la población con su entorno y recurso natural con el fin de establecer una solución integral con la propuesta del plan maestro a lo largo del Río Shullcas, el desarrollo del tramo 1 y la propuesta del Centro de Interpretación del Agua.

Con ello, la realización de un plan maestro de borde de río contempla la ejecución de múltiples proyectos a desarrollar en corto, mediano y largo plazo. Así, el Parque Lineal Ribereño Shullcas concebido como plan maestro de borde de río contempla objetivos relacionados a activar el espacio con la implementación de equipamientos, espacios públicos de temáticas relacionadas a la caracterización del lugar para establecer flujo constante durante las distintas horas del día convirtiendo a este en un espacio seguro; 
Asimismo, el objetivo de conectar relacionadas estrategias por medio de puentes y pasarelas solucionan problemas de ruptura de trama urbana, Del mismo modo, la finalidad de integrar se establece con la creación de ejes ecológicos transversales y longitudinales al Río Shullcas para generar un sistema integral de espacios de interés cultural, social, recreativos y ambientales con la ribera de Shullcas y por último el objetivo de recuperar alude a la incorporación de vegetación nativa que al ser elementos únicos de la zona propician el sentido de identidad con la población

El estudio contextual del lugar es la base para poder determinar la aplicación de las teorías mencionadas, los estudios de casos analizados y las metodologías de intervención sobre el territorio de Huancayo. Así cada estudio mencionado se complementa entre sí para el desarrollo de estrategias y directrices urbanísticas y del diseño de la propuesta integral del Parque y el tramo 1 de manera que contribuya al carácter del paisaje integrando la Ribera del Shullcas con el paisaje de este modo se establece el análisis del paisaje en dos escalas correspondiendo cada uno al paisaje local y paisaje urbano respectivamente con las propuestas indicadas.

El análisis de ambos permite el entendimiento del paisaje por medio de la evolución, organización, definición de patrones, recursos paisajísticos y conflictos urbanos para determinar los rasgos y caracterización del paisaje y evaluar el grado de calidad paisajística en la que se encuentra y justificar el tipo de intervención que se requiere. Con las consideraciones de la ribera del Shullcas, se requiere la intervención del Parque lineal ribereño del tipo de modificación del paisaje que considera la modificación del aspecto físico del territorio para establecer una estructura y configuración clara de la ribera y se aprecie un paisaje integral entre ribera, suelo agrícola y medio urbano al igual que en la intervención del tramo 1 se requiere del tipo de modificación del paisaje en donde la configuración de la sección este acorde con la transición del medio urbano y el área de protección ecológica venerable a inundaciones.

De ese modo, cada uno de los aportes señalados en los distintos marcos son herramientas para establecer y aplicar el desarrollo de objetivos, estrategias urbanísticas y diseño proyectual de la propuesta integral del Parque Lineal Riberateño Shullcas y del tramo 1. Además de acoplar teorías interpretativas en el diseño del paisaje para generar sentido de identidad con el huancaíno y proponer el Centro de Interpretación del Agua como medio de concientización sobre el cuidado y valoración del recurso del río. 


\section{CAPÍTULO VIII: PROYECTO}

\subsection{Urbano-paisajista}

\subsubsection{Parque Lineal Ribereño Shullcas}

\subsubsection{Definición del ámbito de intervención}

El diseño parte con la definición del ámbito de intervención a escala territorial que está conformada por el área de la ribera del Shullcas y la ciudad de Huancayo (ficha 8.1). Actualmente, está constituida por área libre, zona de protección ecológica (establecida por la municipalidad), asentamiento de viviendas en zonas de alto riesgo a inundaciones, por equipamiento y terrenos industriales y de otros usos no compatibles con la ribera. El área de intervención abarca longitudinalmente entre la altura de la Av. 28 de Julio cruzando el Río Mantaro hasta las cercanías de la urbanización Las Retamas de San Luis al otro extremo. Esta consideración de ambos límites se determina por ser zonas de transición rural con la ciudad. Con respecto al área de alcance transversal de la propuesta, varía de acuerdo a las avenidas del Río Shullcas que oscila entre los 3200 y 3310 m.s.n.m aproximadamente.

La ribera presenta explanadas amplias, en la zona de la desembocadura; partes estrechas, en el centro de la ciudad y nuevamente, en dirección al Huaytapallana, aparecen áreas libres que se convierten en suelo agrícola aledaño al borde del río. El área total de intervención corresponde a 290 Ha con una extensión de 13.5 km lineales. 

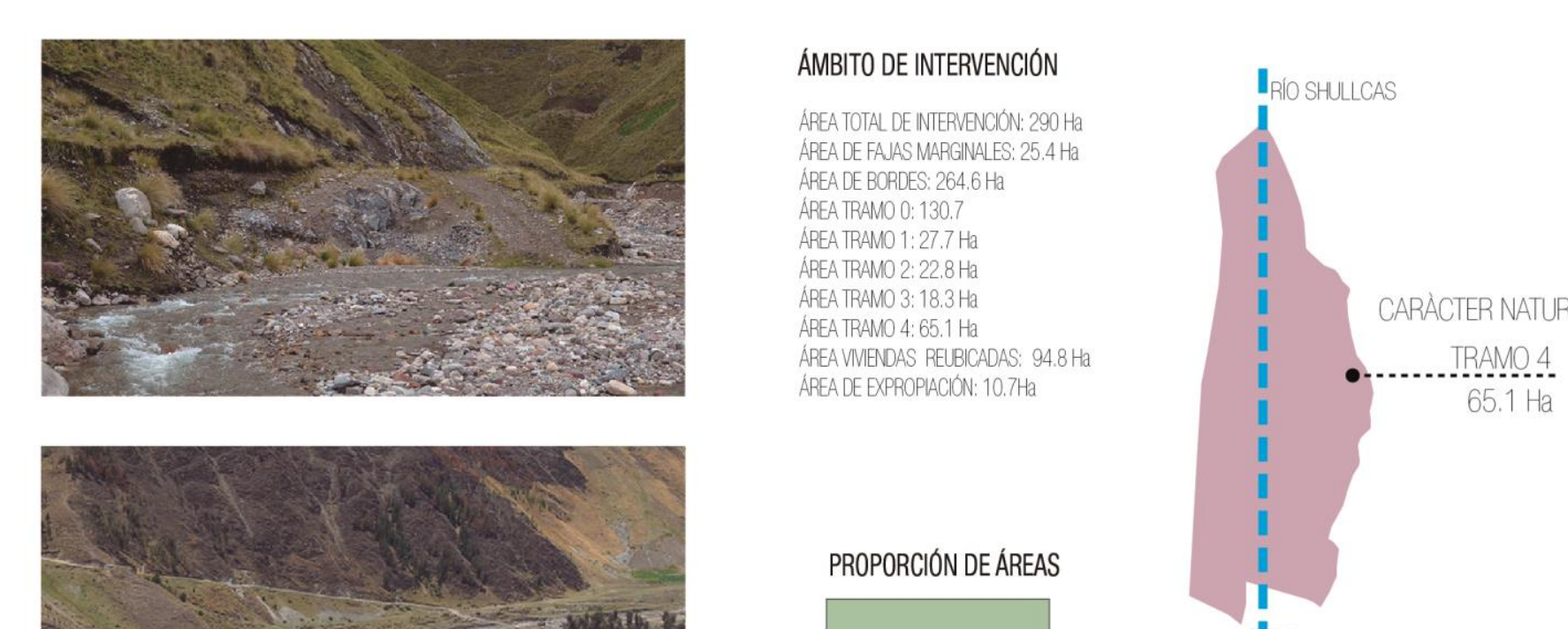

TRAMOS

El área de intervención del Parque Lineal Ribereño Shulcas tiene como objetivo integrar la ciudad de Huancayo. En la actualidad está conformado por:

1. Espacio público disponible

2. Viviendas precarias asentadas en zonas de riesgo que serán

3. Terrenos con usos no compatibles a la zonificación establecida

Retiro del rí (fajas marginales) en ambos bordes
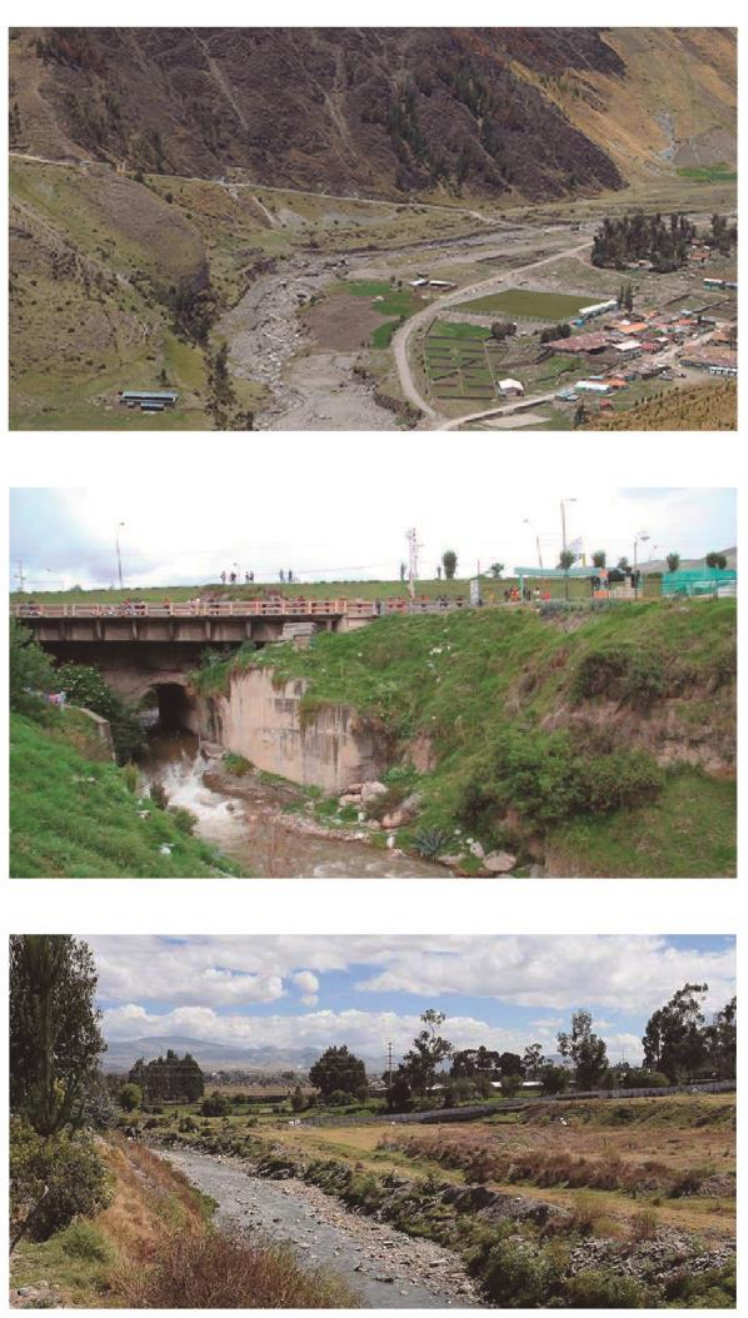

TRAMO 3
$18.3 \mathrm{Ha}$

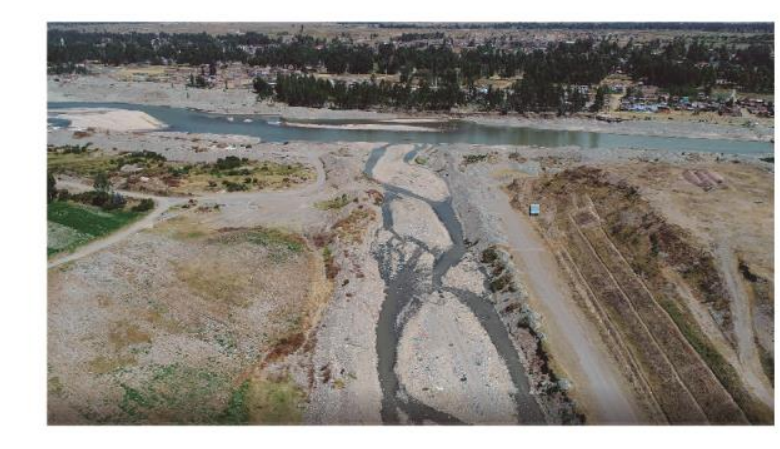

EYENDA DEFINICIÓN DEL ÁMBITO

\begin{tabular}{|c|c|}
\hline $\begin{array}{l}\text { AAEA DEE ÁMBTTO } \\
\text { TRAMO O }\end{array}$ & \\
\hline TRAMO 0 & \\
\hline TRAMO 2 & \\
\hline TRAMO 3 & \\
\hline $\begin{array}{l}\text { TRAMO } 4 \\
\text { TEREVNOS PRVADOS }\end{array}$ & \\
\hline 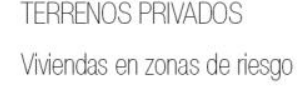 & \\
\hline Terrenos no compaatibes & \\
\hline $\begin{array}{l}\text { Tererenos conservados } \\
\text { EAALS MABGNAAE FS }\end{array}$ & \\
\hline
\end{tabular}

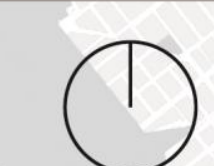

I. CARÁCTER AMBENTAL

-....TRAMO1.

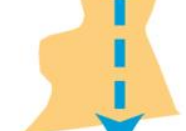

CARACTR ECOL OGICO

C....TAMO O
$130.7 \mathrm{Ha}$
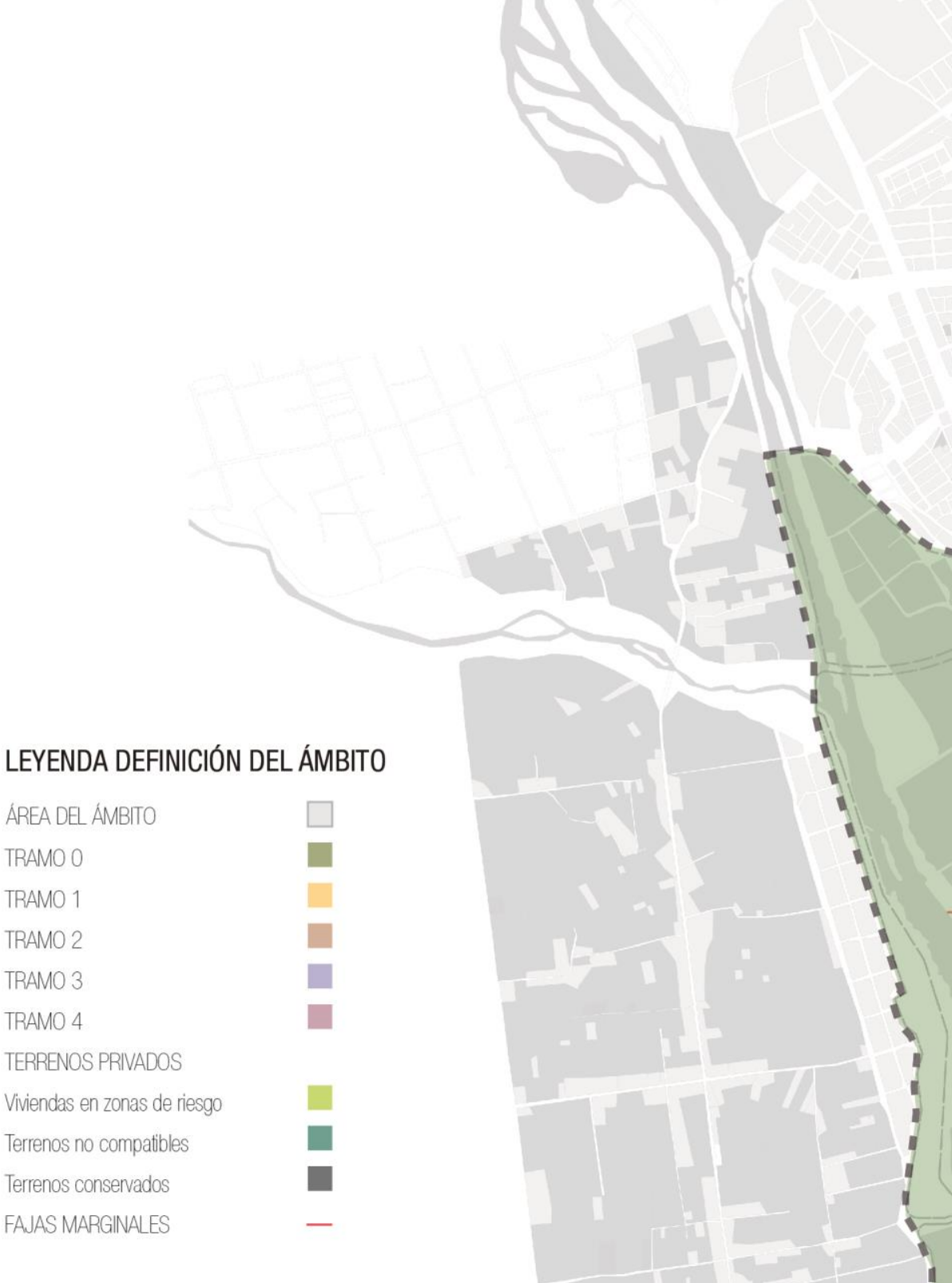


\subsubsection{Toma de partido}

La extensión de la propuesta concibe al río como eje ordenador urbano-paisajístico que implementa espacios públicos abiertos, equipamiento cultural, deportivo y recreativo en la ribera que parte del entendimiento de la caracterización particular del paisaje local y urbano de la ciudad. Con ello se configura cinco tramos que corresponden a las dinámicas del lugar y al análisis de los componentes urbanos delimitados entre el medio urbano y rural

En los extremos longitudinales se establecen los tramos ecológico y natural, ubicando el primero cerca a la desembocadura del Río Mantaro y el segundo, el natural, en dirección al Huaytapallana. Los tres restantes componen la extensión del Río Shullcas insertado en el medio urbano conformado por los tramos de carácter histórico, ambiental y educativo-residencial. Así, la propuesta parte de la configuración de tramos correspondientes a la lógica del paisaje local y urbano inmediato.

Asimismo, se definen las construcciones a mantener en la ribera que formarán parte de la propuesta que a diferencia de otras serán estatizadas o tendrán un cambio de uso debido a estar ubicadas en áreas de inundación alta o ser infraestructura que genere conflictos paisajísticos. Se propone la reubicación de estas edificaciones con la finalidad de establecer una imagen integral de la Ribera del Shullcas como un espacio de uso público. Los equipamientos importantes considerados a integrarse con la intervención son la Sociedad de Beneficencia de Huancayo ubicado en la esquina con el Jr. Carrión, el Centro comercial Open Plaza y el Terminal Terrestre, este último conservando, el terreno para proponer otro tipo de equipamiento debido al conflicto paisajístico y de movilidad urbana que ocasiona proponiendo su nueva ubicación en la periferia del casco urbano de la ciudad para mejorar la congestión vehicular de la zona.

\subsubsection{Objetivos y estrategias}

La definición de los tramos de intervención se establece por medio de lineamientos claves que buscan solucionar conflictos urbanos existentes, los cuales son ejes de acción en relación a conectar, activar, tejer y recuperar la ribera del Shullcas. Con ello, estos objetivos permiten establecer estrategias particulares que responden a la intención base del parque lineal como eje integrador de la ciudad conformado por puentes, pasarelas y corredores verdes que unirán 
barrios, áreas verdes, parques, plazas e infraestructura existente del casco urbano con la Ribera del Shullcas y el valioso suelo agrícola que circunda la ciudad,

La idea es generar un corredor biótico metropolitano que integre los elementos naturales a la ciudad. Asimismo, se busca la activación de este espacio por medio de incorporación de equipamiento y parques, este último como instrumento de equilibrio entre el área edificable y área libre en la ciudad, además de incrementar espacio público a escala metropolitana, también, se busca la preservación de especies autóctonas de la región, un recurso natural, como estrategia que conecta la red biótica del valle con escenarios cultural, paisajes y áreas de recreación que por medio de su recorrido establezca espacios sociales integrales de aprendizaje y asimismo este pueda servir como medio de protección del Río Shullcas y del suelo agrícola contra la expansión urbana. A continuación, se explicará a mayor detalle (en las fichas 8.2, 8.3, 8.4, 8.5 y 8.6) el desarrollo de objetivos y estrategias que configuran la propuesta del Parque Lineal Ribereño Shullcas. 


\section{OBJETIVOS Y ESTRATEGIAS}

\section{CONECTAR}

El Río Shullcas es el borde natural de la ciudad de Huancayo que actualmente se ha converitio en un elemento de fragmentación urbana debido un crecimiento urbano no planificado

政 es y transversales orientados particularmente al peatón y cicilista

CONEXIONES TRANSVERSALES

CONECTAR TRANSVERSALMENTE LA CIUDAD CON El RIOO

SHULLCAS MEDIANTE PASARELAS PEATONALES.

a ciudad actualmente posee 6 conexiones trasversales vehiculares que están acompañadas de una sección peatonal muy angosta (1 metro) no amigable para el recorrido ni segura. Conectar transversalmente de manera peatonal a través de pasarelelas permite la unión de los bordes del in

\section{CONEXIONES LONGTUDINALES}

2.CREAR PUENTES LONGITUDINALMENTE QUE CONECTEN CON DE

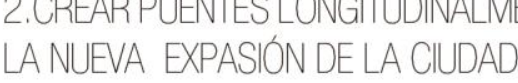

Huancayo se ha expandido al Sur-Oeste de la ciudad con los distritos de Huamancacca P Pilcomayo, (cruzando el Rí Mantaro). Actualmente existe una conexión vericular fuera de esta zona de crecimiento de manera que no se encuentra conectadad directamente con el centro de la ciudad. Los

3.GENERAR RECORRIDO LONGITUDAL VEHICULAR EXTERNO AL

\section{RÍO SHULLCAS}

Se propone generar un recorrido longitudinal vehicular externo y paralelo a l parque lineal sin irrumpir con la dinámica peatonal que busca un vínculo con la naturalezz desde la ciudad

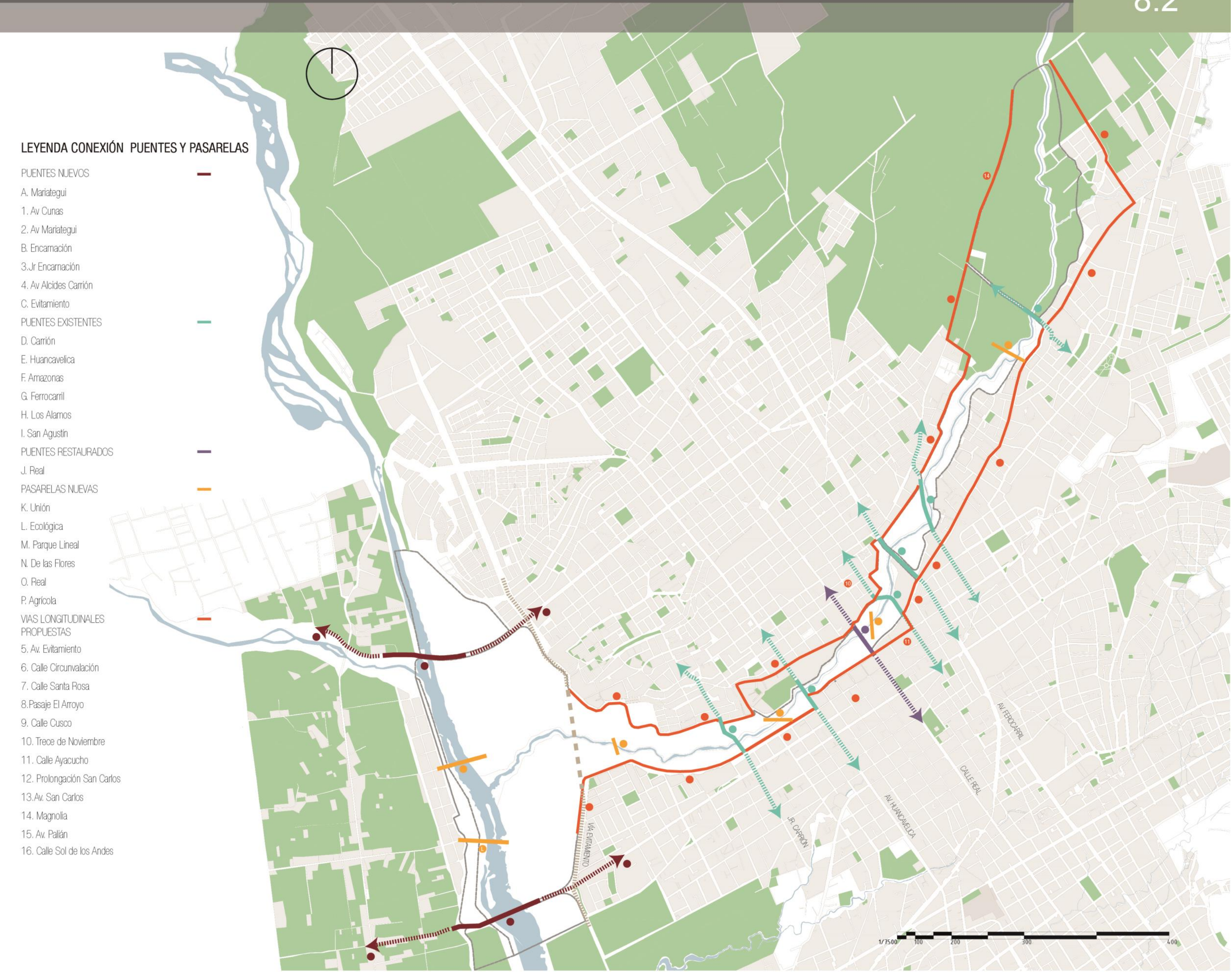




\section{CREAR ESPACIO PÚBLICO}

El espacio púbilic cumple una función importante en el desarrollo humano, calidad ambiental incremento de superficie de área verde y mejora en las condiciones para el desarrollo de la
biodiversidad urbana. La propuesta del Parcue Lineal Ribereño Shullcas será uno de los futuros

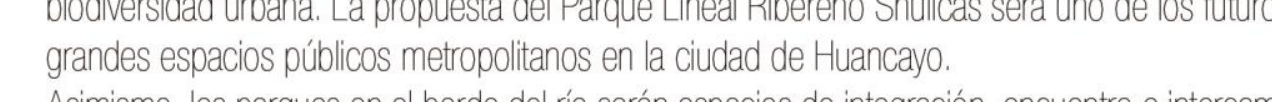

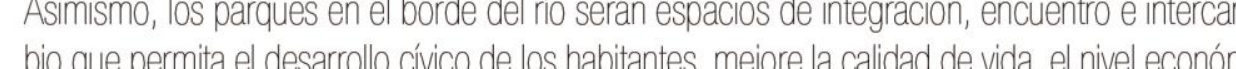

co y el aspecto social La propuesta clasifica dos tipos de vacios verdes: Nodos transicion y

ESPACIO PÚBLICO- NODOS

1 CREAR UN PARQUE LINEAL PARA INCREMENTAR EL PORCENTA.

JE DE ESPACIOS RECREATVOS DE LA CIUDAD

El áreal ibrec comprende (A) vias, (B) plazas, (C) parques, (D) forestal y (E) agícola con un total de 5685 Ha. El porcentaje con mayor área es la agícola con 66.2\% (E1) a diferencia del area de plazas y parques con $0.06 \%$ (B1) y $0.2 \%$ (C1) y un total de $15 \mathrm{Ha}$. La ciudad posee un atto déficit de espacio público recreativo correspondiente a $7.7 \mathrm{~m} 2$ por habitante (Optimo $8 \mathrm{~m} 2)$. La propuesta aumenta el áreal libre a $5870.5 \mathrm{Ha}$ con un área de esparcimiento que asciende a $305 \mathrm{Ha}$ ( $5.2 \%$
del total-B2+C2) Esto corresponde a un promedio de $5.83 \mathrm{~m} 2$ más de lo actual por persona La propuesta convierte al borde del río en un eje estructurante con un gran parque ambiental, ultural y deportivo integrado a la ciudad.

\section{ESPACIO PÚBLICO- TRANSICIÓN}

2.CREAR UN PARQUE FCOLÓGGCO OUE SIBVA DE CONTENCIÓN A LA EXPANSIÓN DE LA CIUDAD E INCREMENTE EL ESPACIO PÚBLLCO

La ciudad continúa expandiéndose en zonas agricolas aumentando la mancha urbana y perdiendo áreas naturales. La propuesta busca amortiguar este daño con la

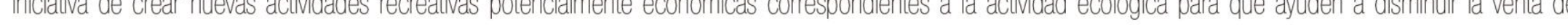

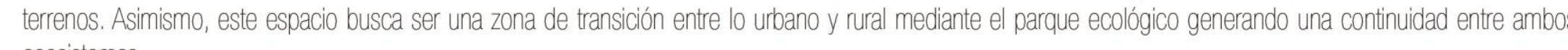
ecosistemas

\section{ESPACIO PÚBLLCO- CONEXIÓN}

3. CREAR CORREDORES VERDES QUE CONECTEN PARQUES IMPORTANIES DE LA CIUDAD CON EL PARQUE LINEAL DEL RÍO SHULLCAS

Los parques se encuentran desarticulados en la ciudad, de manera que la propuestat tiene como finalidad tejer estos vacíos verdes y conectarlos con la propuesta del parque ineal del Rio Shuilcas, Los corredores permiten la continuidad de los essacios verdes recreativos conformando un gran sistema integral conectado al nuevo eje estructurador natural del Río Shullcas (que funciona como parque a escala metropolitana)

\section{OBJETIVOS ESTRATECIAS} FICHA

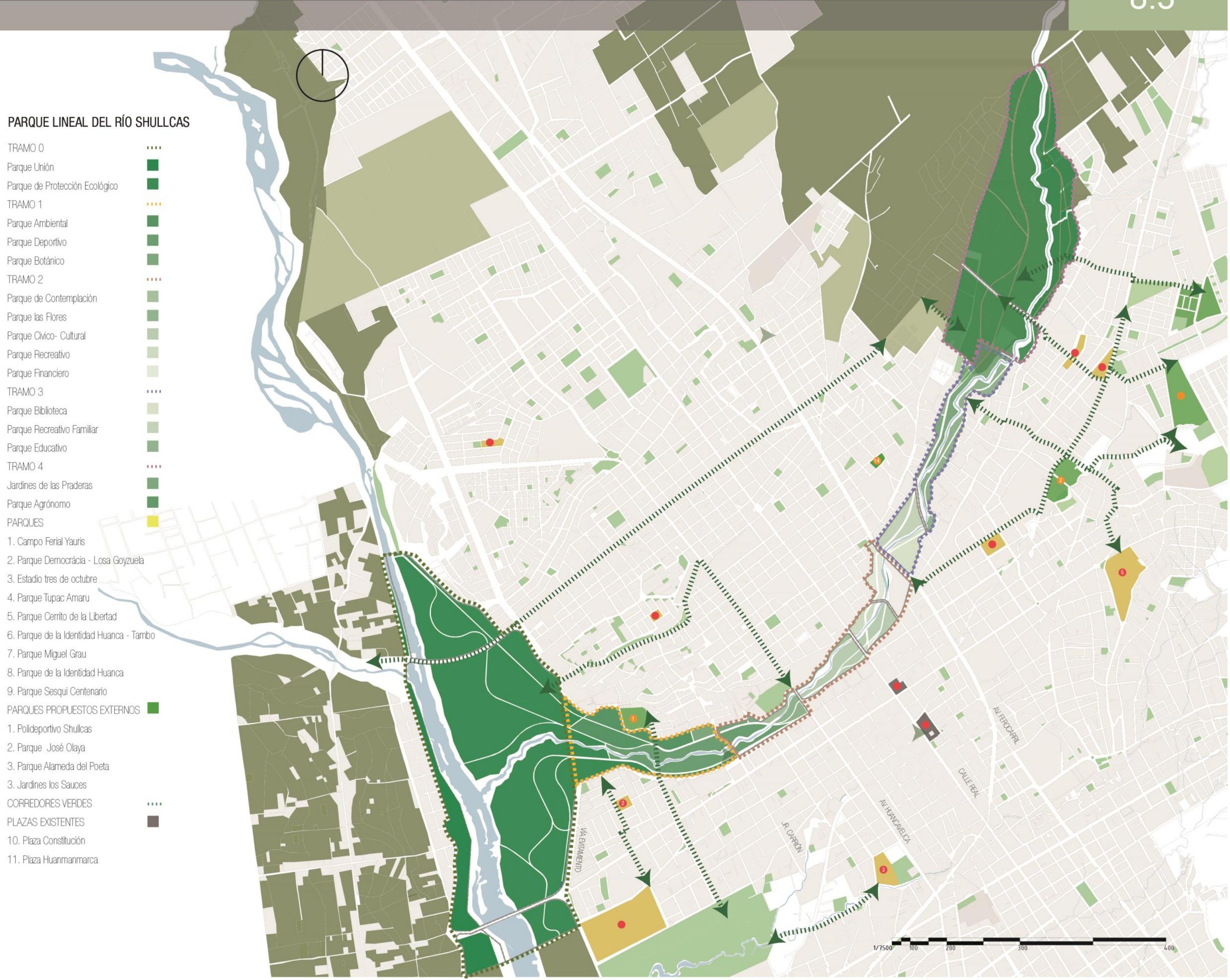




\section{TEJER}

La acción de tejer consta de articular e interconectar espacios (equipamiento) importantes de la ciudad propias de la dinámica urbana. La propuesta utiliza un sistema de recorridos, acompañados de elementos de vegetación, que conectan infraestucturas existentes con nuevos servicios complementarios of faltantes en la ciudad y establecidos en el parque lineal del Río Shullcas. La propuesta se clasifica en 3 tipologías de articulación: Ciudad / Río, Infraestructura ecológica y equipamiento.

\section{ARTICULAR - CIUDAD/RIOO}

1. CREAR CORREDORES DE VEGETACIÓN QUE PERMITAN LA

TRANSIIOÓN TRANSVERSAL ENTRE LA CIUDAD Y ELL RíO

La zona urbana y la del rí requieren de una transición que permita permeabilidad entre ellos. La propuesta acompaña longitudinalmente con ejes arborzzados a vías aledañas al parque como "colchón" de amortización entre ambos paisajes (urbano y natura).

\section{ARTCULAR - NTRAESTRUCTURA ECOLÓGiCA}

2.CREAR CORREDOERS VERDES QUE ARTCULEN LA CIUDAD

ONGITUDINALMENTE CON LA INFRAESTRUCTURA AGRICOLA

La infraestructura agricola y la malla urbana están fragmentadas y discontinuas. La propuesta de corredores verdes a lo largo del parque lineal permite la articulación del área agrícola del noreste y el suroeste a manera de transición, con la zona rural y la ciudad.

\section{ARTICULAR - EQUIPAMENTOS}

3.CREAR CORREDORES VERDES ARBOLADOS QUE TEJAN LOS

EQUPAMIIEN

LINEAL DEL RIOO SHULLCAS

Los corredores de vegetación acompañan al peatón y cicista integrando las actividades y equipamientos de la ciudad con el nuevo eje estructurador del Rió Shullcas.

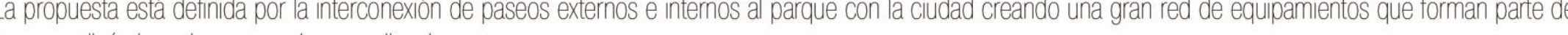
a nueva dinámica urbana con el parque lineal.

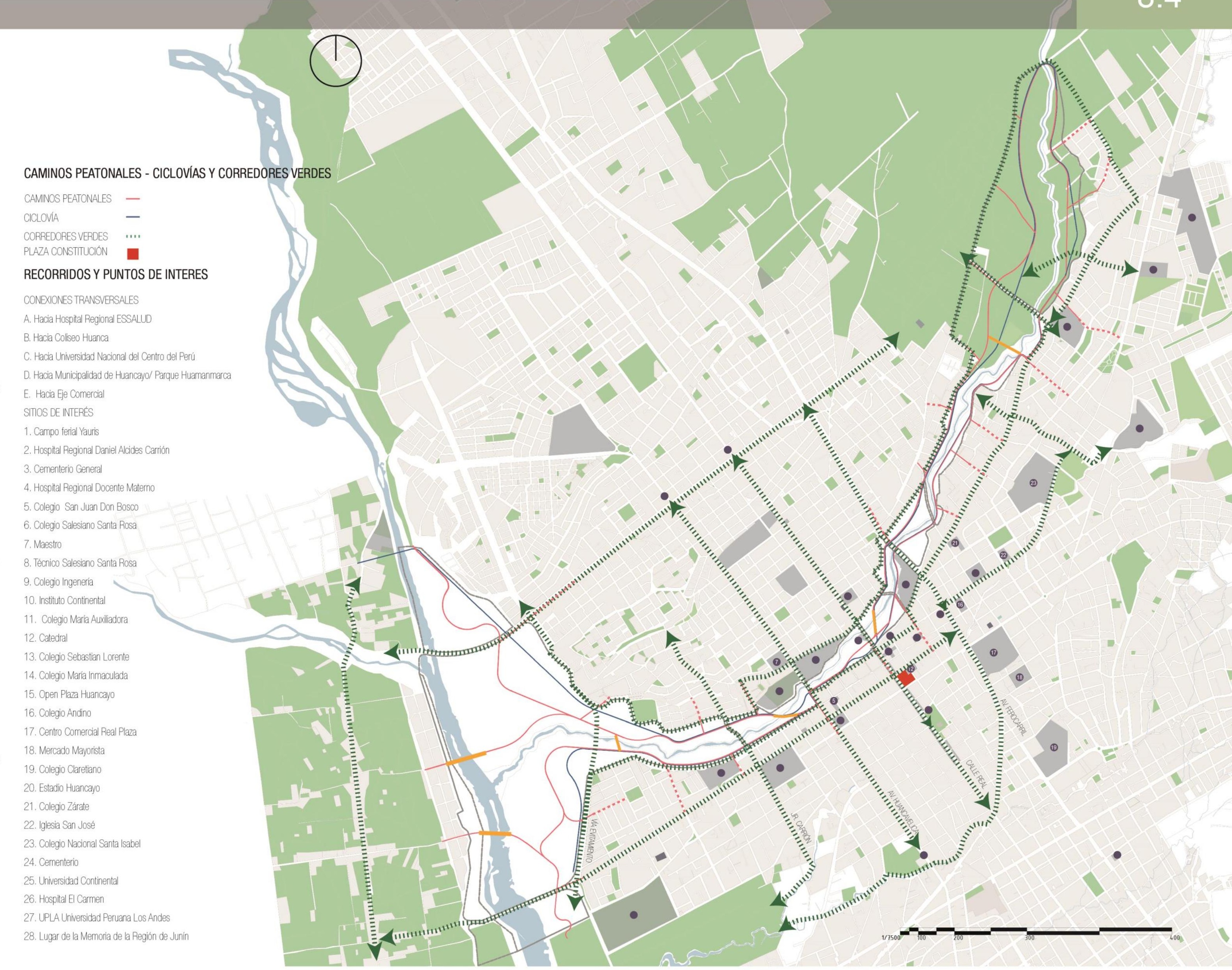


4.INCORPORAR NUEVO EQUIPAMIENTO

El pargue del Río Shulcas como nuevo eje natural estructurador propone diversos programas a lo largo del parque a fin de transformar, reactivar e integrar el uso del borde del río para la mejora de calidad de vida de la población. Albergarí equipamiento cultural, comercial, ecológico y residencial. Se busca la mejora de dotación de equipamiento fattante, principalmente escenarios culturales en ayuda a la recuperación y cuidado del entorno y del ríi; escenarios deportivos y espacios de aprendizaje por medio de recorridos de paisaje y vegetación que en conjunto forman un parque integral de recreación y educación.

\section{DOTACIÓN}

DOTAR DE NUEVOS EQL UPAMENTOS A LA CUIDAD.

El equipamiento básico consta de (A) Reccreación, (B) Salud, (C) Cultura, (D) Comercio y (E) Educación con un total de $537.5 \mathrm{Ha}$. El porcentaje con mayor área es (B)

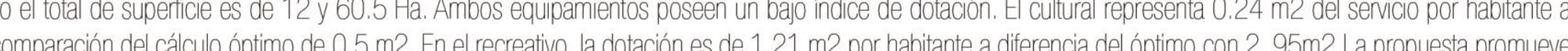

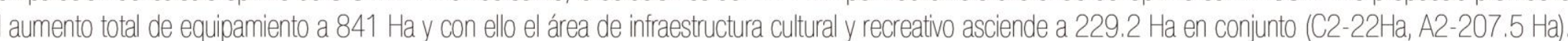
Ambos casos, la dotación por habitante aumenta (Culural de $0.24 \mathrm{~m} 2$ a $0.44 \mathrm{~m} 2$ y recreativo de 1.21 a $4.16 \mathrm{~m} 2$ por habitante).

\section{CLASIFICACIÓN YTIPOS}

2 CUADRO DE NLEVO EOLPAMIENTO DIERENTE A LA ZONEICA

CIOON DE LA CIUDAD DE HUANCAYO

Los equipamientos consideradoss por la Municipalidad de Huancayo se definen por: comercio, recreación, cultural, salud y educación. La propuesta busca identificar

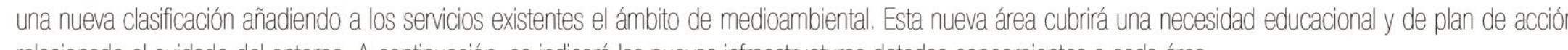

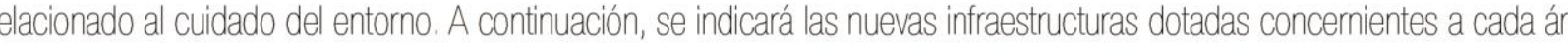

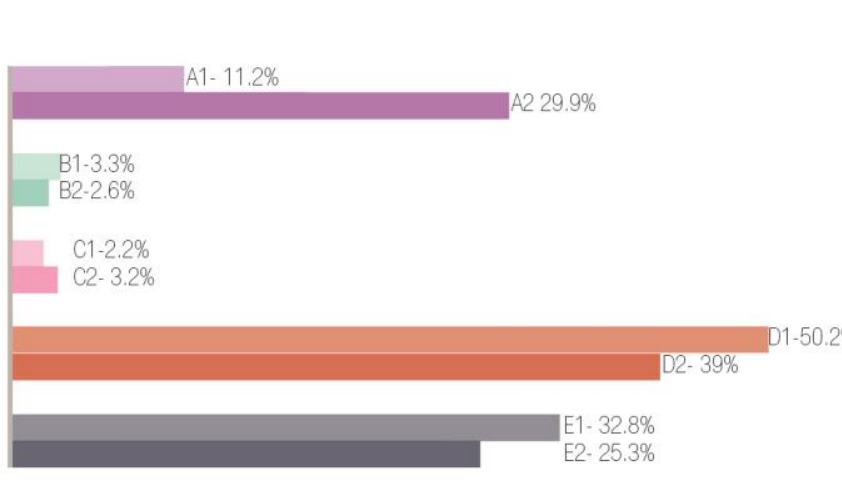

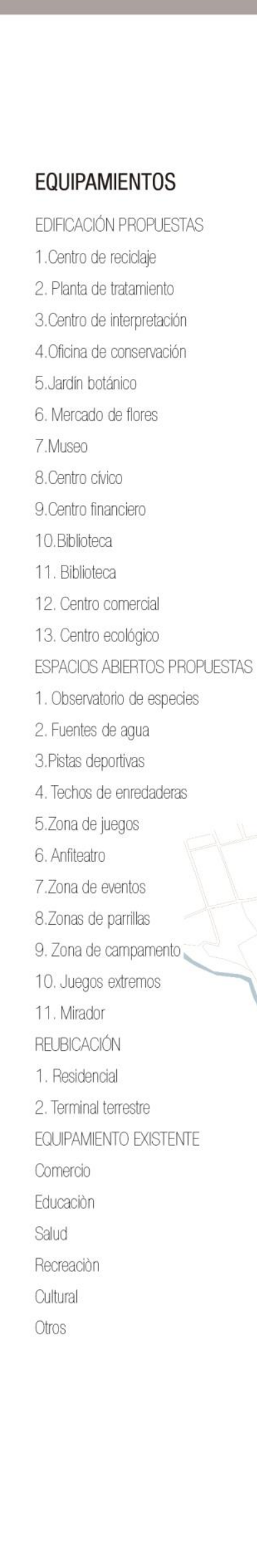
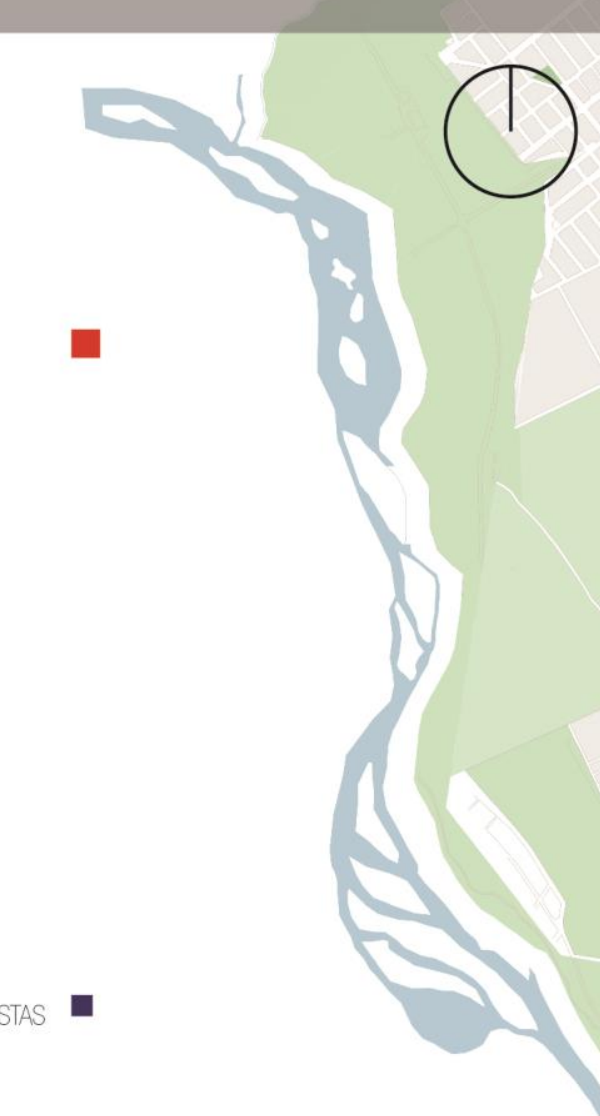

(1)

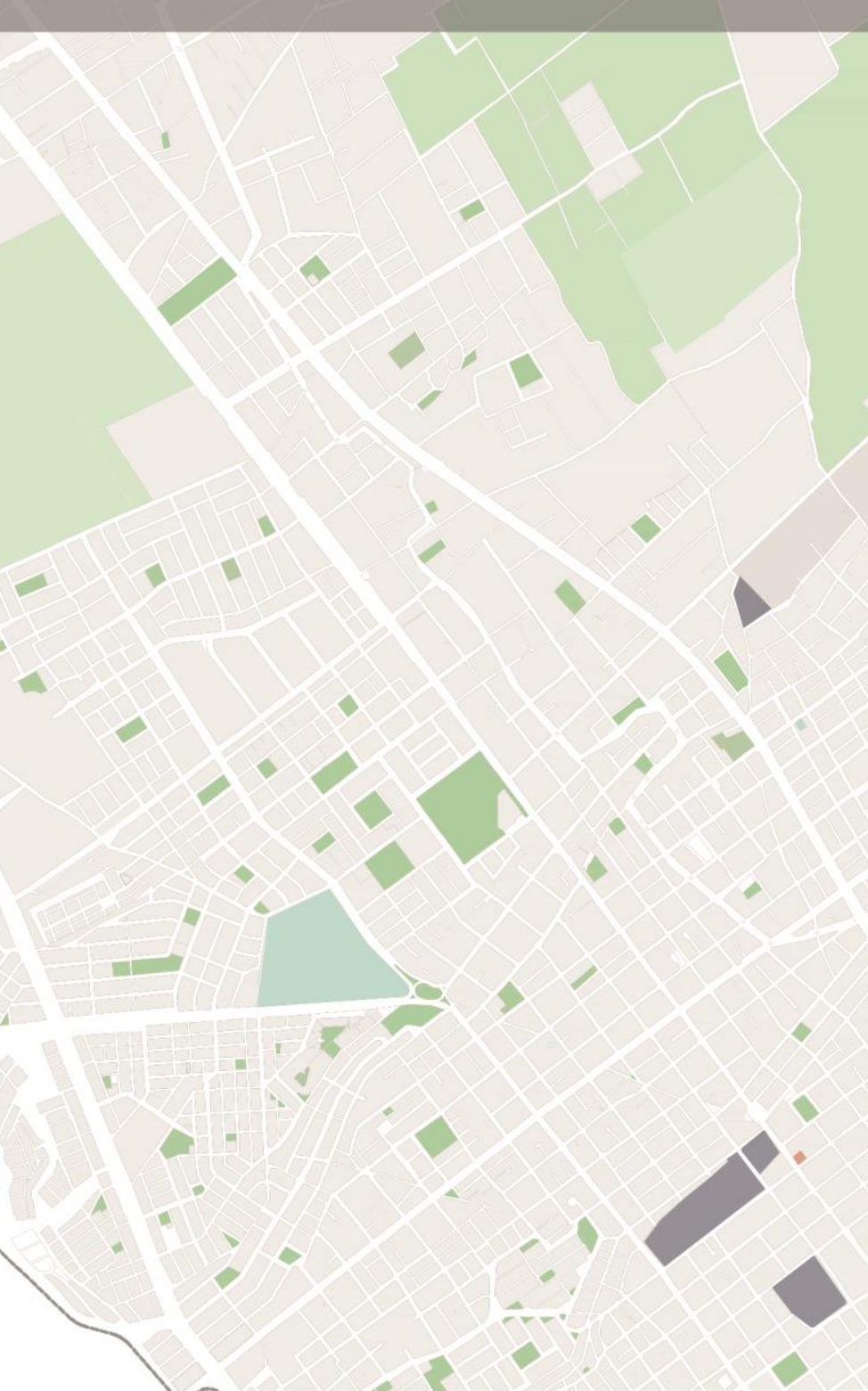

30

$\because:$

is)

te

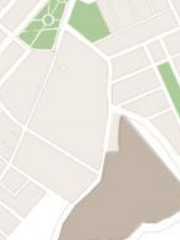


5.RECUPERAR PATRIMONIO NATURAL

La subcuenca del Shullcas posee una variedad aproximada de 77 especies vegetales. Entre las más representativas 18 especies que se adaptan fácilmente al clima y tipo de suelo.

作 y valoración del patrimonio natural del valle contemplada desde la ciudad creando desarrollo formativo y de concientización entorno a la naturaleza.

1 INSERTAR EL SISTEMA DE ESPECIES VEGETALES PROPIOS

DEL VALLEAL PARQUE LINEAL DEL RÍO SHULLCAS

La intervención se basa en la recuperación de especies vegetales autóctonas de la región como iniciativa de revaloración y cuidado del medio ambiente. La propuesta

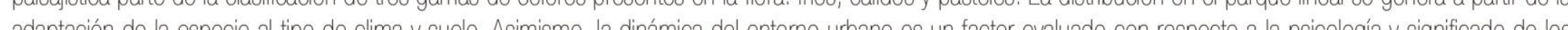
colores
coliocion te

Aolues

$$
x>2>\frac{1}{2}
$$

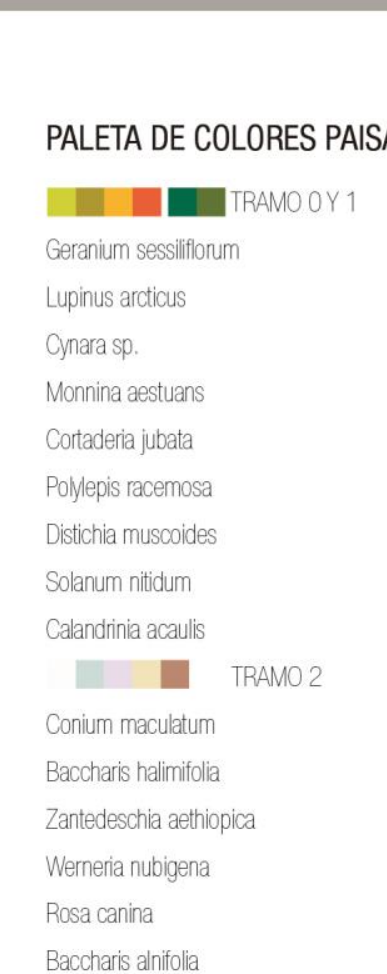

la naturaleza. to cual se relaciona con los colores frios propios al tioo ded dima más seco v helado

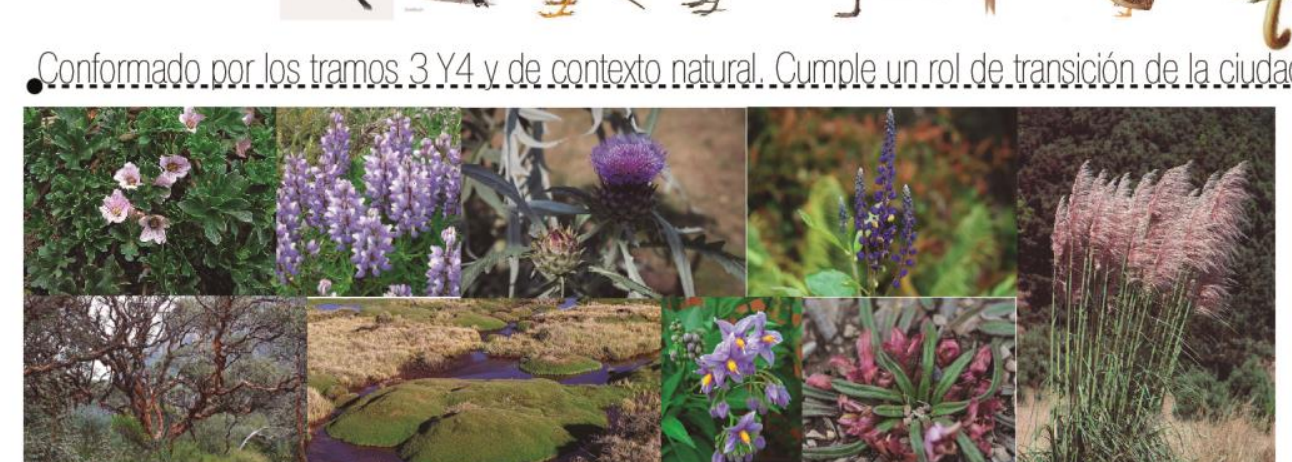
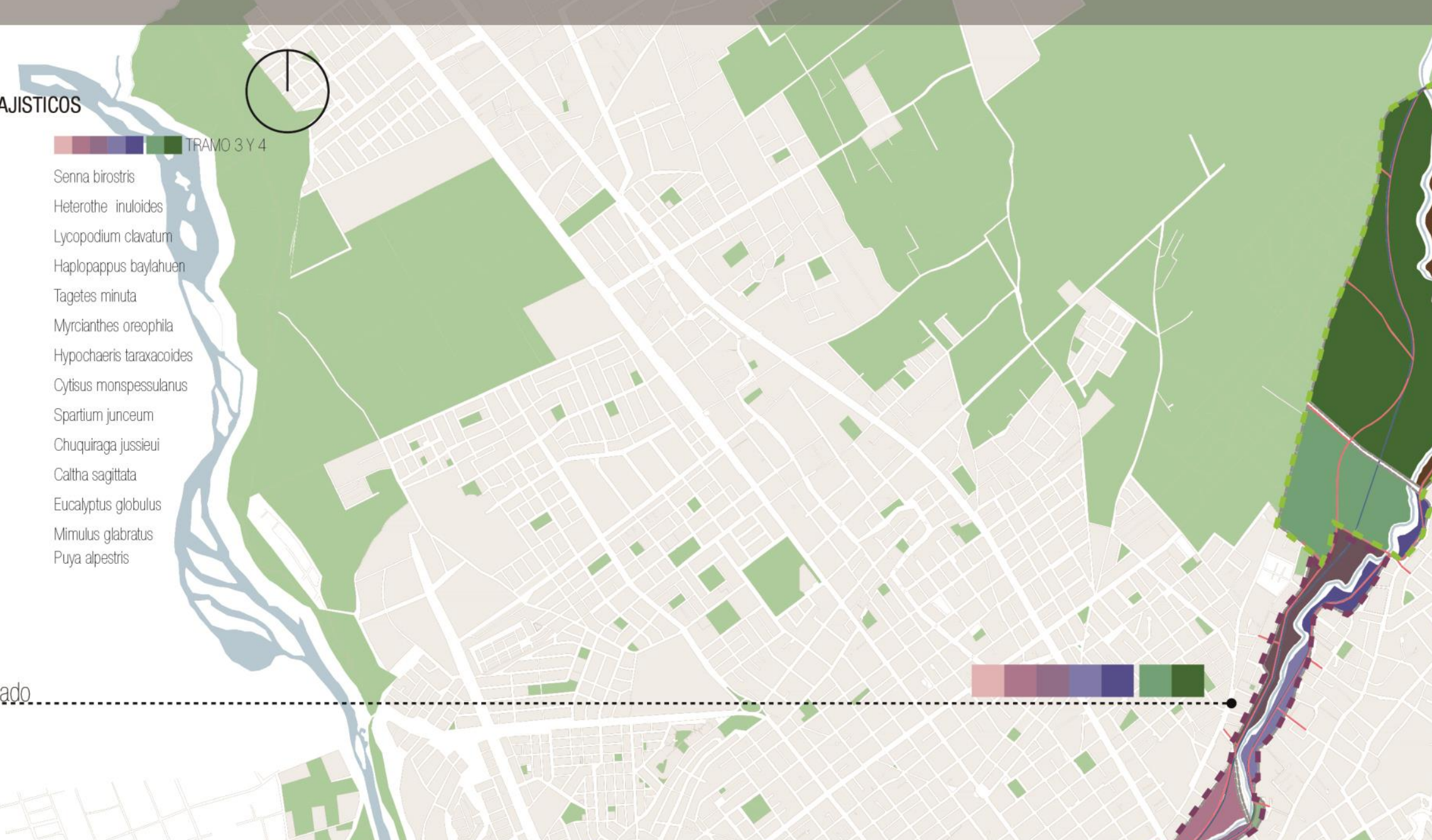

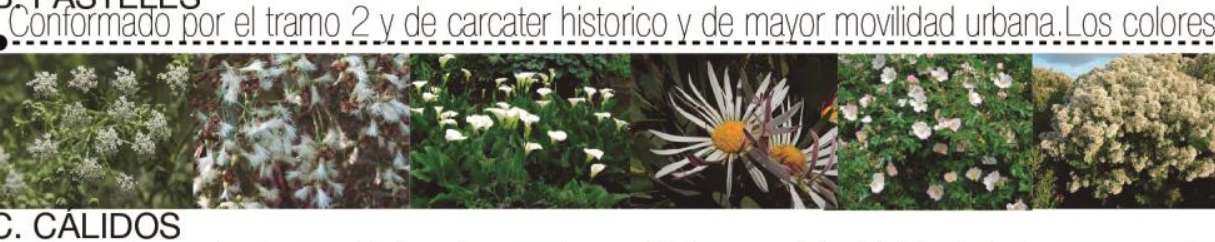

Conformado por los tramos 0-1 y de carcater ecológico y ambiental. El rol de la preservación y cuidado de las especies se relaciona con los colores vivos y calidos propios de la naturalezz.
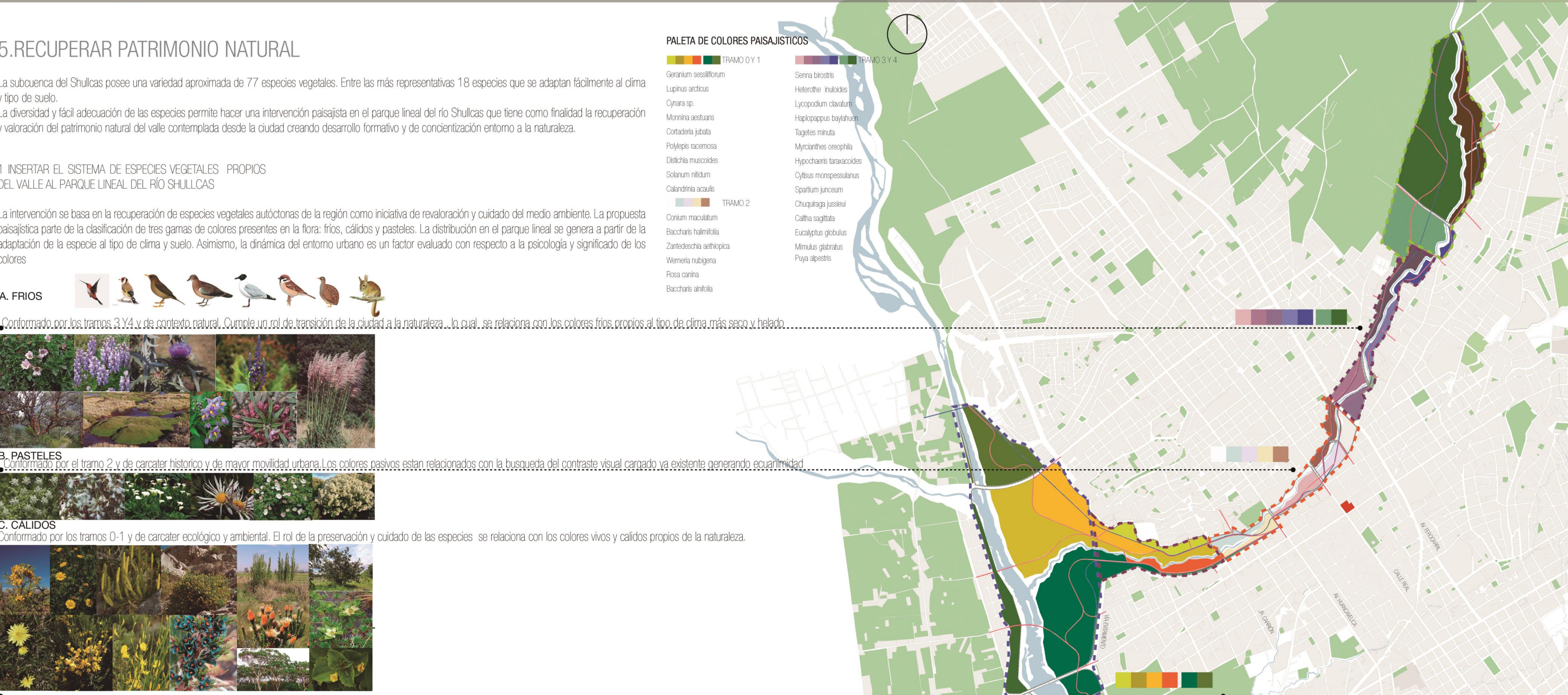


\subsubsection{Usuarios y capacidad}

La propuesta del Parque Lineal Ribereño Shullcas corresponde al tipo de Parque zonal orientado a un rango poblacional de 100 mil a 300 mil habitantes catalogado por el PDU Huancayo ya que la definición de metrópoli está orientada a poblaciones mayores al millón de habitantes. Sin embargo, es importante señalar que en el documento "Diagnóstico del Sistema Urbano Nacional" elaborada por una consultoría externa define a la Ciudad de Huancayo como Metrópoli Regional al estar conformada por un total de 410,505 habitantes.

De este modo el Parque Lineal Ribereño Shullcas se considera parque zonal por los factores explicados, pero con proyecciones de tipo de parque de escala metropolitana cubriendo el déficit de espacio público que comprende áreas recreativas y pasivas. Este último con un área de $0.82 \mathrm{~m}^{2}$ por habitante, considerado por debajo de los $8 \mathrm{~m} 2$ óptimo referenciales de Organismo Mundial de Salud (OMS). Con ello, el área a cubrir corresponde a 335 Ha. y la intervención de 290 Ha destina 140 Ha a espacio público útiles.

La configuración de los cinco tramos que conforma el parque integral son considerados parques sectoriales. Cada uno de estos orientados a una ratio de población de 10 a 30 mil habitantes con un área destinada de $2 \mathrm{~m}^{2}$ por habitante. Así las superficies establecidas del tramo 0 (ecológico) es de 130.7 Ha.; tramol (ambiental), 27.7 Ha.; tramo 2(histórico), $22.8 \mathrm{Ha}$; tramo 3 (educativo) $18.3 \mathrm{Ha}$; y el tramo 4(natural), $65.1 \mathrm{Ha}$.

\subsubsection{Propuesta del Plan Maestro del Parque Lineal Ribereño Shullcas}

La intervención en los bordes del Río Shullcas es un medio de oportunidad para restablecer la conexión de la ciudad Huancayo con su territorio y proporcionar mejoras en las condiciones urbanas de forma óptima y sostenible. Con ello, el desarrollo de la propuesta se apoya de teorías que están relacionadas con el estudio de actuaciones similares y del tipo de análisis paisajístico de la ciudad. Las siguientes fichas muestran el Plan Maestro del Parque Lineal Ribereño Shullcas (ficha 8.7, 8.8 y 8.9). A continuación, se detalla un listado de los autores que han aportado en la base conceptual de la propuesta 
del Plan Maestro del Parque Lineal Ribereño Shullcas a partir de los términos paisaje, espacio público, diseño urbano e interpretación profundizados en el marco teórico. Además de indica los aportes concluyentes del marco normativo y operativo de los casos de regeneración

Tabla 8. 1 Aplicación del Marco Teórico al diseño del Parque Lineal Ribereño Shullcas

\begin{tabular}{|c|c|c|}
\hline AUTOR & APORTES & PROYECTO \\
\hline \multirow[b]{3}{*}{ Maderuelo } & $\begin{array}{l}\text { Paisaje construcción } \\
\text { cultural }\end{array}$ & $\begin{array}{l}\text { El paisaje como medio productivo de tierra fértil y de } \\
\text { desarrollo no ornamento }\end{array}$ \\
\hline & $\begin{array}{l}\text { Contemplación - } \\
\text { Escenarios urbanos }\end{array}$ & $\begin{array}{l}\text { Creación de espacios que albergue dinámicas urbano - } \\
\text { paisajísticas }\end{array}$ \\
\hline & $\begin{array}{l}\text { Planificación - Paisaje } \\
\text { urbano integral- } \\
\text { entender el carácter del } \\
\text { lugar, no implantar } \\
\quad \text { modelos }\end{array}$ & $\begin{array}{c}\text { Propuesta integral que contempla resolver problemas } \\
\text { urbanos como falta de espacio público, equipamiento } \\
\text { cultural, fragmentación urbana e imagen urbana difusa. Se } \\
\text { busca intervenir considerando el propio carácter } \\
\text { paisajístico de la ciudad. }\end{array}$ \\
\hline \multirow{4}{*}{ Garrett } & \multirow{2}{*}{$\begin{array}{l}\text { Intervención del } \\
\text { paisaje- Equilibrio }\end{array}$} & $\begin{array}{l}\text { Bordes difuso en la ciudad - Configurar espacios de } \\
\text { transición entre medio urbano y rural }\end{array}$ \\
\hline & & $\begin{array}{l}\text { Área edificada vs área libre en el paisaje urbano - Aumento } \\
\text { de área pública utilizable y recreativa para la población }\end{array}$ \\
\hline & $\begin{array}{l}\text { Potencializar carácter } \\
\text { del lugar }\end{array}$ & Establecer vínculo social con la intervención del paisaje \\
\hline & $\begin{array}{l}\text { Diseño del paisaje } \\
\text { humanizado }\end{array}$ & $\begin{array}{l}\text { Contemplar forma, espacio, disposición de los elementos } \\
\text { naturales en el diseño de los espacios públicos. }\end{array}$ \\
\hline \multirow[b]{2}{*}{ Jordi Borja } & $\begin{array}{l}\text { Regularización pública } \\
\text { del espacio }\end{array}$ & $\begin{array}{c}\text { Regularización de propiedad de la ribera del Shullcas } \\
\text { como espacio público, en algunos casos se expropia } \\
\text { viviendas y reubica en zonas no vulnerables. }\end{array}$ \\
\hline & $\begin{array}{l}\text { Espacio público- } \\
\text { Cohesión social, } \\
\text { mixto, reflejo de } \\
\text { autoestima colectiva }\end{array}$ & $\begin{array}{l}\text { Espacio público que contemple diversidad de actividades } \\
\text { para el uso, disfrute e integración de la población con la } \\
\text { ciudad. }\end{array}$ \\
\hline \multirow{3}{*}{ Law Olmsted } & Parque experimental & $\begin{array}{l}\text { Propuesta de actividades correspondientes al carácter del } \\
\text { tramo }\end{array}$ \\
\hline & $\begin{array}{l}\text { Sistema de parques - } \\
\text { igualdad e integración } \\
\text { social }\end{array}$ & $\begin{array}{l}\text { Propuesta de una red de espacios públicos interconectados } \\
\text { por corredores verdes }\end{array}$ \\
\hline & $\begin{array}{l}\text { Espacio público con } \\
\text { valor paisajístico }\end{array}$ & Recuperación de flora y fauna nativa de Huancayo \\
\hline \multirow{4}{*}{ Jan Gehl } & \multirow{3}{*}{$\begin{array}{l}\text { Espacio público - } \\
\text { invita a realizar } \\
\text { actividades necesarias } \\
\text {, voluntarias y } \\
\text { espontáneas }\end{array}$} & $\begin{array}{c}\text { Creación de espacios con propuesta de variedad de } \\
\text { actividades recreativas }\end{array}$ \\
\hline & & $\begin{array}{c}\text { Creación de espacios de paso que articulen la ciudad ( } \\
\text { ciclovías) }\end{array}$ \\
\hline & & Aumentar el confort del usuarios para mayor estancia \\
\hline & $\begin{array}{l}\text { Eliminar barreras entre } \\
\text { espacio público y } \\
\text { edificio }\end{array}$ & $\begin{array}{l}\text { Crear relación entre el espacio público y edificación a } \\
\text { partir la definición de una red de corredores verdes que } \\
\text { interconecte a ambos elementos de la ciudad }\end{array}$ \\
\hline
\end{tabular}




\begin{tabular}{|c|c|c|}
\hline \multirow{9}{*}{ Jane Jacobs } & $\begin{array}{l}\text { diseño urbano - } \\
\text { diversidad urbana }\end{array}$ & Contemplar la variedad de usos en el espacio público \\
\hline & $\begin{array}{l}\text { Creación de hitos } \\
\text { urbanos }\end{array}$ & $\begin{array}{l}\text { Creación de lugares representativos que concentren una } \\
\text { gran cantidad de habitantes }\end{array}$ \\
\hline & \multirow{5}{*}{$\begin{array}{l}\text { Creación de un sistema } \\
\text { integrado de espacios } \\
\text { públicos y conexiones }\end{array}$} & Eliminación del tránsito pesado en el área de la propuesta. \\
\hline & & $\begin{array}{l}\text { Reducción del vehículo privado - propuesta de vías } \\
\text { paralelas de bajo transito }\end{array}$ \\
\hline & & $\begin{array}{c}\text { Mayor áreas peatonalizadas - creación de red peatonal } \\
\text { integral de }\end{array}$ \\
\hline & & $\begin{array}{l}\text { Creación de espacios de estancia (actividades en la ribera } \\
\text { como espacio público) }\end{array}$ \\
\hline & & $\begin{array}{l}\text { Creación de una red integral de corredores y espacios } \\
\text { públicos }\end{array}$ \\
\hline & \multirow{2}{*}{$\begin{array}{l}\text { Naturaleza de la } \\
\text { ciudad conformado } \\
\text { por las veredas, los } \\
\text { parques y los barrios }\end{array}$} & $\begin{array}{c}\text { Creación de sistema peatonal que defina lo público y } \\
\text { privado y alberge un flujo constante y establezca un } \\
\text { espacio seguro }\end{array}$ \\
\hline & & $\begin{array}{l}\text { Creación de parques que promuevan su uso constante y } \\
\text { cubran necesidades de la población }\end{array}$ \\
\hline Kevin Lynch & $\begin{array}{l}\text { La percepción de las } \\
\text { personas sobre la } \\
\text { imagen de la ciudad } \\
\text { se da a partir de } 5 \\
\text { componentes :sendas, } \\
\text { bordes, barrios, nodos } \\
\text { e hitos }\end{array}$ & $\begin{array}{c}\text { La intervención de la ribera del Shullcas como propuesta } \\
\text { urbana paisajista busca definirse por elementos naturales y } \\
\text { edificables que construyen la imagen integral del paisaje } \\
\text { urbano. }\end{array}$ \\
\hline Steven Holl & $\begin{array}{l}\text { Borde -superposición } \\
\text { del paisaje urbano y } \\
\text { natural - conexiones de } \\
\text { la ciudad- espacios } \\
\text { mediadores }\end{array}$ & $\begin{array}{l}\text { Se propone que parte del espacio intermedio entre el } \\
\text { paisaje de la ribera y la ciudad se convierta en un eje de } \\
\text { conexión longitudinal a este a fin de poder integrar los } \\
\text { nuevos barrios existentes con el resto del paisaje urbano. }\end{array}$ \\
\hline $\begin{array}{l}\text { Batty y } \\
\text { Longley }\end{array}$ & $\begin{array}{l}\text { Bordes- marcan } \\
\text { transiciones de } \\
\text { territorios en forma, } \\
\text { identidad y escala }\end{array}$ & $\begin{array}{c}\text { Se propone un espacio de transición entre la ciudad y el } \\
\text { paisaje de la ribera que contemple elementos significativos } \\
\text { y propios del lugar }\end{array}$ \\
\hline Tilden & $\begin{array}{l}\text { Interpretación - } \\
\text { Revelar significados a } \\
\text { través del contacto } \\
\text { directo con el recurso }\end{array}$ & \multirow{2}{*}{$\begin{array}{l}\text { Se propone actividades relacionadas al contacto directo } \\
\text { con elementos naturales }\end{array}$} \\
\hline Bob Peart & $\begin{array}{l}\text { Proceso de } \\
\text { comunicación que } \\
\text { revela significados } \\
\text { por medio de la } \\
\text { experiencia. }\end{array}$ & \\
\hline Don Aldridge & $\begin{array}{c}\text { Incrementar la } \\
\text { conciencia del } \\
\text { visitante de forma que } \\
\text { despierte el deseo de } \\
\text { contribuir a la } \\
\text { conservación del } \\
\text { medio. }\end{array}$ & $\begin{array}{c}\text { A partir de la regeneración de la ribera del Shullcas como } \\
\text { un espacio público activo que articule la ciudad y permita } \\
\text { la recuperación de flora y fauna nativa así como el cuidado } \\
\text { del Río Shullcas }\end{array}$ \\
\hline Morales & $\begin{array}{l}\text { La interpretación } \\
\text { despierta curiosidad, } \\
\text { generar un cambio de }\end{array}$ & $\begin{array}{l}\text { La intención de los objetivos de activar la ribera es la } \\
\text { herramienta para propiciar la interacción de la población }\end{array}$ \\
\hline
\end{tabular}




\begin{tabular}{|c|c|c|}
\hline & $\begin{array}{l}\text { actitud a partir de la } \\
\text { experiencia recreativa } \\
\text { e intelectual }\end{array}$ & $\begin{array}{l}\text { con actividades recreativas, contemplativas y educativas } \\
\text { para establecer un vínculo con la ribera. }\end{array}$ \\
\hline \multirow{4}{*}{$\begin{array}{l}\text { Countryside } \\
\text { Comission - } \\
\text { Peart y Wood }\end{array}$} & \multirow{4}{*}{$\begin{array}{l}\text { Los } 5 \text { componentes del } \\
\text { proceso de la } \\
\text { interpretación como } \\
\text { medio para la } \\
\text { planificación } \\
\text { interpretativa: } \\
\text { Lineamientos, análisis } \\
\text { del recurso, usuario, } \\
\text { selección de medios y } \\
\text { evaluación. }\end{array}$} & $\begin{array}{c}\text { El lineamiento de interpretación corresponde a la ribera del } \\
\text { río Shullcas es un área de dominio fluvial considerado } \\
\text { como recurso paisajista de interés natural que se encuentra } \\
\text { en estado de degradación. }\end{array}$ \\
\hline & & $\begin{array}{c}\text { Al análisis del recurso se consideran los recursos como la } \\
\text { flora, fauna, el recurso hídrico y componentes históricos } \\
\text { relativos a la ribera Shullcas }\end{array}$ \\
\hline & & $\begin{array}{l}\text { Al análisis del usuario se considera en general a los } \\
\text { habitantes de Huancayo y en particular al grupo que } \\
\text { pertenece al rango de } 15 \text { a } 59 \text { años de edad. }\end{array}$ \\
\hline & & $\begin{array}{l}\text { La selección de medios se establece por medio del } \\
\text { objetivo de activar y recuperar la ribera con la } \\
\text { implementación de programas de interacción directa con } \\
\text { los elementos naturales. }\end{array}$ \\
\hline Veverka & $\begin{array}{c}\text { Establece los } \\
\text { lineamientos } \\
\text { interpretativos en } \\
\text { relación al aprendizaje, } \\
\text { comportamiento y } \\
\text { emociones }\end{array}$ & $\begin{array}{l}\text { Conformado por el objetivo de aprendizaje el cual consta } \\
\text { de establecer a la ribera del Shullcas como un medio de } \\
\text { recurso paisajista en la ciudad. El objetivo de } \\
\text { comportamiento busca revalorar en la población los } \\
\text { recursos y elementos naturales que posee el territorio } \\
\text { huancaíno. Con respecto a los objetivos emocionales, estos } \\
\text { se establecen por medio de la selección de actividades y } \\
\text { programa interactivo con los usuarios. }\end{array}$ \\
\hline & $\begin{array}{l}\text { Proceso de } \\
\text { interpretación- } \\
\text { entender el recurso, el } \\
\text { usuario y desarrollo de } \\
\text { medios }\end{array}$ & $\begin{array}{l}\text { Complemento de la teoría en el análisis de la población de } \\
\text { Huancayo y en la selección de actividades y programas } \\
\text { con los objetivos de activar y recuperar en la propuesta del } \\
\text { Plan Maestro del Parque Lineal Ribereño Shullcas }\end{array}$ \\
\hline $\begin{array}{l}\text { Badaracco y } \\
\text { Scull }\end{array}$ & $\begin{array}{l}\text { Determina criterios de } \\
\text { evaluación para la } \\
\text { identificación de } \\
\text { potenciales } \\
\text { interpretativos }\end{array}$ & $\begin{array}{l}\text { El valor de singularidad y atractivo no son claramente } \\
\text { reconocibles debido al estado de degradación que se } \\
\text { encuentra en la zona .Por lo que el proyecto busca } \\
\text { potencializar la ribera del Shullcas como un espacio de } \\
\text { público que recupere sus elementos naturales, asimismo } \\
\text { considerar el factor de seguridad con la contemplación } \\
\text { del uso de las áreas de muy alta vulnerabilidad } \\
\text { exclusivamente como espacio público. }\end{array}$ \\
\hline $\begin{array}{l}\text { Countryside } \\
\text { Comission }\end{array}$ & $\begin{array}{l}\text { Determina aspectos a } \\
\text { evaluar en el análisis } \\
\quad \text { del usuario }\end{array}$ & $\begin{array}{l}\text { La consideración de los intereses y necesidades de la } \\
\text { población para el establecimiento diversidad de } \\
\text { actividades con diferentes horarios a fin de poder } \\
\text { establecer una configuración de uso del espacio del parque }\end{array}$ \\
\hline Pennyfather & $\begin{array}{l}\text { Determina medios de } \\
\text { interpretación de } \\
\text { carácter participativo }\end{array}$ & $\begin{array}{l}\text { En la propuesta de Plan Maestro, en este punto, se centra } \\
\text { en la iniciativa de establecer oportunidades de } \\
\text { participación e interacción con el parque así como el } \\
\text { diseño de senderos principales para su recorrido }\end{array}$ \\
\hline
\end{tabular}

Fuente: elaboración propia 
Tabla 8. 2 Aplicación del Marco normativo y operativo al diseño de la propuesta del

\section{Parque Lineal Ribereño Shullcas}

\begin{tabular}{|c|c|c|}
\hline \multirow{3}{*}{$\begin{array}{l}\text { Marco Normativo - } \\
\text { Metodología del } \\
\text { estudio del Paisaje }\end{array}$} & $\begin{array}{l}\text { Determinación de criterios del } \\
\text { paisaje }\end{array}$ & $\begin{array}{l}\text { Respetar la topografía y vegetación del } \\
\text { lugar, definición de bordes urbanos y } \\
\text { espacios de transición, integración } \\
\text { paisajística y visual, preservar vistas } \\
\text { hacia lo paisajes de mayor valor, } \\
\text { Establecer actividades económicas, } \\
\text { intervenir adecuadamente los } \\
\text { accesos potenciar el suelo no } \\
\text { urbanizado, y favorecer el acceso y } \\
\text { disfrute a los paisajes en un contexto de } \\
\text { movilidad sostenible }\end{array}$ \\
\hline & & $\begin{array}{c}\text { Permitió establecer los límites de área de } \\
\text { intervención comprender las tres } \\
\text { unidades paisajísticas de la Huancayo } \\
\text { conformadas por la Ribera del Shullcas, } \\
\text { área rural y urbana }\end{array}$ \\
\hline & $\begin{array}{l}\text { Definición del ámbito de } \\
\text { intervención, identificación de las } \\
\text { unidades del paisaje para la toma } \\
\text { de acción de medidas y acciones } \\
\text { de la propuesta }\end{array}$ & $\begin{array}{l}\text { Las medidas y acciones puntuales se } \\
\text { plantean con la incorporación de } \\
\text { infraestructura verde conformado por la } \\
\text { integración y continuidad de espacios } \\
\text { libres, recursos ambientales, culturales, } \\
\text { visuales, sociales y conexiones } \\
\text { ecológicas funcionales que formen un } \\
\text { parte todo del sistema de espacio abiertos } \\
\text { y corredores y además de la activación } \\
\text { de la propuesta por medio de programas } \\
\text { establecidos con la finalidad de aseguran } \\
\text { la preservación y la puesta en valor del } \\
\text { paisaje concerniente a la ribera del } \\
\text { Shullcas que se encuentra en estado de } \\
\text { degradación. }\end{array}$ \\
\hline $\begin{array}{l}\text { Marco Operativo - } \\
\text { Regeneración }\end{array}$ & $\begin{array}{l}\text { Similitud de problemática urbana } \\
\text { : fragmentación territorial perdida } \\
\text { de elementos y recursos naturales } \\
\text {, transporte no planificado - }\end{array}$ & $\begin{array}{l}\text { Ha permitido la definición de objetivos } \\
\text { generales del Plan Maestro con la } \\
\text { finalidad de regenerar los bordes del río a } \\
\text { partir de las acciones de conectar, tejer, } \\
\text { integrar, recuperar y activar la Ribera del } \\
\text { Shullcas con la ciudad de Huancayo. }\end{array}$ \\
\hline
\end{tabular}

Fuente: elaboración propia 


$$
2
$$




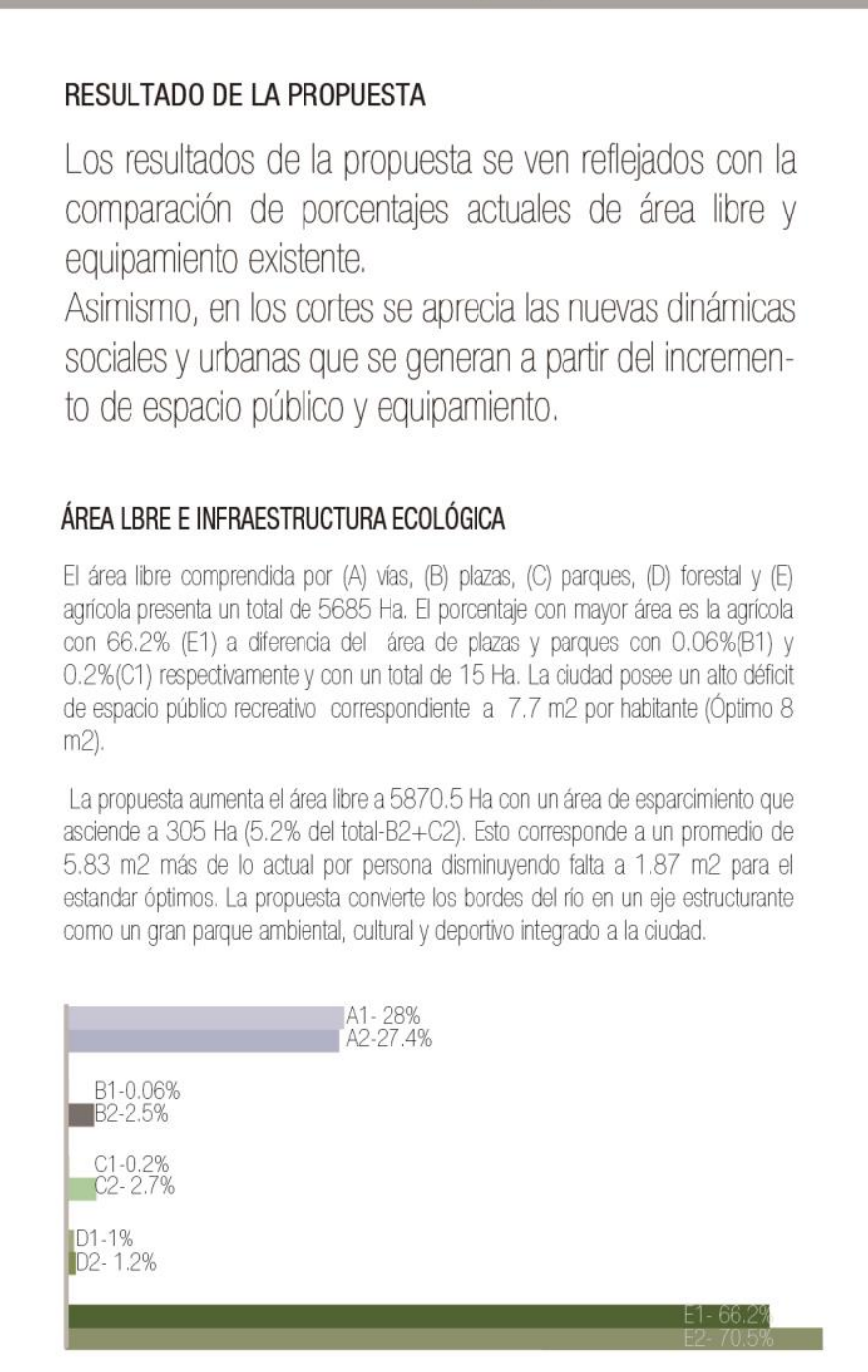

EQUPAMMENTO

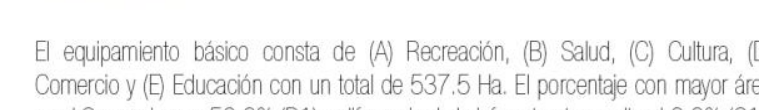

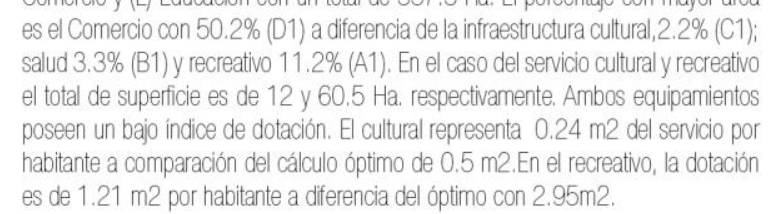

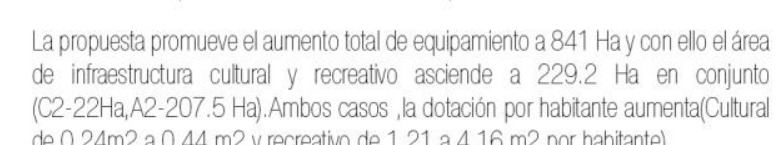

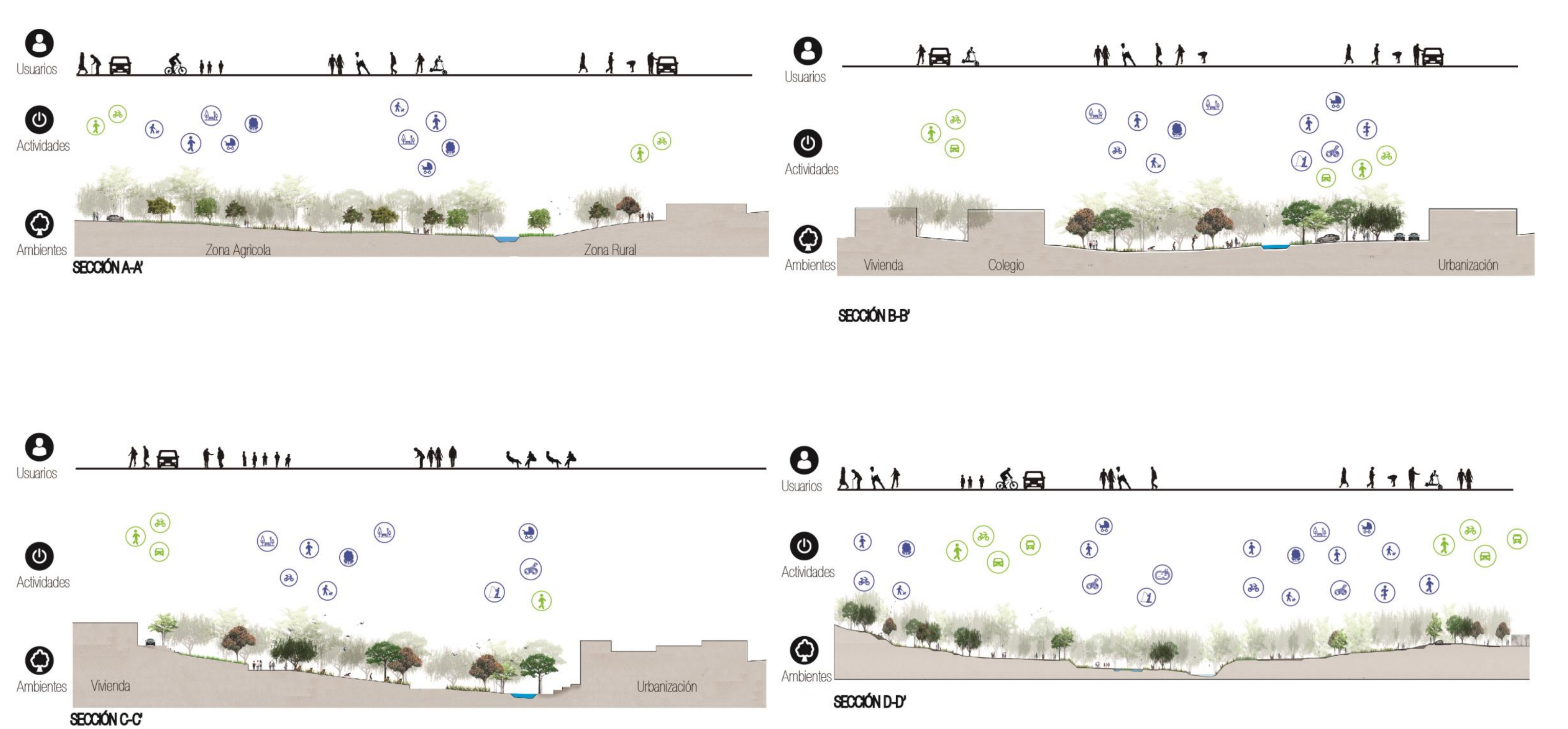



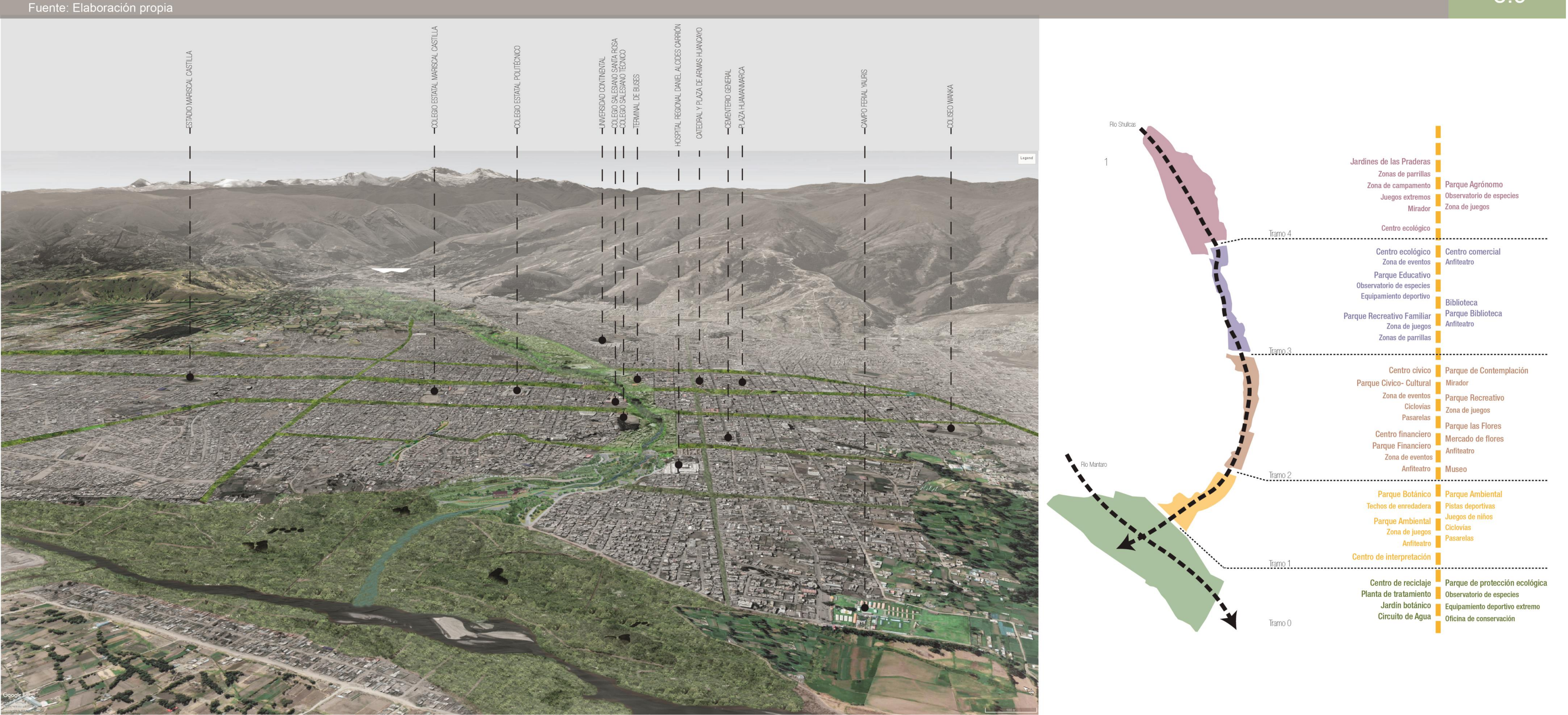


\subsubsection{Tramo 1}

\subsubsection{Definición del ámbito de intervención}

El diseño parte por la definición del ámbito de intervención de los tramos a nivel sectorial, de los cuales el tramo 1 corresponde al de carácter ambiental con un área de 27.7 Ha. Este se encuentra ubicado entre el puente Daniel Alcides Carrión y la futura proyección de la Vía Evitamiento.

Los márgenes de la ribera en donde se emplaza la propuesta pertenecen a dos distritos con diferentes contextos urbanos. La margen izquierda perteneciente al distrito de Huancayo es una zona urbana consolidada con viviendas en su mayoría de dos a tres niveles. También, en ella, se localiza parte del área de protección ecológica en dirección a la desembocadura del Shullcas. Por otro lado, en la margen derecha se ubica el Hospital Regional Alcides Carrión considerado punto referente e hito en la zona. Esta margen pertenece al distrito de El Tambo, conformado por un área semiurbana de viviendas en parte sin consolidar y con presencia aún de algunos campos de cultivo en la zona. A continuación, se explicará gráficamente (ficha 8.10) la ubicación y delimitación del tramo 1 en el contexto general de la propuesta. 


\section{UBICACIÓN}

E Tramo 1, del Parque Ribereño Shullcas, está delimita. do transversalmente por la Av. Daniel Acides Carión y por dos vís vahicureses de bain intensidad que son verdes del Master Plan

El área de intervención es de $27.7 \mathrm{Ha}$. y el recorrido se da de manera transversal y longitudinal, cuenta con 3 pasarelas peatonales, dos vias transversades de access vehicular y dos vías vehiculares longitudinales

La margen izquierda del Tramo 1 pertenece al distrito de Huancayo, se encuentra en una zona urbana consolidda con inges: la margen derecha netenece al distrito de - Tambo y se encuentra en una zona semiurinana dond aún se mantiene los campos de cultivo.

El carácter ambiental y recreativo que tiene el Tramo 1 es debido a la cercania a la zona de protección ecológica - de la ciudad y a la presencia de un hito cercano como Hospital Regional Daniel Accides Carion

Kevin Lynch define hito como un punto de referencia exterior al observador. Este equipamiento es definido de que lo hace visible desde diferentes puntos de la ciuda El tramo 1 está conformado por 4 zonas que son: Jardin Botánico, Parcue Ambiental, Zona de Protección ecollgica y Parque Recreativo

El jardín botánico se ubica cerca a la Av. Daniel Acides Carrión debido a su cercanía a la feria dominical tradicicial que sel leva a cabo en la ciudad. EP Parque recreatio Alcides Carión con acceso directo a hospital y equipa miento complementario. Finalmente, el Parcue Ambient se ubica cerca de la zona de protección ecolócica cono un medio de transición entre la ciudad y el área verde.
VAA EUTMMENO VIA MEROPOLITANA DE 4 CABARLES

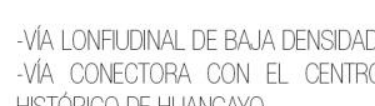

2 CALLL LOS COSMOS

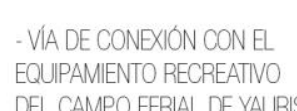

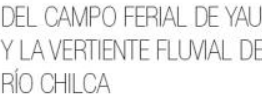

3AVENDA GATLINA HUANCA

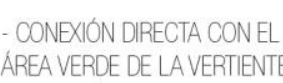

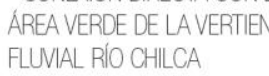

4.JIRON CARRIÓN

- VIA CONECTORA DEL
DISTRTOO DEE TAMBO

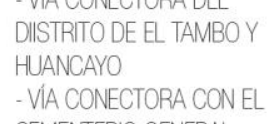

CEMENEROBO GEVERLL

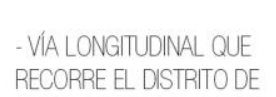

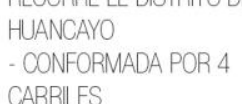

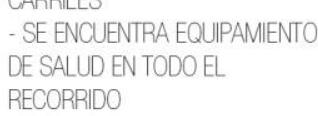

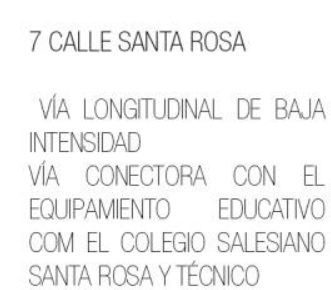

8 CAlleE a A RoYO

- VA L LNGGrUDONLL DE BANA

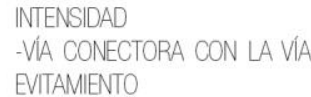

9. AV MARIATEGUI

- VA LONGTUDINLL OUE
RECORBE EL DISTRTO DE EL

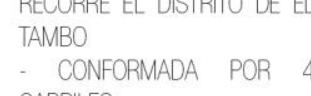

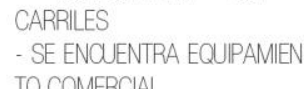
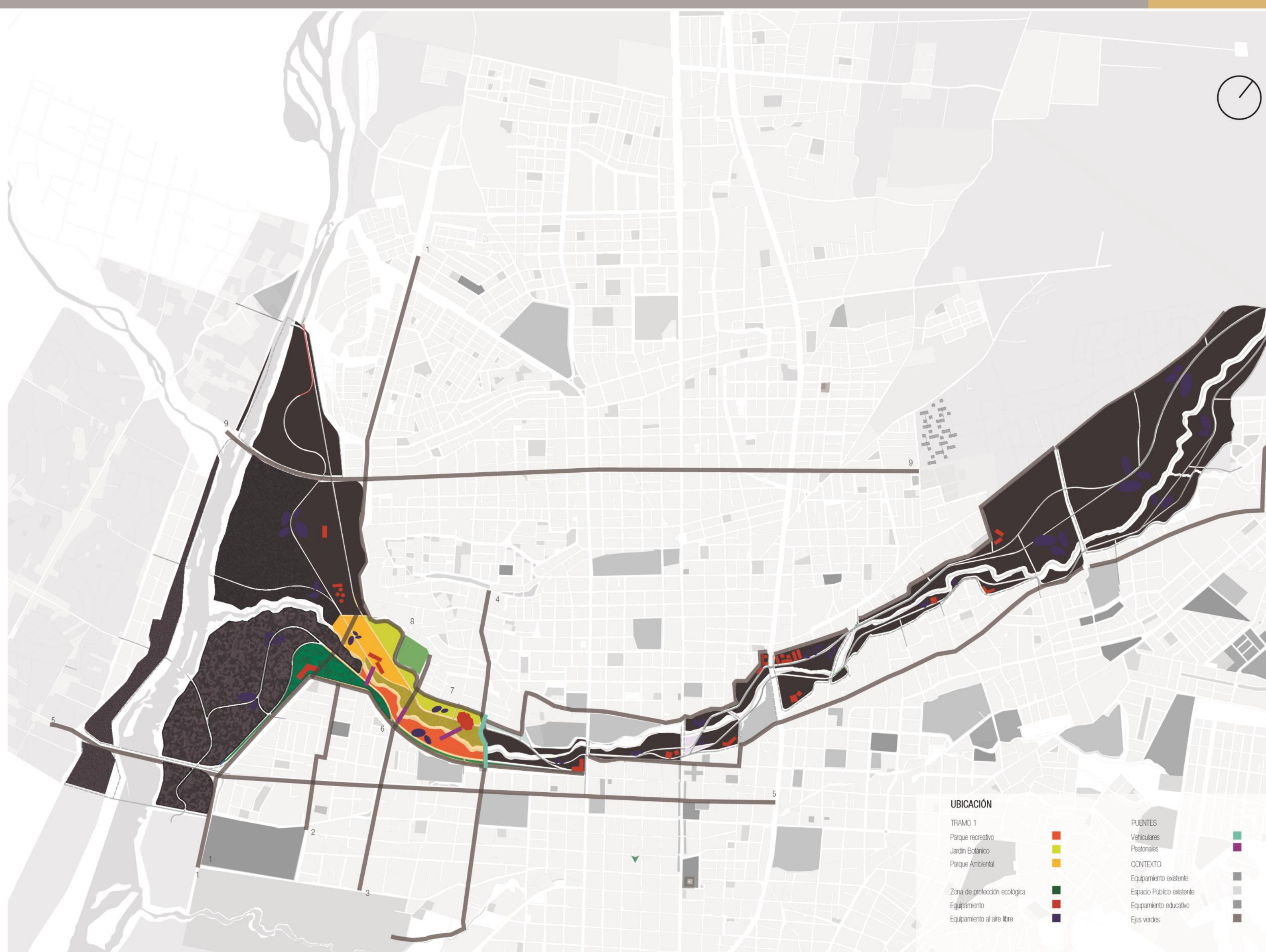


\subsubsection{Toma de partido}

La toma de acciones de la intervención parte del estudio de componentes del paisaje propios de la zona. El tramo está formado por áreas libres, un sector de zona de protección ecológica, área agrícola (actualmente amenazada por la venta y construcción en ella), construcciones ubicadas en zonas de riego muy alto (vulnerables a inundaciones) e infraestructura con usos no compatibles a la zonificación. Con ello, se considera la medida de expropiación del Master Plan que plantea la reubicación de las áreas que presentan conflictos paisajísticos debido a su condición de vulnerabilidad a inundaciones o infraestructura con usos no compatibles.

Asimismo, el estudio del paisaje urbano del sector muestra el estado de degradación al presentar el mayor índice de contaminación en la ribera y del Río Shullcas, la identificación de características potenciales como oportunidad para transformar y establecer una estructura y configuración del paisaje urbano del tipo de carácter ambiental que corresponda a las condiciones y necesidades a través de la incorporación de espacios de recreación y contacto con el medio natural.

Así, el tramo 1 parte de la definición de tres zonas particular (parque ambiental, parque recreativo y el jardín botánico) en respuesta a las dinámicas urbanas existentes al contexto inmediato y en conjunto con el área de protección ecológica ya establecida. , los cuales serán explicados con mayor detalle en (ficha 8.11)

Finalmente, la lógica del diseño considera de la lectura y estudio del paisaje entendido como un sistema definido por componentes que estructuran el terreno (topografía, hidrografía, vegetación, actividades, entre otros.). La intervención busca ser el resultado de la interpretación del conjunto de componentes del territorio. Por lo que la metodología proyectual parte de la composición entre capas de los elementos urbanos y naturales que constituyen la ribera del Shullcas. 


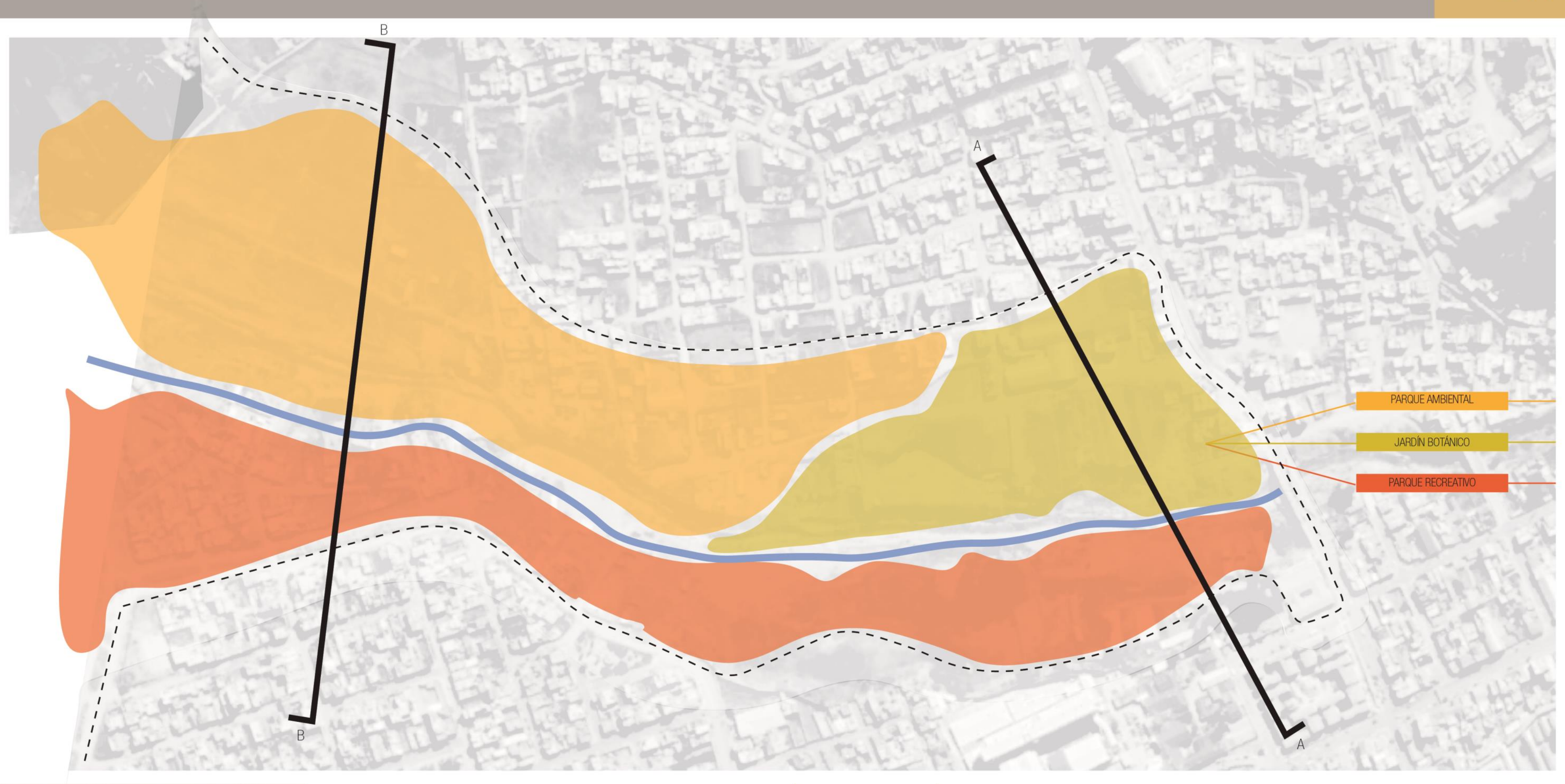

El área del Tramo 1 es de $27.7 \mathrm{Ha}$. De los cuales $10.39 \mathrm{Ha}$. pertenecen al Parque Ambiental, $6.65 \mathrm{Ha}$. al Parque Recreativo y

El terreno mantiene una topografía plana en comparación con los otros tramos del Paraue Lineal Ribereño Shullcas; la extensión de terreno es amplia debido a la ausencia de consolidación urbana comparada con los otros tramos.

Se visualiza parcelas agrícolas, en un $70 \%$ del terreno además de viendas en proceso de consolitación.

Los bordes del Río Shullcas presentan un atto indice de contaminación de suel y y agua, no existe contaminación sonora debido a ausencia de consolidación urbana.

El caudal promedio del Río Shullcas es de $5 \mathrm{~m} 3 / \mathrm{s}$ y en época de sequia desciende a $1.5 \mathrm{~m} / 3 / \mathrm{s}-\mathrm{A}$ ancho promedio es de 12 metros y tiene una pendiente de $7.5 \%$ con un dessivel de 2000 metros en $15 \mathrm{~km}$

En la zona baja del Río Shullcas donde se ubica el Tramo 1, la emperatura media es de $13.6^{\circ}$ y la máxima es de $21^{\circ}$, mientras que en el invierno varía de $1.2^{\circ}$ a $10.5^{\circ}$

Las siguientes láminas mostrarán un análisis detallado de la zona aledaña al Tramo.

\section{CORTE TRANERSALA

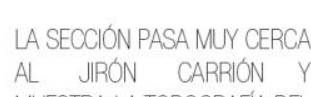

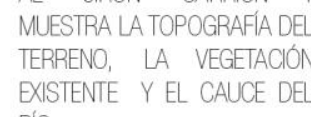 \\ 2 MAGENES TRAMO 1

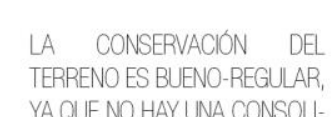

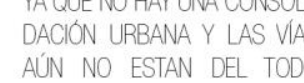 \\ ASFALIADAS.
ALAN MANIIENE UN USO
AGRBOLAA. \\ 3 CORTET TRANUVESALL B

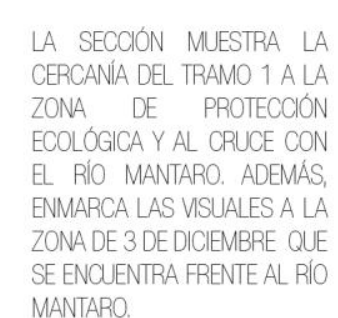

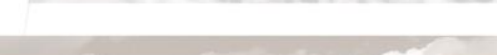
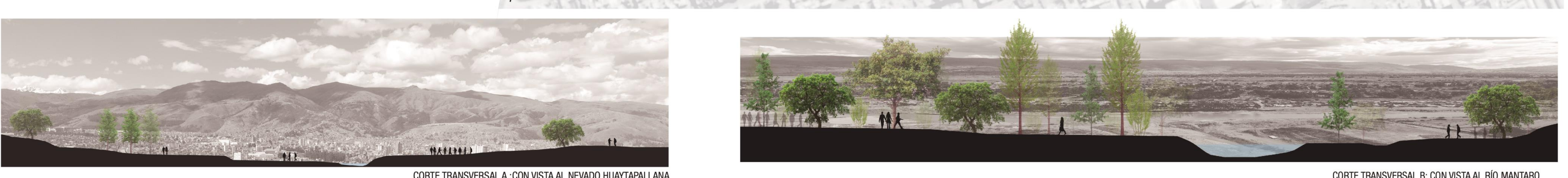


\subsubsection{Concepto}

La idea conceptual del diseño se desarrolla con la búsqueda de revaloración del paisaje. La ubicación particular del tramo 1 en relación al Parque Lineal Ribereño Shullcas se establece en la transición del área urbana y zona de tierra productiva insertada en la ciudad, por ello su carácter genera la intención de analizar la composición de parcelas y tipologías como la principal unidad de paisaje de suelo agrícola. A continuación, se detallará en (ficha 8.12) los elementos extraídos del concepto que configuran el diseño del lugar considerando su carácter productor. 


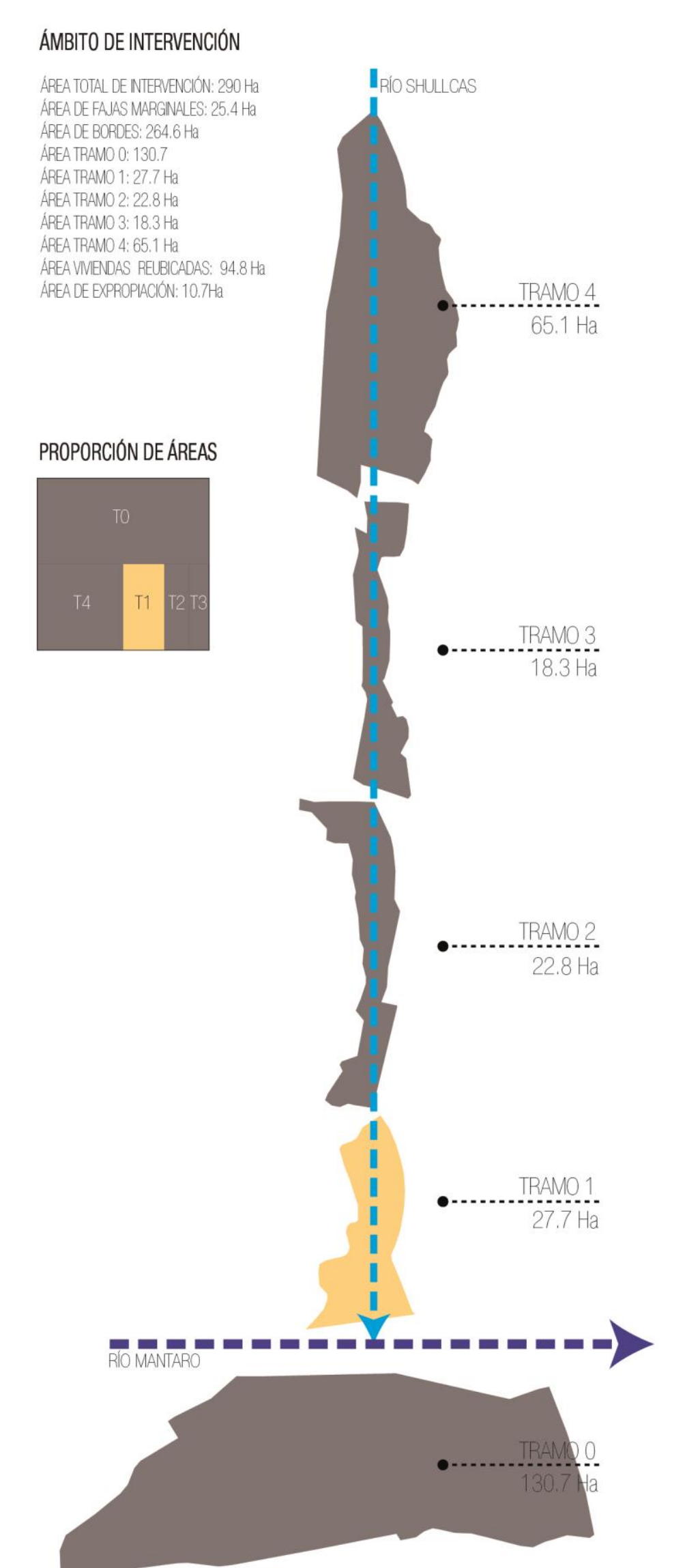

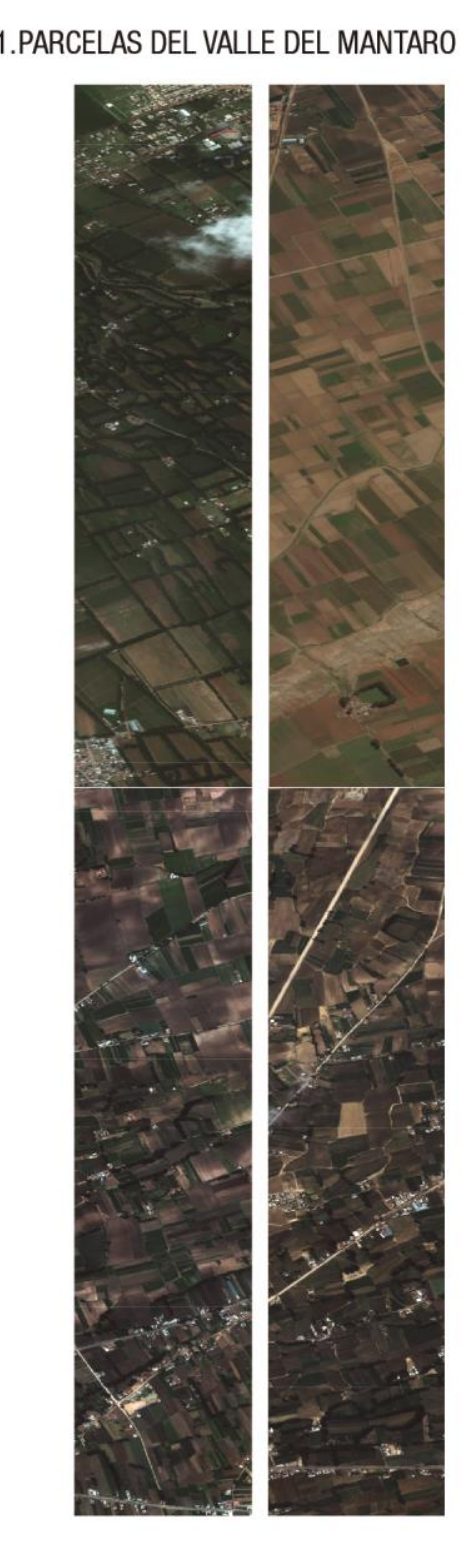

2. TIPOS DE PARCELAS

El concepto de diseño del Tramo 1 propone revalorar el Parque Lineal Ribereño

La ubicación del Tramo 1 esta en la intersección del área urbanay productiva de la ciudad, es por eso el inteŕśs de no perder la esencia del lugar.

En consecuencia se hace un estudio morfológico y de composición de las parcelas existentes en la zona, para poder extraer elementos que aporten al diseño.

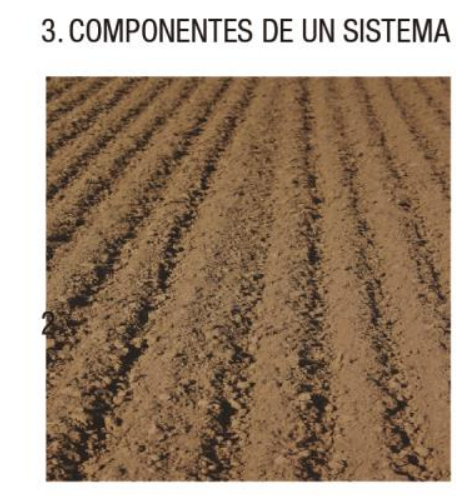

TIPOS DE PARCEIAS

Forma:

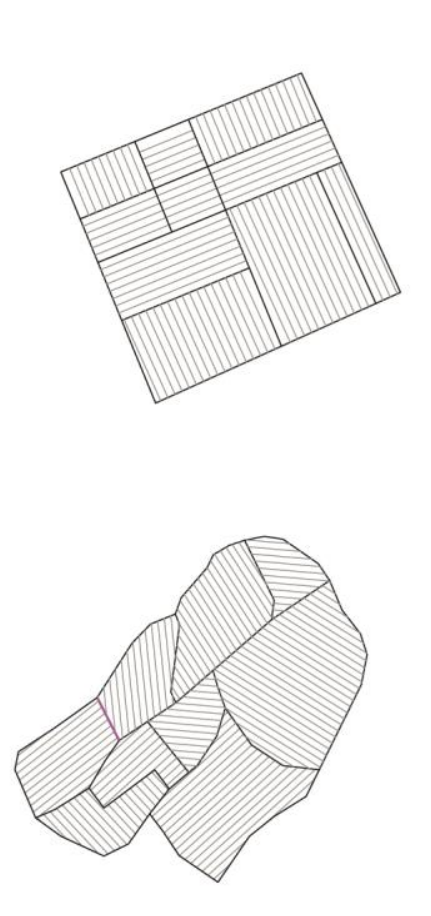

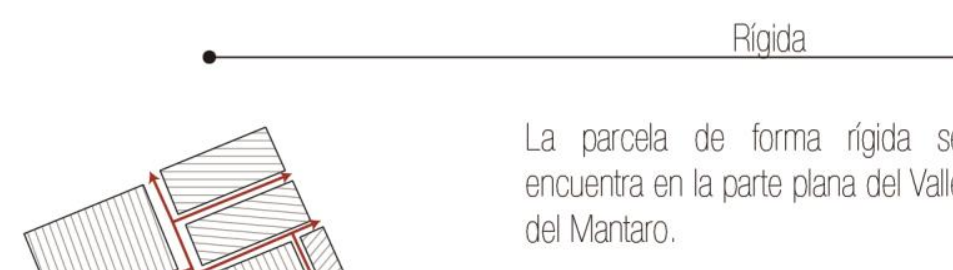
del Mantario a parte plana del Valle

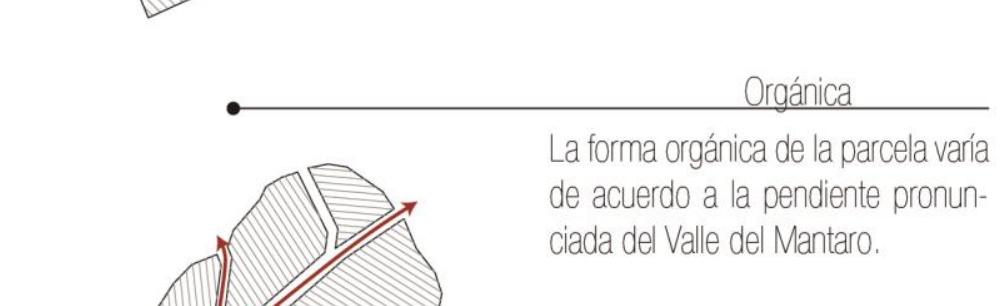

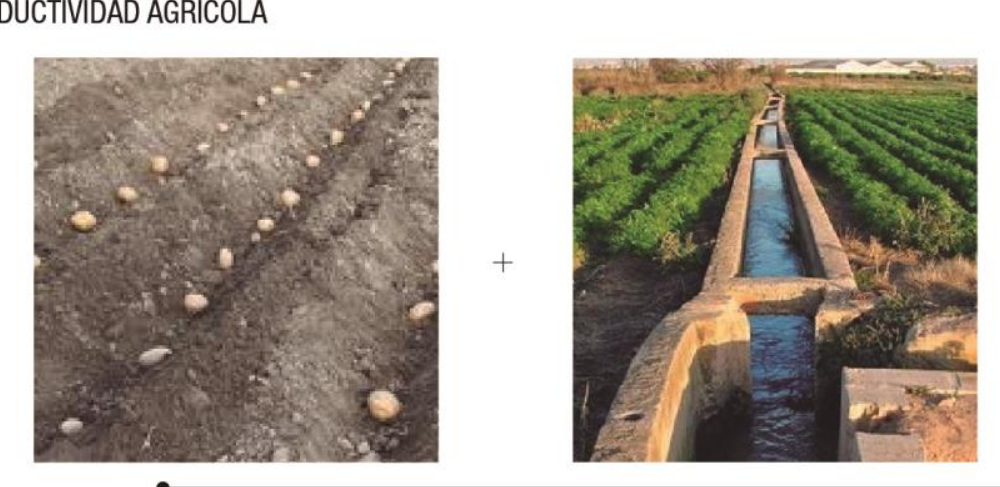

F. Es un sistema compuesto por capas

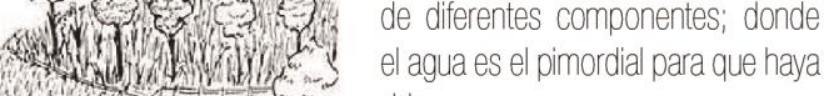
Ita coniunito de parcelas forma

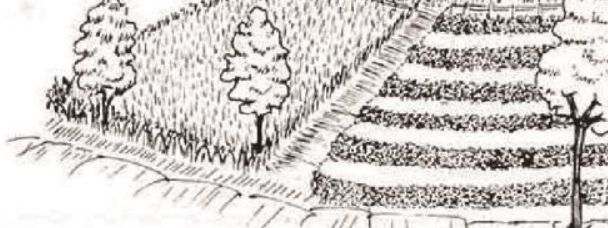
El coniunto de
paisaje agrícola.
Composición
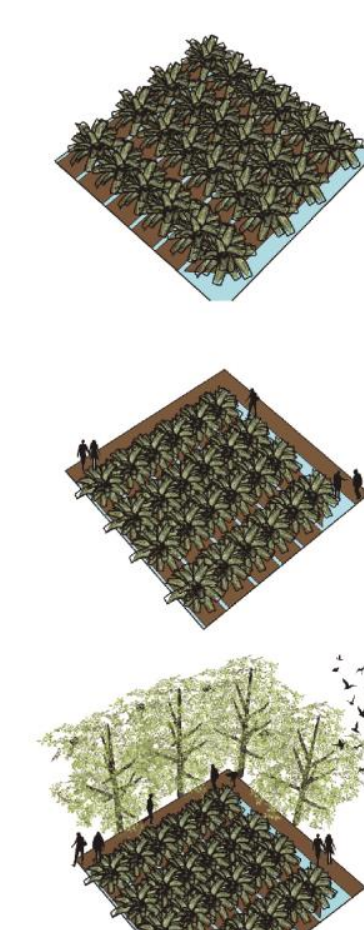

$\frac{\overline{---1}}{\text { Canninos }}$ o

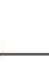

$\overline{\frac{----}{\text { Caminos }}}+\approx \approx \approx$

$\overline{\overline{--.-}}+\underset{\text { Caminos }}{\text { Arboles }}$

$$
\text { TOPOGRAFIA MED DEALCANTARILLDO }
$$




\subsubsection{Cálculo de Usuarios, programa y cabida}

El cálculo del programa y cabida se tomó en cuenta de acuerdo al estudio del Parque de Arganzuela, que forma parte de la intervención del Río Manzanares. E1 análisis, establece un ratio de áreas como referente para realizar la cabida. La metodología de cálculo se basa en la relación de las áreas de los paquetes programáticos y la cantidad de usuarios que el parque estima. En el caso del Parque Arganzuela, por ser parte del parque metropolitano Madrid Río, se toma en 500 mil de habitantes

En el caso de Huancayo, primero se define la población directa al proyecto que conforma un estimado de 362139 mil habitantes. Posteriormente, se establece un cálculo con los ratios establecidos de área verde (0.42), infraestructura cultural- ambiental (0.18), áreas de paseos (0.05), juegos (0.02), áreas deportivas (0.014), comercio (0.002) y administración (0.014). El cálculo total a intervenir da un aproximado de $24 \mathrm{Ha}$. 
La propuesta surge de una primera lectura y estudio del paisaje entendido como un sistema que esta compuesto por elementos que estructuran el terreno (topografía, hidrografía, vegetación, clima, etc.) Luego como punto de partida se realiza un analisis tipológico de la parcela ya que es la principal unidad de paisaje dentro del contexto de huancayo además de ser el principal recurso de producción agrícola. Con ambas iniciativas, la intervensión busca ser el resultado de la interpretación del conjunto de componentes del territorio. De modo que la la metodología proyectual se basa a partir de la composición orgánica entre capas de los elementos que constitual del proyecto del parque ribereño del Río Shullcas.

\section{ELEMENTOS ESTRATEGICOS}

\section{TOPOGRAFÍA}

El proyecto se asienta entre los niveles de 3203 hasta aproximademente los 3230 m.s.n.m. siendo una de las partes más bajas del recorrido del Río Shullcas. El terreno presenta diferenciación de niveles entre los dos margenes del río. En el derecho conformados por poca pendiente a lo largo del terreno mientras que el lado izquierdo presenta pendientes pronunciadas entre el inicio del parque con la ciudad y en partes del borde del Río generando un contacto más visual a diferencia del otro margén de contacto directo

\section{MOVILIDAD Y TRANSPORTE}

La movilidad en la propuesta no busca centralizarse en el interior del parque sino entendido como parte de un sistema integral de movilidad. De modo que la importancia del estudio previo de paraderos y rutas de buses existentes en la zona son analisadas para generar una propuesta de movilidad integral en la ciudad. Como parte de la propuesta primero se toma en cuenta el plantamiento existente de la vía de evitamiento pasa por el tramo 1 , sin embargo se propone el soterramiento de la vía en esa sección para no fragmentar la continuidad del parque y con la cercania de la desmbocadura del río. Por otro lado se platea ejes verdes que acompañan la idea de vias vehiculares contiguas al parque. de baja intensidad Asimismo, en este recorrido se ubican paraderos de buses y estacionamientos de manera estratégica que conectan a equipamientos o nodos importante

\section{PROGRAMA E USUARIOS}

Las propuestas programáticas tienen como principal objetivo la activación continua en el parque ribereño relacionado con la ciudad, por ello las actividades planteadas se vinculan con el caracter especifico de cada sector, unas más relacionadas a la naturaleza y otras a equipamientos de recreación, etc. En el tramo 1 se conforma 3 grandes zonas ( parque deportivo, ambiental y Jardín botánico) y un sector de transición pertenenciente al tramo 0 ( Protección ecológica). Por otro lado, el parque ribereño como conjunto de parques, plazas etc. plantea una serie de elementos transversales que tejen el parque en global. Estos equipamientos consta de áreas de servicios, miradores y puestas de arte.

\section{PAVIMENTOS - TEXTURAS}

La pavimentación es una estrategía que complementa y define los espacios ya establecidos para una mejor experiencia y disfrute del lugar. La propuesta plantea tipos colores y texturas (duras y blandas) en los difrentes uso del parque ribereño ( recorrido, áreas de estancia,zonas de juego y bordes exteriores)

\section{FLORA Y FAUNA}

La propuesta de flora y fauna parte de la interpretación cromático del paisaje posterior al analisis climático y de vegetación de la zona . Como desarrollo del caracter del tramo 1, se plantea situaciones paisajisticas a manera de patrones en el paisaje que involucran diversidad de colores y escalas para la defición de estas.

\section{PAQUETES PROGRAMÁTICOS Y CABIDA}

\section{A. PROGRAMA Y CABIDA}

Posterioremente a la explicación de la capa de elementos que involucra el tramo 1 del parque ribereño se plantea paquetes programáticos generales para establecer un calculo de áreas. Por otro lado se ha tomado en cuenta el estudio del referente del parque Arganzuela que forma parte del proyecto del Río Madrid a modo de establecer un ratio y realizar una cabida.

La metodología del calculo del ratio se basa en la relación de las áreas de los paquetes programáticos y la cantidad de usuarios del parque. En el caso del paque Arganzuela, por ser un parque metropolitano se toma en cuenta la cantidad de población de la ciudad de Madrid. Del mismo modo se establece con Huancayo.

\section{CÁLCULO DE ÁREAS}

Referente programa - Parque La Arganzuela, Madrid

Cantidad de habitantes: 5 millones

Para obtener los ratios:

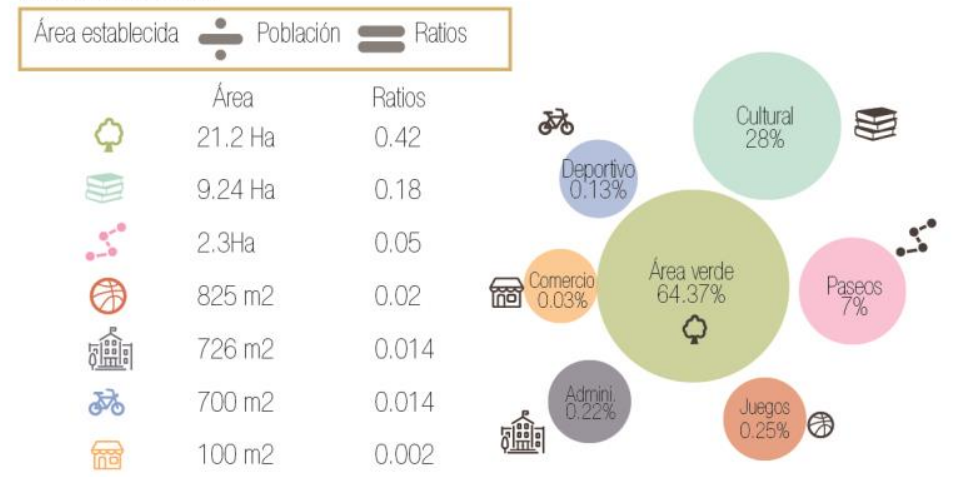

\section{CÁLCULO DE ÁREAS}

Cantidad de habitantes del la provincia de Huancayo: 362139

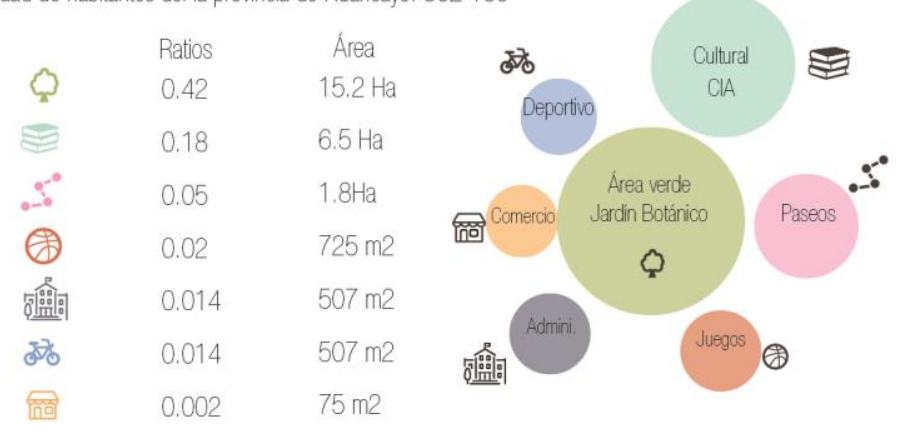

24 ha.

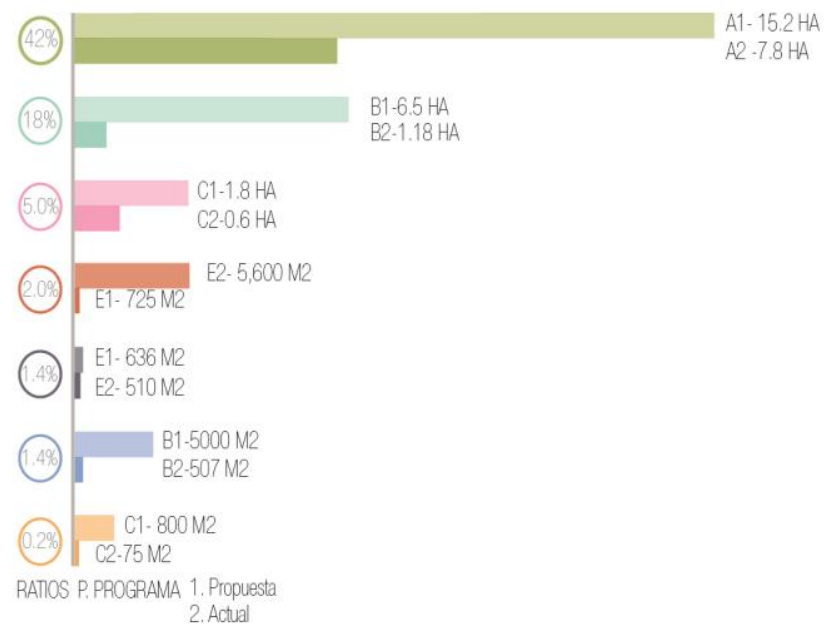




\subsubsection{Estrategias proyectuales}

Las estrategias proyectuales parten de la composición de capas de elementos urbanos y naturales basados en la topografía, movilidad, programa y actividades, tipos de pavimentos, mobiliario y flora y fauna que son respuesta de los objetivos (conectar, activar, integrar, tejer y recuperar) del Plan Maestro del Parque Lineal Ribereño Shullcas. Con ello la propuesta busca establecer una proporción equilibrada entre estos elementos urbanos y naturales a escala sectorial con el fin de mantener una armonía en el pasaje. A continuación (la ficha 8.14) se detalla la composición en capas del proyecto.

El primer elemento conformado por la topografía, aproxima al proyecto entre los niveles de 3203 hasta los 3230m.s.n.m. siendo una de las partes más bajas del recorrido del Río Shullcas. El terreno presenta diferenciación de niveles entre los dos márgenes del río. El derecho conformado por poca pendiente a lo largo del terreno mientras que el lado izquierdo presenta pendientes pronunciadas entre el inicio del parque con la ciudad y en partes del borde del Río generando un contacto del tipo visual a diferencia del otro margen de contacto directo.

Con respecto a la estrategia de movilidad (ficha 8.15), la propuesta no busca centralizarse en el interior del parque sino, que, al ser parte de un sistema integral se desarrolla de manera bilateral (externa e interna). Así la importancia del estudio previo de paraderos y rutas de buses existentes en la zona son analizados para generar la propuesta integral en la ciudad. Como parte de la propuesta primero se toma en cuenta la definición del trazado de la vía evitamiento que pasa en el extremo del tramo 1; sin embargo, se propone el soterramiento de este en la sección del parque para no fragmentar la continuidad. Por otro lado, en la (ficha 8.16) se plantea ejes verdes que acompañan la idea de vías vehiculares contiguas al parque de baja intensidad; asimismo, en este recorrido se ubican paraderos de buses y estacionamientos de manera estratégica que conectan a equipamientos o nodos importantes integrados a una red de corredores verdes que tejen la ciudad.

El programa y actividades se establecen con el principal objetivo de activar continuamente el parque ribereño en relación a las dinámicas de la ciudad, por ello las actividades planteadas se vinculan con el carácter específico de cada sector, unas más relacionadas a la naturaleza y otras a equipamientos de recreación. El tramo 1 está conformado por 3 grandes zonas (parque deportivo, ambiental y jardín botánico) y un 
sector de transición de protección ecológica. Por otro lado, el parque ribereño como conjunto de parques, plazas y equipamientos plantea (ficha 8.17) una serie de elementos transversales que tejen el parque con áreas de servicios, miradores y puestas de arte, tomándose en cuenta la relación de estos con la topografía (ficha 8.19). Asimismo, se considera los distintos horarios de las actividades para asegura un flujo constante en el parque, el cual se explica con mayor detalle (ficha 8.18)

La consideración del tipo de pavimentación y la incorporación de mobiliario configuran el objetivo de integrar como estrategia que complementa y define los espacios ya establecidos para una mejor experiencia y disfrute del lugar. La propuesta de pavimentos (ficha 8.22 y 8.23) plantea tipos de colores y texturas (duras y blandas) en los diferentes usos como recorrido, áreas de estancia, zonas de juego y bordes exteriores a lo largo del tramo. La propuesta de mobiliario, parte de la necesidad de mejorar las condiciones del lugar implementando iluminaria, bancas, racks de bicicleta, paneles informativos etc. para propiciar mayor uso y disfrute del parque.

La estrategia de inclusión de flora y fauna parte de la interpretación cromática del paisaje previo al análisis climático y de tipos de vegetación de la zona. Como desarrollo del carácter del tramo, se plantea (ficha 8.24 y 8.25 ) situaciones, escenas paisajísticas a manera de tipos de patrones, las cuales se definen por medio de diversidad de colores y escalas que propicien la contemplación del paisaje. 
ESTRATEGIAS GENERALES Y CABIDA

\section{1 .2 .5}

FICHA

8.14

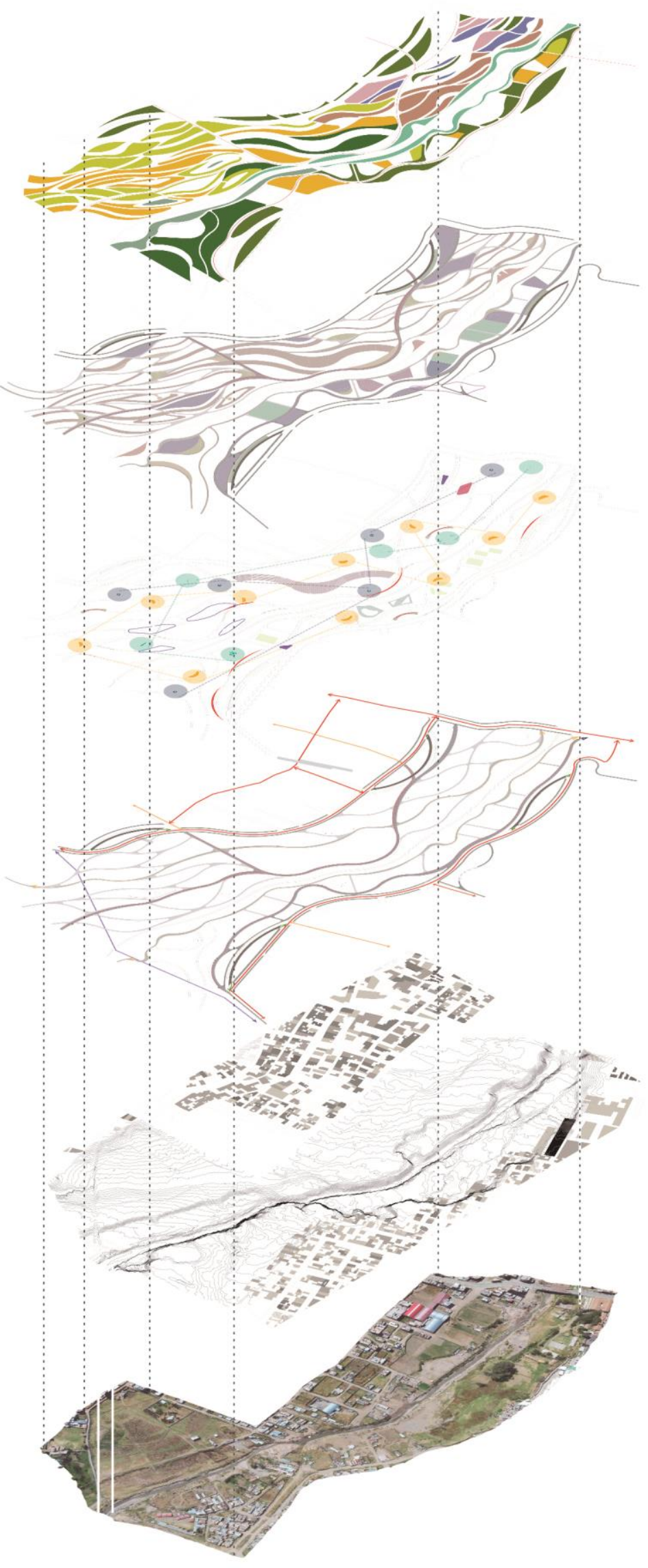

\section{FAUNA Y FLORA}

La propuesta de recuperación y revaloración de la fauna y flora de la ciudad parte como medio de reconexión con la población y su entorno. Se establecen diferentes situaciones para el disfrute y contemplación.

\section{PAVIMENTOS- TEXTURA}

E establecimiento de textura en pavimentos permite mejor definición de las actividades y espacios generados

\section{EQUIPAMIENTO}

La propuesta parte de tres tipos de actividades ( Jardín botánico Parque ambiental y Parque recreativo) que corresponden al estudio de dinamicas urbanas. Al mismo tiempo se establece equipamientos transversales que acompañan el recorrido general de

\section{Actividades para la recativación de espacios (Jahn Gehi)}

\section{MOVILIDAD Y TRANSPORTE}

La propuesta parte de la concepción de movilidad como sistema integral. El parque se integra a una red conjunta con la ciudad por medio de paraderos, ciclovías y ejes verdes.

Bordes / Espacios de fragmentación (Lynch)

\section{TOPOGRAFÍA Y CONTECTO URBANO}

Se genera una delimitación de superficies a tratar de acuerdo al contexto urbano , zonificación y zonas de riego.

VISTA AÉREA - DRON 
ESTRATEGIAS

\section{MOVILIDAD Y TRANSPORTE}

Un buen sistema de movilidad ayuda a reducir los efectos negativos de la ciudad.

Huancayo, en la actualidad no cuenta con un sistema de movilidad integrado y accesible., aún teniendo al Río Shullcas como eje estructurante.

Después del análisis realizado decidimos intervenir respecto a la movilidad y accesibilidad. Aprovechando la jerarquía del río creamos un sistema de circuito ambiental sostenible que consta de ejes verdes, caminos para el transporte peatonal y una red de ciclovía que articule la ciudad. Un nuevo corredor biótico metropolitano.

\section{MOVILIDAD EXTERNA AL PARQUE}

\section{CORREDORES VERDES}

Se crea dos tipos de ejes verdes para el Parque Lineal Ribereño Shullcas. E primero está compuesto por una vía vehicular, ciclovia, vegetación y vía peatonal y conecta el Tramo 1 vehicularmente con el área verde y espacio público existente. Los principales dentro del tramo 1 son las paralelas al parque, el Jirón Carrón, Catalina Huanca, Vía evitamiento, hasta antes del soterramiento y el Jr. Cañete.

El segundo tipo esta compuesto por una vía peatonal, ciclovía y vegetación. Estos ejes conectan el parque con el equipamiento y área verde existente.

\section{CREAR VÍAS VEHICULARES DE BAJA INTENSIDAD}

Las vias de baja intensidad están compuestas por dos carriles vehiculares, carril de ciclovia, carril de buses de transporte público, paraderos necesarios distanciados cada 400 metros aproximadamente, veredas y vegetación. De esta manera se convierte en un eje verde que permite la conexión con el resto de la ciudad.

\section{CREAR PARADEROS}

Los paraderos fueron ubicados de acuerdo al equipamiento existente y propuesto dentro del Tramo 1 y de acuerdo a la norma de movilidad y transporte que menciona la distancia máxima entre paraderos será de 400 metros. Con esa lógica se crea seis paraderos que se ubican en el plano adjunto.

\section{CREAR ESTACIONAMENTOS}

El acceso a los estacionamientos se ubica a partir del estudio del remate de vías vehiculares importantes, además se tuvo en cuenta en equipamiento cercano, en este caso, el Hospital Daniel Alcides Carrión.

\section{SOTERRAMIENTO VIA EVITAMIENTO}

Para generar un flujo constante y una unidad en el parque, se enterrará la Vía evitamiento, que es una vía de conexión provincial

\section{MOVILIDAD DEL PARQUE}

\section{CAMINO PRINCIPAL}

Se creo un camino de 6 metros de ancho a lo largo de todo el parque Lineal, se origina a partir de la cota continua del terreno, en el recorrido hay tramos que se ensanchan generando áreas de estancia con mobiliario para el descanso. Son las "venas" del parque que conectan los equipamientos principales

\section{CAMINO DE PASEO}

Se creo un camino de 3 metros de ancho, que recorre las áreas principales del parque, como el jardín botánico, el parque ambiental y el parque recreativo en ambas márgenes del Rio Shullcas. Hay tramos que se ensanchan para generar diversas situaciones en el recorido. Por su escala, son equivalentes a las "arterias" de un sistema.

\section{MOVILIDAD EN RELACIÓN AL PARQUE}

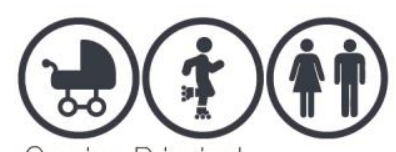

Camino Principal

$1 \mathrm{~km}$ de recorrido en el Tramo 1

Vía conectora con el Parque lineal Ribereño Shullcas

Cota continua del terreno

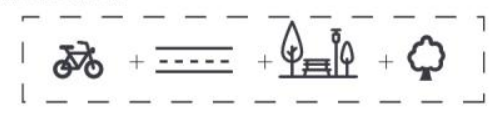

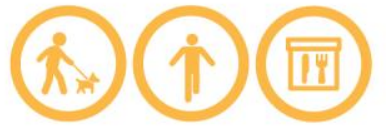

Camino de Paseo

$1.5 \mathrm{~km}$ de recorrido en el Tramo 1

Camino que conecta todo el equipamiento y programa del parque

compuesta por: camino+ áreas de estancia+vegetación

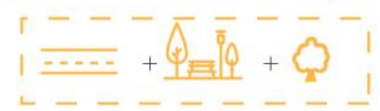

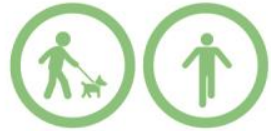

\section{Camino articuladores}

\section{$3 \mathrm{~km}$ de recorrido en el Tramo}

Caminos que permiten conocer la diversa vegetación del parque

compuesta por: camino+ vegetación

$$
\begin{aligned}
& 1----\frac{-}{3} \\
& 1-\cdots+--1
\end{aligned}
$$

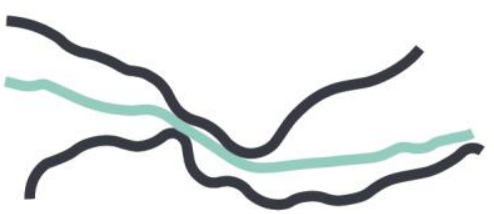

MOVILIDAD EN RELACIÓN CIUDAD + PARQUE

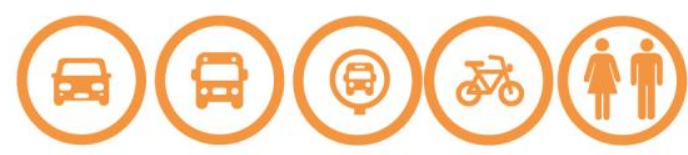

\section{Ejes verdes}

$1.5 \mathrm{~km}$ de recorrido en el Tramo 1

Corredores verdes que dan acceso a los estacionamientos del parque, contienen paraderos y conectan con el resto de la ciudad de Huancayo. Las vias vehiculares son de baja intensidad

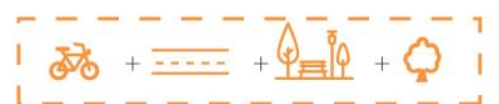

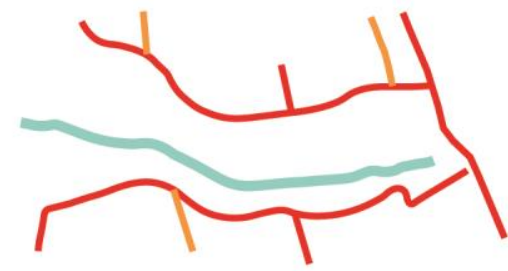


1. MOVILIDAD Y TRANSPORTE

TIPOS DE EJES VERDES

Tipo 1
的

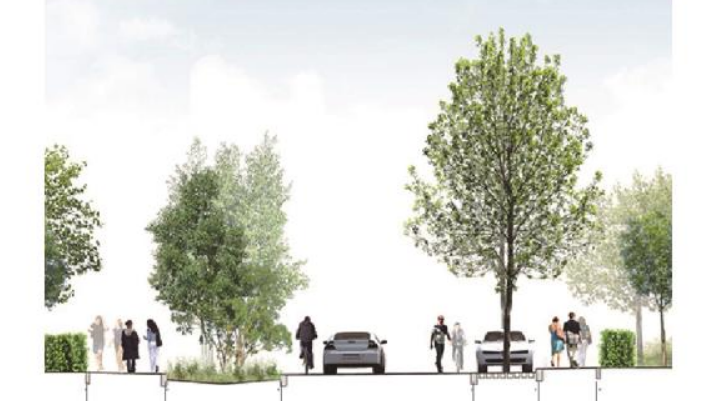
250,350 . 600 20m, 200 . I. I $_{F}$

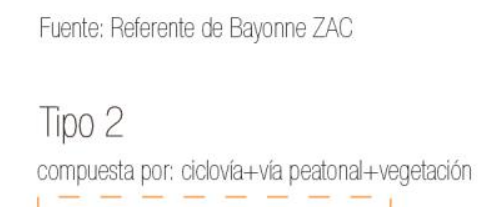

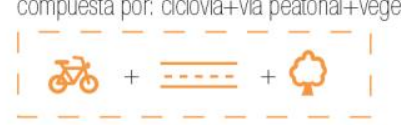
(1.) 19:

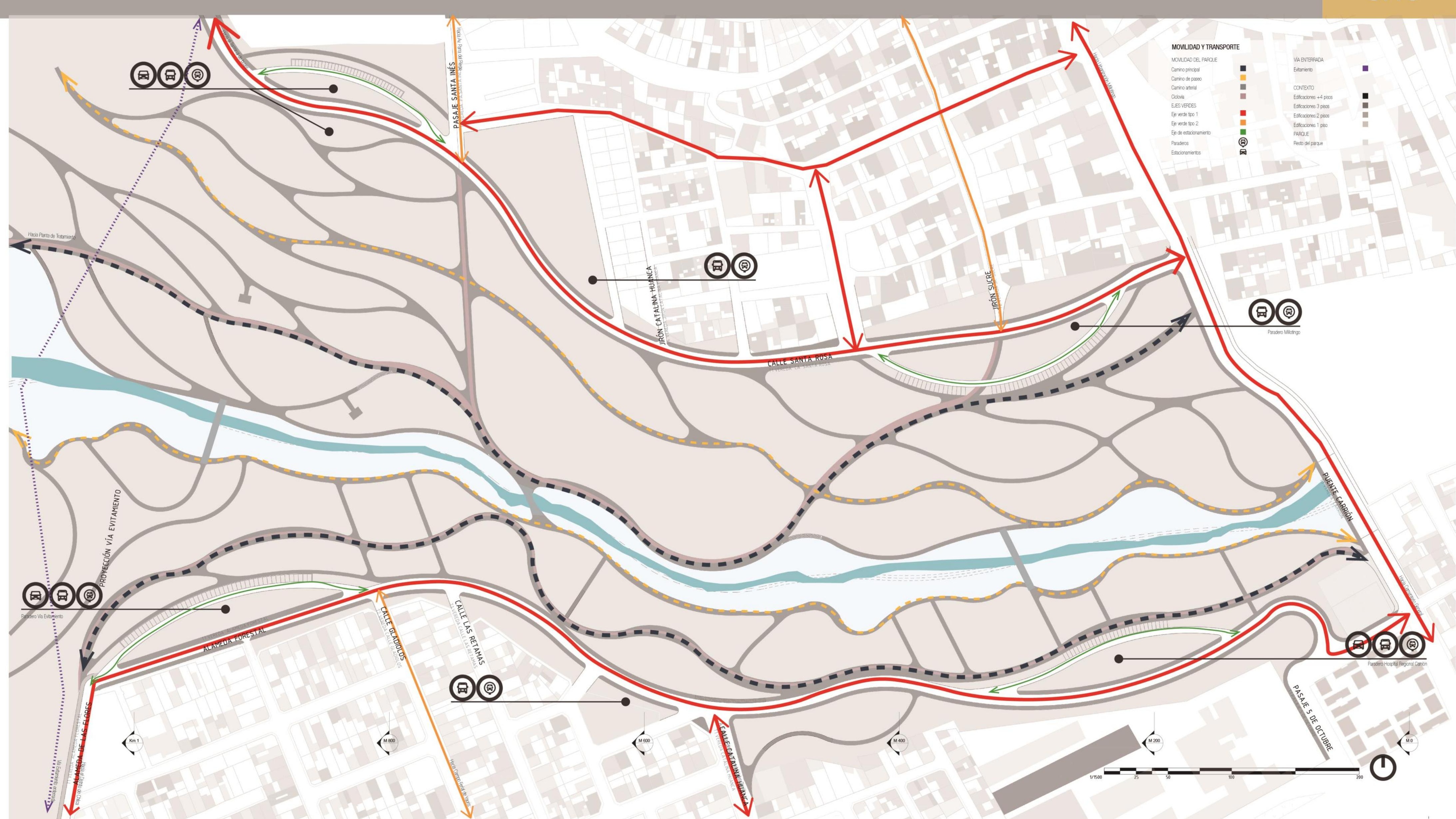


2. PROGRAMA Y ACTIVIDADES

\section{EQUPAMENTO TRANUVESSAL}

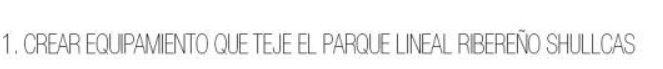

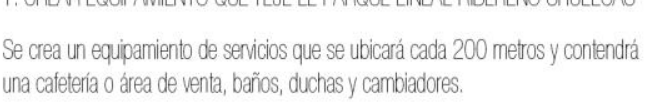

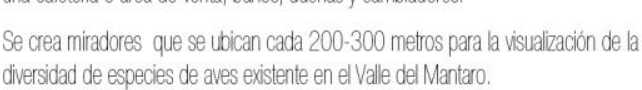

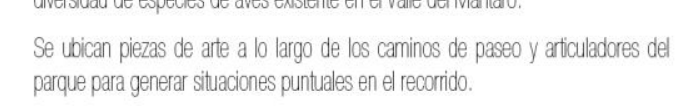

\section{EQUPPAMENTO JARDÍ BOTANCO}

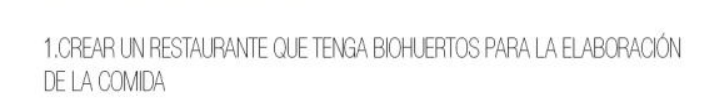

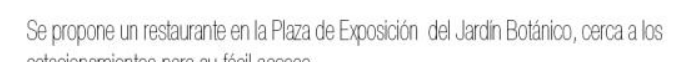

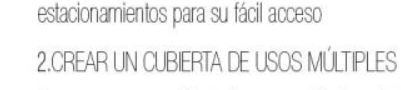

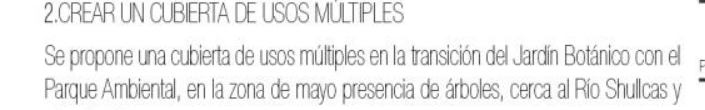

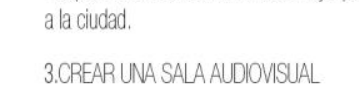

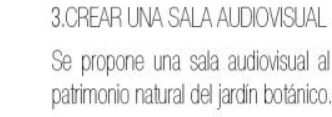

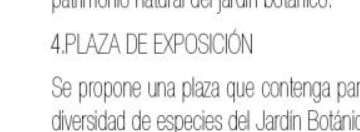

EQUPAMEETO PARQUEAMBENTAL

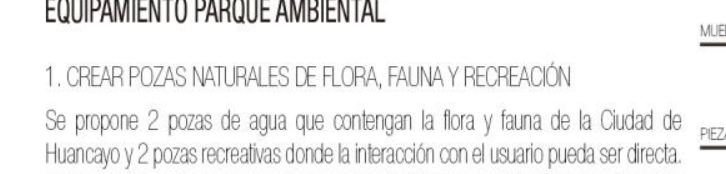

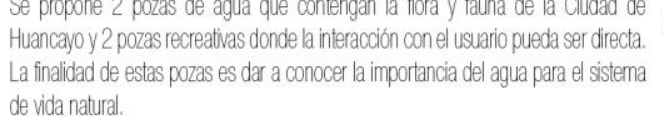

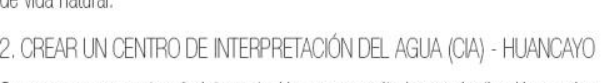

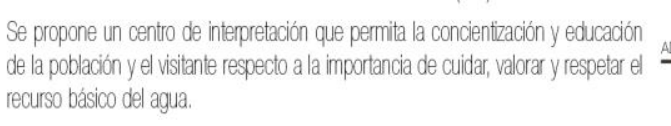

EOUIPAMENTO PAROUE RECEEATIVO

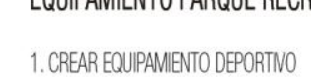

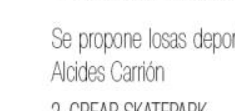

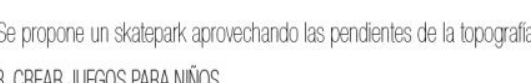

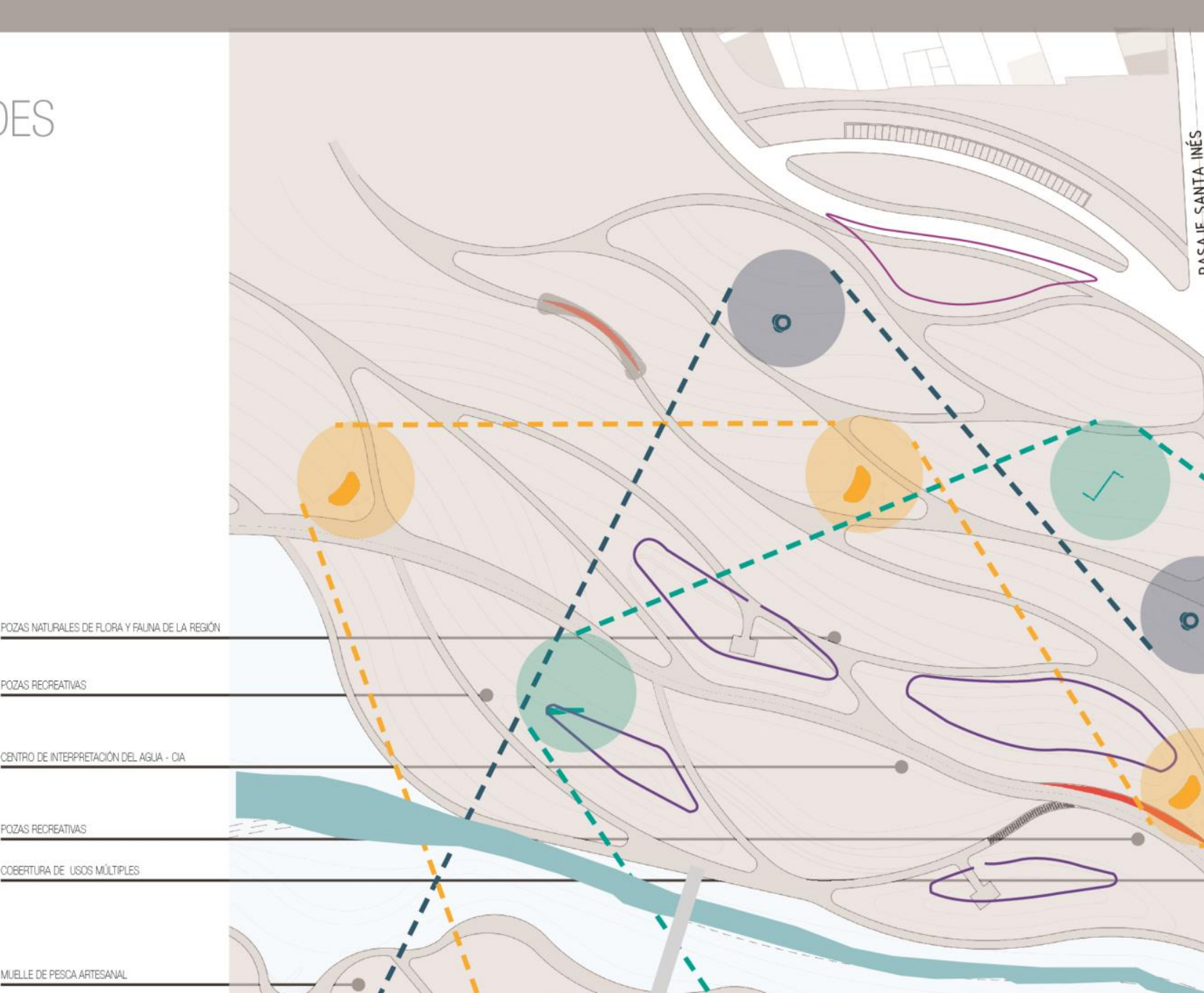

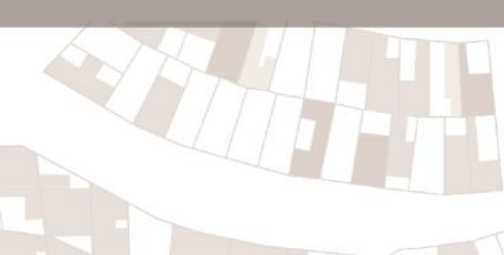
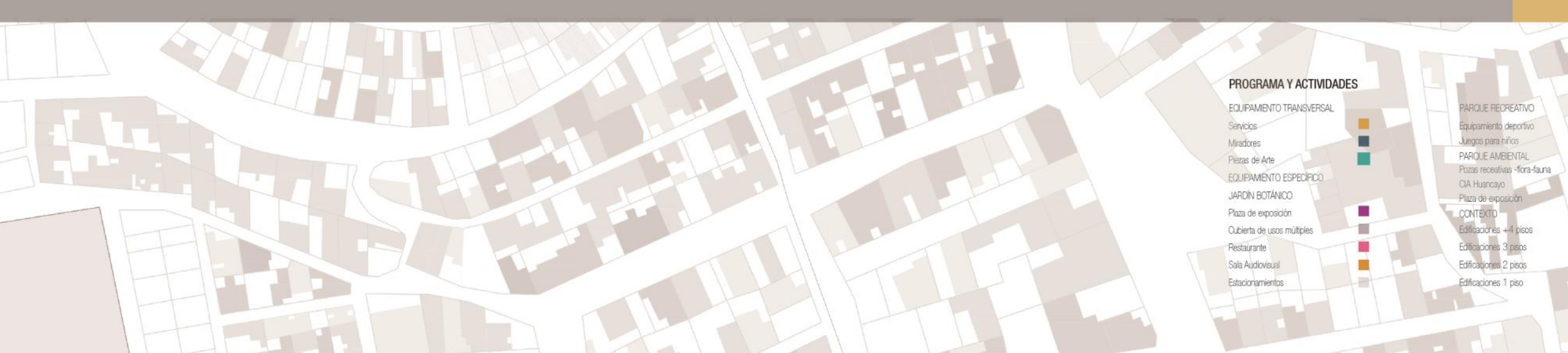

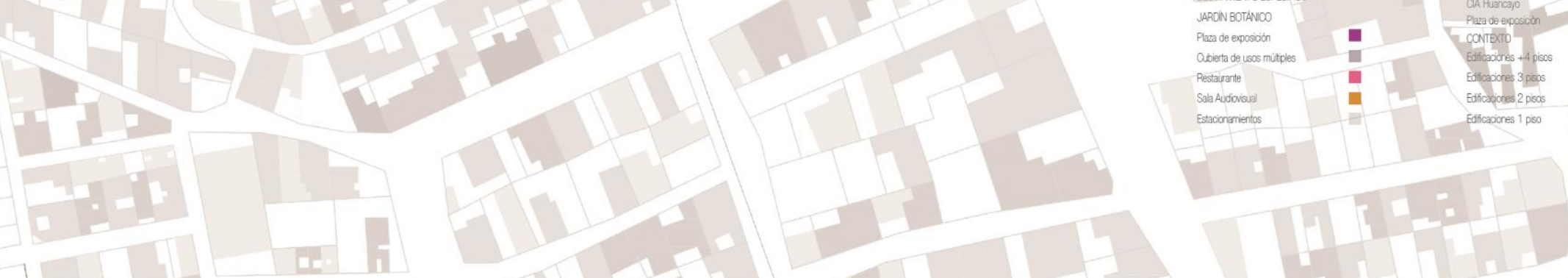

(1).
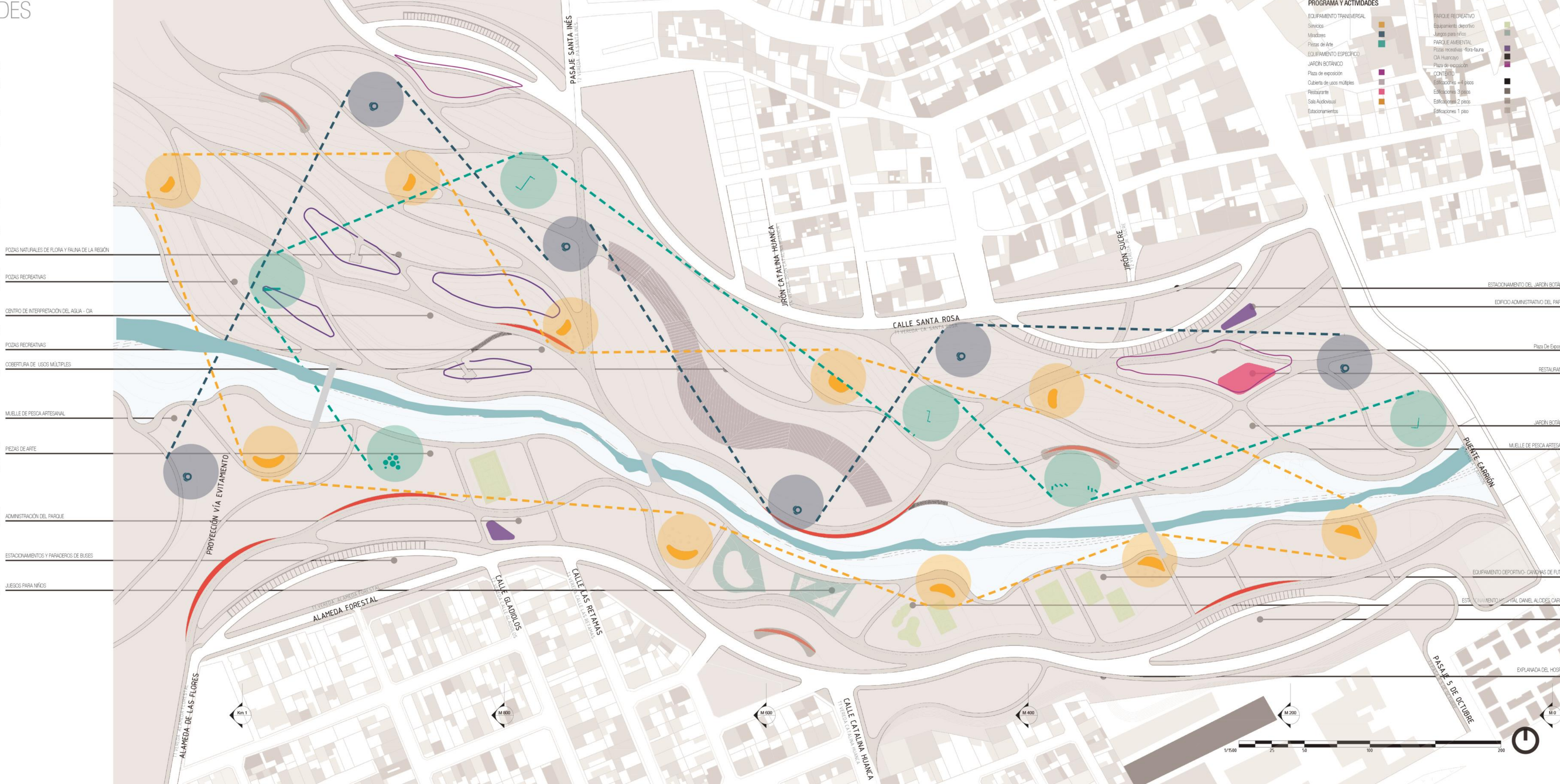


\section{ESTRATEGIAS}

\section{1 .2 .5}

Fuente: Elaboración propia

\section{PROGRAMA Y ACTIVIDADES}

El interés de generar un nuevo corredor biótico metropolitano de la ciudad de Huancayo es de reconectar al poblador con el patrimonio natural que aún posee y concientizar a este sobre la importancia que tiene dentro de la ciudad.

Para poder activar este corredor biótico es necesario crear espacios que contengan un programa y actividades en relación con la naturaleza para el visitante.

El tramo 1 contiene como áreas generales al Parque Ambiental, Jardín Botánico y Parque Recreativo y finalmente una zona de protección ecológica de la ciudad.

\section{EQUIPAMIENTO DE ACUERDO AL FLUJO PEATONAL}

\section{7:00 am - 9:0 am}

\section{Densidad peatonal}

La población que inicia el recorrido es

Madres de familia, escolares, trabajadores y estudiantes universitarios

\section{1:00 pm - 03:00 pm}

\section{Densidad peatonal}

La población que inicia el recorrido son

Escolares, estudiantes universitarios, turistas y personas de la tercera edad

\section{7:00 pm - 09:00 pm}

Densidad peatonal

La población que usa las instalaciones es

Turistas, Trabajadores, estudiantes universitarios

Parque Ambiental

Jardin Botánico

Parque Recreativo

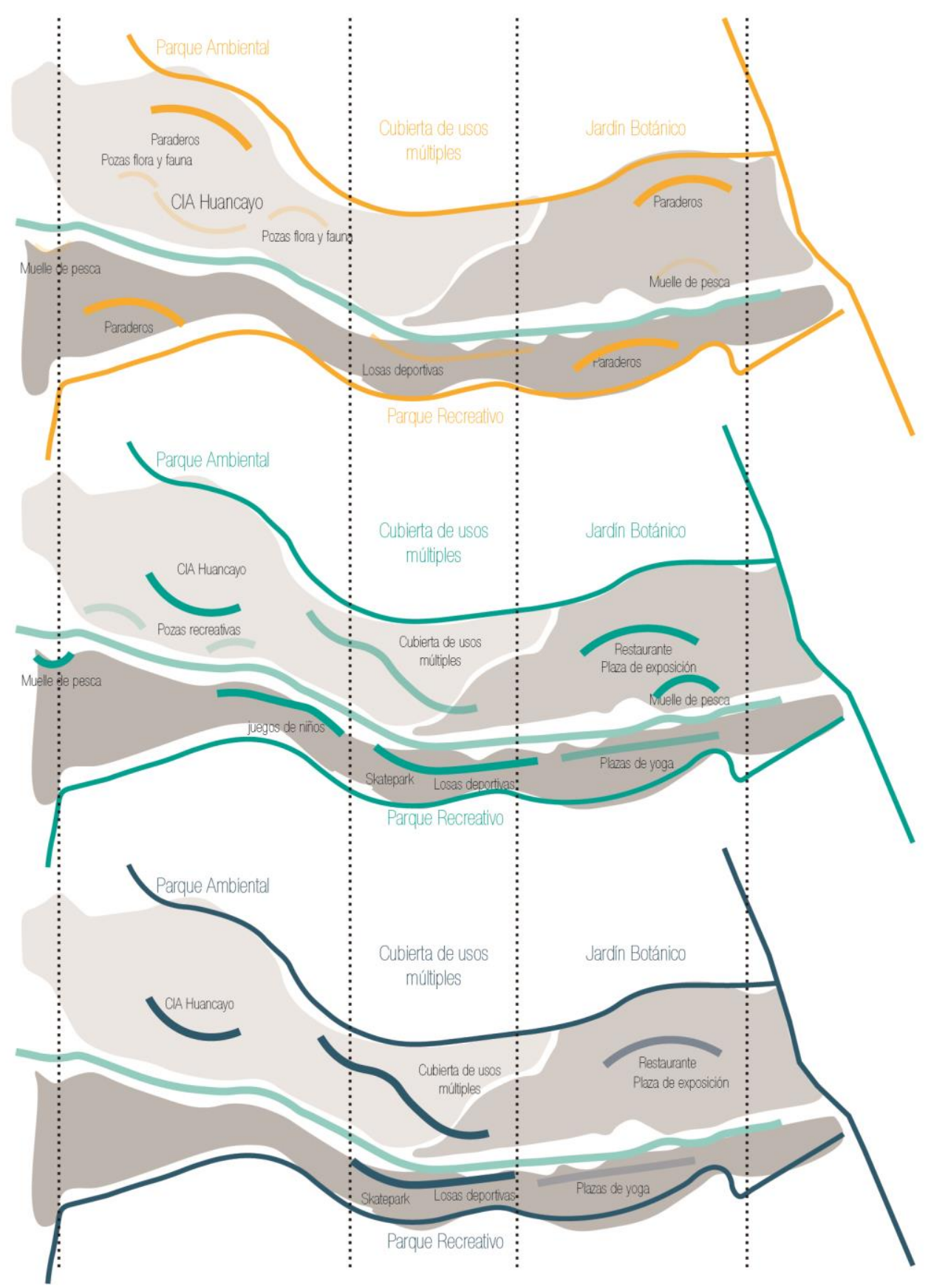




\section{ESTRATEGIAS}

\section{PROGRAMA Y ACTIVIDADES}

El interés de generar un nuevo corredor biótico metropolitano de la ciudad de Huancayo es de reconectar al poblador con el patrimonio natural que aún posee y concientizar a este sobre la importancia que tiene dentro de la ciudad.

Para poder activar este corredor biótico es necesario crear espacios que contengan un programa y actividades en relación con la naturaleza para el visitante.

El tramo 1 contiene como áreas generales al Parque Ambiental, Jardín Botánico y Parque Recreativo debido a su cercanía a la zona de protección ecológica de la ciudad.

\section{ACTIVIDADES DE ACUERDO AL EQUIPAMIENTO}

ACTIVIDADES RECREATIVAS

$\begin{array}{ll}\text { Muelles de pesca } & \text { Skatepark } \\ \text { Miradores } & \text { Cubierta de usos mútiples } \\ \text { Juegos de niños } & \text { Pozas recreativas } \\ \text { Skatepark } & \text { Plazas de yoga }\end{array}$

ACTMIDADES CULTURALES

CIA HUANCAYO

Interactua con el arte

Restaurantes + arte

\section{Exposición de Piezas de arte}

Sala audiovisual

Sala audiovisual
Shows de música, teatro

a

(2)

(6) (19)

(Q)

\%

(ख)

(i)

(1) 1

(A.) (190)

(19) (2) अन

(圆) (i)

(1) ख

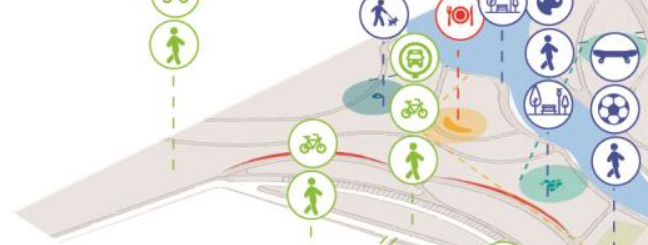

(1)

ACTIVDADES EDUCATIVAS

Recorrido de especies

Zona de protección

de flora y fauna

ecológica

Miradores

Presentaciones audiovisuales

CIA Huancayo

ACTIVIDADES AMBIENTALES

CIA HUANCAYO

Minihuerto ecológico

Pozas de flora y fauna

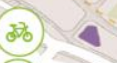

(i)

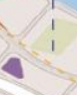

: 1

(1)
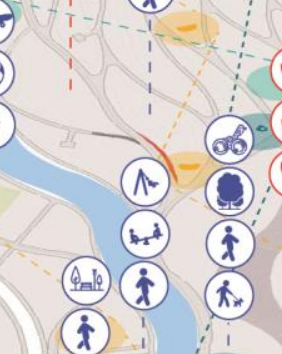

(स)
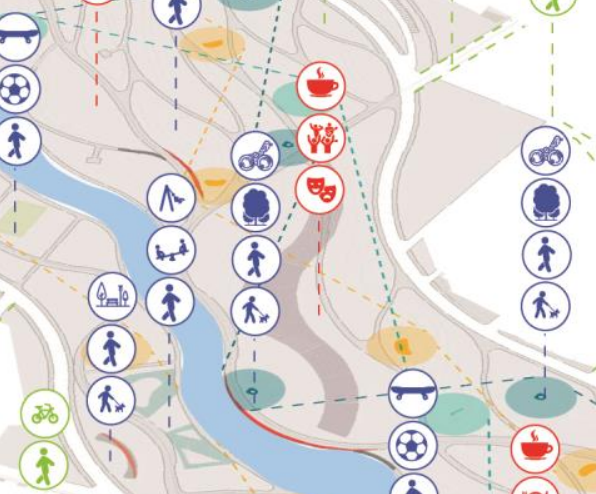
2. RELACIÓN TRANSVERSAL DEL PROGRAMA CON EL RíO

El corte A-A comprende por la margen dereccha el Parque Ambiental que contiene pozzas de agua recreativas,

de flora y fauna. La margen izuierda comprende la plaza de la Zona de Protección ecológica.
El corte C-C comprende por la margen derecha el límite del Jardín Botánico y Parque Ambiental.

El corte C-C comprende por la margen dereccha el limite del Jardín Botánico y Parque Ambiental.
Los cortes presentan los tipos de usuarios y actividades genereadas en diversos ambientes del parque.
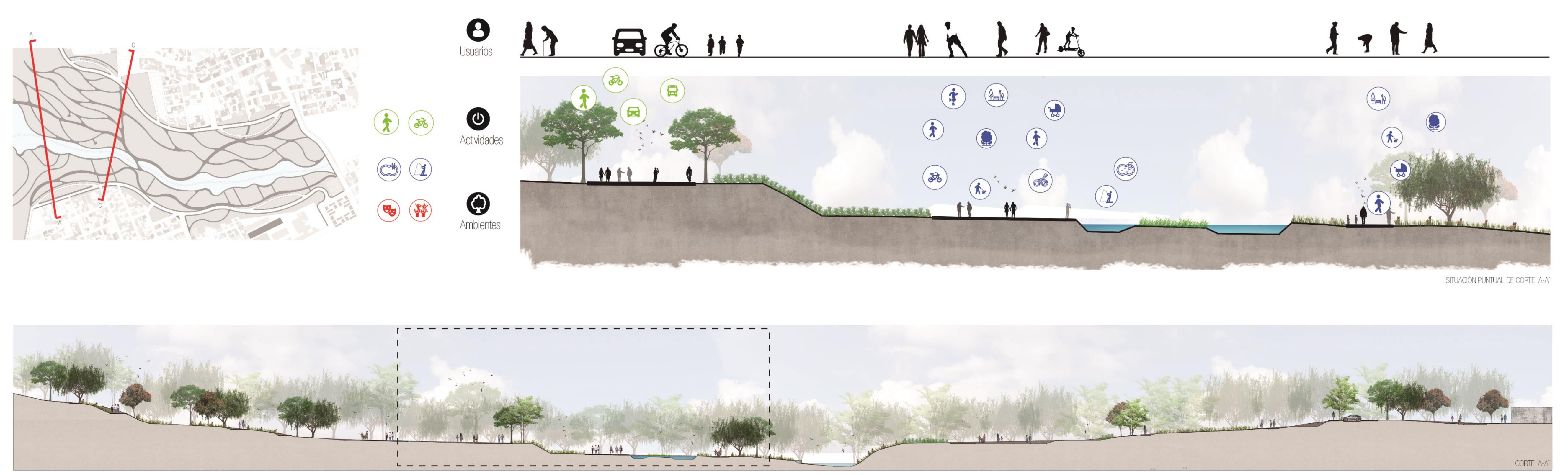


\section{RELACIÓN TRANSVERSAL DEL PROGRAMA CON EL RíO}

El corte A-A comprende por la margen derecha el Parque Ambiental que contiene pozzas de agua recreativas,

de floray fauna. La margen izauierda comprende la plaza de la Zona de Protección ecológica.
El corte C-C comprende por la marcen derecha el limite del Jardín Botánico y Parcuue Ambiental.

El corte C-C comprende por la margen derechha el límite del Jardín Botánico y Parque Ambiental.
Los cortes presentan los tipos de usuarios y accividades generadas en diversos ambientes del pargue.

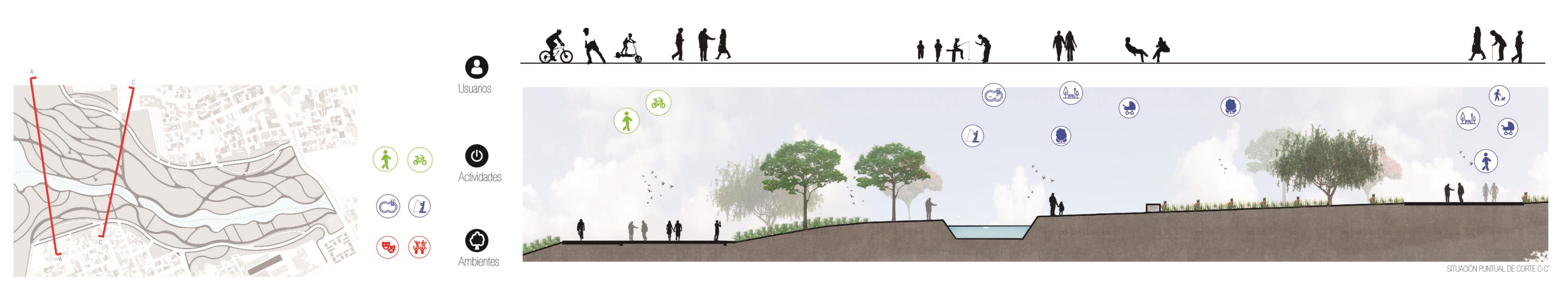




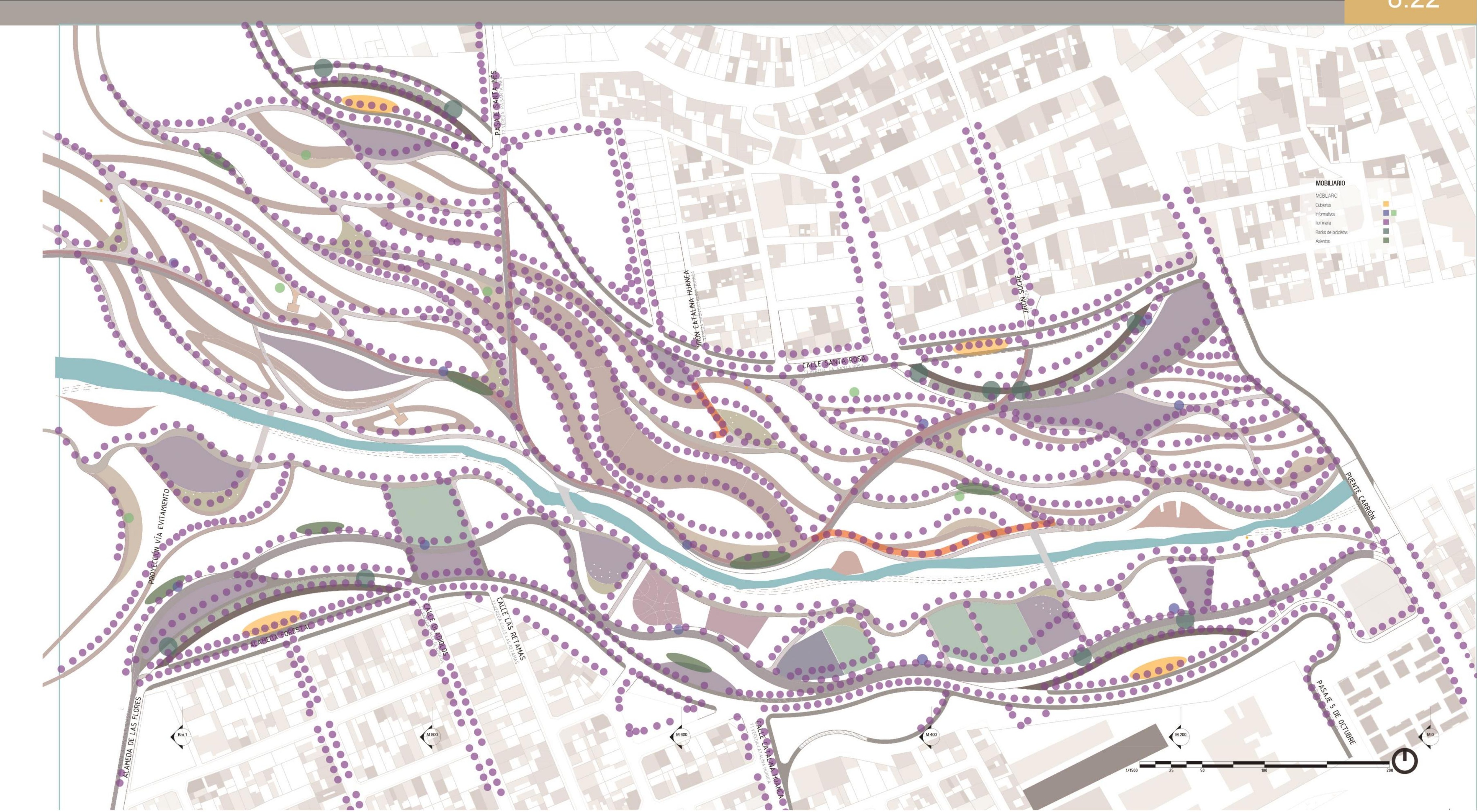

De acuerdo a las estrategias de movilidad y programa, se busca establecer diferentes tipos de pavimentiación el caso de espaciós de estancia o de paso. La propoues de pavimentación es importante ya que cada elementi es parte de la experiencia del disfrute. Como parte de - propuesta , la composicion está relacionada a las texur y colores que permitrán acondicionar y definir los

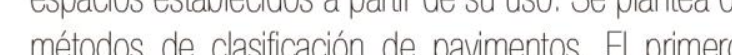
constituido por tipo de texturas de acuerdo a la materia lidad y el segundo por el tipo de uso.

CLASIFICACIÓN DE PAVIMENTACIÓN

1. POR TETURAS

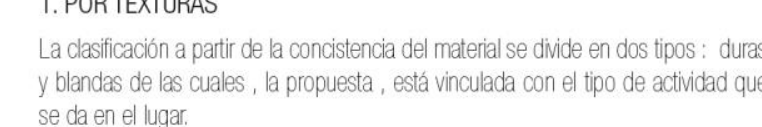
1A. PAMMENTO DURO

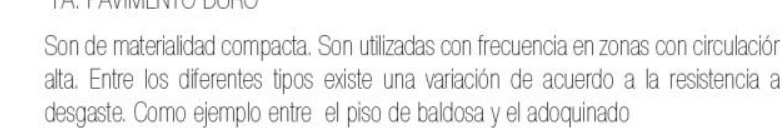
18. PAMMENTOBANDO

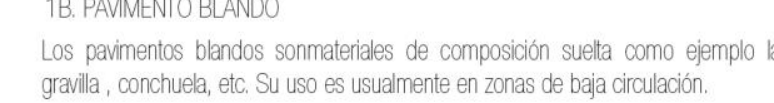

2 POR USO

2A. . . ECORBROO

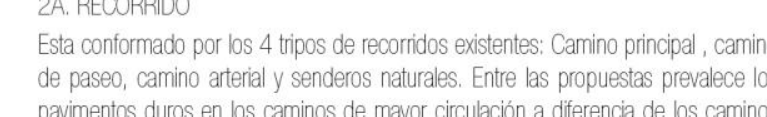

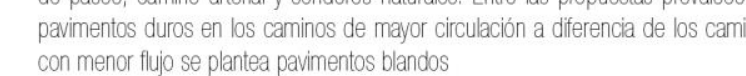

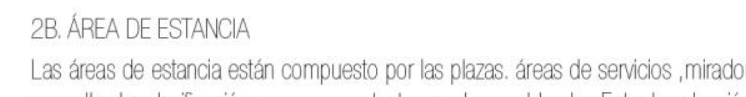

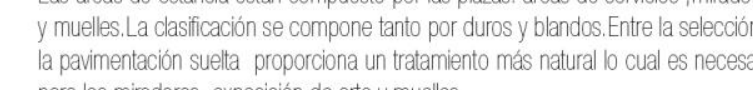

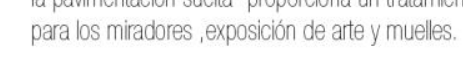


ESTRATEGIAS

\section{1 .2 .5}

FICHA

8.23

Fuente: Elaboración propia

3. PAVIMENTOS

TEXTURAS DURAS

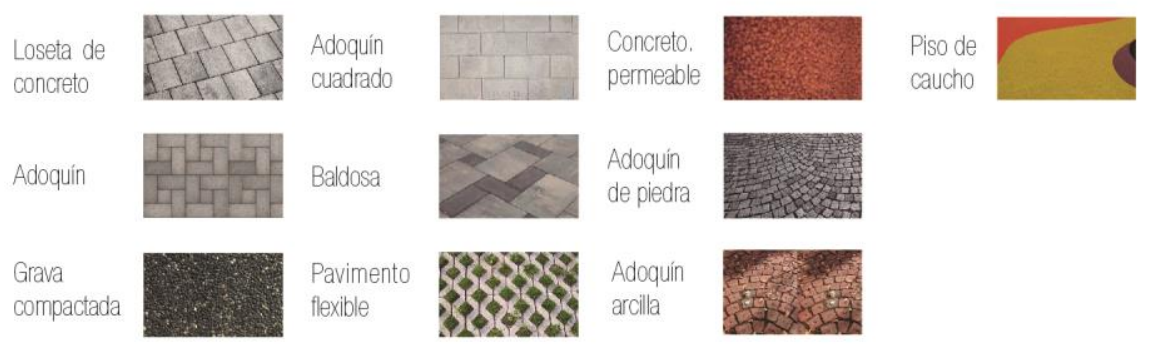

USOS Y TEXTURAS

Recorrido

CAMINO PRINAPAL

$8+\cdots+\ldots$

CAMINO PASEO

$: \cdots+9$
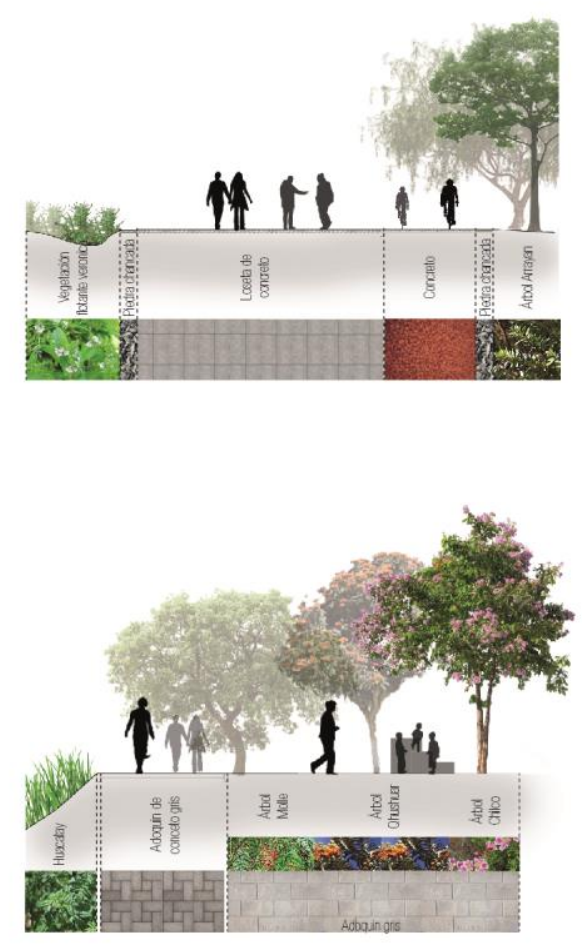

TEXTURAS BLANDAS

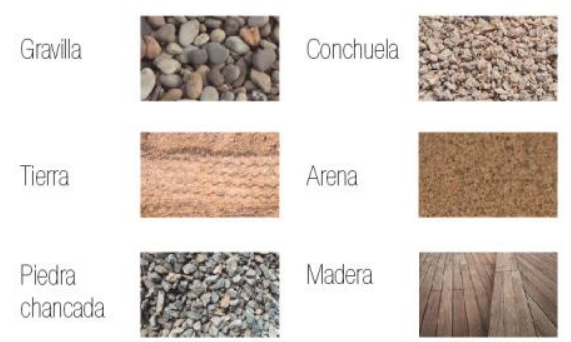

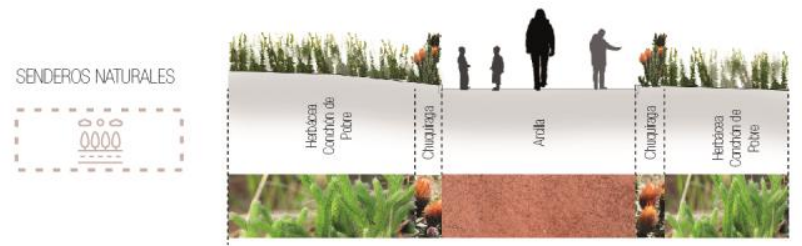

CAMNO ARTERIAL

$+\infty$

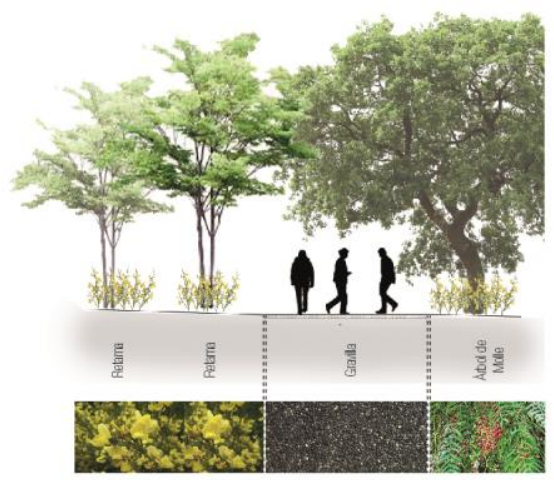

Áreas de estancia

Plaza CIA- Huancayo

Plaza de Exposidión CIA

Plaza de Exposición Jardén Botánico

Plaza de Zona de Protección Ecolobgica

Plaza Carión

Plaza Recreatva

Plaza Libertador

Servicios

Centros de senvicos
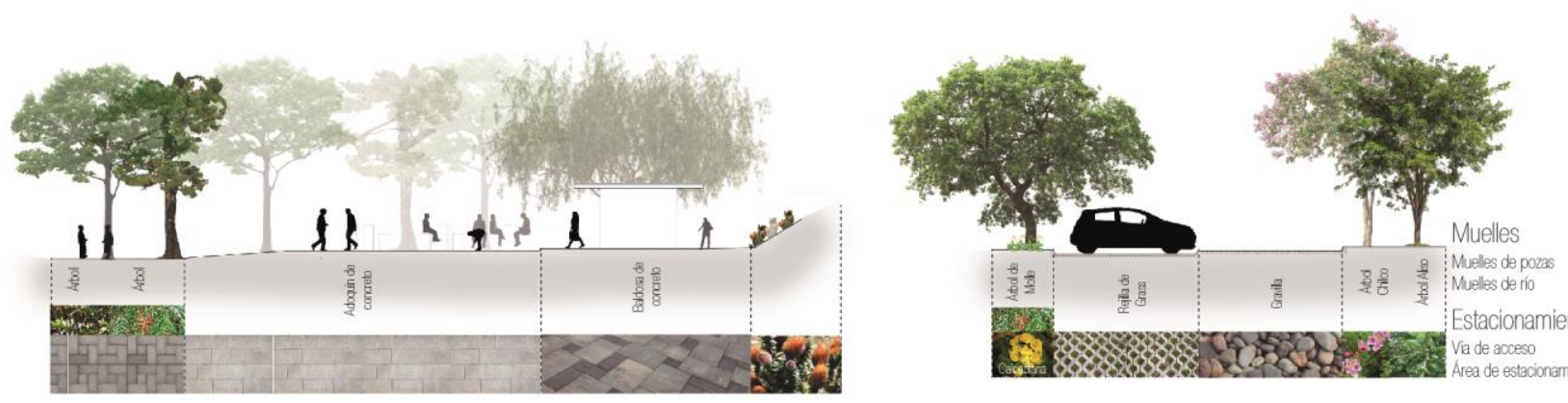

51 है Estacionamientic 


\section{FLORA Y FAUNA}

La recuperación y valoración del patrimonio natural del valle relacionada con su contexto urbano propone un proxximo con la ciudad. Con ello, la intervención por

tramos se desarrollla a partir de la interpretación del caraccter cromático del paisaje. En el caso del tramo 1 se cón de colores vivos y de carácter más calido como parte baja del recorrido del Rio Shulcas

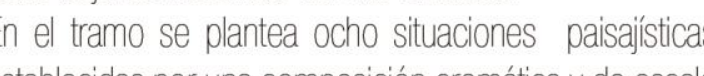

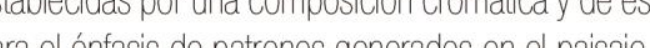
PATRONES PAISAISTIICOS

1.BB-BOSOUECALDC

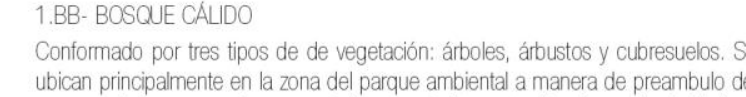
rescis

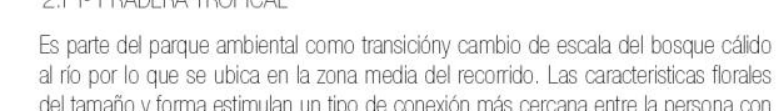

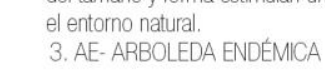

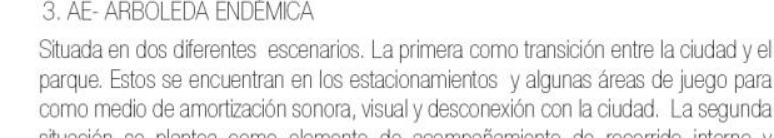

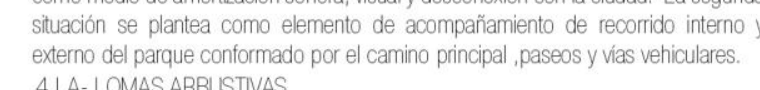

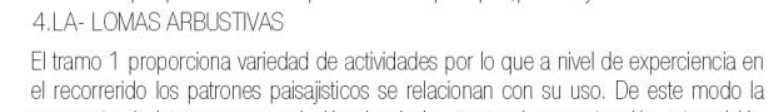

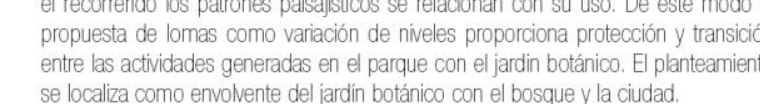

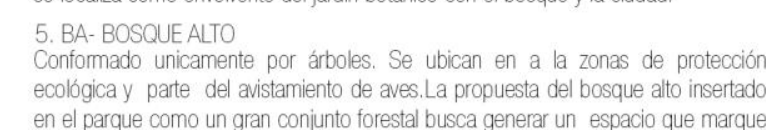

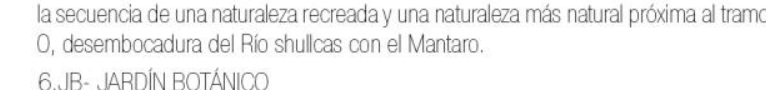

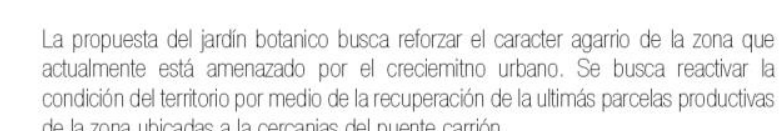
7. AF- CAMPOS H.OFALES

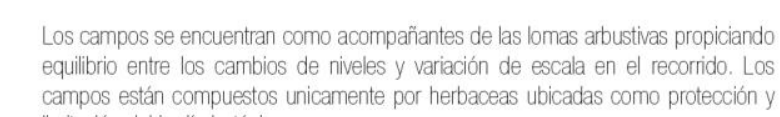

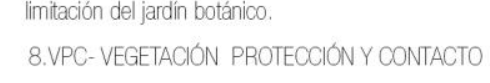

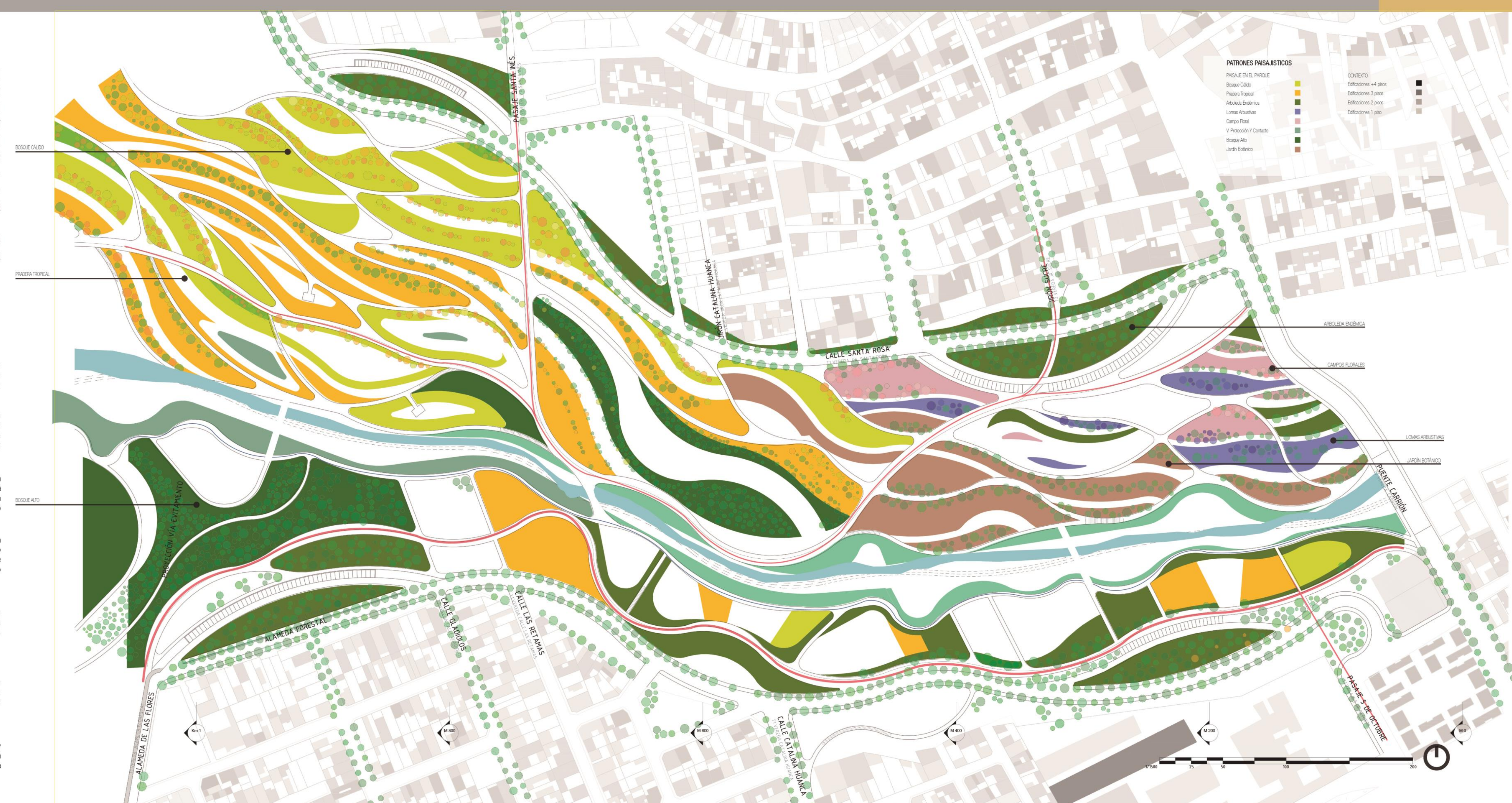


COMPOSICIÓN DE LOS PATRONES

BC BOSQUE CÁldo

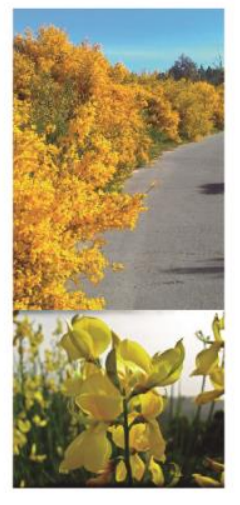

PT PRADERA TROPICAL

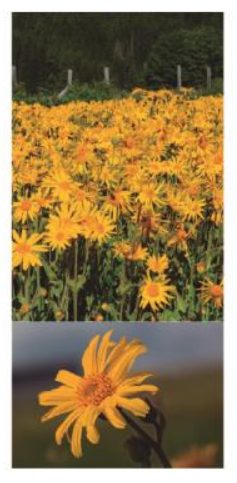

AE ARBOLEDA ENDÉmica

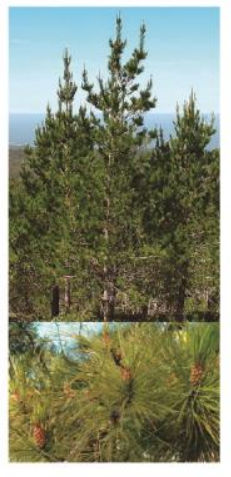

LA LOMAS ARBUSTINAS
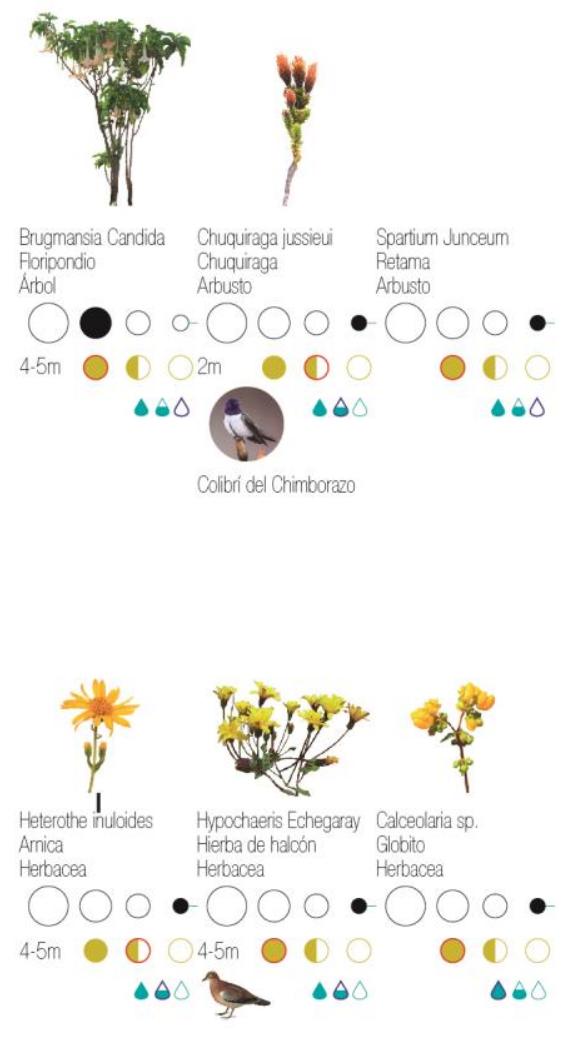

Senna Birostris
Cytisus Monspessulanus

Senna Versicolor

Buddleja Corícea

Brugmansia Sanguinea

Hypochaeris taraxacoides Puya apestris
Bidens andicola Kunth Bidens andicola Kunth
Brugmansia Candida
CF
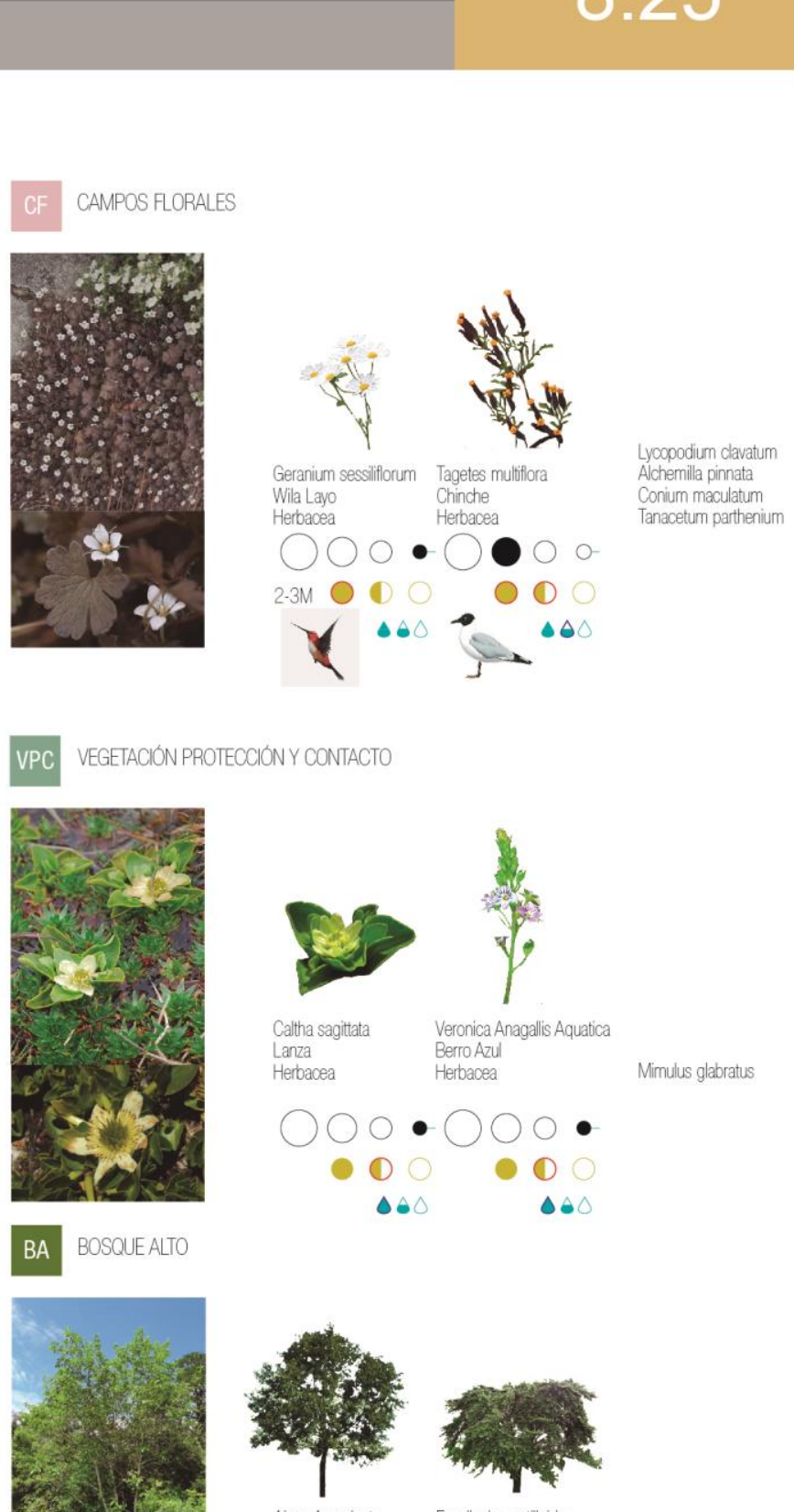

VPC VEGEEACIÓN PROTECCOÓN Y CONTACTO
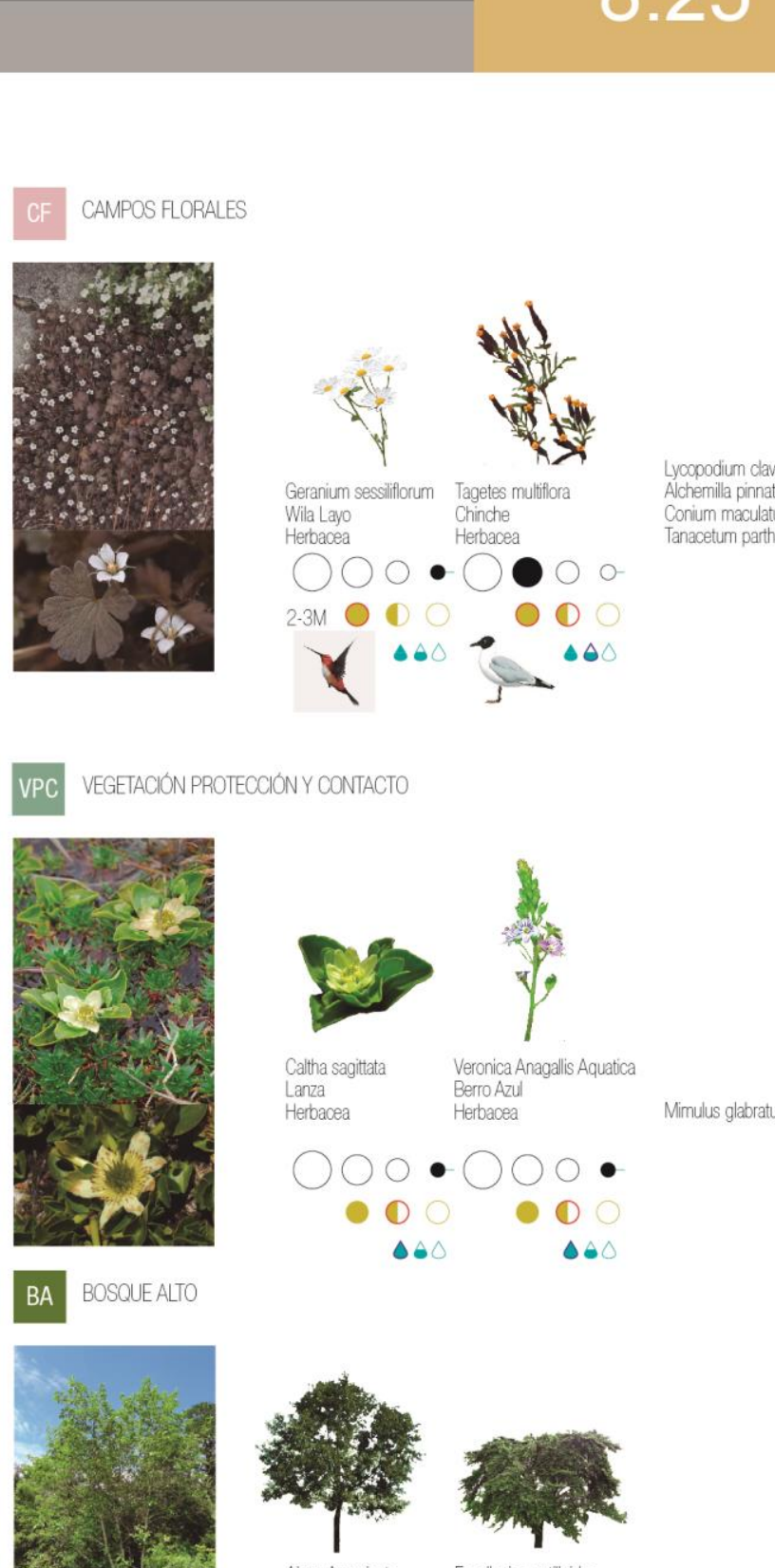

BA BOSQUEALTO

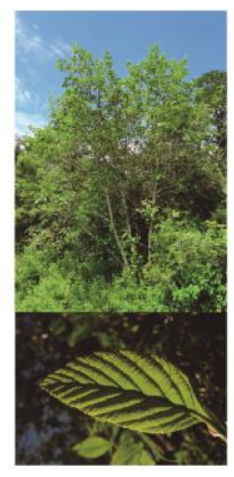

JB JARDIÓN BOTÁNICO

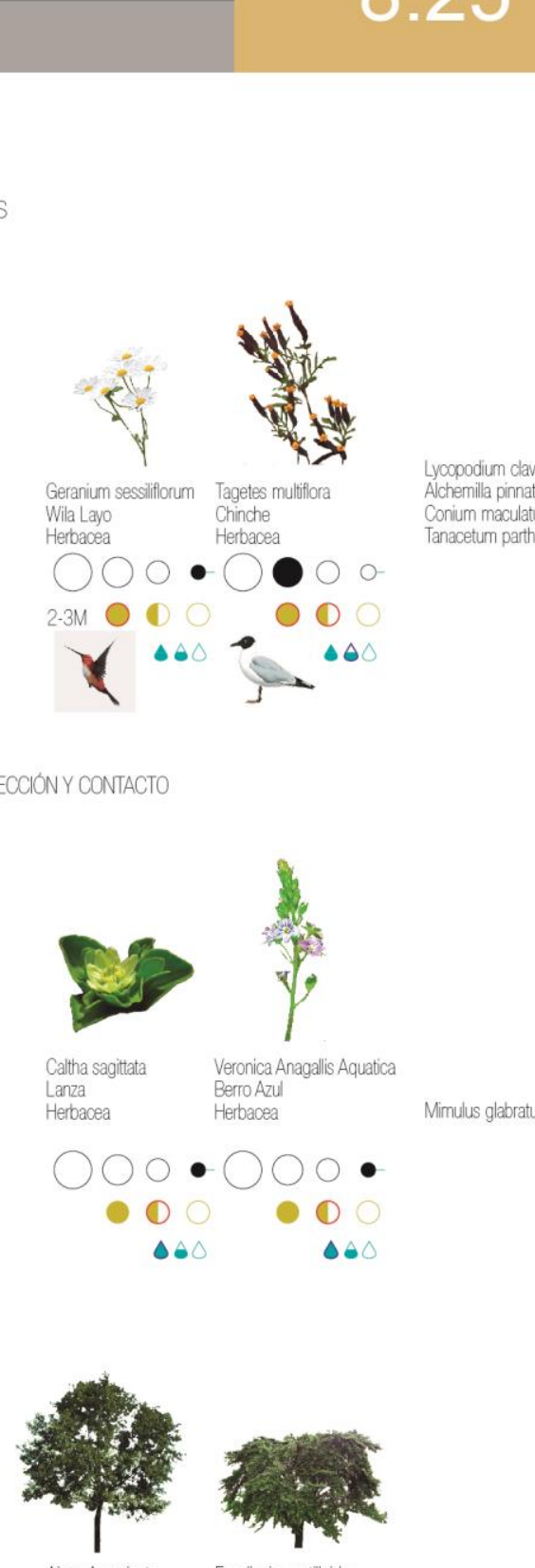

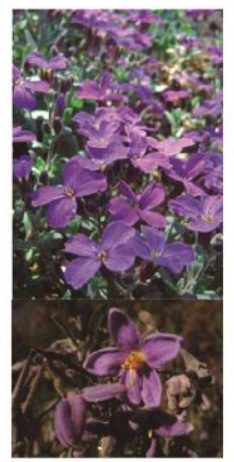
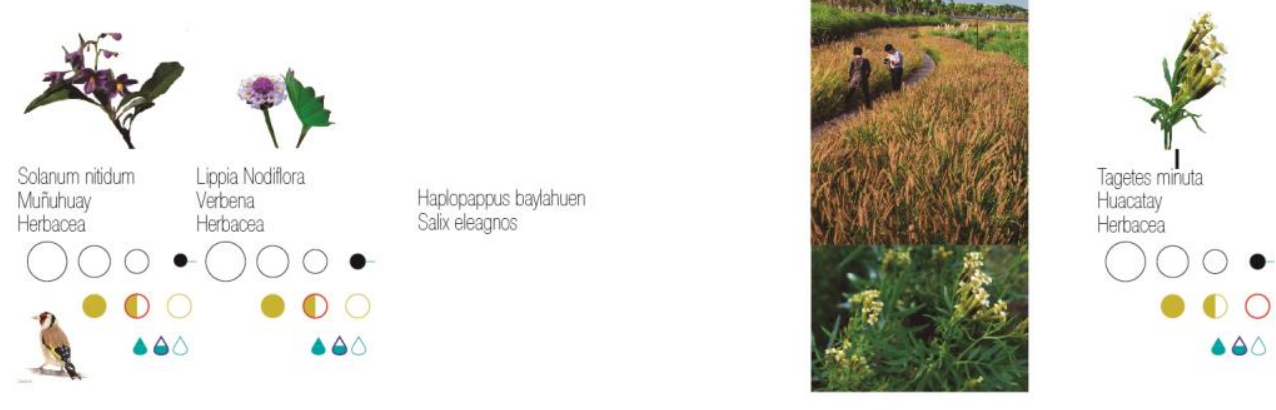


\subsubsection{Propuesta del tramo 1}

La intervención en los bordes del tramo 1 es un medio de oportunidad de reacción inmediata de la propuesta del Plan Maestro del Parque Ribereño Shullcas con el fin de proporcionar mejoras en las condiciones urbanas y paisajísticas propias del lugar que refuerzan la idea de la Ribera del Shullcas como eje estructurador de Huancayo. Con ello, el desarrollo de la propuesta se apoya en teorías que están relacionadas con el estudio de actuaciones similares y del tipo de análisis paisajístico urbano. A continuación, se detalla un listado de los autores que han aportado en la base conceptual de la propuesta del Plan Piloto Tramo 1 mediante los términos paisaje, espacio público, diseño urbano e interpretación.

Con ello, las intenciones establecidas en la propuesta pueden ser cuantificadas para estimar los cambios en la mejora en la falta de equipamiento y del área de espacio público haciendo una comparación de paquetes programáticos (ficha 8.26) actuales con la propuesta actual.

Finalmente, parte del aporte de la propuesta del desarrollo del tramo 1 a partir de las teorías han permitido la reflexión a la idea del paisaje y la ciudad. Ambos términos estudiados por autores como Kevin Lynch desde una perspectiva de la imagen propia de la ciudad, a diferencia de Maderuelo y Garrett que parten de una concepción integral del paisaje.

Kevin Lynch, desde la perspectiva del diseño urbano plantea el estudio de la ciudad comprendida desde una lectura visual de componentes que establece el paisaje urbano. Con ello, su libro "La imagen de la ciudad" aporta la comprensión de la ciudad a partir de cinco elementos espaciales que logran codificarse en conjunto como una imagen propia de la ciudad. Por otra parte, Maderuelo, sostiene la idea que el paisaje integra todo aquel espacio tangible en donde la población se ha manifestado culturalmente a partir de múltiples intervenciones en el territorio, de este modo el territorio de una ciudad no solo está conformada por la urbe, esto claramente se aprecia con la clasificación establecida por Garrett Eckbo, la cual contempla dos medios físicos: urbano y rural.

Así, mediante estas teorías la tesis busca entender una imagen integral de la ciudad de Huancayo, extendiendo la comprensión de la ciudad de Lynch a una escala macro 
territorial en donde existe un conjunto integrado de unidades territoriales tanto natural y urbana. A continuación, se explicará (ficha 8.28) el aporte equivalente de cada uno de estos cinco componentes espaciales de la ciudad establecidos por Lynch a una imagen del paisaje.

Tabla 8. 3 Aplicación del Marco Teórico al diseño del Plan Piloto Tramo 1

\begin{tabular}{|c|c|c|}
\hline Tilden & $\begin{array}{l}\text { Interpretación - Revelar } \\
\text { significados a través del } \\
\text { contacto directo con el } \\
\text { recurso }\end{array}$ & \multirow{4}{*}{$\begin{array}{l}\text { Se propone actividades como el área del } \\
\text { Jardín botánico, además de la relación del } \\
\text { contacto directo con la flora fauna y el recurso } \\
\text { hídrico a fin de que la población genere un } \\
\text { vínculo de valoración y cuidado con el paisaje }\end{array}$} \\
\hline Bob Peart & $\begin{array}{l}\text { Proceso de comunicación } \\
\text { que revela significados por } \\
\text { medio de la experiencia. }\end{array}$ & \\
\hline Don Aldridge & $\begin{array}{l}\text { Incrementar la conciencia } \\
\text { del visitante de forma que } \\
\text { despierte el deseo de } \\
\text { contribuir a la conservación } \\
\text { del medio ambiente. }\end{array}$ & \\
\hline Morales & $\begin{array}{c}\text { Acción de despertar } \\
\text { curiosidad que tiene como } \\
\text { intensión generar un cambio } \\
\text { de actitud por medio de la } \\
\text { experiencia recreativa e } \\
\text { intelectual }\end{array}$ & \\
\hline \multirow{3}{*}{ Veverka } & \multirow{3}{*}{$\begin{array}{c}\text { Establece los lineamientos } \\
\text { interpretativos en relación al } \\
\text { aprendizaje, comportamiento } \\
\text { y emociones }\end{array}$} & $\begin{array}{l}\text { Objetivo de aprendizaje: Proveer } \\
\text { conocimiento del recurso hídrico como elemento } \\
\text { natural y paisajístico en la ciudad de Huancayo. }\end{array}$ \\
\hline & & $\begin{array}{c}\text { Objetivo emocional: Se establece por } \\
\text { medio de las actividades que promueven la } \\
\text { interacción del visitante a partir de la experiencia } \\
\text { y exploración. }\end{array}$ \\
\hline & & $\begin{array}{c}\text { Objetivo de comportamiento: } \\
\text { Concientizar sobre el recurso del Río Shullcas } \\
\text { con la finalidad de valorar y el cuidar este } \\
\text { componente de la ribera. }\end{array}$ \\
\hline \multirow{4}{*}{$\begin{array}{l}\text { Countryside } \\
\text { Comission - } \\
\text { Peart y Wood }\end{array}$} & \multirow{4}{*}{$\begin{array}{l}\text { Los } 5 \text { componentes del } \\
\text { proceso de la interpretación } \\
\text { como medio para la } \\
\text { planificación interpretativa: } \\
\text { Lineamientos, análisis del } \\
\text { recurso, usuario, selección } \\
\text { de medios y evaluación. }\end{array}$} & $\begin{array}{l}\text { El lineamiento corresponde a la } \\
\text { oportunidad de caracterización ambiental del } \\
\text { tramo. Este presenta la perdida de las últimas } \\
\text { áreas agrícolas en el casco urbano a consecuencia } \\
\text { de la desvalorización y contaminación del lugar. }\end{array}$ \\
\hline & & $\begin{array}{l}\text { El análisis del recurso corresponde a los } \\
\text { elementos del paisaje como la flora, fauna, el } \\
\text { recurso hídrico y área agrícola. }\end{array}$ \\
\hline & & $\begin{array}{l}\text { Al análisis del usuario se considera en } \\
\text { general a los habitantes de Huancayo en } \\
\text { particular al grupo que pertenece al rango de } 15 \text { a } \\
59 \text { años de edad. }\end{array}$ \\
\hline & & $\begin{array}{l}\text { La selección de medios se establece con } \\
\text { la proposición de actividades que promuevan la } \\
\text { interacción con el paisaje correspondiente al } \\
\text { carácter particular del tramo (Jardín botánico, } \\
\text { parque recreativo y ambiental) y de dinámicas } \\
\text { urbanas que determinan patrones de visitas y } \\
\text { configuración del espacio en el tiempo. }\end{array}$ \\
\hline
\end{tabular}




\begin{tabular}{|c|c|c|}
\hline \multirow{4}{*}{$\begin{array}{c}\text { Countryside } \\
\text { Comission }\end{array}$} & \multirow{4}{*}{$\begin{array}{c}\text { Determina aspectos a } \\
\text { evaluar en el análisis del } \\
\text { usuario }\end{array}$} & $\begin{array}{l}\text { Patrones de visita: Se configura a través } \\
\text { de programas que promueven distintas } \\
\text { actividades en el transcurso del día }\end{array}$ \\
\hline & & $\begin{array}{l}\text { Grupos especiales: El parque parte de la } \\
\text { idea de un espacio de equidad por lo que el } \\
\text { diseño considera el uso inclusivo de mayores de } \\
\text { edad y discapacitados. }\end{array}$ \\
\hline & & $\begin{array}{c}\text { Interés: La definición de actividades } \\
\text { parte del entendimiento de las dinámicas urbanas } \\
\text { con el fin de incorporar espacios interés como de } \\
\text { esparcimiento. }\end{array}$ \\
\hline & & $\begin{array}{c}\text { Necesidades: El diseño considera la } \\
\text { implementación de módulos de servicios que } \\
\text { cubran usos básicos como servicios higiénicos, } \\
\text { kiosco entre otros. }\end{array}$ \\
\hline \multirow{6}{*}{$\begin{array}{c}\text { Badaracco y } \\
\text { Scull }\end{array}$} & $\begin{array}{l}\text { Proceso de interpretación- } \\
\text { entender el recurso, el } \\
\text { usuario y desarrollo de } \\
\text { medios }\end{array}$ & $\begin{array}{l}\text { El análisis del paisaje local en conjunto } \\
\text { con el análisis de usuario permiten la selección } \\
\text { de actividades a fin de activar y establecer un } \\
\text { vínculo de valoración de la población con su } \\
\text { entorno paisajístico de la ribera del Shullcas }\end{array}$ \\
\hline & \multirow{5}{*}{$\begin{array}{l}\text { Determina criterios de } \\
\text { evaluación para la } \\
\text { identificación de potenciales } \\
\text { interpretativos }\end{array}$} & $\begin{array}{c}\text { Singularidad: Establecida por el } \\
\text { potencial ambiental, además las características } \\
\text { topográficas que permiten la activación y } \\
\text { contemplación directa con la ribera. }\end{array}$ \\
\hline & & $\begin{array}{l}\text { Atractivo: Elementos visuales } \\
\text { interesantes; con potencial de implementación de } \\
\text { actividades (Jardín botánico, pozas y áreas } \\
\text { recreativas) correlativas al paisaje. }\end{array}$ \\
\hline & & $\begin{array}{l}\text { Acceso: Conservación de caminos con } \\
\text { valor paisajístico y Configuración de ingresos que } \\
\text { permitan una fluidez espacial entre la ciudad y el } \\
\text { parque. }\end{array}$ \\
\hline & & $\begin{array}{l}\text { Afluencia. Se considera en el diseño los } \\
\text { flujos y nodos existentes como paraderos y } \\
\text { equipamientos para la definición de ingresos. }\end{array}$ \\
\hline & & $\begin{array}{l}\text { Seguridad: Consideración de los sectores } \\
\text { vulnerables a inundación por lo que se establece } \\
\text { áreas de esparcimiento como medida de } \\
\text { prevención en las zonas de muy alto y alto riesgo. }\end{array}$ \\
\hline \multirow{4}{*}{ Pennyfather } & \multirow{4}{*}{$\begin{array}{l}\text { Determina medios de } \\
\text { interpretación de carácter } \\
\text { participativo }\end{array}$} & $\begin{array}{c}\text { Senderos: Se diseña tres caminos } \\
\text { (camino principal, el de paseo y articuladores) } \\
\text { que permiten movilizarse y explorar la diversidad } \\
\text { de actividades en el parque }\end{array}$ \\
\hline & & $\begin{array}{c}\text { Miradores: Se propone miradores } \\
\text { integrados al parque a } 200 \text { a } 300 \mathrm{~m} \text { de distancia } \\
\text { para ofrecer un diferente ángulo panorámico de } \\
\text { la flora y fauna. }\end{array}$ \\
\hline & & $\begin{array}{l}\text { Puntos de distancia: Se propone un } \\
\text { sistema de equipamiento transversal conformado } \\
\text { por miradores, servicios y puesta de arte ubicados } \\
\text { en cada cierta distancia como estrategia de } \\
\text { interacción y descubrimiento del visitante, }\end{array}$ \\
\hline & & $\begin{array}{l}\text { Participación insitu: Las estrategias de } \\
\text { programa se define en el parque por cuatro } \\
\text { paquetes (jardín botánico, equipamiento } \\
\text { transversal, parque recreativo y ambiental) que } \\
\text { proporcionan actividades de interacción con el } \\
\text { paisaje. }\end{array}$ \\
\hline
\end{tabular}




\section{RESULTADO DE LA APROPUESTA}

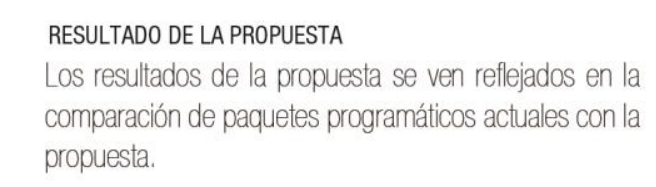

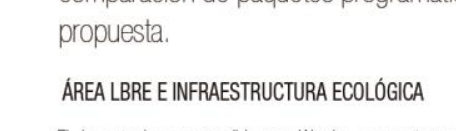

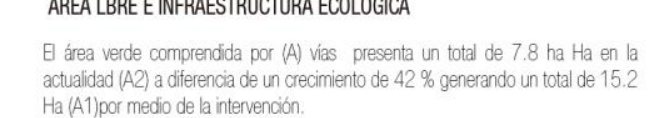

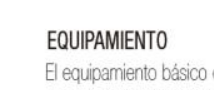

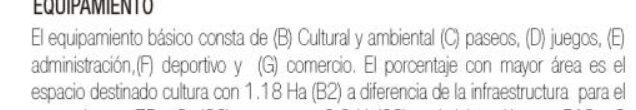

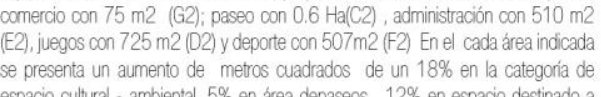

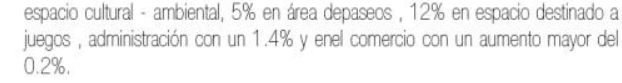

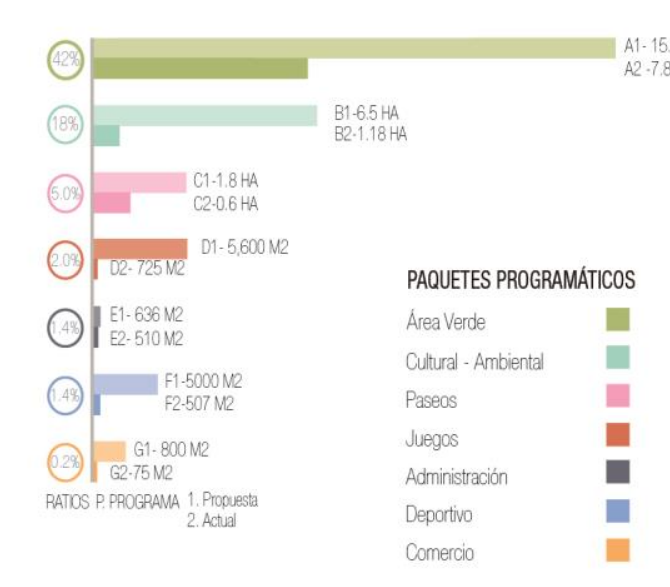

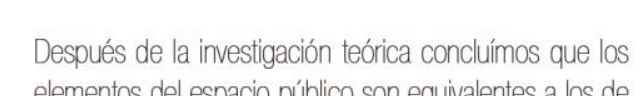

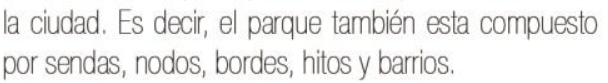

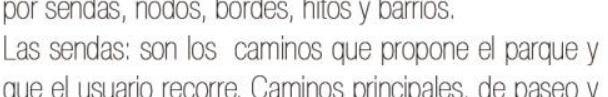
Ls nodos: son las áreas de permanenciád donde se

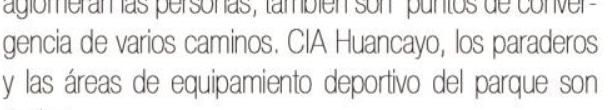
Los bordes: son ejes ordenadoreses, En el Tramo 1 el bordid natural es es Rio Sialulcas y yos extremos del

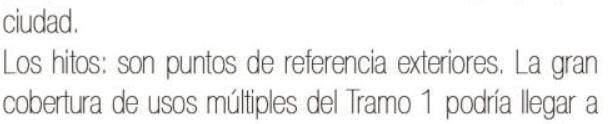

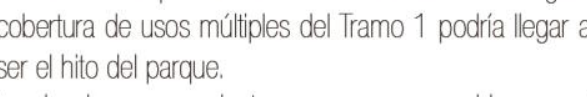
Los barrios: son conjunintos aue son reconocidos por el

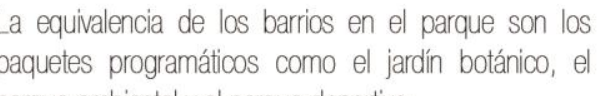

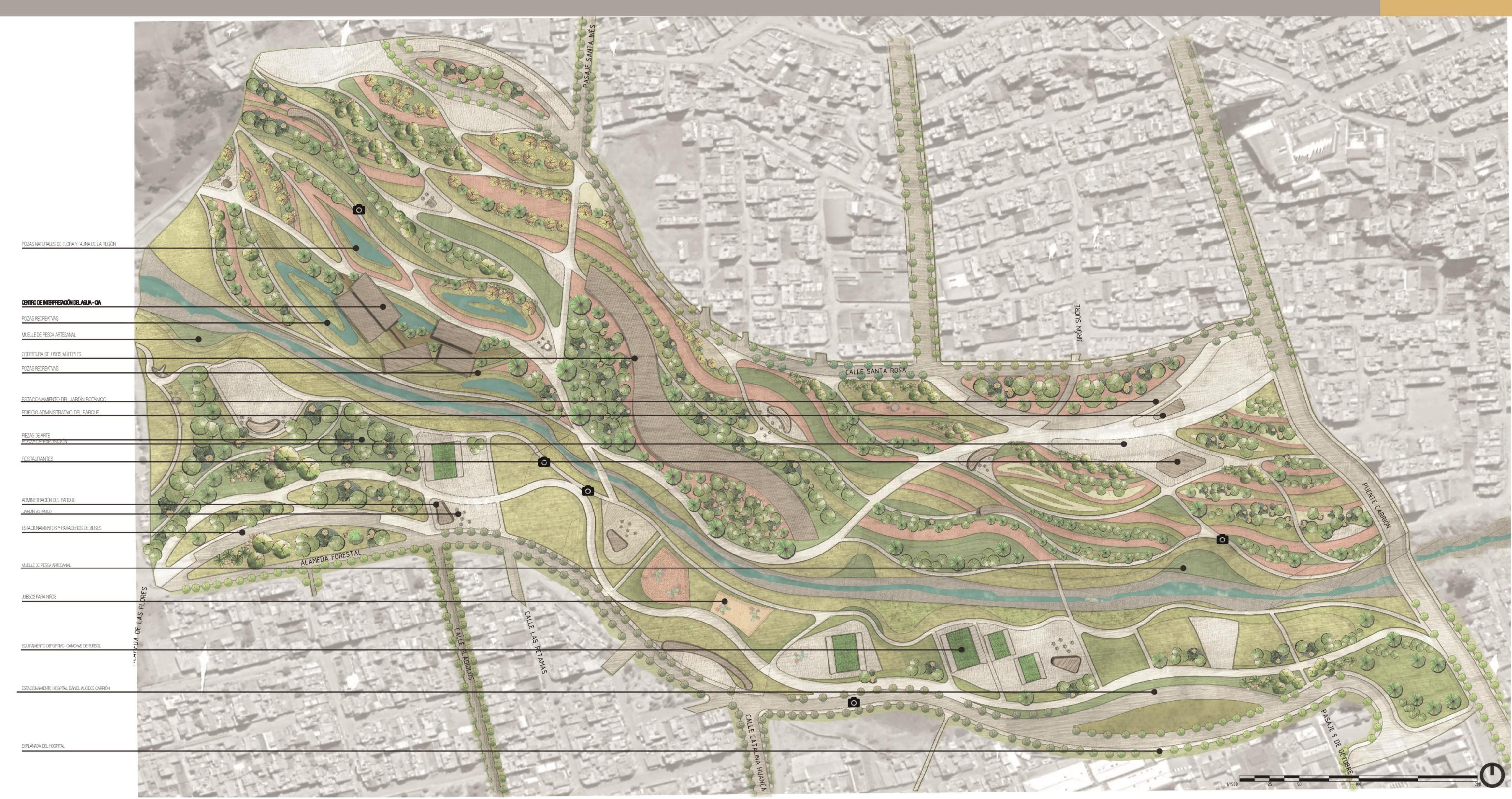




\section{PASARELA DE CONEXX́N DEL Río SHULLCAS}

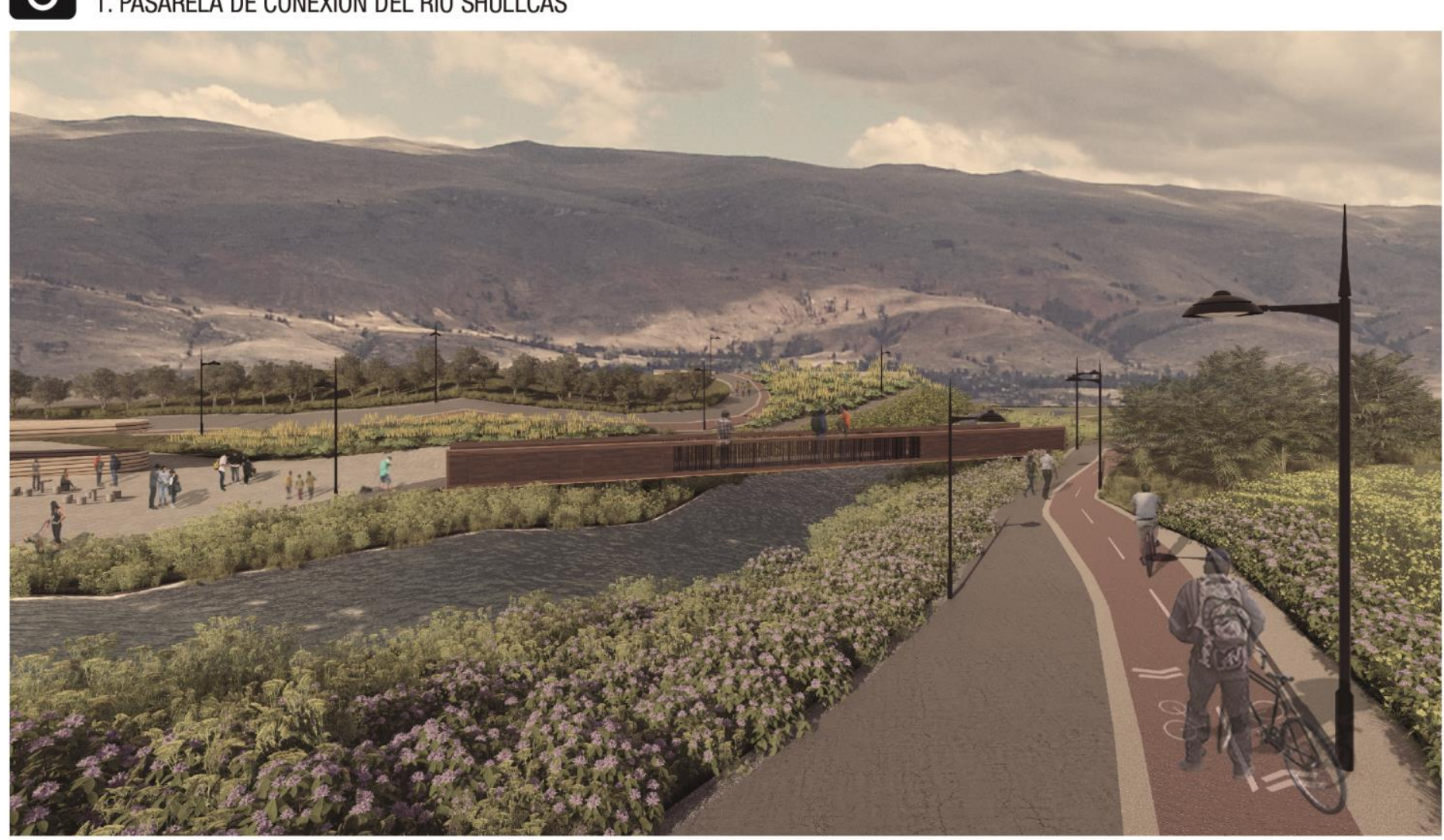

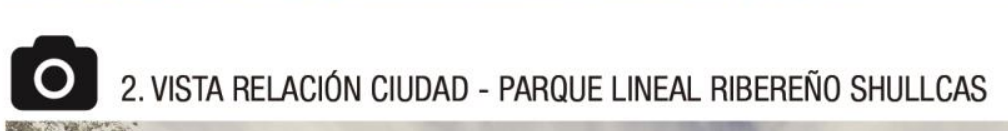

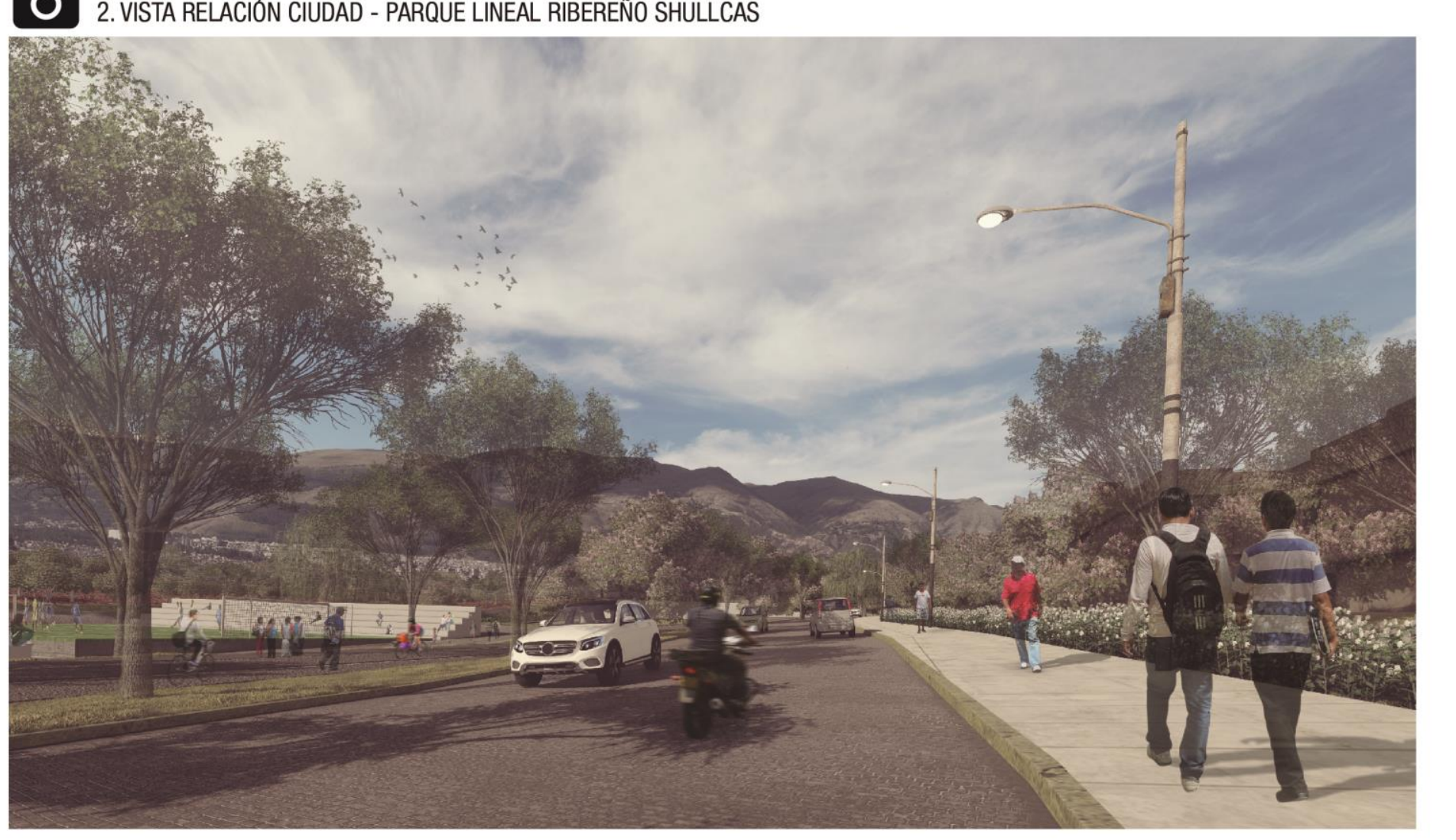

\section{3 ISTA POZAS NATURALLEY Y CIA HUANCAYY}

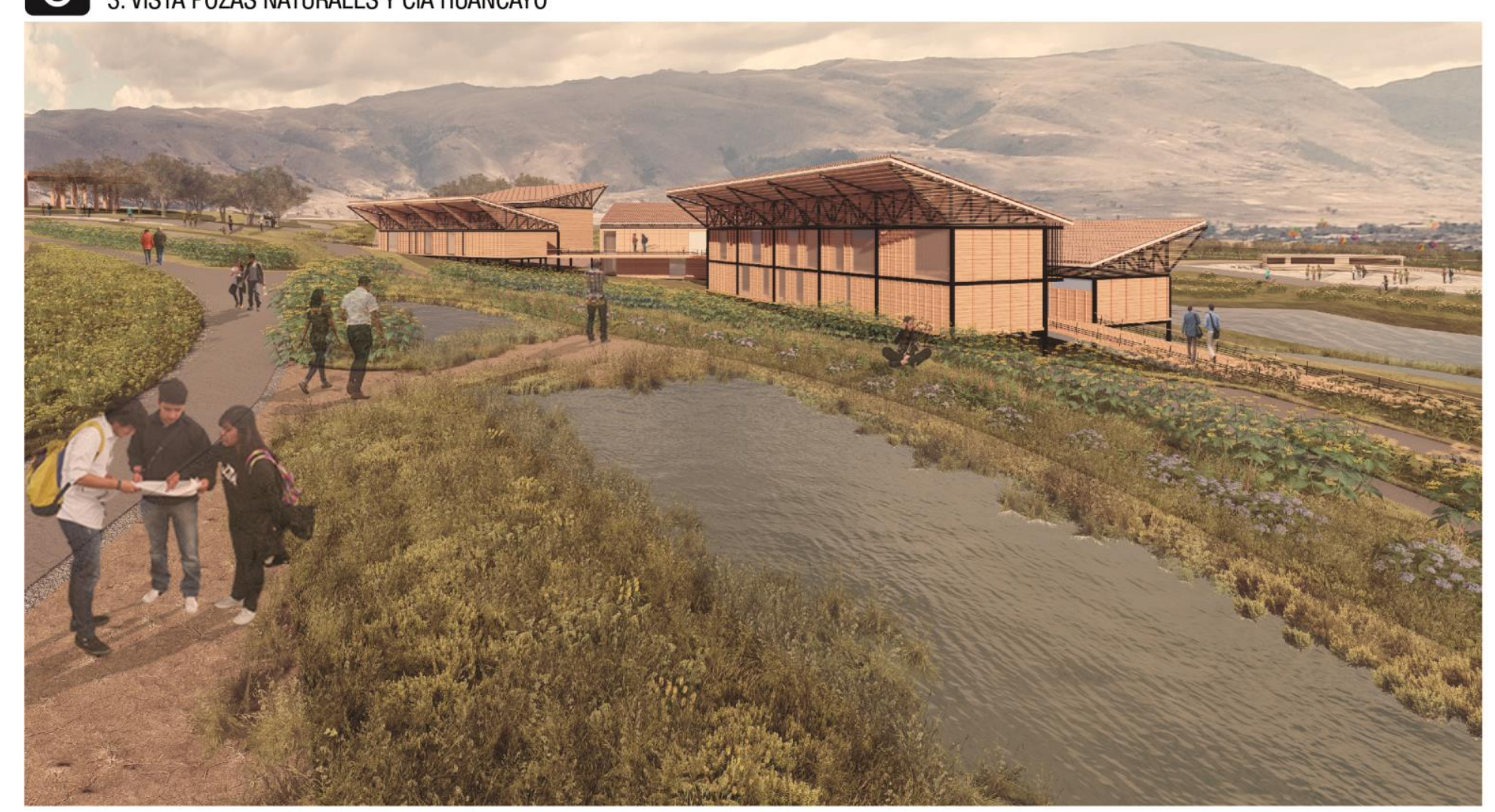

4. VISTA CAMINo DE PASE0

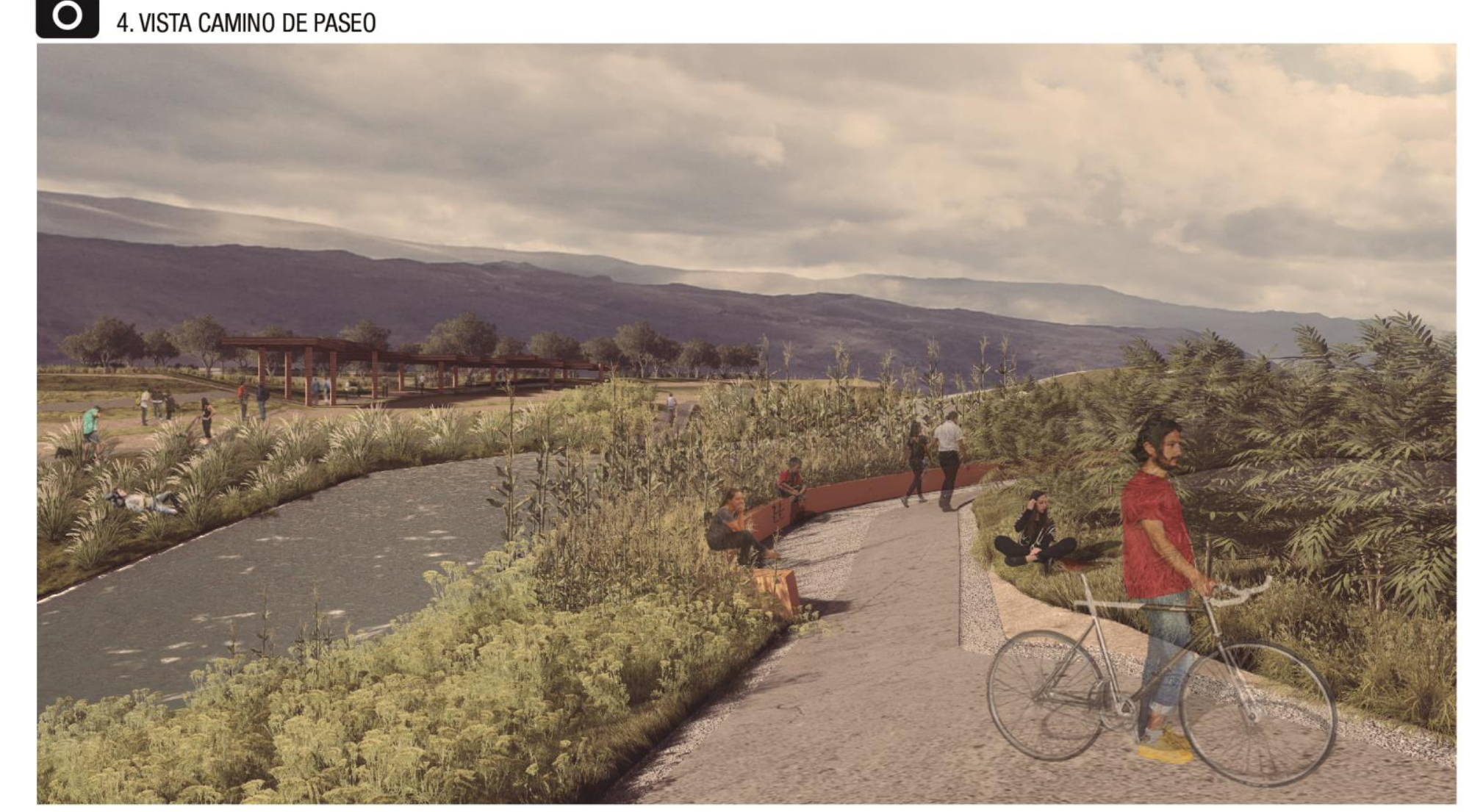

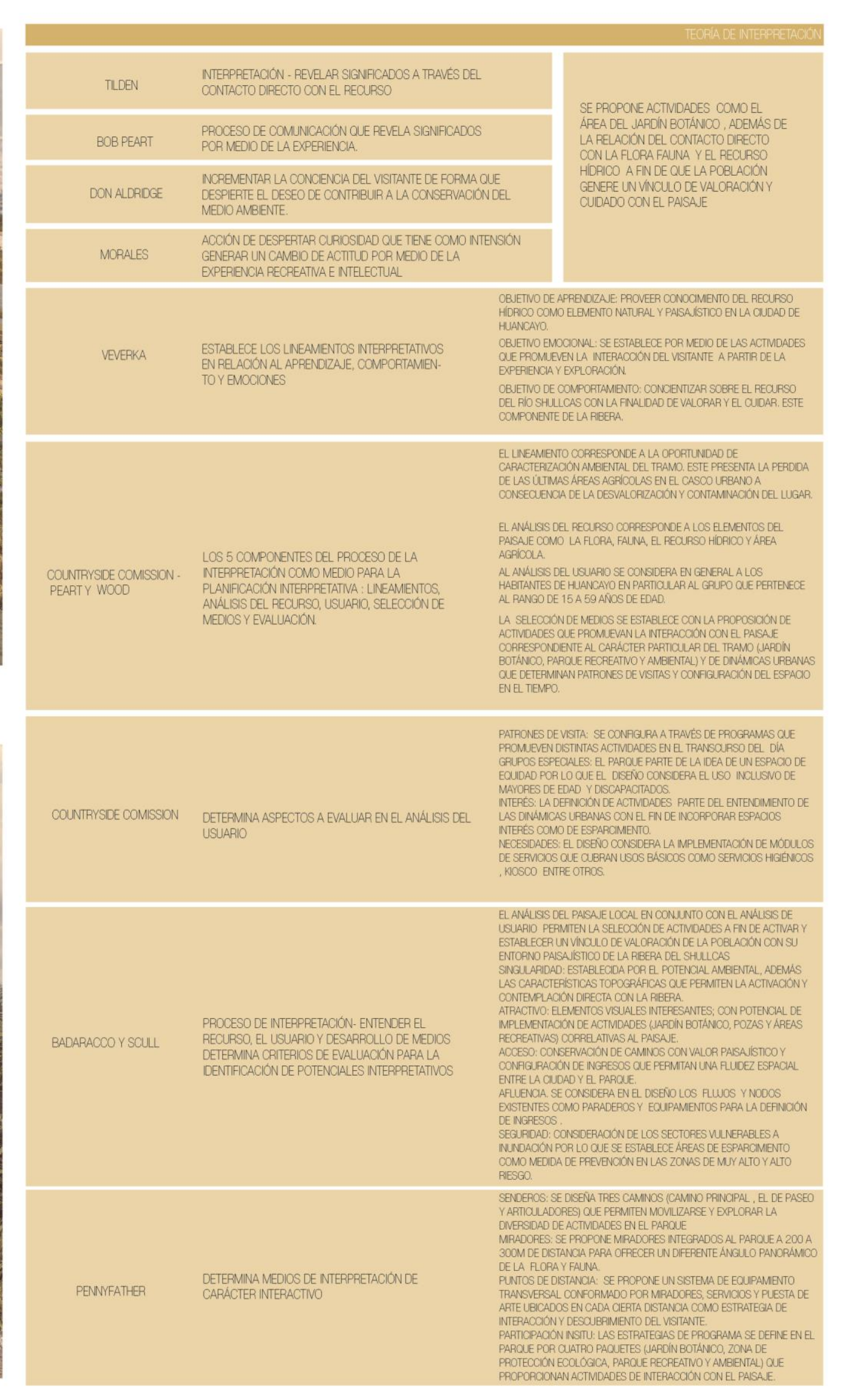




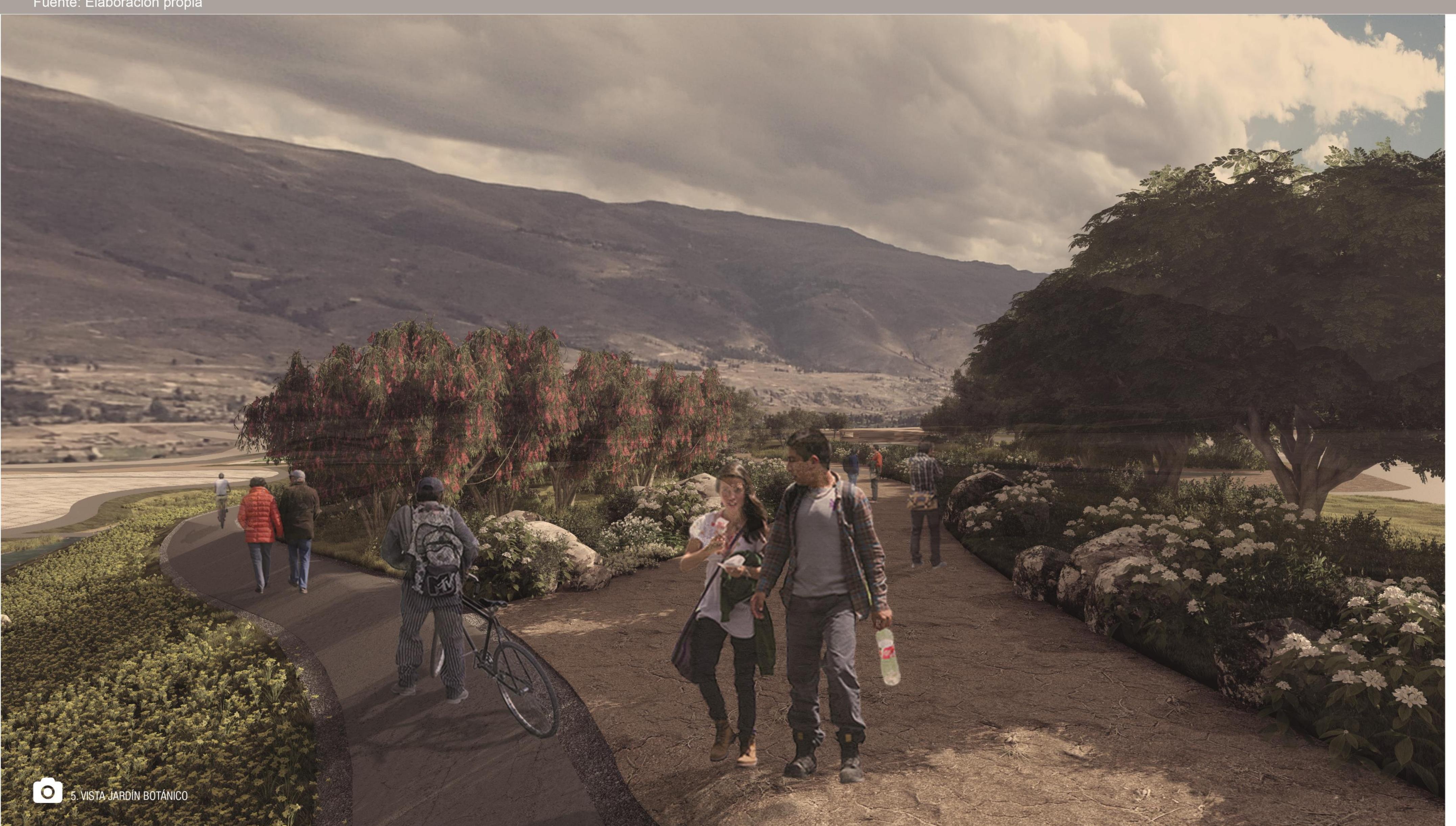

Después de la investigación teórica conclúmos que los elementos del espacio . compuesto por sendas, nodos, bordes, hitos y barrios.

Las sendas: son los caminos que propone el parque y que el usuario recorre. Caminos principales, de paseo y arteriales

Los nodos: son las áreas de permanencia donde se aglomeran las personas, lambién son puntos de convergencia de varios caminos. CIA Huancayo, los paraderos y las áreas de equipamiento deportivo del parque son nodos.

Los bordes: son ejes ordenadores. En el Tramo 1 el borde natural es el Río siullas y los extremos del pargue son bordes de transición entre el parque y

Los hitos: son puntos de referencia exteriores. La gran cobertura de usos matiples del Tramo 1 podría llegar a ser el hito del parque

Los barrios: son conjuntos que son reconocidos por el observador al mantener

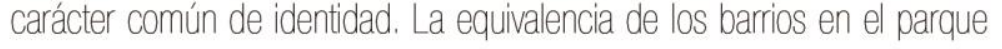

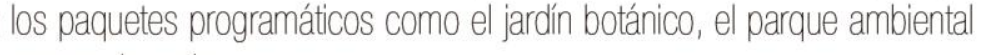
el parque deportive 


\subsection{Arquitectura}

\subsubsection{Centro de Interpretación del Agua (CIA)}

\subsubsection{Ubicación}

El Centro de Interpretación del Agua de la Ciudad de Huancayo (CIA) se emplaza en el Parque Ambiental del Tramo 1 ocupando un área de $2.7 \mathrm{Ha}$. La infraestructura colinda con el frente del Río Shullcas, el camino principal (eje conector del Tramo con el resto del Parque Lineal Ribereño Shullcas), y con las pozas naturales y recreativas, las cuales forman parte de la unidad paisajística de tipo bosque cálido propuesto como estrategia recuperación de la flora uy fauna de la región. A continuación, (ficha 8.29) se explicará gráficamente la ubicación del CIA. 

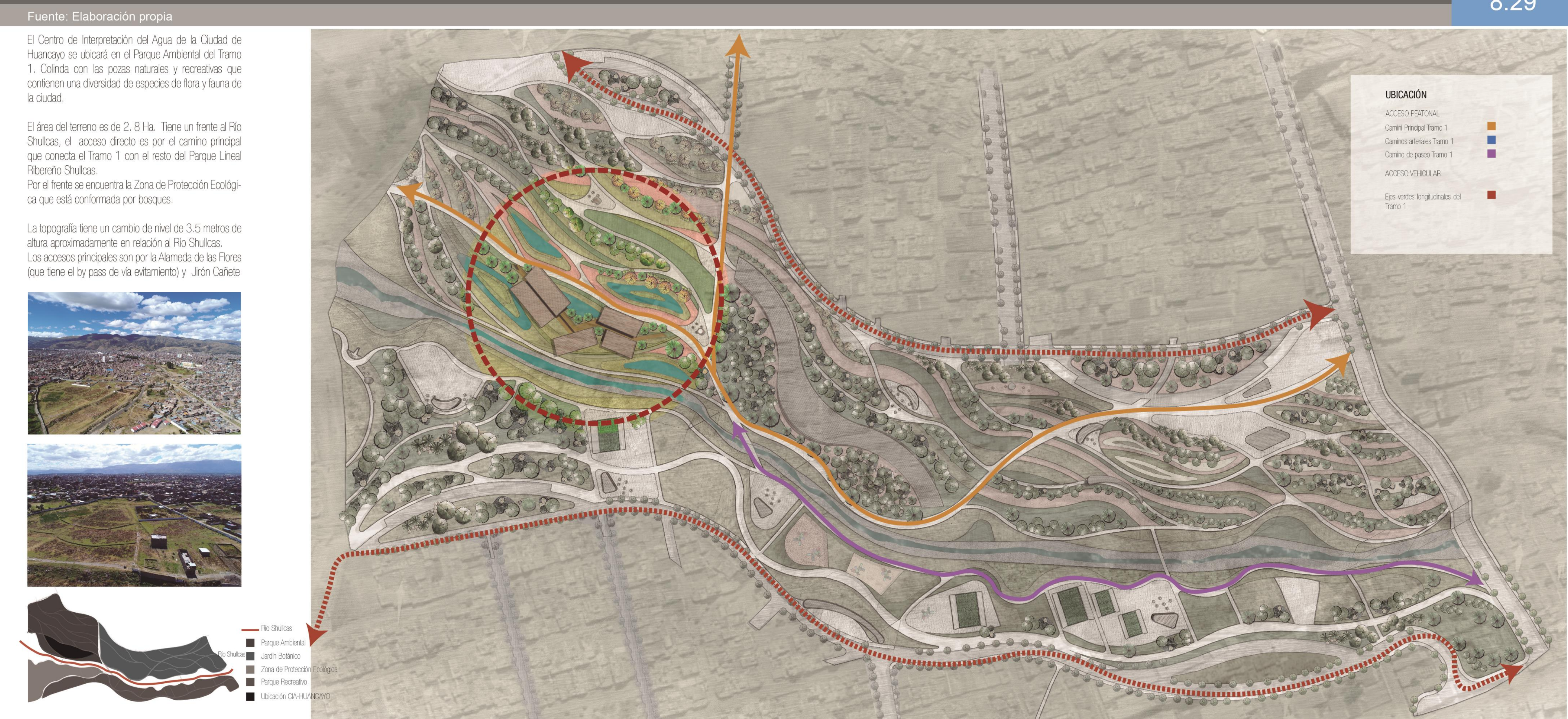


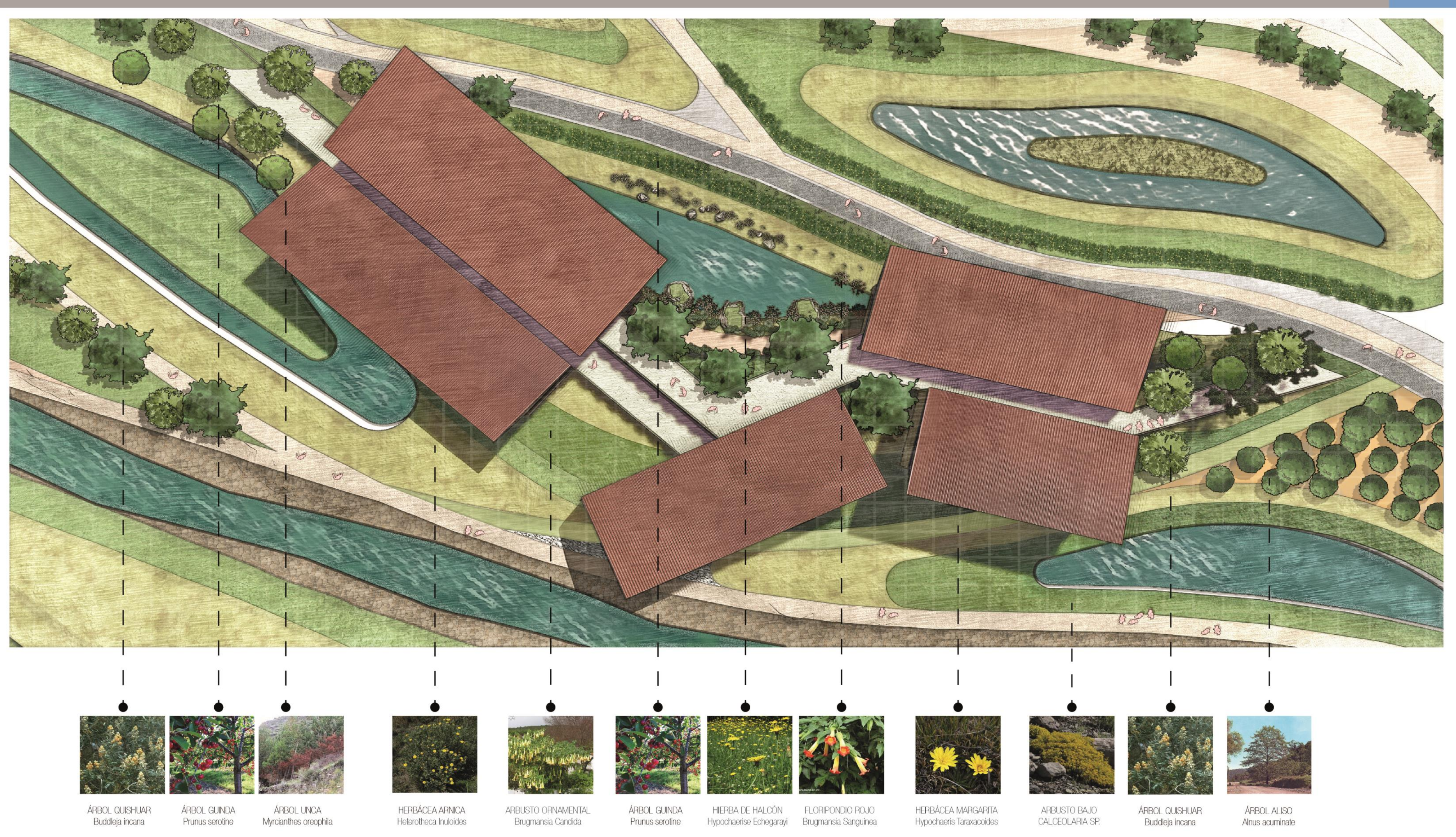




\subsubsection{Toma de partido}

El diseño del Centro de Interpretación del agua surge de la necesidad de incrementar el equipamiento cultural faltante para la ciudad de Huancayo. La infraestructura propuesta contribuirá a la valoración y concientización sobre el cuidado del recurso del río, ya que actualmente se encuentra olvidado y en estado de contaminación.

Para la ubicación del Centro de Interpretación del Agua (CIA-Huancayo) se pretende propiciar un contacto directo con el entorno, por ello se plantea insertar este equipamiento de carácter ambiental-cultural dentro del parque ambiental del tramo 1 por tener mayor relación con las dinámicas, actividades y oportunidades de contacto con el lugar. Asimismo, es importante señalar que la intensión de generar sentido de conciencia con el entorno natural no es exclusiva de la arquitectura, sino que esta es una pieza más del conjunto propuesto en donde el paisaje y la arquitectura se integran como propuesta de interpretación en la valoración del recurso del agua del Río Shullcas. 


\subsubsection{Concepto}

La lógica de diseño parte de la lectura y estudio del paisaje entendido como un sistema de componentes establecidos como concepto del tramo 1. Con ello, la metodología conceptual asienta de manera abstracta la idea de composición de capas de los elementos urbanos y naturales que constituyen la ribera aterrizados a una lógica espacial.

El diseño del Centro de Interpretación del Agua parte de tres ideas bases relacionadas al desarrollo paisajístico con la arquitectura. Estas se interpretan (ficha 8.31) a partir de la mancha, fluidez y capas, cada una ubicadas en dos tipos de estratos diferenciados por el medio rígido y etéreo (flotante).

El estrato rígido, relacionado a la topografía del terreno, establece una relación con la superficie artificial, de manera que se tiene como intención principal que la arquitectura se pose en el paisaje sin alterar la superficie. Asimismo, en el estrato etéreo, se define los espacios que la arquitectura quiere albergar delimitados por la idea de mancha como el tipo de relación espacial constituidos por tres tipos: el interno, externo e intermedio, cada uno de estos con su particular relación entre ellos y con el entorno. Los espacios exteriores son los de mayor relación directa con la naturaleza; los espacios interiores, de protección; y los espacios, intermedios, de transición entre lo natural y artificial.

Finalmente, el sentido de fluidez, entendido como la intensión de emplazar el proyecto de manera que continúe la direccionalidad del paisaje y que este a su vez contemple el recorrido de tipo lineal que corresponde a una lógica longitudinal concordante y de acompañamiento con el entorno. 


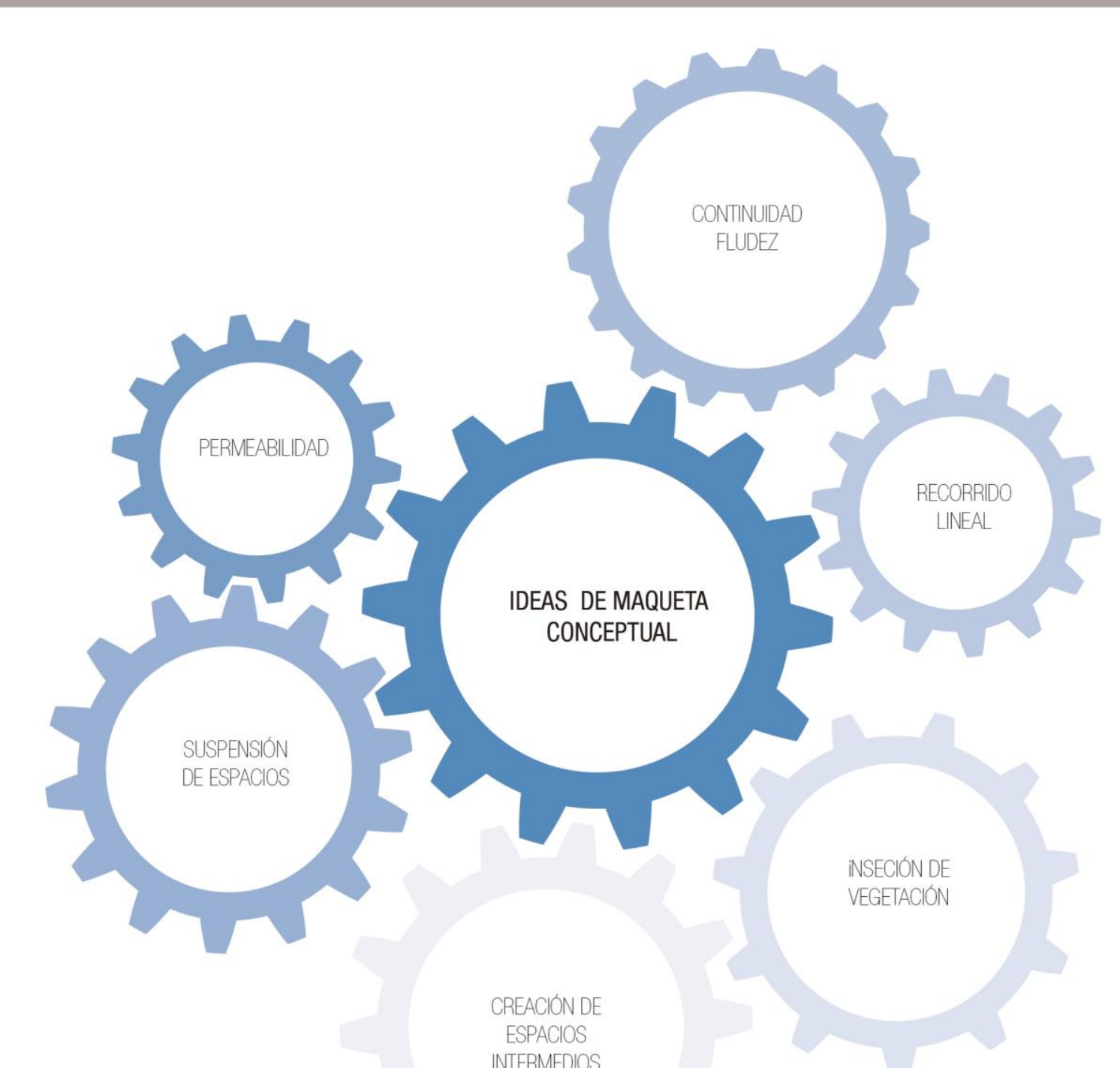

CREACOÓN DE
ESPACOS
INIERMEDOSS

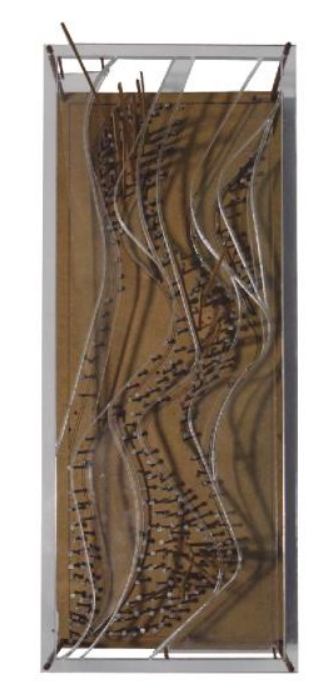

MAQUETA CONCEPTO VISTA ISOMÉTRICA

Chavs — Supericie atifical

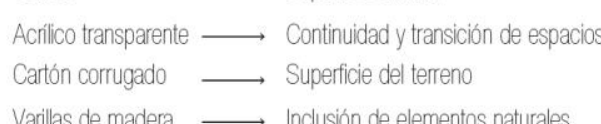

IDEAS BÁSICAS DEL PROYECTO EN RELACIÓNA L LA AROUITECTURA

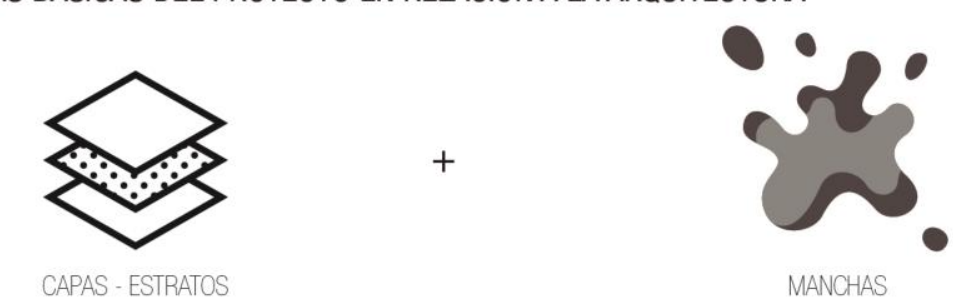

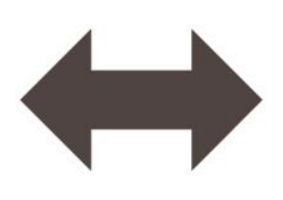

TIPOS DE ESTRATOS

TIPOS DE MANCHAS

LONGITUGDINALIDAD

ESTRATOPAliod

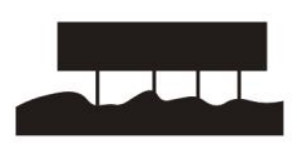

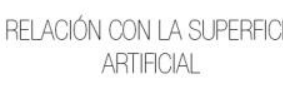

$=$

RELACOON OON LOS TPPOS DE
ESPACOS

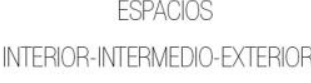

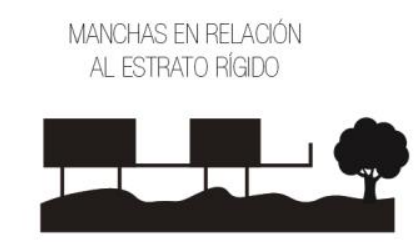

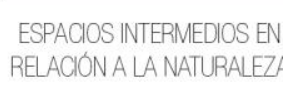

MANCHAS ENNEEACOÓN
AL ESTRATO LLTANANE

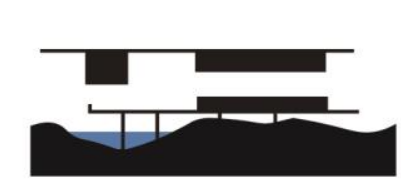

ESPACOS NTERMEDOSEN EN tro de envilazamento

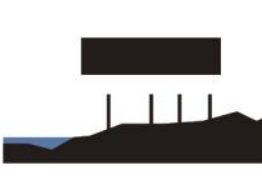

(1)

$\underline{1}$
MAQUETA CONCEPTO VISTA EN PLANTA

Canos — sunerficie atricical

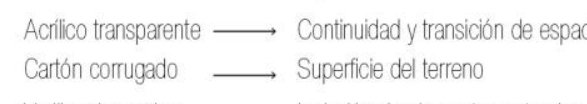

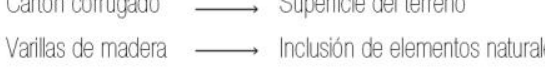

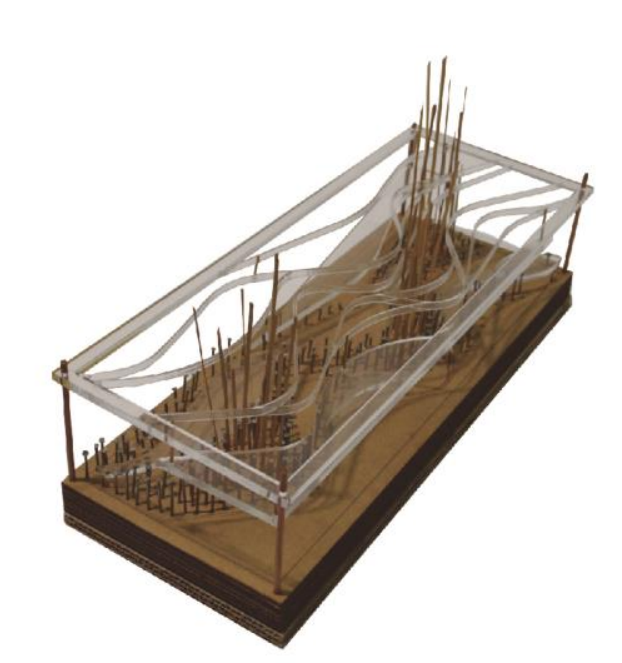

mourta concepto VISTA FRONTAL

conposióón

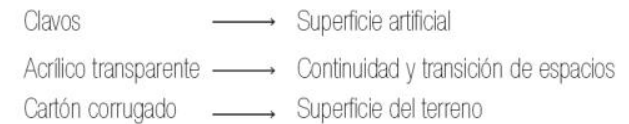

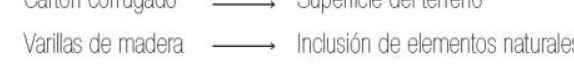

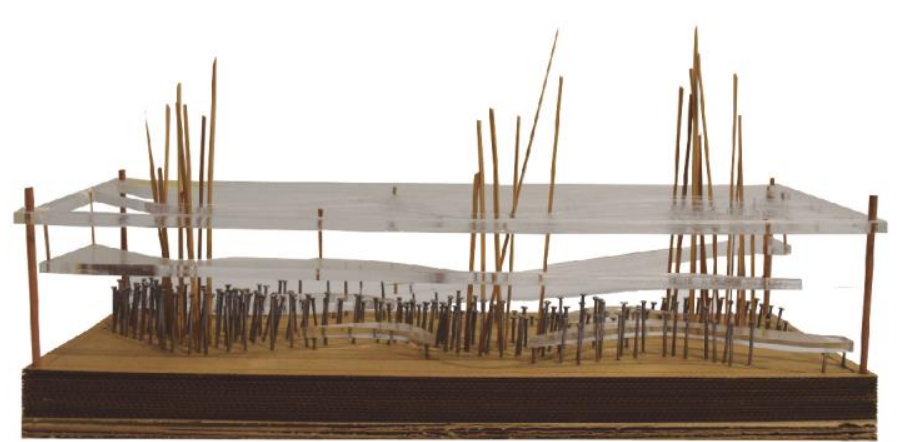




\subsubsection{Estrategias proyectuales}

La definición del diseño proyectual parte de 9 estrategias que moldean la formalidad, emplazamiento, orientación, materialidad, etc. para establecer la mejor aproximación espacial de la arquitectura con el entorno.

La primera estrategia inicia con la idea de crear un edificio suspendido que genera espacios de protección mediante una plataforma activa que genere el menor impacto en el paisaje y que pueda establecer espacios que no sean afectados por las posibles inundaciones al desborde del Río Shullcas. Posteriormente, la conformación de espacios propios de la arquitectura se establece a través de orientaciones óptimas de iluminación, confort térmico, ventilación y de la definición de visuales importantes hacia el río, la ciudad y el valle del Mantaro como herramienta de interpretación y de conexión visual contemplativa particular de cada actividad generada desde la arquitectura hacia el paisaje.

El desarrollo de paquetes programáticos parte de la distinción de tres unidades autónomas con indistintas aproximaciones con el entorno que sin embargo no dejan de estar conectados como la idea de un sistema en conjunto. La pieza de anexo de estos se define formalmente por la circulación libre del tipo lineal que traspasa y une la intervención con el parque. Con ello, surge la necesidad de implementar un espacio intermedio entre las unidades programáticas, la circulación externa y el entorno, que se configure como un punto de encuentro y estadía para los usuarios

La vegetación, también cumple un papel importante en el recorrido del CIA de manera que la arquitectura y la vegetación compartan un mismo plano jerárquico. Con ello, la disposición de los bloques se entrelaza entre capas de vegetación dando una experiencia de recorrido diferencial exterior e interior. En donde el exterior comparte una dualidad entre la arquitectura y el entorno.

Como se ha mencionado, el cuidado del entorno es base primordial para generar el menor impacto posible con el territorio en conjunto con la búsqueda de un recorrido como espacio intermedio que acompañe visuales y sirva de anexo a los paquetes programáticos del CIA. Así, se plantea relaciones espaciales a diferentes alturas que van asentándose de acuerdo a la topografía generando una secuencia de recorrido a distintos tiempos con encuentros visuales hacia el paisaje. 
Posteriormente, El clima de la ciudad también es un factor importante a considerar como respuesta formal a las fuertes precipitaciones en las temporadas de invierno. Se plantea techos inclinados con pendiente de $30^{\circ}$ que a su vez no interfieran como barrera visual principalmente del Río Shullcas y del valle, por lo que se establece los techos con inclinación a un agua orientada indistintamente de un bloque con el otro.

Finalmente, la selección del material parte de la necesidad de poder construir sin grandes remociones en el terreno y establecer espacios del tipo planta libre, por lo que la intensión de uso de metal como material de gran resistencia, de obtención de grandes luces, rápido montaje y reutilizable, permite la mínima remoción del paisaje interfiriendo mínimamente en la topografía y preservando la vegetación. Por otro lado, el material complementario al acero, se propone la madera como recurso extensivo de la arquitectura del lugar en relación a la tipología de techos de madera que funcionan como cubierta en la ciudad de Huancayo. Asimismo, la madera al ser un material orgánico es no homogéneo y buen conductor del calor, sonido, electricidad y propiedades acústicas.

A continuación, (ficha 8.32) se explicará gráficamente la secuencia formal de las estrategias proyectuales. 
Las estrategias a tomar en cuenta para el diseño del CAA-HUANCAYO son 9: Proponer una plataforma actira Ineal, quiebres y visuales, fragmentación, circulación pubicica que atraviesa el proyectio, aturar de las ediricacio

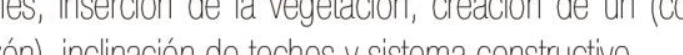

a lámina contiene a detalle la mutación del edificio

partir del las estrategias mencionadas
01 PLATAFORMA ACTINA LINEAL

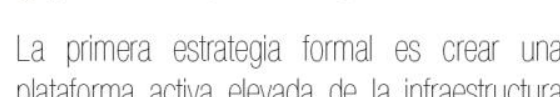

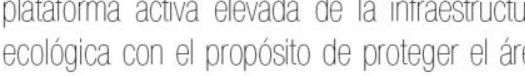

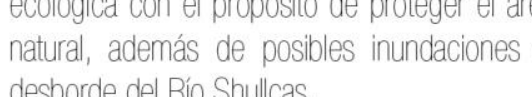

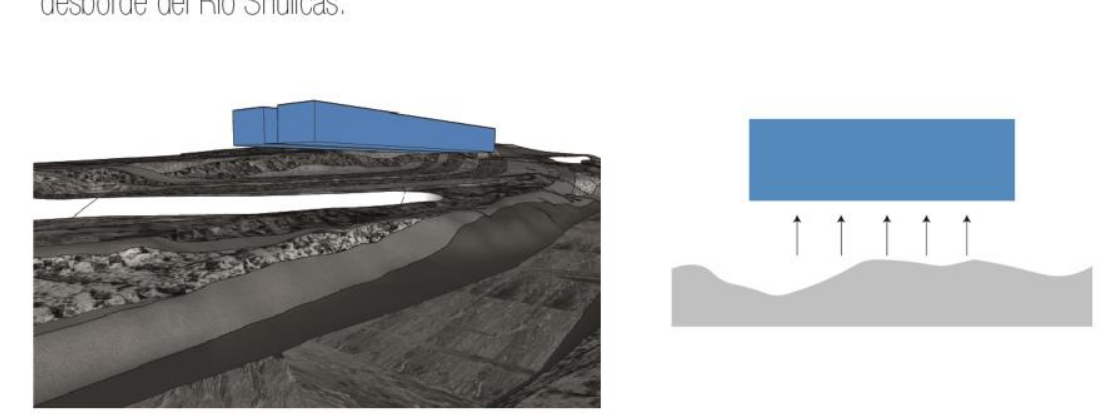

\section{QUIEBRES Y VISUALES}

La segunda estratega tormal es 1 la creacón dé

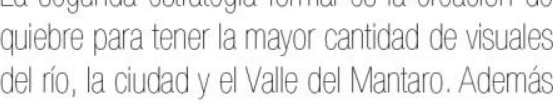

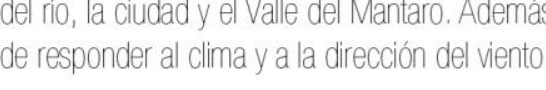

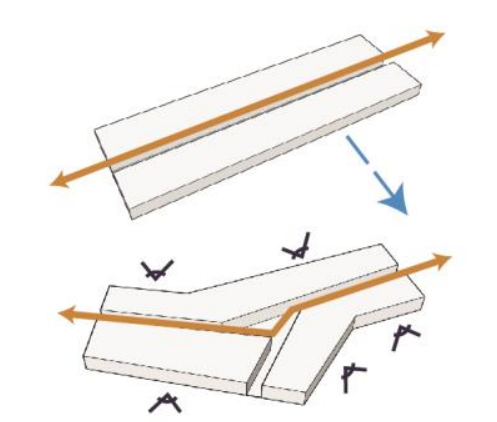

\section{FRAGMENTACIÓN}

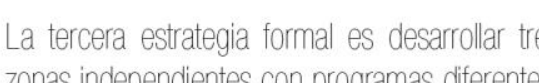

espaciós a vilizer por el vusario que serán

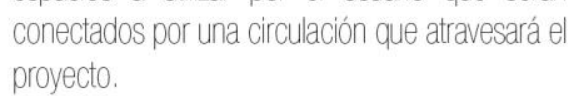

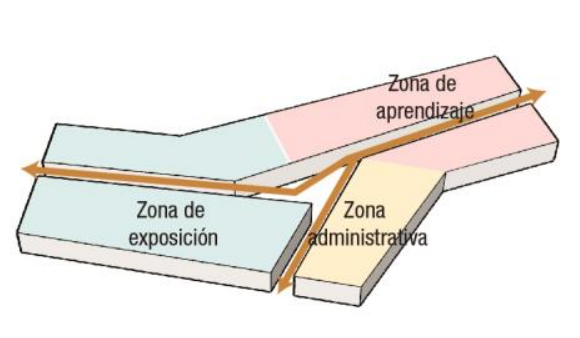

04 CIRCULACIÓN PÚBLICA QUE

TRAVESA EL PROYECTO

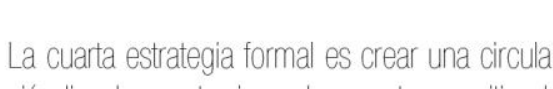

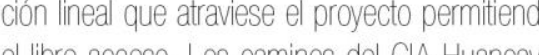

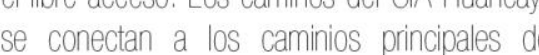

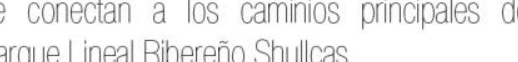

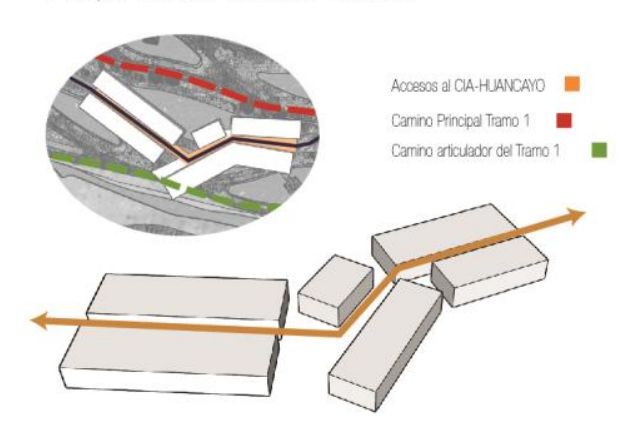

05 ALTURA DE LAS EDIFICACIONES

La soppina estatega formal es difierenciar las

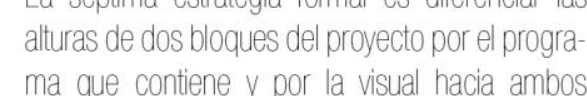

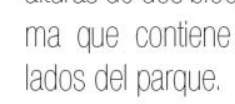

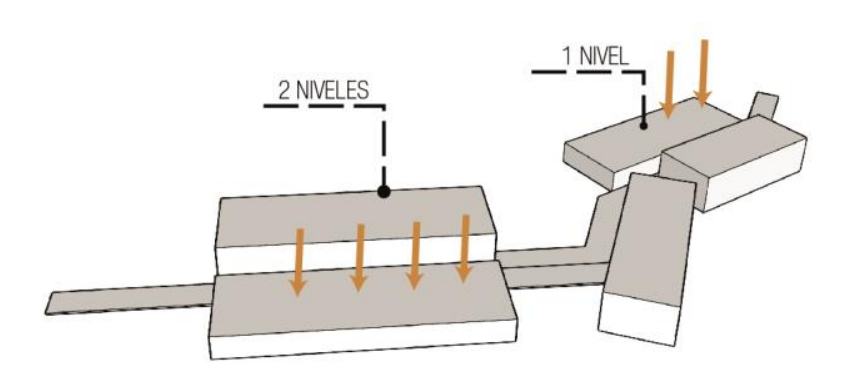

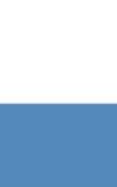

\section{i}

i

06 INSERCIÓN DE LA VEGETACIÓN La sexta estrategal a tormal es insetrar la vegetacón para no perderla revaloracaín del patimiconio

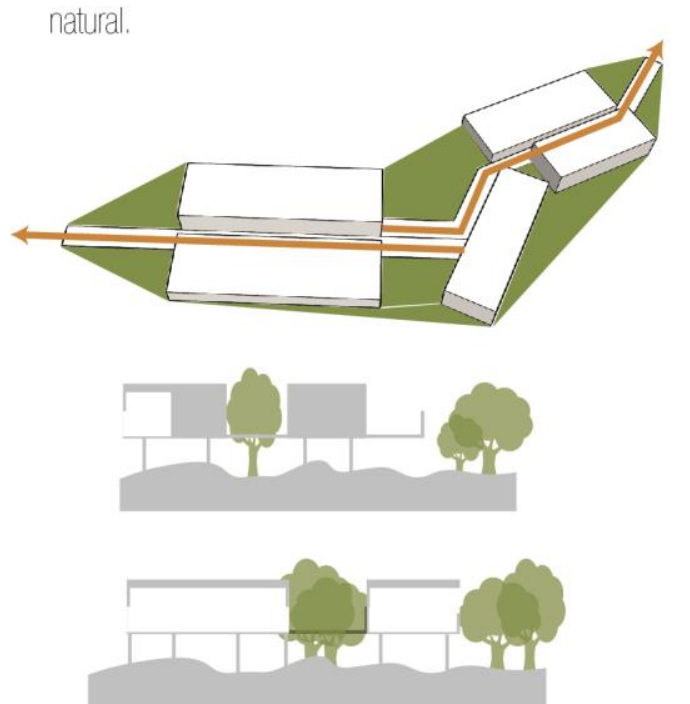

07 CREACIÓN DE UN "CORAZÓN" La quinta estrategia formal es la creación de un de encuennto a los usuarios; además de ser un
espacio de transición entre la naturaleza del parcue $y$ la arcuitectura.

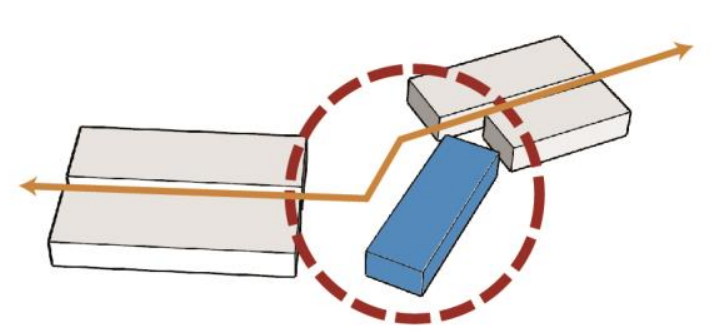

08 INCLINACIÓN DE TECHOS

La octava estrategia formal es la indilinacín y Huancayo mantiene precipitaciones intensas en

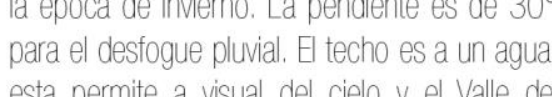
Mesta permiter

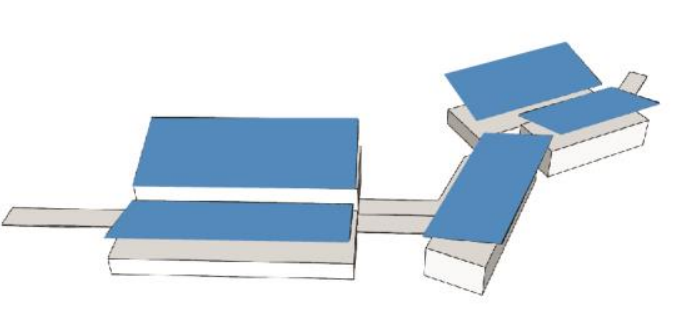

09 SISTEMA CONSTRUCTIVO:

METAL + MADERA

La novena estrategia tormal es la selección del

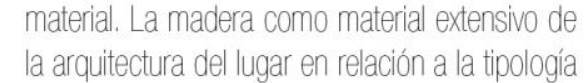
de techos de madera que tuncionan como cubierta en la ciudad de Huancayo. Asimismo, la homogéneo y buen conductoror del calor, sonicido

Por otro lado, el metal es un material de gran pesistencia, permite obtener grandes luces, es de rapido montäe, es un material reutilizable, permite la minima remoción del paisaje

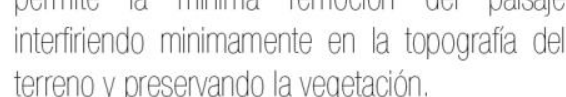

\section{i}




\subsubsection{Cálculo de usuarios, programa y cabida}

El cálculo de usuarios toma como base el estudio de análisis de usuarios de la teoría de interpretación con el fin de garantizar un proceso de interpretación óptimo. Primero se establece las cualidades de los tipos de grupo de visitantes, por lo que se plantea cuatro tipos de usuarios: permanentes, fijos, semipermanentes y visitantes. (ficha 8.33) Los usuarios permanentes lo conforman la mayor población (niños, adolescentes y joven) de la ciudad de Huancayo. Los usuarios fijos son los trabajadores que necesita el Centro de Interpretación para su funcionamiento. Los usuarios semipermanentes son la población adulta-mayor de la ciudad y los usuarios visitantes conformada por la población extranjera nacional e internacional. Con esta clasificación se establece patrones de visitas proporcionando horarios que cubran el uso de los usuarios estimados.

Por otro lado, la definición de paquete programático también considera las recomendaciones de la teoría de la interpretación considerando el interés relacionado a actividades recreativas o de conocimiento y necesidades conformadas por servicios básicos que el usuario requiere, por ejemplo, servicios higiénicos y área de comida. Con ellos se determina 4 paquetes programáticos conformados por exposición, formación, contemplación y servicios. (ficha 8.34) 


\section{Fuente: Elaboración propia}

La Ciudadd de Huancayo cuenta con una gran cantidad tes y joven-adulta.

E CIA-HUANCAYO tendrá diversos tipos de usuarios: Permanentes, fijos, semipermanentes y visitantes.

Los usuarios permanentes lo conforma la mayor poblacion de la ciucad de Huancayo. Los usuarios fijos son los para el funcionamiento. Los usuarios seminermanentes son la población adulta-mayor de la ciudad. Los usuarios usitantes son la poblacion extanjera nacional e interna visitantes
cional.
El total de

It total de usuarios que se estima para el CIA-Huancayo es de 281,236 personas

La finalidad del CIA-Huancayo es concientizar y educar a a población a través de la interpretacición que engloba pavetes programáticos que han sido pensados a partio de la experiencia que los usuarios quieren en los espacios.

El Centro de Interpretación del Agua cuenta con 4 paquetes programáticos: Paquete de exposición, talleres. contemplación y servicios

Los paqueles programaticos engloban una diversidad de stivadades de acuerdo al contenido del espacio.

Asimismo, según el Reglamento Nacional de Edificacic

por persona.

1 TTPOS DE USSAATOS

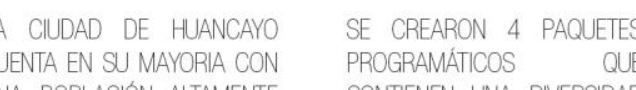

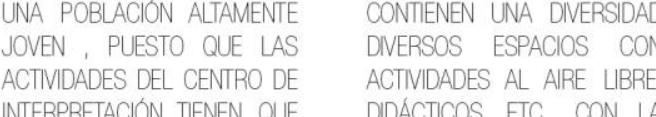

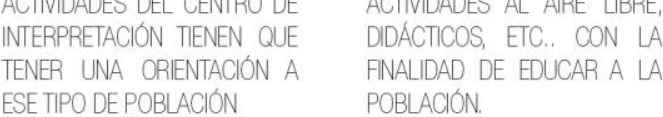

\section{TIPOS DE USUARIOS}

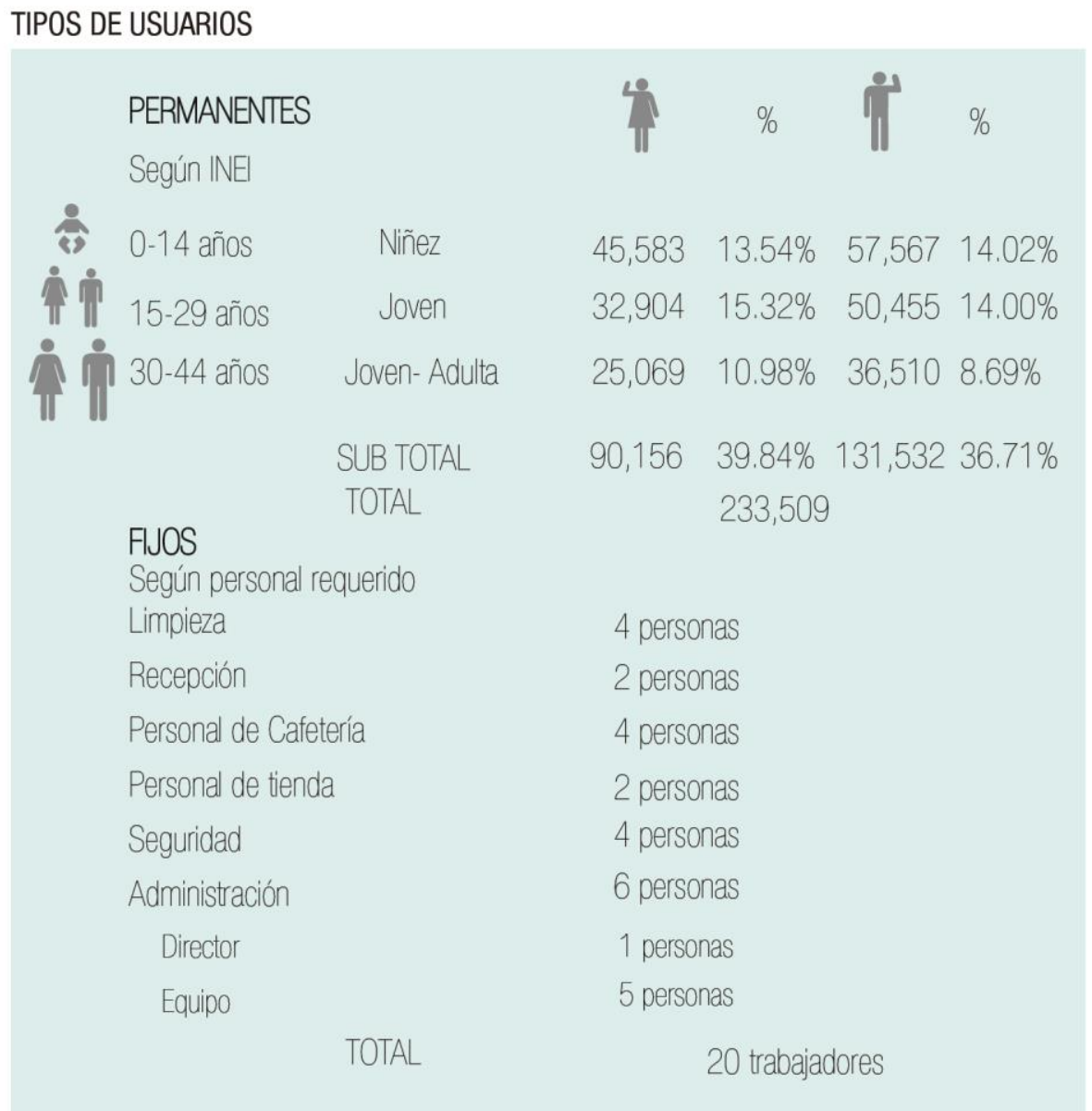

PAQUETES PROGRAMÁticos - AFORO PARA EL CENTRO DE INTERPRETACIÓN SEGÚN RNE

-Tpos de salas constenido de as salas

\begin{tabular}{|c|c|c|c|c|c|c|c|}
\hline \multirow{10}{*}{ EXPOSICIOON } & $\begin{array}{l}\text { Tipos de salas } \\
\text { Galera de Enseñarza }\end{array}$ & Contenido de las salas & $\begin{array}{l}\text { RNE } \\
4 \mathrm{~m} 2 \text { por personara }\end{array}$ & \multirow{8}{*}{ TALLRESS } & \multirow{2}{*}{$\begin{array}{l}\text { Tipos de salas } \\
\text { Taller de Recidaje } \\
\text { No nocestla contatto } \\
\text { directo ocon el exterior }\end{array}$} & Contenido de las salas & \multirow[t]{2}{*}{$\begin{array}{c}\text { RNE } \\
2.5 \mathrm{~m} 2 \text { por persona }\end{array}$} \\
\hline & $\begin{array}{l}\text { Estructura espacalal } \\
\text { de secuencia informativa }\end{array}$ & 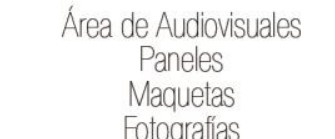 & \multirow{4}{*}{$3 \mathrm{~m} 2$ por persona } & & & Actividades manuales & \\
\hline & Gadería Temporal & & & & \multirow{3}{*}{ 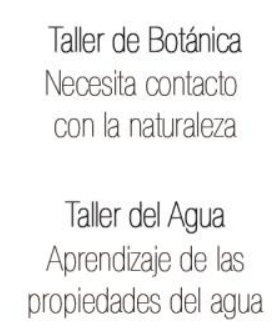 } & \multirow{2}{*}{ Actividades sensoriales } & \multirow{2}{*}{$2.5 \mathrm{~m} 2$ por persona } \\
\hline & Estructura espacial & $\begin{array}{l}\text { Presentaciones de } \\
\text { trabajios de talleres }\end{array}$ & & & & & \\
\hline & Sala de percepción & antistios & & & & \multirow[t]{2}{*}{ Mini Laboratorio } & $2.5 \mathrm{~m} 2$ por persona \\
\hline & $\begin{array}{l}\text { Estructura espacial } \\
\text { al are libre }\end{array}$ & $\begin{array}{l}\text { Espadodo sensorial, las pozzas } \\
\text { elementios protagononstas }\end{array}$ & \multirow{3}{*}{$3 \mathrm{~m} 2$ por persona } & & \multirow{2}{*}{$\begin{array}{l}\text { Sala de Presentaciones } \\
\text { No necessita contactio } \\
\text { directo con el exterior }\end{array}$} & & \multirow[t]{2}{*}{$1.0 \mathrm{~m} 2$ por persona } \\
\hline & Sala de Conservación & & & & & $\begin{array}{l}\text { Pequeñon } \\
\text { Adudionio }\end{array}$ & \\
\hline & 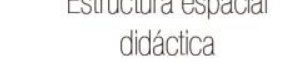 & 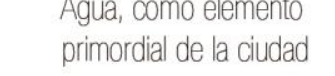 & & & & & \\
\hline & Sala de Puesta en Valor & & $3 \mathrm{~m} 2$ por persona & UNIIEIVILAUIUN & Miridodres & & \\
\hline & $\begin{array}{l}\text { Estructurara espocial } \\
\text { de plantilibe }\end{array}$ & $\begin{array}{l}\text { Exposiciones dda artistas } \\
\text { tadose }\end{array}$ & & & & & \\
\hline
\end{tabular}

CANTIDAD DE USUARIOS DEL CIA HUANCAYO

$$
\begin{aligned}
& \text { Usuarios Permanentes + Usuarios Fiios } \\
& 233,50920 \\
& 233,530
\end{aligned}
$$

\begin{tabular}{|c|c|c|}
\hline & $\begin{array}{l}\text { Museo Salesiano } \\
\text { Santa Rona }\end{array}$ & Museo Wari \\
\hline Extanjeros & & 3 \\
\hline Nacionales & 10 & 10 \\
\hline Local & 6 & 6 \\
\hline \multirow[t]{2}{*}{ Regional } & 8 & 10 \\
\hline & 28 personas & 29 personas \\
\hline
\end{tabular}

VISTANIES
Según cantidad de visitas diarias a equipamiento cuttural

TOTAL DE USUARIOS DE CENTRO DE INTERPRETACIÓN $\quad 281,236$ DEL AGUA

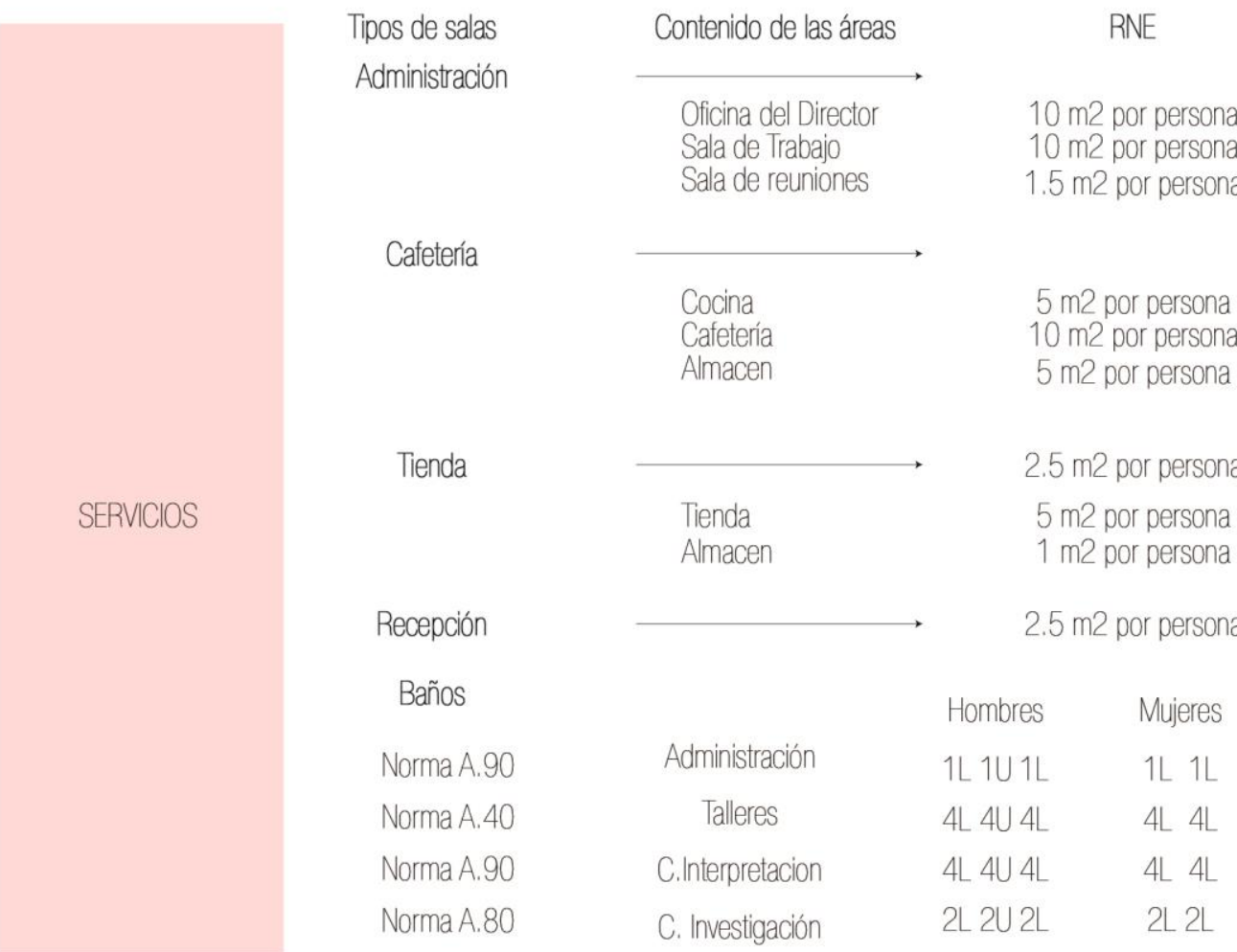




\section{RNE \\ AFORO \\ CANTIDAD DE VISTAS DIARIAS}

$4 \mathrm{~m} 2$ por persona

$3 \mathrm{~m} 2$ por persona

$3 \mathrm{~m} 2$ por persona

$3 \mathrm{~m} 2$ por persona

$3 \mathrm{~m} 2$ por persona

50 personas

50 personas

30 personas

30 personas

30 personas

El organigrama de paquetes programáticos muestra ta

El organigrama de paquetes programáticos muesta
liealidad del proyecto, con una circulación central.

1. AFOORO

2. TURNOS DEATENOOON

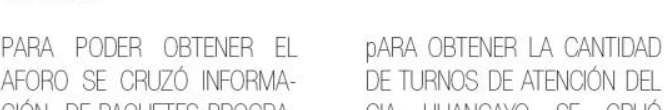

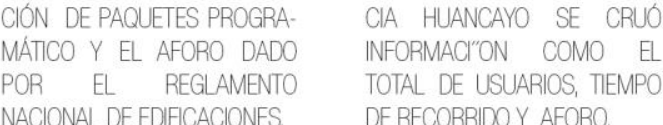

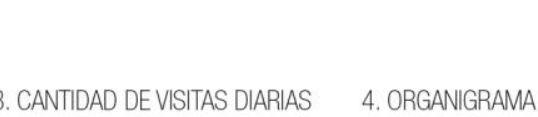

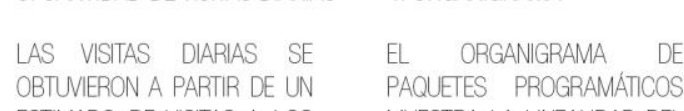

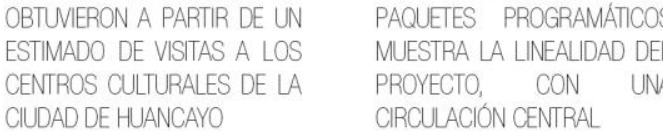

$2.5 \mathrm{~m} 2$ por persona $\quad 20$ personas

$2.5 \mathrm{~m} 2$ por persona $\quad 20$ personas

$2.5 \mathrm{~m} 2$ por persona $\quad 20$ personas

$1.0 \mathrm{~m} 2$ por persona $\quad 100$ personas

\begin{tabular}{|c|c|c|c|c|c|}
\hline \multirow{4}{*}{ 檫 } & \multirow{4}{*}{ TALLERES } & Taller de Reciclaje & 50 & $2.5 \mathrm{~m} 2$ por persona & 20 personas \\
\hline & & Taller de Botánica & 50 & $2.5 \mathrm{~m} 2$ por persona & 20 personas \\
\hline & & Taller del Agua & 50 & $2.5 \mathrm{~m} 2$ por persona & 20 personas \\
\hline & & Sala de Presentaciones & 100 & $1.0 \mathrm{~m} 2$ por persona & 100 personas \\
\hline \multirow{11}{*}{ 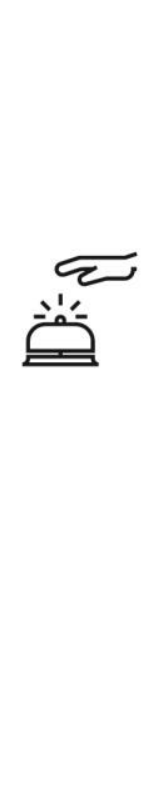 } & \multirow{10}{*}{ SERVICIOS } & \multirow{4}{*}{$\begin{array}{l}\text { Administración } \\
\text { Oficina del Director } \\
\text { Sala de Trabajo } \\
\text { Sala de reuniones }\end{array}$} & & \multirow{4}{*}{$\begin{array}{l}10 \mathrm{~m} 2 \text { por persona } \\
10 \mathrm{~m} 2 \text { por persona } \\
1.5 \mathrm{~m} 2 \text { por persona }\end{array}$} & \multirow{4}{*}{$\begin{array}{l}2 \text { personas } \\
4 \text { personas }\end{array}$} \\
\hline & & & 15 & & \\
\hline & & & 40 & & \\
\hline & & & 12 & & \\
\hline & & Cafetería & & & \\
\hline & & $\begin{array}{l}\text { Cocina } \\
\text { Cafetería }\end{array}$ & $\begin{array}{l}15 \\
190\end{array}$ & $\begin{array}{l}5 \mathrm{~m} 2 \text { por perisona } \\
10 \mathrm{~m} 2 \text { por persona }\end{array}$ & 20 personas \\
\hline & & Almacen & 10 & $5 \mathrm{~m} 2$ por persona & 2 personas \\
\hline & & Tienda & & & \\
\hline & & Tienda & 50 & 5 m2 por persona & 1 persona \\
\hline & & Almacen & 5 & 1 m2 por persona & 50 personas \\
\hline & TOTAL & & 1,237 & & 500 PERSONAS \\
\hline
\end{tabular}

TURNOS DE ATENCIÓN
POR DÍA

\section{PORCENTAUE}

\begin{tabular}{|c|c|c|}
\hline Extranieros & 15 Extranjeros & $15 \%$ \\
\hline Nacionales & 15 Nacionales & $15 \%$ \\
\hline Local & 40 Locales & $40 \%$ \\
\hline Regional & 30 Regionales & $30 \%$ \\
\hline
\end{tabular}

ORGANGRAMA DE PAQUETES PROGRAMÁtICOS

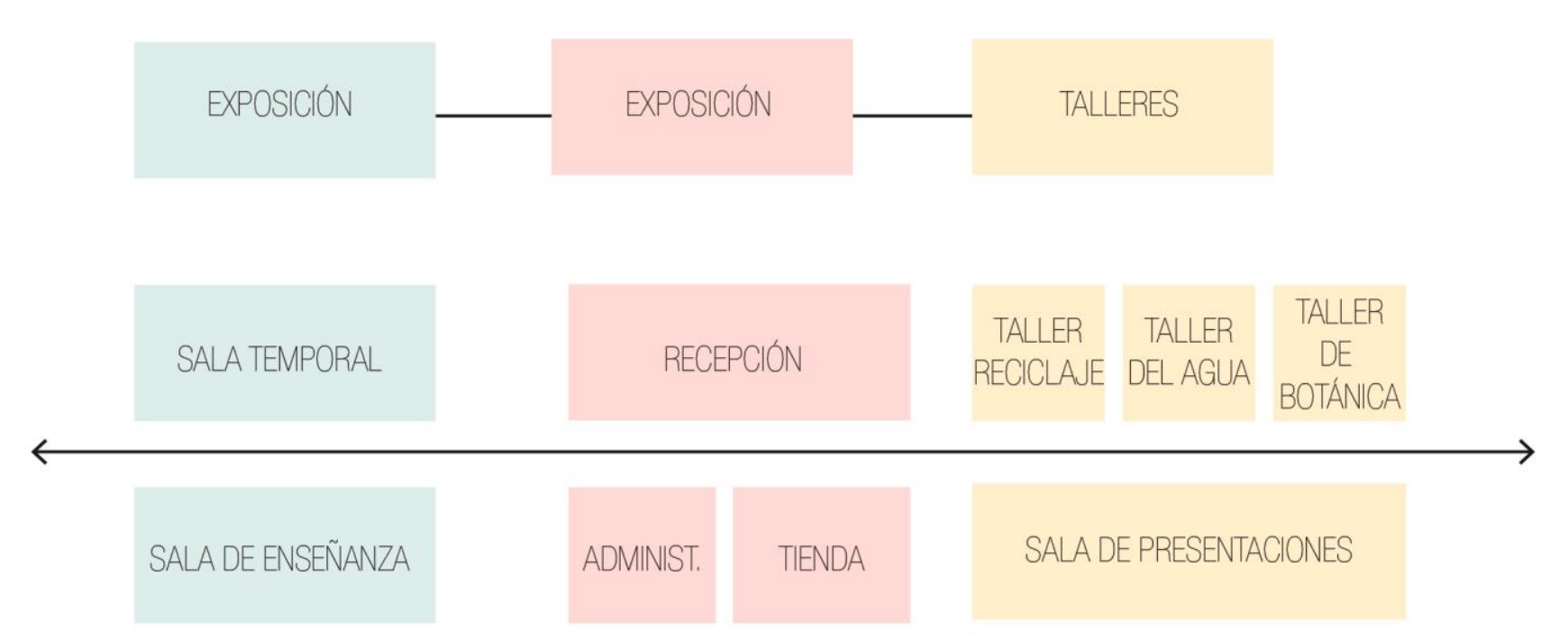

TOTAL DE USUAROS
TIEMPO DE RECORRIDO

2-3 HORAS

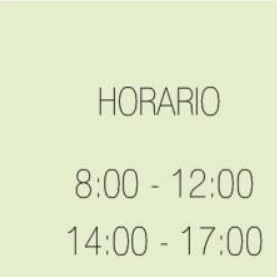

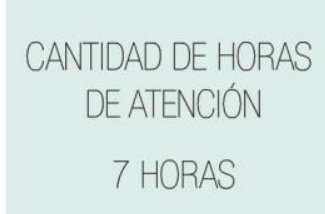

CANTIDAD DE TURNOS $281,236 / 500$
562 TURNOS

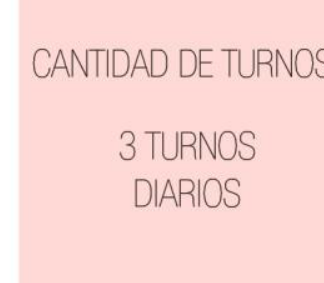

CANTIDAD DE TURNOS
18 TURNOS
SEMANALES

CANTIDAD DE TURNOS 


\subsubsection{Propuesta Centro de Interpretación del Agua Huancayo}

La propuesta del Centro de Interpretación del Agua (CIA) parte de la necesidad de incremento de equipamiento cultural en la ciudad con la finalidad de que pueda contribuir a la concientización, educación y cuidado del río.

Es importante indicar que CIA es parte de un proyecto urbano integral que inicia desde una intervención macro territorial y posteriormente a escala barrial, que busca la mejora de las condiciones urbanas de la ciudad en relación a la ribera del Shullcas como un todo en el sistema urbano de Huancayo.

La arquitectura es pieza fundamental que engrana las acciones urbanas a diferentes escalas y concreta un espacio para la población. En ella se busca cerrar la labor de revaloración de la ribera con la transmisión y educación del cuidado del Río Shullcas.

A continuación, se explicará el desarrollo del proyecto piloto del centro de interpretación del Agua a través de conclusiones de estudio de proyectos similares y dela teoría de interpretación que ha servido de apoyo a la base conceptual.

Tabla 8. 4 Aplicación del Marco Teórico al diseño del Centro de Interpretación del Agua

\begin{tabular}{|c|c|c|}
\hline \multirow{4}{*}{$\begin{array}{c}\text { Marco } \\
\text { operativo }\end{array}$} & \multirow{4}{*}{ Centros de interpretación } & $\begin{array}{c}\text { La arquitectura está relacionada al paisaje natural } \\
\text { ubicado en la periferia del casco urbano. }\end{array}$ \\
\hline & & $\begin{array}{l}\text { Ha permitido definir los paquetes programáticos } \\
\text { generales. }\end{array}$ \\
\hline & & $\begin{array}{c}\text { Concluye en la utilización de materiales locales como } \\
\text { lógica sostenible. }\end{array}$ \\
\hline & & $\begin{array}{l}\text { Ha permitido definir una secuencia lineal partir de las } \\
\text { tipologías estudiadas. }\end{array}$ \\
\hline Tilden & $\begin{array}{l}\text { Interpretación - Revelar } \\
\text { significados a través del } \\
\text { contacto directo con el } \\
\text { recurso }\end{array}$ & \\
\hline Bob Peart & $\begin{array}{l}\text { Proceso de comunicación que } \\
\text { revela significados por } \\
\text { medio de la experiencia. }\end{array}$ & $\begin{array}{l}\text { Se propone áreas de experiencia recreativa e } \\
\text { intelectual en el proceso del recorrido del CIA a fin } \\
\text { de que el visitante genere un vínculo de valoración y } \\
\text { cuidado con el recurso del agua y del Río Shullcas. }\end{array}$ \\
\hline Don Aldridge & $\begin{array}{l}\text { Incrementar la conciencia del } \\
\text { visitante de forma que } \\
\text { despierte el deseo de }\end{array}$ & \\
\hline
\end{tabular}




\begin{tabular}{|c|c|c|}
\hline & $\begin{array}{l}\text { contribuir a la conservación } \\
\text { del medio ambiente. }\end{array}$ & \\
\hline Morales & $\begin{array}{c}\text { Acción de despertar } \\
\text { curiosidad que tiene como } \\
\text { intensión generar un cambio } \\
\text { de actitud por medio de la } \\
\text { experiencia recreativa e } \\
\text { intelectual }\end{array}$ & \\
\hline \multirow{3}{*}{ Veverka } & \multirow{3}{*}{$\begin{array}{l}\text { Establece los lineamientos } \\
\text { interpretativos en relación al } \\
\text { aprendizaje, comportamiento } \\
\text { y emociones }\end{array}$} & $\begin{array}{l}\text { Objetivo de aprendizaje: Proveer conocimiento de los } \\
\text { usos y beneficios del recurso hídrico como elemento } \\
\text { natural y paisajístico en la ciudad de Huancayo. }\end{array}$ \\
\hline & & $\begin{array}{l}\text { Objetivo emocional: Se establece por medio de las } \\
\text { actividades que promueven la interacción del } \\
\text { visitante a partir de la experiencia y exploración. }\end{array}$ \\
\hline & & $\begin{array}{l}\text { Objetivo de comportamiento: Concientizar sobre el } \\
\text { recurso del Río Shullcas con la finalidad de valorar y } \\
\text { cuidar este componente de la ribera. }\end{array}$ \\
\hline \multirow[b]{4}{*}{$\begin{array}{l}\text { Countryside } \\
\text { Comission - } \\
\text { Peart y Wood }\end{array}$} & \multirow[b]{4}{*}{$\begin{array}{l}\text { Los } 5 \text { componentes del } \\
\text { proceso de la interpretación } \\
\text { como medio para la } \\
\text { planificación interpretativa: } \\
\text { Lineamientos, análisis del } \\
\text { recurso, usuario, selección de } \\
\text { medios y evaluación. }\end{array}$} & $\begin{array}{l}\text { El lineamiento corresponde a la oportunidad de } \\
\text { revalorar el recurso del agua del Río Shullcas el cual } \\
\text { se encuentra en estado de contaminación. }\end{array}$ \\
\hline & & $\begin{array}{c}\text { El análisis del recurso corresponde a la interpretación } \\
\text { de los beneficios y usos que agua proporciona al } \\
\text { desarrollo humano. }\end{array}$ \\
\hline & & $\begin{array}{c}\text { Al análisis del usuario se considera cuatro tipos de } \\
\text { usuarios, (permanentes, fijos, semipermanentes y } \\
\text { visitantes) }\end{array}$ \\
\hline & & $\begin{array}{l}\text { La elección del área de emplazamiento del CIA se } \\
\text { establece por medio del carácter del parque ambiental } \\
\text { que forma parte del tramo 1, además de las } \\
\text { cualidades espaciales del área que contribuyen a la } \\
\text { interacción con el paisaje intervenido. Asimismo, la } \\
\text { selección de medios se establece con la proposición } \\
\text { de actividades que promuevan la interacción del } \\
\text { recurso hídrico a partir de tres pozas de agua que son } \\
\text { reflejo de situaciones como el hábitat de peces, } \\
\text { vegetación y de recreación. Por último se estable una } \\
\text { programación por turnos que contribuyen a definir } \\
\text { una secuencia de }\end{array}$ \\
\hline \multirow{4}{*}{$\begin{array}{l}\text { Countryside } \\
\text { Comission }\end{array}$} & \multirow{4}{*}{$\begin{array}{l}\text { Determina aspectos a evaluar } \\
\text { en el análisis del usuario }\end{array}$} & $\begin{array}{l}\text { Patrones de visita: Se configura a través de turnos } \\
\text { establecidos en el transcurso. }\end{array}$ \\
\hline & & $\begin{array}{l}\text { Grupos especiales: El diseño del CIA contempla el } \\
\text { uso de mayores de edad, niños y personas } \\
\text { discapacitadas. }\end{array}$ \\
\hline & & $\begin{array}{l}\text { Interés: Las actividades propuestas parten del interés } \\
\text { del visitante por el contacto con el paisaje y } \\
\text { recreación. De ahí parte la necesidad de la creación } \\
\text { de pozas naturales que involucren el contacto con la } \\
\text { vegetación, los animal y de uso recreativo. }\end{array}$ \\
\hline & & \\
\hline
\end{tabular}




\begin{tabular}{|c|c|c|}
\hline & & $\begin{array}{c}\text { Necesidades: Se complementa con aulas talleres para } \\
\text { la formación del visitante sobre el cuidado del agua } \\
\text { del río. (Botánico, reciclaje y agua) }\end{array}$ \\
\hline \multirow{5}{*}{$\begin{array}{l}\text { Badaracco y } \\
\text { Scull }\end{array}$} & \multirow{5}{*}{$\begin{array}{l}\text { Determina criterios de } \\
\text { evaluación para la } \\
\text { identificación de potenciales } \\
\text { interpretativos }\end{array}$} & $\begin{array}{l}\text { Singularidad: Establecida por el potencial del lugar, } \\
\text { las características topográficas que permiten el } \\
\text { contacto directo con el recurso. }\end{array}$ \\
\hline & & $\begin{array}{l}\text { Atractivo: Elementos visuales aprovechados como } \\
\text { herramientas para la contemplación del Río Shullcas. }\end{array}$ \\
\hline & & $\begin{array}{c}\text { Acceso: Conservación de caminos con valor } \\
\text { paisajístico y Configuración de ingresos que permitan } \\
\text { una fluidez entre la ciudad y el parque. }\end{array}$ \\
\hline & & $\begin{array}{l}\text { Afluencia. Se considera en el diseño los flujos y } \\
\text { nodos existentes como paraderos y equipamientos } \\
\text { para la definición de ingresos que conecten con los } \\
\text { caminos generales del parque y el CIA }\end{array}$ \\
\hline & & $\begin{array}{c}\text { Seguridad: Consideración de los sectores vulnerables } \\
\text { a inundación por lo que se establece áreas de } \\
\text { esparcimiento como medida de prevención en las } \\
\text { zonas de muy alto y alto riesgo. }\end{array}$ \\
\hline \multirow{4}{*}{ Pennyfather } & \multirow{4}{*}{$\begin{array}{l}\text { Determina medios de } \\
\text { interpretación de carácter } \\
\text { participativo }\end{array}$} & $\begin{array}{l}\text { Senderos: Se diseña un recorrido abierto que conecta } \\
\text { el CIA con el camino principal del parque. }\end{array}$ \\
\hline & & $\begin{array}{l}\text { Miradores: Se propone un sector que permite la } \\
\text { contemplación directa con la ribera del Shullcas. }\end{array}$ \\
\hline & & $\begin{array}{l}\text { Puntos de distancia: Se propone la conformación de } \\
\text { espacios cerrados que concluyen con la salida al } \\
\text { recorrido externo de manera que se configura tiempos } \\
\text { en el transcurso de su recorrido que permiten una } \\
\text { interacción y descubrimiento del visitante con el } \\
\text { paisaje y la arquitectura. }\end{array}$ \\
\hline & & $\begin{array}{l}\text { Participación insitu: Las estrategias de programa se } \\
\text { define con talleres que están pensadas para } \\
\text { complementarse con interacción directa con el lugar. }\end{array}$ \\
\hline
\end{tabular}

Fuente: elaboración propia 


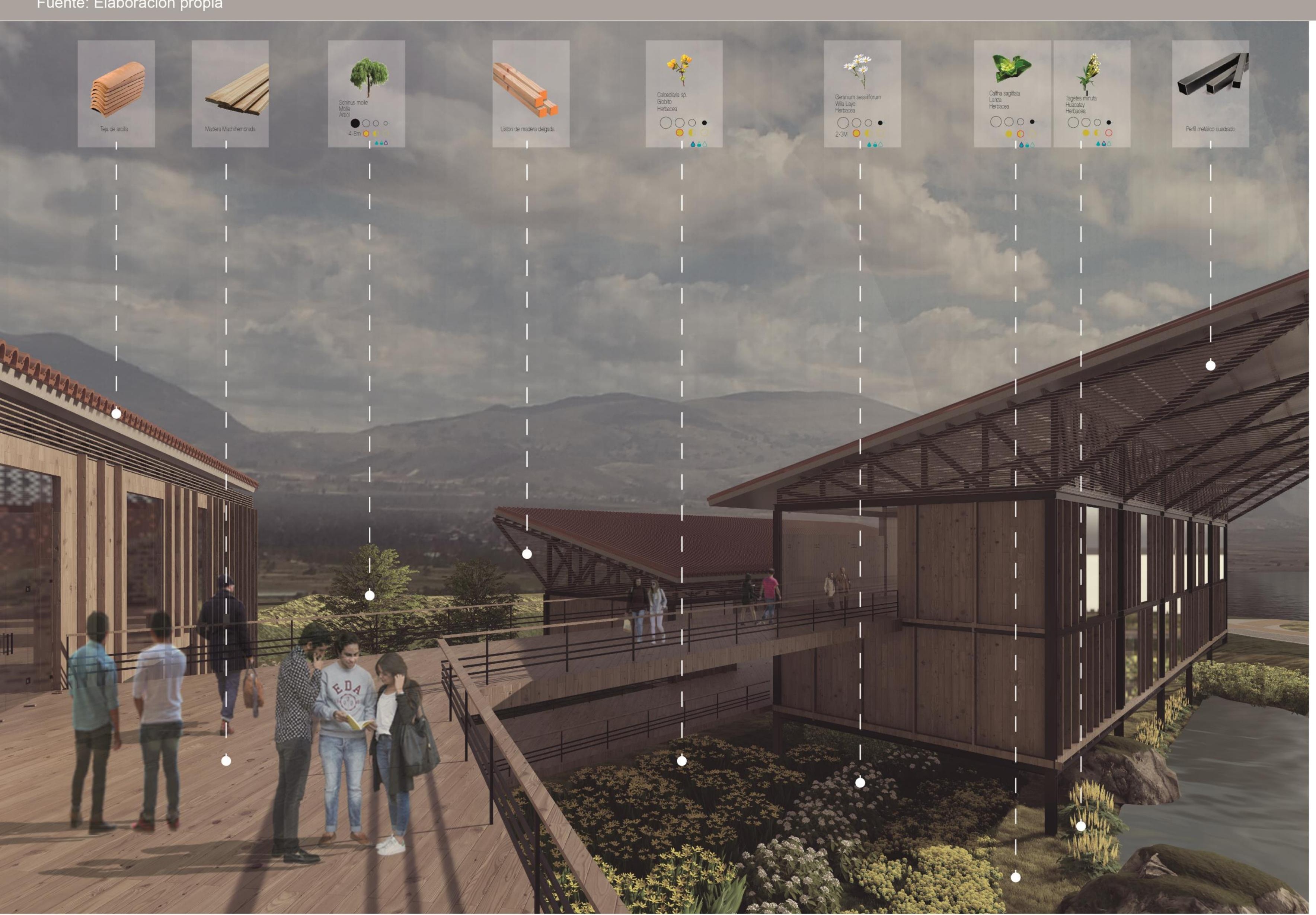

CIA HUANCAYO PROPONE EDUCAR Y CONCIENTIZAR A LA POBLACIÓN SOBRE EL NTERPRETACIÓN EN LEL AGUA DEL RIO SHULLCAS USANDO COMO HERRAMIENTA LA EL PAISAJE

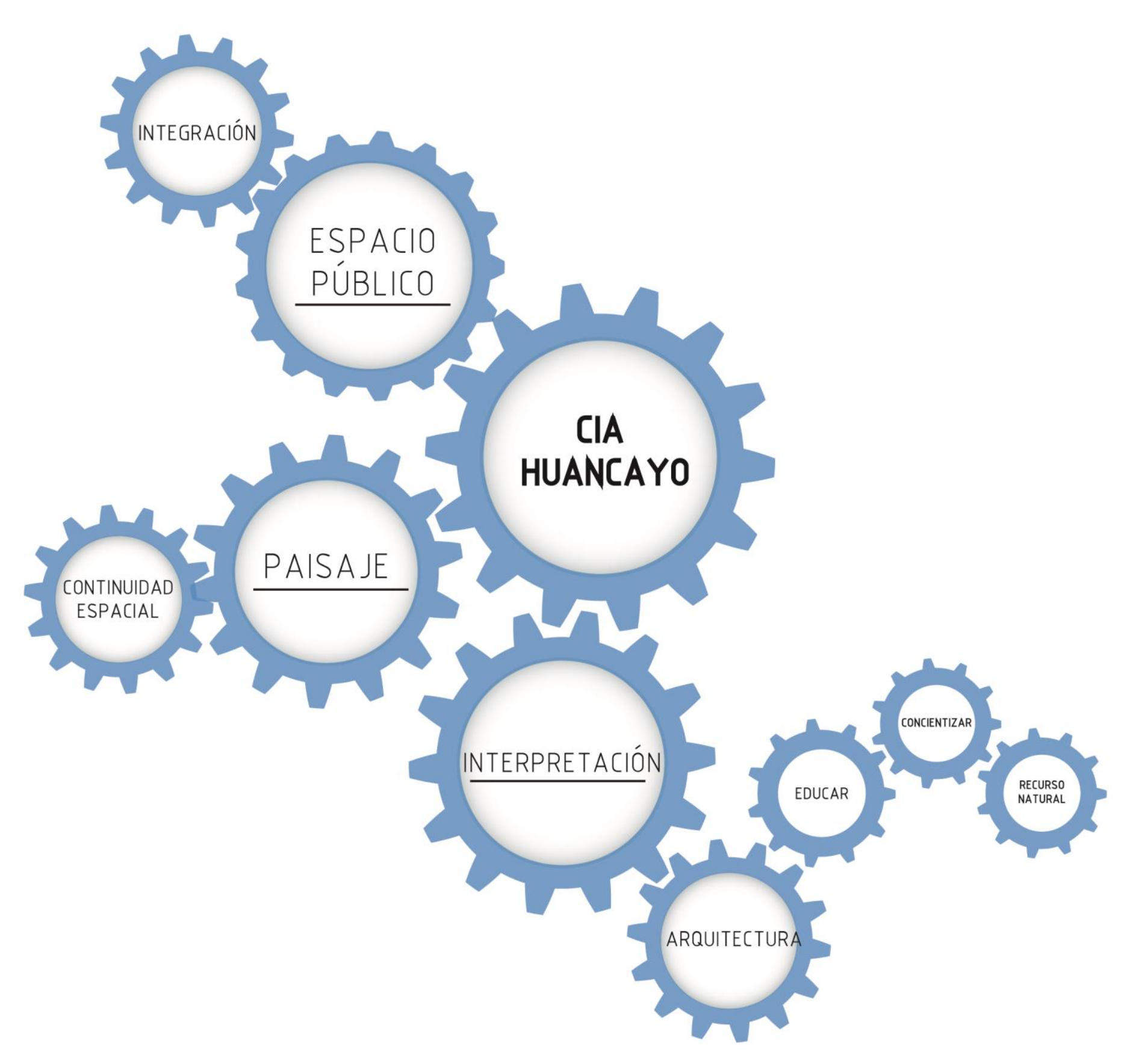




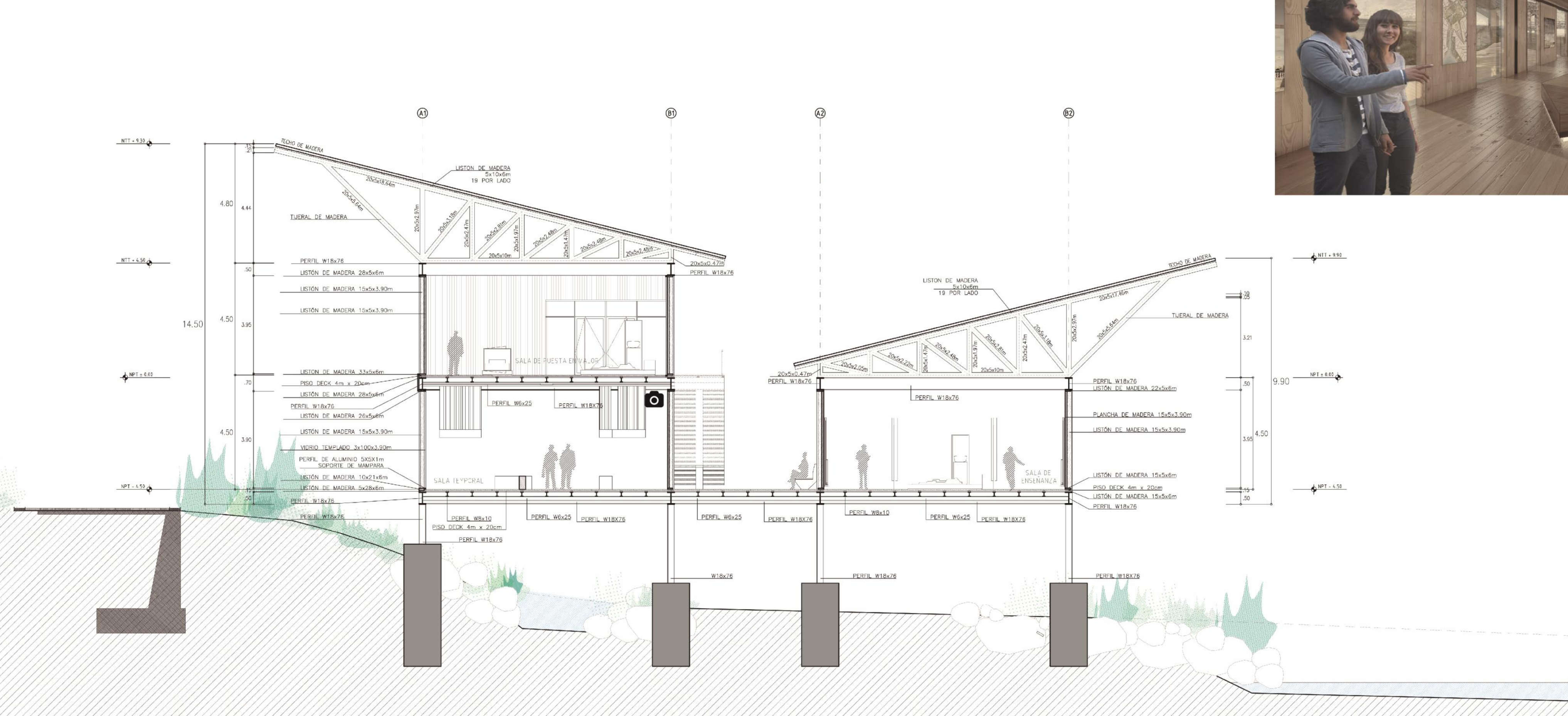


(3)
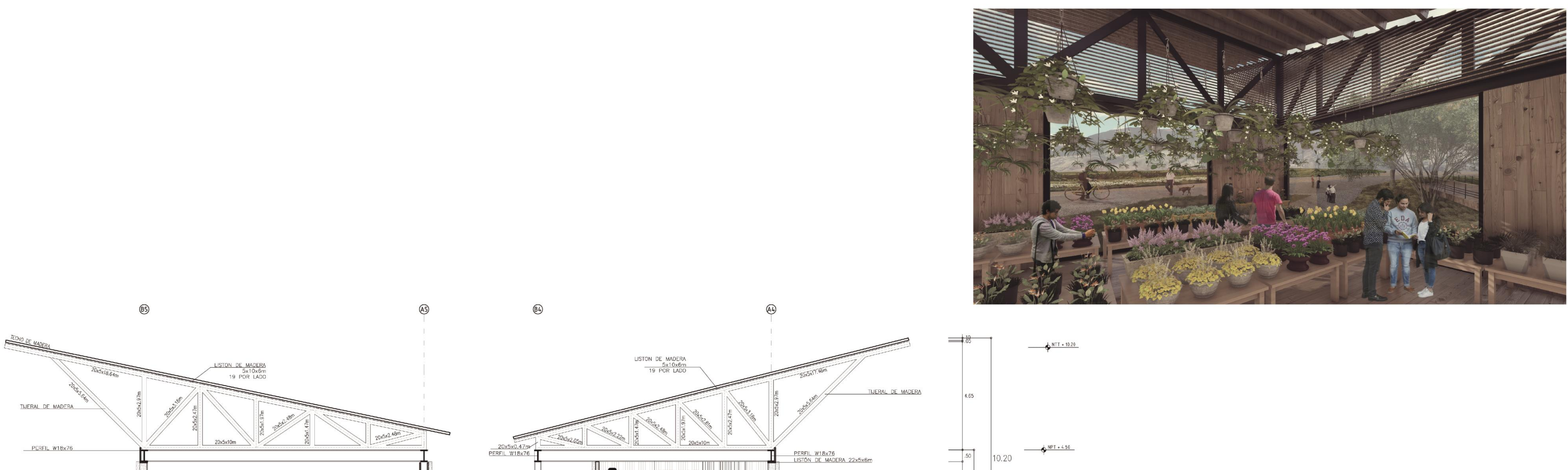
T)
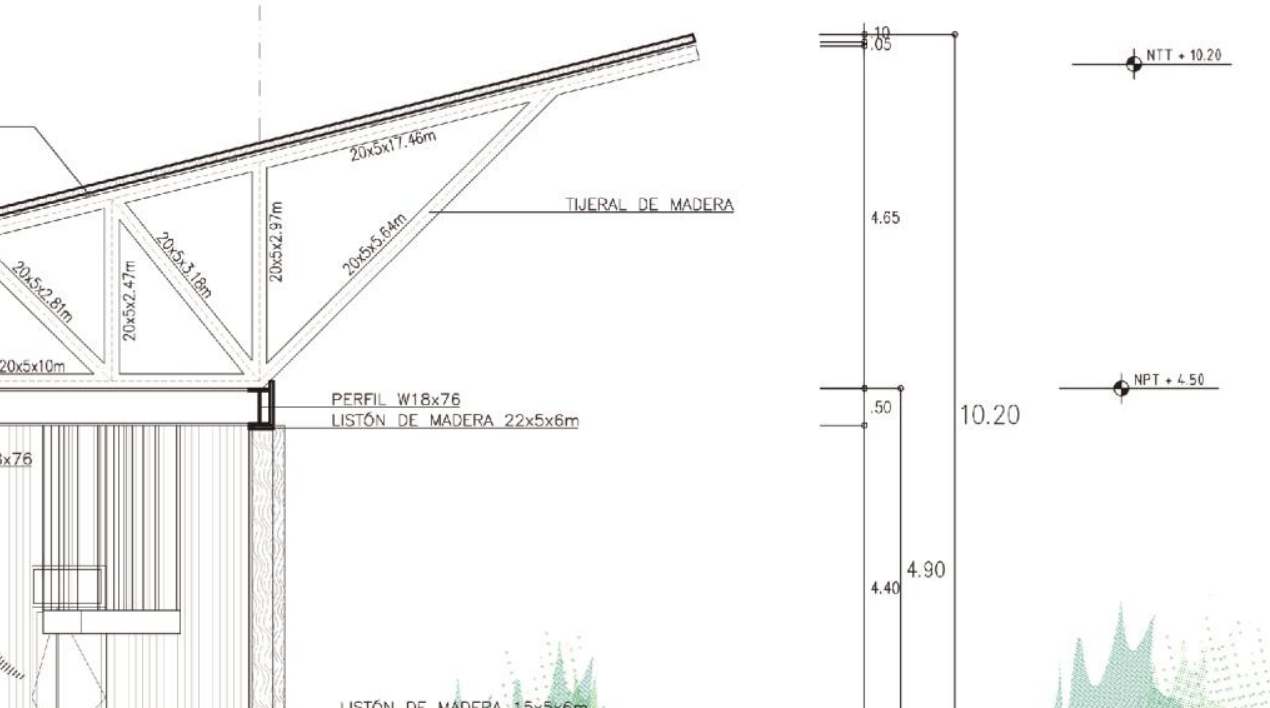

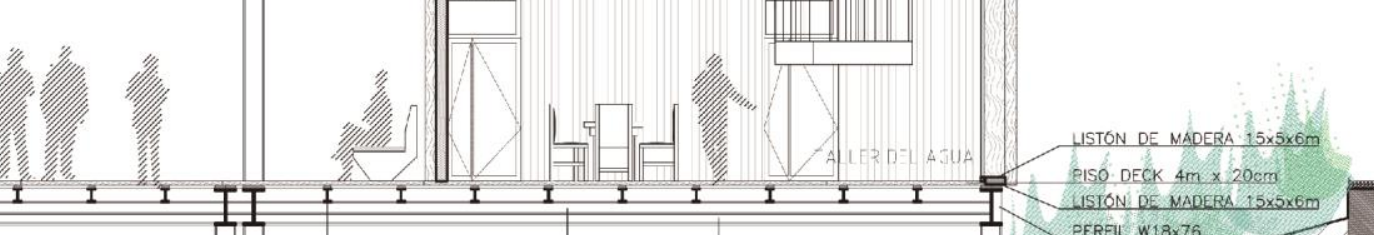
- 

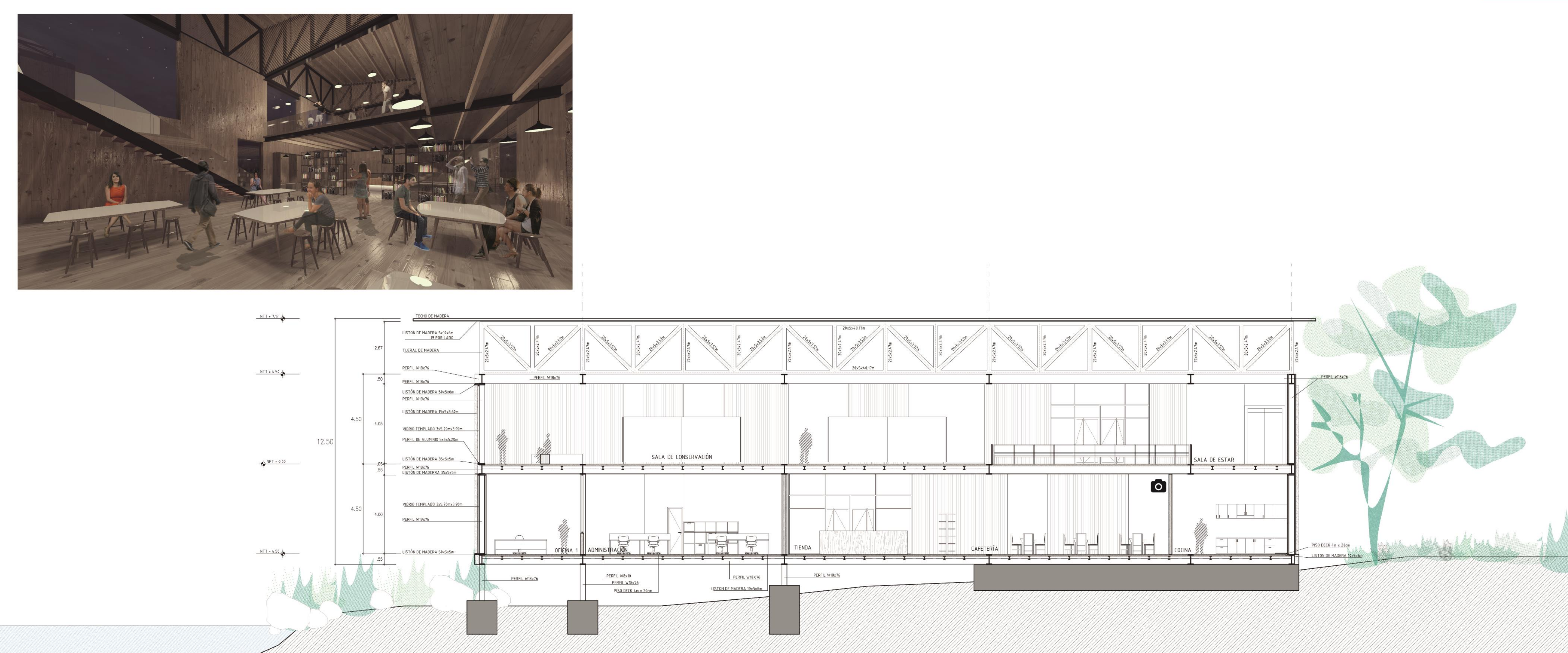
-

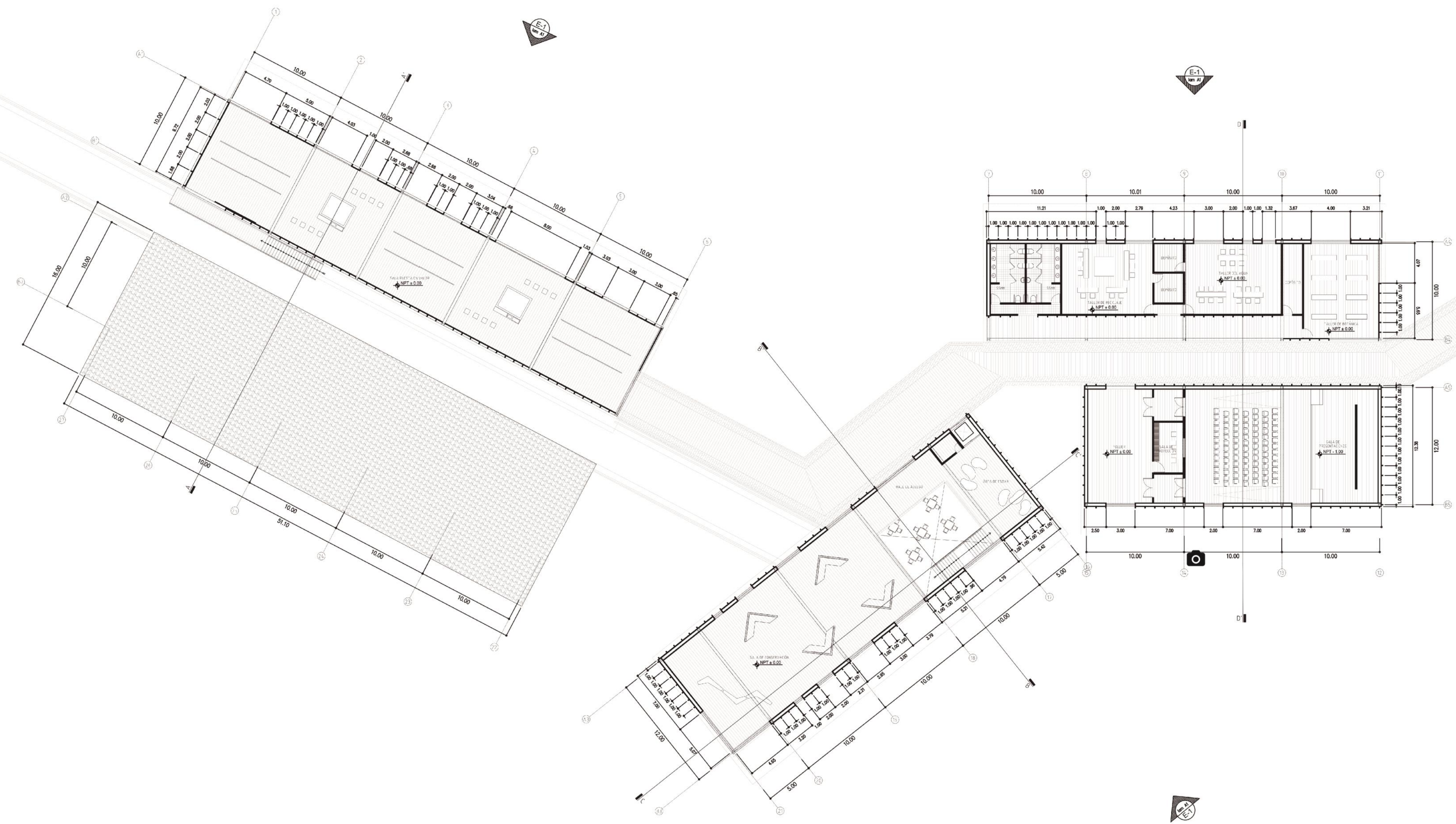




\subsection{Viabilidad y gestión}

Para la realización de un proyecto de gran envergadura como es el Parque Lineal Ribereño Shullcas, se genera tres ejes estratégicos (sostenibilidad ambiental, sostenibilidad social y cultural y sostenibilidad económica) los cuales deberán ser los pilares de gestión (ficha 8.41). Asimismo, al ser un plan maestro se debe tener en cuenta que la gestión será por etapas y periodos de gobierno. Por lo tanto, tomando como referente la estructura de financiamiento del Jardín Botánico de Medellín, la siguiente lámina (ficha 8.42) muestra el periodo de tiempo de ejecución de cada tramo de la propuesta, las mesas de trabajo y las entidades y actores que tendrán un rol en la ejecución.

Para llevar a cabo un proyecto como este deberá haber un planeamiento de gestión del concurso urbano paisajista que deberá ser llevado a cabo por el Gobierno Regional de Junín, el cual tendrá etapas, esta deberá ser llevada a cabo con el concurso de ingeniería encargada de los estudios previos a la ejecución (ficha 8.44). Para el desarrollo de gestión de la tesis nos basaremos en que el proyecto Parque Lineal Ribereño Shullcas es el ganador del concurso.

El Parque Lineal Ribereño Shullcas está compuesto por cinco elementos que deben ser gestionados según la propuesta (ficha 8.45), por lo tanto, el proyecto más que una intención es una necesidad social y ambiental. Esta iniciativa, tomando como referente el proyecto Parque del Río Medellín, tendría un costo aproximado de 500 millones de dólares en sus 13 kilómetros de recorrido. Por eso es importante plantearse la factibilidad a largo plazo. Cabe mencionar que para lograr una regeneración urbana completa se genera el plan piloto TRAMO 1 con la intención de intervenir la zona con mayor potencial de renovación urbana inmediata. 


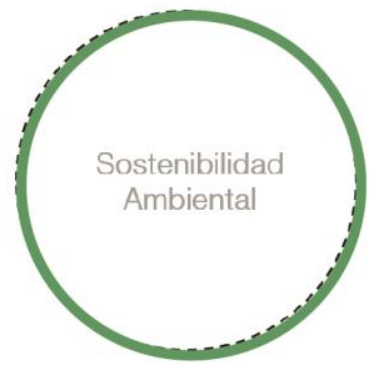

1. SOSTENIBILIDAD AMBIENTAL

Los proyectos y acciones del Plan de recuperación del Río Shullcas deberán enfocarse en las buenas prácticas ambientales, disminución de impactos negativos del territorio y la conservación de recursos naturales.

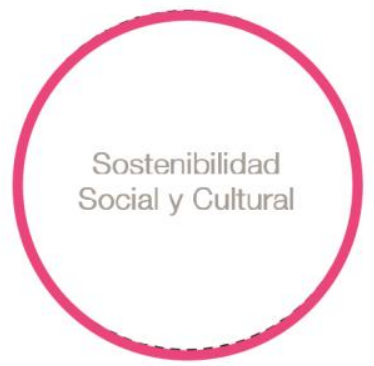

2. SOSTENIBILIDAD SOCIAL Y CULTURAL

Las acciones y proyectos del PLan deberán estar enfocadas a la promoción y puesta en valor de la identidad local, donde los ciudadanos puedan hacer uso de los espacios propuestos libremente, respetando la diversidad cultural y social, con dinámicas propias frente a su entorno.

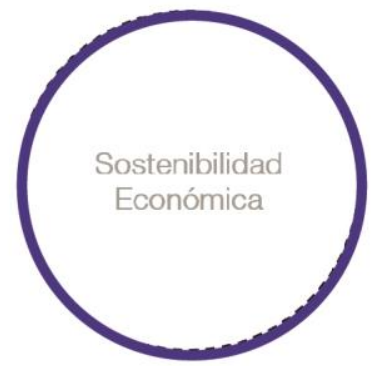

3. SOSTENIBILIDAD ECONÓMICA

Las acciones a desarrollar deben tener la capacidad de perdurar en el tiempo mediante la generación de ingresos, asegurando un mantenimiento regular y un cuidado por parte de la población.
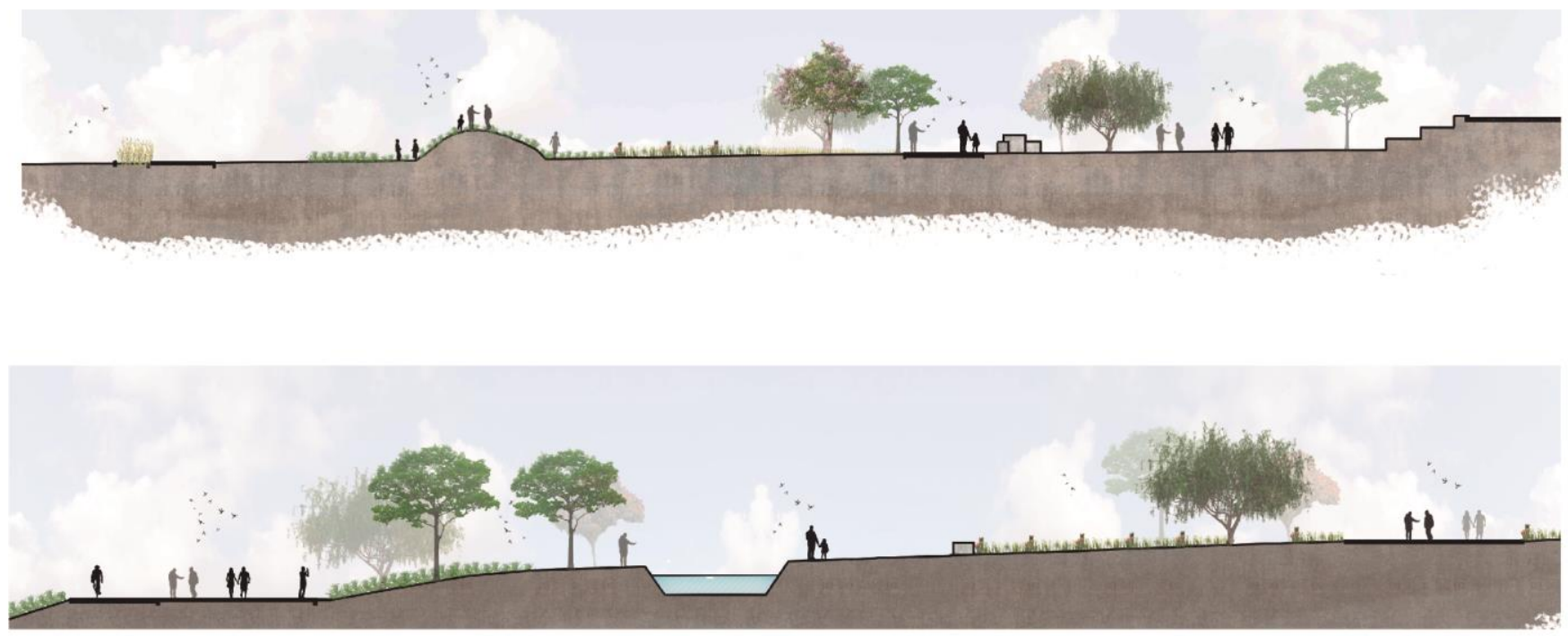
La puesta en marcha de un plan maestro para la recuperación de un ro es un proyecto ambicioso y que por lo tanto requiere de una (ivastion donde se involucten a diversos actores desde el gobiemo

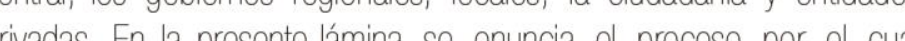
chería pasar la elaboración del plan maestro, una linea de tiempo

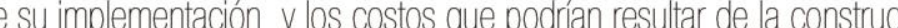
ción del primertramo solamente dado que es el que mayor desarroIlo tiene en la tesis.

Solamente el centro de interpretación, que tiene un área edificada

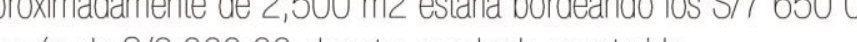
rezh des/3060.00

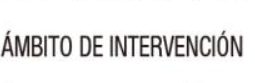

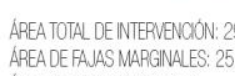
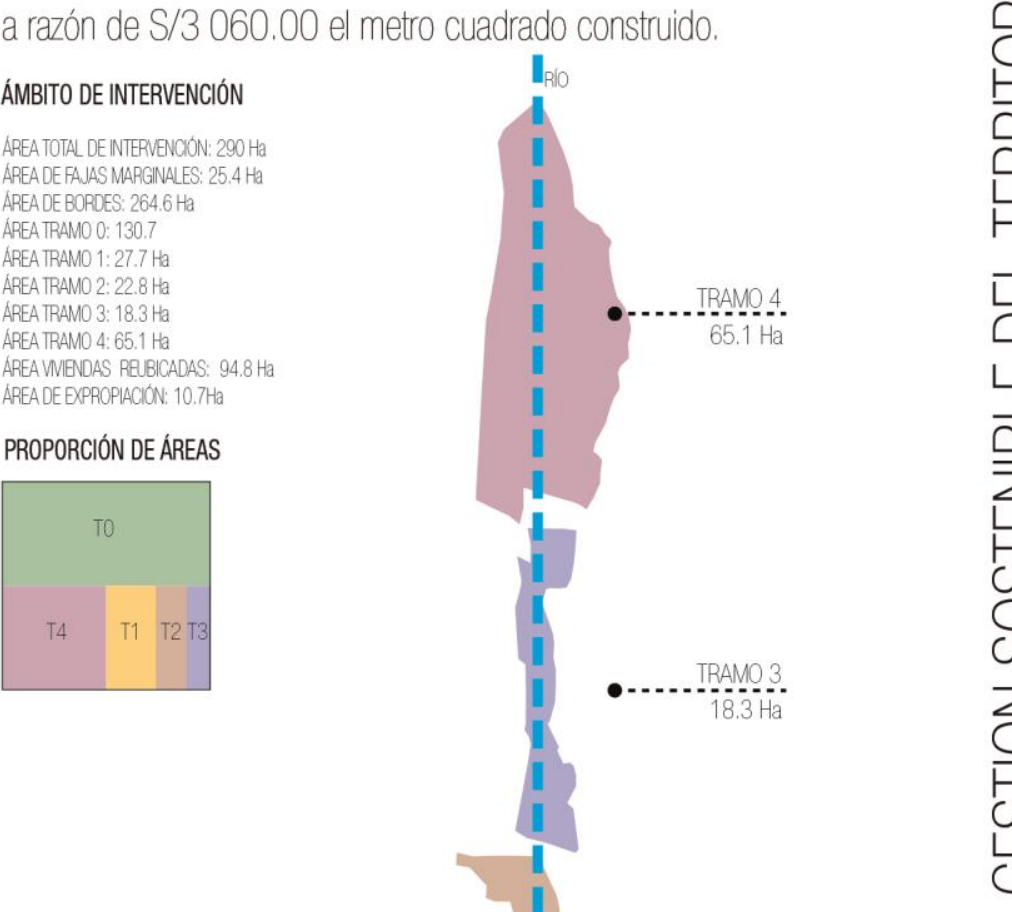

$\frac{\oslash}{\widetilde{\gamma}} \quad \stackrel{\mathrm{DE}}{\mathrm{O}}$

\section{ENTIDADES}

MUNIIIPIOS TAMBO

GOBIERNO REGIONAL GOBIERNO CENTRAL

MINCET
MTC

MTC
MVCS

THORIDAD NACION

EMPRESAS PRIVADAS

CUADRO DE RELACIONES ENTRE ENTIDADES - PROYECTOS - ACTOORES

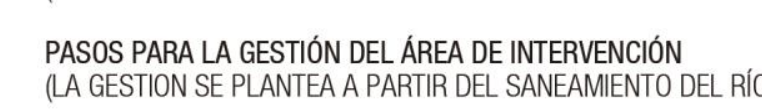

(1) PLAN MAESTRO DE LARECUPFRACIÓN DEL RIO SHULLCAS.

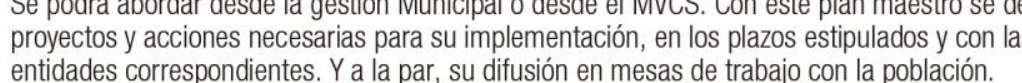

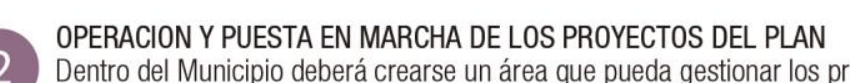

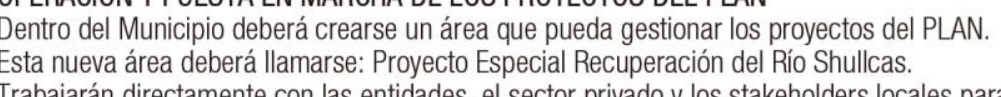

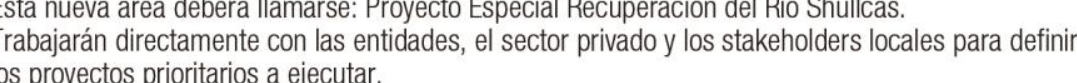

(3) EINANCIAMIIENTO

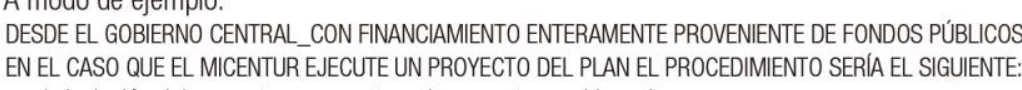

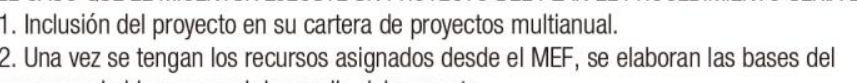

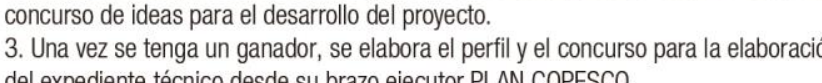

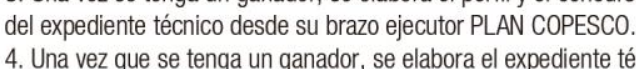

-..... TPANO2.2.

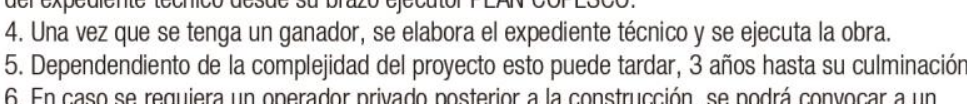

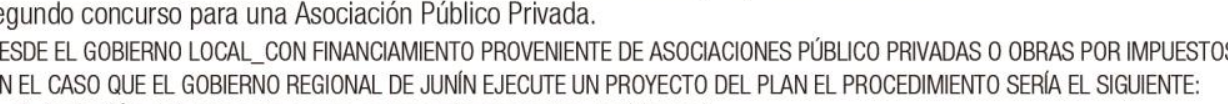

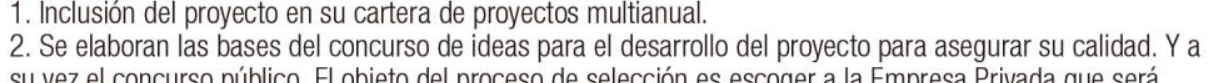

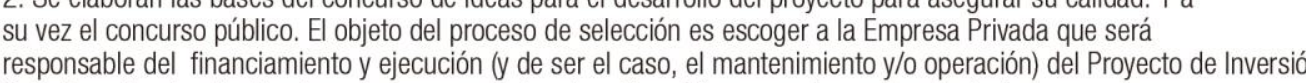

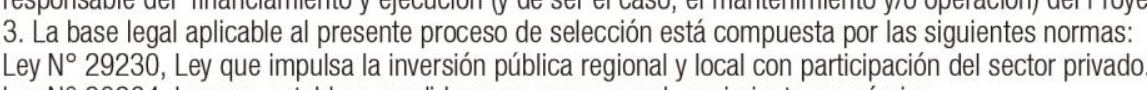

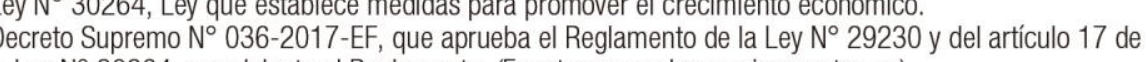

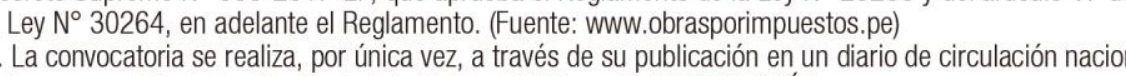

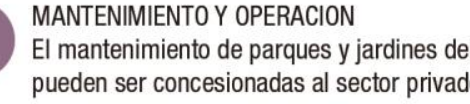

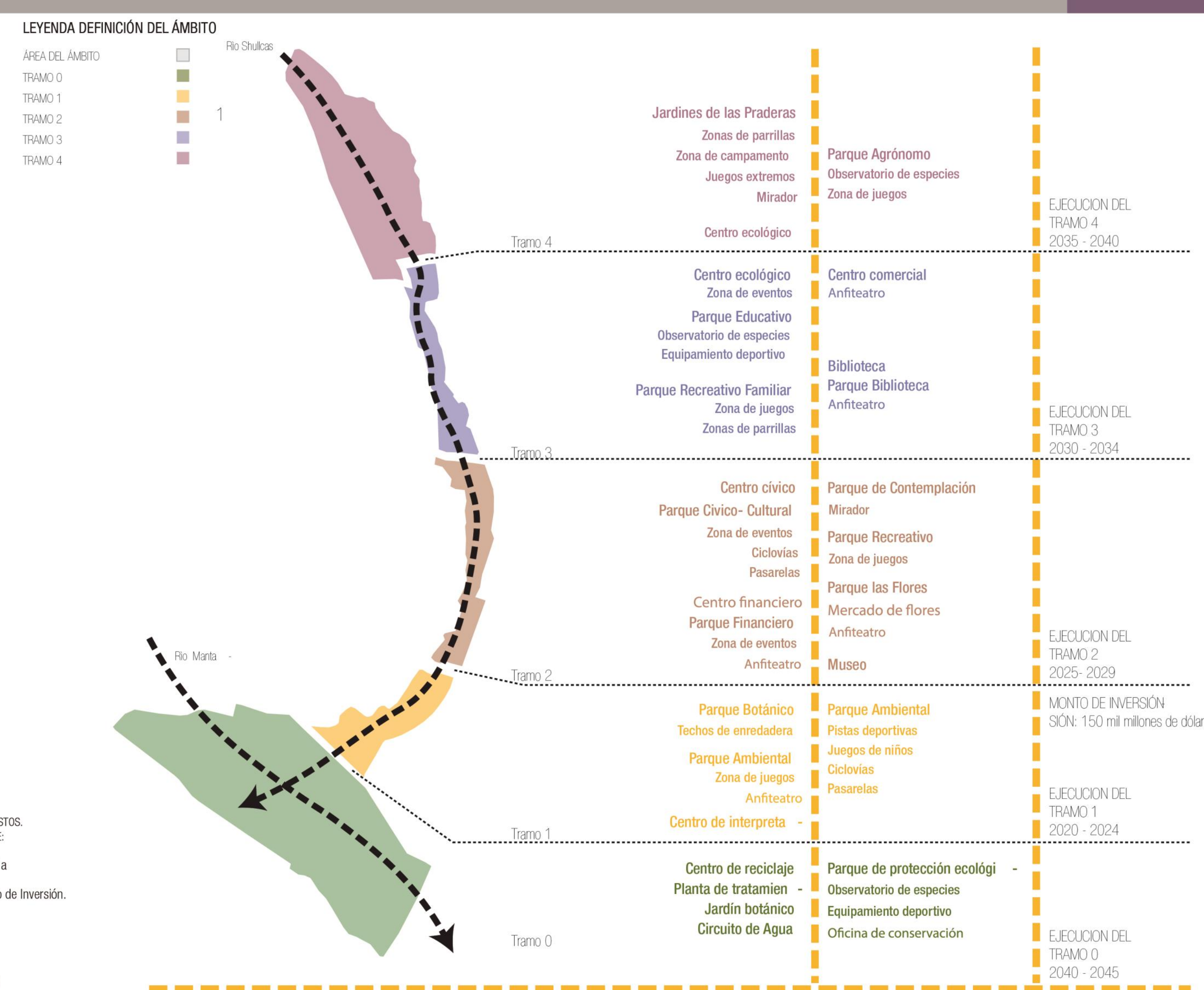

LIINEA DEL TIEMPO PARA LA IMPLEMENTACIÓN DEL MASTER PLAN DEL RÍO SHULLLAS 2020 - 2050 


\section{GESTION DEL COSTO}

La puesta en marcha de un plan maestro para la recuperación de un río es un proyecto ambicioso y que por lo tanto requiere de una inversión por etapas.

Como referente de estudio de inversión tomaremos a dos proyectos. Parque La Arganzuela (España) y Parque del Río (Colombia)

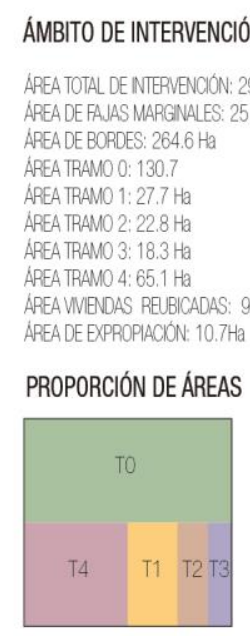

$\mathrm{Ha}$

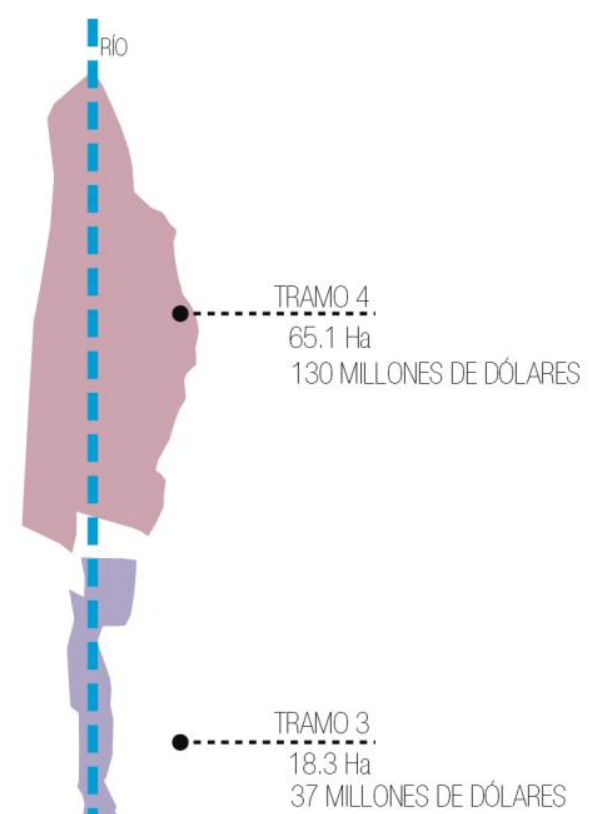

37 MILLONES DE DÓLARES

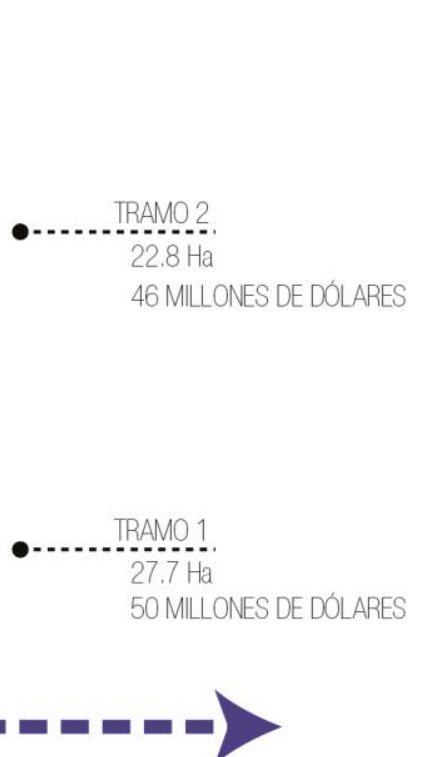
TRAMOO

\section{CUADRO DE COSTO \\ (ESTRUCTURA TOMADA DE FINACIAMIENTO \\ DE PARQUE DEL RÍO MEDELLIN)}

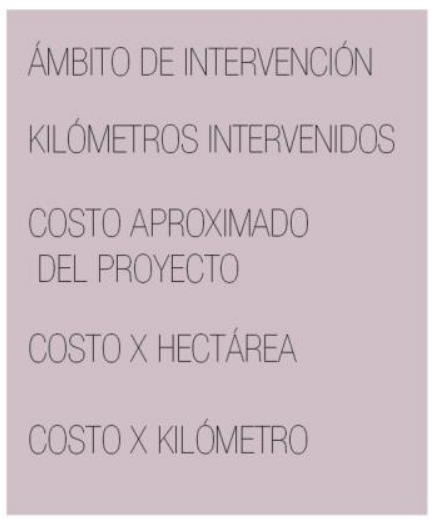

$423 \mathrm{Ha}$.

$26 \mathrm{KM}$

1000 MILLONES DE DÓLARES

2.5 MILLONES DE DÓLARES

38.5 MILLONES DE DÓLARES

CUADRO DE COSTO

(PARQUE LINEAL RIBEREÑO SHULLCAS)

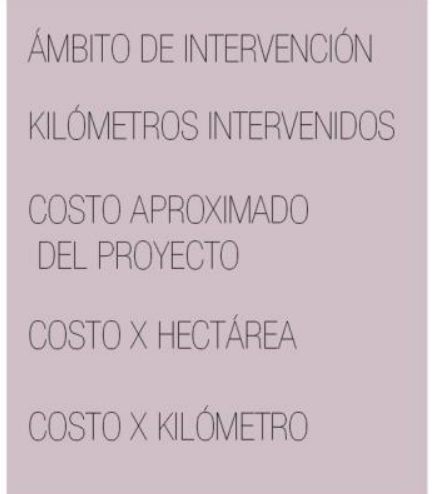

$290 \mathrm{Ha}$.

$13 \mathrm{KM}$

500 MILLONES DE DÓLARES

2 MILLONES DE DÓLARES

38.5 MILLONES DE DÓLARES 
Fuente: Elaboración propia

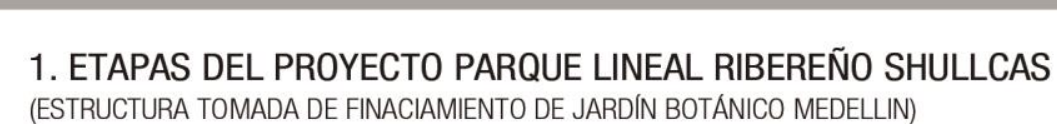

GESTION DEL CONCURSO URBANO PAISAJISTA

La gestión del un plan maestro deberá ser realizado por etapas sibien es ciento, una de las lapas es la del concurso arquitectio utilzará al Parque Lineal Ribereño Shullcas como el proyecto ganador.

ganador.
Además de el proyecto arquitectónico, el desarrollo de la ilos estudios de ingenería debe ser en paralelo para lograr un proyec. to integral.

Por otro lado, es importante mencionar las bases de gestión que regirán al proyecto urbano, como son el programa de gobierno de ordenamiento teritorial de la ciudad de Huancay.

Asimismo, según la metododogía del PMBOK, se desglosará de manera genéríca la gestión de cada componente del proyecto.

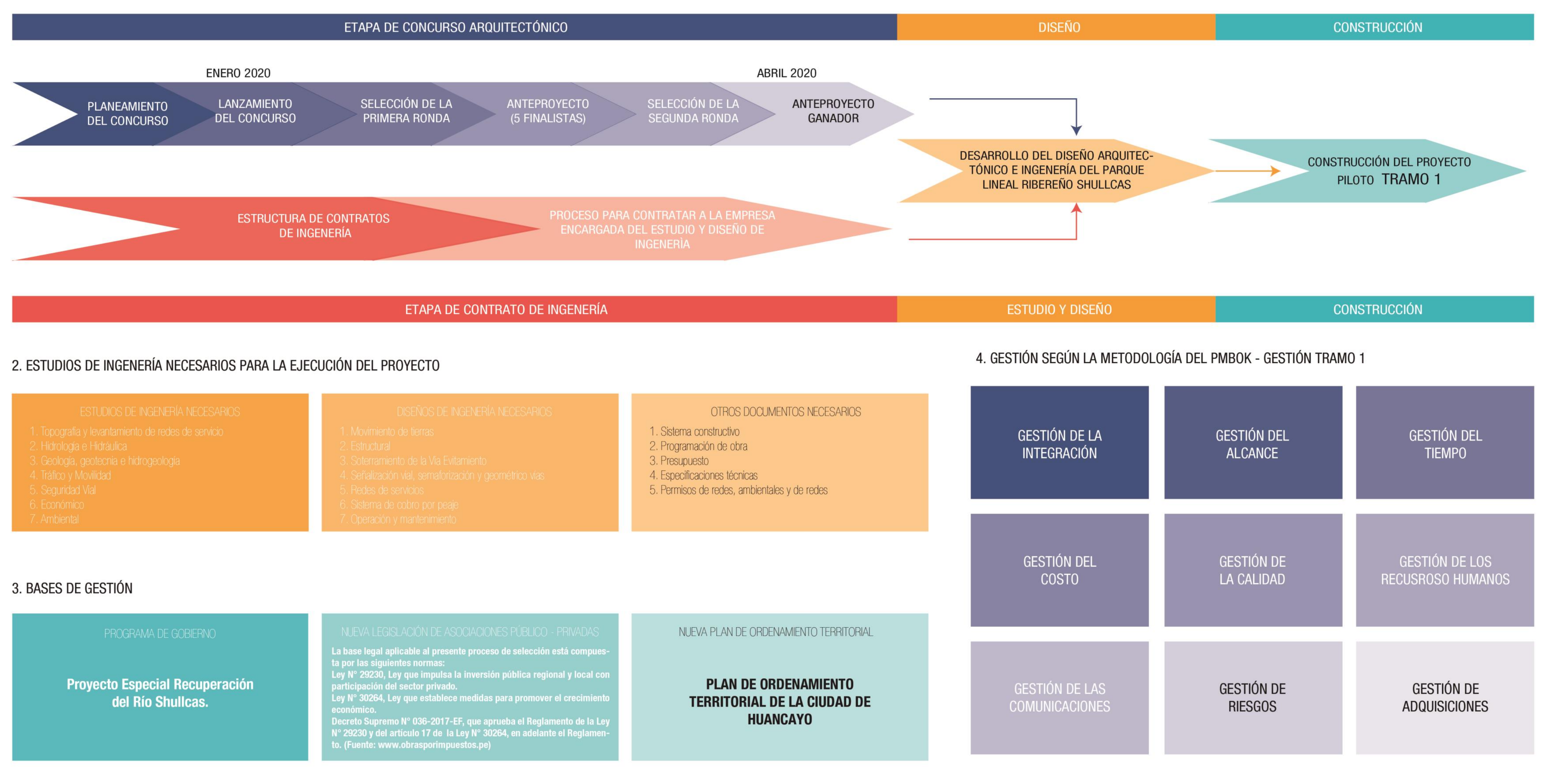




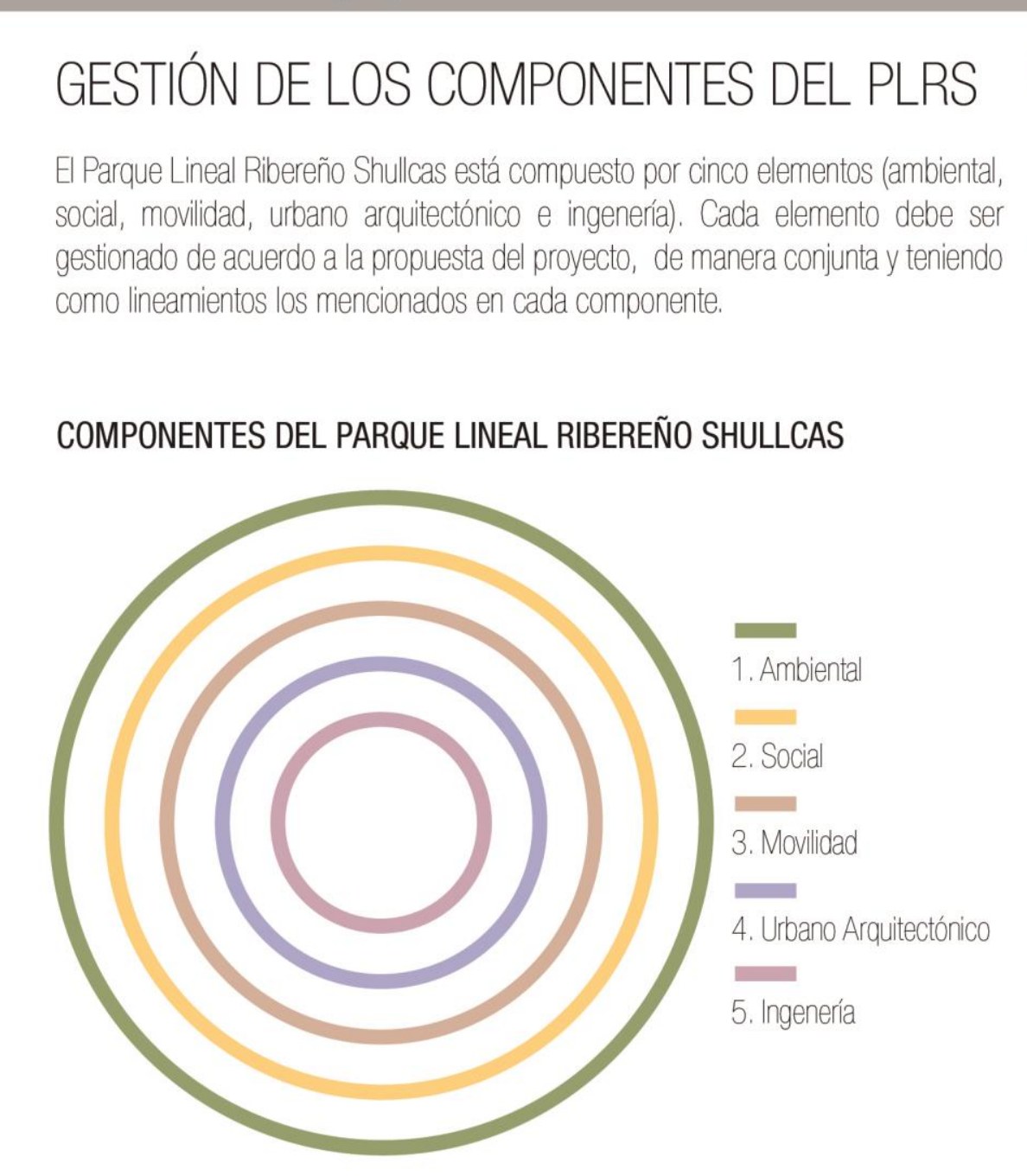

1. Ambiental

Naturalezay C Ciudad: Potenciar los espacios Verdes - Conectividad Ecológica - Aumentio de la

Moulilidad Sostenible: Que pirime l I movilidad no motorizada sobre la motorizada para promover

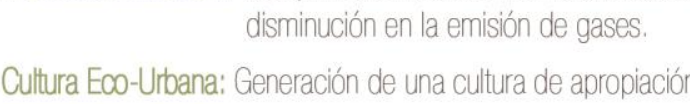

Sostenimientio del parcuue: Promover vilización de energias I Imoias, el ahorro y uso adecuado de agua y el manejo integral de los residuos.

2500 árboles a sembrar de 40 especies y una diversidad de fauna que se implementará por la vegetación
Lineamientos generales

Sostenible ambientalmente

* Mejoramiento continuo del paisaje

* Aumento de infraestructura ecológica

*Aumento de bosques urbanos

*Aumento de flora y fauna

\begin{tabular}{|c|}
\hline Agua \\
\hline Flora \\
\hline Fauna \\
\hline Aire \\
\hline Suelo \\
\hline Sonido \\
\hline luminación \\
\hline
\end{tabular}

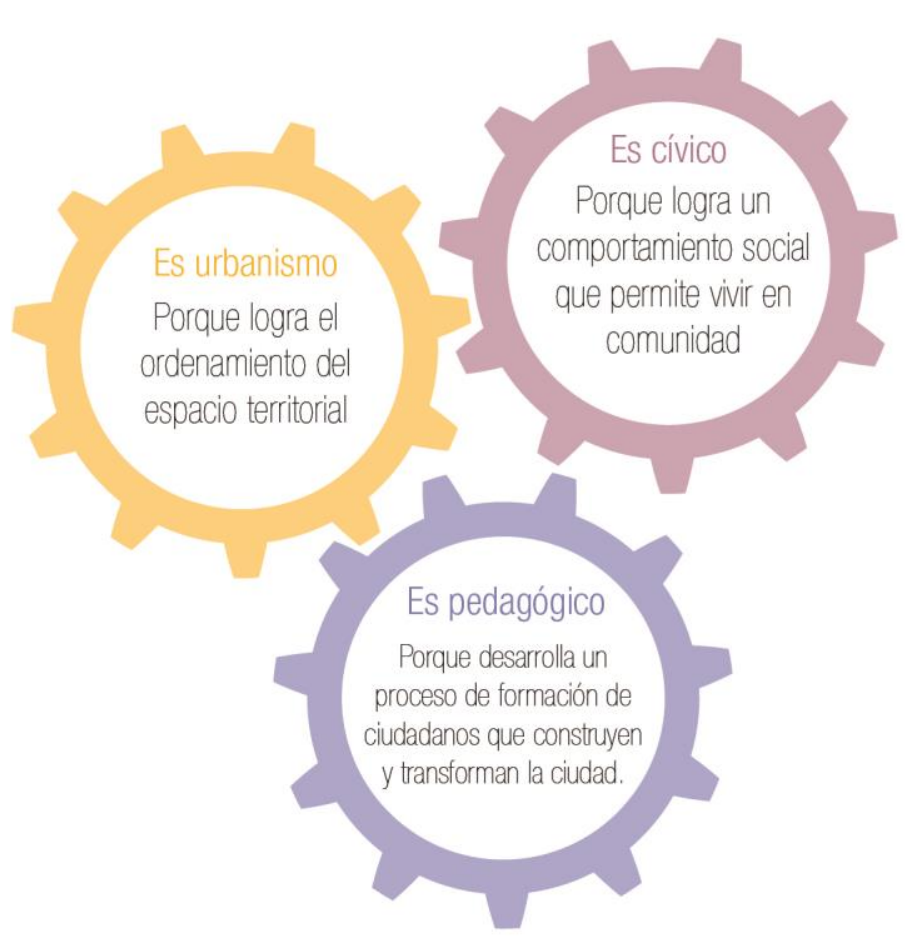

Estudio ambiental:

- Inventario de árboles del corredor del ría

-

- Recorridos pedagógicos a sitios de interés ambiental y jornadas de sensibilizaciór ensibilizacicion

\section{Social}

Contribuir con la viabilidad social del proyecto Parque Lineal Ribereño Shullcas a partir de la creación e molementación de estrategias de información, participación y comunicación con las comunidades a implementación de estrategias de inforrmación, participación y comunicación con

nformación: Reuniones de socialización / Eventos de ciudad / Jormadas de apropiación / Atriculación interinstitucional / Presencia en el teritorí

Participación: Talleres consultivos / Mesas paricicipativas

sistematización y memoria: Entrevistas / Conversatorios / Eiercicios Etnográfices Cartografía Social / Recorridos fotográficos

Apropiación y cultura ciuddadana: Jornadad de apropiación / Urbanismo táctico / jormadas
Area de influencia directa

2 Diststios: Tambo y Huancayo

3 Sectores
9 Subsectores

Se realizará estrategias de información,participación y comunicación en los distritos sectores y subsectores

3. Movilidad

Mejora de vías: Con el proyecto se mejorrará $72 \mathrm{~km}$ de vías en ambas márgenes del Río Shullcas. De manera transversal se soterrarál la vía evitamiento

Senderos y puentes: 3 puentes nuevos, 1 puente restaurado y 6 pasarelas nuevas

Interconexión: 14 colegios, 4 univiersidades, 3 equipamientos de salud interconectados por el Parque Lineal Ribereño Shullcas. Se calcula una población cercana a los 100000 interconectados con el parque

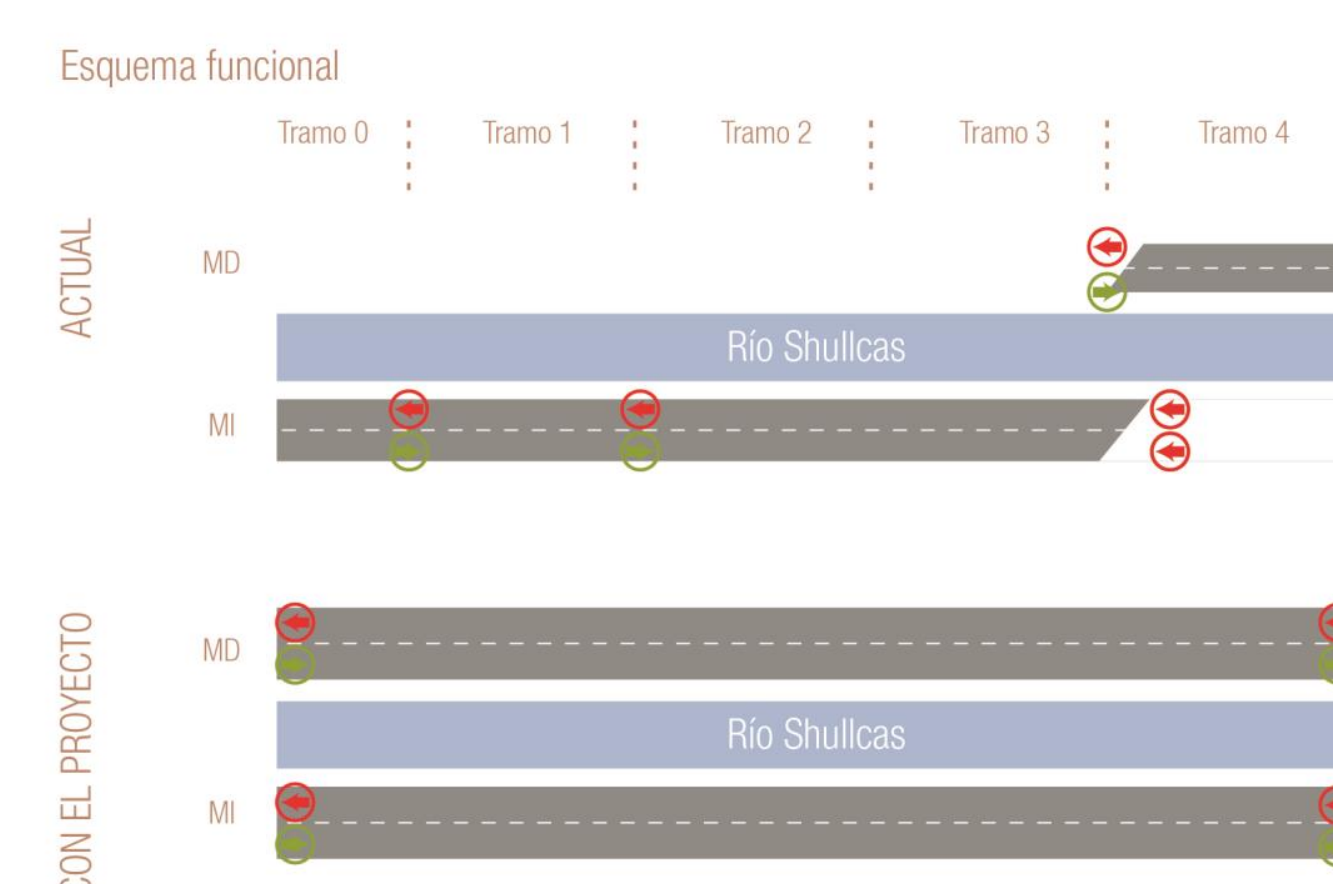

Creación de vías y bermas según normativa Racionalización de la circulación de flujos vehiculares

4. Urbano Arquitectónico

Equipamiento: 13 equipamientos nuevos a lo largo del Río Shullcas, 11 essacios abiertos. E mantenimiento y operación de las edificaciones se desarrollará por el sector privado

\section{Ingenería}

Estudios de ingenería: Para la ejecución de la obra se tendrá que realizar una lictación pública para la ellección de la empresa que se encargará de la obra 


\subsection{Gestión según el PMBOK}

La Guia de los Fundamentos para la dirección de proyectos (PMBOK, 2017) menciona que "un proyecto es un esfuerzo temporal que se lleva a cabo para obtener un producto, un servicio o resultado único" (p. 4). Por lo tanto, un proyecto es temporal, tiene un objetiv determinado y nunca hay igualdad con otro.

Parque lineal Ribereño Shullcas es un proyecto que requiere de una gestión urbana, es decir no solo debe ser visto como la construcción de un gran parque o como la restauración de un río; sino es parte de una solución más grande que es regular el crecimiento acelerado, no planificado de la ciudad, además de mejorar el sistema vial que en la actualidad es un problema grande; asimismo el plan busca estimular el crecimiento inmobiliario de la ciudad a partir de la mejora de la calidad del espacio público.

La fusión del PMBOK (Como instrumento de gestión) y El proyecto Parque del Río, Medellín nos proporcionarán herramientas de cómo abordar la gestión del Plan Piloto TRAMO 1.

El proyecto es viable a lo largo de su desarrollo, la elaboración y ejecución de un plan piloto servirá como experiencia para optimizar las subsecuentes etapas como para invitar a inversiones privadas que serán atraídas por el éxito del proyecto, logrando así figuras de colaboración público privada. Por lo tanto, el plan piloto TRAMO 1 se entiende como un proyecto de reacción inmediata.

La duración de la ejecución del Tramo 1 deberá contemplar un periodo de gobierno (4 años), por lo tanto, esto significa que la fase de estructuración y planeación deberá durar máximo los dos primeros años, es decir la gestión de la integración, alcance y calidad del diseño deberán ser cerradas en los dos primeros años. El tercer y cuarto año de gobierno deberán contemplar la licitación y ejecución de las dos etapas del proyecto

A continuación, las siguientes láminas (ficha $8.46,8.47$ ) detallan la gestión según la metodología del PMBOK para el plan piloto TRAMO 1. 
GESTIÓN SEGÍN LA METODOLOGÍA DEL PMBOK

En esta lámina se presenta cinco puntos de gestión según el PMBOK (gestión de la integración, alcance, calidad, tiempo y comunicaciones). El estudio presentado toma como referente la gestión del proyecto "Parques del Rí- Medellin".

\section{GESTIÓN SEGÚN LA METODOLOGÍA DEL PMBOK}

1 GESTONOLELANIEGACOCON

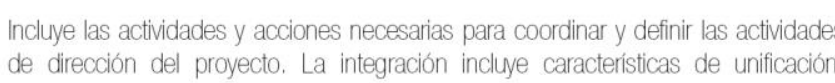

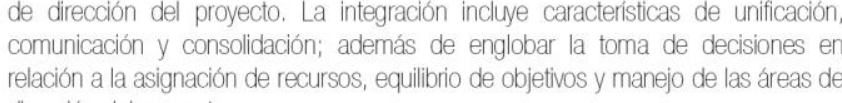

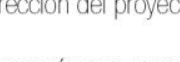

$2 G E S T O N$ DEE ALCANCE

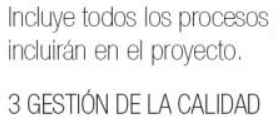

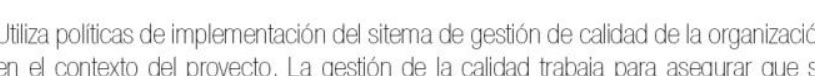

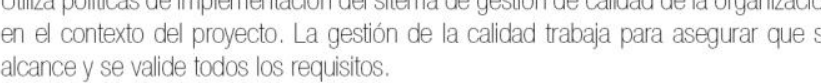

4 GESTÓN DEL TENPOO

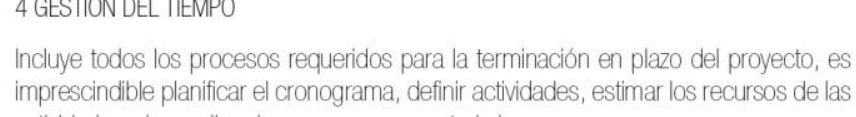

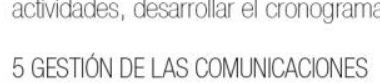

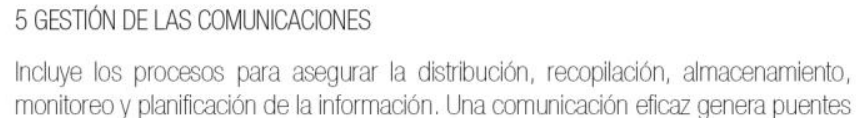

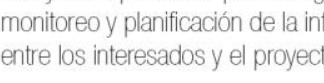

\section{GESTIÓN DE LA INTEGRACIÓN}

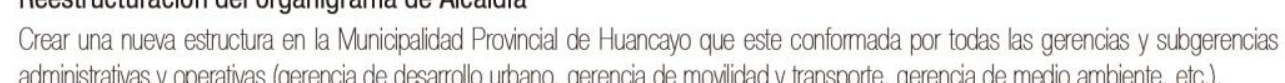

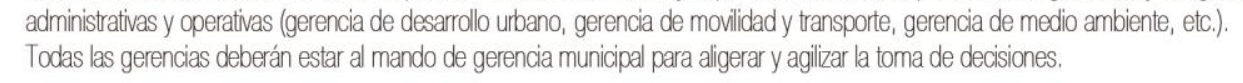

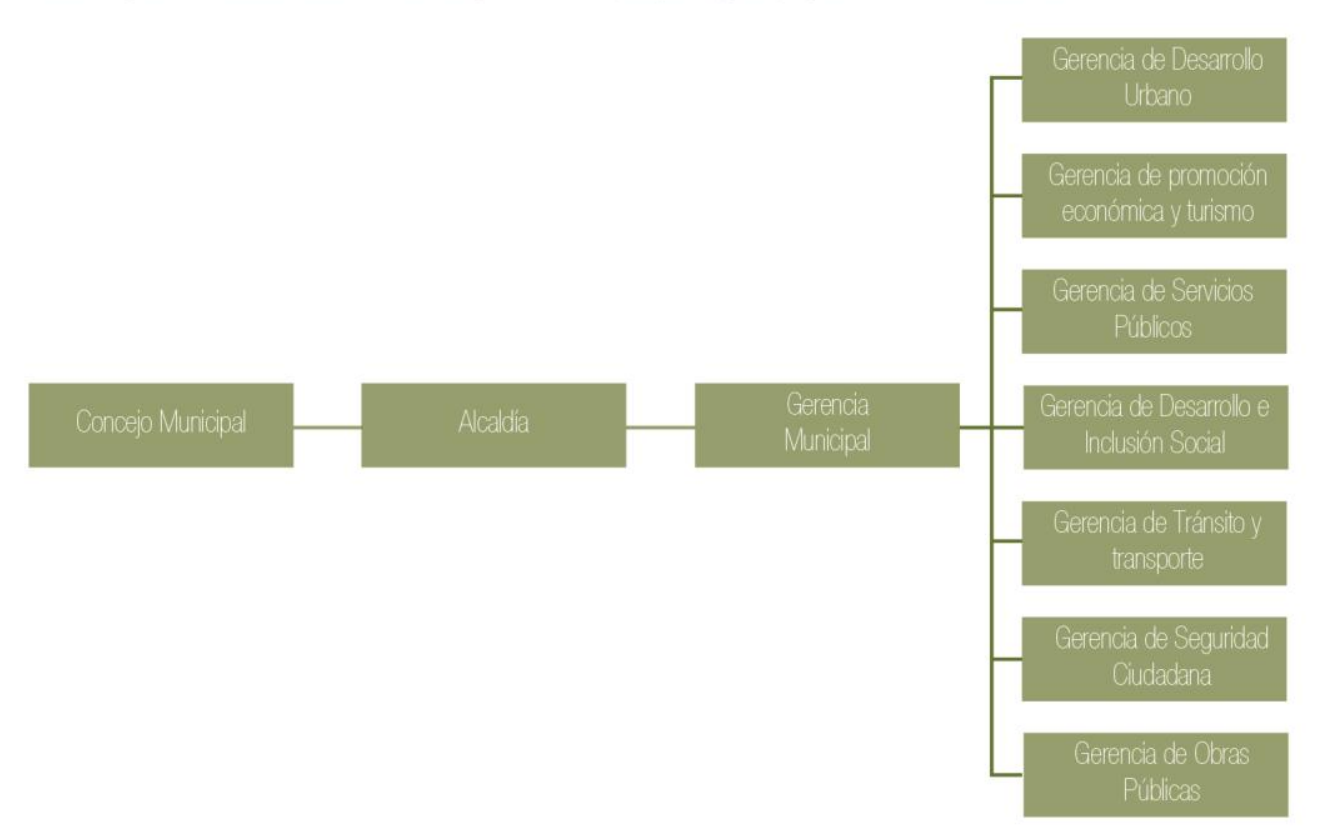

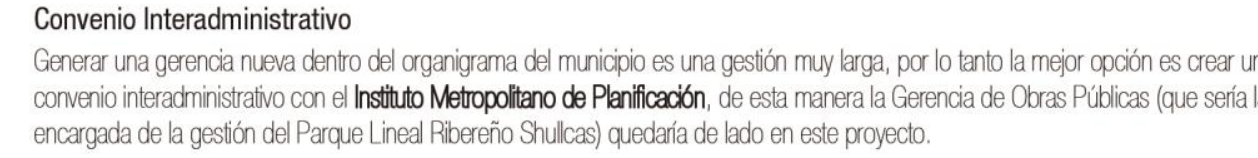

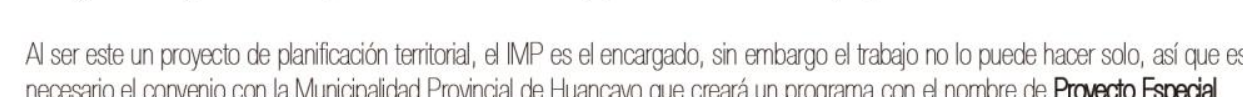

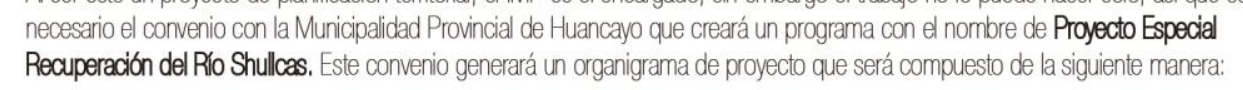
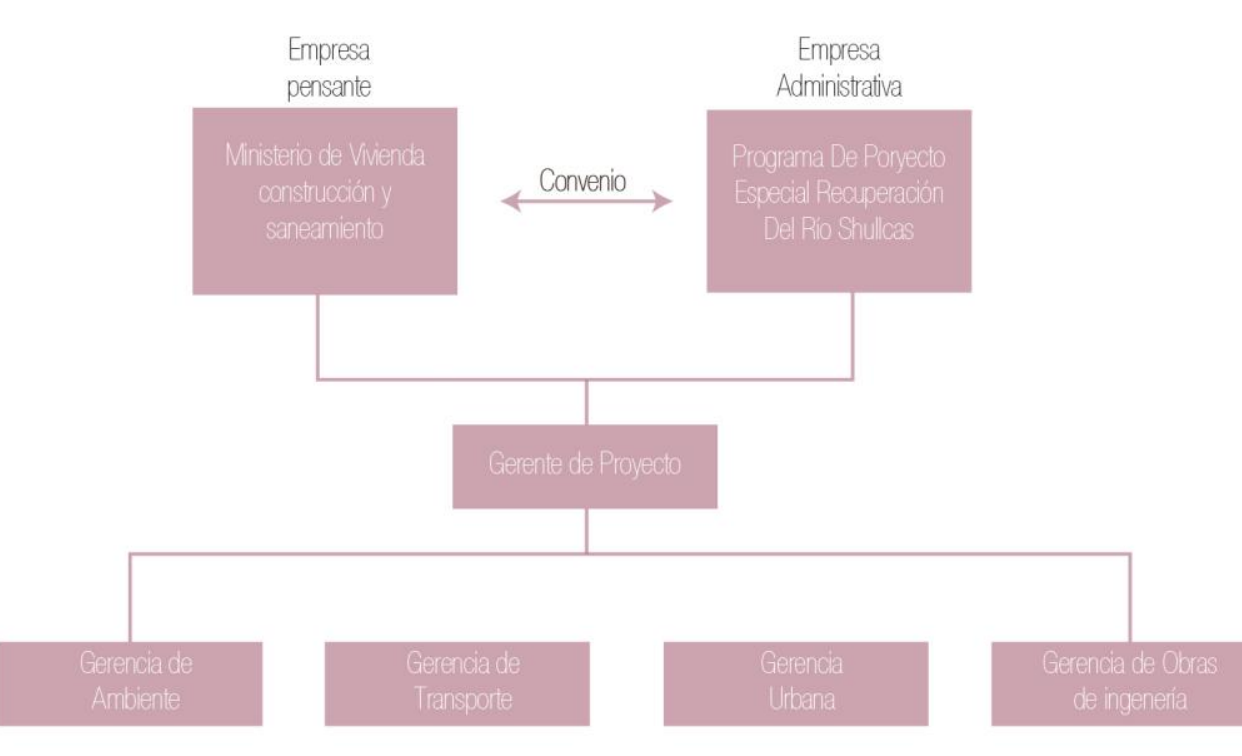

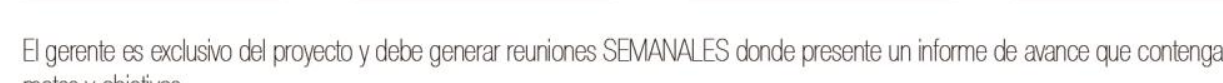

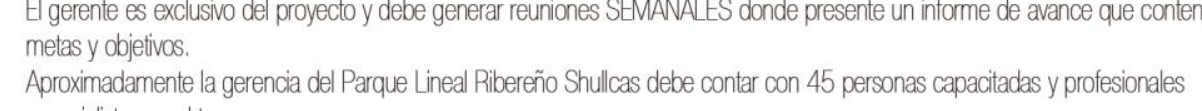

\section{GESTIÓN DEL ALCANCE}

Selección del proyecto piloto - TRAMO

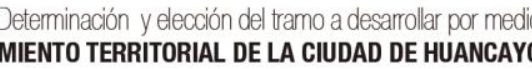

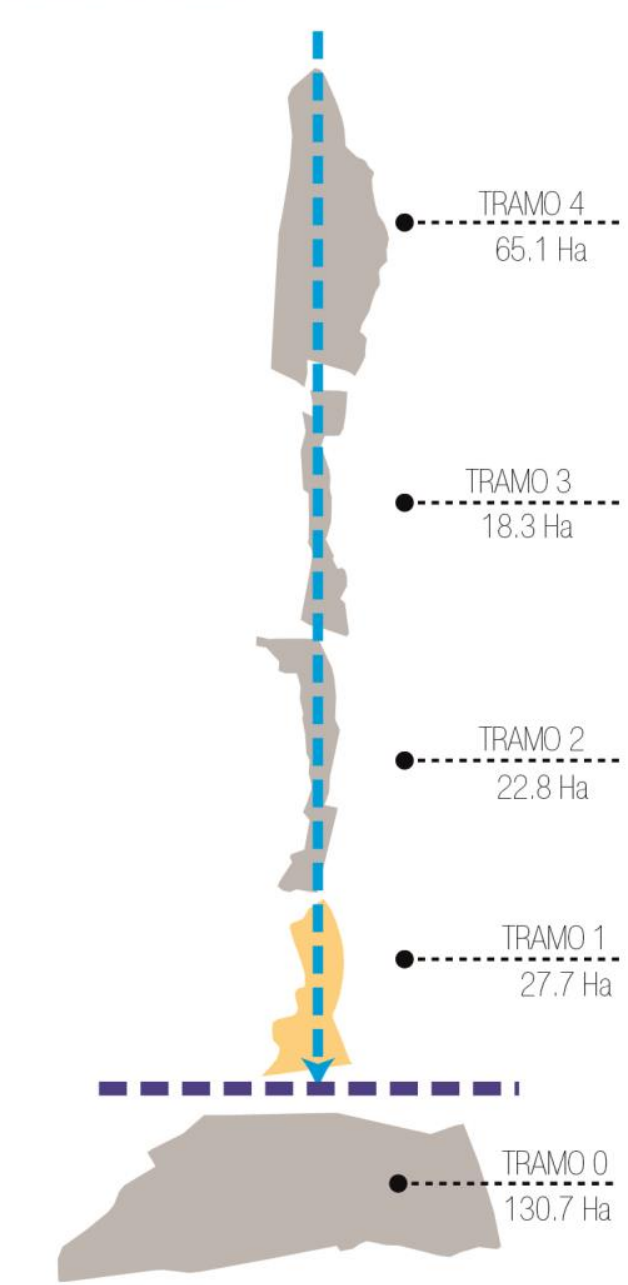

Panificación a largo plazo: Inclusión en el Plan de Ordenamiento Territorial

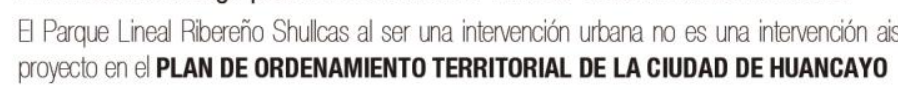

\section{GESTIÓN DE LA CALIDAD}

Establecimeinto de calidad
Se extablocerá estandares de carldat

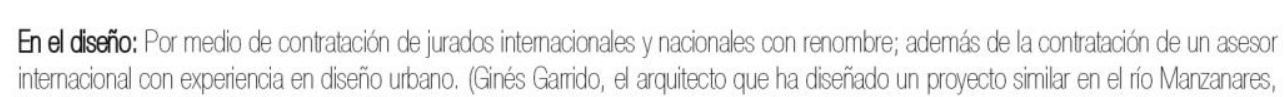

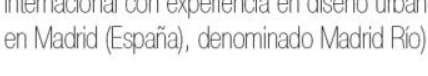

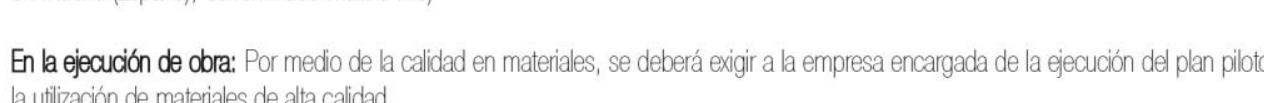

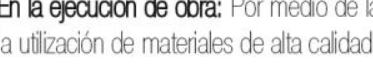

\section{GESTIÓN DEL TIEMPO}

Duración del proyecto piloto - TRAMO
Los perídos de gociemn regional duran 4 aitios

proyedcos de infreastuctura a gan escala.
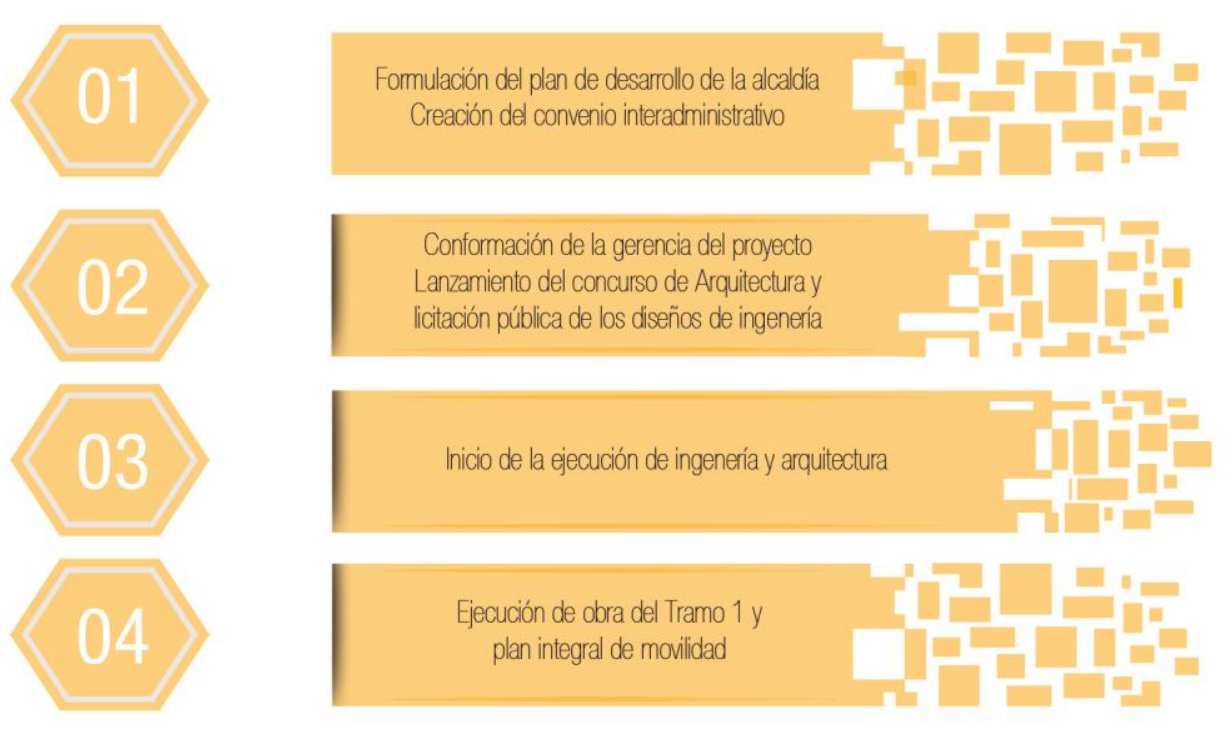

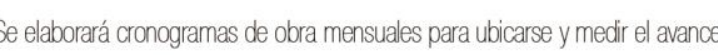

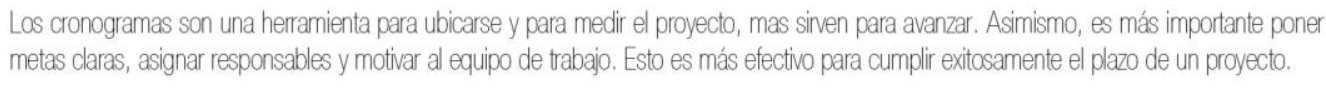

5. GESTIÓN DE LAS COMUNICACIONES

El nombre del proyecto y la importancia

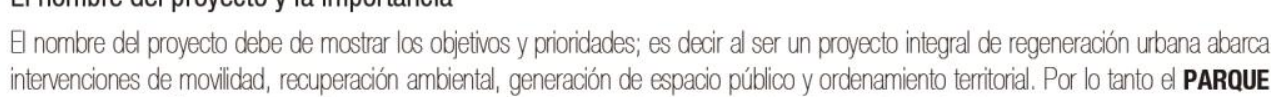

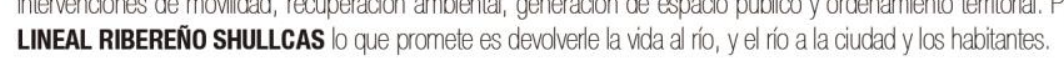

La estrategia de comunicación

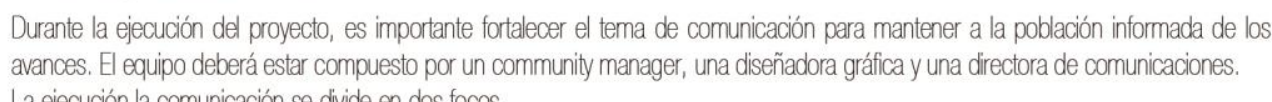
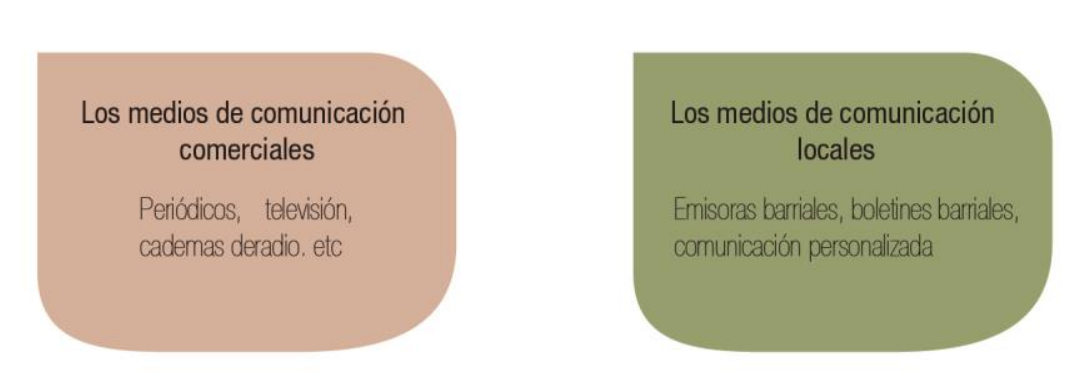

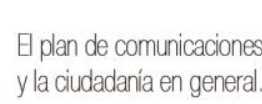

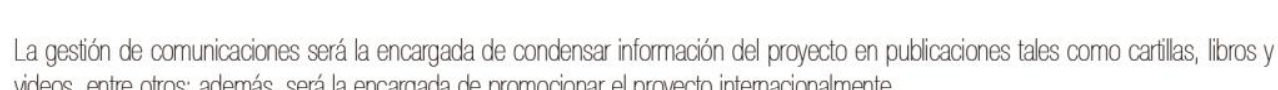


GESTIÓN SEGÚN LA METODOLOGÍA DEL PMBOK

En esta lámina se presenta cuatro puntos de gestión segun el PMMBOK (gestion del costo, recursos humanos, como referente la gestión del proyecto "Parques del RíoMedellin"

\section{GESTIÓN SEGÚN LA METODOLOGIÁ DEL PMBOK}

6 GESTIÓN DEL COSTO

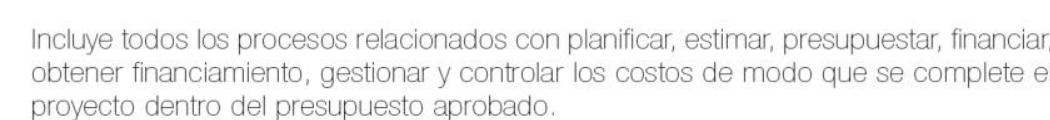
GESTIÓN DE LOS RECURSOS HUMANOS

Incliye todos los processos aue organizan, conducen y gestioan al equipo de trabajio
El equipo deberá ser compuesto por personas con roles y responsabilidades bien

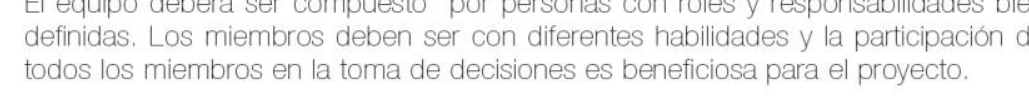
8 GESTIÓN DE LOS RIESGOS

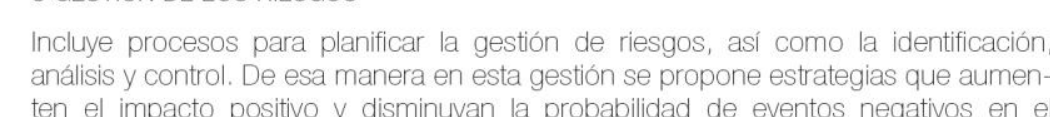
ter el impacto positivo y
proyecto.
9 GESTIÓN DE ADQUISIIIONES

Incluye todos los procesos necesarios para la adquisición de productos, senvicios o

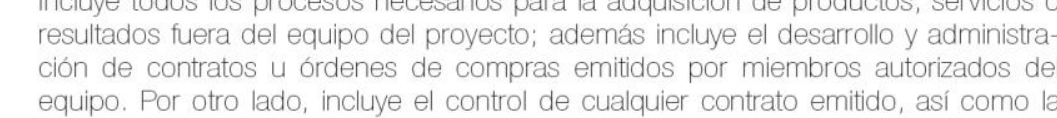

6. GESTIÓN DEL COSTO

Costo en dólares

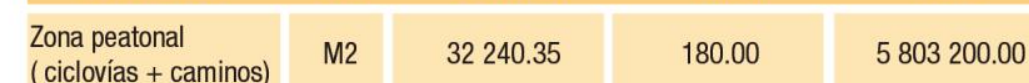

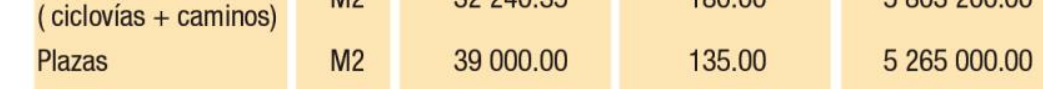

\begin{tabular}{|l|c|c|c|c|}
\hline Pasarelas & M2 & 323.54 & 80.00 & 25883.20 \\
\hline
\end{tabular}

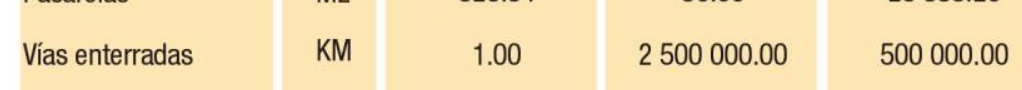

\begin{tabular}{l|l|l|l|l|}
\hline Zonas verdes & M2 & 25240.35 & 200.00 & 5048070.00 \\
\hline
\end{tabular}

\begin{tabular}{l|c|c|c|c|}
\hline Vas a nivel & KM & 2.3 & 1000000.00 & 2300000.00 \\
\hline
\end{tabular}

\begin{tabular}{|l|l|l|l|l|}
\hline Mobiliario & UND & 60 & 300.00 & 18000.00 \\
\hline
\end{tabular}

\begin{tabular}{l|l|l|l|l|}
$\begin{array}{l}\text { Redes eléctricas } \\
\text { e hidrosanitarias }\end{array}$ & $\%$ & 0.12 & 180.00 & 2515218.39 \\
\hline
\end{tabular}

Valor total del proyecto
23475371.59

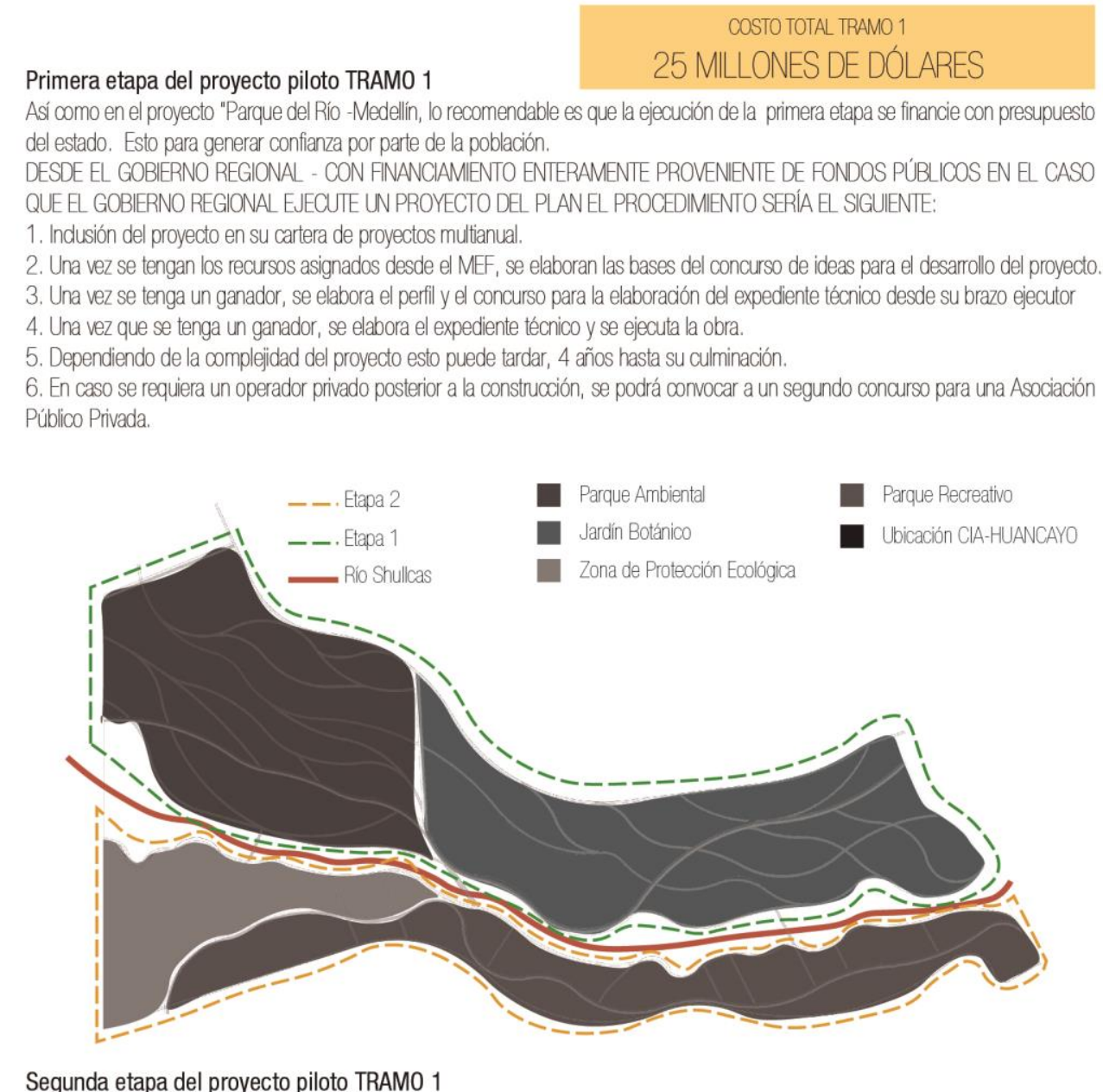

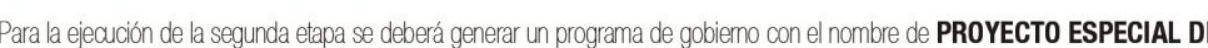

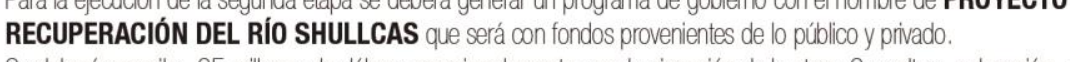

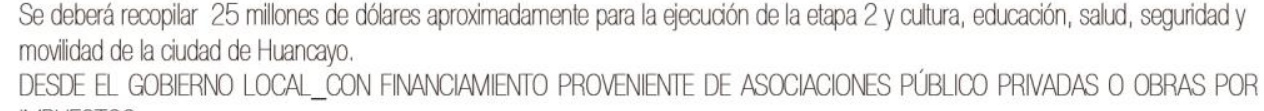

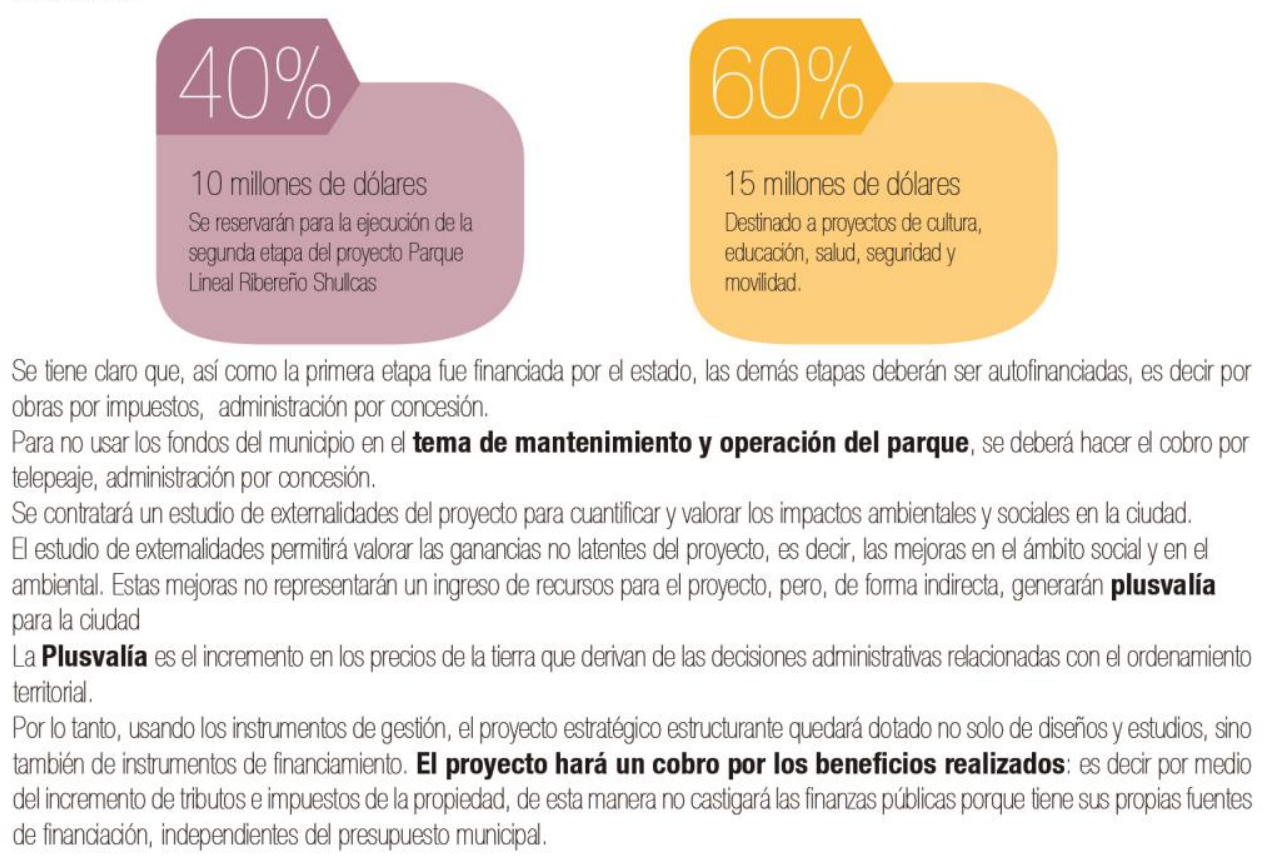

7. GESTIÓN DE LOS RECURSOS HUMANOS

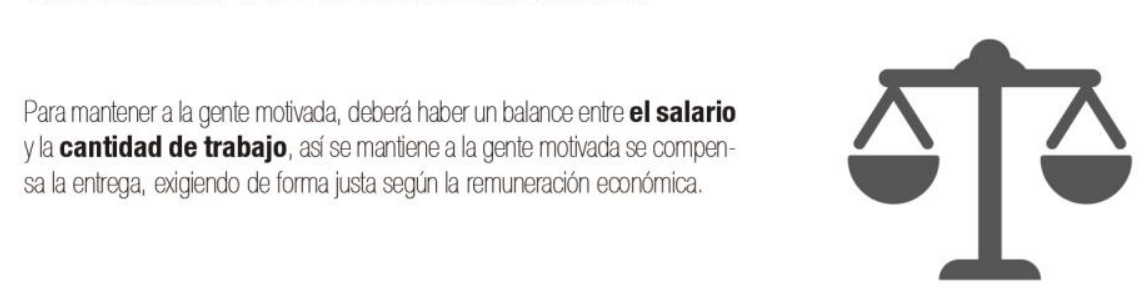

Aser un proyecto ubanono los equipos de

Arquitectura

Coordinación entre el diseño de arquitectura e ingenería

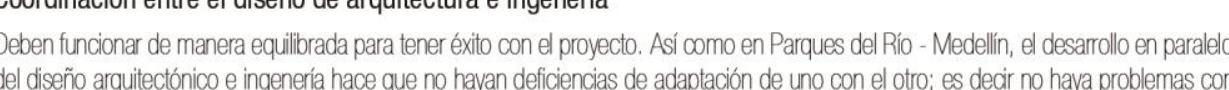

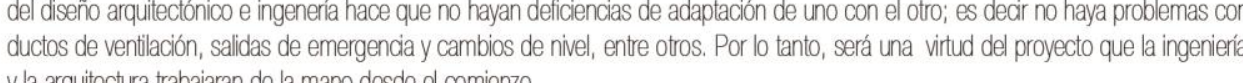

\section{Coordinación con la gerencia}

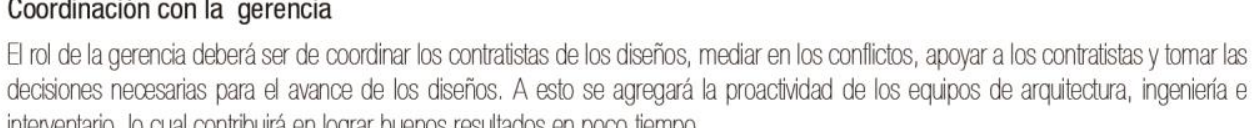

\section{GESTIÓN DE RIESGOS}

\section{Gestión de riesgo $\longleftrightarrow$ Ejecución de obra}

Crear un programa de movilidad integral durante la ajeccución de obra

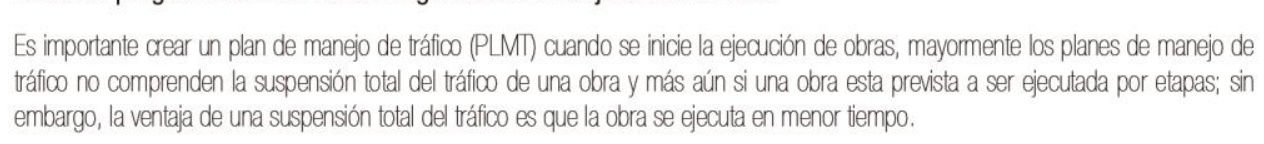

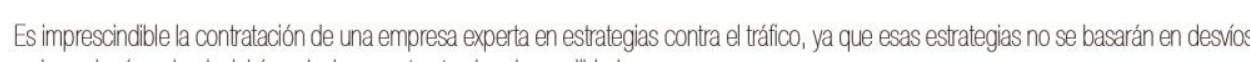

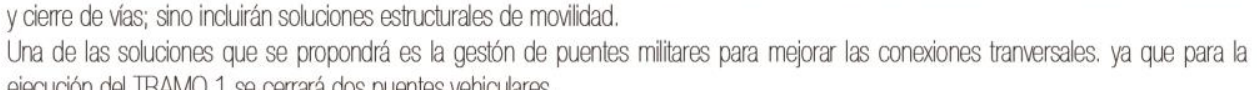

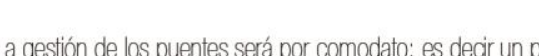

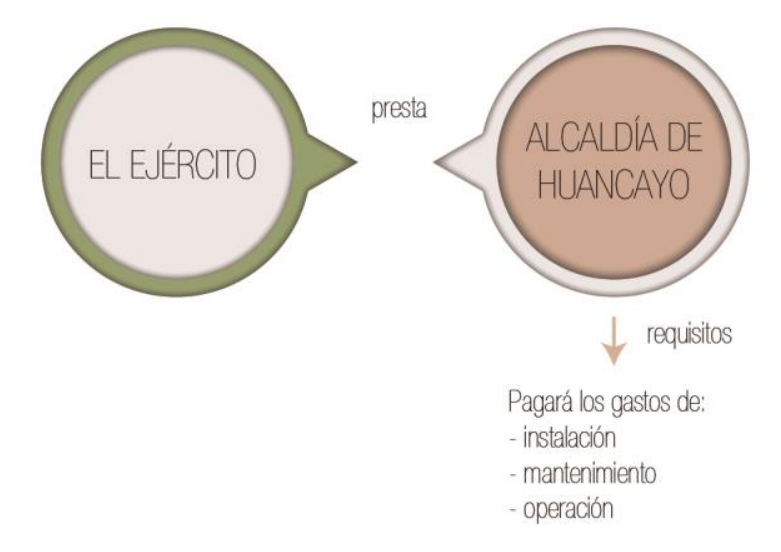

9. GESTIÓN DE ADQUISICIONES

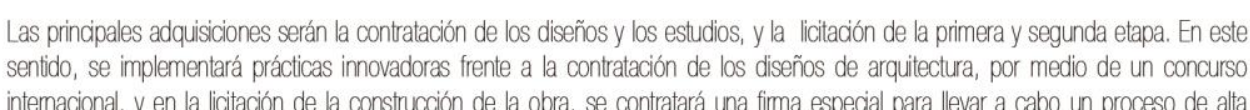

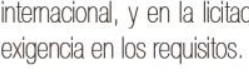

Concurso intemacional de arcuitectur

(1)

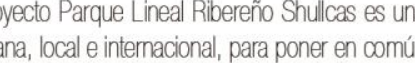

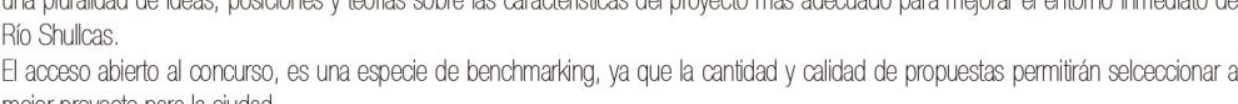

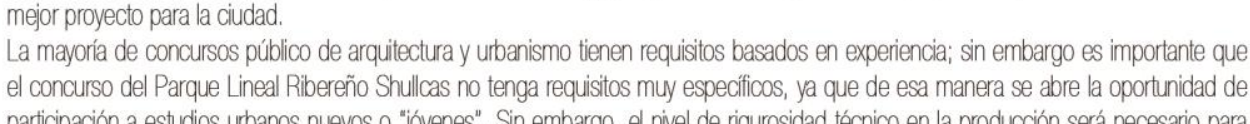

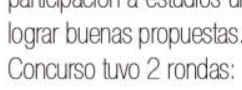

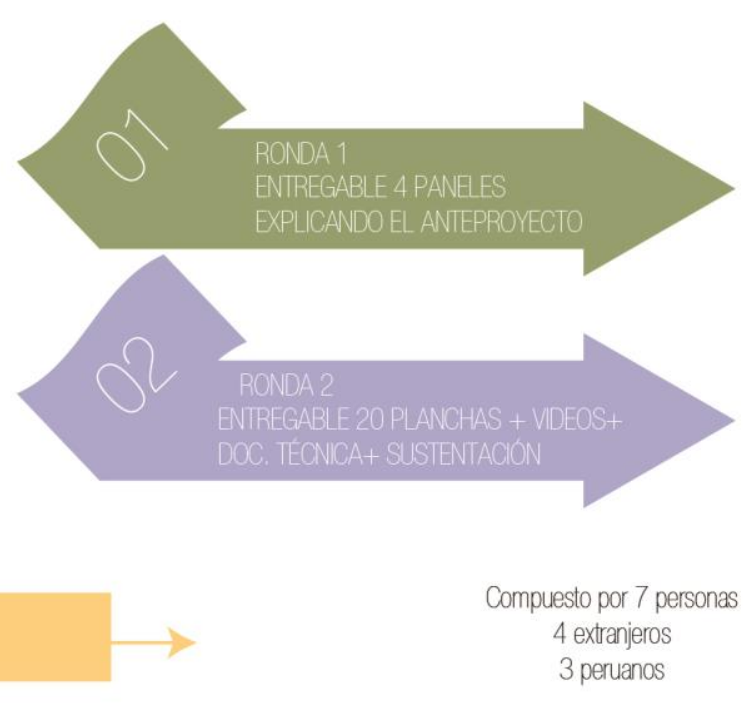

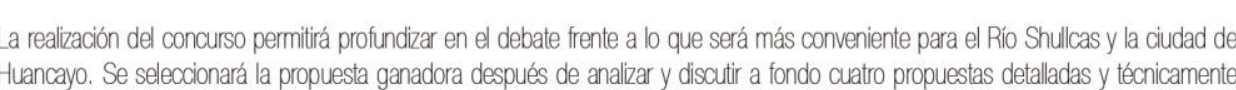

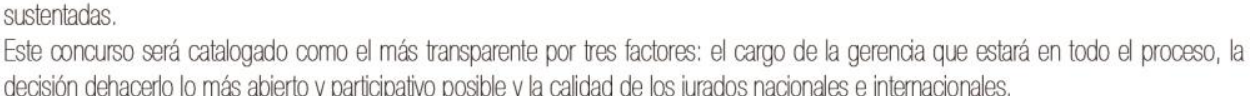

Proceso internacional de licitación de obra

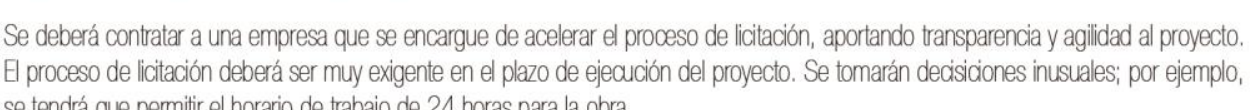

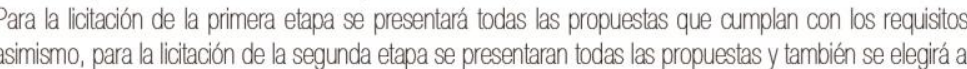




\section{REFERENCIAS}

Comité Internacional para la Museología de ICOM. (2009). Conceptos fundamentales de museologia . En F. Mairesse, A. Desvallées, \& B. Deloche (Ed.). (págs. 91128). Bélgica: Musée royal de Mariemont . Obtenido de

http://network.icom.museum/fileadmin/user_upload/minisites/icofom/pdf/ISS\% 2038-2009.pdf

"Consejo Internacional del Muesos"[ICOM]. (s.f.). Consejo Internacional del Muesos. Obtenido de Misioes y objetivos: https://icom.museum/es/sobrenosotros/misiones-y-objetivos/

"La Empresa de Desarrollo Urbano". (s.f.). Obtenido de http://www.edu.gov.co/site/actualidad/741-parque-del-rio-medellin-equidadinclusion-e-integracion

Aldridge, D. (1973). Mejora de la Interpretación de los Parques y la Comunicación con el Público. Segunda Conferencia Mundial sobre Parques Nacionales Yellowstone y Grand Teton (págs. 18-27). Estados Unidos: Yellowstone y Grand Teton.

Arcila, M., \& López, J. A. (2015). Los centros de interpretación como motor de desarrollo turístico local, ¿un modelo fracasado? el caso de la provincia de Cadiz. Boletín de la Asociación de Geógrafos Españoles, 143-165. Obtenido de https://dialnet.unirioja.es/servlet/articulo?codigo $=5035571$

Arguedas, J. (1982). Valle del Mantaro.

Autoridad Nacional del Agua [ANA]. (2010). Autoridad Nacional del Agua. Obtenido de Evaluación de los Recursos Hídricos Superficiales en la Cuenca del Mantaro: http://www.ana.gob.pe/media/390314/evaluacion\%20rh\%20superficiales\%20rio \%20mantaro.pdf

Autoridad Nacional del Agua [ANA]. (15 de Junio de 2016). Ministerio de Agricultura y Riego. Obtenido de Resolución Jefatural No 153-2016-ANA: http://www.ana.gob.pe/sites/default/files/normatividad/files/r.j._153-2016ana.pdf

Ayuntamiento de Madrid. (Enero de 2010). Universidad Politécnica de Valencia. Obtenido de http://www.upv.es/contenidos/CAMUNISO/info/U0643712.pdf

Banco Internacional de Desarrollo [BID]. (s.f.). Banco Internacional de Desarrollo [BID]. Obtenido de ¡Qué es CES?: https://www.iadb.org/es/ciudades

Bazan, H. (2014). La Interpretación del Patrimonio como estrategia para la educación y socialización del patrimonio en el medio rural. Monográfico(9), 21-40. Obtenido de file://C:/Users/Daniel/Downloads/DialnetLaInterpretacionDelPatrimonioComoEstrategiaParaLaE-5385929.pdf 
Betancur, J. (2012). Intervención del río Medellín:la Sociedad de Mejoras Públicas y la administración municipal de Medellín, 1940-1956. HISTOrelo.Revista de Historia Regional y Local, 239-274. Obtenido de http://www.scielo.org.co/scielo.php?pid=S2145132 X2012000200009\&script $=$ sci_abstract\&tlng=es

Beveridge, C. (2009). Ville Montreal. Obtenido de MOUNT ROYAL IN THE WORKS OF FREDEDIRCK LAW OLMSTED:

http://ville.montreal.qc.ca/pls/portal/docs/PAGE/BUREAU_MTROYAL_FR/M EDIA/DOCUMENTS/OLMSTED-VISION-MONT\%20ROYAL-AVRIL2009VERSION\%20ANGLAISE-FINAL.PDF

Bonilla Di Tolla, E. (Julio de 2010). Universidad de Lima. Obtenido de Una Aproximación al paisaje cultural del Valle del Mantaro:

http://fresno.ulima.edu.pe/sf\%5Csf_bdfde.nsf/imagenes/AA3BC569BC3136440 52577F500596E1C/\$file/13-28-bonilla.pdf

Borja, J. (2002). Ciudadania y globalización. Revista del CLAD Reforma y democracía(22), 1-11. Obtenido de http://siare.clad.org/revistas/0041400.pdf

Borja, J. (2002). Colegio de Arquitectos de Cataluña. Obtenido de La Ciudad del Deseo: http://roderic.uv.es/bitstream/handle/10550/45626/8386.pdf? sequence $=1 \&$ isAllowed $=$ y\&fbclid $=$ IwAR2F7_FGxDWeFV2TNMYbLci mD9De3K0V-Z4Q35bz2AizwGWI4L1G52IUeW0

Borja, J. (2012). World Prest. Obtenido de Espacio Publico al Derecho y la Ciudad: ttps://debatstreballsocial.files.wordpress.com/2013/03/espacio_publico_derecho _ciudad jordiborja.pdf?fbclid=IwAR2n8M4cNH193qHGmV8byoZTFR $\bar{R} H O-$ srQy5CKYnU5wk2vkFc902P7PR0NSjk

Borja, J. (2014). La Entrevista a Jordi Borja. La Colmena(7), 103-107. Obtenido de http://revistas.pucp.edu.pe/index.php/lacolmena/article/view/12516/13077

Centro de Cultura Contemporanea de Barcelona [CCCB]. (7 de Noviembre de 2006). Centro de Cultura Contemporanea de Barcelona . Obtenido de Ciudades inclusivas retos de la iversidad urbana :

http://www.cccb.org/es/actividades/ficha/ciudades-inclusivas-retos-de-ladiversidad-urbana/218435? fbclid=IwAR2 miP-3SQpkZOVrK3Z8pezOkRpKY2Ob195N_xNOmwEXFyIwyz06FCp-OQ

Chávez, O. (1925). Huancayo. Huancayo: Librería e Imprenta Lazo Sánchez.

Chilman, K. (2006). Using Participant Observation to Study Recreation Management Decision-making. Northeastern Recreation Research Symposium (págs. 103107). Illinois: USDA Forest Service y Northeastern Research Station. Obtenido de

https://www.fs.fed.us/ne/newtown_square/publications/technical_reports/pdfs/2 006/341\%20papers/chilman341.pdf

Colegio de Arquitectos del Peru [CAP]. (2016). Colegio de Arquitectos del Peru. Obtenido de Reglamento Nacional de Edificaciones: http://www.caplima.pe/PortalCAP2017/rne/ 
Comité Internacional de Museos. (09 de Junio de 2017). ICOM. Obtenido de https://icom.museum/wpcontent/uploads/2018/07/2017_ICOM_Statutes_SP_01.pdf

Consorcio para el Desarrollo Sostenible de la Ecorregión Andina. (09 de Enero de 2015). Superintendencia Nacional de Servicios de Saneamiento. Obtenido de https://www.sunass.gob.pe/MRSE/4dhr_info_shullcas_09_01_2015.pdf

Cortez Mallma, A. (2010). La Cultura Huanca o "Wanca" . Wallallo, 7-10.

Diccionario de la Real Academia Española [DRAE]. (2019). Diccionario de la Real Academia Española. Obtenido de Diccionario de la Real Academia Española: https://dle.rae.es/

Eckbo, G. (1950). Landscape for living. Nueva York: Architectural Records con Duell, Sloan y Pearce.

Espinoza Soriano, W. (1971). Los Huancas Aliados de la Conquista: tres informaciones inéditas sobre la participacion indigena en la conquista del Peru. Huancayo.

ETS de Aruitectura Universidad de Málaga. (2 de Marzo de 2015). Conferencia Javier Maderuelo. Obtenido de [Archivo de vídeo]: https://www.youtube.com/watch? $\mathrm{v}=9 \mathrm{cu}-\mathrm{vzol}-\mathrm{qI}$

Gavidia, M. (2002). El agua y la ciudad. En P. De la Cal, \& F. Pellicer, Ríos y ciudad.Aportes para la recuperaciónde los ríos y riberas de Zaragoza (págs. 33-34). Zaragoza: Intitución "Fernando el Católico". Obtenido de http://www.upv.es/contenidos/CAMUNISO/info/U0643698.pdf

Gehl, J. (2006). La humanización del espacio urbano : La vida social entre los edificios. Barcelona: Reverté.

Gehl, J. (2010). Cities for people. Washington DC: Island Press.

Gobierno Regional Junin. (s.f.). Gobierno Regional Junin. Obtenido de Visión y misión: http://www.regionjunin.gob.pe/pagina/id/vision_y_mision/

Gonzáles, Hernández, Perló, \& Zamora. (2010). Universidad Nacional Autónoma de México. Obtenido de http://www.economia.unam.mx/cedrus/descargas/rescate_rios_digital.pdf

Grupo de Análisis para el Desarrollo [GRADE]. (2009). Desarrollo Rural Territorial y Adaptación al Cambio Climático. Adaptación al Cambio Climático en contextos de DTR - Zona de Estudio en el Perú: Zona Central del Valle del Mantaro, (pág. 30). Lima. Obtenido de http://siteresources.worldbank.org/EXTSOCIALDEVELOPMENT/Resources/2 44362-1232059926563/5747581-1239131985528/59997621242914244952/Peru_Inception_Report.pdf

Guerra Carrillo, J., Ruiz Zocoalaya, R., Salame Mubarak, R., Caso Osorio, E., Ramos Ayllón, C., \& Martinez Quintanilla , E. (2015). Diagnóstico urbano 2015-2025. Obtenido de http://munihuancayo.gob.pe/portal/upload/documentos/2015/gerencia_subgeren cia/desarrollo_urbano/plan/DiagnosticoPDU.pdf.

Holl, S. (1991). Edge of a city. Nueva York: Princeton Architectural Press. 
Instituto Nacional de Estadística e Informática . (Agosto de 2008). INEI. Obtenido de https://www.inei.gob.pe/media/MenuRecursivo/publicaciones_digitales/Est/Lib 1136/libro.pdf

Instituto Nacional de Estadística e Informática [INEI]. (2007). INEI. Obtenido de INEI: https://www.inei.gob.pe/media/MenuRecursivo/publicaciones_digitales/Est/Lib 1340/cuadros/cap12.pdf

Instituto Nacional de Estadística e Informática. (Junio de 2018). Instituto Nacional de Estadística e Informática. Obtenido de https://www.inei.gob.pe/media/MenuRecursivo/publicaciones_digitales/Est/Lib 1530/libro.pdf

Jacobs, J. (1961). Muerte y Vida de las Grandes Ciudades. Madrid: Capitan Swing Libros, S.L.

Larsen, D. (2003). MEANINGFUL INTERPRETATION The Interpretatión Process Model. Fort Washington: Eastern National.

Longley, \& Battry. (1994). Fractal Cities. Londres: Academis Press INC.

Lynch, K. (1976). La Imagen Urbana de la Ciudad. España: Gustavo Gili.

Maderuelo, J. (2004). Aquello que llamamos paisaje. Visions de L'Escola Tècnica Superior d'Arquitectura, 20-25.

Maderuelo, J. (2010). El pasisaje urbano. Estudios Geográficos, 575- 600.

María Pinilla, C. (2004). Arguedas en el Valle del Mantaro. (PUCP) Fondo Editorial.

Martín, C. (2011). Estudio analítico descriptivo de los centros de interpretación patrimonial en españa (Tesis de Doctorado). Universidad de Barcelona, Barcelona.

Ministerio de Salud [MINSA]. (24 de Abril de 2008). Dirección General de Salud Ambiental . Obtenido de

http://www.digesa.minsa.gob.pe/depa/rios/2008/SHULCAS_2008.pdf

Ministerio de vivienda y urbanismo de Chile [MINVU]. (2017). La dimensión Humana en el espacio público. Santiago.

Ministerio de Vivienda, Contrucción y Saneamiento [MVCS]. (s.f.). Ministerio de Vivienda, Contrucción y Saneamiento. Obtenido de Ley general de desarrollo urbano:

http://eudora.vivienda.gob.pe/OBSERVATORIO/DESTACADOS/Propuesta_L GDU.pdf

Ministerio del Ambiente [MINAM]. (Mayo de 2013). CARE. Obtenido de Plan de Gestión Integrado de Recursos Hídricos de la Subcuenca del Río Shullcas: http://www.care.org.pe/wp-content/uploads/2015/06/Plan-de-Gestion-Integradode-Recursos-Hidricos-de-la-subcuenca-del-rio-Shullcas.pdf

Ministerio del Ambiente. (31 de Julio de 2008). El Peruano Diario Oficial. Obtenido de file://C:/Users/User/Downloads/1458.pdf

Ministerio del Ambiente. (10 de Octubre de 2012). Ministerio del Ambiente. Obtenido de Ejes Estratégicos de la Gestión Ambiental: http://www.minam.gob.pe/wp- 
content/uploads/2013/06/EJES-ESTRATEGICOS-DE-LA-GESTIONAMBIENTAL.pdf

Morales, J. (1983). La interpretación ambiental y la gestión del medio. I Jornadas de educación ambiental (págs. 213-216). Barcelona: Ministerio de Obras Públicas y Urbanismo.

Morales, J. (1992). Manual para la interpretación ambiental en áreas silvestres protegidas. Sevilla: Sociedad Europea de Educación Ambiental. Obtenido de http://www.fao.org/3/a-ai179s.pdf

Morales, J. (1998). La interpretación del patrimonio natural y cultural : todo un camino por recorrer. Boletín PH(25), 150-157. Obtenido de https://www.google.com.pe/url?sa=i\&source=images\&cd=\&ved=2ahUKEwiSp ZHM4vvfAhUJnOAKHT17BIcQjRx6BAgBEAU\&url=http\%3A\%2F\%2Fwww .iaph.es $\% 2$ Frevistaph $\% 2$ Findex.php $\% 2$ Frevistaph $\% 2$ Farticle $\% 2$ Fview $\% 2$ F732 \&psig=AOvVaw17T_UsWzgkag61a4aOxsMC\&ust=1548053438027183

Morales, J. (2004). Interpretación de Patrimonio. Obtenido de La planificación interpretativa asegura la excelencia en interpretación: http://www.interpretaciondelpatrimonio.com/docs/pdf/Planificacioninterpretativ a.pdf

Municipalidad Metropolitana de Lima e Intituto Metropolitano de Planificación. (2014a). Plan Metropolitano de Desarrollo Urbano PLAM Lima y Callao 2035 (Tomo 1) (Vol. 1). Lima.

Municipalidad Metropolitana de Lima e Intituto Metropolitano de Planificación. (2014b). Plan Metropolitáno de Desarrollo Urbano PLAM Lima y Callao 2035 (Tomo1) (Vol. 3).

Municipalidad Provincial de Huancayo. (2014). Municipalidad Provincial de Huancayo. Obtenido de

https://www.munihuancayo.gob.pe/documentos/2014/informe_anual/memoria2 014.pdf

Municipalidad Provincial de Huancayo. (2015). Municipalidad Provincial de Huancayo. Obtenido de

http://munihuancayo.gob.pe/portal/upload/documentos/2015/gerencia_subgeren cia/desarrollo_urbano/plan/DiagnosticoPDU.pdf

Muñoz, A. (2012). Guía metodológica. Estudios de paisaje. Valencia: La Imprenta CG.

National Association for Interpretation. (Enero de 2009). National Association for Interpretation. Obtenido de https://www.interpnet.com/docs/BP-MethodsJan09.pdf

Neufert, E. (1975). Arte de proyectar arquitectura (Vol. 39). Barcelona: Gustavo Gili.

Olmsted, F. (1968). Landscape into Citycape. Nueva York.

Organismo de Evaluación y Fiscalización Ambiéntal [OEFA]. (Diciembre de 2014). Organismo de Evaluación y Fiscalización Ambiéntal. Obtenido de https://www.oefa.gob.pe/?wpfb_dl=13926

Organismo Mundial de Salud[OMS]. (s.f.). Organismo Mundial de Salud. Obtenido de Acerca de la OMS: https://www.who.int/about/es/ 
Otaola, P. (2000). El Bilbao de Bilbao Ría 2000. Bidebarrieta, 73-88. Obtenido de http://www.bidebarrieta.com/revista/8

Peart, B. (1977). Definition of Interpretation. Association of Interpreters Naturalists Workshop.

Pérez, J. (2012). Medellín Metropolitana una aproximación a la ciudad, la crisis como oportunidad. Cuaderno Urbano, 138-169. Obtenido de http://www.scielo.org.ar/scielo.php?script=sci_arttext\&pid=S185336552012000100007

Perez, Patiño, Spera, Garcia, Tarchópulos, \& Cardona. (Junio de 2015). El Plan de Ordenamiento Territorial de Medellín 2014: un modelo territorial para la intervención estratégica. Barcelona: VII Seminario Internacional de Investigación en Urbanismo, Barcelona-Montevideo, junio 2015. Obtenido de http://hdl.handle.net/2117/80323

Pinto, V., Gili, R., \& Velasco, F. (Septiembre de 2015). Comunidad de Madrid. (F. Canal, Ed.) Obtenido de http://www.madrid.org/bvirtual/BVCM019290.pdf

Plan de Desarrollo Urbano de Huancayo [PDU]. (2015). Municipalidad Provincial de Huancayo. Obtenido de Municipalidad Provincial de Huancayo_Subgerencia Desarrollo Urbano:

https://www.munihuancayo.gob.pe/documentos/2015/gerencia_subgerencia/des arrollo_urbano/plan/DiagnosticoPDU.pdf

Programa de las Naciones Unidas para el Medio Ambiente \{PNUMA\}. (s.f.). Programa de las Naciones Unidas para el Medio Ambiente. Obtenido de El PNUMA y los jóvenes: https://www.un.org/youthenvoy/es/2013/08/el-pnuma-ylos-jovenes/

Rojas, A. M. (1997). EL RÍO Y LA CIUDAD. Bitácora Urbano Territorial, 41-44. Obtenido de https://dialnet.unirioja.es/servlet/articulo?codigo $=4008079$

Samalvides, L. (2005). Huancayo. Biografía de una ciudad. Huancayo, Junín: Colegio de Arquitectos del Perú.

Tilden, F. (2006). La interpretción de nuestro patrimonio (Primera edición en castellano ed.). Sevilla: Asociación para la interpretación del patrimonio.

Veverka, J. (2003). John Veverka \& Associates. Obtenido de https://webcache.googleusercontent.com/search?q=cache:i8E_IMzpOMYJ:https ://portal.uni-freiburg.de/interpreteurope/service/publications/recommendedpublications/veverka_truly_interpretive_exhibits.pdf $+\& c d=16 \& \mathrm{hl}=\mathrm{en} \& \mathrm{ct}=\mathrm{clnk}$ $\& \mathrm{gl}=\mathrm{pe}$

Wieser Rey, M. (2011). Pontificia Universidad Católica del Perú. Departamento de Arquitectura. Obtenido de Pontificia Universidad Católica del Perú.

Departamento de Arquitectura: http://repositorio.pucp.edu.pe/index/handle/123456789/28699 